\title{
Comportamento Dinâmico de Lajes Maciças de Concreto Leve com Pérolas de EPS
}

\author{
VERSÃO CORRIGIDA \\ A versão original encontra-se na Escola de Engenharia de São Carlos
}

Tese apresentada ao Departamento de Engenharia de Estruturas da Escola de Engenharia de São Carlos da Universidade de São Paulo para a obtenção do título de Doutor em Ciências, Programa de Engenharia Civil (Estruturas).

Orientador: Prof. Dr. Libânio Miranda Pinheiro.

São Carlos

2015 
AUTORIZO A REPRODUÇÃO E DIVULGAÇÃO TOTAL OU PARCIAL DESTE TRABALHO, POR QUALQUER MEIO CONVENCIONAL OU ELETRÔNICO, PARA FINS DE ESTUDO E PESQUISA, DESDE QUE CITADA A FONTE.

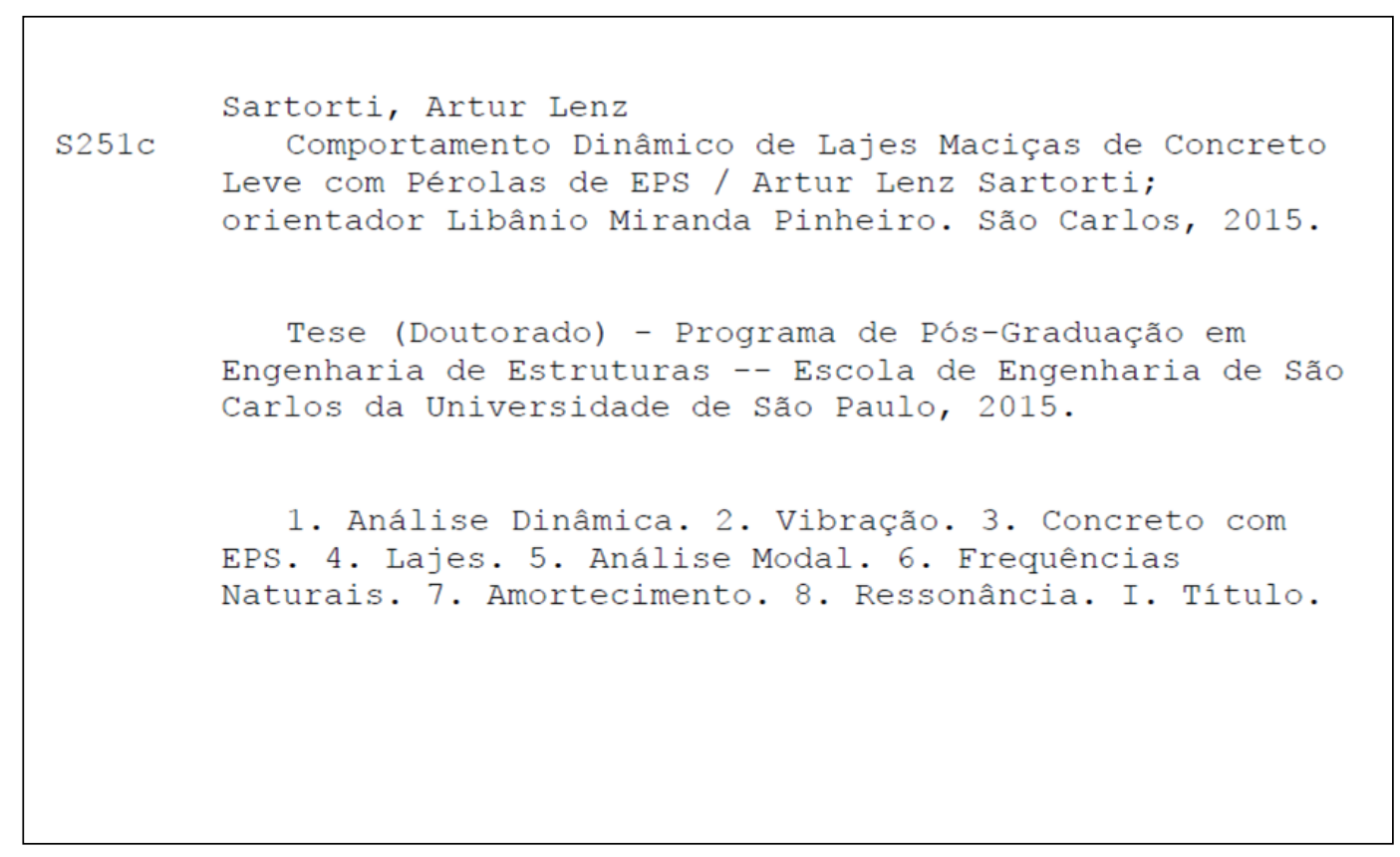




\section{FOLHA DE JULGAMENTO}

Candidato: Bacharel ARTUR LENZ SARTORTI.

Título da Tese: "Comportamento dinâmico de lajes maciças de concreto leve com pérolas de EPS".

Data da defesa: 03/07/2015

\section{Comissão Julgadora:}

Prof. Dr. Libânio Miranda Pinheiro (Orientador)

(Escola de Engenharia de São Carlos/EESC)

Prof. Dr. Ricardo Carrazedo

(Escola de Engenharia de São Carlos/EESC)

Prof. Dr. Cláudius de Sousa Barbosa

(Escola Politécnica/EP-USP)

Prof. Dr. Leandro Mouta Trautwein

(Universidade Estadual de Campinas/UNICAMP)

Prof. Dr. Walter Libardi

(Universidade Federal de São Carlos/UFSCar)
Resultado:
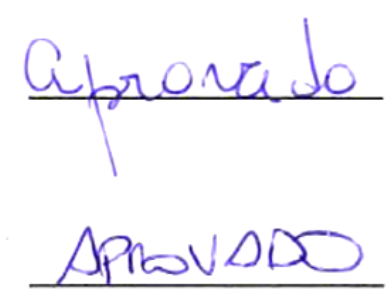
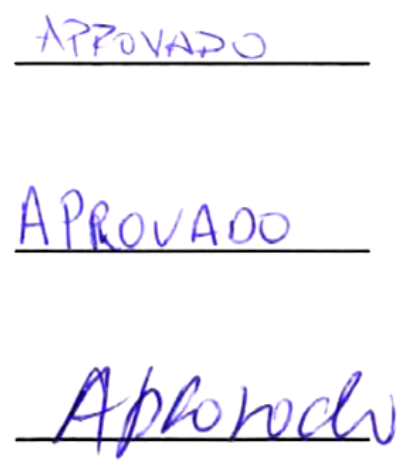

Coordenador do Programa de Pós-Graduação em Engenheira Civil (Engenharia de Estruturas):

Prof. Titular Humberto Breves Coda

Presidente da Comissão de Pós-Graduação:

Prof. Associado Paulo Sergio Lima Segantine 

À minha esposa Cristiane pelo companheirismo, paciência e amor. Aos meus pais Orlando e Marlene pela educação e incentivo. 



\section{AGRADECIMENTOS}

A vida é uma caminhada que não pode ser feita solitariamente. A companhia de outros acaba sendo constante e essencial. Os favores que recebemos de outras pessoas valem muito mais que um simples obrigado. Entretanto, lembrar-se de agradecer é importante, pois quem agradece recebe mais do que aquele a quem o agradecimento é oferecido. Quero, em simples linhas, dizer obrigado a algumas pessoas que me auxiliaram nessa caminhada.

Primeiramente agradeço a Deus, que é meu Criador, pela vida, pela esperança e companhia invisível, mas perceptível, em todos os momentos.

Ao meu orientador, Prof. Dr. Libânio Miranda Pinheiro. Seus conselhos e lições me tornaram um profissional mais equilibrado e competente. Sua orientação foi de primeira linha. Seu comprometimento com essa pesquisa foi integral. Obrigado!

Ao Prof. Dr. Ricardo Carrazedo que, com vasta experiência em dinâmica das estruturas, foi indispensável para a realização deste trabalho. Sou grato por sua dedicação, esclarecimentos e colaboração nesta tese.

À minha família, que suportou pacientemente as longas horas de dedicação à pesquisa e estudos. Ao meu filho, Artur Perassol Sartorti, e especialmente à minha querida companheira, Cristiane Perassol Sartorti, muito obrigado!

Aos meus pais, Marlene Lenz Sartorti e Orlando Sartorti, pelo incentivo, apoio e pela educação. Serei eternamente grato por esse presente. À minha sogra, Silvani Moreira, pelo apoio.

Os companheiros de estudo e pesquisa Bianca Pereira Moreira Ozório, Thiago Catoia, Lara Kawai Marcos, Tiago Marrara Juliani, Gustavo de Miranda Saleme Gidrão e Hildebrando José Farkat Diógenes, foram importantíssimos na troca de informações e no apoio.

Um agradecimento especial deve ser feito aos funcionários do Laboratório de Estruturas do SET. Luiz Vicente Vareda, Mario Botelho, Jorge Luis Rodrigues Brabo, Fabiano Dorneles, Douglas Francisco Dutra Rompa e Romeu Bessan Neto não mediram esforços em auxiliar de diversas formas o programa experimental deste trabalho.

Algumas pessoas, empresas e instituições contribuíram para a realização dos ensaios. Ao Eng ${ }^{\circ}$ José Milton Kerbauy, detentor da patente do Concreto Ultraleve ${ }^{\circledR}$, pelo fornecimento dos materiais constituintes do CLEPE. À empresa Otto Baumgart, na pessoa do Eng ${ }^{\circ}$ Ricardo Faria, pelo fornecimento do graute. À Jeruel Plásticos, na pessoa do Sr. José Fernando de 
Jesus, pelo fornecimento dos espaçadores de armaduras. À UNICAMP, pela autorização de utilização do software SAP $2000^{\circledR}$.

Obrigado aos meus alunos e ex-alunos Andrews Magaieski Greep, Edwalter Stabenov Junior, Raphael Morais, Tiago Guimarães César, Samuel de Freitas Barboza, Denison de Souza Hanelt e Murilo Aziz, que me auxiliaram na execução dos ensaios.

Aos amigos Luciano Pereira Lopes e José Alves Martins, pelo auxílio na construção das alvenarias de sustentação das lajes ensaiadas.

Agradeço também, aos conselhos e companheirismo profissional dos engenheiros Itamar Vizotto e Leandro Dias Küster.

Com a ciência de que posso cometer erros e injustiças, quero, na pessoa da secretária da pós-graduação Rosi Aparecida Jordão Rodrigues, agradecer a todos os demais funcionários e professores do Departamento de Estruturas da Escola de Engenharia de São Carlos da Universidade de São Paulo (SET/EESC/USP).

Agradeço ao Centro Universitário Adventista de São Paulo, campus Engenheiro Coelho (UNASP - EC), o auxílio moral e financeiro que recebi ao longo desses anos. Agradeço também ao UNASP - EC pela formação profissional que ali recebi, em especial ao Prof. Dr. Julio Soriano.

À Universidade Estadual de Campinas (UNICAMP), na pessoa do Prof. Tit. Nilson Tadeu Mascia, pela formação obtida no mestrado.

Finalmente, quero agradecer ao SET/EESC/USP pela oportunidade de conclusão deste sonho pessoal. 
"Não to mandei eu? Sê forte e corajoso; não temas, nem te espantes, porque o Senhor, teu Deus, é contigo por onde quer que andares.” 



\section{RESUMO}

\section{SARTORTI, A. L. Comportamento Dinâmico de Lajes Maciças de Concreto Leve com}

Pérolas de EPS. 2015. 251p. Tese (Doutorado) - Departamento de Engenharia de Estruturas da Escola de Engenharia de São Carlos da Universidade de São Paulo, São Carlos, 2015.

O Concreto Leve Estrutural com Pérolas de EPS (CLEPE), ou simplesmente Concreto com EPS, é uma alternativa na execução de lajes maciças. Como possui uma redução da ordem de $50 \%$ no peso próprio em relação ao Concreto Convencional (CC), suas características dinâmicas são diferentes. Neste trabalho descreve-se o comportamento dinâmico de lajes de CLEPE que são comparadas com as de CC por meio de ensaios dinâmicos e uma análise paramétrica. Nos ensaios dinâmicos focou-se a obtenção de três fatores imprescindíveis em uma análise dinâmica, que são as frequências naturais, os modos de vibração (deformadas modais) e o amortecimento estrutural, valor determinado experimentalmente que constitui dado de entrada em simulações numéricas. Os resultados experimentais indicam que o fator de amortecimento do CLEPE é ligeiramente maior que o do CC. Já os resultados da análise paramétrica revelam que a diminuição da rigidez é preponderante em relação à diminuição da massa do CLEPE, o que acarreta na diminuição das frequências naturais das lajes com este material. Mesmo com um amortecimento maior, as lajes de CLEPE apresentam maior sensibilidade às vibrações. Esta constatação, entretanto, não exclui o CLEPE como um material estrutural, apenas indica que, como no uso de qualquer material, as estruturas com CLEPE também devem ser verificadas com relação ao comportamento dinâmico.

Palavras-chave: Análise Dinâmica; Vibração; Concreto com EPS; Lajes; Análise Modal; Frequências Naturais; Amortecimento; Ressonância. 



\begin{abstract}
SARTORTI, A. L. Dynamic Behavior of Massive Slabs of Lightweight Concrete with EPS Beads. 2015. 251p. Thesis (PhD) - Departamento de Engenharia de Estruturas da Escola de Engenharia de São Carlos da Universidade de São Paulo, São Carlos, 2015.

The Structural Lightweight Concrete with EPS Beads (SLCEB), or simply EPS concrete, is an alternative in the execution of massive slabs. As it has a reduction in the order of $50 \%$ in selfweight in relation to the Ordinary Concrete (OC), its dynamic characteristics are different. In this work it is described the dynamic behavior of SLCEB slabs whose are compared with those of OC by means of dynamic tests and a parametric analysis. The obtainment of three essential factors in a dynamic analysis, which are natural frequencies, the ways of vibration (deformed modal), and the structural damping, experimentally determinate value which constitutes an input data in numerical simulations are focused in the dynamical tests. The experimental results indicate that the damping factor of SLCEB is a little bigger than the OC ones. Although, the results of the parametric analysis indicate that the decrease of stiffness is preponderant in relation to the decrease of the SLCEB mass, which result in some decrease of natural frequencies of slabs with this material. In despite of having a bigger damping, the SLCEB slabs expose a bigger sensibility to vibrations. However, this observation does not exclude the SLCEB as a structural material. It only means that as in use of any material, the SLCEB structures must be also verified in relation to the dynamic behavior.
\end{abstract}

Keywords: Dynamic Analysis; Vibration; EPS Concrete; Modal Analysis; Natural Frequencies; Damping; Resonance. 



\section{LISTA DE ABREVIATURAS E SIGLAS}

ABNT - Associação Brasileira de Normas Técnicas;

ABRAPEX - Associação Brasileira de Poliestireno Expandido;

ACI - American Concrete Institute (Instituto Americano no Concreto);

ARI - Alta Resistência Inicial;

ASTM - American Society for Testing and Materials (Sociedade Americana para Ensaios e Materiais);

BS - British Standard (Norma Britânica);

CA - Concreto Armado;

CC - Concreto Convencional;

CLE - Concreto Leve com EPS;

CLEPE - Concreto Leve Estrutural com Pérolas de EPS;

CLPE - Concreto Leve com Pérolas de EPS;

CP - Cimento Portland;

$\mathbf{C P}$ - Corpo de Prova;

DFT - Discrete Fourier Transform (Transformada Discreta de Fourier);

ECD - Ensaios de Caracterização Dinâmica;

ECE - Ensaios de Caracterização Estática;

EESC - Escola de Engenharia de São Carlos;

ELS-VE - Estado Limite de Vibração Excessiva;

ELU - Estado Limite Último;

EPS - Expanded Polystyrene (Poliestireno Expandido);

EVA - Ethylene-vinyl Acetate (Etileno-acetato de Vinila);

FFT - Fast Fourier Transform (Transformação Rápida de Fourier);

FRF - Frequency Responce Function (Função da Resposta em Frequência);

ISO - International Organization for Standardization (Organização Internacional para Normalização);

LVDT - Linear Variable Differential Transformer (Transformador Diferencial Variável Linear);

MDOF - Multi Degree of Freedom (Múltiplos Graus de Liberdade);

MEF - Método dos Elementos Finitos;

NBR - Norma Brasileira; 
PIM - Power Input Method (Método da Entrada de Energia);

PS - Polyestyrene (Poliestireno);

PSD - Power Spectrum Density (Espectro de Densidade de Potência);

RMS - Root Mean Square (Média da Raiz Quadrada);

SDOF - Single Degree of Freedon (Um Grau de Liberdade);

SET - Departamento de Engenharia de Estruturas da EESC-USP;

UNASP - EC - Centro Universitário Adventista de São Paulo - Campus Engenheiro Coelho;

UNICAMP - Universidade Estadual de Campinas;

USP - Universidade de São Paulo;

VDM - Vibration Dose Value (Parâmetro de vibração). 


\section{LISTA DE SÍMBOLOS}

\section{Letras Minúsculas}

$a_{0}$ - amplitude da frequência fundamental;

$a_{i}$ - coeficientes que determinam a área de cada janela;

$a_{s, c a l, x}$ - área de aço calculada na direção x;

$a_{s, c a l, y}$ - área de aço calculada na direção y;

$a_{s, \min }$ - área de aço mínima;

$a(t)$ - aceleração em função do tempo $t$;

$b_{w}$ - largura da peça fletida;

c - coeficiente de amortecimento;

$c_{c}$ - coeficiente de amortecimento crítico;

$c_{\text {nom }}$ - cobrimento nominal da armadura;

$d$ - altura útil;

$d_{x}$ - altura útil na direção $\mathrm{x}$;

$d_{y}$ - altura útil na direção y;

$d t$ - variação do tempo;

$d \varepsilon$ - variação da deformação;

$d \sigma$ - variação da tensão;

$f$ - força;

$f_{c}$ - resistência do concreto à compressão;

$f_{c d}$ - resistência de cálculo do concreto à compressão;

$f_{c i}$ - resistência à compressão de um corpo de prova $i$ de concreto;

$f_{c k}$ - resistência característica do concreto à compressão;

$f_{c m}$ - resistência média do concreto à compressão;

$f_{D}$ - força de dissipação;

$f_{I}$ - força de inércia;

$f_{l}$ - frequência fundamental para a barra em modo longitudinal; 
$f_{n}$ - frequência natural;

$f_{S}$ - força de restauração;

$f_{t}$ - frequência fundamental para a barra em modo torcional;

$f_{y d}$ - resistência de cálculo de escoamento do aço;

$f_{p}$ - frequência da atividade desenvolvida;

$f(t)$ - função da força harmônica no tempo;

$g_{k}$ - valor característico da ação permanente adicional;

$\left[g_{c i}\right]^{T}$ - i-ésima linha da matriz de participação modal estocástica;

$h_{\text {laje }}$ - espessura da laje;

$h(t)$ - amplitude;

i - contador;

$j$ - contador ou número complexo $j=\sqrt{-1}$;

$k$ - coeficiente de rigidez linear de mola ou uma constante;

$k_{c}$ e $k_{s}$ - coeficientes para o cálculo de armadura de flexão;

$\ell_{x}-$ menor vão da laje;

m - massa ou um contador;

$m_{x d}$ - momento fletor de cálculo na direção x;

$m_{y d}$ - momento fletor de cálculo na direção y;

$m q_{\text {x ou y }}$ - momento fletor na direção x ou na direção y;

p - número de ciclos ou valor da carga uniformemente distribuída;

$p_{d}$ - valor de cálculo do carregamento para ELU;

$p p_{k}$ - valor característico do peso próprio;

$q_{k}$ - valor característico da ação variável;

$s$ - desvio padrão;

$t$ - tempo;

$v$ - velocidade;

$x$ - coordenada da direção do movimento vibratório;

$x_{0}$ - amplitude inicial;

$x_{p}$ - amplitude final; 
$\{x\}$ - vetor de deslocamento;

$\{\dot{x}\}$ - vetor de velocidade;

$\{\ddot{x}\}$ - vetor de aceleração;

$y_{k}$ - sinais discretos no tempo;

$w_{k}$ - janela de dados.

\section{Letras Maiúsculas}

$A_{s}$ - área de aço;

$[C]$ - matriz e amortecimento;

D - diâmetro do corpo de prova;

E - módulo de elasticidade;

$E_{c}$ - módulo de elasticidade estático do concreto;

$E_{c, d}$ - módulo de elasticidade dinâmico do concreto;

$E_{n}$ - representação da amplitude do n-ésimo harmônico;

$\{F\}$ - vetor de força;

$F_{p}$ - fator de pico da vibração considerada;

$F\left(\omega_{e x}\right)$ - força harmônica em função da frequência de excitação $\omega_{e x}$;

$G$ - módulo de elasticidade transversal dinâmico do concreto ou peso de uma pessoa;

$H_{i j}(\omega)$ - resposta da estrutura em FRF;

$K$ - fator de correção;

$[K]$ - matriz de rigidez;

$L$ - comprimento do corpo de prova;

$M$ - fator de magnificação dinâmica ou momento fletor em uma peça;

$[M]$ - matriz de inércia;

$N$ - número de graus de liberdade, unidade de força Newton ou número de valores discretos dos sinais;

$S_{y}$ - matriz das funções de densidade espectral de resposta;

$\hat{S}_{m}\left(\omega_{m}\right)$ - estimativa da matriz de funções de densidade espectral;

$T$ - tempo de duração total dos sinais; 
$T_{1}^{\prime}$ - fator de correção;

$T_{n}$ - período natural;

$T_{p}$ - período constante ou período do passo humano;

$X_{0}$ - deslocamento estático da estrutura;

$\{X\}$ - vetor de constantes;

$X\left(\omega_{e x}\right)$ - deslocamento em função da frequência de excitação $\omega_{e x}$;

$Y(\omega, T)$ - DFT de resposta discreta no tempo;

$\left[Z\left(\omega_{e x}\right)\right]$ - matriz de rigidez dinâmica.

\section{Letras Gregas Minúsculas}

$\alpha_{i}$ - coeficiente da série de Fourier do i-ésimo harmônico;

$\alpha\left(\omega_{e x}\right)$ - função da resposta em frequência de deslocamento denominada de receptância;

$\delta$ - variância ou valor do decremento logarítmico;

$\dot{\varepsilon}$ - taxa de variação da deformação no tempo;

$\emptyset$ - diâmetro da barra de aço;

$\phi_{i}$ - ângulo de diferença de fase;

$\phi_{\text {ref }}$ - diâmetro de referência para armadura longitudinal de tração;

$\gamma$ - massa específica;

$\lambda$ - valor complexo;

$\lambda_{i}$ - valores próprios do sistema;

$v$ ou $\mu$-coeficiente de Poisson;

$\left[v_{c i}\right]$ - i-ésima linha da matriz de resposta modal;

$\mu_{x}$ - coeficiente adimensional para cálculo de momento fletor na direção x;

$\mu_{y}$ - coeficiente adimensional para cálculo de momento fletor na direção y;

$\theta_{n}$ - representação da fase do $n$-ésimo harmônico;

$\rho$ - massa específica;

$\rho_{1}$ - taxa de armadura longitudinal;

$\rho_{\min }$ - taxa mínima de armadura;

$\dot{\sigma}$ - taxa de variação da tensão no tempo; 
$\omega$ - frequência natural circular;

$\omega_{d}$ - frequência natural amortecida;

$\omega_{e x}$ - frequência excitadora;

$\omega_{m}$ - frequência discreta arbitrária;

$\omega_{\text {min }}$ - taxa mecânica de armadura mínima;

$\omega_{n}$ - frequência circular do sistema;

[ $\omega]$ - matriz de frequências naturais;

$\zeta$ - fator de amortecimento ou razão de amortecimento.

\section{Letras Gregas Maiúsculas}

$\Delta f$ - inverso da duração total dos sinais;

$\Delta t$ - intervalo de tempo entre os valores discretos dos sinais;

[Ф] - matriz modal.

\section{Unidades de Medida}

dB - decibel;

cm - centímetro;

g - grama;

$\mathrm{G}$ - giga $\left(10^{9}\right)$;

$\mathrm{Hz}$ - Hertz;

$\mathrm{k}$ - quilo $\left(10^{3}\right)$;

K - Kelvin;

m - metro;

mm - milímetro;

$M$ - mega $\left(10^{6}\right)$;

$\mathrm{N}$ - Newton;

$\mathrm{Pa}$ - Pascal;

$\mathrm{S}$ - segundo;

W - Watt. 



\section{SUMÁRIO}

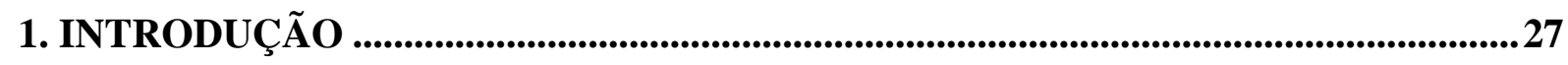

1.1 Justificativa ..............................................................................................................29

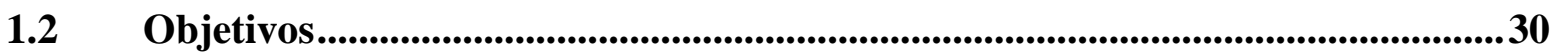

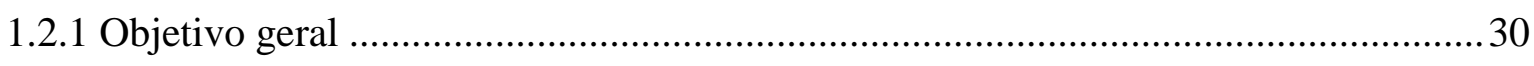

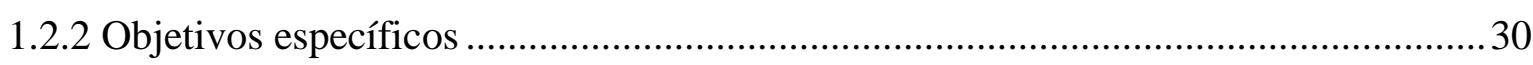

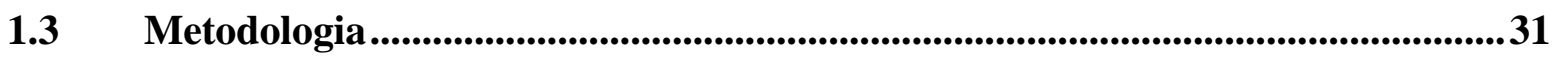

1.4 Conteúdo do trabalho..........................................................................................31

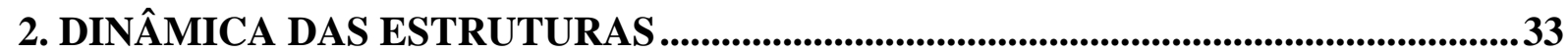

2.1 Sistemas de um grau de liberdade.....................................................................................35

2.1.1 Equação do movimento, frequência natural e fator de amortecimento ........................35

2.1.2 Ressonância e antirressonância..............................................................................39

2.2 Sistemas de múltiplos graus de liberdade............................................................................40

2.3 Análise modal ..................................................................................................................4

2.3.1 Análise modal clássica...........................................................................................48

2.3.2 Análise modal estocástica ..........................................................................................53

2.3.2.1 Funções de densidade espectral .....................................................................54

2.3.2.2 Estimativa das funções de densidade espectral da resposta .................................55

2.4 Técnicas da análise modal experimental ...........................................................................57

2.4.1 Fixação da estrutura .................................................................................................

2.4.2 Excitação da estrutura ...........................................................................................58

2.4.3 Aquisição de sinais ................................................................................................60

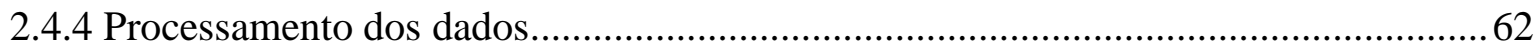

2.4.5 Identificação dos parâmetros modais..........................................................................68

2.4.6 Mensuração do amortecimento ................................................................................69

2.4.6.1 Decremento Logarítmico ................................................................................... 70

2.4.6.2 Largura de Banda ou Meia Potência....................................................................71

2.5 Caracterização dinâmica do concreto.............................................................................73

2.5.1 Comparação entre o módulo de elasticidade estático e o dinâmico ..............................77

2.5.2 Amortecimento de estruturas de concreto ………………………………………........ 82

2.6 Aceitabilidade dos níveis vibratórios em estruturas de concreto ..................................84 


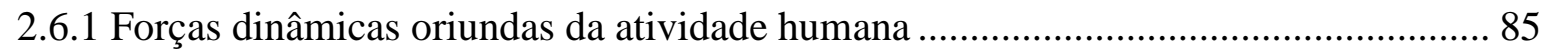

2.6.2 Limites e recomendações devidas ao desempenho estrutural .................................. 90

2.6.3 Limites e recomendações devidas à sensibilidade e ao conforto humano ................. 91

3. CONCRETO LEVE ESTRUTURAL COM PÉROLAS DE EPS............................... 97

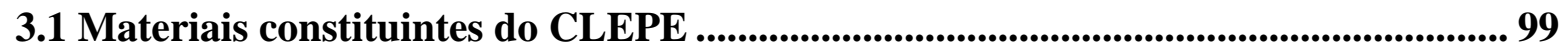

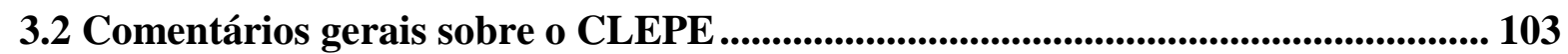

3.3 CLEPE, concreto com agregados leves e concreto celular ................................... 105

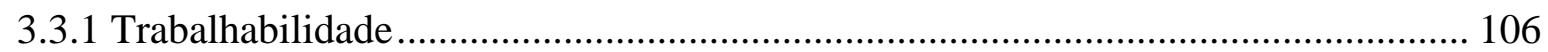

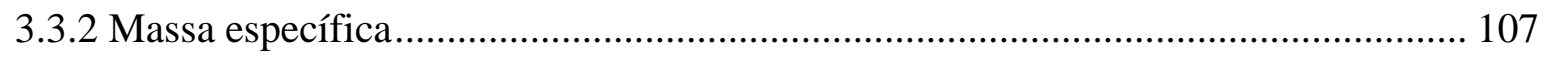

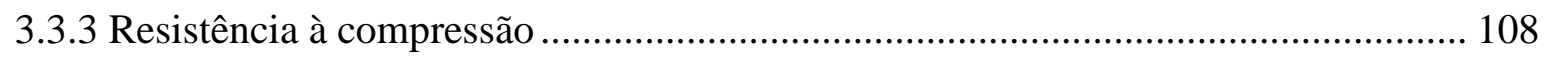

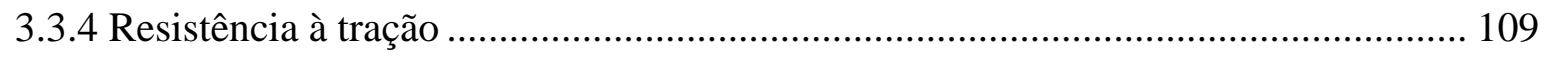

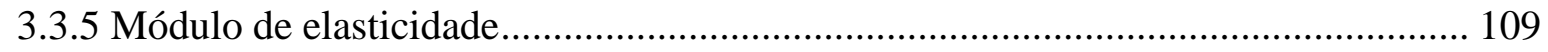

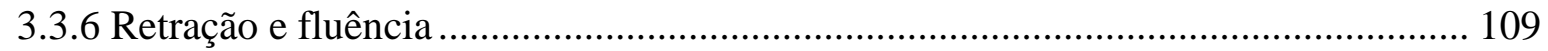

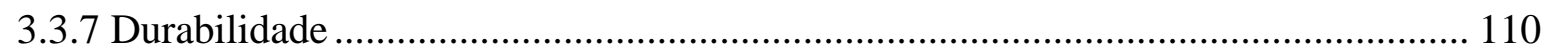

3.4 Aplicabilidade do CLEPE na construção civil ...................................................... 110

4. PROGRAMA EXPERIMENTAL - DESCRIÇÃO E PREPARATIVOS.................. 113

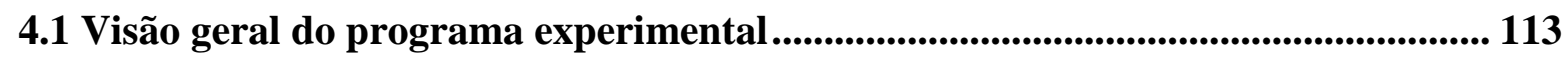

4.2 Modelos e configuração dos ensaios dinâmicos sobre alvenaria............................. 114

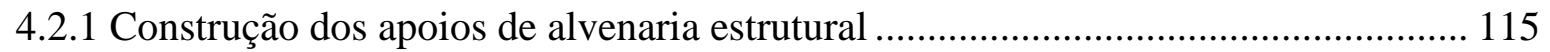

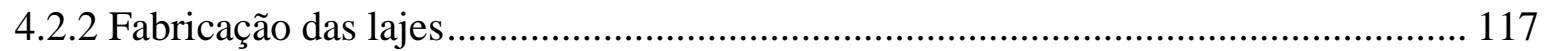

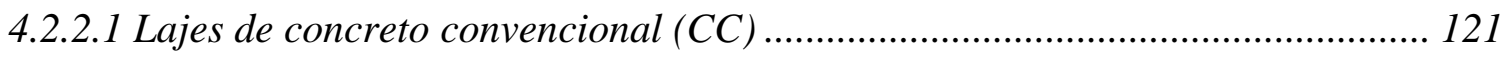

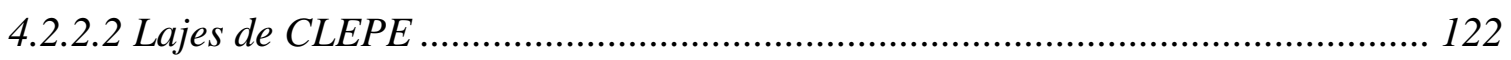

4.2.3 Configuração dos ensaios dinâmicos das lajes....................................................... 124

4.2.3.1 Configuração do $1^{\circ}$ ensaio dinâmico ................................................................... 127

4.2.3.2 Configuração do $2^{\circ}$ ensaio dinâmico ................................................................. 128

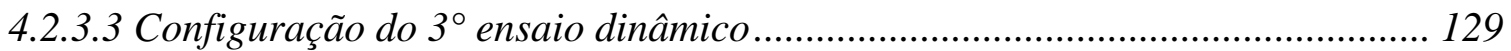

4.2.3.4 Configuração do $4^{\circ}$ ensaio dinâmico .................................................................. 130

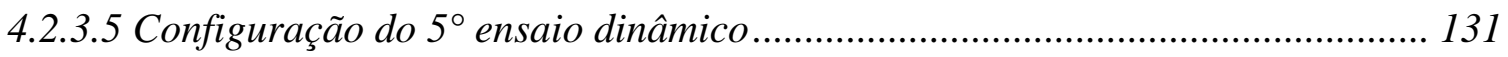

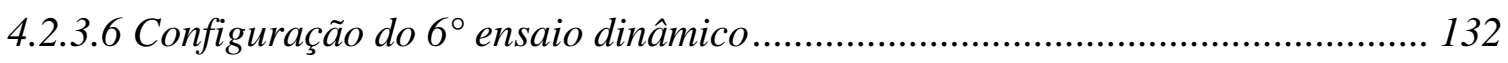

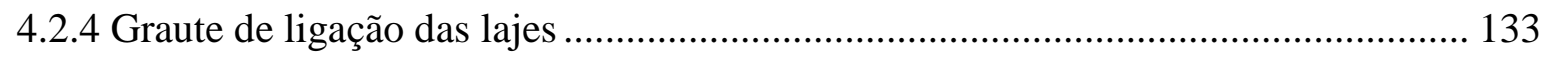


5. CARACTERIZAÇÃO DOS MATERIAIS DAS LAJES SOBRE ALVENARIA......135

5.1 Ensaios de caracterização dinâmica............................................................................135

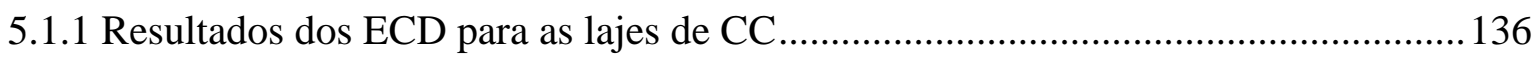

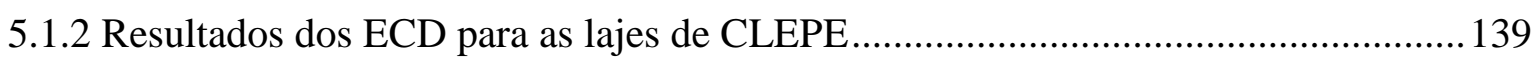

5.2 Ensaios de caracterização estática .....................................................................143

5.2.1 Resultados e análise dos ECE para as lajes de CC .................................................. 144

5.2.2 Resultados e análise dos ECE para as lajes de CLEPE ...........................................145

6. RESULTADOS DOS ENSAIOS DINÂMICOS SOBRE ALVENARIA.......................147

6.1 Resultados do ensaio dinâmico piloto com a laje 6 de CC ...................................147

6.2 Resultados dos ensaios dinâmicos das lajes de CC ................................................158

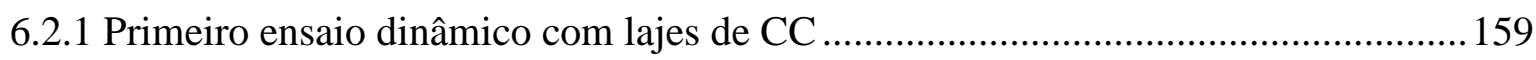

6.2.2 Segundo ensaio dinâmico com lajes de CC ............................................................... 160

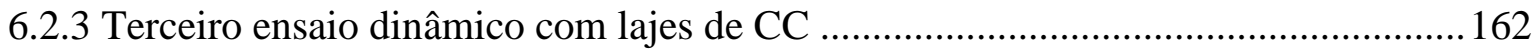

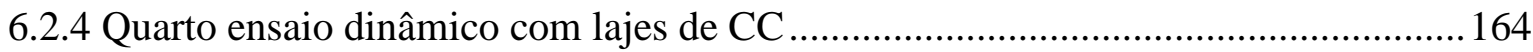

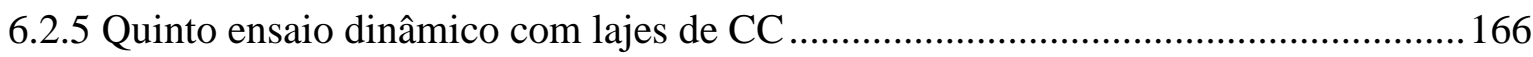

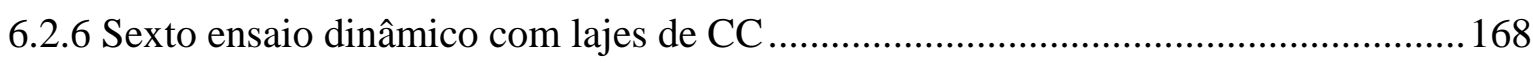

6.3 Resultados dos ensaios dinâmicos das lajes de CLEPE ..........................................170

6.3.1 Primeiro ensaio dinâmico com lajes de CLEPE ....................................................... 170

6.3.2 Segundo ensaio dinâmico com lajes de CLEPE ......................................................171

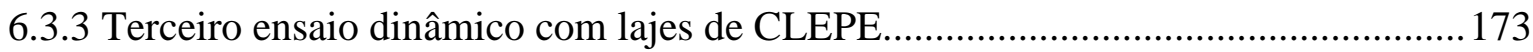

6.3.4 Quarto ensaio dinâmico com lajes de CLEPE ..........................................................174

6.3.5 Quinto ensaio dinâmico com lajes de CLEPE ......................................................... 176

6.3.6 Sexto ensaio dinâmico com lajes de CLEPE ............................................................ 178

6.4 Observações gerais dos ensaios dinâmicos .............................................................179

7. ENSAIOS DINÂMICOS EM LAJES SOBRE MOLAS...........................................181

7.1 Resultados do ensaio dinâmico da laje de C. .......................................................187

7.2 Resultados do ensaio dinâmico da laje de CLEPE ..................................................191

7.3 Caracterização dinâmica e estática dos concretos das lajes sobre molas ................195

7.4 Comentários sobre os ensaios dinâmicos das lajes sobre molas .................................196 
8. ANÁLISE PARAMÉTRICA EM LAJES DE CC E DE CLEPE.............................. 199

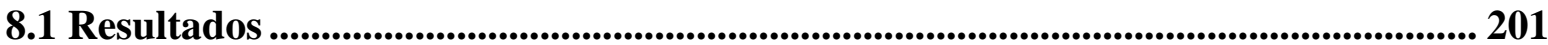

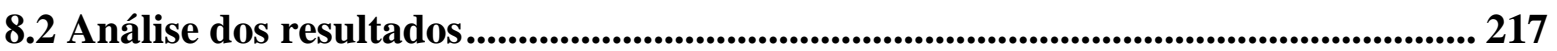

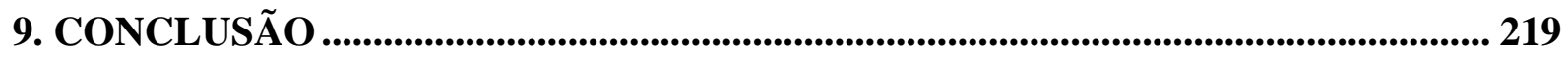

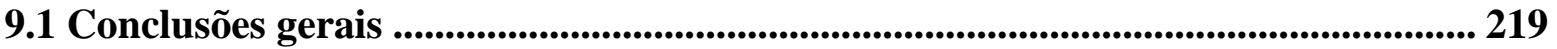

9.2 Conclusões sobre as características dos materiais .............................................. 220

9.3 Conclusões sobre o estudo paramétrico entre lajes de CC e de CLEPE................ 222

9.4 Sugestões para trabalhos futuros........................................................................ 223

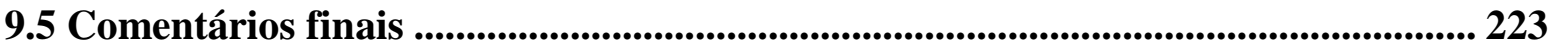

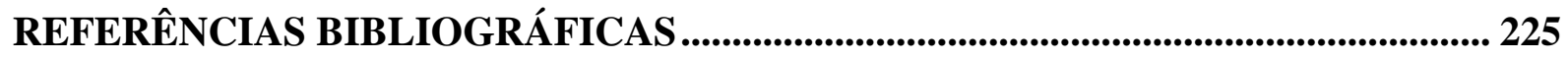

APÊNDICE A - DIMENSIONAMENTO DA ARMADURA DAS LAJES .................... 235

A.1 Lajes de concreto com densidade normal ........................................................... 235

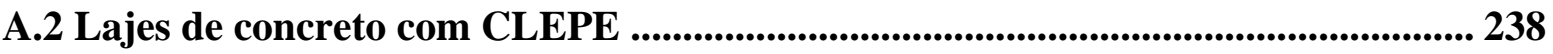

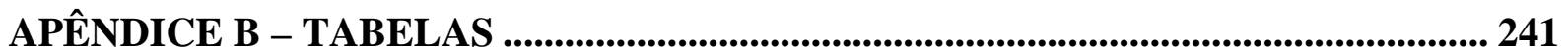




\section{Introdução}

A demanda por moradias tem motivado e impulsionado o surgimento de novos materiais de construção, com características ainda pouco conhecidas. Nesse contexto, o concreto leve estrutural com pérolas de EPS (poliestireno expandido), apesar de não ser inédito, ressurge como uma alternativa para a execução de lajes em obras de interesse social e em outras edificações, inclusive de outros sistemas construtivos, como, por exemplo, paredes portantes.

De fato, o concreto leve estrutural com pérolas de EPS (peso específico da ordem de $12 \mathrm{kN} / \mathrm{m}^{3}$ ) mostra-se vantajoso por reduzir significativamente o peso próprio das peças em que ele é empregado. Essa redução, da ordem de 50\%, é explicada pela baixa densidade do EPS e pelo fato de não absorver água.

Por outro lado, percebe-se que existe uma tendência de fornecer maiores níveis de conforto e segurança aos usuários das edificações, garantindo implicitamente um adequado desempenho estrutural. Essas exigências estão sendo asseguradas aos usuários através da aplicação de normas, regulamentos e leis cada vez mais rígidas e restritas, que responsabilizam o projetista, o fabricante do material e o executor da obra, com detalhes aos quais não era dada maior atenção, há alguns anos. Um exemplo claro é a aplicação da ABNT NBR 15575-2:2013, que trata do desempenho exigido dos sistemas estruturais.

Uma dessas exigências é o comportamento dinâmico das estruturas. Estudos e pesquisas recentes têm demonstrado que prejuízos à saúde humana têm sido gerados pela exposição (por tempo considerável) a vibrações excessivas ou pela utilização de estruturas que não respeitam limites máximos para as vibrações. Também as vibrações excessivas têm sido responsáveis por grandes casos de manifestações patológicas estruturais.

A análise dinâmica desenvolvida nesta pesquisa busca a determinação de três itens imprescindíveis em qualquer análise desse tipo, que são as frequências naturais, os modos de vibração (deformadas modais) e o amortecimento estrutural, valor determinado experimentalmente e que constitui dado de entrada em simulações numéricas. Esses parâmetros são de extrema importância quando é desenvolvido um projeto estrutural. 
Em geral, as normas e os regulamentos definem um limite mínimo para a frequência natural da estrutura. A ideia inerente nesse conceito é afastar o máximo possível a frequência de excitação da frequência natural, evitando a ressonância.

As deformadas modais, além de indicarem a forma de movimentação da estrutura em uma determinada frequência natural, auxiliam na determinação dos pontos em que devem ser medidas as respostas da estrutura.

Em casos nos quais os efeitos dinâmicos sobre a estrutura são excessivos, a elevação do fator de amortecimento é uma das possíveis soluções. Portanto, a determinação do amortecimento da estrutura é importante na análise dinâmica.

Essa análise é denominada análise modal, que é um processo para determinação das características dinâmicas inerentes de um sistema, em forma de frequências naturais, fatores de amortecimento e modos de vibração, aplicando-os para formular um modelo matemático para o seu comportamento dinâmico. Esse modelo matemático é referido como o modelo modal do sistema, e suas características são conhecidas como os seus dados modais (HE e FU, 2001).

Tanto a análise teórica (modelo em elementos finitos) quanto a análise experimental fazem parte da análise modal. A vantagem da utilização do modelo teórico e do experimental é a retroalimentação. Em outras palavras, o modelo teórico fornece dados iniciais para o planejamento do modelo experimental, que por sua vez alimenta o modelo teórico com dados mais realistas, calibrando esse modelo teórico e possibilitando futuras análises com maior domínio dos parâmetros envolvidos.

Para que a análise dinâmica seja realizada com sucesso, o material precisa ter as características físicas (principalmente o módulo de elasticidade) avaliadas de forma dinâmica. Sendo assim, a determinação do módulo de elasticidade dinâmico do concreto, nesta pesquisa, é feita através do Sonelastic ${ }^{\circledR}$, que é um equipamento acoplado a um software que, ao captar o som emitido pelo material, devido a um pequeno impacto, realiza uma transformada rápida de Fourier (FFT) e mede a resposta do corpo de prova. Com essa resposta é possível a determinação das frequências naturais e do fator de amortecimento do material. Com a frequência natural, é possível obter o denominado módulo de elasticidade dinâmico, imprescindível para esse tipo de análise. Destaca-se que esse ensaio é não destrutivo, podendo ser realizado inúmeras vezes. Maiores detalhes são apresentados no Capítulo 4 deste trabalho.

Popularmente, o termo “concreto” refere-se a algo sólido e que possui peso considerável. A associação do termo "leve" ao concreto pode causar certa perplexidade ao público leigo, que não esperaria tal característica em um concreto. Entretanto, a necessidade 
de atender a especificações precisas, como a redução do peso próprio das estruturas, levou a ciência do concreto a desenvolver soluções especiais, entre elas o concreto leve.

A origem da aplicação dos concretos leves remonta a 1850 anos, no Panteão romano, reconstruído, após um incêndio, pelo imperador Adriano, com a utilização de agregado graúdo de cinza vulcânica muito porosa e leve (AÏTCIN, 2000).

Nesse contexto, com a aplicação de um material relativamente novo e pouco estudado, como o concreto leve estrutural com pérolas de EPS (CLEPE), torna-se imperativo o estudo das propriedades físicas, reológicas e dinâmicas do material. As propriedades físicas e reológicas do CLEPE foram estudadas na pesquisa de Catoia (2012) e são brevemente abordadas nesta pesquisa. Porém, não existe um trabalho sobre as propriedades dinâmicas do CLEPE, inclusive quando empregado em lajes maciças.

A ausência de pesquisas sobre o comportamento dinâmico do CLEPE em lajes motiva o desenvolvimento deste trabalho, pois se compreende que tal material tem grandes possibilidades de aplicação, reduzindo o custo global da edificação e contribuindo como uma alternativa à sustentabilidade na construção civil.

\subsection{Justificativa}

Observando-se as ações em uma edificação, e destacando-se entre elas o peso próprio da estrutura, nota-se que este representa boa parte do total de esforços que a estrutura deve resistir. Fracionando-se em três grupos principais os elementos da superestrutura de um edifício, têm-se os pilares, as vigas e as lajes.

Os pilares são elementos que, em geral, contribuem pouco para o peso total da estrutura e resistem cargas da ordem de cem vezes maiores que seu peso próprio. Situação semelhante acontece com as vigas, que resistem cargas dezenas de vezes maiores que seu peso. Porém, isso não acontece nas lajes.

Estas, em grande parte dos casos, possuem baixos níveis de tensão em serviço, mas, por possuírem pouca rigidez (devido à inércia reduzida), muitas vezes necessitam ter sua espessura aumentada, o que acarreta uma grande elevação do seu peso próprio. Assim sendo, a maior parte do peso próprio da estrutura de um edifício é dada pelas lajes, que possuem, via de regra, as menores tensões.

Fica justificada então a busca pela redução do peso próprio das lajes, o que pode ser conseguido com o uso de concretos de reduzido peso específico. O CLEPE, portanto, é uma 
possibilidade e uma alternativa, já que pode apresentar um peso específico da ordem de $12 \mathrm{kN} / \mathrm{m}^{3}$, metade do relativo ao concreto convencional (CC), que em média é de $24 \mathrm{kN} / \mathrm{m}^{3}$.

Porém, a redução de massa da estrutura e a diferença no módulo de elasticidade do material alteram suas propriedades dinâmicas e, como já foi comentado, o excesso de vibrações em uma estrutura pode não apenas gerar danos a ela, mas também incômodos aos usuários.

Não existindo pesquisas sobre o comportamento dinâmico do CLEPE, fica justificada a importância desta pesquisa para a correta compreensão do comportamento dinâmico de lajes com CLEPE e para o aperfeiçoamento da utilização do material na construção civil.

\subsection{Objetivos}

Apresentam-se aqui os objetivos do trabalho, tanto o geral quanto os específicos.

\subsubsection{Objetivo geral}

O objetivo geral consiste em avaliar o comportamento dinâmico de lajes maciças feitas com CLEPE, fazendo-se uma comparação com o comportamento dinâmico de lajes com as mesmas características, porém feitas com concreto convencional (CC).

\subsubsection{Objetivos específicos}

Destacam-se os seguintes objetivos específicos:

- Caracterizar experimentalmente as propriedades de módulo de elasticidade, massa específica e amortecimento do CLEPE e compará-las com as do CC;

- Avaliar experimentalmente o comportamento dinâmico de lajes produzidas com CLEPE, comparando-o ao de lajes semelhantes de CC;

- Realizar um estudo paramétrico e comparativo do comportamento dinâmico de lajes de CLEPE e de concreto convencional. 


\subsection{Metodologia}

O estudo desenvolvido nesta tese compreende as etapas de revisão bibliográfica, análise experimental e análise paramétrica.

A revisão bibliográfica engloba conceitos sobre dinâmica das estruturas, ensaios dinâmicos de caracterização do material concreto, aceitabilidade de vibrações em estruturas e conceitos relacionados ao CLEPE.

A parte experimental da tese engloba dois grupos de ensaios dinâmicos. No primeiro grupo foram analisadas lajes apoiadas sobre alvenarias. Em detrimento das condições de contorno complexas com a alvenaria de apoio, o programa experimental prosseguiu com um segundo grupo de ensaios dinâmicos, com lajes apoiadas sobre molas.

Para a execução da parte experimental, previamente foram realizadas análises numéricas para a definição dos pontos de leitura e de excitação durante os ensaios dinâmicos. Os resultados foram processados em rotinas que contemplam a análise modal estocástica. Com os resultados processados, obtiveram-se as frequências naturais e as deformadas modais. Utilizando-se um filtro passa-banda, o sinal de uma determinada frequência natural foi obtido, e assim, estimou-se o amortecimento modal pelo método do decremento logarítmico.

Com os resultados dos ensaios dinâmicos de caracterização e os ensaios dinâmicos nas lajes, foi desenvolvida uma análise paramétrica em lajes de concreto convencional e de CLEPE. Para tanto, foram elaborados no software SAP $2000^{\circledR}$, modelos de lajes com diferentes alturas e vãos, aplicando-se a ação dinâmica de caminhar de uma pessoa de $80 \mathrm{~kg}$. Os resultados foram avaliados com base em critérios de aceitabilidade das estruturas frente ao conforto humano.

Finalmente, são apresentadas comparações e conclusões relativas às diferentes análises realizadas.

\subsection{Conteúdo do trabalho}

São dois os capítulos destinados à revisão bibliográfica:

- O Capítulo 2 apresenta os conceitos relativos à dinâmica das estruturas. Nele, também, são discutidos os ensaios de caracterização dinâmica dos materiais e os critérios de aceitabilidade das vibrações em estruturas;

- No Capítulo 3 é descrito com mais detalhes o CLEPE e sua relação com outros concretos leves. 
O programa experimental está dividido em quatro capítulos:

- No Capítulo 4 apresenta-se um panorama geral do programa experimental, incluindo os preparativos para os ensaios sobre alvenaria;

- O Capítulo 5 descreve a metodologia dos ensaios de caracterização dos materiais, indicando também os resultados dessa caracterização;

- Os ensaios dinâmicos das lajes sobre alvenaria têm seus resultados e discussões apresentados no Capítulo 6;

- No Capítulo 7 encontram-se os ensaios dinâmicos de duas placas apoiadas sobre molas; como nas lajes anteriores, nestas também foi usado o software SAP $2000^{\circledR}$.

Com a finalidade de observar o comportamento das lajes de CLEPE em relação às de CC no quesito dinâmico, foi realizada, no Capítulo 8, uma análise paramétrica frente à ação de caminhada de uma pessoa. Para essa análise também foi utilizado o SAP $2000^{\circledR}$.

O Capítulo 9 traz as principais conclusões da tese, indicando valores recomendados para uso na avaliação dinâmica de estruturas com CLEPE, em situações de projeto. 


\section{Dinâmica das Estruturas}

Neste capítulo serão apresentados os conceitos básicos de análise dinâmica, caracterização dinâmica do concreto e aceitabilidade dos níveis vibratórios em estruturas.

O estudo dinâmico em estruturas civis tem ganhado terreno no mercado brasileiro, sendo que em alguns países essa já é uma prática corrente. Nóbrega (2004) e Almeida (2010) destacam a necessidade desse estudo, tendo em vista: necessidade de economia dos recursos energéticos; tendência arquitetônica de estruturas mais leves e esbeltas; desenvolvimento de materiais mais resistentes; adoção de técnicas construtivas mais rápidas, como a utilização de elementos pré-moldados; alto grau de degradação e sérias patologias devidas a excessos vibratórios em edificações já existentes; mudança, forma e intensidade de algumas ações; possibilidade da utilização de técnicas computacionais que refinem e agilizem a análise.

Faisca (2003) aborda o assunto da análise dinâmica de estruturas como importante quesito de aceitabilidade da construção, devida a excessos vibratórios que podem gerar desconforto e até mesmo doenças aos usuários. Bachmann et al. (1997) comentam que o corpo humano pode sentir deslocamentos vibratórios da ordem de 0,001 mm, sendo que as pontas dos dedos são 20 vezes mais sensíveis. Alguns efeitos deletérios às pessoas, pontuados pelos citados autores, são: insegurança, tonturas e náuseas.

A dinâmica das estruturas tem como grande objetivo a mensuração de deslocamentos, velocidades e acelerações nos elementos constituintes da estrutura que é submetida a ações dinâmicas que provocam vibrações, conforme Lima e Santos (2008). De acordo com Almeida (2005) e Diógenes (2010), vibração é o movimento oscilatório de uma estrutura ou objeto em torno de um ponto fixo, que é sua deformada estática.

As ações dinâmicas geram quatro tipos de vibração, segundo Clough e Penzien (1995). No primeiro grupo estão as ações harmônicas, que geralmente seguem uma função seno ou cosseno. As ações periódicas formam o segundo grupo e caracterizam-se por apresentar repetições em intervalos periódicos de tempo (período). O terceiro grupo são as ações transientes, que geralmente têm sua resposta estimada estatisticamente, como os tremores de terra. No quarto e último grupo têm-se as ações impulsivas, que também são transientes, porém com um tempo de duração muito curto. 
Harris (2002) afirma ainda que a vibração pode ser descrita como determinística ou aleatória. A determinística segue um modelo estabelecido, de modo que o valor da vibração em qualquer momento futuro é totalmente previsível, a partir da história do passado (vibração harmônica e periódica). Já a vibração é aleatória quando o seu valor futuro é imprevisível, exceto com base na probabilidade (vibração transiente e impulsiva).

Conforme Almeida (2005) e Balachandran e Magrab (2011), os sistemas vibratórios podem ser classificados em:

- Discretos, quando apresentam um número finito de graus de liberdade ${ }^{1}$. Exemplo: massas discretas e corpos rígidos;

- Contínuos, quando não é possível determinar um número finito de graus de liberdade. Exemplo: vigas, pilares e placas;

- De vibração livre, quando não existe força dinâmica aplicada no sistema;

- De vibração forçada, quando a vibração é impelida por forças externas;

- Conservativos, quando não apresentam elementos dissipadores de energia (amortecedores). É também denominada vibração não amortecida;

- Não conservativos, quando apresentam elementos dissipadores de energia. Também é denominada vibração amortecida;

- Lineares, quando as relações características entre forças e velocidade (amortecedor) e forças e deslocamentos (molas) podem ser expressas de forma linear, e os efeitos podem ser sobrepostos;

- Não lineares, quando as relações características entre forças e velocidade (amortecedor) e forças e deslocamentos (molas) são expressas de forma não linear, e os efeitos não podem ser sobrepostos.

Entre as aplicações e as vantagens do uso da análise dinâmica podem ser citados os seguintes pontos:

- A análise dinâmica de estruturas é um meio eficaz de identificar, quantificar e localizar danos na estrutura. Desenvolvimento de danos locais ou globais (fissuras e vazios no concreto) gera perda de rigidez ou de massa, modificando as frequências naturais e os modos de vibração da estrutura [ALMEIDA (2010)];

\footnotetext{
${ }^{1}$ Rao (2011), p.14, define graus de liberdade como "o número mínimo de coordenadas independentes necessário para determinar completamente as posições de todas as partes de um sistema, em qualquer instante de tempo”.
} 
- Com os conceitos da dinâmica foram desenvolvidos ensaios e técnicas para a investigação das propriedades do concreto, como é observado em Malhotra (1986). Esses ensaios são não destrutivos, tendo como principal característica a possibilidade de serem executados em estruturas reais, permitindo uma futura conferência de resultados na mesma amostra (reprodutividade do ensaio);

- A análise modal, a determinação das frequências naturais, a determinação de velocidades e de acelerações vibratórias e o monitoramento de estruturas são ainda outras vantagens da análise dinâmica experimental e numérica, conforme Inman (2001).

\subsection{Sistemas de um grau de liberdade}

Os sistemas que podem ter o movimento vibratório descrito por apenas uma coordenada independente são chamados de sistemas de um grau de liberdade (single degree of freedom - SDOF). Apesar de terem uma aplicação limitada para estruturas civis, sua abordagem é justificada neste trabalho por apresentar conceitos importantes utilizados nos sistemas de múltiplos graus de liberdade (multi degree of freedom - MDOF) e na análise modal.

\subsubsection{Equação do movimento, frequência natural e fator de amortecimento}

As equações de movimento de um sistema vibratório são diferenciais e baseadas nas Leis de Newton. Balachandran e Magrab (2011) apresentam dois métodos para a determinação da equação governante do movimento. O primeiro consiste no equilíbrio de forças, e o segundo, na utilização das equações de Lagrange. A determinação da equação do movimento pelo método da somatória de forças é ilustrada em seguida, com base no sistema vibratório SDOF mostrado na Figura 2.1.
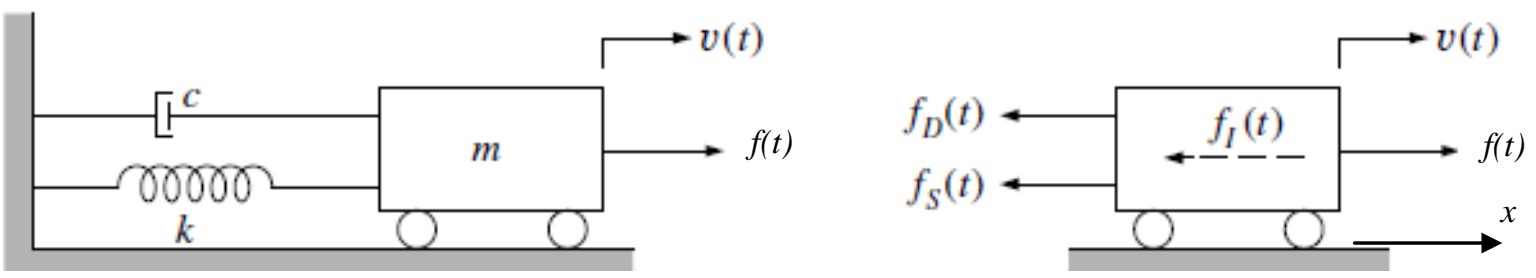

Figura 2.1 - Esquema de um sistema SDOF.

Fonte: Clough e Penzien (1995), p. 15. 
Sendo:

$x$ a coordenada independente na direção em que ocorre o movimento; o deslocamento que a massa $m$ efetua no eixo $x$ é denominado de amplitude de deslocamento;

$m$ a massa do sistema vibratório;

$v(t)$ a velocidade com a qual a massa $m$ se desloca;

c o valor do coeficiente de amortecimento viscoso ${ }^{2}$ linear;

$k$ a constante de rigidez da mola linear;

$f(t)$ a força solicitante externa em função do tempo $t$;

$f_{D}(t)$ a força de dissipação (força do amortecedor) em função do tempo $t$;

$f_{S}(t)$ a força de restauração (força da mola) em função do tempo $t$;

$f_{I}(t)$ a força de inércia (força da massa) em função do tempo $t^{3}$.

As forças individuais da mola, do amortecedor e da massa são expressas pelas Equações 2.1 a 2.3, respectivamente.

$$
\begin{aligned}
& f_{S}(t)=k \cdot x \\
& f_{D}(t)=c \cdot v(t)=c \cdot \frac{d x}{d t}=c \cdot \dot{x} \\
& f_{I}(t)=m \cdot a(t)=m \cdot \frac{d^{2} x}{d t^{2}}=m \cdot \ddot{x}
\end{aligned}
$$

Sendo:

$a(t)$ a aceleração em função do tempo $t$.

Fazendo a somatória das forças expressas no diagrama de corpo livre da Figura 2.2, tem-se a equação do movimento para um sistema SDOF (Equação 2.4).

$$
m . \ddot{x}+c . \dot{x}+k \cdot x=f(t)
$$

A Equação 2.4 é denominada equação do movimento para um sistema SDOF em vibração forçada. Fazendo-se a parcela $f(t)=0$, obtém-se a Equação 2.5, que é a equação do movimento para um sistema SDOF em vibração livre.

$$
m . \ddot{X}+c . \dot{X}+k . x=0
$$

${ }^{2}$ Existem três formas básicas de amortecimento: amortecimento viscoso (nesta situação existe um coeficiente de proporcionalidade entre a força e a velocidade ou coeficiente de amortecimento); amortecimento de Coulomb ou atrito seco, no qual a energia é dissipada pelo atrito entre superfícies secas; amortecimento estrutural, sólido ou histerético, que decorre do fato de que, quando os materiais são submetidos a tensões cíclicas, a relação tensão-deformação segue caminhos diferentes para carga e descarga. A área contida no ciclo de histerese é numericamente igual à energia dissipada [DIÓGENES (2010)]. O amortecimento viscoso é o mais comum [BALACHANDRAN E MAGRAB (2011)]. Ainda Franceschini e Gomes (2010) correlacionam também o amortecimento elétrico causado pelo corte ou cruzamento de campos magnéticos.

${ }^{3}$ O princípio d'Alembert afirma que o equilíbrio dinâmico de um sistema pode ser obtido pela adição de uma força fictícia, chamada força inercial, que é proporcional à aceleração, com constante igual à massa do sistema e sentido contrário ao do movimento [CLOUGH E PENZIEN (1995)]. 
Quando o amortecimento é desprezível ou teoricamente inexistente, a Equação 2.6 expressa a equação do movimento para um sistema SDOF em vibração livre não amortecida.

$$
m \cdot \ddot{x}+k \cdot x=0
$$

As Equações 2.4 a 2.6 são diferenciais ordinárias e sua solução é aqui discutida brevemente. Para a solução de equações diferenciais ordinárias pode ser utilizado o método das Transformadas de Laplace.

Para condições inicias, $x(0)=X_{0}$ e $\dot{x}(0)=V_{0}$, segundo Lima e Santos (2008), a solução da Equação 2.6 é dada por (Equação 2.7):

$$
x(t)=X_{0} \cdot \cos \left(\omega_{n} \cdot t\right)+\frac{V_{0}}{\omega_{n}} \cdot \operatorname{sen}\left(\omega_{n} \cdot t\right)
$$

Sendo:

$\omega_{n}$ a frequência circular do sistema dada pela Equação 2.8, em rad/s.

$$
\omega_{n}=2 \cdot \pi \cdot f_{n}=\sqrt{\frac{k}{m}}
$$

Sendo:

$f_{n}$ a frequência natural do sistema dada pela Equação 2.9, em Hz.

$$
f_{n}=\frac{\omega_{n}}{2 . \pi}=\frac{1}{2 . \pi} \cdot \sqrt{\frac{k}{m}}=\frac{1}{T_{n}}
$$

Sendo:

$T_{n}$ o período natural, expresso em segundos, e equivale ao tempo necessário para que o sistema complete um ciclo quando solicitado à frequência natural.

Retomando a Equação 2.5, para a qual existe o amortecimento do sistema, um conceito importante é o do fator de amortecimento ou razão de amortecimento $\zeta$, dado pela Equação 2.10.

$$
\zeta=\frac{c}{2 \cdot m \cdot \omega_{n}}=\frac{c}{2 \sqrt{k \cdot m}}=\frac{c \cdot \omega_{n}}{2 \cdot k}
$$

O fator de amortecimento é uma quantidade adimensional. O coeficiente de amortecimento $c$ pode ser comparado com um coeficiente de amortecimento crítico $c_{c}$ (Equação 2.11). O coeficiente de amortecimento crítico possui o significado de que, quando o amortecedor possui como constante $c=c_{c}$, a estabilização do sistema vibratório será a mais rápida possível e não haverá oscilação em torno do ponto de equilíbrio estático.

$$
c_{c}=2 \cdot m \cdot \omega_{n}=2 \sqrt{k \cdot m}
$$


Quando $c=c_{c}$, então $\zeta=1$ e o sistema é dito criticamente amortecido. Se $c>c_{c}$, então $\zeta>1$ e o sistema é denominado superamortecido. Mesmo o amortecimento do sistema superamortecido sendo maior que o crítico, a estabilização do sistema ocorre em um tempo maior que o do sistema criticamente amortecido, mas também não há oscilação em torno do ponto de equilíbrio estático. Se $c<c_{c}$, então $0<\zeta<1$ e o sistema é denominado subamortecido, apresentando oscilações em torno do ponto de equilíbrio estático. A Figura 2.2 ilustra a resposta dos três tipos de sistemas amortecidos.

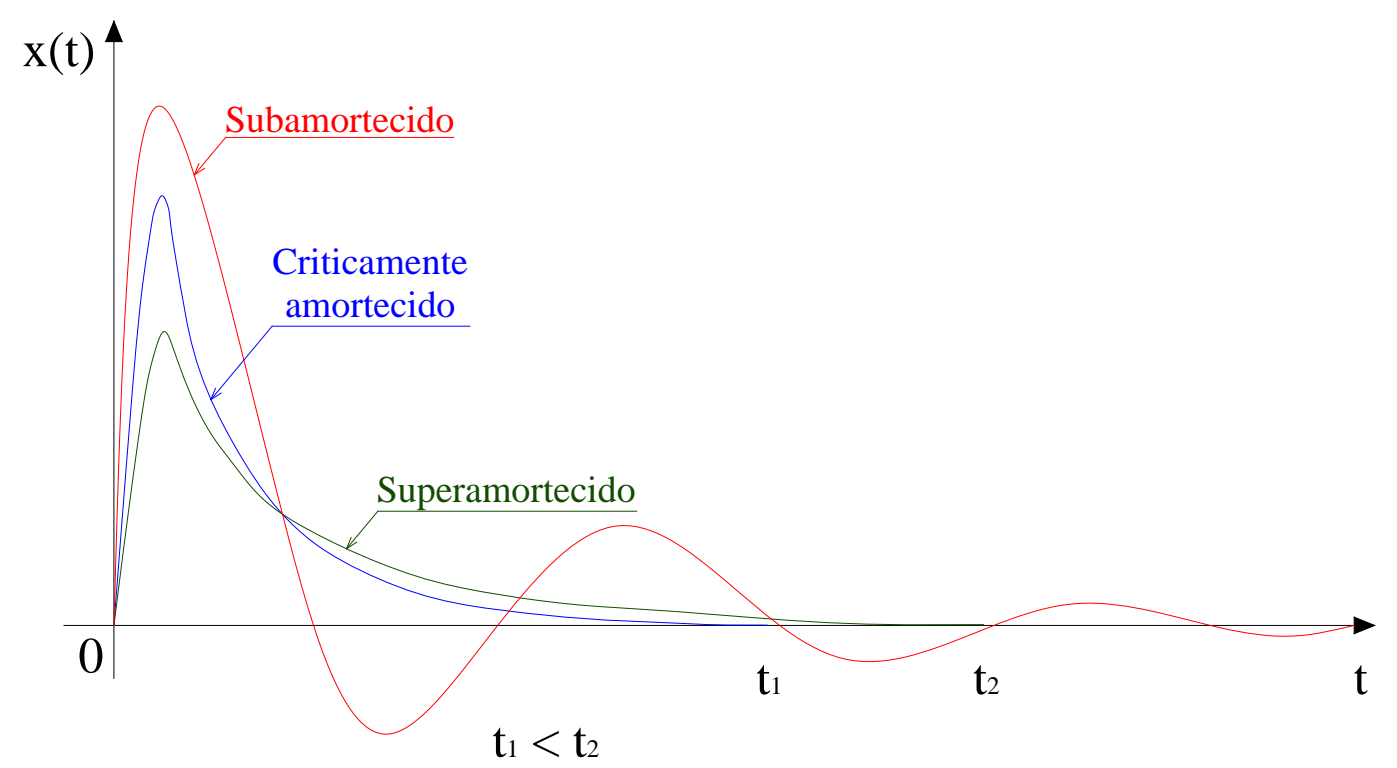

Figura 2.2 - Resposta de um sistema SDOF com diferentes características de amortecimento. Fonte: Adaptado de Tipler (2000).

Observa-se que a maior parte das estruturas civis são sistemas subamortecidos. A resposta em deslocamentos é dada pela Equação 2.12.

$$
x(t)=X_{0} \cdot e^{-\zeta \cdot \omega_{n} t} \cdot \cos \left(\omega_{d} \cdot t\right)+\frac{V_{0}+\zeta \cdot \omega_{n} \cdot X_{0}}{\omega_{d}} \cdot e^{-\zeta \cdot \omega_{n} t} \cdot \operatorname{sen}\left(\omega_{d} \cdot t\right)
$$

Sendo:

$\omega_{d}$ a frequência natural amortecida expressa pela Equação 2.13.

$$
\omega_{d}=\omega_{n} \cdot \sqrt{1-\zeta^{2}}
$$

Não são indicadas neste trabalho as soluções para sistemas criticamente amortecidos e superamortecidos, bem como para a Equação 2.4, com forças harmônicas ou periódicas, que podem ser encontradas nos trabalhos de Clough e Penzien (1995), Inman (2001), Meirovitch (2001) e Chopra (2007), entre outros. 


\subsubsection{Ressonância e antirressonância}

O fenômeno da ressonância é observado quando a frequência da força excitadora aproxima-se da frequência natural da estrutura. A consequência desse fenômeno é um grande aumento na amplitude do movimento mesmo que a excitação imposta seja mínima. A Figura 2.3 ilustra a amplificação do movimento (relativo ao deslocamento estático) em função da razão frequência excitadora pela frequência natural. Observa-se que o fator de amortecimento possui grande influência na amplitude da resposta.

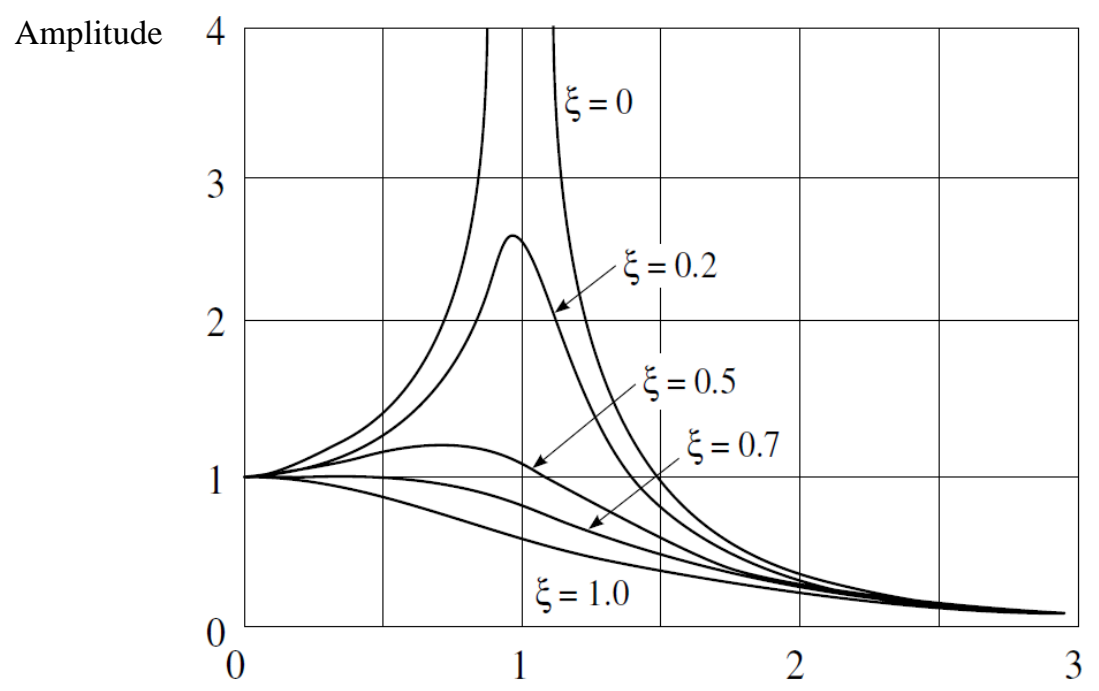

Frequência de excitação/ Frequência natural

Figura 2.3 - Variação da amplitude dinâmica em função da frequência de excitação e do fator de amortecimento.

Fonte: Clough e Penzien (1995), p. 38.

No caso de estruturas civis, quando ocorre a ressonância, pequenas forças externas provocam deslocamentos significativos, tornando o movimento perceptível e desconfortável aos usuários. Como exemplo, pode citar-se a ponte norte-americana de Tacoma, que entrou em ressonância devido à ação do vento ter uma frequência próxima à frequência natural da estrutura e também por sofrer autoexcitação. Uma maneira simples de prevenir a amplificação excessiva é projetar a estrutura de forma que a frequência natural seja a mais alta possível, distanciando-se das frequências excitadoras. Quanto maior o amortecimento ou mais alta a frequência natural da estrutura, menor a possibilidade de ocorrer a ressonância.

As medidas possíveis para a redução dos efeitos vibratórios são descritas, entre outros autores, por Bachmann et al (1997), Ebrahimpour e Sack (2005), Diógenes et al (2009a) e Diógenes et al (2009b). 


\subsection{Sistemas de múltiplos graus de liberdade}

Um sistema de múltiplos graus de liberdade (MDOF) tem o número de graus determinado pela quantidade de elementos inerciais e vinculações presentes. Quando o sistema é contínuo (viga, pilar, placa etc.), o número de graus de liberdade é infinito. Porém este grau infinito pode ser reduzido sendo definido pelo número de nós discretizados no modelo. Quanto mais nós são inseridos, maior a precisão na resposta. Por esse motivo, a utilização computacional, particularmente valendo-se do Método dos Elementos Finitos (MEF), é muito viável e aconselhável para a análise teórica de sistemas MDOF.

A análise do sistema MDOF pode ser encarada com uma combinação de vários sistemas SDOF. Assim, o sistema MDOF apresenta um conjunto de massas, amortecimentos e rigidezes, as quais se relacionam com acelerações, velocidades e deslocamentos, respectivamente. A Figura 2.4 ilustra um sistema MDOF.

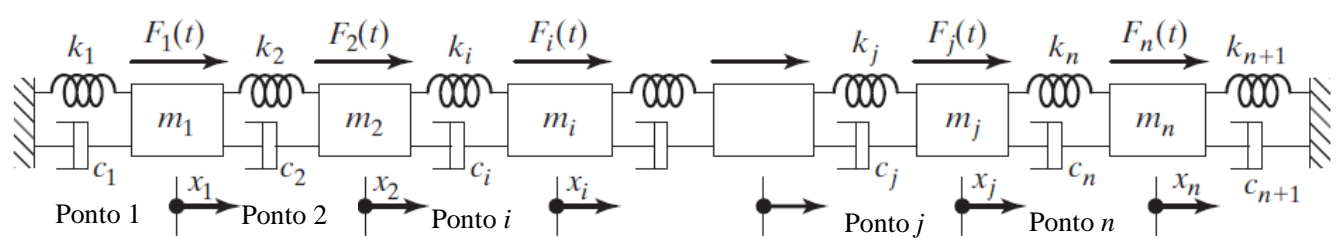

(a)

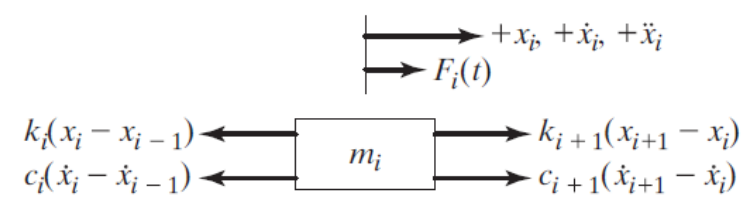

(b)

Figura 2.4 - (a) Representação de um sistema MDOF; (b) Diagrama de corpo livre de um elemento de inércia do sistema MDOF.

Fonte: Rao (2011), p. 558.

Assim sendo, uma representação adequada para a equação do movimento de um sistema MDOF é apresentar as massas, amortecimentos e rigidezes em matrizes, e as acelerações, velocidades e deslocamentos em vetores, como mostram as Equações 2.14 a 2.16 .

$$
\begin{aligned}
& {[M] .\{\ddot{x}\}+[C] .\{\dot{x}\}+[K] .\{x\}=\{F\}} \\
& \{\ddot{x}\}=\left\{\begin{array}{c}
\ddot{x}_{1} \\
\ddot{x}_{2} \\
\vdots \\
\ddot{x}_{N}
\end{array}\right\},\{\dot{x}\}=\left\{\begin{array}{c}
\dot{x}_{1} \\
\dot{x}_{2} \\
\vdots \\
\dot{x}_{N}
\end{array}\right\},\{x\}=\left\{\begin{array}{c}
x_{1} \\
x_{2} \\
\vdots \\
x_{N}
\end{array}\right\},\{F\}=\left\{\begin{array}{c}
F_{1} \\
F_{2} \\
\vdots \\
F_{N}
\end{array}\right\}
\end{aligned}
$$

(Equação 2.14) 


$$
\begin{aligned}
& {[M]=\left[\begin{array}{ccccc}
m_{1} & 0 & 0 & \cdots & 0 \\
0 & m_{2} & 0 & \cdots & 0 \\
0 & 0 & m_{3} & \cdots & 0 \\
\vdots & \vdots & \vdots & \ddots & 0 \\
0 & 0 & 0 & \cdots & m_{N}
\end{array}\right]} \\
& {[C]=\left[\begin{array}{cccccc}
\left(c_{1}+c_{2}\right) & -c_{2} & 0 & 0 & \cdots & 0 \\
-c_{2} & \left(c_{2}+c_{3}\right) & -c_{3} & 0 & \cdots & 0 \\
0 & -c_{3} & & & & \vdots \\
0 & 0 & & \ddots & -c_{N-1} & 0 \\
\vdots & \vdots & & -c_{N-1} & \left(c_{N-1}+c_{N}\right) & -c_{N} \\
0 & 0 & \cdots & 0 & -c_{N} & \left(c_{N}+c_{N+1}\right)
\end{array}\right]} \\
& {[K]=\left[\begin{array}{cccccc}
\left(k_{1}+k_{2}\right) & -k_{2} & 0 & 0 & \cdots & 0 \\
-k_{2} & \left(k_{2}+c_{3}\right) & -k_{3} & 0 & \cdots & 0 \\
0 & -k_{3} & & & & \vdots \\
0 & 0 & & \ddots & -k_{N-1} & 0 \\
\vdots & \vdots & & -k_{N-1} & \left(k_{N-1}+k_{N}\right) & -k_{N} \\
0 & 0 & \cdots & 0 & -k_{N} & \left(k_{N}+k_{N+1}\right)
\end{array}\right] \text { (Equação 2.16) }}
\end{aligned}
$$

Sendo:

[M] a matriz de inércia;

[C] a matriz e amortecimento viscoso;

$[K]$ a matriz de rigidez;

$\{\ddot{x}\}$ o vetor de aceleração;

$\{\dot{x}\}$ o vetor de velocidade;

$\{x\}$ o vetor de deslocamento;

$\{F\}$ o vetor de força;

$N$ o número de graus de liberdade.

Partindo de um caso de vibração livre não amortecida, a Equação 2.14 é escrita na forma da Equação 2.17.

$$
[M] .\{\ddot{x}\}+[K] .\{x\}=\{0\}
$$

Sendo que o sistema definido pela Equação 2.17 é um sistema linear de equações diferenciais ordinárias com coeficientes constantes, a solução pode ser considerada na forma da Equação 2.18.

$$
\{x(t)\}=\{X\} . e^{\lambda . t}
$$


Sendo:

t o tempo;

$\lambda$ um valor complexo;

$\{x(t)\}$ o vetor deslocamento;

$\{X\}$ o vetor de constantes.

Substituindo a Equação 2.18 na Equação 2.17, tem-se (Equação 2.19):

$$
\left[[K]+\lambda^{2} \cdot[M]\right] .\{X\} \cdot e^{\lambda . t}=\{0\}
$$

(Equação 2.19)

Já que a Equação 2.19 deve ser satisfeita para todos os instantes de tempo, tem-se a Equação 2.20:

$$
\left[[K]+\lambda^{2} \cdot[M]\right] .\{X\}=\{0\}
$$

(Equação 2.20)

O sistema de equações algébricas lineares, representado pela Equação 2.20, possui uma solução trivial $\left(X_{i}=0\right)$. Entretanto, essa solução não é a esperada. Logo, existe um problema de autovalor. Balachandran e Magrab (2011) afirmam que as incógnitas são $\lambda^{2}, X_{1}, X_{2}, \ldots, X_{N}$. Uma vez que há $N$ equações e $N+1$ incógnitas, no máximo, o que pode ser feito é resolver para $\lambda^{2}$ as razões $X_{2} / X_{1}, X_{3} / X_{1}, \ldots, X_{N} / X_{1}$. A grandeza $\lambda^{2}$ é denominada autovalor e o vetor $\{X\}$ de autovetor. Os valores de $\lambda^{2}$ são definidos pelas raízes da Equação 2.21 característica.

$$
\operatorname{det}\left[[K]+\lambda^{2} \cdot[M]\right]=0
$$

(Equação 2.21)

Visto que as matrizes de inércia e rigidez são matrizes $N \times N$, a expansão da Equação 2.21 é um polinômio de grau $2 N$ em $\lambda$ para um sistema de $N$ graus de liberdade. Portanto, é possível visualizar esse polinômio como um polinômio de $N$-ésima ordem em $\lambda^{2}$ com $N$ raízes ou autovalores $\lambda_{1}^{2}, \lambda_{2}^{2}, \ldots, \lambda_{N}^{2}$. Os autovetores associados são soluções da Equação 2.22.

$$
\left[[K]+\lambda_{j}^{2} \cdot[M]\right] .\{X\}_{j}=\{0\}
$$

Os autovetores ficam estabelecidos pela Equação 2.23.

$$
\{X\}_{1}=X_{11}\left\{\begin{array}{c}
1 \\
X_{21} / X_{11} \\
\vdots \\
X_{N 1} / X_{11}
\end{array}\right\},\{X\}_{2}=X_{12}\left\{\begin{array}{c}
1 \\
X_{22} / X_{12} \\
\vdots \\
X_{N 2} / X_{12}
\end{array}\right\}, \ldots,\{X\}_{N}=X_{1 N}\left\{\begin{array}{c}
1 \\
X_{2 N} / X_{1 N} \\
\vdots \\
X_{N N} / X_{1 N}
\end{array}\right\}
$$

Ao escrever a Equação 2.23, supõe-se que $X_{1 j} \neq 0$ para $j=1,2, \ldots, N$. Na Equação 2.23, $\{X\}_{1}$ está associado ao autovalor $\lambda_{1}^{2}$, e é denominado primeiro autovetor ou primeiro modo de vibrar, e assim por diante. 
Os autovetores $\{X\}_{j}$ são independentes de uma constante de escala diferente de zero devido à natureza do problema de autovalor. Para evitar essa independência, é feita uma normalização $X_{11}=1, X_{12}=1, \ldots, X_{1 N}=1$.

Fisicamente, os autovetores fornecem informações sobre as posições espaciais relativas dos vários elementos de inércia do sistema MDOF. Dessa forma, para oscilação livre em $\lambda_{j}$, cada massa $m_{j}$ se move por uma distância fixa em relação a $m_{k}$. Os modos resultantes do processo de normalização são chamados de modos normais.

Os modos de vibrar são colocados em uma matriz modal [Ф], que é a Equação 2.24:

$$
[\Phi]=\left[\begin{array}{cccc}
1 & 1 & \cdots & 1 \\
X_{21} / X_{11} & X_{22} / X_{12} & \cdots & X_{2 N} / X_{1 N} \\
\vdots & \vdots & \ddots & \vdots \\
X_{N 1} / X_{11} & X_{N 2} / X_{12} & \cdots & X_{N N} / X_{1 N}
\end{array}\right]
$$

Para as matrizes $[M]$ e $[K]$, os autovalores $\lambda^{2}$ da Equação 2.20 são reais, e os autovetores associados $\{X\}_{j}$ também são reais. Assim sendo, é comum escrever que $\lambda^{2}=(j \omega)^{2}=-\omega^{2}$, sendo $\omega$ uma grandeza positiva. A Equação 2.21 fica escrita como a Equação 2.25, donde obtêm as $N$ frequências naturais do sistema de $N$ graus de liberdade.

$$
\operatorname{det}\left[[K]-\omega^{2} \cdot[M]\right]=0
$$

Os autovetores (vetores modais) associados a cada frequência natural são determinados pela Equação 2.26.

$$
\left[[K]-\omega_{j}^{2} \cdot[M]\right] .\{X\}_{j}=\{0\}
$$

É comum colocar as frequências naturais em ordem crescente, de modo que $\omega_{1} \leq \omega_{2} \leq \ldots \leq \omega_{N}$.

\subsection{Análise modal}

Análise modal é o processo da determinação das características inerentes dinâmicas de um sistema em formas de frequências naturais, fatores de amortecimento e modos de vibração, e usá-los para formular um modelo matemático para o seu comportamento dinâmico. O modelo matemático formulado é referido como o modelo modal do sistema, e a informação para as características são conhecidas como os seus dados modais (HE e FU, 2001). 
De acordo com He e Fu (2001), ao contrário da teoria clássica de vibração, que é voltada somente à resposta de um sistema dinâmico, a análise modal preocupa-se com as propriedades intrínsecas desse sistema.

É importante salientar os dois grandes ramos da análise modal. Em primeiro lugar, tem-se a análise modal teórica, que se baseia na descrição das propriedades físicas de um sistema para se obter o modelo modal. Tal descrição geralmente contém as matrizes de massa, rigidez e amortecimento do sistema. Assim, é um caminho de dados espaciais para modelar o sistema modal. Em segundo lugar, a análise modal experimental obtém o modelo modal a partir de dados medidos em função de resposta em frequência (FRF) ou medidas de dados de resposta livre de vibração. Assim, é um caminho de dados de resposta para modelar o sitema modal. As Figuras 2.5 e 2.6 ilustram o que foi exposto neste parágrafo.

\section{ANÁLISE TEÓRICA}

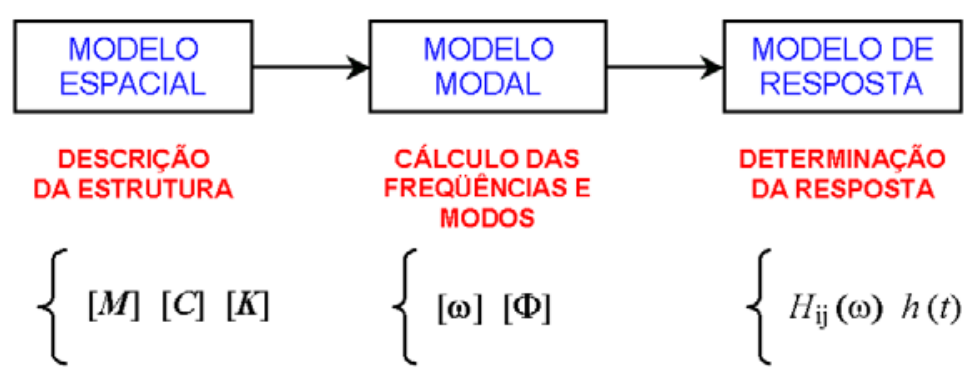

Figura 2.5 - Esquema da análise modal teórica de um sistema vibratório.

Fonte: Nóbrega (2004), p. 82.

\section{ANÁLISE EXPERIMENTAL}

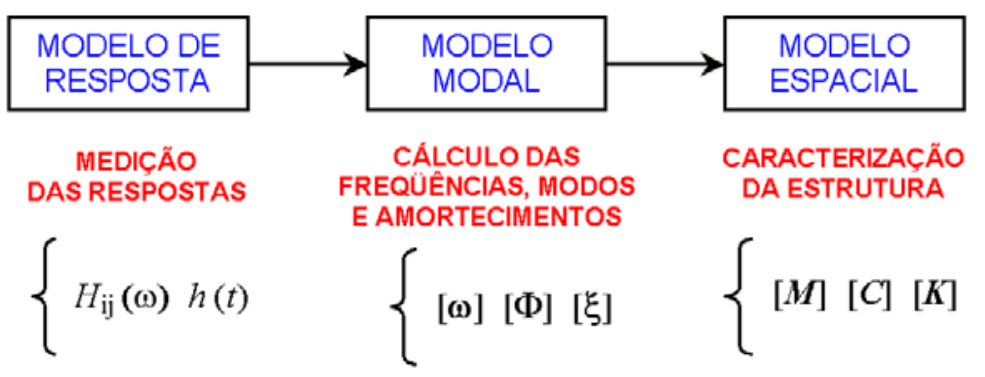

Figura 2.6 - Esquema da análise modal experimental de um sistema vibratório.

Fonte: Nóbrega (2004), p. 82.

Sendo:

[M] a matriz de inércia;

[C] a matriz e amortecimento; 
[K] a matriz de rigidez;

$\zeta$ o fator de amortecimento;

[ $\omega]$ a matriz de frequências naturais;

[Ф] a matriz modal;

$H_{i j}(\omega)$ e $h(t)$ as respostas da estrutura em FRF e amplitudes.

Ambas as técnicas teórica e experimental são englobadas pela análise modal. As teorias modais têm sua base em um modelo físico de um sistema dinâmico que compreende a massa, rigidez e propriedades de amortecimento. Essas propriedades podem ser administradas em forma de equações diferenciais parciais. A solução das equações fornece as frequências naturais e os modos de vibração e suas respostas de vibração forçada. Um modelo matricial também pode ser montado com matrizes de inércia, rigidez e amortecimento. Essas matrizes são incorporadas a um conjunto de equações diferenciais normais de movimento. O princípio da superposição de um sistema linear dinâmico permite transformar essas equações em um problema de autovalor. A solução fornece os dados modais do sistema.

A análise teórica pelo MEF permite a discretização de quase todas as estruturas lineares dinâmicas, o que aumentou muito a capacidade e o alcance da análise modal teórica. Por outro lado, o rápido desenvolvimento nas últimas duas décadas da capacidade de aquisição de dados e processamento tem possibilitado grandes avanços no campo experimental da análise modal, o que se tornou conhecido como teste modal.

Segundo He e Fu (2001), o teste modal clássico é uma técnica experimental utilizada para derivar o modelo modal de um sistema linear e invariante no tempo vibratório. A base teórica da técnica é garantida após o estabelecimento da relação entre a resposta de vibração em um local e a excitação, no mesmo local ou em outro, como uma função da frequência de excitação. Essa relação, que muitas vezes é uma função matemática complexa, é conhecida como função de resposta em frequência (FRF). Combinações de excitação e de resposta, em locais diferentes, levam a um conjunto completo de funções de resposta em frequência, que pode ser representado por uma matriz FRF do sistema. Essa matriz é geralmente simétrica, o que reflete a reciprocidade estrutural do sistema.

Resumindo, a análise modal experimental envolve três fases constituintes: preparação para os testes, medições de resposta de frequência e identificação de parâmetros modais. A preparação do teste envolve a seleção de uma estrutura de suporte e do tipo da força de excitação, o(s) local(is) de excitação, o hardware para medir a força e as respostas, a determinação de um modelo de geometria estrutural, que consiste em marcar os pontos onde a 
resposta deve ser medida; e identificação de mecanismos que podem conduzir a medições incorretas. Durante o teste clássico, um conjunto de dados FRF é medido e armazenado, que é então analisado para identificar os parâmetros modais da estrutura testada.

Algumas aplicações da análise modal, segundo Ewins (1984), McConnell (1995) e He e Fu (2001), são descritas a seguir:

- Corrigir e atualizar com dados experimentais (principalmente o amortecimento) os modelos de MEF;

- Modificar parâmetros na estrutura, como massa, rigidez e amortecimento, visando melhorar seu comportamento estrutural;

- Avaliar a sensibilidade à vibração, buscando reduzir efeitos danosos;

- O modelo matemático de análise estrutural pode ser reduzido quando a análise modal tem interesse em uma faixa de frequências baixas;

- Prever o comportamento dinâmico quando da aplicação de uma força ou um conjunto de forças;

- Identificar e mensurar forças que estejam excitando o sistema;

- Gerenciar problemas complexos de dinâmica, isolando as partes de interesse;

- Determinar as respostas dinâmicas da estrutura em conjunto com os elementos não estruturais (paredes, divisórias, esquadrias etc.);

- Identificação de dano estrutural pelas alterações da resposta dinâmica da estrutura danificada em relação à estrutura sã;

- O modelo modal pode gerar respostas a frequências em uma determinada faixa, as quais irão acionar atuadores de controle ativo de vibração;

- Desenvolver e qualificar um produto;

- Monitorar as condições de funcionamento de uma estrutura.

Nem sempre a análise modal experimental é encarada como um passo importante para determinação de parâmetros de projeto. Neste contexto, Ewins (2000) comenta que a ideia de que a análise modal experimental pode desempenhar um papel importante no processo do projeto de uma estrutura não é evidente no meio técnico. A experimentação pode desempenhar um papel fundamental no projeto, especialmente quando existe uma devida integração com processos analíticos computacionais.

Segundo Allemang e Brown (2002), a análise modal experimental é o processo de determinação dos parâmetros modais (frequências naturais, fatores de amortecimento, vetores modais e dimensionamento modal) de um sistema linear invariante no tempo. Os parâmetros modais são muitas vezes determinados por meio de análise, tais como a de elementos finitos. 
Uma definição de análise vibratória experimental, onde a análise modal se encontra, é dada por McConnell (1995, p. 10):

"Ensaios de vibração são a arte da ciência de medição e compreensão da resposta da estrutura, enquanto exposta a um ambiente dinâmico específico, e, se necessário, simular esse ambiente de uma forma satisfatória para assegurar que a estrutura funcione adequadamente quando exposta a um ambiente dinâmico em condições de campo."

Especificamente para a análise modal, Ewins (2000) apresenta a definição de que um teste modal é aquele que é realizado a fim de construir um modelo matemático da estrutura inteiramente baseado em dados vibratórios medidos.

Esses testes modais podem ser executados laboratorialmente em ambiente controlado ou então em situação de funcionamento real da estrutura. A avaliação modal de uma estrutura em condições reais de funcionamento é particularmente interessante quando as excitações reais às quais a estrutura está sujeita não são possíveis ou são de difícil reprodução em laboratório. Também é utilizada quando as excitações operacionais são estocásticas, medindose então somente a resposta do sistema (RODRIGUES, 2004).

A determinação dos parâmetros modais em função dos dados experimentais apresentará sucesso caso ocorra a correta avaliação dos erros e precisões de cada uma das etapas do processo. Essas etapas são comentadas por Allemang e Brown (2002):

- Teoria da análise modal, que se refere à parte da teoria da vibração clássica que explica a existência de frequências naturais, fatores de amortecimento e modos de vibração para sistemas lineares. Essa teoria inclui tanto modelos discretos como modelos contínuos. Também inclui modos reais normais, bem como os modos de vibração complexos e as soluções possíveis para os parâmetros modais;

- Métodos da análise modal experimental, que envolvem a relação teórica entre quantidades medidas e a teoria clássica de vibração, muitas vezes são representados como equações diferenciais matriciais;

- Aquisição dos dados modais, que engloba os aspectos práticos da aquisição dos dados que são necessários para servir como entrada para a fase de estimativa dos parâmetros modais. Muito cuidado deve ser tomado para assegurar que os dados correspondam aos requisitos da teoria, bem como os requisitos do algoritmo numérico envolvido na estimação dos parâmetros modais. Os requisitos teóricos envolvem preocupações, tais como a linearidade do sistema e a invariância no tempo;

- Estimativa dos parâmetros modais, que está relacionada com o problema prático de estimar os parâmetros modais, com base em uma escolha de modelo matemático que se justifique a partir dos dados medidos; 
- Apresentação e validação dos dados modais, que é o processo para fornecer uma visão física ou interpretação dos parâmetros modais. Por exemplo, esse processo pode ser simplesmente o apuramento numérico da frequência amortecida e dos vetores modais. Mais frequentemente, a apresentação de dados modais envolve a impressão e a animação de tais informações.

Rodrigues (2004) classifica a análise modal experimental em duas grandes áreas. A primeira compreende a análise modal clássica, na qual é possível fazer o controle das forças de entrada que solicitam dinamicamente o sistema e relacionar os dados de entrada com os de saída (acelerações, velocidades e deslocamentos), através de modelos matemáticos que são comumente as funções de resposta em frequência (FRF). A segunda área é a da análise modal estocástica, na qual não existe controle das forças de entrada no sistema. As forças na análise modal estocástica podem ser oriundas da própria utilização da estrutura (ações operacionais), e não é possível mensurá-las, a não ser por análise estatística.

A análise modal clássica muitas vezes não pode ser aplicada de forma econômica às estruturas civis. Assim sendo, a análise modal estocástica surge como uma opção importante no campo da engenharia civil.

Nos itens 2.3.1 e 2.3.2 são apresentadas algumas particularidades das análises modais clássica e estocástica, respectivamente. Muitas técnicas referidas a ensaios no domínio da análise modal clássica também são utilizadas na análise modal estocástica, justificando a apresentação dos principais pontos das duas técnicas.

\subsubsection{Análise modal clássica}

A forma mais eficaz de investigação para análise modal clássica é a utilização da função de resposta em frequência (FRF).

Seja um sistema SDOF conforme o apresentado na Figura 2.1. Imagina-se que esse sistema SDOF possua um amortecimento viscoso e que ele seja solicitado por uma força harmônica, definida pela Equação 2.27.

$$
f(t)=F\left(\omega_{e x}\right) \cdot e^{j \cdot \omega_{e x} \cdot t}
$$

Sendo:

$f(t)$ a função da força harmônica no tempo;

$F\left(\omega_{e x}\right)$ a força harmônica em função da frequência de excitação $\omega_{e x}$;

$j$ o número complexo $j=\sqrt{-1}$;

$t$ o tempo. 
A resposta desse sistema será outra função harmônica dada pela Equação 2.28.

$$
x(t)=X\left(\omega_{e x}\right) \cdot e^{j \cdot \omega_{e x} \cdot t}
$$

Sendo:

$x(t)$ a função da resposta de deslocamento no tempo;

$X\left(\omega_{e x}\right)$ o deslocamento em função da frequência de excitação $\omega_{e x}$.

Substituindo as Equações 2.27 e 2.28 na Equação 2.4, que é a do movimento, e rearranjando-se, obtém-se a razão do deslocamento pela força, que é a Função de Resposta em Frequência, indicado na Equação 2.29.

$$
\alpha\left(\omega_{e x}\right)=\frac{X\left(\omega_{e x}\right)}{F\left(\omega_{e x}\right)}=\frac{1 / m}{\omega^{2}-\omega_{e x}^{2}+j \cdot 2 \cdot \omega \cdot \omega_{e x} \cdot \zeta}=\frac{1}{k-\omega_{e x}^{2} \cdot m+j \cdot \omega_{e x} \cdot c}
$$

Sendo:

$\alpha\left(\omega_{e x}\right)$ a função da resposta em frequência de deslocamento denominada de receptância;

$\omega$ a frequência natural circular;

$\zeta$ o fator de amortecimento;

$m$ a massa do sistema;

$k$ a rigidez da mola;

c o coeficiente de amortecimento viscoso.

A FRF é a principal função da qual a análise modal clássica depende. Existem ainda duas outras FRF's. As FRF's de mobilidade e de acelerância que relacionam a velocidade e a aceleração com a força excitadora respectivamente.

A exibição gráfica de uma FRF desempenha um papel vital na análise modal clássica. Diferentes exposições gráficas destacam informações diferentes em cada FRF. Como a análise modal experimental muitas vezes depende de ajuste de curva de FRF, boa compreensão da FRF em formas gráficas é imperativa. Uma típica FRF de receptância é representada na Figura 2.7.

He e Fu (2001) destacam que a apresentação tridimensional da FRF é completa porque mostra a sua verdadeira face. No entanto, é difícil de ser usada, especialmente para a análise modal, onde as características, tais como as ressonâncias, têm de ser distinguidas facilmente pela visualização. A partir da Figura 2.7, pode-se ver da forma 3-D que quando projetada para o plano de frequência versus real, observa-se o referido plano real da FRF. Da mesma forma, a projeção para o plano de frequência versus imaginária corresponde ao chamado plano imaginário da FRF, e que para o plano real versus imaginário é o plano de Nyquist. Essas parcelas (e suas variações) destacam aspectos diferentes da FRF. 


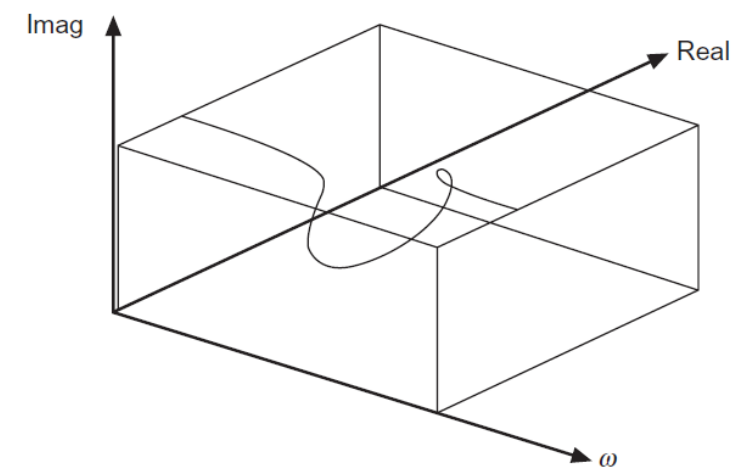

Figura 2.7 - Esquema tridimensional (3-D) de uma FRF de receptância.

Fonte: He e Fu (2001), p. 82.

O gráfico de amplitude pode ser desenhado em um plano com a frequência nas abscissas e a amplitude nas ordenadas. A Figura 2.8 ilustra um gráfico da FRF de receptância. Vale destacar que as formas dos gráficos de mobilidade e acelerância são muito próximas.

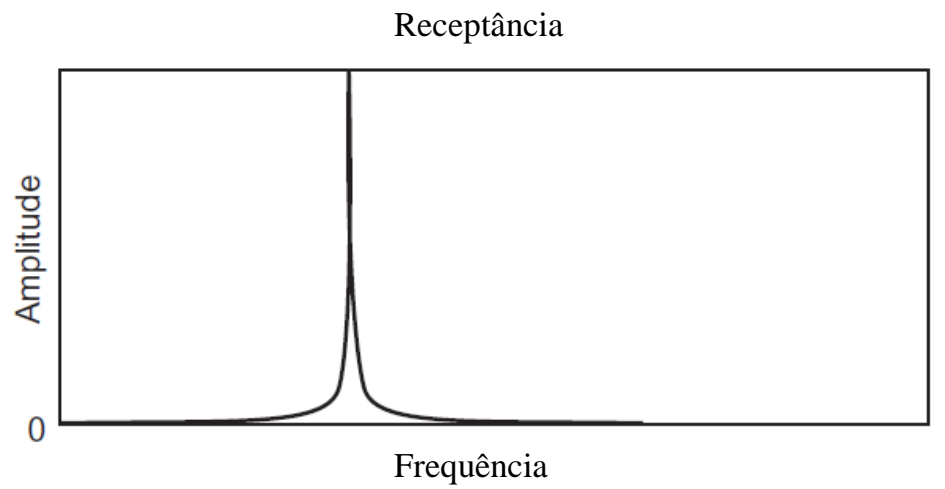

Figura 2.8 - Exemplo de gráfico de amplitude de uma FRF de receptância.

Fonte: He e Fu (2001), p. 83.

O pico no gráfico da Figura 2.8 indica o ponto de ressonância. Outra forma de apresentação dessa curva é com a escala logarítmica (log), ficando as amplitudes em decibéis (dB) e a frequência em escala log. No gráfico de escala logarítmica, é possível ver distintamente as regiões dominadas pela rigidez (região antes da ressonância), amortecimento (região da ressonância - pico) e massa (região pós-ressonância), fazendo-se estimativas da rigidez e massa do sistema.

Em um sistema MDOF, para uma excitação harmônica, a matriz da FRF de receptância é definida como o inverso da matriz de rigidez dinâmica, conforme apresentado por He e Fu (2001), e indicado na Equação 2.30.

$$
\left[\alpha\left(\omega_{e x}\right)\right]=\left[Z\left(\omega_{e x}\right)\right]^{-1}=\left([K]-\omega_{e x}^{2} \cdot[M]\right)^{-1}
$$


Sendo:

$\left[Z\left(\omega_{e x}\right)\right]$ a matriz de rigidez dinâmica.

É importante saber que, embora definida de uma vibração forçada, a matriz FRF de receptância reflete as propriedades de um sistema linear de vibração, semelhante às frequências naturais e modos de vibração do sistema. Por conseguinte, eles não dependem de forças externas. A dependência só pode ocorrer se o comportamento dinâmico do sistema é não linear. A Figura 2.9 ilustra o gráfico de amplitude contra frequência de uma matriz FRF de receptância. Observa-se que cada pico superior do gráfico indica uma ressonância (onde ocorre uma frequência natural do sistema) e cada pico inferior uma antirressonância.

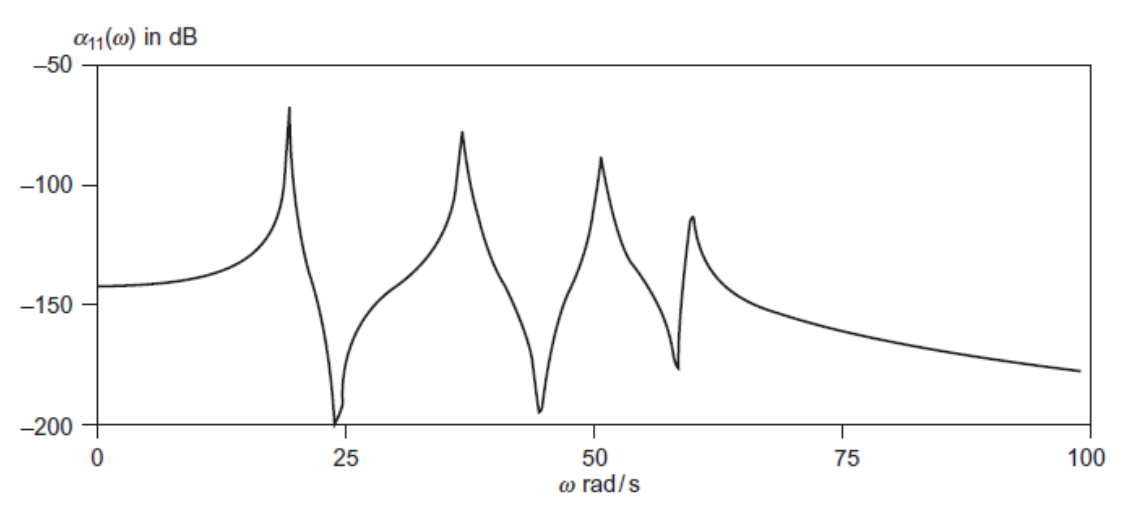

Figura 2.9 - Exemplo de gráfico de amplitude de FRF de receptância de um sistema MDOF. Fonte: He e Fu (2001), p. 103.

A visualização gráfica de uma FRF em um sistema MDOF amortecido é semelhante à mostrada para o sistema MDOF não amortecido na Figura 2.9.

Conforme He e Fu (2001), a análise modal experimental clássica envolve a medição da FRF em uma estrutura de teste. A abordagem tradicional é fornecer à estrutura uma entrada conhecida, medir o resultado e prosseguir com a identificação. Para essa medição, usam-se entradas de força para que a FRF possa ser derivada diretamente da força e de outras informações de resposta. A força de excitação pode ser aleatória, sinusoidal, periódica ou por impactos. Teoricamente, o tipo de força não importa como a FRF é definida. Na prática, é usual ser utilizada uma força que possua energia suficiente e componentes de frequência tais que possam excitar todos os modos de vibração de interesse, para permitir que ocorra o mínimo de erros de processamento de sinal. Existe ainda uma limitação quanto à capacidade do hardware disponível para a análise.

Allemang e Brown (2002) e Nóbrega (2004) exemplificam um processo de análise modal experimental clássica. Para tanto, seja a Figura 2.10 onde é ilustrada uma viga discretizada em diversos pontos (nós) e onde estão apresentados os três primeiros modos de vibração. 


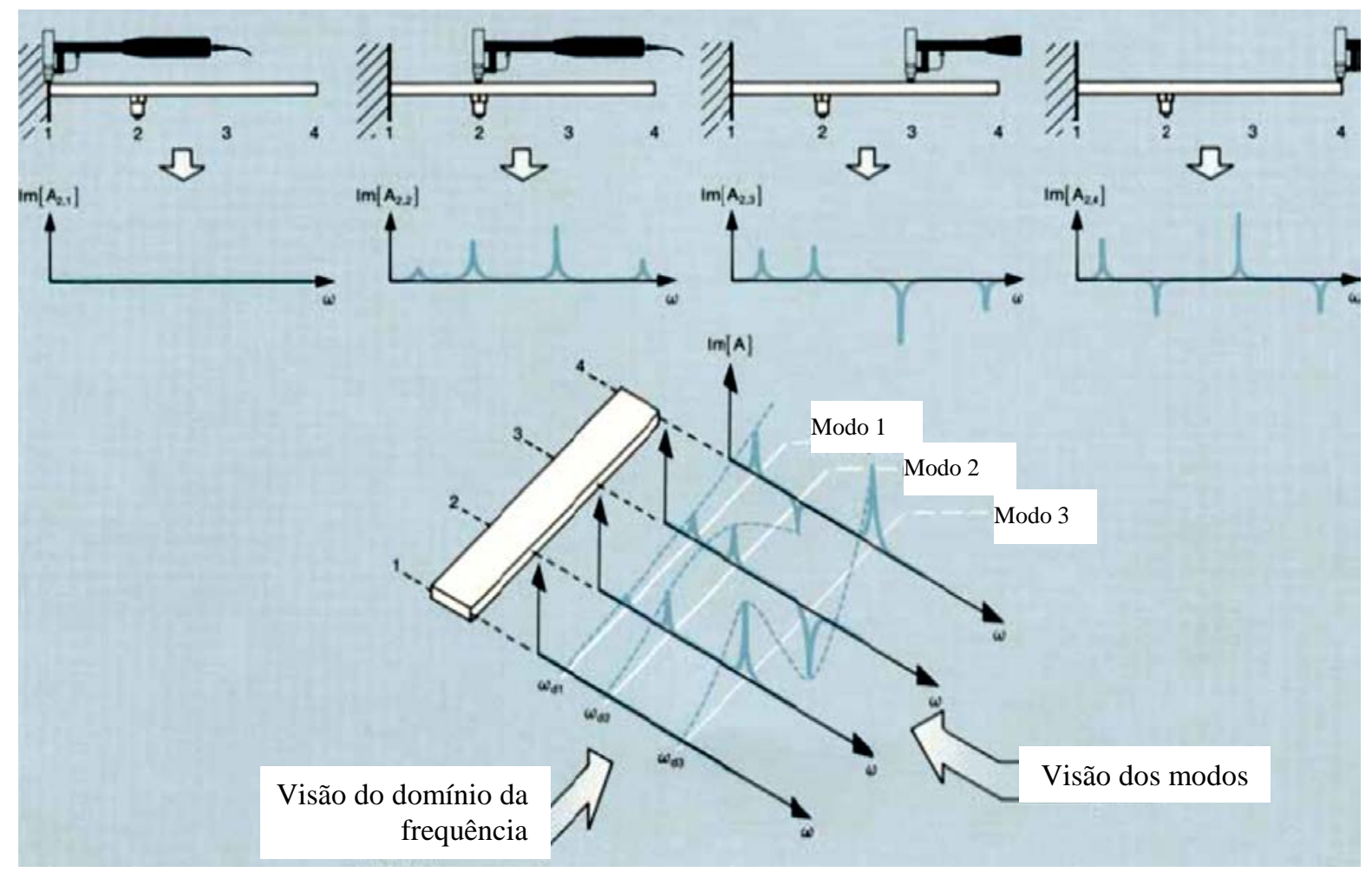

Figura 2.10 - Exemplo de análise modal experimental utilizando a parte imaginária da FRF. Fonte: Brüel \& Kjaer (1988), p. 27.

Após o ensaio, obtém-se a FRF de cada ponto, em função da frequência de excitação e da aplicação da força em outro ponto. Constrói-se então a curva de amplitude da FRF, como ilustrado na Figura 2.9. Os picos indicam as respectivas frequências naturais de cada modo.

Para a obtenção do modo de vibração, considera-se apenas a parte imaginária, ou real, da FRF, dependendo se a FRF é de acelerância ou de mobilidade respectivamente. Assim, considerando-se uma FRF de acelerância e fixando-se uma certa frequência de excitação, verifica-se o valor imaginário medido para cada ponto onde foi fixado o sensor. Esse valor corresponde à coordenada do modo de vibração nesse ponto, e a diferença de fase entre a força de excitação e a resposta (em fase ou em oposição) indica o sinal da coordenada (para cima ou para baixo), montando a forma da deformada modal (modo de vibração).

Os métodos de análise modal clássica podem ser de dois tipos. No primeiro, estão os métodos ditos modo a modo. Eles pressupõem que cada modo, na região da ressonância, possui influência única sobre ela, e que os demais modos não são significativos nessa região da FRF. Assim sendo, cada modo é identificado separadamente. O segundo grupo é denominado de métodos multimodo, onde os modos são identificados simultaneamente em uma faixa de frequência medida. A influência de cada modo sobre o outro também é considerada. 
A análise experimental clássica está fundamentada em quatro hipóteses básicas, conforme Ewins (1984), McConnell (1995) e He e Fu (2001), que são:

- A estrutura é linear, o que implica que a resposta de uma estrutura a um conjunto de forças aplicadas é a soma das respostas individuais de cada força;

- A estrutura obedece ao teorema de reciprocidade de Maxwell, teorema que afirma existir uma relação direta entre os deslocamentos generalizados da estrutura com as forças generalizadas que provocam esses deslocamentos, atuantes em pontos distintos da estrutura, independentemente da ordem de aplicação;

- A estrutura é invariante no tempo, ou seja, durante o ensaio, a estrutura não deve apresentar variações na massa, na rigidez e no amortecimento;

- A estrutura é observável, o que significa que as medidas de entrada e de saída contêm dados suficientes para formar as FRF e definir os parâmetros modais.

É usual também que as forças aplicadas solicitem a estrutura em níveis nos quais possa ser garantida a elasticidade do material.

\subsubsection{Análise modal estocástica}

De acordo com Rodrigues (2004), a análise modal estocástica é de grande utilidade na engenharia civil pelo fato de que as estruturas civis são de grandes dimensões e de difícil excitação forçada. Em outras palavras, é mais economicamente conveniente analisar uma edificação com as ações de ocupação ou outra ação transiente não mensurável do que com shakers e geradores mecânicos de vibração com massa excêntrica.

Apesar da grande vantagem da análise modal experimental na aplicação em estruturas civis, em relação à análise modal clássica, podem ser listadas as seguintes desvantagens, enumeradas por Rodrigues (2004):

- Pelo fato das forças de excitação não serem controladas, a resposta estrutural medida pode ter um nível muito baixo, conduzindo a relações sinal-ruído, que, em geral, são inferiores às obtidas em ensaios com controle das forças de excitação. Esse problema pode ser minimizado com a utilização de equipamentos de grande precisão;

- Como a excitação é aleatória, pode ocorrer que alguns modos não sejam excitados e, portanto, não identificados. Isso pode ser amenizado através de uma análise modal numérica prévia, com uma discretização de malha de pontos de medição e excitação convenientemente adotada;

- Mesmo sendo identificadas as frequências naturais, coeficientes de amortecimento e deformadas modais, pelo fato de não se medirem as forças de excitação, não é possível 
identificar as componentes modais normalizadas pela massa da estrutura, sendo este um aspecto que é importante para a modificação de modelos numéricos com base nas características dinâmicas experimentais;

- As características dinâmicas são avaliadas para níveis de resposta que podem ser muito baixas; isso tem grande influência sobre os coeficientes de amortecimento.

Rodrigues (2004, p. 111) afirma que:

"Podem-se considerar, fundamentalmente, dois grupos de métodos de identificação modal estocástica: o primeiro grupo compreende os métodos de análise de sinal, também denominados métodos não paramétricos; o segundo grupo corresponde aos métodos de ajuste de modelos, também designados por métodos paramétricos. Nos métodos do primeiro grupo, as séries de resposta medidas em diferentes pontos dos sistemas estruturais são analisadas e relacionadas entre si, tendo por base a sua transformação para o domínio da frequência, normalmente através do algoritmo da FFT. Estes métodos são por isso também designados por métodos no domínio da frequência. No segundo grupo de métodos, são utilizadas diferentes técnicas para ajustar modelos, ou com base nas funções de correlação da resposta dos sistemas estruturais ou mesmo diretamente nas próprias séries temporais de resposta. Estes métodos são assim também designados por métodos no domínio do tempo."

Dentre os métodos de identificação modal estocástica não paramétricos, podem ser citados os da estimativa das funções de densidade espectral, o método básico no domínio da frequência e o método de decomposição no domínio da frequência. Já entre os métodos paramétricos, destacam-se os que estimam as funções de correlação da resposta (método direto, método utilizando FFT’s e método do decremento aleatório), os métodos de ajuste às funções de correlação da resposta (método do multiple reference Ibrahim time domain, métodos least squares complex exponential e polyreference time domain e o método de identificação estocástica em subespaços baseado na análise das funções de correlação da resposta dos sistemas) e os métodos de ajuste às séries de resposta no tempo (método de identificação estocástica em subespaços com ajuste direto às séries de resposta de um sistema, modelos vetoriais autorregressivos com média móvel e modelos vetoriais autorregressivos).

Para maiores detalhes sobre esses métodos, recomenda-se a leitura do texto de Rodrigues (2004). No presente trabalho, foi utilizado o método não paramétrico de estimativa das funções de densidade espectral, em particular o da densidade espectral de potência Power Stectrum Density (PSD). Nos itens 2.3.2.1 e 2.3.2.2 descrevem-se os princípios desse método.

\subsubsection{Funções de densidade espectral}

Este item pretende apresentar resumidamente a forma de uma matriz de funções de densidade espectral da resposta de uma estrutura, conforme apresentado por Rodrigues (2004). 
A Equação 2.31 apresenta a matriz das funções de densidade espectral de resposta $\left(S_{y}\right)$ de uma estrutura onde se deseja apenas observar as acelerações, como é o caso deste trabalho.

$$
S_{y}(\omega)=\sum_{i=1}^{n}\left(\begin{array}{l}
\frac{\omega^{4} \cdot\left[v_{c i}\right] \cdot\left[g_{c i}\right]^{T}}{\left(\lambda_{i}\right)^{2} \cdot\left(j \cdot \omega-\lambda_{i}\right)}+\frac{\omega^{4} \cdot\left[v_{c i}^{*}\right] \cdot\left[g_{c i}^{*}\right]^{T}}{\left(\lambda_{i}^{*}\right)^{2} \cdot\left(j \cdot \omega-\lambda_{i}^{*}\right)}+ \\
+\frac{\omega^{4} \cdot\left[v_{c i}\right] \cdot\left[g_{c i}\right]^{T}}{\left(\lambda_{i}\right)^{2} \cdot\left(-j \cdot \omega-\lambda_{i}\right)}+\frac{\omega^{4} \cdot\left[v_{c i}^{*}\right] \cdot\left[g_{c i}^{*}\right]^{T}}{\left(\lambda_{i}^{*}\right)^{2} \cdot\left(-j \cdot \omega-\lambda_{i}^{*}\right)}
\end{array}\right)
$$

Sendo:

$\omega$ a frequência circular (rad/s);

j o número complexo $j=\sqrt{-1}$;

$\left[g_{c i}\right]^{T}$ a i-ésima linha da matriz de participação modal estocástica;

$\left[v_{c i}\right]$ a $i$-ésima linha da matriz de resposta modal;

$\lambda_{i}$ valores próprios do sistema.

Os elementos da diagonal principal da matriz de funções de densidade espectral são designados por autoespectros. Já os restantes dos elementos são chamados de espectros cruzados.

\subsubsection{Estimativa das funções de densidade espectral da resposta}

Müller et al. (2010, p. 3795), afirmam que "uma das formas mais comuns de estudar a característica frequencial de um sinal é pela estimativa espectral. O espectro de potência pode ser estimado para sinais determinísticos e estocásticos”.

Quando o sinal é determinístico, a análise da série de Fourier ou sua transformada é a mais indicada. Quando o sinal é estocástico, aparecem as técnicas paramétrica e não paramétrica. A técnica paramétrica assume que o sinal foi gerado por um modelo conhecido (harmônico, polo-zero, autorregressivo etc.). Essa técnica pode gerar erros quando o modelo escolhido for inconveniente. Já a técnica não paramétrica deixa que o próprio sinal determine a forma do estimador. Müller et al. (2010) dizem que esses métodos são baseados na transformada discreta de Fourier (DFT) do segmento de sinal analisado. Entre estes métodos não paramétricos, um dos mais conhecidos é o do periodograma para a estimação do espectro de potência utilizado neste trabalho. 
Musolino (2011) apresenta o periodograma de Welch como sendo derivado e melhorado do periodograma de Bartllet. Para maiores informações sobre o periodograma de Welch, recomenda-se a leitura de Müller et al. (2010).

As DFT de resposta discreta no tempo $Y(\omega, T)$, de sinais discretos no tempo $y_{k}$, aos quais foi aplicada uma janela de dados $w_{k}$, podem ser expressas conforme a Equação 2.32.

$$
Y\left(\omega_{m}, T\right)=\Delta t \cdot \sum_{k=0}^{N-1} w_{k} \cdot y_{k} \cdot e^{-j \cdot \omega \cdot k \cdot \Delta t}
$$

Sendo:

$\omega_{m}$ a frequência discreta arbitrária ( $\left.\mathrm{rad} / \mathrm{s}\right)$;

j o número complexo $j=\sqrt{-1}$;

$\Delta t$ o intervalo de tempo entre os valores discretos dos sinais $y_{k}$;

$N$ o número de valores discretos dos sinais $y_{k}$;

$T$ a duração total dos sinais $y_{k}$.

Rodrigues (2004) indica que a escolha usual de valores discretos de frequência $\omega_{m}$ é dado pala Equação 2.33 .

$$
\omega_{m}=(m \cdot 2 . \pi) /(N . \Delta t)
$$

Sendo:

$m$ um contador igual a $0,1,2, \ldots, N-1$.

A resolução em frequência da DFT é igual ao inverso da duração total dos sinais ( $\Delta f$ ) (Equação 2.34).

$$
\Delta \omega_{m}=(2 . \pi) /(N . \Delta t) \Leftrightarrow \Delta f=1 /(N . \Delta t)
$$

Nas frequências $\omega_{m}$ os valores transformados fornecem as componentes de Fourier, conforme a Equação 2.35 .

$$
Y_{m}=\frac{Y\left(\omega_{m}\right)}{\Delta t}=\sum_{k=0}^{N-1} w_{k} \cdot y_{k} \cdot e^{-j \cdot \frac{2 \cdot \pi \cdot m \cdot k}{N}}
$$

Rodrigues (2004) afirma que uma forma eficiente de realizar o cálculo da DFT é através da transformada rápida de Fourier (Fast Fourier Transform - FFT) (ver item 2.4.4.a).

A estimativa da matriz de função de densidade espectral das respostas $y_{k}$ pode ser calculada a partir das suas DFT, $Y\left(\omega_{m}\right)$, através da Equação 2.36 . 


$$
\hat{S}_{m}\left(\omega_{m}\right)=\frac{1}{N \cdot \Delta t \cdot \sum_{k=0}^{N-1}\left|w_{k}\right|^{2}} \cdot Y^{*}\left(\omega_{m}\right) \cdot Y^{T}\left(\omega_{m}\right)
$$

Sendo:

$\hat{S}_{m}\left(\omega_{m}\right)$ a estimativa da matriz de funções de densidade espectral.

$\mathrm{Na}$ prática, dos ensaios dinâmicos avaliados com o processo da estimativa de densidade espectral, obtêm-se gráficos que apresentam densidades em função da frequência. Na presente tese foram utilizados, para a identificação das frequências naturais dos sistemas ensaiados, gráficos de espectro de densidade de potência (PSD), ver Capítulo 5. Nesses gráficos, um pico representa uma frequência natural do sistema.

Fica indicado o trabalho de Rodrigues (2004) para maior aprofundamento no método de análise modal estocástica de estimativa das funções de densidade espectral de resposta.

\subsection{Técnicas da análise modal experimental}

São descritas aqui algumas técnicas gerais da análise experimental de estruturas que servem tanto para a análise modal clássica quanto para a análise modal estocástica, de acordo com Rodrigues (2004).

\subsubsection{Fixação da estrutura}

He e Fu (2001) comentam que a fixação da estrutura em um laboratório é um passo importante, pois deve representar o esquema real da estrutura in loco.

Conforme Ewins (1984), as condições de contorno possíveis podem ser livres ou engastadas. Uma condição livre não é possível de ser reproduzida exatamente. Entretanto, podem ser utilizados apoios suficientemente elásticos e suaves para simular a estrutura como corpo rígido. Exemplos desses apoios são molas de constante baixa, fios de náilon e elástico.

Embora a vinculação ideal para ter a resposta da peça estrutural seja a livre, a simulação em laboratório deve representar mais fielmente possível a condição real da estrutura. Essa é uma vantagem do ensaio modal in situ, pois nessa configuração a vinculação efetiva da estrutura é avaliada. 


\subsubsection{Excitação da estrutura}

O método de excitação é importante para a realização de testes modais precisos. Embora teoricamente os dados das FRF não devam depender das excitações e das respostas, na prática a precisão e a qualidade dos dados das FRF dependem, entre muitos fatores, da escolha de excitação na análise modal clássica. Essa escolha deve considerar qual a excitação que melhor solicitará dinamicamente a estrutura em questão. Na análise modal estocástica a excitação adotada deve excitar os modos de interesse. Obviamente, na análise estocástica pode ser que não seja possível excitar todos os modos com as ações operacionais ou impactos aleatórios na estrutura.

Outros pontos de grande relevância são a disponibilidade de equipamentos e a respectiva logística, antes, durante e após o ensaio. Na sequência são comentadas brevemente as características gerais dos equipamentos de excitação e os sinais de excitação.

\section{a) Equipamentos de excitação}

Os equipamentos de excitação mais comuns são os excitadores eletromagnéticos (shakers) e os martelos de impacto. Conforme Nóbrega (2004), os shakers são capazes de gerar forças senoidais e aleatórias. Como esses equipamentos são colocados sobre as estruturas, He e Fu (2001) comentam que eles devem ter influência controlada sobre a massa do sistema, e deve ser certificada a condição de que eles excitarão a direção desejada.

Os martelos de impacto possuem um transdutor piezoelétrico em sua ponta. São capazes de transmitir forças transientes com característica de impacto. Entretanto, possuem uma desvantagem, pois geram grande quantidade de ruído de leitura. Por outro lado, são de fácil manuseio, acessíveis, e não alteram a massa do sistema. Outra vantagem é a capacidade de excitar a estrutura em vários pontos durante um ensaio, procedimento mais trabalhoso de ser realizado com o shaker.

Quando uma estrutura é ensaiada dinamicamente in situ, geralmente são utilizados excitadores rotativos de massa excêntrica (gerador mecânico de vibração com massa excêntrica), excitadores eletrodinâmicos, grandes martelos de impacto ou excitação operacional como de veículos, vento ou pessoas. Rodrigues (2004) apresenta uma vasta revisão sobre os equipamentos de excitação e leitura de sinais vibratórios. Esse autor também comenta que uma forma de excitar a estrutura é por meio da fixação de um grande peso que é liberado repentinamente. Esse mecanismo de excitação foi utilizado em ensaios na estrutura de ampliação do aeroporto da ilha da Madeira em Portugal. 
b) Forças ou sinais de excitação

He e Fu (2001) descrevem uma gama de tipos de sinais de excitação que podem ser utilizados em testes modais:

- O sinal senoidal é o método mais tradicional para o teste modal clássico. A força contém uma única frequência de cada vez, e a excitação varia de uma frequência para outra com um incremento definido, permitindo que a estrutura vibre harmonicamente em cada frequência. Essa excitação é eficaz para estruturas que são estimuladas com um alto nível de vibração, para a caracterização de não linearidade de uma estrutura, e para excitar modos de vibração normais de uma estrutura amortecida. Sua desvantagem é o tempo que geralmente é grande para a aquisição do sinal;

- O sinal aleatório é uma forma muito utilizada, e existem várias formas de ele ser executado. O sinal aleatório puro é um sinal contínuo. Ele contém todas as frequências dentro da faixa de frequências da estrutura. Uma excitação pseudoaleatória é uma sequência aleatória que se repete continuamente. Para uma estrutura que se comporta de forma não linear, a excitação aleatória tem a tendência de linearizar o comportamento, a partir dos dados de medição. A função de resposta de frequência derivada da medida da excitação aleatória será então a FRF linearizada;

- Na excitação de impacto, o tempo do sinal de força é um pulso com frequência não controlada. Em termos de equipamentos, a técnica de excitação de impacto é relativamente simples em comparação com excitação senoidal feita por um shaker. É uma técnica conveniente e muito prática para testes de campo e de laboratório. Por causa de nenhuma ligação física (nenhum equipamento ligado à estrutura) entre a excitação e a estrutura, o teste de impacto evita o problema da interação do equipamento de excitação com a estrutura. Isso significa que é possível medir as quantidades exatas de amortecimento. As principais desvantagens da excitação de impacto são tão notáveis quanto as suas vantagens. É difícil controlar tanto o nível de força ou a gama de frequências do impacto. Isso pode afetar a relação sinal-ruído na medição, o que resulta em dados de baixa qualidade. O impacto normalmente não pode ser repetido de igual maneira, a não ser que um equipamento especial seja desenvolvido. A Figura 2.11 ilustra variadas formas de forças de excitação e suas respectivas respostas na estrutura. 
EXCITAÇÃO
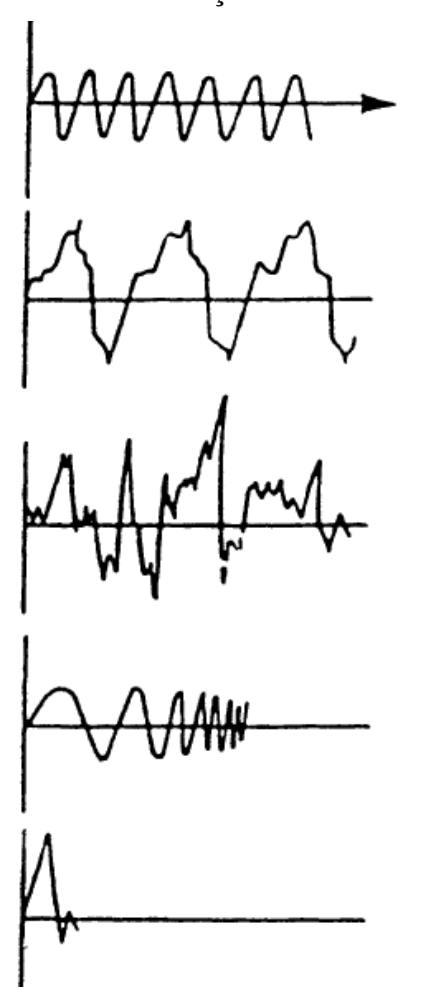

RESPOSTA
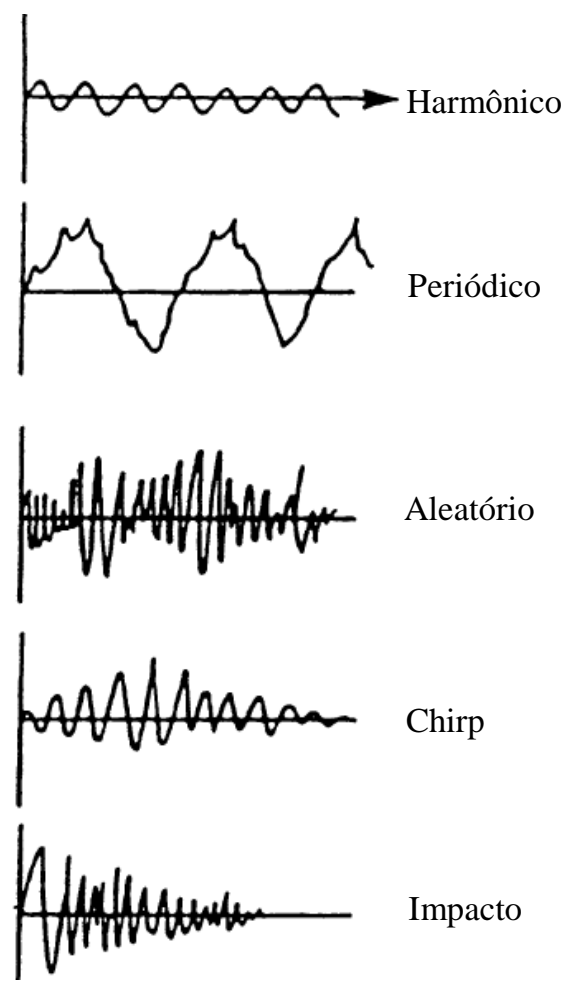

Figura 2.11 - Exemplo de sinais de excitação e suas respectivas respostas.

Fonte: Ewins (2000), p. 214.

\subsubsection{Aquisição de sinais}

Teoricamente, uma estrutura real tem um número infinito de graus de liberdade e, por conseguinte, de modos de vibração. Nenhum experimento é capaz de cobrir a totalidade. Desse modo, os dados medidos de uma estrutura são sempre incompletos. Quando se tratar de uma estrutura que foi discretizada por um modelo de análise numérica, como o MEF, o número de graus de liberdade utilizados é geralmente muito maior do que o número de locais de medição que ocorrem em um ensaio. Assim sendo, os dados medidos experimentalmente são incompletos novamente (HE e FU, 2001).

Primeiramente, os dados medidos podem abranger apenas uma gama limitada de frequências, compreendendo apenas uma parte dos modos de vibração. Portanto, a partir dos dados medidos, pode-se derivar um número incompleto de modos de vibração. A faixa de frequências medidas é determinada pelo interesse da estrutura, pela limitação do hardware disponível, pela montagem do acelerômetro ou pelo intervalo, dentro do qual o comportamento dinâmico da estrutura é requerido, denominando-se de incompletude de frequência. 
Em segundo lugar, o número de coordenadas utilizadas na elaboração dos ensaios é geralmente muito menor do que o número de graus de liberdade utilizados em um modelo de análise teórica, o que significa que a descrição espacial de modos de vibração não é completa. Essa é a incompletude espacial. O número de coordenadas utilizadas no experimento é determinado pelo custo e pelo tempo envolvidos na realização do ensaio, a acessibilidade de coordenadas sobre a estrutura ou a capacidade de medir todas as coordenadas desejadas. Para os modos de vibração em baixas frequências, um número pequeno de coordenadas é suficiente para descrever os modos de vibração. Entretanto, modos de frequências mais altas têm de ser delineados através de um número maior de coordenadas. Um número insuficiente de coordenadas pode deixar de descrever adequadamente as formas modais de vibração ou causar aliasing espacial (ver item 2.4.4.c), onde um modo de alta frequência é confundido como um de baixa frequência.

Segundo Rodrigues (2004), a resposta dos sistemas vibratórios pode ser observada em termos das grandezas de deslocamento, velocidade ou aceleração. Em princípio, qualquer uma das grandezas pode ser medida, porém a resposta em deslocamentos é mais evidente para frequências mais baixas, e as respostas em aceleração, para as frequências mais altas. Entretanto, a medição de deslocamentos é um tanto complicada, já que precisa ser feita a partir de uma base fixa independente da estrutura. A medida de sinais de velocidade é mais aplicada ao domínio de monitoramento sísmico. Assim sendo, a aceleração é a medida que usualmente é praticada.

Os acelerômetros mais comuns são os piezoelétricos. Eles consistem basicamente de uma massa acoplada sobre cristais piezoelétricos. Quando a massa se movimenta (compressão ou deslizamento), esses cristais possuem a propriedade de emitir sinais elétricos interpretados em forma de aceleração da estrutura, pelo sistema de aquisição de dados.

Além dos acelerômetros piezoelétricos, são ainda encontrados os acelerômetros piezoresistivos capacitivos e os acelerômetros do tipo force balance ou do tipo servo.

Nóbrega (2004) destaca que os equipamentos de aquisição de dados ainda podem englobar sistemas óticos com laser, extensômetros elétricos e transdutores de deslocamento do tipo Linear Variable Differential Transformer (LVDT).

Quanto à qualidade da aquisição dos sinais, Ewins (2000) afirma que a principal preocupação é de se proteger contra a incursão de erros sistemáticos, como os causados pelo uso incorreto do equipamento ou instalação dos transdutores. Esses erros são muito mais difíceis de serem detectados e erradicados do que são os de caráter mais aleatório, como os ruídos, e uma vez incorporados nos dados, irão degradar seriamente a eficácia do modelo. 


\subsubsection{Processamento dos dados}

Para o correto entendimento do processamento de dados obtidos na análise dinâmica experimental são, em seguida, descritos alguns pontos de maior relevância.

a) Série de Fourier

Conforme Joaquim e Sartori (2003), é devido aos estudos de Jean Baptiste Joseph Fourier (1768-1830) o conceito de que uma função periódica pode ser decomposta em uma série de sinais senoidais e cossenoidais, com amplitudes variáveis e frequências harmônicas ${ }^{4}$ múltiplas da frequência fundamental (natural). Esse postulado ficou conhecido como série de Fourier (Equação 2.37). A condição fundamental para se construir uma série de Fourier é que o sinal seja periódico, que a função que representa o sinal tenha um número finito de descontinuidades, máximos e mínimos, e que seja integrável em toda sua extensão.

$$
x(t)=\frac{a_{0}}{2}+\sum_{n=1}^{\infty}\left[E_{n} \cdot \cos \left(2 \cdot \pi \cdot n \cdot f_{0} \cdot t+\theta_{n}\right)\right]
$$

Sendo:

$x(t)$ a função periódica em função do tempo $t$;

$a_{0}$ a amplitude da frequência fundamental $f_{0}=1 / T$, sendo $T$ o período;

$E_{n}$ a representação da amplitude do n-ésimo harmônico;

$\theta_{n}$ a representação da fase do $n$-ésimo harmônico.

O valor de $a_{0}, E_{n}$ e $\theta_{n}$ são dados pelas Equações 2.38 a 2.40 respectivamente.

$$
\begin{aligned}
& a_{0}=\frac{2}{T} \cdot \int_{-T / 2}^{T / 2} x(t) \cdot d t \\
& E_{n}=\sqrt{a_{n}^{2}+b_{n}^{2}} \\
& \theta_{n}=\operatorname{arctg}\left(\frac{b_{n}}{a_{n}}\right)
\end{aligned}
$$

Os valores de $a_{n}$ e $b_{n}$ são dados pelas Equações 2.41 e 2.42:

\footnotetext{
${ }^{4}$ Os harmônicos são componentes do sinal vibratório que geram a "complexidade” da forma da onda no domínio do tempo. Quanto maior o número de harmônicos em um som, mais complexa será a forma da onda.
} 


$$
\begin{aligned}
& a_{n}=\frac{2}{T} \cdot \int_{-T / 2}^{T / 2} x(t) \cdot \cos \left(2 \cdot \pi \cdot n \cdot f_{0} \cdot t\right) \cdot d t \\
& b_{n}=\frac{2}{T} \cdot \int_{-T / 2}^{T / 2} x(t) \cdot \operatorname{sen}\left(2 \cdot \pi \cdot n \cdot f_{0} \cdot t\right) \cdot d t
\end{aligned}
$$

Uma das formas de apresentar as amplitudes dos harmônicos que compõem um determinado sinal é através do espectro de amplitude. A Figura 2.12 ilustra um espectro de amplitudes de um sinal periódico.
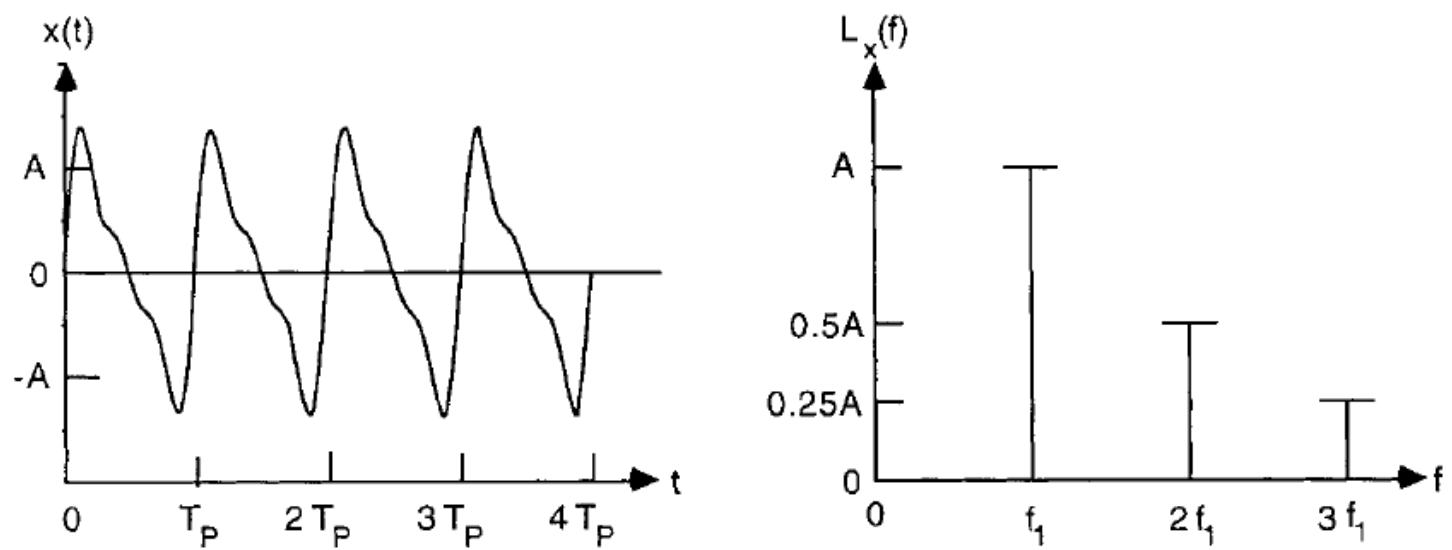

Figura 2.12 - Exemplo de espectro de amplitudes dos harmônicos de um sinal. Fonte: Piersol (2002), p. 22.5.

Observa-se que quanto maior o harmônico, menor será sua contribuição para a forma original do sinal. Assim sendo, o conhecimento do sinal no domínio da frequência é muito importante, pois através de sua análise é possível verificar quais harmônicos são significativos na sua composição e quais harmônicos podem ser desprezados sem que o sinal perca suas características fundamentais.

Um sinal pode ser escrito no domínio do tempo ou da frequência. O termo domínio do tempo refere-se à forma como o sinal é obtido em relação ao tempo. O domínio da frequência refere-se às amplitudes de cada uma das senoides que compõem o sinal original. Cada senoide é um harmônico. Portanto, o domínio da frequência nada mais é que o espectro de amplitudes dos harmônicos. A Figura 2.13 ilustra um sinal qualquer composto de quatro senoides (harmônicos). O domínio do tempo ilustra a curva observável. O domínio da frequência é a expressão das amplitudes de cada senoide. A soma de todas as senoides gera a curva do domínio do tempo. 


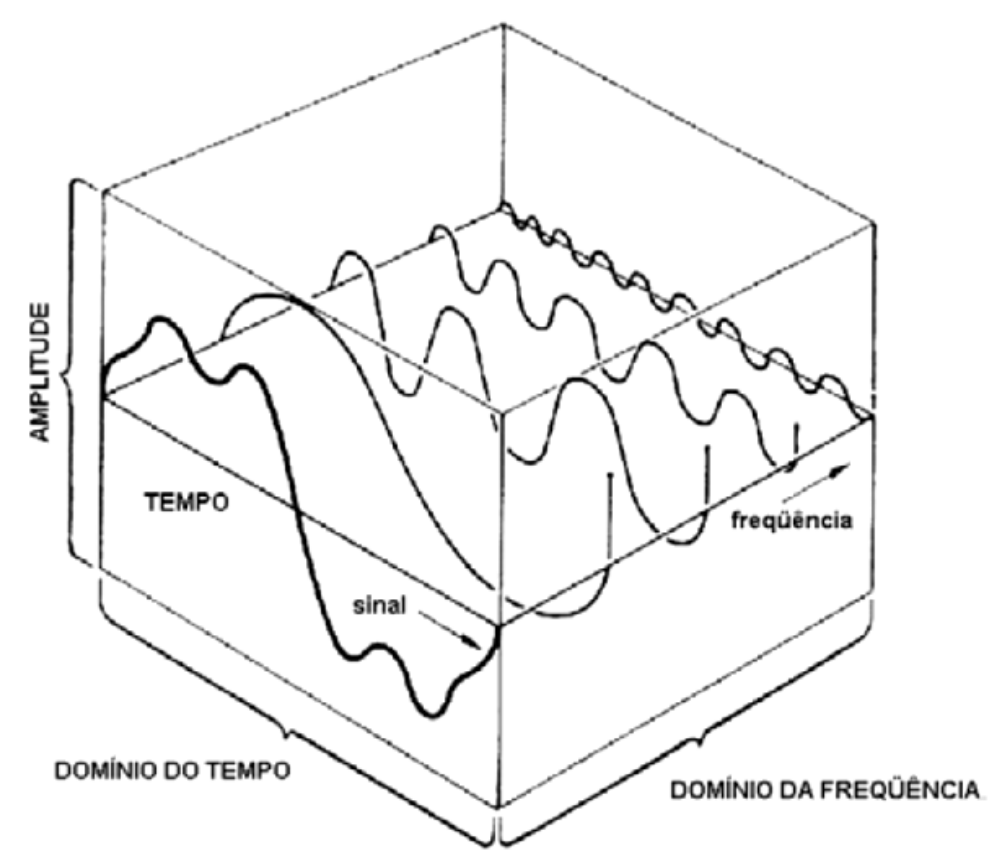

Figura 2.13 - Sinal não senoidal no domínio do tempo composto de quatro sinais senoidais. Fonte: Allemang e Brown (2002), p. 21.18.

\section{b) Transformada ou integral de Fourier}

Joaquim e Sartori (2003) apresentam a transformada de Fourier como a solução para transformar um sinal não periódico em um sinal que possa ser representado por um espectro de frequências.

Os sinais discretos são calculados pela DFT (Discrete Fourier Transform) para o domínio da frequência. Entretanto, a DFT exige um trabalho computacional extremamente grande. Sendo assim, foram desenvolvidos algoritmos que fazem uso das propriedades da DFT para reduzirem o volume de cálculos, fazendo a conversão de sinais discretos no domínio do tempo para o domínio da frequência, os quais podem ser expressos em espectros de amplitude e de fase.

O processo de sintetização é denominado de FFT (Fast Fourier Transform). Esses algoritmos são, de forma resumida, uma maneira eficiente de calcular a DFT de um sinal, o que compõe a base matemática de um sistema de aquisição de sinais. Fica a indicação do trabalho de Allemang e Brown (2002) para a compreensão da forma de aquisição de sinais, e o de Joaquim e Sartori (2003) para a ampliação dos conceitos matemáticos da DFT. 


\section{c) Aliasing}

Conforme Randall (2002), o fenômeno de “aliasing” é um erro na amostragem do sinal discreto medido no tempo. Os algoritmos da DFT não são capazes de detectar que a taxa de aquisição do sinal no tempo foi inferior ao necessário.

A Figura 2.14 ilustra esse fenômeno. Nela, são apresentados dois sinais contínuos de frequência iguais a $3 \mathrm{~Hz}$ (A) e $5 \mathrm{~Hz}$ (B). Os pontos são os sinais discretos colhidos que, pelo fenômeno de aliasing com taxa de aquisição de $4 \mathrm{~Hz}$, geraram uma frequência equivalente de $1 \mathrm{~Hz}$. O efeito de aliasing é combatido por filtros antialiasing que evitam esse fenômeno.
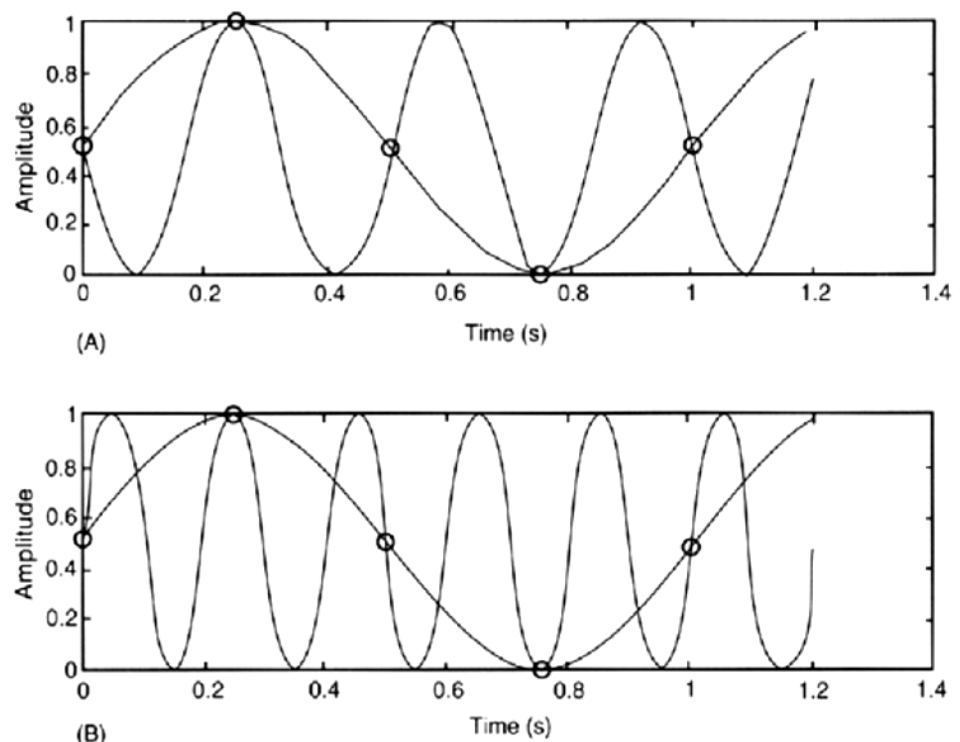

Figura 2.14 - Efeito de aliasing na obtenção de sinais discretos.

Fonte: Randall e Tordon (2002) apud Nóbrega (2004), p. 103.

\section{d) Leakage}

Outro efeito é o leakage e é comentado por Randall (2002). Resumidamente, o efeito de leakage é um “vazamento” que ocorre no cálculo da FFT, pelo fato do sinal transgredir a hipótese fundamental de periodicidade requerida pela FFT. Ele é combatido de três formas:

- Forçando com que o sinal na janela de dados corresponda a um número inteiro de períodos;

- Para longos sinais transitórios aumenta-se o comprimento da janela até que o todo tempo transiente esteja contido no interior do registro de dados;

- Através da aplicação de janelas de tempo especiais que têm melhores características de vazamento do que as janelas retangulares. 
Em relação à terceira alternativa, Ewins (1984) afirma que existe uma gama de janelas de aquisição de sinais para diferentes classes de problemas. McConnell (1995) indica que as principais janelas são a retangular, a Hanning, a Kaiser-Bessel e a flat top. Uma janela é uma função dada pela Equação 2.43, que pode ser definida para um intervalo de tempo $t$ $(0<t<T$ ), sendo $T$ o período. A Figura 2.15 ilustra essas janelas.

$$
W(t)=a_{0}-a_{1} \cos (\omega . t)+a_{2} \cos (2 . \omega . t)-a_{3} \cos (3 . \omega . t)+a_{4} \cos (4 . \omega . t)
$$

Sendo:

$a_{i}$ os coeficientes que determinam a área de cada janela, dados pela Tabela 2.1;

$\omega$ a frequência natural analisada.

Tabela 2.1: Coeficientes da função de janela.

\begin{tabular}{|c|c|c|c|c|c|}
\hline \multirow{2}{*}{ Função } & \multicolumn{5}{|c|}{ Coeficientes } \\
\cline { 2 - 6 } & $a_{0}$ & $a_{1}$ & $a_{2}$ & $a_{3}$ & $a_{4}$ \\
\hline Retangular & 1 & --- & --- & --- & -- \\
\hline Hanning & 1 & 1 & --- & --- & --- \\
\hline Kaiser-Bessel & 1 & 1,298 & 0,244 & 0,003 & 0,032 \\
\hline Flat top & 1 & 1,933 & 1,286 & 0,388 & \\
\hline
\end{tabular}

Fonte: McConnell (1995), p. 289.

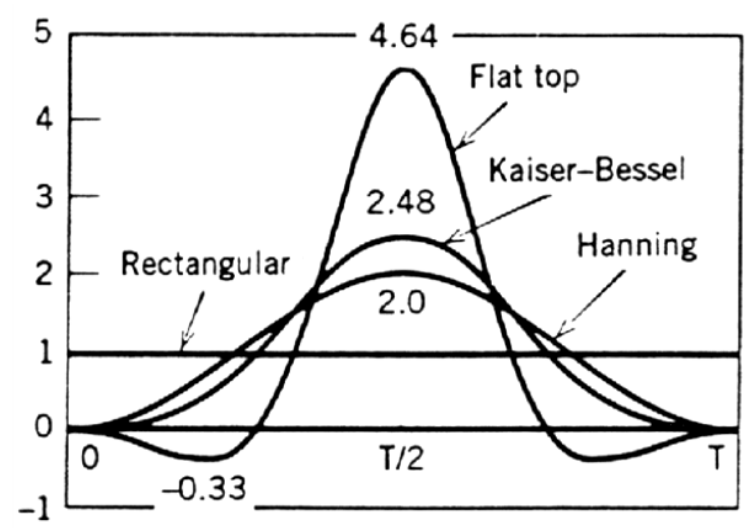

Figura 2.15 - Formato da janela de aquisição no domínio do tempo.

Fonte: McConnell (1995), p. 289.

Ewins (1984) apresenta a Figura 2.16, na qual são descritas quatro formas de janelas de aquisição de sinais. Nota-se que a (c) é do tipo Cosino Taper. A janela Hanning (b) e a Cosino Taper (c) são comumente utilizadas para sinais contínuos, como os produzidos por vibrações periódicas ou aleatórias. A forma exponencial (d) é utilizada para vibração transiente, onde a informação mais importante encontra-se na primeira parte dos dados gravados. 
e) Cálculo da média (Averaging)

O cálculo da média envolve várias aquisições do mesmo sinal para garantir a confiabilidade. A média tem como objetivo suavizar os ruídos do sinal. Nóbrega (2004) comenta que uma desvantagem desse processo é a linearização de efeitos não lineares. A Figura 2.17 ilustra o cálculo da média de um sinal aleatório. Em (A) o sinal não foi repetido, em (B) o sinal foi repetido oito vezes e em (C), 128 vezes.

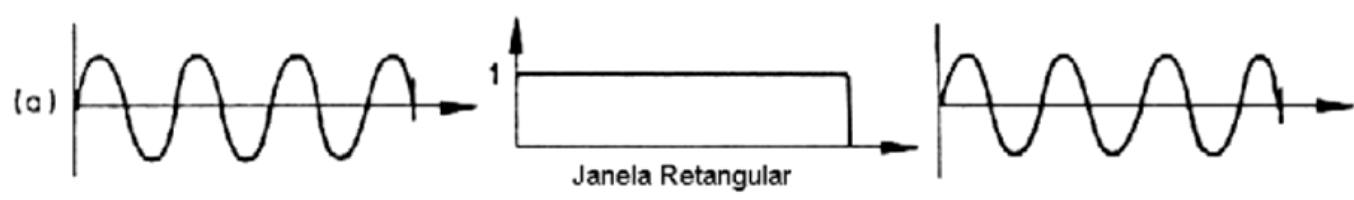

(b)

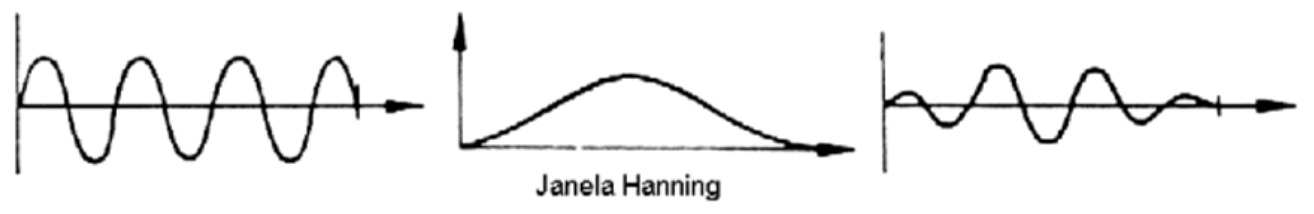

(c)

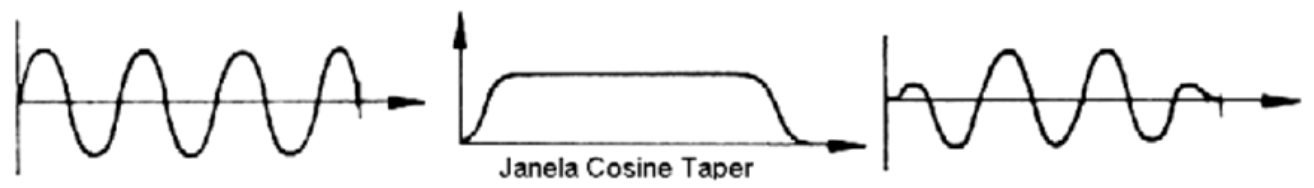

(d)
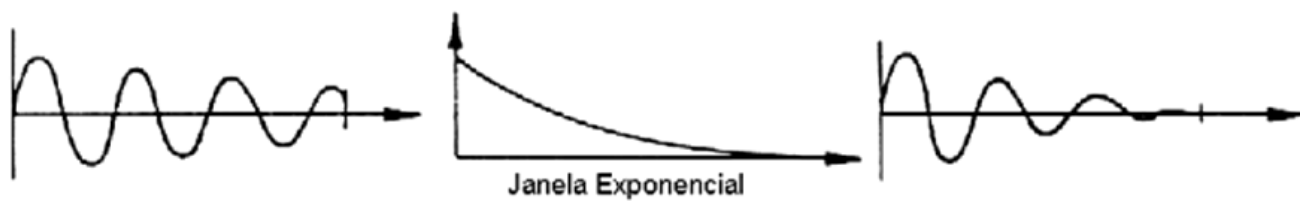

Figura 2.16 - Formatos de janelas de aquisição e respectivos resultados.

Fonte: Ewins (1984), p. 121.

\section{f) Função de coerência}

A função de coerência é útil no contexto de uma excitação aleatória, segundo Nóbrega (2004). As funções de coerência são algoritmos estimadores da qualidade da análise. Uma função de coerência naturalmente indica resultados “mal condicionados”, como:

- Ruídos nas medidas;

- Erros sistemáticos de resolução no espectro;

- O sistema é não linear;

- A resposta medida é devida a uma combinação da excitação desejada e de outra fonte externa. 


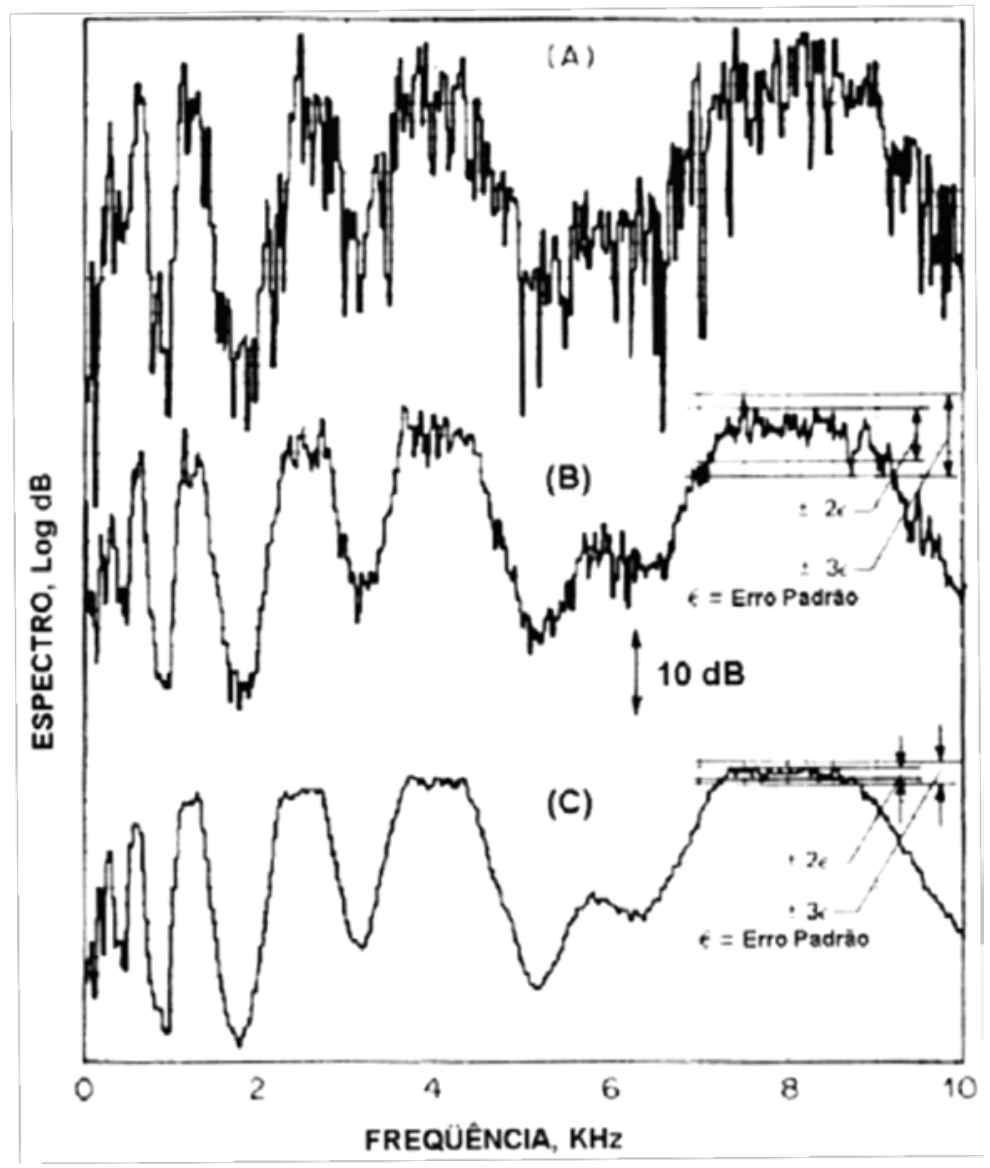

Figura 2.17 - Efeito do cálculo da média.

Fonte: Nóbrega (2004), p. 105 adaptado de Randall (2002), p. 14.23.

\subsubsection{Identificação dos parâmetros modais}

Após o processamento dos dados experimentais, a identificação dos parâmetros modais (amortecimento, frequências naturais e modos de vibração) pode ser realizada no domínio do tempo ou no domínio da frequência.

Os métodos da análise modal clássica geralmente utilizam as FRF. Já um dos métodos da análise modal estocástica, que foi utilizado neste trabalho, é o da estimativa do espectro da densidade de potência (PSD).

Os autores He e Fu (2001) comentam ainda que muitas vezes a determinação de frequências naturais e modos de vibração da FRF ou do PSD é dificultada pelos ruídos captados no sinal. Nem todos os picos de uma FRF ou do PSD são ressonâncias, pois podem também ser ruídos do sinal. Um meio para a correta identificação pode ser a sobreposição de várias FRF ou diagramas de PSD de alguns pontos para identificação dos parâmetros verdadeiros. 


\subsubsection{Mensuração do amortecimento}

A determinação do amortecimento de um material não é uma tarefa simples. Gaul e Schmidt (2007) afirmam que a energia dissipada por um material depende da forma de fixação do corpo de prova e do atrito com o ar. A consideração exata desses fatores que interferem na mensuração do amortecimento é difícil. Apesar de gerarem um erro ao serem consideradas como parcelas de amortecimento do material, para estruturas civis essa incerteza é desprezível. A quantidade de amortecimento também depende da frequência excitadora, amplitude e temperatura às quais o material estará sujeito.

Os principais métodos de mensuração do amortecimento são o decremento logarítmico e o método da meia potência ou largura de banda [FRANCESCHINI E GOMES (2010)]. Esses dois métodos são aplicáveis quando da análise de estruturas em vibração livre. Para vibrações permanentes o amortecimento pode ser mensurado pela análise modal (amortecimento modal) conforme comentado por Diógenes (2010).

É importante ressaltar que a determinação do amortecimento é feita experimentalmente, pois analiticamente somente é possível estimar o seu valor. Diógenes (2010) comenta que a estimativa experimental pode ser feita pelos seguintes métodos, entre outros: decremento logarítmico; peak-piking ; circle fit; inverse FRF; least-squares; Dobson's method; power input method (PIM) e o método da meia potência ou largura da banda. Franceschini e Gomes (2010) apresentam resultados de avaliação do amortecimento de forma experimental pelo método do Random Decrement para estruturas submetidas a ações vibratórias em serviço (excitação aleatória). Entretanto, estes últimos autores concluíram que o método do Random Decrement possui uma restrição de análise quando se aplicam excitações com uma faixa de frequências muito grande.

Uma forma de estimar analiticamente o amortecimento é o denominado amortecimento proporcional ou amortecimento de Rayleigh. Ele é obtido pela soma dos produtos das constantes $\alpha$ e $\beta$, obtidas por interpolação linear a partir dos fatores de amortecimento, pelas matrizes de massa e rigidez respectivamente. Para maiores detalhes sobre o amortecimento proporcional, podem ser consultadas as referências de Clough e Penzien (1995) e Meirovitch (2001).

Lima e Santos (2008, p. 39) destacam que:

“O amortecimento em uma estrutura não depende apenas do material de que é feita. Vários outros fatores influenciam, como material e disposição das divisórias em um prédio, tipos das ligações entre os elementos estruturais, sistema estrutural, dentre outros. Em estruturas já existentes é possível, embora nem sempre viável, a 
determinação experimental do amortecimento. Em estruturas em fase de projeto ou a serem construídas, a determinação do amortecimento é simplesmente impossível. Assim sendo, tem-se que aproveitar resultados de experiências anteriores em estruturas semelhantes, onde os amortecimentos tenham sidos medidos. Seria desejável que na conclusão da obra as propriedades dinâmicas da mesma, dentre elas o amortecimento, pudessem ser verificadas experimentalmente.

É importante ressaltar que o amortecimento a ser adotado depende das condições de carregamento a que a estrutura será submetida. Carregamentos que despertem ciclos de grandes deformações inelásticas, naturalmente, corresponderão a maiores valores para os amortecimentos.”

A última afirmação de Lima e Santos (2008) é bem compreendida quando se verifica o comportamento do concreto armado em relação ao amortecimento. Isso é discutido com maiores detalhes no item 4.4 deste trabalho.

Fazendo uma comparação entre os métodos do decremento logarítmico e o da largura de banda ou meia potência, Pereira et al (2012, p.230) comentam que:

\begin{abstract}
“A escolha do método depende da faixa do amortecimento, da frequência de vibração, da praticidade requerida e do hardware disponível. O método do decremento logarítmico é mais adequado para baixo e médio amortecimento e consiste no cálculo a partir da atenuação da vibração do material ou estrutura em função do tempo após uma excitação por impulso. O método da largura de banda de meia potência é mais adequado para médio e alto amortecimento. O método do decremento logarítmico é o mais prático, contudo demanda de uma capacidade superior de processamento de sinal. Ambos os métodos consideram um modelo para os cálculos, normalmente o modelo de amortecimento viscoelástico equivalente, em que o decremento da amplitude de vibração em função do tempo é tido como exponencial e o amortecimento não depende da frequência de vibração.”
\end{abstract}

Na sequência são descritos resumidamente os métodos do decremento logarítmico e da largura de banda ou meia potência.

\title{
2.4.6.1 Decremento Logarítmico
}

Balachandran e Magrab (2011) apresentam a Equação 2.44 para mensuração do fator de amortecimento pelo método do decremento logarítmico.

$$
\zeta=\frac{1}{\sqrt{1+(2 . \pi / \delta)^{2}}}
$$

Sendo:

$\delta$ o valor do decremento logarítmico entre duas medidas de amplitudes $x_{0}$ e $x_{p}$ distanciadas por $p$ ciclos (número de períodos), dado pela Equação 2.45 .

$$
\delta=\frac{1}{p} \cdot \ln \left(\frac{x_{0}}{x_{p}}\right)=\frac{1}{p} \cdot \ln \left(\frac{x(t)}{x\left(t+p \cdot T_{p}\right)}\right)=\frac{2 \cdot \pi \cdot \zeta}{\sqrt{1-\zeta^{2}}}
$$


Sendo:

$T_{p}$ o valor do período constante de um sistema subamortecido em vibração livre, indicado pela Equação 2.46.

$$
T_{p}=\frac{2 . \pi}{\omega_{d}}
$$

Ainda, para pequenos valores de $\zeta(\zeta<0,1)$ pode-se escrever a Equação 2.47 .

$$
\delta \cong 2 . \pi . \zeta
$$

Deve-se salientar que a decadência da amplitude apenas indica que existe a dissipação de energia. Porém, a totalidade da dissipação energética pode ser a soma de parcelas como o amortecimento do material, atritos em juntas e fissuras e devido à ligação nos apoios.

Outra forma de estimar o amortecimento é um ajuste visual. Cria-se uma curva teórica da resposta vibratória, ajustando-se o fator de amortecimento até que a curva teórica fique sobrescrita a curva real. Este processo é denominado de fitting. Ou seja, o procedimento consiste em ajustar as variáveis da Equação 2.12 variando o fator de amortecimento até que a curva teórica descrita pela Equação 2.12 seja igual a curva do sinal obtido experimentalmente.

\subsubsection{Largura de Banda ou Meia Potência}

Franceschini e Gomes (2010) descrevem resumida e didaticamente o método da meia potência. Nesse método o fator de amortecimento é determinado das frequências para as quais o fator de magnificência dinâmica $M$ seja o valor dado pela Equação 2.48.

$$
M=\frac{M_{\text {máx }}}{\sqrt{2}}=\frac{1}{2 \cdot \zeta \cdot \sqrt{2}}
$$

A equação da magnificação dinâmica $M$ é dada pela Equação 2.49:

$$
M=\frac{x}{F_{0} / k}=\frac{x}{X_{0}}=\frac{1}{\sqrt{\left(1-\beta^{2}\right)^{2}+(2 . \zeta . \beta)^{2}}}
$$

Sendo:

$M$ o fator de magnificação dinâmica;

$X$ o deslocamento da estrutura em um determinado ponto, devido à vibração;

$X_{0}$ o deslocamento estático da estrutura;

$k$ a constante de mola;

$\zeta$ o fator de amortecimento;

$\beta$ a razão entre a frequência excitadora e a frequência natural da estrutura. 
Com o desenvolvimento das Equações 2.48 e 2.49 encontra-se a Equação 2.50.

$$
\beta^{2}=1-2 . \zeta^{2} \pm 2 \cdot \zeta \cdot \sqrt{\zeta^{2}-1}
$$

Desprezando-se os valores de $\zeta^{2}$, obtêm-se as Equações 2.51 e 2.52 .

$$
\begin{aligned}
& \beta_{1}^{2}=1-2 . \zeta \\
& \beta_{2}^{2}=1+2 . \zeta
\end{aligned}
$$

Subtraindo-se a Equação 2.51 da 2.52 e fazendo-se $\beta_{1}+\beta_{2} \approx 2$ (Figura 2.18), chegase à Equação 2.53 que indica o valor do fator de amortecimento.

$$
\begin{aligned}
& \beta_{2}^{2}-\beta_{1}^{2}=1+2 \cdot \zeta-1+2 \cdot \zeta=4 \cdot \zeta=\left(\beta_{2}-\beta_{1}\right) \cdot \underbrace{\beta_{2}+\beta_{1}}_{\approx 2}) \\
& \therefore \\
& \zeta=\frac{1}{2} \cdot\left(\beta_{2}-\beta_{1}\right)
\end{aligned}
$$

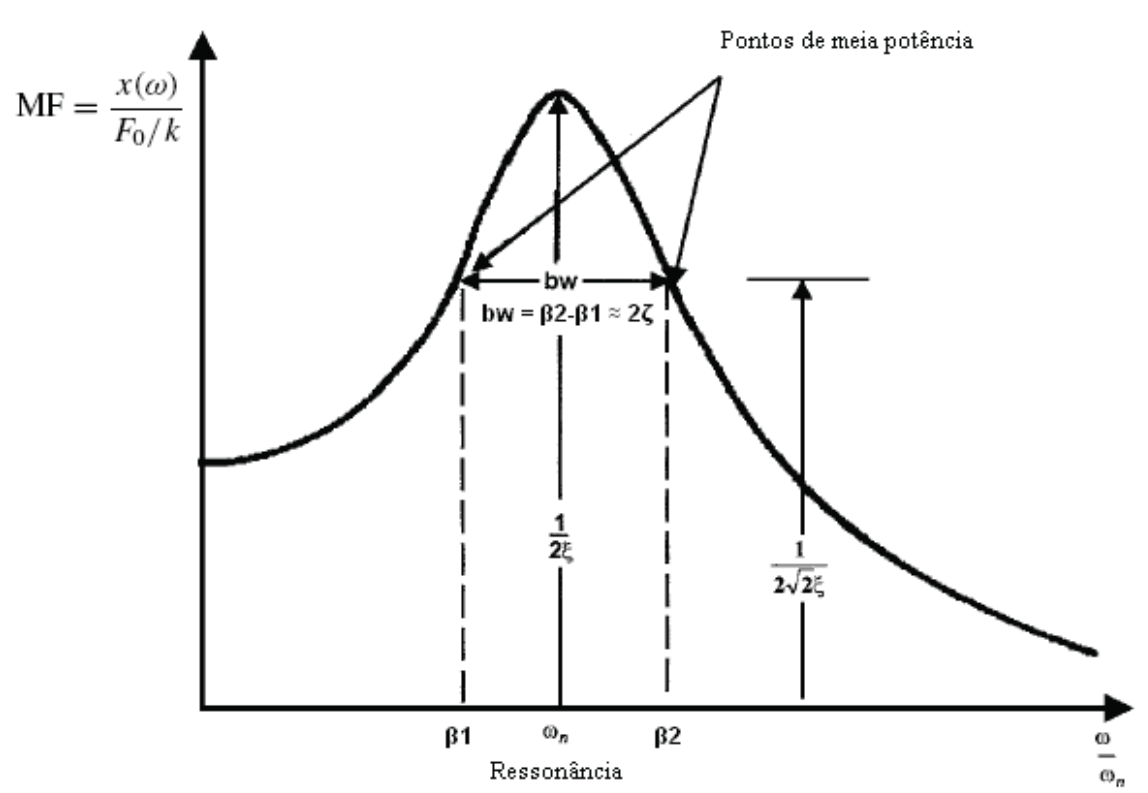

Figura 2.18 - Curva esquemática utilizada para a determinação do fator de amortecimento no método da meia potência.

Fonte: Franceschini e Gomes (2010), p. 43.

Ainda conforme Franceschini e Gomes (2010, p. 43):

"Experimentalmente este gráfico (Figura 2.4) pode ser obtido por meio da excitação harmônica da estrutura sob amplitude de força constante e uma varredura em frequência nos limites de frequência de interesse, medindo-se a amplitude da resposta da estrutura em deslocamento, para cada frequência excitada, dividida pela resposta estática para a mesma força com frequência nula. Alternativamente este gráfico também pode ser obtido fazendo-se a Transformada de Fourier da resposta em aceleração do sistema dividida pelo quadrado da respectiva frequência, sendo este sistema submetido a uma vibração livre amortecida, provocada por um impacto na estrutura." 


\subsection{Caracterização dinâmica do concreto}

Este item trata sobre o módulo de elasticidade dinâmico. É também descrita resumidamente a característica de amortecimento das estruturas de concreto.

A utilização de ensaios dinâmicos para caracterização do material apresenta grande vantagem em relação a processos destrutivos. Por exemplo, Diógenes et al. (2011) afirmam que o monitoramento da qualidade do concreto pode ser realizado durante toda a vida útil da estrutura, através do mesmo corpo de prova.

Diógenes et al. (2012) afirmam que as técnicas experimentais para a determinação de propriedades do material são divididas em três grupos: 1) excitação por impulso; 2) velocidade sônica (ultrassom) e 3) frequência de ressonância. Malhotra (1986) apresenta o diagrama da Figura 2.19, na qual são apresentados vários métodos de caracterização dinâmica. Observa-se na Figura 2.19 que a quantidade de métodos é grande, gerando a possibilidade de inúmeros instrumentos e equipamentos de avaliação.

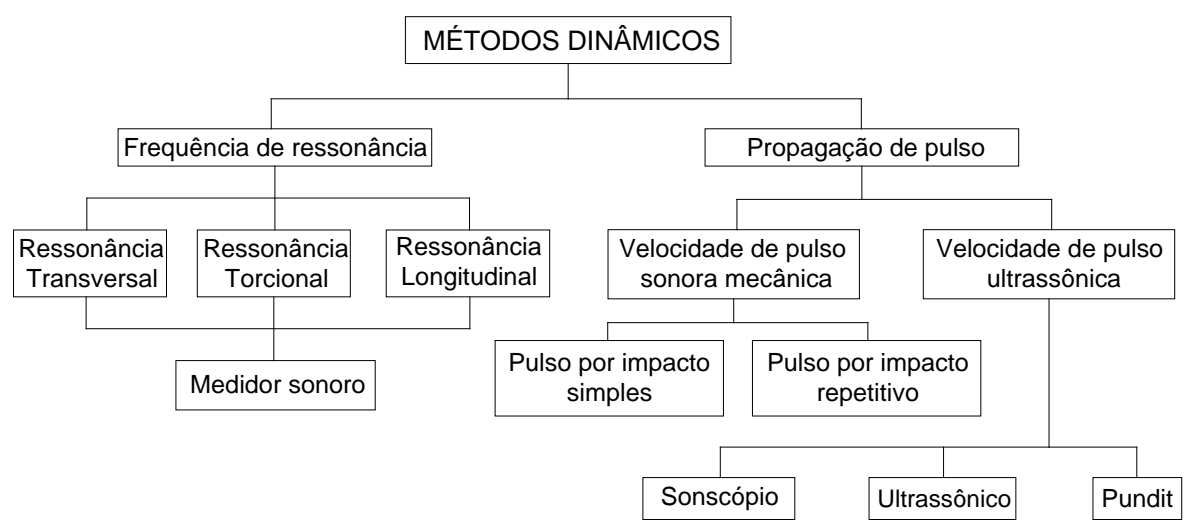

Figura 2.19 - Métodos dinâmicos para caracterização do concreto.

Fonte: Malhotra (1986), p. 54.

Segundo Diógenes et al. (2012), na técnica da frequência de ressonância obtém-se a frequência fundamental de ressonância do elemento estrutural ensaiado (prismático ou cilíndrico), e é uma das mais difundidas na engenharia. É utilizada tanto em laboratório quanto em estruturas reais, seja para a determinação do módulo de elasticidade dinâmico, do coeficiente de Poisson dinâmico, da rigidez dinâmica, do amortecimento do material ou de outro parâmetro qualquer.

Diógenes et al. (2012) ainda comentam que na técnica de excitação por impulso, o corpo de prova é sustentado por fios nos pontos nodais. No sentido de vibração de interesse, o corpo de prova recebe um leve impacto que o induz a uma resposta acústica. Essa resposta é 
composta por uma ou mais frequências naturais de vibração, das quais é calculado o módulo de elasticidade.

Já a técnica de velocidade sônica baseia-se no tempo de propagação (flight time) de um pulso sônico ou ultrassônico de curta duração ao longo do corpo de prova (frequência acima de $20 \mathrm{kHz}$ ), sendo essa técnica regulamentada pela ASTM C597:2009. Entretanto, uma grande incerteza na medida está na estimativa do coeficiente de Poisson, conforme Malhotra (1986), já que apenas a velocidade longitudinal do som é medida e seria necessário conhecer também a velocidade transversal. Sendo assim, os erros na medida são proporcionais à dispersão entre o valor real do coeficiente de Poisson e o estimado. Neville (1997) considera que essa técnica não apresenta confiabilidade, já que alguns parâmetros podem acarretar alteração no valor do módulo de elasticidade de até 11\%.

Diógenes et al. (2011) comenta o funcionamento do sistema Sonelastic ${ }^{\circledR}$, desenvolvido pela ATCP - Engenharia Física, para a caracterização não destrutiva de módulos de elasticidade e do amortecimento de materiais, a partir das frequências naturais obtidas pela técnica de excitação por impulso, e que respeita a ASTM - C215:2008. Nesse sistema de aquisição, o módulo de elasticidade e o amortecimento são calculados a partir do som emitido pelo corpo de prova ao sofrer um impacto. Essa resposta acústica é composta pela frequência natural do corpo de prova, que é proporcional ao módulo de elasticidade associado à direção da vibração. A Figura 2.20 ilustra o funcionamento do Sonelastic ${ }^{\circledR}$.

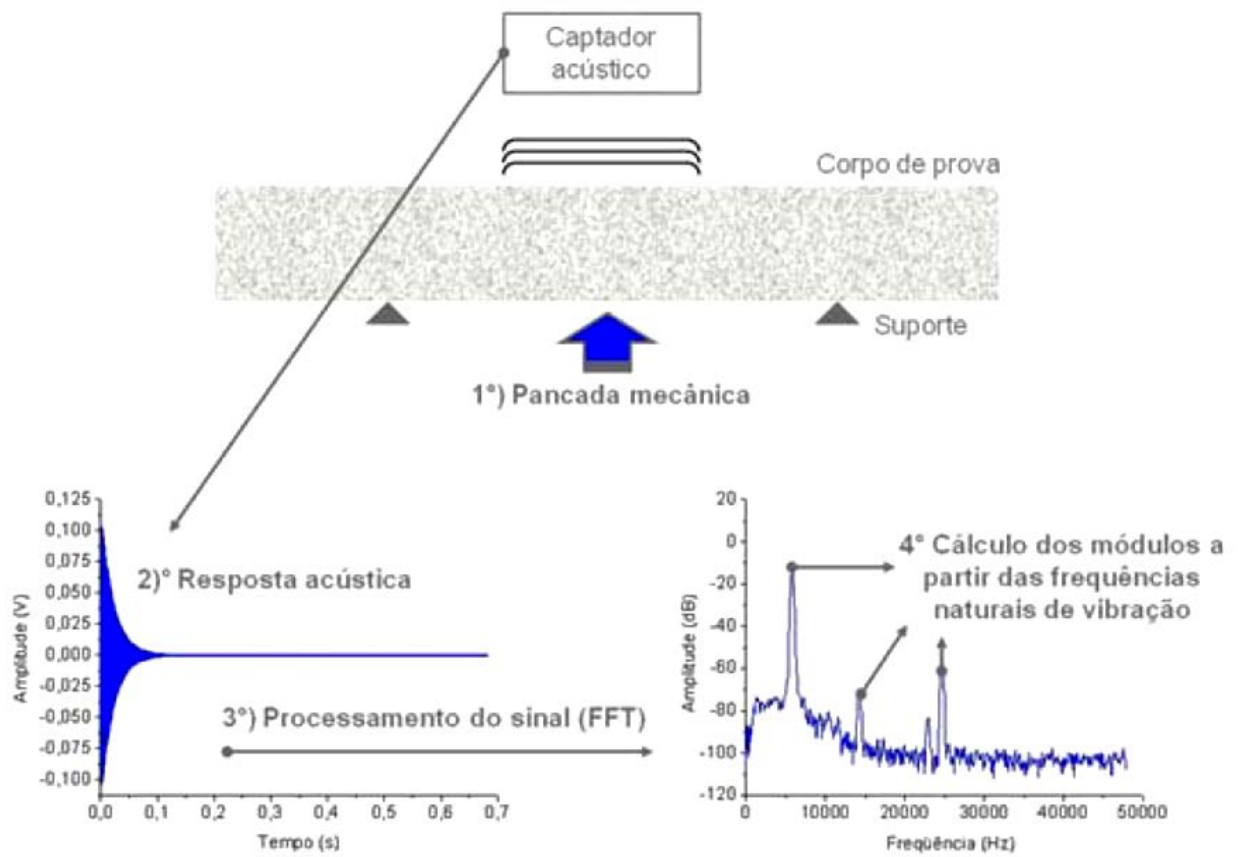

Figura 2.20 - Princípio de funcionamento do Sonelastic ${ }^{\circledR}$.

Fonte: Diógenes et al. (2012), p. 3. 
Comentando o Sonelastic ${ }^{\circledR}$, Diógenes et al.(2011), na página 805, ainda afirmam que:

"Para geometrias simples, como barra, cilindro, disco e placa, existe uma relação unívoca entre as frequências naturais com as dimensões e a massa do corpo de prova, parâmetros que podem ser facilmente medidos com um paquímetro e uma balança.

Conhecendo-se as dimensões, a massa e as frequências naturais de vibração, o cálculo do módulo de elasticidade é imediato. O amortecimento nesse sistema de aquisição é calculado a partir do decremento logarítmico da amplitude de vibração, a partir da taxa de atenuação do sinal.”

A particularidade do Sonelastic ${ }^{\circledR}$ está no fato de que a resposta acústica do corpo de prova é capturada empregando um captador acústico (microfone simples), ao invés da utilização de um acelerômetro fixado ao corpo de prova, como ocorre na maioria dos sistemas de aquisição convencionais para ensaios não destrutivos. Outro aspecto importante desse sistema consiste em não demandar hardwares adicionais, pelo fato de serem utilizadas as placas de áudio já disponíveis nos computadores atuais.

Captado o sinal é feita a FFT (Fast Fourier Transform - Transformada Rápida de

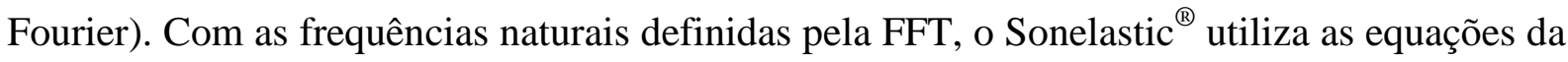
ASTM E1876-1:2005 para o cálculo do módulo de elasticidade dinâmico flexional, longitudinal e transversal [ATCP (2012)]. Nas Equações 2.54, 2.57 e 2.60 são reproduzidas as equações da ASTM E1876-1:2005 para cálculo de módulos de elasticidade dinâmicos flexionais, longitudinais e transversais, respectivamente, para corpos de prova cilíndricos.

$$
E_{f}=1,6067 \cdot\left(L^{3} / D^{4}\right) \cdot\left(m \cdot f^{2}\right) \cdot T_{1}^{\prime}
$$

Sendo:

$E_{f}$ o módulo de elasticidade dinâmico flexional (Pa);

$L$ o comprimento do corpo de prova (mm);

$D$ o diâmetro do corpo de prova (mm);

$m$ a massa do corpo de prova (g);

$f$ a frequência fundamental para a barra em modo flexional $(\mathrm{Hz})$;

$v$ o coeficiente de Poisson;

$T_{1}^{\prime}$ um fator de correção dado pela Equação 2.55:

$$
\begin{aligned}
& T_{1}^{\prime}=1+4,939 \cdot\left(1+0,0752 \cdot v+0,8109 \cdot v^{2}\right) \cdot(D / L)^{2}-0,4883 \cdot(D / L)^{4}+ \\
& -\left[\frac{4,691 \cdot\left(1+0,2023 \cdot v+2,173 \cdot v^{2}\right) \cdot(D / L)^{4}}{1+4,754 \cdot\left(1+0,1408 \cdot v+1,536 \cdot v^{2}\right) \cdot(D / L)^{2}}\right]
\end{aligned}
$$

A incerteza envolvida na quantificação do módulo de elasticidade dinâmico flexional é dada pela Equação 2.56 . 


$$
\Delta E_{f}=\frac{2 . E}{1,73205} \cdot \sqrt{\left(\frac{3 . \Delta L}{L}\right)^{2}+\left(\frac{4 . \Delta D}{D}\right)^{2}+\left(\frac{\Delta m}{m}\right)^{2}+\left(\frac{2 . \Delta f}{f}\right)^{2}+\left(\frac{\Delta v}{40 . v}\right)^{2}}
$$

O módulo de elasticidade dinâmico longitudinal é dado pela Equação 2.57.

$$
E_{\ell}=16 \cdot m \cdot f_{l}^{2} \cdot\left(L / \pi \cdot D^{2} \cdot K\right)
$$

Sendo:

$E_{\ell}$ o módulo de elasticidade dinâmico longitudinal (Pa);

$L$ o comprimento do corpo de prova (mm);

$D$ o diâmetro do corpo de prova (mm);

$m$ a massa do corpo de prova (g);

$f_{l}$ a frequência fundamental para a barra em modo longitudinal (Hz);

$v$ o coeficiente de Poisson;

$K$ um fator de correção dado pela Equação 2.58:

$$
K=1-\left[\left(\pi^{2} \cdot v^{2} \cdot D^{2}\right) /\left(8 \cdot L^{2}\right)\right]
$$

A incerteza envolvida na quantificação do módulo de elasticidade dinâmico longitudinal é dada pela Equação 2.59 .

$$
\Delta E=\frac{2 . E}{1,73205} \cdot \sqrt{\left(\frac{\Delta L}{L}\right)^{2}+\left(\frac{2 . \Delta D}{D}\right)^{2}+\left(\frac{\Delta m}{m}\right)^{2}+\left(\frac{2 . \Delta f_{l}}{f_{l}}\right)^{2}+\left(\frac{\Delta v}{40 . v}\right)^{2}}
$$

O módulo de elasticidade dinâmico transversal é dado pela Equação 2.60.

$$
G=16 \cdot m \cdot f_{t}^{2} \cdot\left(L / \pi \cdot D^{2}\right)
$$

Sendo:

G o módulo de elasticidade dinâmico transversal (Pa);

$L$ o comprimento do corpo de prova;

$D$ o diâmetro do corpo de prova;

$m$ a massa do corpo de prova;

$f_{t}$ a frequência fundamental para a barra em modo torcional $(\mathrm{Hz})$.

A incerteza envolvida na quantificação do módulo de elasticidade dinâmico transversal é dada pela Equação 2.61.

$$
\Delta G=\frac{2 . G}{1,73205} \cdot \sqrt{\left(\frac{\Delta L}{L}\right)^{2}+\left(\frac{2 . \Delta D}{D}\right)^{2}+\left(\frac{\Delta m}{m}\right)^{2}+\left(\frac{2 . \Delta f_{t}}{f_{t}}\right)^{2}}
$$


A Figura 2.21 ilustra o fluxograma para a determinação do módulo de elasticidade dinâmico, módulo de elasticidade dinâmico transversal e coeficiente de Poisson ( $v$ ou $\mu$ na Figura 2.21).

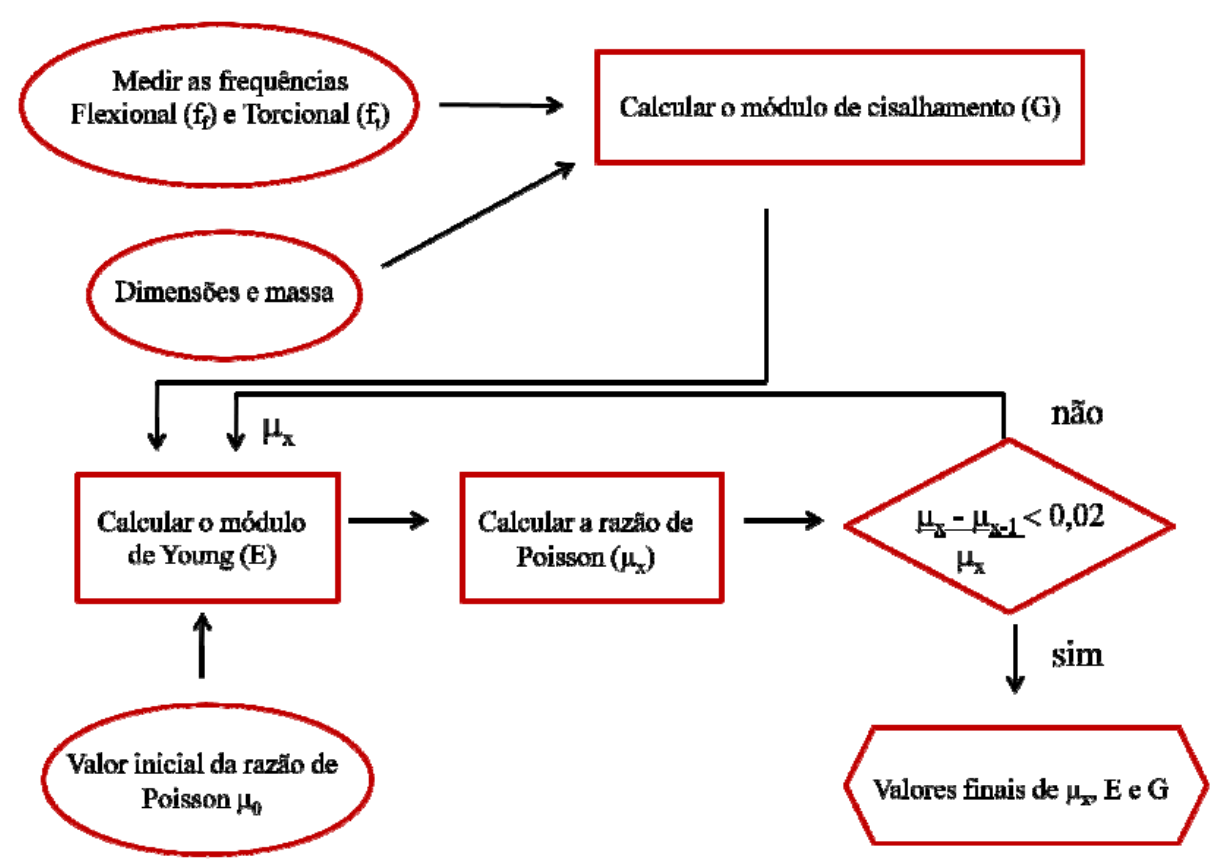

Figura 2.21 - Processo iterativo para a determinação simultânea de E, G e $\mu$ no Sonelastic ${ }^{\circledR}$. Fonte: Cossolino e Pereira (2010), p. 22.

\subsubsection{Comparação entre o módulo de elasticidade estático e o dinâmico}

Mehta e Monteiro (2008) deixam implícito o conceito de que o termo "módulo de elasticidade” ou “módulo de deformação elástico" somente poderia ser utilizado para a parte reta do diagrama tensão versus deformação, e na ausência dessa parte reta, deveria ser usado para a reta tangente na origem. O módulo de elasticidade estático do concreto, por ser medido da declividade de retas em relação à curva tensão versus deformação não linear, é medido de quatro formas básicas, ilustradas na Figura 2.22. O termo “módulo de elasticidade”, apesar de ser reconhecido mundialmente, deveria ser denominado como “módulo de Young”.

Primeiramente, tem-se o módulo tangente, que é dado pela declividade de uma linha traçada de forma tangente à curva de tensão versus deformação, em qualquer ponto. O módulo tangente inicial é a declividade da reta tangente ao início da curva tensão versus deformação do concreto.

Em segundo lugar tem-se o módulo secante, que é obtido pela declividade de uma reta traçada da origem até um ponto da curva tensão versus deformação, que corresponde geralmente à tensão de $40 \%$ da tensão de ruptura. 


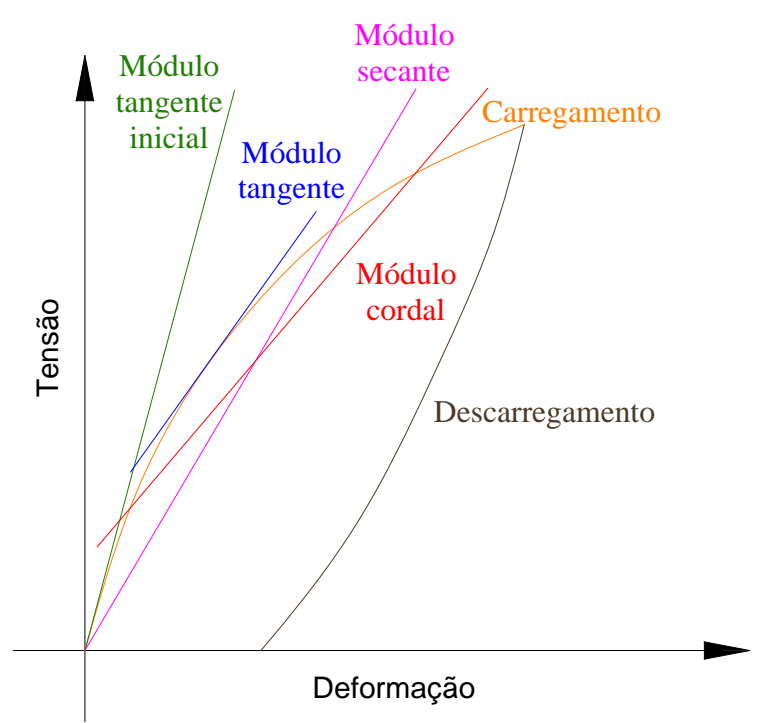

Figura 2.22 - Tipos de módulo de elasticidade estático para o concreto.

Fonte: Neville e Brooks (2013), p. 208.

Finalmente tem-se o módulo cordal, obtido pela declividade de uma reta traçada entre dois pontos da curva tensão versus deformação.

Entretanto, para a análise de estruturas que são submetidas a terremotos ou a forças de impacto, é mais apropriada a utilização do módulo de elasticidade dinâmico. Também a análise dinâmica de conforto deve ser avaliada com esse módulo. Esse módulo geralmente é 20\%, 30\% ou 40\% maior que o módulo estático, conforme Mehta e Monteiro (2008). Porém, esses autores não afirmam qual módulo estático seria esse.

Diógenes et al. (2011) afirmam que a dificuldade para determinação de um módulo de elasticidade estático advém da não linearidade da curva tensão versus deformação, o que não acontece com o módulo de elasticidade dinâmico ( $\left.E_{c, d}\right)$, facilmente obtido sem interferência direta na amostra, isto é, sem provocar fissuração da amostra, como ocorre no ensaio estático destrutivo.

O $E_{c, d}$ pode fornecer informações a respeito da deformabilidade do concreto, da rigidez de um elemento estrutural, de suas ligações com outros elementos bem como da integridade da estrutura, inclusive quando submetidas a ações estáticas. A qualidade e a reprodutibilidade dos resultados dos ensaios dinâmicos fazem com que o módulo dinâmico seja um parâmetro global, obtido de maneira integrada e com um alto grau de precisão, podendo ser medido em um mesmo corpo de prova durante um bom período da vida útil da estrutura. Sendo assim, o $E_{c, d}$ é empregado em ensaios que avaliam as alterações do concreto frente a ataques químicos e a ciclos de congelamento e descongelamento, dando ao ensaio não 
destrutivo de módulo de elasticidade qualidades de avaliação da durabilidade estrutural (DIÓGENES et al., 2011).

Neville (1997) comenta que na determinação do $E_{c, d}$ é aplicada uma tensão muito baixa no corpo de prova, não induzindo nenhuma microfissura e não ocorrendo fluência. Assim, o $E_{c, d}$ refere-se a efeitos quase que puramente elásticos, sendo próximo ao valor do módulo tangente inicial estático. No entanto, devido à heterogeneidade do concreto, não é esperada uma relação simples entre o $E_{c, d}$ e os módulos estáticos.

Conforme Neville (1997), p. 421:

"A relação entre o módulo de elasticidade estático e o módulo dinâmico, que é
sempre menor do que a unidade, é tanto maior quanto maior a resistência do
concreto e, provavelmente por esse motivo, aumenta com a idade. Essa relação
variável entre os módulos significa que não existe uma forma simples de, a partir do
valor do módulo dinâmico $E_{c, d}$, que é fácil de ser determinado, obter um valor
estimado do módulo estático $E_{c}$, cujo conhecimento é necessário para projetos
estruturais.”

Não obstante, Neville (1997) apresenta quatro relações simples (Equações 2.62 a 2.65) como segue:

- Lyndon e Balandran:

$$
E_{c}=0,83 \cdot E_{c, d}
$$

Sendo:

$E_{c}$ o módulo de elasticidade estático;

$E_{c, d}$ o módulo de elasticidade dinâmico.

- Código Britânico BS 8110-2:2001:

$$
E_{c}=1,25 \cdot E_{c, d}-19
$$

Sendo:

$E_{c}$ o módulo de elasticidade estático em GPa;

$E_{c, d}$ o módulo de elasticidade dinâmico em GPa.

Para concretos com mais de $500 \mathrm{~kg}$ de cimento por metro cúbico e concretos com agregados leves, deve ser utilizada a Equação 2.64.

$$
E_{c}=1,04 \cdot E_{c, d}-4,1
$$

Sendo:

$E_{c}$ o módulo de elasticidade estático em GPa;

$E_{c, d}$ o módulo de elasticidade dinâmico em GPa. 
- Popovics:

$$
E_{c}=k \cdot E_{c, d}^{1,4} \cdot \rho^{-1}
$$

Sendo:

$E_{c}$ o módulo de elasticidade estático;

$E_{c, d}$ o módulo de elasticidade dinâmico;

$k$ uma constante que depende das unidades de medida;

$\rho$ a massa específica do concreto.

Quando submetido a ações dinâmicas, as propriedades do material podem aumentar ou diminuir segundo Bachmann et al. (1997). Esses autores apresentam relações entre o módulo de elasticidade estático e o dinâmico em função da taxa de variação de deformação no tempo (Equação 2.66) e da taxa de variação de tensão no tempo (Equação 2.67).

$$
\begin{aligned}
& \dot{\varepsilon}=\frac{d \varepsilon}{d t} \\
& \dot{\sigma}=\frac{d \sigma}{d t}
\end{aligned}
$$

Sendo:

$\dot{\varepsilon}$ a taxa de variação da deformação no tempo;

$\dot{\sigma}$ a taxa de variação da tensão no tempo;

$d \varepsilon$ a variação da deformação;

$d \sigma$ a variação da tensão;

$d t$ a variação do tempo.

Com essas taxas de variação, Bachmann et al. (1997) apresentam as Equações 2.68 a 2.71, que relacionam os módulos estático e dinâmico em função das taxas de variação, com base em uma taxa de variação inicial. Observa-se que quando a velocidade de carregamento dinâmico é menor, a diferença entre os módulos diminui (Equações 2.70 e 2.71). Ainda é comentado que nos casos de ações dinâmicas diferentes de impactos, o acréscimo no valor do módulo dinâmico sobre o estático não supera $20 \%$.

$$
\begin{aligned}
& E_{c, d} / E_{c}=\left(\dot{\sigma} / \dot{\sigma}_{0}\right)^{0,025} \text { com } \dot{\sigma}_{0}=1 \mathrm{~N} / \mathrm{mm}^{2} . \mathrm{s} \\
& E_{c, d} / E_{c}=\left(\dot{\varepsilon} / \dot{\varepsilon}_{0}\right)^{0,026} \text { com } \dot{\varepsilon}_{0}=30 \times 10^{-6} \mathrm{~s}^{-1} \\
& E_{c, d} / E_{c}=\left(\dot{\sigma} / \dot{\sigma}_{0}\right)^{0,016} \text { com } \dot{\sigma}_{0}=0,1 \mathrm{~N} / \mathrm{mm}^{2} . s \\
& E_{c, d} / E_{c}=\left(\dot{\varepsilon} / \dot{\varepsilon}_{0}\right)^{0,016} \text { com } \dot{\varepsilon}_{0}=3 \times 10^{-6} \mathrm{~s}^{-1}
\end{aligned}
$$


Sendo:

$\dot{\varepsilon}_{0}$ a taxa de variação da deformação no tempo inicial;

$\dot{\sigma}_{0}$ a taxa de variação da tensão no tempo inicial.

Descrevendo a comparação entre o módulo estático e o dinâmico, Malhotra (1986) destaca os seguintes pontos:

- O módulo dinâmico é geralmente maior que o estático. A diferença entre os dois depende do grau de precisão e do preparo dos experimentos, bem como da aplicação de fatores de correção corretos para o módulo dinâmico;

- A idade das amostras eleva a relação entre módulo estático e dinâmico. Amostras mais antigas tendem a ter uma relação tendendo a 1,0, isto é, quase igualdade entre o módulo estático e o dinâmico;

- Para altos valores do módulo estático, os módulos estático e dinâmico mostram concordância.

Neville (1997) ainda comenta que se acredita que qualquer relação entre os módulos estático e dinâmico não seja influenciada pelo ar incorporado, pelo método de cura, pela condição do ensaio ou pelo tipo de cimento utilizado.

Por outro lado, Malhotra (1986) apresenta uma série de fatores que influenciam a determinação do $E_{c, d}$, descritos resumidamente em seguida:

- Proporções da mistura e propriedades dos agregados: o $E_{c, d}$ é afetado pelo módulo dos materiais constituintes do concreto. O módulo de elasticidade aumenta com o acréscimo da taxa de agregados, para um concreto com teor de cimento e relação água/cimento constantes. Observou-se que o aumento da quantidade de água e de ar incorporado afetou adversamente o $E_{c, d}$;

- Efeito do tamanho da amostra: o tamanho do corpo de prova influência o valor de $E_{c, d}$. Amostras maiores, devido ao seu tamanho e peso maiores, possuem frequências ressonantes menores. Entretanto, Malhotra (1986) descreve que maiores valores de $E_{c, d}$ foram obtidos em corpos de prova maiores do que nos de menor tamanho;

- Condições de cura: o $E_{c, d}$ é grandemente reduzido após 48 horas de secagem ao ar. Após esse período, a redução é bem menor se o corpo de prova é exposto ao ar. O aumento da temperatura durante a cura eleva o valor do módulo. Entretanto, deve-se observar que o aumento da temperatura pode provocar uma dilatação e posterior retração do concreto, 
gerando fissuração. $\mathrm{O}$ concreto mantido úmido apresenta uma elevação no $E_{c, d}$ com o decorrer do tempo, quando comparado ao mesmo concreto seco;

- Resistência e idade do concreto: Diógenes et al. (2011) afirmam que a elevação da resistência e o aumento da idade do concreto tendem a elevar o valor do $E_{c, d}$. Para as mesmas condições de cura, o $E_{c, d}$ aumenta com a elevação da resistência. A Figura 2.23 ilustra a variação da relação entre os módulos estático e dinâmico com o aumento da resistência que ocorre ao longo do tempo. Observa-se que a relação tende a estabilizar em um valor da ordem de 0,8 .

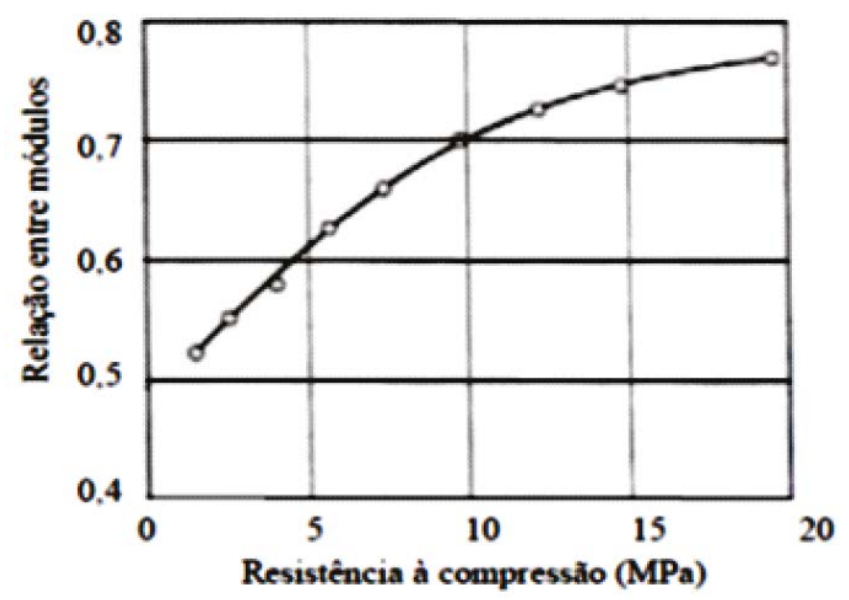

Figura 2.23 - Relação de módulos (estático/dinâmico) em função da resistência à compressão. Fonte: Diógenes et al. (2011), p. 806.

\subsubsection{Amortecimento de estruturas de concreto}

As propriedades do amortecimento de estruturas de concreto armado e protendido são descritas por Bachmann et al. (1997). O amortecimento de tais estruturas em um intervalo semielástico (antes do escoamento do aço) depende principalmente do estado de fissuração da peça, o qual depende fortemente do nível de tensão.

Na Figura 2.24 é representado o gráfico que descreve o desenvolvimento do fator de amortecimento $\zeta$ em função do nível de tensão em uma viga simplesmente apoiada sujeita a tensões devidas à flexão.

A Tabela 2.2 apresenta valores de referência para o fator de amortecimento de diferentes materiais. Vale destacar que o amortecimento de uma estrutura engloba o valor do amortecimento do material puro e o valor do amortecimento das ligações estruturais. 
Observando-se a Figura 2.24 e a Tabela 2.2, verifica-se que para uma baixa intensidade de tensão, correspondente ao estado não fissurado da peça (Estádio I), o fator de amortecimento é relativamente pequeno $(\zeta<0,01)$, e é caracterizado como viscoso.

Com a formação de fissuras, o amortecimento começa a crescer, e com o final da fissuração (ainda com tensões relativamente baixas) o amortecimento é máximo, com o dobro ou o triplo do valor inicial. Nessa faixa, o amortecimento possui uma parcela menor de amortecimento viscoso e uma parcela preponderante de amortecimento por atrito seco.

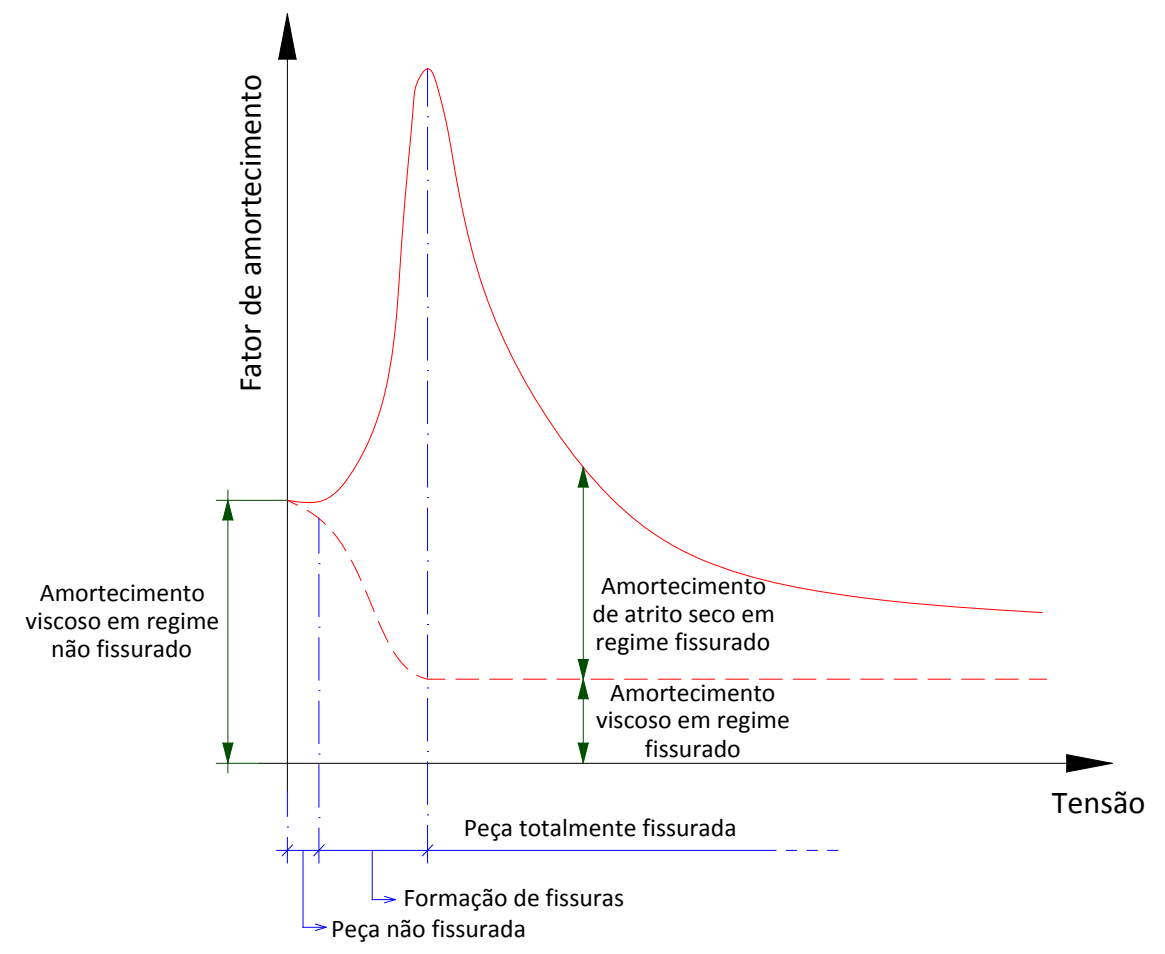

Figura 2.24 - Fator de amortecimento equivalente de uma peça de concreto armado em diferentes estados de tensão.

Fonte: Bachmann et al. (1997), p. 165.

Tabela 2.2: Fator de amortecimento viscoso equivalente para diferentes materiais.

\begin{tabular}{|l|c|}
\hline \multicolumn{1}{|c|}{ Material } & $\zeta$ \\
\hline Concreto armado não fissurado. & $0,007-0,010$ \\
\hline Concreto armado com fissuração completa, porém com baixo nível de tensão. & $0,010-0,040$ \\
\hline $\begin{array}{l}\text { Concreto armado com fissuração completa, alto nível de tensão, porém sem } \\
\text { escoamento do aço. }\end{array}$ & $0,005-0,008$ \\
\hline Concreto protendido não fissurado. & $0,004-0,007$ \\
\hline Concreto protendido levemente fissurado (protensão limitada e parcial). & $0,008-0,012$ \\
\hline Compósitos. & $0,002-0,003$ \\
\hline Aço. & $0,001-0,002$ \\
\hline
\end{tabular}

Fonte: Bachmann et al. (1997), p. 166. 
Entretanto, com a elevação da tensão, o amortecimento diminui rapidamente, devido à abertura das fissuras, e tende a estabilizar com um valor menor que o inicial, devido somente ao amortecimento viscoso.

\subsection{Aceitabilidade dos níveis vibratórios em estruturas de concreto}

O objetivo do presente item é a apresentação de alguns indicativos sobre a aceitabilidade dos níveis vibratórios em estruturas civis. A aceitabilidade dos níveis vibratórios pode ser avaliada levando-se em consideração o desempenho da estrutura (aspectos estruturais) e quanto à sensibilidade humana à vibração (aspectos humanos).

Porém, o tipo de excitação dinâmica influência grandemente nos níveis exigidos para aceitabilidade estrutural. Em outras palavras, uma estrutura submetida a excitações devidas à ação de máquinas apresenta limites de aceitabilidade às vibrações diferentes dos relativos à mesma estrutura submetida a ações de movimento humano. Assim sendo, neste trabalho, foi escolhida a análise de estruturas frente a ações dinâmicas humanas (ver Capítulo 8), em particular, a ação de caminhada. Então, aqui neste capítulo, são apresentados critérios da literatura técnica para a modelagem e a mensuração da atividade vibratória devida a movimentos do corpo humano.

As características dinâmicas de uma estrutura são significativamente influenciadas pela sua rigidez, geometria e massa. Comentando particularmente a rigidez, Krunka (2014) afirma que, a redução da rigidez estrutural, com o objetivo de transmitir uma perspectiva atraente para um edifício, leva à diminuição das frequências fundamentais e, portanto, dificulta o bom desempenho dinâmico da estrutura.

Barrett et al. (2006) afirmam que as medidas necessárias para resolver um problema de vibração exagerada, após a estrutura estar construída, tanto levando-se em conta os aspectos estruturais quanto os humanos, geralmente são de difícil implementação e de elevado custo. O enfrentamento do problema na fase de projeto torna as soluções potencialmente mais simples e econômicas. Os custos de uma intervenção pós-construção envolvem não somente os detalhes técnicos da solução, mas também possíveis despesas judiciais, taxas, receitas de aluguel do imóvel, entre outras.

Com a visão apresentada nos parágrafos anteriores, são indicados na sequência limites normativos e/ou recomendações para limitação do desconforto humano e da ineficiência estrutural devida a problemas vibratórios com a ação dinâmica provocada por pessoas em 
movimento sobre a estrutura. Obviamente os valores recomendados e limites apresentados não abrangem todas as indicações encontradas na literatura técnica. Entretanto, essas aqui apresentadas foram consideradas as mais relevantes para esta pesquisa.

\subsubsection{Forças dinâmicas oriundas da atividade humana}

Bachmann et al. (1997) afirmam que movimentos rítmicos do corpo humano, de uma ou mais pessoas, com duração de até 20 segundos ou mais, podem conduzir a forças dinâmicas de caráter periódico. As excitações humanas podem ser originadas no caminhar, correr, dançar, pular, bater palmas etc.

Jönsson e Hansen (1994) afirmam que o movimento humano pode causar vários tipos de cargas dinâmicas periódicas ou transientes. As cargas periódicas são principalmente devidas a saltar, correr, dançar, caminhar e balançar o corpo. Cargas transientes resultam principalmente de cargas de impulso único, como um salto único de uma posição mais elevada. Portanto, simples movimentos humanos comumente podem ser modelados como sendo periódicos. Isso é reafirmado por Krunka (2014) quando comenta que os movimentos de pular/saltar, correr, caminhar ou subir/descer uma escada são considerados de caráter periódico, e não transiente, pois representam uma sequência de cargas de impulso. Como uma carga transiente, pode ser categorizado um movimento que executa apenas um único impulso para a estrutura com efeitos decadentes depois de certo período de tempo.

Ampliando a visão do assunto, Murray et al. (2003) afirmam que um conjunto de várias pessoas somente gerará cargas periódicas quando em atividades rítmicas como dançar ou em ginástica aeróbica. Um grupo de pessoas andando ou correndo sem sincronismo gera uma força dinâmica que deve ser modelada como transiente. Portanto, ao caminhar uma pessoa sozinha tem sua força modelada como periódica. Entretanto, um passo apenas (passo isolado de uma pessoa) pode ser modelado como carregamento transiente.

A representação matemática do movimento humano em determinada atividade pode ser feito através de funções. A Figura 2.25 ilustra o diferente desenvolvimento de funções representativas de algumas atividades humanas. A Figura 2.26 ilustra as funções de força para corrida e caminhada descrevendo separadamente cada um dos pés de uma pessoa.

Nas ações humanas, é importante a consideração dos efeitos dos harmônicos mais elevados, pois eles representam uma parcela considerável da força dinâmica. Pavic e Reynolds (2002) ainda destacam que os harmônicos superiores nas ações humanas podem ser estimados com múltiplos inteiros da frequência do movimento humano, sendo capazes de 
provocar ressonância. As Figuras 2.27 a 2.30 ilustram, respectivamente, a descrição gráfica da função de força, o espectro discreto de força de Fourier, a representação gráfica da função de força e o espectro contínuo de amplitude de força de Fourier, de um movimento de salto com os dois pés juntos em um ponto fixo.
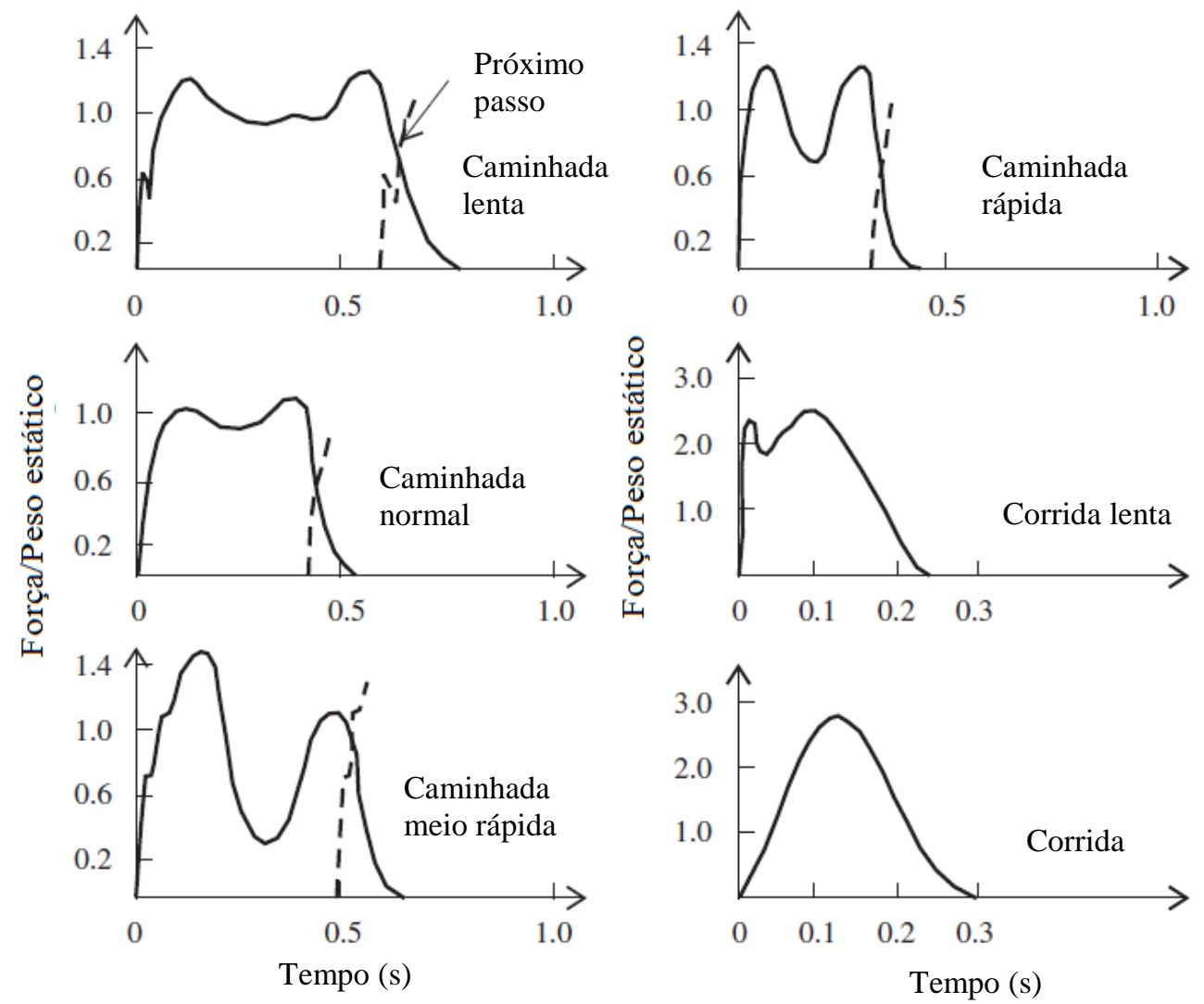

Figura 2.25 - Funções representativas de força versus tempo para atividades humanas.

Fonte: Racic, Pavic e Brownjohn (2009), p. 9.

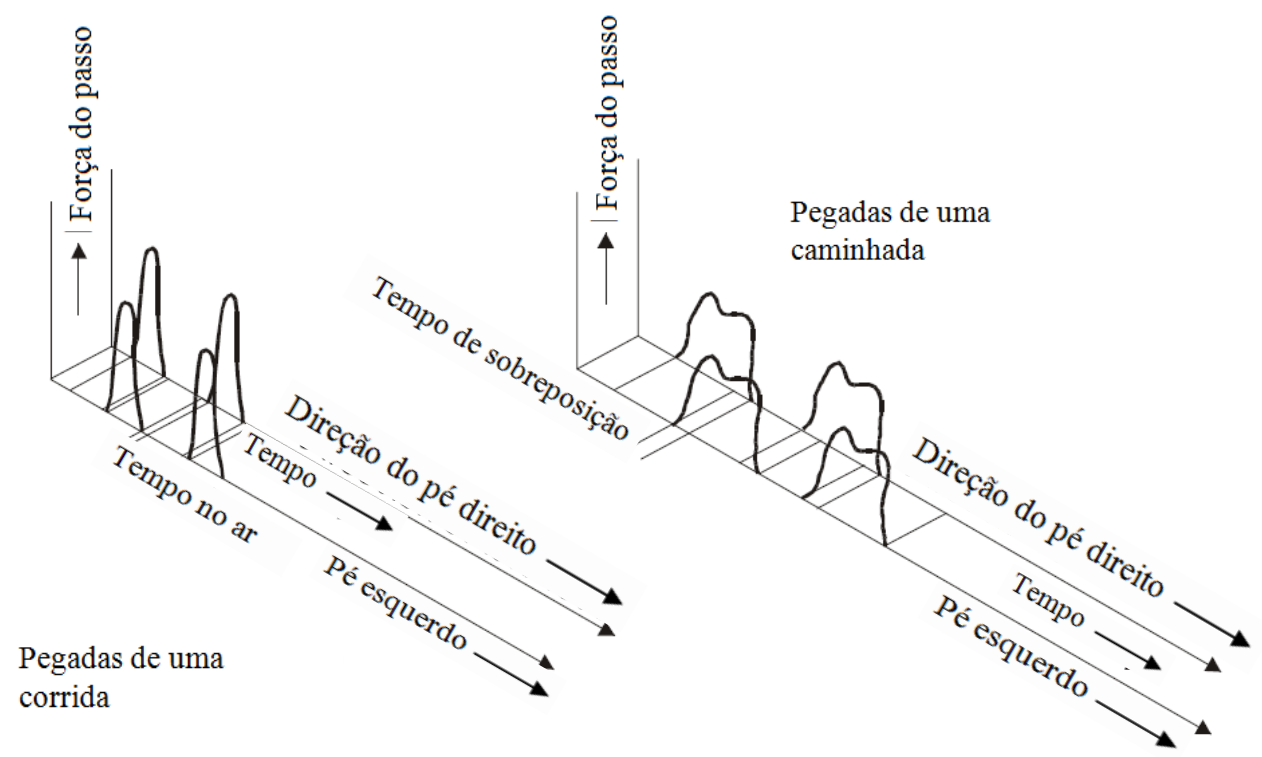

Figura 2.26 - Funções representativas de força versus tempo para corrida e caminhada. Fonte: Pavic e Reynolds (2002), p. 75. 


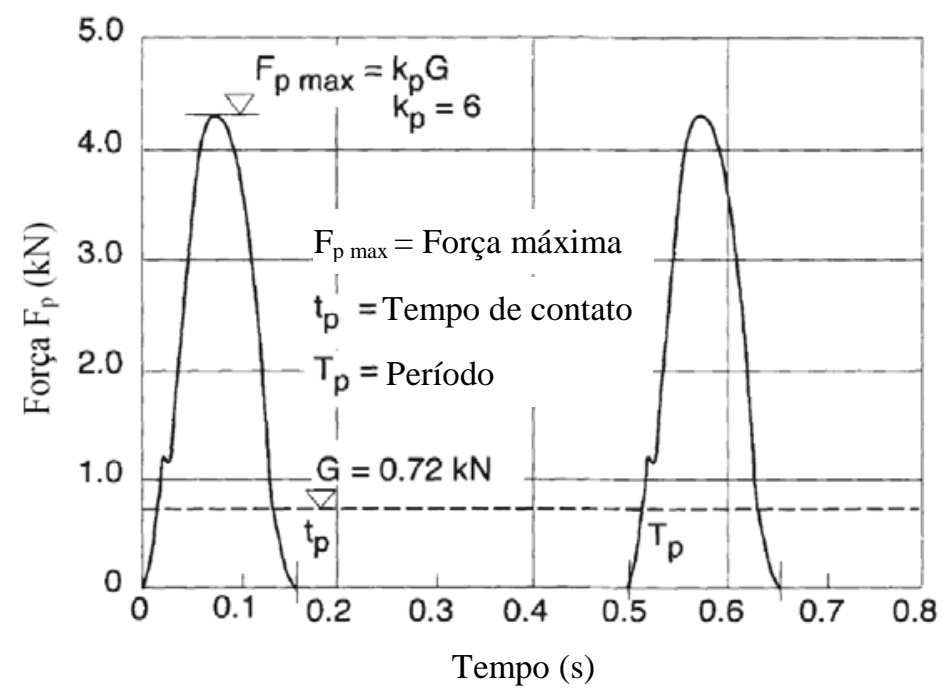

Figura 2.27 - Função de força do movimento de salto de uma pessoa com peso de 0,72 kN, com os dois pés juntos em um local fixo.

Fonte: Bachmann et al. (1997), p. 186.

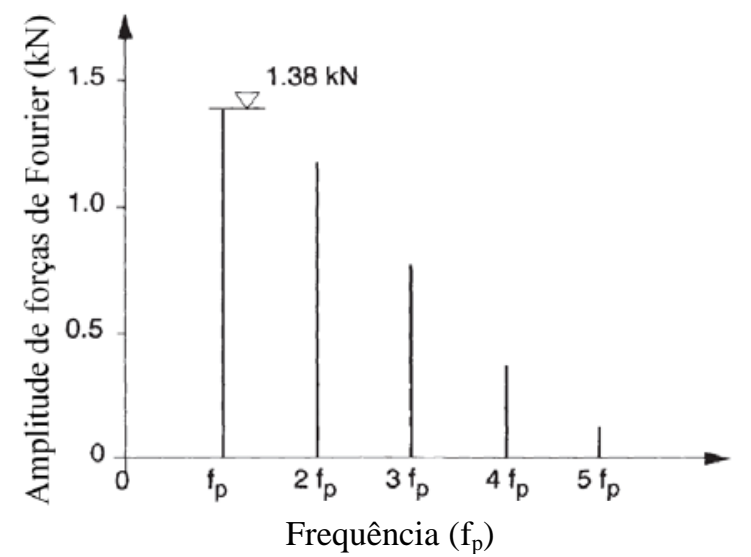

Figura 2.28 - Espectro discreto de amplitude de força de Fourier para o movimento descrito na Figura 2.27 até o quinto harmônico.

Fonte: Bachmann et al. (1997), p. 186.

Observa-se na Figura 2.28 que, além do primeiro harmônico, os demais também podem ser importantes na avaliação da força.

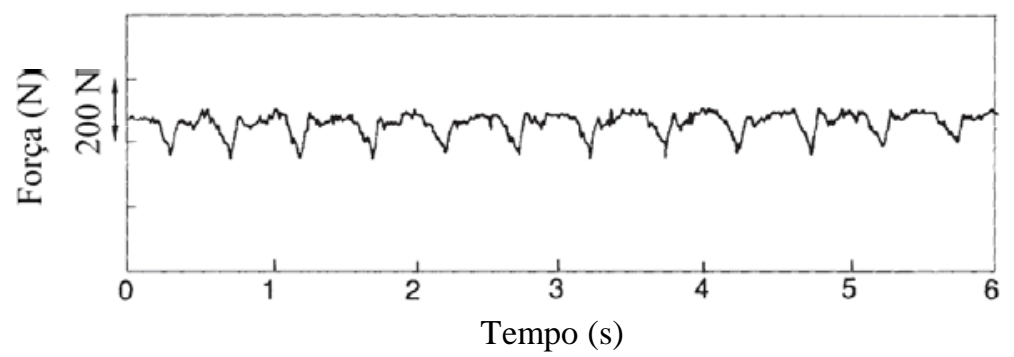

Figura 2.29 - Gráfico da força ao movımento aa Figura 2.27.

Fonte: Bachmann et al. (1997), p. 187. 


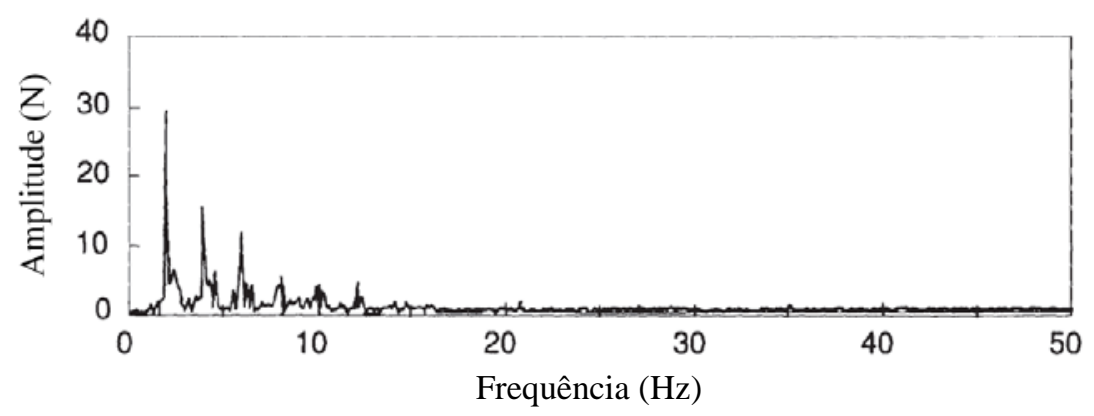

Figura 2.30 - Espectro contínuo de amplitude de Fourier do movimento da Figura 2.27.

Fonte: Bachmann et al. (1997), p. 187.

A Tabela 2.3 apresenta a faixa de frequência para algumas atividades humanas representativas.

Tabela 2.3: Tipos representativos de atividades humanas e sua aplicação em estruturas.

\begin{tabular}{|c|c|c|c|c|c|}
\hline \multicolumn{3}{|c|}{ Tipos representativos de atividades } & \multicolumn{3}{|c|}{ Gama de aplicação } \\
\hline Designação & Definição & $\begin{array}{c}\text { Faixa de } \\
\text { frequência } \\
\text { (Hz) }\end{array}$ & Atividade específica & $\begin{array}{c}\text { Frequência } \\
\text { da atividade } \\
(\mathrm{Hz})\end{array}$ & $\begin{array}{c}\text { Tipo de estrutura onde se } \\
\text { aplica }\end{array}$ \\
\hline \multirow{3}{*}{ Caminhada } & \multirow{3}{*}{$\begin{array}{l}\text { Andar com contato contínuo } \\
\text { com o piso. }\end{array}$} & \multirow{3}{*}{1,6 a 2,4} & Caminhada leve. & 1,7 & \multirow{3}{*}{$\begin{array}{l}\text { - Estruturas para pedestres } \\
\text { (passarelas, escadas, piers etc.); } \\
\text { - Construções de escritórios. }\end{array}$} \\
\hline & & & Caminhada normal. & 2,0 & \\
\hline & & & Caminhada rápida. & 2,3 & \\
\hline \multirow{3}{*}{ Corrida } & \multirow{3}{*}{$\begin{array}{l}\text { Corrida com contato } \\
\text { descontínuo com o piso. }\end{array}$} & \multirow{3}{*}{2,0 a 3,5} & Corrida leve. & 2,1 & \multirow{3}{*}{$\begin{array}{l}\text { - Passarela de pedestres ou pistas } \\
\text { de atletismo. }\end{array}$} \\
\hline & & & Corrida normal. & 2,5 & \\
\hline & & & Corrida rápida. & $>3,0$ & \\
\hline \multirow[t]{2}{*}{ Pular } & \multirow[t]{2}{*}{$\begin{array}{l}\text { Ritmo normal a alto de pulos } \\
\text { com os dois pés em contato } \\
\text { simultâneo com o piso. }\end{array}$} & \multirow[t]{2}{*}{1,8 a 3,4} & $\begin{array}{l}\text { Ginástica aeróbica com } \\
\text { pulos, saltos e corridas } \\
\text { com ritmo musical. }\end{array}$ & 1,5 a 3,4 & \multirow[t]{2}{*}{$\begin{array}{l}\text { - Ginásio de esportes; } \\
\text { - Academias de ginástica. }\end{array}$} \\
\hline & & & Treino de dança Jazz. & 1,8 a 3,5 & \\
\hline Dançar & $\begin{array}{l}\text { Aproximadamente equivalente a } \\
\text { caminhada rápida. }\end{array}$ & 1,5 a 3,0 & $\begin{array}{l}\text { Eventos sociais com } \\
\text { dança clássica (Valsa) } \\
\text { ou moderna (Rumba). }\end{array}$ & 1,5 a 3,0 & $\begin{array}{l}\text { - Salão de dança; } \\
\text { - Salas de concerto ou salões } \\
\text { sociais sem assentos fixos. }\end{array}$ \\
\hline $\begin{array}{l}\text { Batendo } \\
\text { palmas e } \\
\text { saltando com o } \\
\text { corpo na } \\
\text { vertical }\end{array}$ & $\begin{array}{l}\text { Palmas ritmadas em frente ao } \\
\text { peito ou em cima da cabeça, } \\
\text { enquanto salta-se verticalmente } \\
\text { em um movimento de frente } \\
\text { para trás flexionando o joelho } \\
\text { cerca de } 50 \mathrm{~mm} \text {. }\end{array}$ & 1,5 a 3,0 & $\begin{array}{l}\text { Concertos pop com } \\
\text { plateia entusiasmada. }\end{array}$ & 1,5 a 3,0 & $\begin{array}{l}\text { - Salas de concerto e galerias de } \\
\text { espetáculo (arquibancadas), sem } \\
\text { assentos fixos sujeitos a shows } \\
\text { de música pop e rock. }\end{array}$ \\
\hline Palmas & $\begin{array}{l}\text { Palmas ritmadas em frente ao } \\
\text { peito. }\end{array}$ & 1,5 a 3,0 & $\begin{array}{l}\text { Concertos clássicos e de } \\
\text { música pop mais branda. }\end{array}$ & 1,5 a 3,0 & $\begin{array}{l}\text { - Salas de concerto com cadeiras } \\
\text { fixas. }\end{array}$ \\
\hline $\begin{array}{l}\text { Balanço lateral } \\
\text { do corpo }\end{array}$ & $\begin{array}{l}\text { Balanço lateral ritmado do } \\
\text { corpo em pé ou sentado. }\end{array}$ & 0,4 a 0,7 & $\begin{array}{l}\text { Concertos e eventos } \\
\text { sociais. }\end{array}$ & 0,4 a 0,7 & - Galerias de espetáculo. \\
\hline
\end{tabular}

Fonte: Bachmann et al. (1997), p. 189.

A representação da força dinâmica pode ser feita através de equações que simulem os efeitos reais. Bachmann et al. (1997) representam a atividade humana através de uma função de força $F_{p}(t)$ na forma de uma série de Fourier, conforme a Equação 2.72. Nessa equação admite-se que o movimento pode ser escrito por parcelas periódicas representadas pela série de Fourier.

$$
F_{p}(t)=G+\sum_{i=1}^{n}\left[G \cdot \alpha_{i} \cdot \operatorname{sen}\left(2 \cdot \pi \cdot i \cdot f_{p} \cdot t-\phi_{i}\right)\right]
$$


Sendo:

$G$ o peso de uma pessoa (geralmente de $800 \mathrm{~N}$ );

$\alpha_{i}$ o coeficiente da série de Fourier do i-ésimo harmônico (Tabela 2.4);

G. $\alpha_{i}$ a amplitude da força do i-ésimo harmônico;

$f_{p}$ a frequência da atividade desenvolvida (Tabelas 2.3 e 2.4);

$\phi_{i}$ o ângulo de diferença de fase entre o i-ésimo harmônico e o primeiro harmônico

(Tabela 2.4);

i o número do i-ésimo harmônico;

n o número total de harmônicos considerados na análise;

$t$ o tempo em segundos.

A Tabela 2.4 apresenta alguns valores de $\alpha_{i}$ e de $\phi_{i}$, obtidos experimentalmente, para algumas das atividades humanas correntes.

Tabela 2.4: Valores dos coeficientes de Fourier e ângulos de fase para atividades humanas.

\begin{tabular}{|c|c|c|c|c|c|c|c|c|}
\hline \multirow{2}{*}{ Atividade } & \multirow{2}{*}{\multicolumn{2}{|c|}{$\begin{array}{l}\text { Frequência da } \\
\text { atividade }(\mathrm{Hz})\end{array}$}} & \multicolumn{5}{|c|}{ Coeficientes de Fourier e ângulo de fase } & \multirow{2}{*}{$\begin{array}{c}\text { Densidade de } \\
\text { projeto } \\
\left.\text { (pessoas } / \mathbf{m}^{2}\right)\end{array}$} \\
\hline & & & $\alpha_{1}$ & $\boldsymbol{\alpha}_{2}$ & $\phi_{2}$ & $\boldsymbol{\alpha}_{3}$ & $\phi_{3}$ & \\
\hline \multirow{3}{*}{ Caminhada } & Marca passo & 2,0 a 2,4 & 0,4 a 0,5 & 0,1 & \multirow{3}{*}{$\pi / 2$} & \multirow{3}{*}{0,1} & \multirow{3}{*}{$\pi / 2$} & \multirow{3}{*}{ 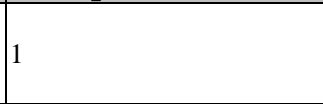 } \\
\hline & Para frente & 2,0 & 0,2 & 0,1 & & & & \\
\hline & Lateral & 2,0 & 0,1 & 0,1 & & & & \\
\hline Corrida & - & 2,0 a 3,0 & 1,6 & 0,7 & - & 0,2 & - & - \\
\hline \multirow{2}{*}{ Pular } & Normal & \multirow{2}{*}{2,0 a 3,0} & 1,8 a 1,7 & 1,3 a 1,1 & \multirow{2}{*}{$\begin{array}{l}\pi\left(1-f_{p} t_{p}\right) \\
t_{p}=\text { período }\end{array}$} & 0,7 a 0,5 & \multirow{2}{*}{$\begin{array}{r}\pi\left(1-f_{p} t_{p}\right) \\
t_{p}=\text { período }\end{array}$} & \multirow{2}{*}{$\begin{array}{l}\text { Em exercícios de } \\
\text { condicionamento = 0,25; } \\
\text { Em casos extremos = 0,5. }\end{array}$} \\
\hline & Rápido & & 1,9 a 1,8 & 1,6 a 1,3 & & 1,1 a 0,8 & & \\
\hline Dançar & - & 2,0 a 3,0 & 0,5 & 0,15 & - & 0,1 & - & $\begin{array}{l}4 \text { e em casos extremos } \\
\text { acima de } 6 .\end{array}$ \\
\hline $\begin{array}{l}\text { Batendo } \\
\text { palmas e } \\
\text { saltando com } \\
\text { o corpo na } \\
\text { vertical } \\
\end{array}$ & - & 1,6 a 2,4 & 0,17 a 0,38 & 0,10 a 0,12 & - & 0,04 a 0,02 & - & $\begin{array}{l}\text { Sem cadeiras fixas } 4 . \\
\text { Em casos extremos acima } \\
\text { de } 6 . \\
\text { Com cadeiras fixas de } 2 \text { a } 3 .\end{array}$ \\
\hline Palmas & Normal & 1,6 a 2,4 & 0,024 a 0,047 & 0,010 a 0,024 & - & 0,009 a 0,015 & - & 2 a 3 \\
\hline \multirow{2}{*}{$\begin{array}{l}\text { Balanço } \\
\text { lateral do } \\
\text { corpo }\end{array}$} & Sentado & \multirow[b]{2}{*}{0,6} & 0,4 & \multirow[b]{2}{*}{ - } & \multirow[b]{2}{*}{ - } & & \multirow[b]{2}{*}{ - } & \multirow{2}{*}{3 a 4} \\
\hline & Em pé & & 0,5 & & & & & \\
\hline
\end{tabular}

Fonte: Bachmann et al. (1997), p. 190.

Por outro lado, Mello et al. (2008) apresentam uma formulação onde é incorporado um efeito de pico transiente representativo do impacto do calcanhar humano no ato da caminhada.

Vale destacar ainda os seguintes comentários:

- Existe uma interação das pessoas com a estrutura, alterando a massa e a rigidez do sistema. Em estruturas pequenas, esse efeito é mais significativo. Krunka (2014) afirma que o corpo humano pode ser assumido como um sistema massa-mola-amortecedor quando imóvel. 
Quando ele está em movimento, influência a estrutura de uma forma diferente e não pode ser tomado como carga morta. Devido a isso que a análise modal de uma estrutura não inclui a massa humana como um peso morto;

- A Equação 2.72 descreve a força em função do tempo, desconsiderando a sua posição no espaço. A simplificação de posicionar uma pessoa em um ponto fixo da estrutura é aceita na literatura técnica. Entretanto, em caso de pontes de pedestres, recomenda-se que seja feita uma análise com pessoas em movimento sobre a estrutura. No Capítulo 8 é desenvolvido um estudo paramétrico posicionando-se uma pessoa no ponto de maior deslocamento estático da estrutura. Essa é uma prática corrente nos escritórios de projeto;

- Pavic e Reynolds (2002) destacam que os seres humanos não são excitadores perfeitos como uma máquina, pois geralmente não mantém uma frequência de estimulação constante.

\subsubsection{Limites e recomendações devidas ao desempenho estrutural}

Os limites e as recomendações apresentadas neste item não têm como objetivo esgotar o assunto. Na verdade, são apresentados os critérios normativos da ABNT NBR 6118:2014.

Nessa Norma não são apresentados grandes detalhes para as análises dinâmicas, ficando o engenheiro projetista como o responsável por grande parte das decisões a serem tomadas com relação à análise dinâmica da estrutura de concreto.

A ABNT NBR 6118:2014 apresenta em suas definições de Estados Limites de Serviço o Estado Limite de Vibração Excessiva (ELS-VE). Esse estado limite é caracterizado por vibrações que atingem os limites estabelecidos para o uso normal da construção.

O item 13.3 dessa Norma relaciona os limites de vibração com os limites de deslocamento excessivo. Segundo ela, quando os limites de deformação são infringidos, podem surgir problemas de vibrações excessivas que prejudicariam a aceitabilidade sensorial dos usuários. Ambos os problemas (deformações e vibrações excessivas) possuem sua origem na redução de rigidez ou do produto de rigidez.

As ações dinâmicas e de fadiga são tratadas conjuntamente no item 23 da ABNT NBR 6118:2014. São definidas duas grandezas: $f$ a frequência própria da estrutura (frequência natural); $f_{c r i t}$ a frequência crítica atuante na estrutura.

A citada Norma admite que a análise das vibrações possa ser feita em regime linear, no caso de estruturas usuais. Ela ainda estabelece que, para garantir um comportamento adequado das estruturas sujeitas a ações dinâmicas, deve-se afastar o máximo possível a 
frequência natural $f_{n}$ da frequência crítica $f_{\text {crit }}$, que é estabelecida na Tabela 2.5, dependente da destinação da edificação. A condição que deve ser atendida é apresentada na Equação 2.73.

$$
f_{n}>1,2 f_{\text {crit }}
$$

Tabela 2.5: Frequência crítica para vibrações verticais para alguns casos especiais de estruturas submetidas a vibrações pela ação de pessoas.

\begin{tabular}{|l|c|}
\hline \multicolumn{1}{|c|}{ Caso } & $f_{\text {crit }}(\mathrm{Hz})$ \\
\hline Ginásio de esportes e academias de ginástica & 8,0 \\
\hline Salas de dança ou de concerto sem cadeiras fixas & 7,0 \\
\hline Passarelas de pedestres ou ciclistas & 4,5 \\
\hline Escritórios & 4,0 \\
\hline Salas de concerto com cadeiras fixas & 3,5 \\
\hline
\end{tabular}

Fonte: ABNT NBR 6118:2014, p. 193.

A ABNT NBR 6118:2014 (p. 192 e 193) ainda afirma que:

\footnotetext{
"Quando a ação crítica é originada por uma máquina, a frequência crítica passa a ser a da operação da máquina. Nesse caso, pode não ser suficiente afastar as duas frequências, própria e crítica. Principalmente quando a máquina é ligada, durante o seu processo de aceleração, é usualmente necessário aumentar a massa ou o amortecimento da estrutura para absorver parte da energia envolvida.”
}

Ainda existe a recomendação de que, em casos onde as prescrições não puderem ser atendidas, deve ser feita uma análise dinâmica mais acurada, conforme Normas Internacionais, quando não existir Norma Brasileira específica.

Bachmann et al. (1997) apresentam valores de frequências que podem atuar sobre diferentes estruturas, sejam elas de origem humana, do vento, de máquinas ou devidas ao tráfego e atividades de construção. Fica aqui a recomendação desse trabalho para a obtenção de valores mais específicos de frequências solicitantes em diversas situações de carregamentos e estruturas específicas.

Segundo a ABNT NBR 6118:2014, o estado limite último provocado por ressonância ou amplificação dinâmica deve ser avaliado em regime elástico linear. Na existência de coeficiente de impacto, este valor deve ser utilizado para a análise.

\subsubsection{Limites e recomendações devidas à sensibilidade e ao conforto humano}

As vibrações podem trazer benefícios e/ou malefícios para o corpo humano sujeito a elas. Dependendo da intensidade e do tempo de exposição, os efeitos benéficos e os maléficos se alteram. Cargnelutti et al. (2011) citam que alguns dos efeitos benéficos da exposição do 
corpo humano em plataformas vibratórias de condicionamento físico são o acréscimo de massa muscular, condicionamento físico com agressão cardíaca mínima e elevação da fixação de cálcio na estrutura óssea. Por outro lado, dependendo das características físicas de cada pessoa, os efeitos deletérios da exposição excessiva à vibração podem ser:

- Em atividades musculares e/ou posturais, na faixa de $1 \mathrm{~Hz}$ a $30 \mathrm{~Hz}$, os indivíduos podem apresentar reflexos lentos e dificuldades de manutenção de uma postura sadia;

- Frequências inferiores a $20 \mathrm{~Hz}$ tendem a elevar a frequência cardíaca;

- Podem existir alterações de ventilação pulmonar e da taxa respiratória com acelerações da ordem de 4,9 m/s² e frequências na faixa de $1 \mathrm{~Hz}$ a $10 \mathrm{~Hz}$.

Ao serem analisados os dados encontrados em Bachmann et al. (1997), observa-se que muitas solicitações sobre as estruturas podem gerar frequências nas faixas listadas anteriormente como deletérias à saúde. Inclusive vibrações induzidas pelo movimento do corpo humano (caminhada, corrida, dança ou salto) podem levar a estrutura a apresentar níveis vibratórios na faixa de vibrações nocivas.

Thuong e Griffin (2011) apresentam diversas curvas de percepção e conforto humano às vibrações verticais (pessoa em pé) encontradas em diversas pesquisas. Essas curvas indicam que a maior sensibilidade encontra-se na faixa de $5 \mathrm{~Hz}$ a $9 \mathrm{~Hz}$, como pode ser observado na Figura 2.31.

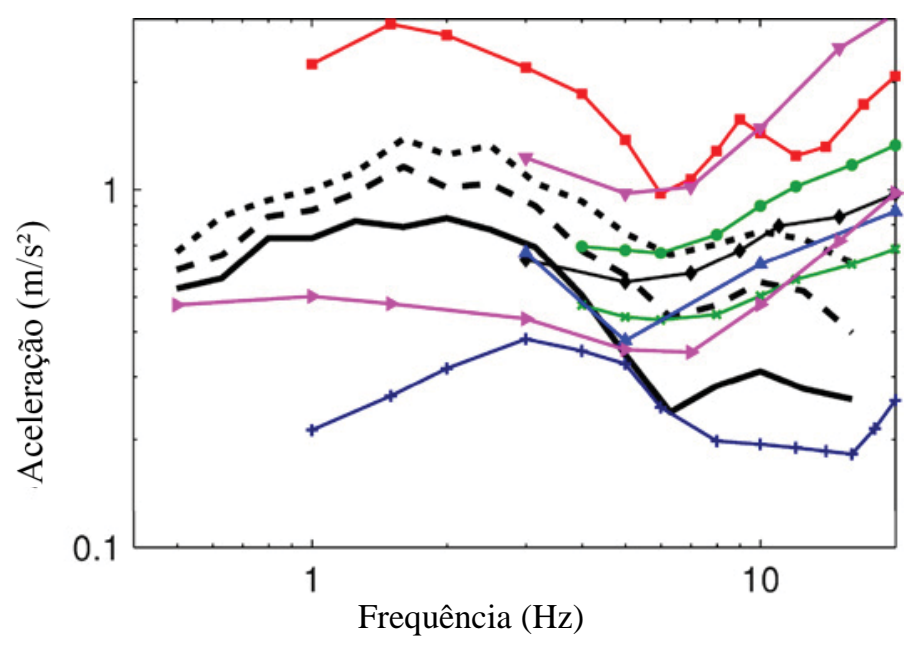

Figura 2.31 - Curvas de sensibilidade à aceleração vertical de pessoas em pé. Fonte: Thuong e Griffin (2011), p. 824.

Cada parte do corpo humano apresenta uma frequência natural. Brüel \& Kjaer (1989) apresentam os valores médios das frequências naturais das partes do corpo humano. A Tabela 2.6 apresenta esses valores. Quando a frequência excitadora atinge o valor da frequência 
natural, fica caracterizada a ressonância. Ao serem observados os valores da Tabela 2.6, é explicado o maior desconforto em frequências de 5 a $9 \mathrm{~Hz}$. As estruturas dos ombros, pernas, braços e abdômen tendem a entrar em ressonância nesta faixa de frequências.

A norma ISO (International Organization for Standardization) 2631-1 (1997) define métodos para a avaliação de vibrações periódicas, aleatórias e transientes de corpo inteiro. Ela indica os principais fatores que influenciam o grau de exposição às vibrações e se este é aceitável ou não. As faixas de frequência atendidas por ela são de 0,5 Hz a $80 \mathrm{~Hz}$ para saúde, conforto e percepção, e de $0,1 \mathrm{~Hz}$ a $0,5 \mathrm{~Hz}$ para doenças laborais.

Tabela 2.6: Frequências naturais de partes do corpo humano.

\begin{tabular}{|l|c|}
\hline Parte do corpo humano & Frequência natural (Hz) \\
\hline Cabeça & $20-30$ \\
\hline Olhos & $20-90$ \\
\hline Ombros & $4-5$ \\
\hline Tórax & $50-100$ \\
\hline Braços & $5-10$ \\
\hline Mãos & $30-60$ \\
\hline Antebraços & $16-30$ \\
\hline Abdômen & $4-8$ \\
\hline Coluna vertebral & $10-12$ \\
\hline Pernas & 2 para pernas dobradas a 20 para pernas esticadas \\
\hline
\end{tabular}

Fonte: Adaptado de Brüel \& Kjaer (1989), p. 8.

Conforme Cargnelutti et al. (2011), a aplicabilidade da ISO 2631-1 (1997) depende do fator de pico apresentado na Equação 2.74. Quando o fator de pico da vibração considerada é menor ou igual a nove ( $\left.F_{p} \leq 9\right)$, os parâmetros da ISO 2631-1 (1997) podem ser aplicados. Se o fator de pico é maior que nove ( $F_{p}>9$ ), os métodos de avaliação da ISO 2631-1 (1997) não são aplicáveis, pois a vibração se caracteriza como de impacto.

$$
F_{p}=\frac{m a ́ x\left|a_{w}(t)\right|}{a_{w}}
$$

Sendo:

$F_{p}$ o fator de pico da vibração considerada;

máx $\left|a_{w}(t)\right|$ o maior valor instantâneo da aceleração avaliada;

$a_{w}$ o valor RMS (root mean square - raiz quadrada média) correspondente a essa aceleração.

Cargnelutti et al. (2011) afirmam que na ISO 2631-1 (1997) os métodos apresentados para a medição de vibrações determinam em que grau a exposição ao nível de vibração será aceitável. Para isto são considerados três níveis de severidade: o primeiro é o limite de 
conforto; o segundo, o limite de perda de eficiência causado por fadiga, relacionado à preservação da eficiência na atividade e é relevante para operadores de máquinas, equipamentos e condutores de veículos automotores; o terceiro é o limite de exposição que oferece perigo à saúde.

Segundo Diógenes et al. (2009b), pode-se dizer que a vibração de um corpo humano é um movimento que ele execute, em relação a um ponto fixo. “A vibração é definida por três variáveis: a frequência $(\mathrm{Hz})$, a aceleração máxima sofrida pelo corpo $\left(\mathrm{m} / \mathrm{s}^{2}\right)$ e pela direção do movimento, que é dada em três eixos: x (das costas para frente), y (da direita para esquerda) e z (dos pés à cabeça)” [Diógenes et al. (2009b), p. 1].

Ainda conforme Diógenes et al. (2009b), p. 2:

“O corpo inteiro é mais sensível na faixa de $4 \mathrm{~Hz}$ a $8 \mathrm{~Hz}$, que corresponde à frequência de ressonância na direção vertical (eixo $z$ ). Na direção $x$ e y, as ressonâncias ocorrem a frequências mais baixas, de $1 \mathrm{~Hz}$ a $2 \mathrm{~Hz}$. Os efeitos da vibração direta sobre o corpo humano podem ser extremamente graves, chegando a danificar permanentemente alguns órgãos do corpo humano. As vibrações danosas ao organismo estão nas frequências de $1 \mathrm{~Hz}$ a $80 \mathrm{~Hz}$, provocando lesões nos ossos, juntas e tendões. As frequências intermediárias, de $30 \mathrm{~Hz}$ a $200 \mathrm{~Hz}$, provocam doenças cardiovasculares, mesmo com baixas amplitudes, e nas frequências altas, acima de $300 \mathrm{~Hz}$, o sintoma é de dores agudas e distúrbios. Alguns desses sintomas são reversíveis, podendo ser reduzido após um longo período de descanso.”

Já que a sensibilidade às vibrações depende da frequência, um método de avaliação ponderando a aceleração pela frequência é conveniente. Assim, o nível vibratório pode ser normalizado para um mesmo nível de desconforto independente da frequência excitadora. Pavic e Reynolds (2002) discutem os meios mais comuns para se compararem os valores ponderados com os limites normativos. Esses meios são os métodos do RMS (Root Mean Square) para vibrações estáveis de longa duração, e o VDM (Vibration Dose Value) para vibrações transientes.

Assim, observando-se os comentários até aqui apresentados, as estruturas civis que possuem frequências naturais baixas estão em situação de possibilidade de ressonância com as ações dinâmicas de ocupação ou do vento. Se essa ressonância for atingida, a amplitude dos movimentos vibratórios tenderá a prejudicar a saúde dos usuários ou trazer desconfortos.

Dentre os diversos critérios para analisar se um pavimento apresenta um determinado nível de conforto, será descrito neste trabalho apenas o critério da ISO 2631-2 (1989). Justifica-se a utilização dessa Norma mais antiga, pois ela apresenta curvas limites de conforto humano frente às acelerações das vibrações.

Ebrahimpour e Sack (2005) comentam que a ISO 2631-2 (1989) trabalha com uma curva base (Figura 2.32) de limite de aceleração RMS. Em função do tipo de edificação e de sua ocupação, são aplicados multiplicadores fornecendo as demais curvas limites. 
Comentando sobre a utilização da ISO 2631-2 (1989), Mello et al. (2007) destacam que essas curvas devem ser utilizadas com cautela, tendo em vista que, em muitos casos, os picos de utilização ficam acima dos limites das curvas da Figura 2.32. Pesquisas demonstraram que o uso dessas curvas pode superestimar os efeitos em vibrações de baixas frequências ou subestimar os efeitos em vibrações de altas frequências.

Assim sendo, na revisão da ISO 2631-2 (1989), essas curvas foram retiradas, pois não levavam em consideração o tipo físico dos usuários, ruídos e outros fatores que influenciam no conforto e na sensibilidade à vibração. A ISO 2631-2 (2003) apenas recomenda que sejam feitas medições e avaliações criteriosas das vibrações nas edificações.

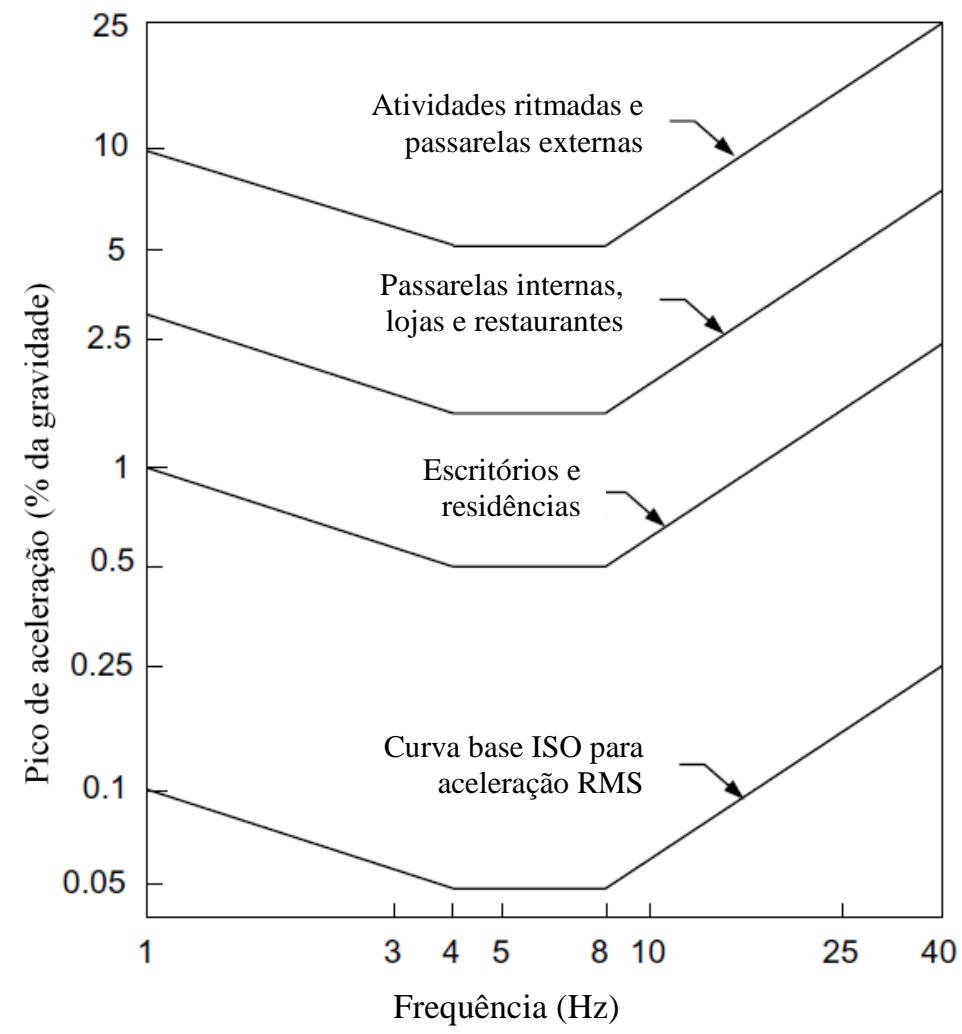

Figura 2.32 - Curvas limites para pico de aceleração relativas ao conforto humano.

Acelerações causadas por atividade humana.

Fonte: Ebrahimpour e Sack (2005), p. 2489.

Como a ISO 2631-2 (2003) não apresenta limites bem definidos, adotou-se neste trabalho as indicações da sua versão mais antiga, de 1989. As curvas da Figura 2.32 foram utilizadas como limites na análise paramétrica desenvolvida no Capítulo 8, a despeito de suas eventuais limitações. 
Outro critério muito simples e que serve para uma pré-análise é o apresentado por Bachmann et al. (1997) na Tabela 2.7. Para o intervalo de frequências de $1 \mathrm{~Hz}$ a $10 \mathrm{~Hz}$, a mensuração do nível vibratório é realizado elo pico de aceleração. Já para a faixa de frequências de $10 \mathrm{~Hz}$ a $100 \mathrm{~Hz}$ o conforto será medido pelo pico de velocidade.

Tabela 2.7: Sensibilidade humana a vibrações harmônicas verticais com a pessoa em pé.

\begin{tabular}{|l|c|c|}
\hline \multicolumn{1}{|c|}{ Sensibilidade } & $\begin{array}{c}\text { Faixa de frequência de } \mathbf{1 ~} \mathbf{~ H z} \text { a } \mathbf{1 0 ~ H z} \\
\left.\text { Pico de aceleração } \mathbf{( m m} / \mathbf{s}^{2}\right)\end{array}$ & $\begin{array}{c}\text { Faixa de frequência de } \mathbf{1 0} \mathbf{~ H z ~ a ~} \mathbf{1 0 0} \mathbf{~ H z} \\
\text { Pico de velocidade (mm/s) }\end{array}$ \\
\hline Pouco perceptível & 34 & 0,5 \\
\hline Claramente perceptível & 100 & 1,3 \\
\hline Desagradável & 550 & 6,8 \\
\hline Intolerável & 1800 & 13,8 \\
\hline
\end{tabular}

Fonte: Bachmann et al. (1997), p. 216. 


\section{Concreto Leve Estrutural com Pérolas de EPS}

Popularmente, o termo "concreto" refere-se a algo sólido e que possui peso considerável. A associação do termo "leve” ao concreto pode causar certa perplexidade ao público leigo, que não esperaria tal característica em um concreto. Entretanto, a necessidade de atender a especificações precisas, como a redução do peso próprio de grandes estruturas, levou a ciência do concreto a desenvolver soluções especiais, entre elas o concreto leve.

Petrucci (1982) define concreto leve como um material caracterizado pela baixa massa específica aparente, em relação aos concretos comuns. Neville (1997) indica que o intervalo prático de valores de massa específica dos concretos leves é de $300 \mathrm{~kg} / \mathrm{m}^{3}$ a $1800 \mathrm{~kg} / \mathrm{m}^{3}$. Porém, nada impede que outras massas específicas, fora desse intervalo, possam ser consideradas como pertencentes a concretos leves.

O ACI 213R-87 (1995) classifica os concretos leves em três grupos, em função da massa específica influenciada diretamente pelo teor de cimento e o tipo de agregado leve utilizado, que pode ser de origem natural ou artificial, conforme descrito por Sbrighi Neto (2011), os quais são: concretos isolantes, destinados principalmente à composição de painéis de vedação isolantes térmicos; concretos com resistências moderadas, que possuem aplicação em enchimentos de pisos e em outras de menor responsabilidade; e concretos estruturais, que devem ter resistência mínima de 17 MPa. A Figura 3.1 ilustra essa classificação.

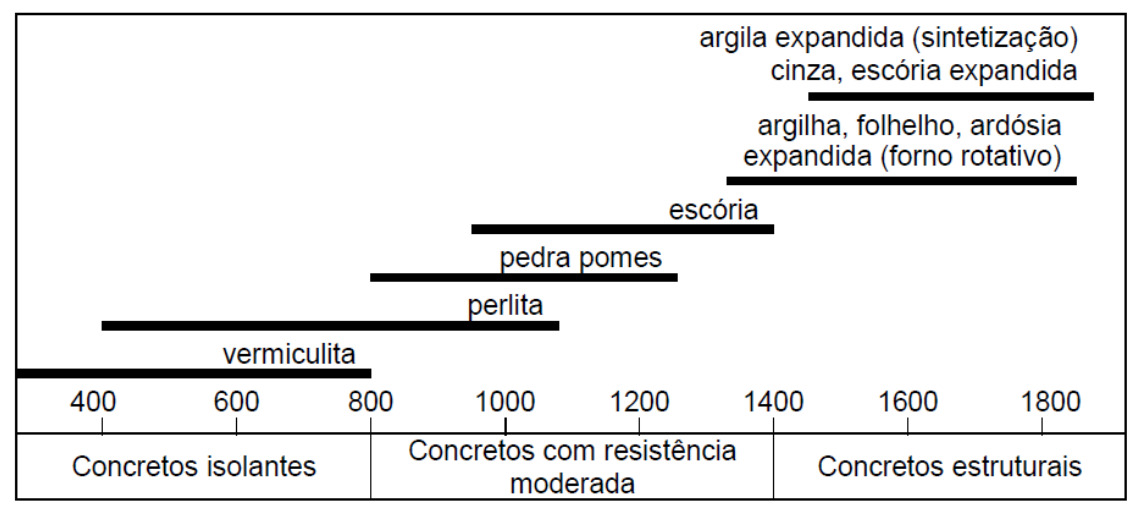

Figura 3.1 - Classificação dos concretos leves em função da massa específica $\left(\mathrm{kg} / \mathrm{m}^{3}\right)$. Fonte: Catoia (2012), p. 37. 
A origem da aplicação dos concretos leves remonta a 1850 anos, no Panteão romano, reconstruído, após um incêndio, pelo imperador Adriano (AÏTCIN, 2000). Um relato histórico interessante pode ser encontrado em Rossignolo e Agnesini (2005) e Rossignolo e Agnesini (2011), do qual se destaca a aplicação de concretos leves em obras emblemáticas e de grande porte, como edifícios altos e grandes pontes.

Outra forma de concreto leve encontrada no mercado é o concreto celular. Neville (1997) define o concreto celular como sendo um concreto onde é introduzido intencionalmente um sistema de bolhas de ar (concreto espuma ou areado) ou de gás estável (concretos porosos), bolhas essas que têm tamanho médio entre 0,1 mm e $1 \mathrm{~mm}$, elevando o volume aparente do concreto e diminuindo a massa específica. Sua aplicação é muito requerida em estruturas de países de clima frio, onde os ciclos de gelo e desgelo são deletérios à estrutura. Ao solidificar, a água livre no concreto se expande, e a pressão interna gerada pela expansão é reduzida com a presença de bolhas de "vazios”, pois a água pode penetrar no interior desses espaços ao se expandir.

Formas de concreto estrutural leve sem finos (sem agregados miúdos) também são utilizadas. Sua classificação e características podem ser consultadas em Neville (1997).

Com o desenvolvimento da tecnologia do concreto e a constante preocupação com a questão da sustentabilidade, surgiu a concepção de concreto leve com adição de poliestireno expandido (EPS).

A Associação Brasileira de Poliestireno Expandido - ABRAPEX (2006) define concreto leve com EPS como um concreto do tipo cimento e areia que, no lugar da pedra britada (agregado graúdo), utiliza EPS em forma de pérolas expandidas ou flocos reciclados. A mistura de cimento e areia, ao endurecer, envolve as partículas de EPS, cujo volume é constituído de $95 \%$ a $98 \%$ de ar, proporcionando um concreto de baixa densidade.

O estudo do concreto leve com EPS é indicado por Chen et al. (2010) como tendo início em 1973, e que nos últimos anos, muitas pesquisas e estudos experimentais conduziram a um bom avanço na tecnologia de concretos com agregados de EPS. Não somente foram avaliados traços, resistências, fluência, retração e desenvolvimento de aplicações, mas também estudos sobre a durabilidade de concretos leves com EPS foram realizados, como pode ser visto em Momtazi et al. (2010). Na pesquisa dos citados autores, vários traços com o uso de EPS foram elaborados, obtendo-se resultados satisfatórios quanto a absorção de água pelo concreto, resistência à condutividade elétrica e concreto em ambiente marinho.

No Brasil, algumas pesquisas foram feitas com o concreto leve com adição de pérolas de EPS. Podem ser citadas as pesquisas de: Sant'Helena (2009), que produziu traços de 
concreto com substituição parcial dos agregados graúdos por EPS em pérolas, nas proporções de $20 \%$ e $40 \%$, chegando a resultados que caracterizam concreto leve sem função estrutural; Porto (2010), que ensaiou corpos de prova cilíndricos para obtenção de resistência à compressão e módulo de elasticidade de concretos "semileves", com agregados graúdos normais e parte do volume de agregados substituído por pérolas de EPS; Catoia (2012), que fez uma extensa caracterização do concreto leve com pérolas de EPS, utilizado nesta pesquisa. Alguns dos resultados obtidos por Catoia (2012) serão apresentados na sequência deste capítulo. Entretanto, nenhuma pesquisa foi desenvolvida no domínio da dinâmica das estruturas para o concreto com EPS.

Ao ser observada a definição de concreto leve com adição de EPS (CLE), observa-se que existem semelhanças entre esse material e os concretos com agregados leves e outras semelhanças entre ele e os concretos celulares. De fato, o termo concreto, segundo Neville (1997), não deveria ser utilizado para esse material, pois ele não possui agregados graúdos. Sugere-se, portanto, neste trabalho, que a classificação do concreto leve com adição de pérolas de EPS (CLPE - variação do concreto leve com EPS) seja enquadrada de forma intermediária entre o concreto leve com agregados leves e o concreto celular. No desenvolvimento deste capítulo procura-se demonstrar que o CLPE e o concreto leve estrutural com pérolas de EPS (CLEPE) apresentam características desses dois concretos. Para tanto, um entendimento dos materiais constituintes do CLPE e do CLEPE deve ser a base, e, posteriormente, devem ser tratados os detalhes dos concretos leves com agregados leves e dos concretos celulares.

Para facilitar o desdobramento da pesquisa, a partir deste item somente será feita referência ao CLEPE (definido com mais detalhes no item 3.2), que engloba todas as características do CLE e do CLPE.

\subsection{Materiais constituintes do CLEPE}

O concreto leve estrutural com pérolas de EPS (CLEPE) tem nomes patenteados de Concreto Ultraleve $^{\circledR}$ e Concreflex ${ }^{\circledR}$. Seus materiais constituintes são cimento, areia, água e EPS (esferas de 1 a 3 mm de diâmetro denominadas pérolas). Além desses materiais, podem ser acrescentados aditivos químicos, como os aceleradores ou retardadores de pega e os superplastificantes, e aditivos minerais, como a sílica ativa e a cinza de casca de arroz. Dos materiais mencionados será descrito brevemente somente o EPS, por entender-se que os 
outros são comumente utilizados, e como suas características para esta aplicação não mudam para o CLEPE, as especificações, constituições, processos de fabricação e comportamento no concreto podem ser pesquisados na literatura técnica especializada.

Catoia (2012) ainda afirma que o CLEPE pode ser produzido com qualquer tipo de cimento, bem como com agregados inertes e puros, e adições necessárias para cada fim específico. Na pesquisa do citado autor, o concreto foi confeccionado somente com cimento, água, agregados miúdos, EPS e superplastificante.

A matéria prima do EPS é o poliestireno (PS) que, conforme Andrade (2007) é um polímero termoplástico ${ }^{5}$, caracterizado pela elevada dureza, rigidez e baixo custo de produção. Apresenta elevadas resistências à tração, amolecendo em temperaturas situadas na faixa de $90^{\circ} \mathrm{C}$ a $95^{\circ} \mathrm{C}$. Sua conformação pode ser obtida por injeção, extrusão ou por moldagem por compressão. É um material insípido, atóxico e inodoro, com baixa absorção de água. Apresenta resistência a álcalis (donde sua aplicação no concreto é favorável) e é solúvel em ésteres, hidrocarbonetos aromáticos, cloratos e derivados de petróleo, como a gasolina, querosene, óleo Diesel, etc. Andrade (2007) ainda cita que existem três formas de PS:

- Comum: conhecido como não modificado ou regular, e que recebe apenas pequenas quantidades de lubrificantes para facilitar a moldagem. É empregado em produtos de baixo custo, como copos descartáveis;

- Resistente ao calor: possui essa resistência devido ao peso molecular mais elevado. Entretanto, possui dificuldade de processamento, sendo por isso empregado em condições de elevada temperatura de trabalho, como peças de máquinas ou de automóveis;

- Resistente ao impacto: devido à incorporação de elastômeros na sua composição, como o estireno-butadieno com 25\% de estireno. Possuem variação em polímeros de média e alta resistência ao impacto, dependendo da concentração de elastômero. É empregado na fabricação de utensílios domésticos e brinquedos.

Segundo a Abrapex (2006), o poliestireno expandido, que possui sigla internacional EPS, foi descoberto em 1949 pelos químicos Fritz Stastny e Karl Buchholz, quando trabalhavam nos laboratórios da Basf, na Alemanha. No Brasil, o EPS é conhecido também pelos nomes comerciais de Isopor $^{\circledR}$ e Estyropor ${ }^{\circledR}$.

O EPS possui uma estrutura celular rígida e é resultado da polimerização do estireno em água. O agente expansor para transformação de PS em EPS é o pentano, um

\footnotetext{
${ }^{5}$ Um polímero termoplástico é aquele que amolece e flui quando submetido a determinados valores de temperatura e pressão, podendo ser moldado. Não apresenta um retículo cristalino predominante e é $100 \%$ reciclável, podendo ser remoldado (ANDRADE, 2007).
} 
hidrocarboneto que se deteriora rapidamente pela ação fotoquímica solar, não comprometendo o ambiente. O EPS é solúvel nas mesmas substâncias que o PS, e ainda é deteriorado pela ação dos raios ultravioletas.

As esferas de PS podem ter até 3 mm de diâmetro, e após a expansão podem aumentar até 50 vezes, com a possibilidade de fusão com outras pérolas de EPS em moldes, formando as mais variadas formas. É atóxico, inodoro e 100\% reciclável, sendo que o produto reciclado apresenta, geralmente, massa específica menor. A absorção de água do EPS é mínima e pode ser considerada praticamente nula. Isto deve ser considerado na composição do concreto.

Os diâmetros das pérolas de EPS podem ser controlados e afetam diretamente a densidade do material final. Comumente é empregado EPS com densidades variando de $9 \mathrm{~kg} / \mathrm{m}^{3}$ a 32,5 kg/m³. Obviamente, quanto mais denso o material, maior o seu custo. Porém, não é o custo que muitas vezes é questionado. A flamabilidade (capacidade de entrar em combustão quando exposto a uma fonte de calor) é que é o quesito mais questionado. Para tanto, adições especiais ao PS resultam em EPS denominado retardante à chama ou autoextinguível (quando a fonte de calor é retirada o fogo se apaga).

Existem duas categorias de EPS divididas em três classes cada. A primeira categoria é o EPS tipo P, que não é retardante à chama; a segunda é a do EPS tipo F, retardante à chama. As classes de material são divididas em função da densidade do EPS. A Tabela 3.1 indica as principais características de cada tipo de EPS, bem como as normas que regem os ensaios de classificação.

Tabela 3.1: Características normativas do EPS conforme a ABNT NBR 11752:2007.

\begin{tabular}{|c|c|c|c|c|c|c|c|c|}
\hline \multirow{2}{*}{ Propriedades } & \multirow{2}{*}{$\begin{array}{l}\text { Norma de } \\
\text { ensaio }\end{array}$} & \multirow{2}{*}{ Unidade } & \multicolumn{3}{|c|}{ Classe P } & \multicolumn{3}{|c|}{ Classe F } \\
\hline & & & I & II & III & I & II & III \\
\hline Massa específica aparente & $\begin{array}{l}\text { ABNT NBR } \\
11949: 2007\end{array}$ & $\mathrm{~kg} / \mathrm{m}^{3}$ & $\begin{array}{c}13- \\
16\end{array}$ & $\begin{array}{l}16- \\
20\end{array}$ & $\begin{array}{l}20- \\
25\end{array}$ & $\begin{array}{c}13- \\
16\end{array}$ & $\begin{array}{l}16- \\
20\end{array}$ & $\begin{array}{l}20- \\
25\end{array}$ \\
\hline $\begin{array}{l}\text { Resistência à compressão } \\
\text { com } 10 \% \text { de deformação }\end{array}$ & $\begin{array}{l}\text { ABNT NBR } \\
8082: 1983\end{array}$ & $\mathrm{kPa}$ & $\geq 60$ & $\geq 70$ & $\geq 100$ & $\geq 60$ & $\geq 70$ & $\geq 100$ \\
\hline Resistência à flexão & $\begin{array}{c}\text { ASTM } \\
\text { C203:1999 } \\
\end{array}$ & $\mathrm{kPa}$ & $\geq 150$ & $\geq 190$ & $\geq 240$ & $\geq 150$ & $\geq 190$ & $\geq 240$ \\
\hline $\begin{array}{l}\text { Absorção de água imerso em } \\
\text { água }\end{array}$ & $\begin{array}{c}\text { ABNT NBR } \\
7973: 2007\end{array}$ & $\mathrm{~g} / \mathrm{cm}^{2} \mathrm{x} 100$ & $\leq 1$ & $\leq 1$ & $\leq 1$ & $\leq 1$ & $\leq 1$ & $\leq 1$ \\
\hline $\begin{array}{l}\text { Permeabilidade ao vapor } \\
\text { d’água }\end{array}$ & $\begin{array}{c}\text { ABNT NBR } \\
8081: 1983 \\
\end{array}$ & Ng/Pa.s.m & $\leq 7$ & $\leq 5$ & $\leq 5$ & $\leq 7$ & $\leq 5$ & $\leq 5$ \\
\hline $\begin{array}{l}\text { Coeficiente de condutividade } \\
\text { térmica a } 23^{\circ} \mathrm{C} \\
\end{array}$ & $\begin{array}{c}\text { ABNT NBR } \\
12094: 1991 \\
\end{array}$ & $\mathrm{~W} /(\mathrm{m} . \mathrm{K})$ & 0,042 & 0,039 & $\begin{array}{c}0,03 \\
7\end{array}$ & 0,042 & 0,039 & 0,037 \\
\hline Flamabilidade & $\begin{array}{l}\text { ABNT NBR } \\
11948: 2007\end{array}$ & --- & \multicolumn{3}{|c|}{$\begin{array}{l}\text { Não retardante à } \\
\text { chama }\end{array}$} & \multicolumn{3}{|c|}{ Retardante à chama } \\
\hline
\end{tabular}

Fonte: Catoia (2012), p. 53. 
Na construção civil, o EPS é empregado principalmente em: enchimento de lajes nervuradas, fôrmas para concreto, isolamento térmico, regularização de piso, enchimento de pisos rebaixados, juntas de dilatação, forros, isolante acústico, painéis divisórios, plataformas flutuantes, enchimento sobre solos moles colapsíveis e concreto leve. O emprego do EPS maximiza a redução do peso próprio da estrutura e de elementos não estruturais, gerando grande economia em vigas, pilares e fundações, justificando sua utilização com grandes relações benefício-custo. Vizotto e Sartorti (2010) obtiveram ótimos resultados com enchimento em EPS, em comparações técnicas e econômicas, para aplicação de lajes nervuradas treliçadas, em relação a lajes nervuradas com cuba plástica e a lajes maciças.

Os diagramas tensão versus deformação para diferentes densidades de EPS podem ser visualizados na Figura 3.2. Nota-se que a resistência do EPS é limitada pela deformação que ele apresenta.

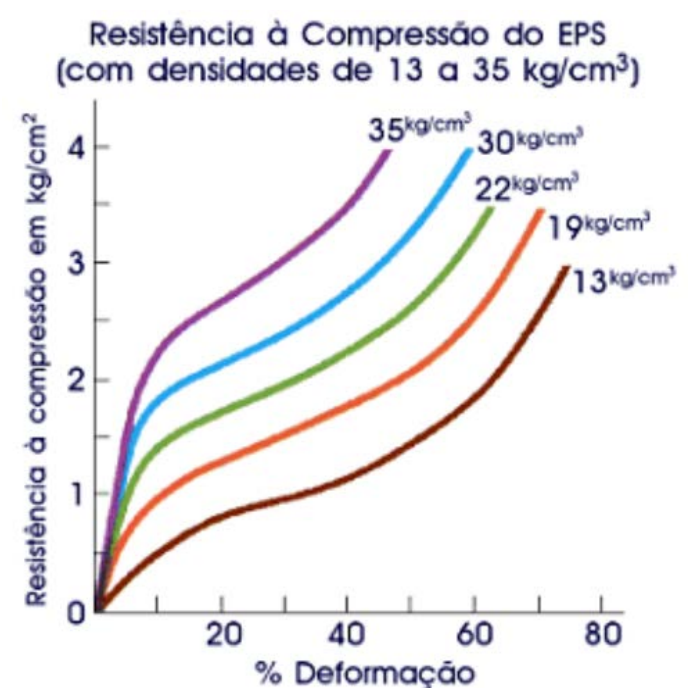

Figura 3.2 - Diagramas tensão versus deformação do EPS em função da densidade.

Fonte: Abrapex (2013).

As vantagens do material EPS são descritas pela Abrapex (2006):

- Baixa condutividade térmica;

- Baixo peso específico;

- Resistência mecânica adequada;

- Baixa absorção de água;

- Facilidade de manuseio;

- Versatilidade;

- Resistência ao envelhecimento;

- Absorção de choques. 


\subsection{Comentários gerais sobre o CLEPE}

Tessari (2006) afirma que o concreto leve com EPS consiste na substituição total ou parcial dos agregados graúdos tradicionais por pérolas ou flocos de EPS. As proporções de substituição de agregados convencionais por EPS variam em função da densidade e da resistência requerida, podendo-se cobrir uma larga faixa de densidades entre $600 \mathrm{~kg} / \mathrm{m}^{3}$ e $1600 \mathrm{~kg} / \mathrm{m}^{3}$. A resistência obtida para um concreto leve com pérolas de EPS determina a possibilidade de classificação apenas como concreto leve com pérolas de EPS (CLPE) ou concreto leve estrutural com pérolas de EPS (CLEPE).

Não existe um limite definido para que o concreto leve com EPS seja considerado como estrutural ou somente como um isolante. A ABNT NBR NM 35:1995 apresenta a Tabela 3.2, na qual são estabelecidos valores mínimos de resistência à compressão para concretos com agregados leves em função de uma massa específica. Observa-se, entretanto, que não convém denominar o EPS como um agregado, pois suas características estão mais relacionadas com um incorporador de ar. Entretanto, Chen et al. (2010) deixam claro que o termo agregado leve de EPS é reconhecido mundialmente.

Tabela 3.2: Resistência à compressão para concretos leves com agregados leves.

\begin{tabular}{|c|c|}
\hline $\begin{array}{c}\text { Valores mínimos de resistência à } \\
\text { compressão aos 28 dias (MPa) }\end{array}$ & $\begin{array}{c}\text { Valores máximos de massa } \\
\text { específica (kg/m } \mathbf{~} \mathbf{)}\end{array}$ \\
\hline 28 & 1840 \\
\hline 21 & 1760 \\
\hline 17 & 1680 \\
\hline
\end{tabular}

Fonte: Catoia (2012), p. 50.

Outra forma de avaliar um concreto leve é através do Fator de Eficiência, apresentado por Rossignolo (2009), e expresso na Equação 3.1.

$$
F E=\frac{f_{c}}{\gamma}
$$

Sendo:

FE o fator de eficiência (MPa.dm³/kg);

$f_{c}$ a resistência à compressão $(\mathrm{MPa})$;

$\gamma$ a massa específica $\left(\mathrm{kg} / \mathrm{dm}^{3}\right)$.

Rossignolo e Agnesini (2011) afirmam que um concreto com fator de eficiência maior ou igual a $25 \mathrm{MPa} \cdot \mathrm{dm}^{3} / \mathrm{kg}$ pode ser considerado de alto desempenho. Obviamente, no atual estado da arte não se espera que o CLEPE tenha um fator de eficiência tão alto, entretanto, 
Catoia (2012) obteve resultados da ordem de $10 \mathrm{MPa} . \mathrm{dm}^{3} / \mathrm{kg}$ a $14 \mathrm{MPa} \cdot \mathrm{dm}^{3} / \mathrm{kg}$ para o fator de eficiência de CLEPE com massas específicas entre $1200 \mathrm{~kg} / \mathrm{m}^{3}$ e $1300 \mathrm{~kg} / \mathrm{m}^{3}$. Esses concretos obtiveram resistência à compressão aos 28 dias entre 14,5 MPa e 18,7 MPa, podendo ser caracterizados como estruturais. Observa-se ainda que um concreto convencional com 25 MPa de resistência à compressão aos 28 dias e massa específica de $2400 \mathrm{~kg} / \mathrm{m}^{3}$ possui fator de eficiência de 10,4 MPa.dm³/kg.

Chen et al. (2010) relatam a obtenção de concretos leves com EPS com resistências de $20 \mathrm{MPa}$ a $40 \mathrm{MPa}$, para massas específicas de $1370 \mathrm{~kg} / \mathrm{m}^{3}$ a $1950 \mathrm{~kg} / \mathrm{m}^{3}$.

Conforme Tessari (2006), o fato do EPS praticamente não absorver água e a possibilidade de um acabamento homogêneo de superfície possibilitam o uso do concreto leve em outros elementos arquitetônicos e de paisagismo. Também sua aplicação em pré-moldados é de grande vantagem. Mehta e Monteiro (2008) afirmam que o concreto leve é bem empregado em pré-moldados, reduzindo o peso de transporte. Entretanto, o CLEPE é particularmente interessante para essa aplicação, pois pela baixa absorção de água do EPS, a mistura torna-se de grande fluidez, como pode ser visto no item 3.3.1 deste trabalho, sobre trabalhabilidade.

A preparação do CLEPE deve ser feita preferencialmente em betoneira, com cuidados especiais para que, devido à baixa densidade, as pérolas de EPS não flutuem em água, o que atrapalharia sua homogeneidade.

A Figura 3.3 ilustra o aspecto da distribuição das pérolas de EPS na matriz do CLEPE. Percebe-se que todas as pérolas são perfeitamente envolvidas pela pasta de cimento e areia.

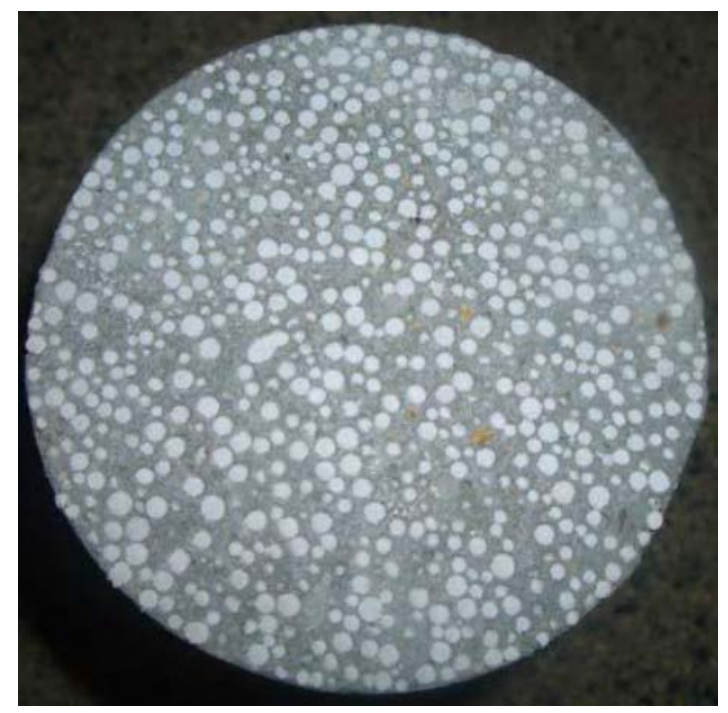

Figura 3.3 - Aparência do CLEPE endurecido.

Fonte: Catoia (2012), p. 51. 
É importante que seja ressaltado o aspecto de que as pérolas de EPS não absorvem água e isto deve ser levado em conta na determinação do traço. Outro fator importante é que as pérolas de EPS apresentam uma carga elétrica estática que tende a repeli-las. Por esse motivo, bem como pela baixa massa específica, a mistura seca de EPS, cimento e areia apresenta um volume maior (1,05 $\mathrm{m}^{3}$ a 1,10 $\mathrm{m}^{3}$ para $1 \mathrm{~m}^{3}$ de concreto). Sendo assim, os traços são comumente tratados em volume, pois a mensuração de massa do EPS é trabalhosa.

Segundo Kerbauy (2010), o CLEPE proporciona a melhoria dos aspectos técnicos e de produtividade dos elementos de concreto, industrializados, pré-moldados ou moldados no local, considerando suas principais características, tais como:

- Baixa massa específica;

- Reduzido tempo de cura;

- Pouco tempo para desmoldagem;

- Facilidade de manuseio, transporte e armazenamento;

- Redução de mão de obra e do uso de equipamentos especiais para peças maiores;

- Facilidade de produção;

- Elevado isolamento térmico e acústico;

- Altos valores iniciais de resistência mecânica e valores finais satisfatórios para emprego estrutural.

Ainda comentando as vantagens do CLEPE, Chen et al. (2010) comentam que a redução do peso próprio de concretos com EPS promovem grandes reduções nos custos e nas dimensões de peças estruturais e das fundações.

\subsection{CLEPE, concreto com agregados leves e concreto celular}

Conforme Mehta e Monteiro (2008), o concreto leve com agregados leves possui a característica de leveza justamente devido à porosidade dos agregados ditos leves. Comumente a resistência à compressão e o módulo de elasticidade dos concretos leves com agregados leves são maiores do que essas propriedades do CLEPE. Entretanto, a massa específica dos outros concretos leves estruturais é maior que a do CLEPE.

O concreto celular é outra forma de concreto leve. Sua maior aplicação é em estruturas que sofrem ciclos de gelo desgelo, conforme já comentado. Geralmente, o sistema estável de bolhas é conseguido pela adição de alumínio em pó na razão de cerca $0,2 \%$ da massa de cimento, conforme Neville (1997). A estrutura final porosa possui semelhança com a pedra- 
pomes Pode conter ou não agregados, sendo que seu uso como concreto estrutural ocorre basicamente com a adição de agregados comuns ou leves na mistura.

$\mathrm{Na}$ sequência, são feitos breves comentários sobre algumas características dos concretos leves estruturais com agregados leves e do concreto celular, em comparação com o CLEPE. Maiores detalhes sobre os concretos com agregados leves podem ser encontrados em Neville (1997), Rossignolo (2003), Rossignolo e Agnesini (2005), Mehta e Monteiro (2008), Rossignolo (2009), Rossignolo e Agnesini (2011) e Neville e Brooks (2013). Nos subitens seguintes, às vezes, esses autores são omitidos, entretanto, a discussão é baseada nos pontos colocados por eles. Para os comentários referentes ao CLEPE, são utilizadas as informações de Catoia (2012).

\subsubsection{Trabalhabilidade}

A trabalhabilidade do concreto com agregados leves é muito influenciada pela absorção de água pelo agregado. Diversos pesquisadores recomendam que o agregado seja pré-saturado. Já outros advogam que ele deve ser utilizado em estado seco. Ainda outros indicam métodos para uma saturação parcial. Em todos os casos, o teor de umidade do agregado afeta muito a trabalhabilidade do concreto.

A trabalhabilidade do concreto com agregados leves também é comprometida em casos de bombeamento. A pressão induzida sobre o concreto eleva a absorção de água do agregado, podendo causar problemas de entupimento e de sobrepressão no sistema.

O concreto celular é do tipo superfluido, e pode ser bombeado e lançado com facilidade, sendo comumente autoadensável. Muitas dosagens de concretos com agregados leves possuem incorporação de ar para melhorar as propriedades de trabalhabilidade.

Um ponto importante no adensamento de concretos com agregados leves e, quando necessário, para o CLEPE, é a frequência do vibrador. Frequências de vibração muito elevadas tendem a segregar a argamassa, no fundo, e os agregados leves ou o EPS, na parte superior.

A preocupação com a perda de trabalhabilidade do CLEPE não acontece em relação ao EPS, já que ele não absorve água. No entanto, isso deve ser levado em consideração quando da dosagem da relação água/cimento (a/c). A perda de trabalhabilidade do CLEPE ocorre devido ao processo de pega, que é acelerado com uma relação a/c mais baixa que o normal em concretos convencionais, principalmente quando se utiliza cimento de alta resistência inicial. 
No trabalho de Catoia (2012), a trabalhabilidade do CLEPE foi constatada tão grande, que se optou pelo ensaio de espalhamento (slump flow), indicado pela ASTM C1611:2006, em vez do tradicional ensaio de abatimento (slump text). O slump flow é comum para concretos autoadensáveis. O valor do espalhamento expressa a capacidade do concreto fluir e escoar pela ação da gravidade, relacionando-se com sua capacidade de preenchimento. A Figura 3.4 ilustra o ensaio realizado, que resultou em um espalhamento de $500 \mathrm{~mm} \pm 50 \mathrm{~mm}$, que, devido à menor massa dos agregados, corresponde a um concreto reodinâmico, que apresenta facilidades para lançamento, adensamento e nivelamento.

Além do espalhamento, os concretos avaliados apresentaram boa coesão, não apresentaram segregação ou flutuação do EPS e não ocorreu exsudação na mistura.

Assim sendo, o CLEPE apresenta uma trabalhabilidade melhor que a do concreto com agregados leves, e quase idêntica à do concreto celular.

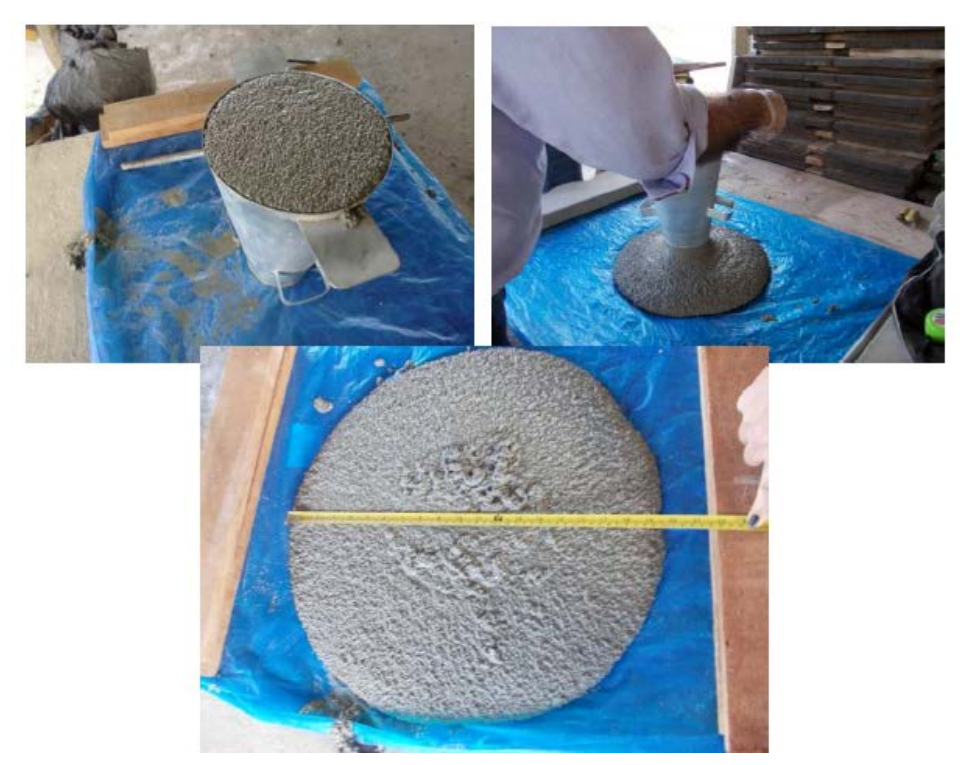

Figura 3.4 - Ensaio típico de espalhamento do CLEPE.

Fonte: Catoia (2012), p. 55.

\subsubsection{Massa específica}

A massa específica dos concretos leves estruturais com agregados leves fica em uma faixa de $1300 \mathrm{~kg} / \mathrm{m}^{3}$ a $2000 \mathrm{~kg} / \mathrm{m}^{3}$. A massa específica é diretamente ligada com a dimensão do agregado (quanto menor a dimensão do agregado, maior a massa específica) e com sua umidade (agregados saturados tendem a elevar a massa específica). Sendo assim, o controle da massa específica nesses concretos é muito complexo, pois a verdadeira relação a/c é de difícil determinação, pois é função da porosidade e da conformação superficial do agregado. 
No concreto celular, o valor da massa específica é muito influenciado pelo teor de umidade do concreto. No estado seco, concretos celulares com o fim de isolamento térmico (que não contêm agregados graúdos) têm massa específica entre $200 \mathrm{~kg} / \mathrm{m}^{3}$ e $300 \mathrm{~kg} / \mathrm{m}^{3}$. Porém, esse concreto não tem fins estruturais. Concretos celulares estruturais possuem massa específica na ordem de $1200 \mathrm{~kg} / \mathrm{m}^{3}$ a $1600 \mathrm{~kg} / \mathrm{m}^{3}$.

Quanto ao CLEPE, a massa específica é facilmente controlável, pois o EPS possui densidade definida e não absorve água. Para aplicações econômicas, a massa específica varia em torno de $1200 \mathrm{~kg} / \mathrm{m}^{3}$ a $1400 \mathrm{~kg} / \mathrm{m}^{3}$. Catoia (2012) obteve valores de $1209 \mathrm{~kg} / \mathrm{m}^{3}$ a $1373 \mathrm{~kg} / \mathrm{m}^{3}$.

\subsubsection{Resistência à compressão}

AÏTCIN (2000) apresenta resultados de concretos leves estruturais de alto desempenho que chegaram até a $100 \mathrm{MPa}$. Entretanto, essa não é a normalidade. A resistência usual dos concretos leves estruturais com agregados leves varia em torno de $17 \mathrm{MPa}$ a $30 \mathrm{MPa}$. O comportamento resistente à compressão é diferente do relativo aos concretos comuns, que via de regra apresentam união de microfissuras, primariamente originárias na zona de transição entre o agregado e a matriz do concreto. Assim sendo, os concretos comuns tendem a ter a linha de ruptura contornando os agregados (HANAI, 2005).

Nos concreto com agregados leves, a resistência à compressão é ditada pela resistência do agregado leve. Devido à porosidade elevada, e quando existe a pré-saturação, a zona de transição entre o agregado leve e a matriz do concreto é fortalecida, e em consequência da proximidade entre os módulos de deformação (agregado e matriz), a linha de ruptura passa pelo agregado leve. Portanto, existe um limite ótimo de resistência da matriz, que além desse determinado valor, não estará sendo utilizada com a capacidade máxima, pois o fator limitante será a resistência do agregado.

O concreto celular, quando não possui agregados graúdos, apresenta resistências da ordem de $1 \mathrm{MPa}$ a $10 \mathrm{MPa}$, sendo que resistências maiores são obtidas pelo aumento no consumo de cimento.

Para a mesma massa específica, o CLEPE não apresenta resistências inferiores às do concreto com agregados leves. A resistência é ditada diretamente pela resistência da matriz. Portanto, para que a resistência à compressão seja maximizada no CLEPE, a matriz deve apresentar uma boa compacidade e resistência. O mecanismo de ruptura é concentrado em falhas e desvios da matriz, não sofrendo maiores influências pelo EPS. A linha de ruptura não 
chega a dividir o corpo de prova quando em situação de pequenas deformações, devido ao efeito de aderência entre o EPS e a matriz. Catoia (2012) obteve resistências à compressão de $13 \mathrm{MPa}$ a $18 \mathrm{MPa}$, para o CLEPE estudado.

\subsubsection{Resistência à tração}

A resistência à tração de concretos com agregados leves é em torno de 6\% a 9\% da resistência à compressão, quando obtida no ensaio de compressão diametral, e de 8\% a 11\%, quando for relativa ao ensaio de tração na flexão. Neville (1997) indica resultados da ordem de $1 \mathrm{MPa}$ a $2 \mathrm{MPa}$.

O CLEPE ensaiado por Catoia (2012) apresentou resultados de 1 MPa a 1,3 MPa para a resistência à tração no ensaio de compressão diametral, e de 1,2 MPa a 1,5 MPa para o ensaio de tração na flexão. Observa-se que são valores próximos aos indicados para concretos com agregados leves.

\subsubsection{Módulo de elasticidade}

Para os concretos com agregados leves, o módulo de elasticidade não é muito influenciado pelo módulo do agregado leve, pois esse tem módulo semelhante ao da matriz do concreto. Os valores variam entre $18 \mathrm{GPa}$ e $26 \mathrm{GPa}$, sendo tipicamente $12 \mathrm{GPa}$ a menos do que os dos concretos comuns.

O concreto celular apresenta baixos valores para o módulo de elasticidade, na ordem de 1,7 GPa a 3,5 GPa.

Catoia (2012) obteve valores de 9 GPa a 12 GPa para o módulo de elasticidade tangente inicial, e de 8 GPa a 11 GPa para o módulo de elasticidade secante, para os CLEPE's ensaiados. Esses valores são menores do que os dos concretos com agregados leves, porém, bem maiores do que os do concreto celular. Isto indica a possibilidade de utilização do CLEPE em elementos fletidos, como lajes maciças ou nervuradas.

\subsubsection{Retração e fluência}

Os concretos com agregados leves apresentam deformação de retração por secagem entre $500 \times 10^{-6}$ e $1000 \times 10^{-6}$. Os valores usuais de fluência estão na ordem de $1600 \times 10^{-6}$. Esses valores são consequência do baixo módulo de elasticidade dos agregados. Entretanto, o baixo módulo de elasticidade interfere mais na fluência do que na retração. Uma das formas 
de minimizar a retração é pré-saturando os agregados. A água absorvida por eles contribui como água disponível para a hidratação do cimento, reduzindo a retração autógena. Porém, o excesso de água na zona de transição pode fragilizar a ligação do agregado com a matriz.

Para o concreto celular, a variação na retração é grande. Para concretos secos em estufa, com $1600 \mathrm{~kg} / \mathrm{m}^{3}$ de massa específica, a retração é em torno de 700 x 10-6. Já para concretos celulares também secos em estufa, porém com massa específica de $400 \mathrm{~kg} / \mathrm{m}^{3}$, a retração fica em torno de $3000 \times 10^{-6}$.

Os diferentes traços de CLEPE ensaiados por Catoia (2012) apresentaram valor médio de deformação de retração de 950 × $10^{-6}$, e um acréscimo da flecha inicial devido à fluência de $140 \%$.

\subsubsection{Durabilidade}

Devido ao módulo de elasticidade do agregado leve ser muito próximo ao da matriz do concreto com agregados leves, quase não existem fissuras na zona de transição. Isso faz com que esse tipo de concreto apresente um bom desempenho quanto à durabilidade. Vale lembrar que a durabilidade em estrutura de concreto está diretamente relacionada à permeabilidade do respectivo concreto.

O concreto celular, apesar de ter um elevado índice de permeabilidade, não apresenta grandes problemas em edificações, nas situações em que não é exposto diretamente às intempéries.

Momtazi et al. (2010) obtiveram resultados satisfatórios para concretos tipo CLEPE em ambientes marinhos. Catoia (2012) apresenta resultados de ensaios de carbonatação de corpos de prova de CLEPE. Os resultados demonstram que existe a penetração de $\mathrm{CO}_{2}$ no CLEPE em profundidade da ordem de $2 \mathrm{~cm}$. Entretanto, devido ao teor alcalino, não foi constatada uma diminuição significativa do $\mathrm{pH}$, nem mesmo em camadas superficiais. Esse comportamento é diferente dos relativos aos concretos comuns, e resulta principalmente do maior consumo de cimento nesses concretos com EPS.

\subsection{Aplicabilidade do CLEPE na construção civil}

A utilização de concretos com EPS apresenta-se não somente como uma alternativa para o descarte do EPS (solução sustentável), mas principalmente como uma alternativa técnica e economicamente favorável. 
O CLEPE pode ser utilizado em diversos elementos estruturais, arquitetônicos e até mesmo decorativos. Lajes, painéis de vedação, mourões de cerca, vasos ornamentais e lixeiras são apenas alguns exemplos do potencial desse material, que aliado com a leveza, oferece um bom acabamento superficial, evitando que sejam visualizadas as pérolas de EPS.

Catoia (2012) elaborou e apresentou diversas tabelas, nas quais é possível comparar lajes maciças de concreto convencional e de CLEPE, diferentes condições de vinculação, geometria e capacidade de carga. Dessas tabelas, fica evidente a grande redução no peso próprio das lajes, que leva a economia em vigas, pilares e fundação.

Na Figura 3.5 é apresentado um pedaço de um painel de laje PI de CLEPE. As Figuras 3.6 e 3.7 ilustram respectivamente uma laje maciça e um painel de fechamento do mesmo material. Portanto, observa-se que na industrialização da construção civil, em particular com elementos pré-moldados, é que o CLEPE possui grande aplicabilidade. Novamente justificase a razão desta pesquisa, pois esse material pode ser amplamente utilizado em lajes de edificações de baixo custo e de interesse social, bem como em edificações de alto padrão.

Cavalcanti et al. (2012) apresentaram um estudo realizado com painéis de vedação de CLEPE em relação a conforto térmico e sustentabilidade. Os resultados obtidos são muito promissores e indicam que o CLEPE possui vantajosas funções de isolação térmica. Entretanto, esse é um assunto que deve ser estudado com maiores detalhes.

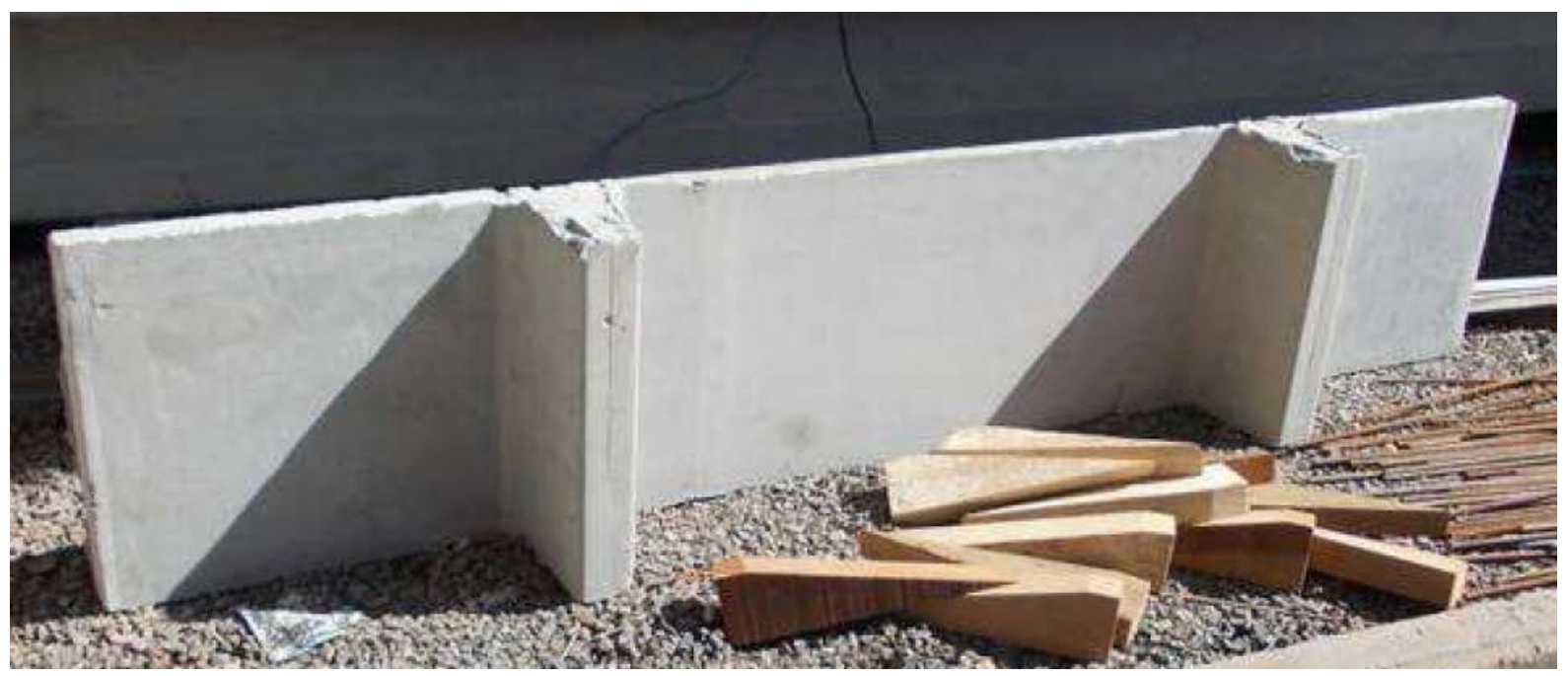

Figura 3.5 - Painel PI de CLEPE.

Fonte: Catoia et al. (2012), p. 13. 


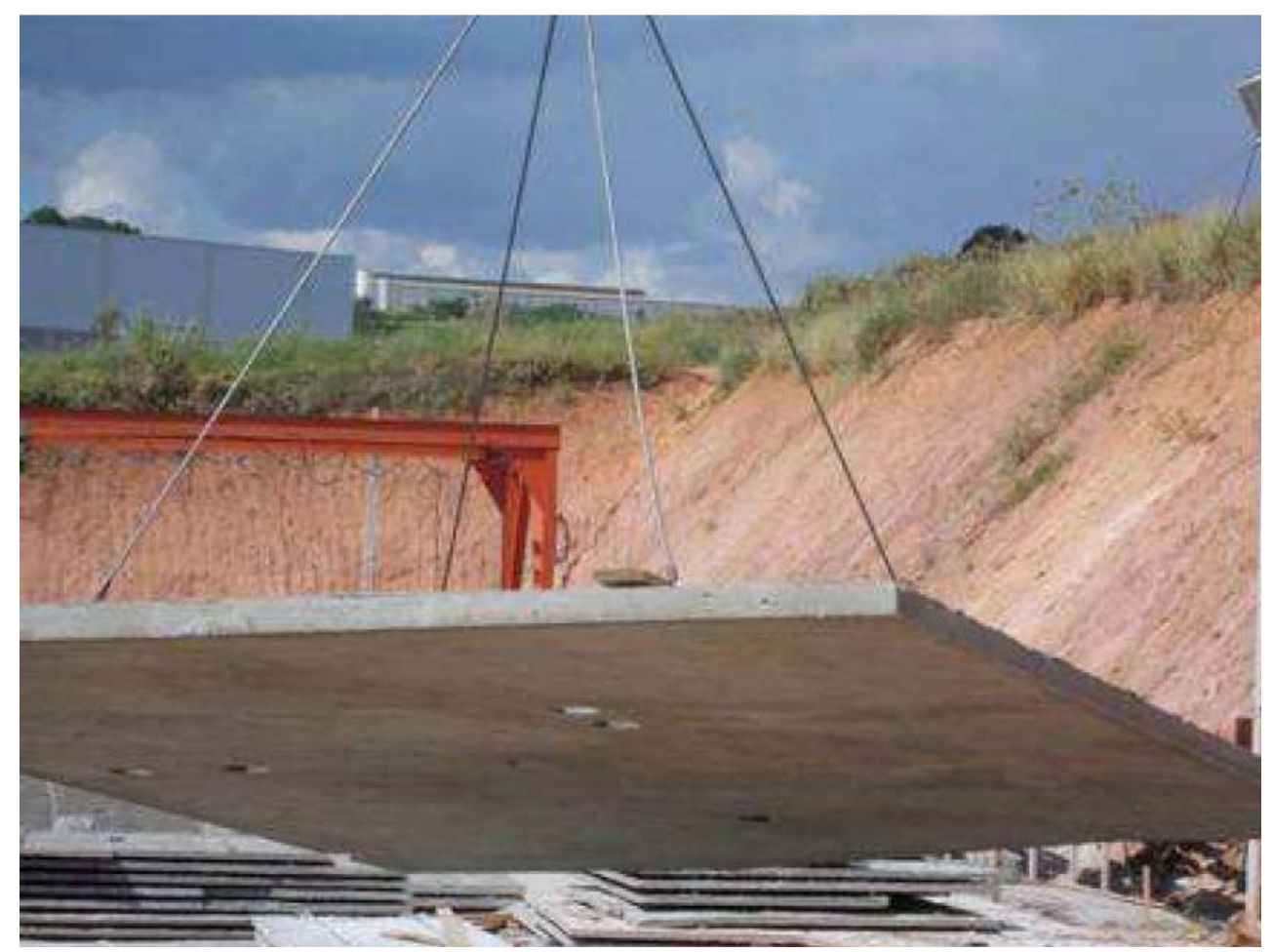

Figura 3.6 - Laje maciça de CLEPE durante o içamento.

Fonte: Catoia et al. (2012), p. 12.

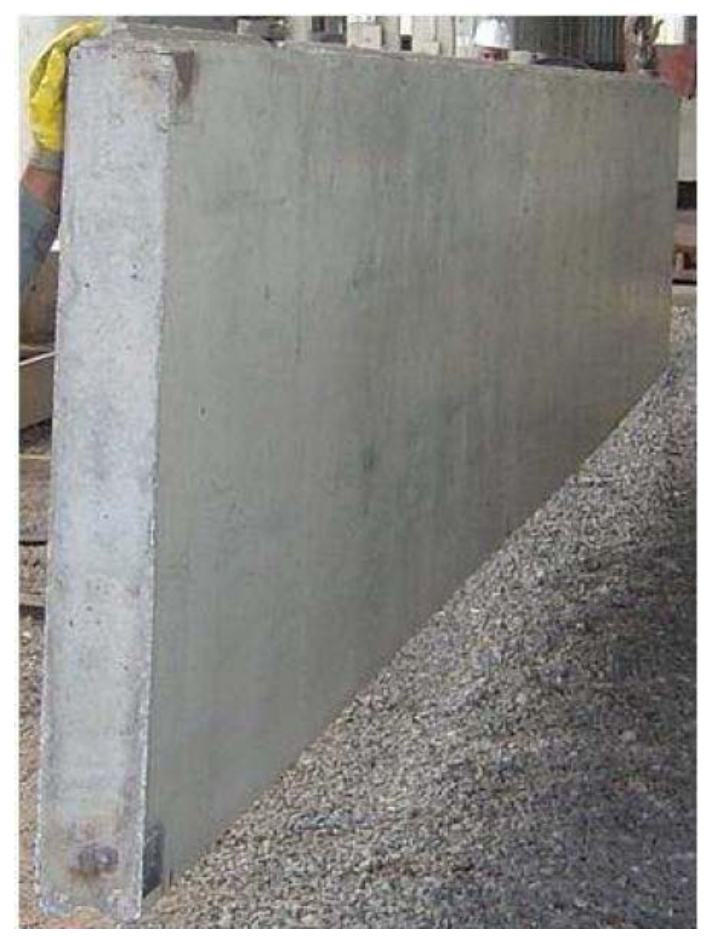

Figura 3.7 - Painel de fechamento confeccionado com CLEPE.

Fonte: Catoia et al. (2012), p. 13. 


\section{Programa Experimental - Descrição e Preparativos}

No presente capítulo é apresentada uma visão geral do programa experimental bem como é tratado o primeiro passo da pesquisa experimental, que foi a preparação e a configuração dos modelos de lajes apoiados sobre alvenarias.

\subsection{Visão geral do programa experimental}

O programa experimental pode ser dividido em dois grupos. Primeiro foram desenvolvidos ensaios dinâmicos em lajes sobre apoios de alvenaria. Posteriormente, foram realizados mais dois ensaios dinâmicos complementares, para confirmação de resultados obtidos no primeiro grupo.

A totalidade dos ensaios do programa experimental é dividida nas seguintes modalidades:

- Ensaios dinâmicos em lajes de concreto sobre alvenaria (Descrição e preparação dos modelos apresentados no Capítulo 4);

- Ensaios de caracterização dinâmica e estática do concreto utilizado nos ensaios das lajes sobre alvenaria (Capítulo 5);

- Resultados e discussões dos ensaios das lajes sobre alvenaria (Capítulo 6);

- Ensaios dinâmicos em lajes sobre molas (Capítulo 7);

- Tabelas complementares (Apêndice B).

A ideia inicial da parte experimental foi avaliar o comportamento de lajes de CLEPE comparadas as de CC apoiadas sobre alvenaria, perfazendo um grupo de ensaios para descrever o comportamento dinâmico desde uma laje isolada até uma com os quatro bordos apresentando continuidade. A Figura 4.1 ilustra o esquema dos modelos que foram ensaiados.

Após a obtenção dos resultados desses ensaios (Capítulo 6), houve a necessidade de ampliação do programa experimental, com os ensaios de duas lajes apoiadas sobre molas (Capítulo 7). 

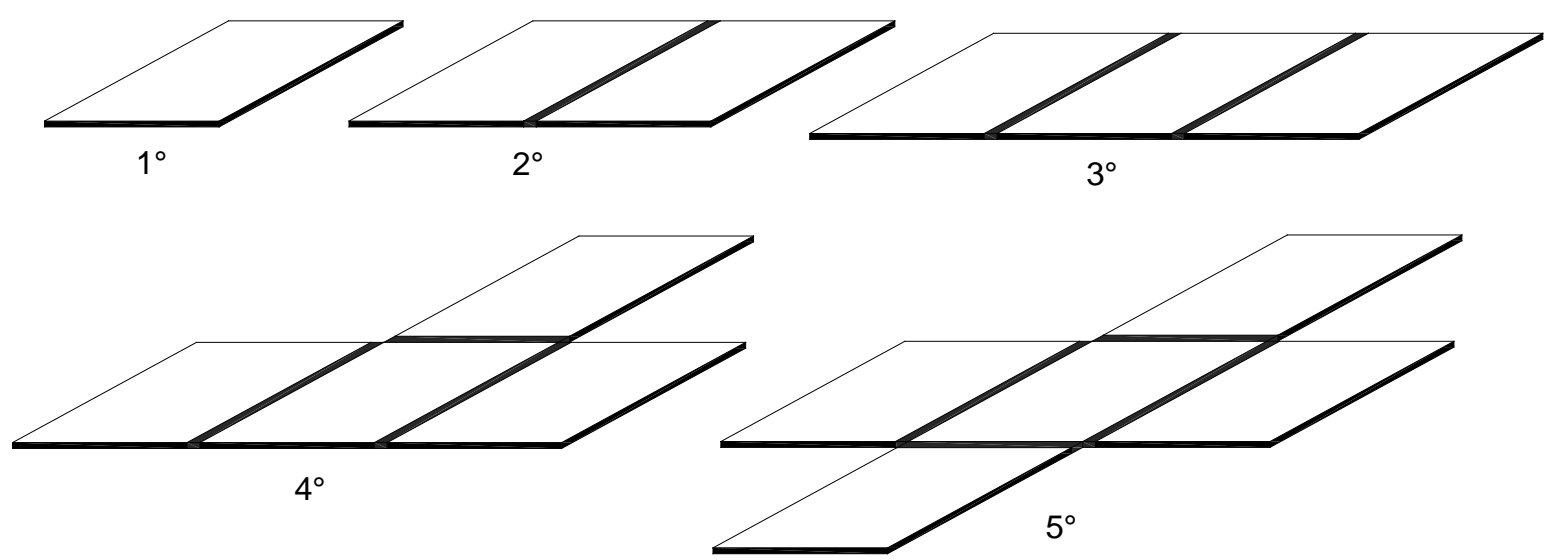

Figura 4.1 - Esquema das lajes apoiadas sobre alvenaria. $1^{\circ}$ laje isolada. $2^{\circ}$ laje com uma continuidade. $3^{\circ}$ laje com duas continuidades. $4^{\circ}$ laje com três continuidades. $5^{\circ}$ laje com quatro continuidades.

Com a visão geral do programa experimental, introduz-se agora o tema objeto do presente capítulo, que trata da preparação dos modelos e as configurações dos ensaios dinâmicos nas lajes apoiadas sobre alvenaria.

\subsection{Modelos e configuração dos ensaios dinâmicos sobre alvenaria}

O objetivo desses ensaios foi determinar o comportamento dinâmico (frequências naturais, fator de amortecimento e deformadas modais) de lajes maciças com concreto de densidade normal (aproximadamente $24 \mathrm{kN} / \mathrm{m}^{3}$ ) e concreto leve com pérolas de EPS (CLEPE - densidade aproximada de $12 \mathrm{kN} / \mathrm{m}^{3}$ ).

As lajes com CLEPE podem ser usadas em habitações uni e multifamiliares de interesse social, podendo ser também aplicadas em outras edificações. O emprego de alvenaria estrutural de blocos de concreto, blocos cerâmicos ou paredes de painéis prémoldados de concreto é comum nas edificações em que se pretende aplicar as lajes com CLEPE. Assim sendo, fica justificada a utilização de alvenaria estrutural de blocos de concreto e de blocos cerâmicos como base nivelada para os ensaios dinâmicos.

Como na maioria dos laboratórios, uma limitação real no Laboratório de Estruturas do SET é a questão do espaço físico disponível para ensaio de lajes. Portanto, foram escolhidas dimensões que atendessem a essa limitação.

Para a geometria das lajes foi adotada uma relação entre o lado maior e o lado menor próxima a 1,20. O lado menor apresenta dimensão de 1,39 m e o maior de 1,69 m, resultando 
em uma relação de 1,216 entre os lados. A espessura dos painéis de laje foi de $5 \mathrm{~cm}$. Essas dimensões, apesar de serem reduzidas, conduziram a resultados satisfatórios na análise numérica, isto é, possibilitam a caracterização dos modos de vibração em faixas de frequências possíveis de serem excitadas com os equipamentos disponíveis.

Os ensaios dinâmicos buscam avaliar o resultado de um painel isolado e, posteriormente, desse painel ligado a outros, levando em conta certo grau de continuidade.

Um detalhe importante de ser destacado é que esse conjunto de ensaios foi feito para lajes com concreto convencional (CC) e lajes com CLEPE.

A sequência do desenvolvimento dos ensaios dinâmicos nas lajes é descrita nos itens a seguir.

\subsubsection{Construção dos apoios de alvenaria estrutural}

Foram construídas alvenarias de blocos cerâmicos e de concreto com 19 cm de largura e aproximadamente $80 \mathrm{~cm}$ de altura (quatro fiadas de blocos). As Figuras 4.2 a 4.6 ilustram as dimensões, a disposição de cada fiada, a construção e a vista final das alvenarias de apoio. Observa-se que nas três primeiras fiadas são dispostas passagens para eventuais observações inferiores dos painéis de laje.

Foi concretada uma cinta superior com concreto convencional, com uma barra de diâmetro 6,3 mm de CA-50 em todo contorno. As juntas de argamassa convencional foram da ordem de $1 \mathrm{~cm}$ de espessura.

As alvenarias foram construídas sobre uma lona plástica, evitando a aderência com o piso do laboratório. Sobre a cinta da $4^{\underline{a}}$ fiada, também foi disposta uma faixa de lona plástica para evitar que o graute, utilizado na ligação das lajes de CC, tivesse aderência com a alvenaria. Este último procedimento justificou-se, pois a mesma alvenaria foi utilizada para ensaiar as lajes com CC e as lajes com CLEPE.

Observa-se que as três fiadas inferiores foram feitas em bloco estrutural cerâmico, já a última fiada foi executada em bloco estrutural de concreto do tipo canaleta. A altura das paredes de $80 \mathrm{~cm}$ foi adotada devido à presença de um trecho de pilar (Figuras 4.5 e 4.6) no espaço destinado aos ensaios. Salienta-se que se não existisse esse pilar, somente uma fiada de blocos estruturais de apoio (cinta) seria necessária para a realização dos ensaios. 


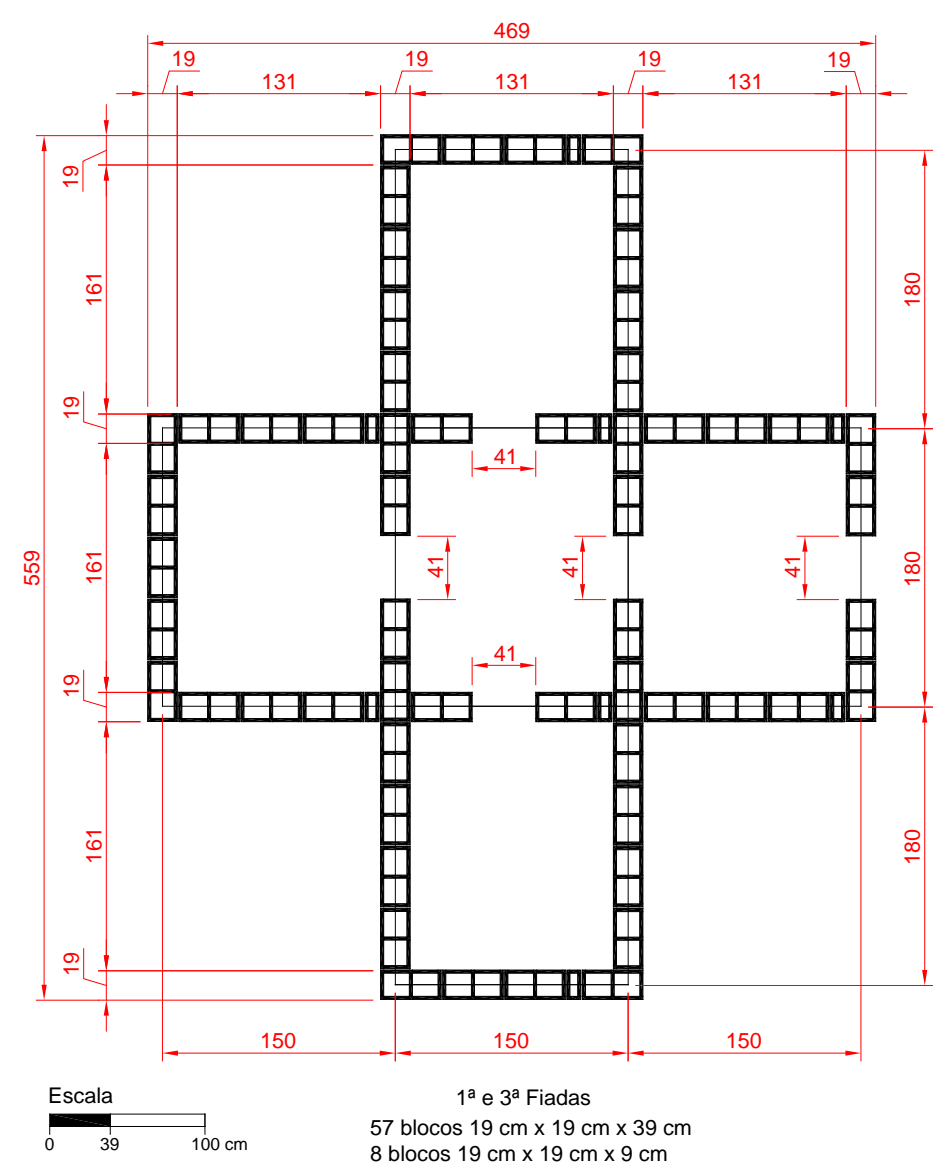

Figura 4.2 - Esquema da $1^{\underline{a}}$ e da $3^{\underline{a}}$ fiada da alvenaria de apoio (cotas em centímetros).

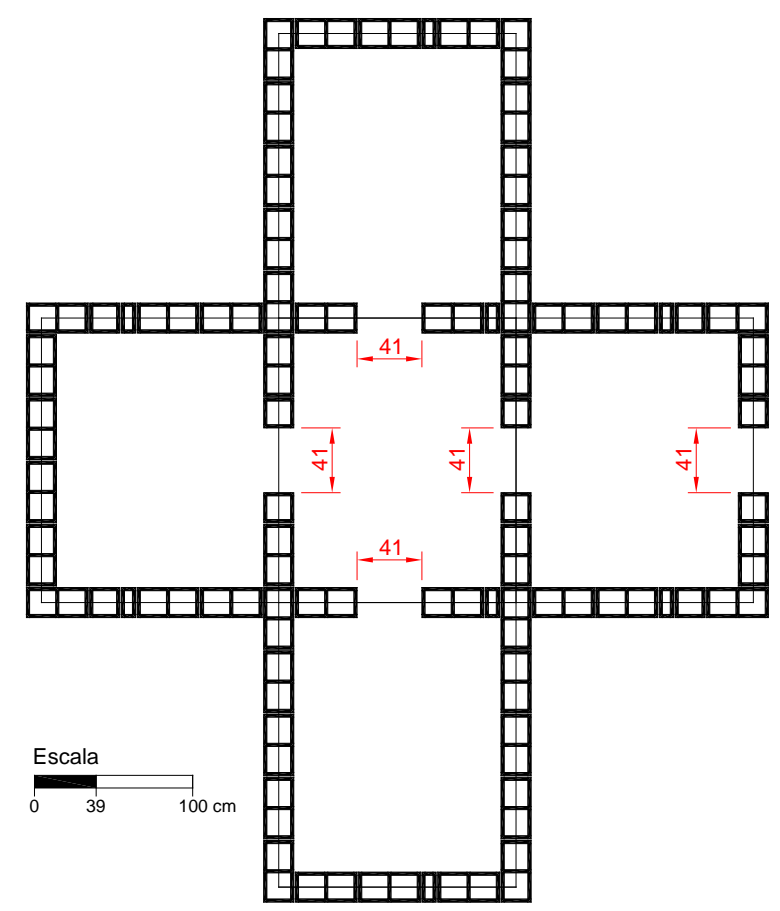

$2^{\mathrm{a}}$ Fiada

52 blocos $19 \mathrm{~cm} \times 19 \mathrm{~cm} \times 39 \mathrm{~cm}$

10 blocos $19 \mathrm{~cm} \times 19 \mathrm{~cm} \times 19 \mathrm{~cm}$

8 blocos $19 \mathrm{~cm} \times 19 \mathrm{~cm} \times 9 \mathrm{~cm}$

Figura 4.3 - Esquema da $2^{\mathrm{a}}$ fiada da

alvenaria de apoio (cotas em centímetros).

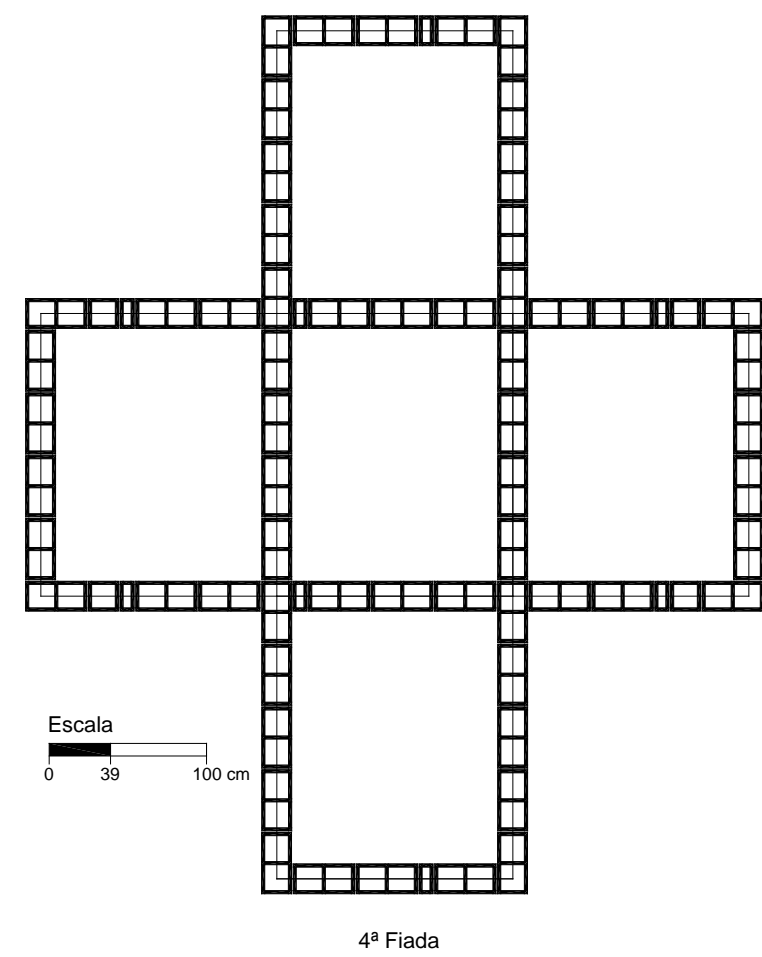

60 blocos canaleta $19 \mathrm{~cm} \times 19 \mathrm{~cm} \times 39 \mathrm{~cm}$ 4 blocos canaleta $19 \mathrm{~cm} \times 19 \mathrm{~cm} \times 19 \mathrm{~cm}$

8 blocos canaleta19 $\mathrm{cm} \times 19 \mathrm{~cm} \times 9 \mathrm{~cm}$

Figura 4.4 - Esquema da $4^{\mathrm{a}}$ fiada da alvenaria de apoio (cotas em centímetros). 

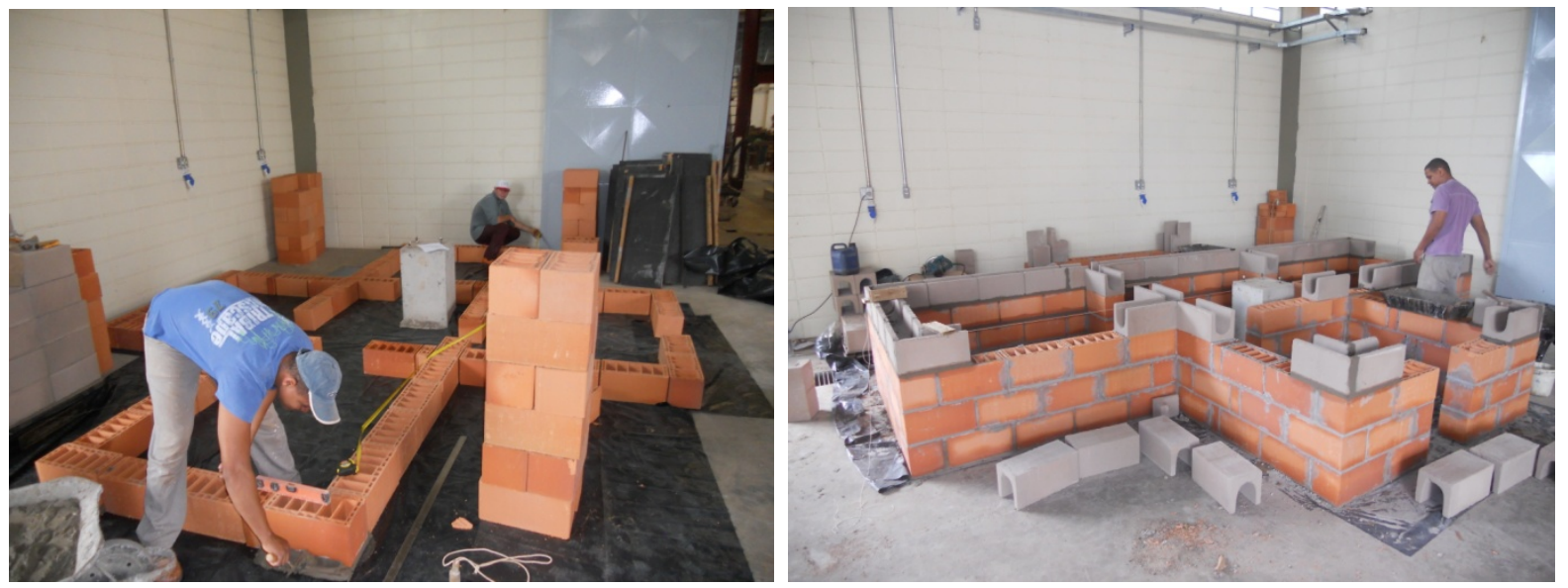

Figura 4.5 - Construção das alvenarias de sustentação das lajes.
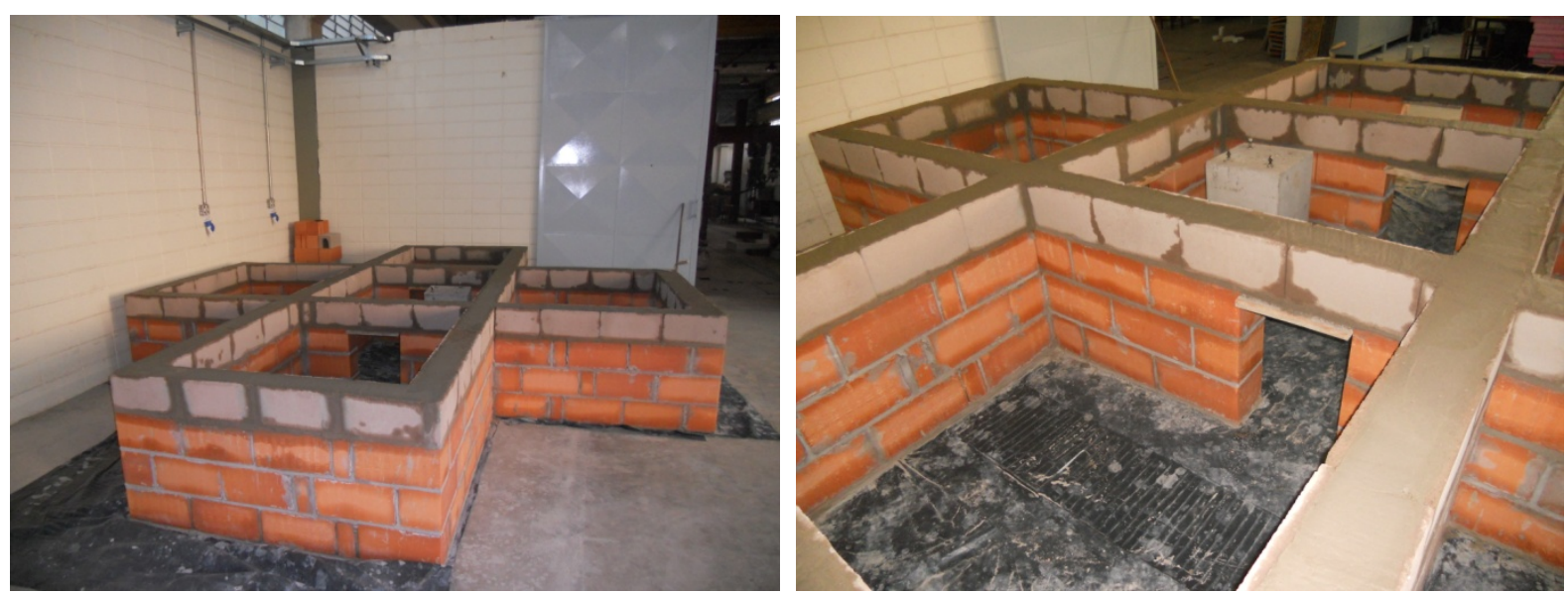

Figura 4.6 - Vista final das alvenarias de sustentação das lajes para os ensaios dinâmicos.

\subsubsection{Fabricação das lajes}

São descritos aqui procedimentos gerais da fabricação das lajes que foram apoiadas nas alvenarias. Os pormenores das lajes de CC e de CLEPE são descritos nos itens 4.2.2.1 e 4.2.2.2.

Foram concretados seis painéis para cada tipo de concreto. As formas para a confecção dos painéis foram de compensado naval, o que garantiu bom acabamento das peças. A armadura foi posicionada com espaçadores adequadamente colocados para garantir o posicionamento desejado.

As formas tinham aberturas nas laterais, permitindo que a tela ultrapassasse o limite da forma (franjas da tela). Essas franjas foram úteis para a posterior ligação entre os painéis de laje. A Figura 4.7 mostra as dimensões da forma. 


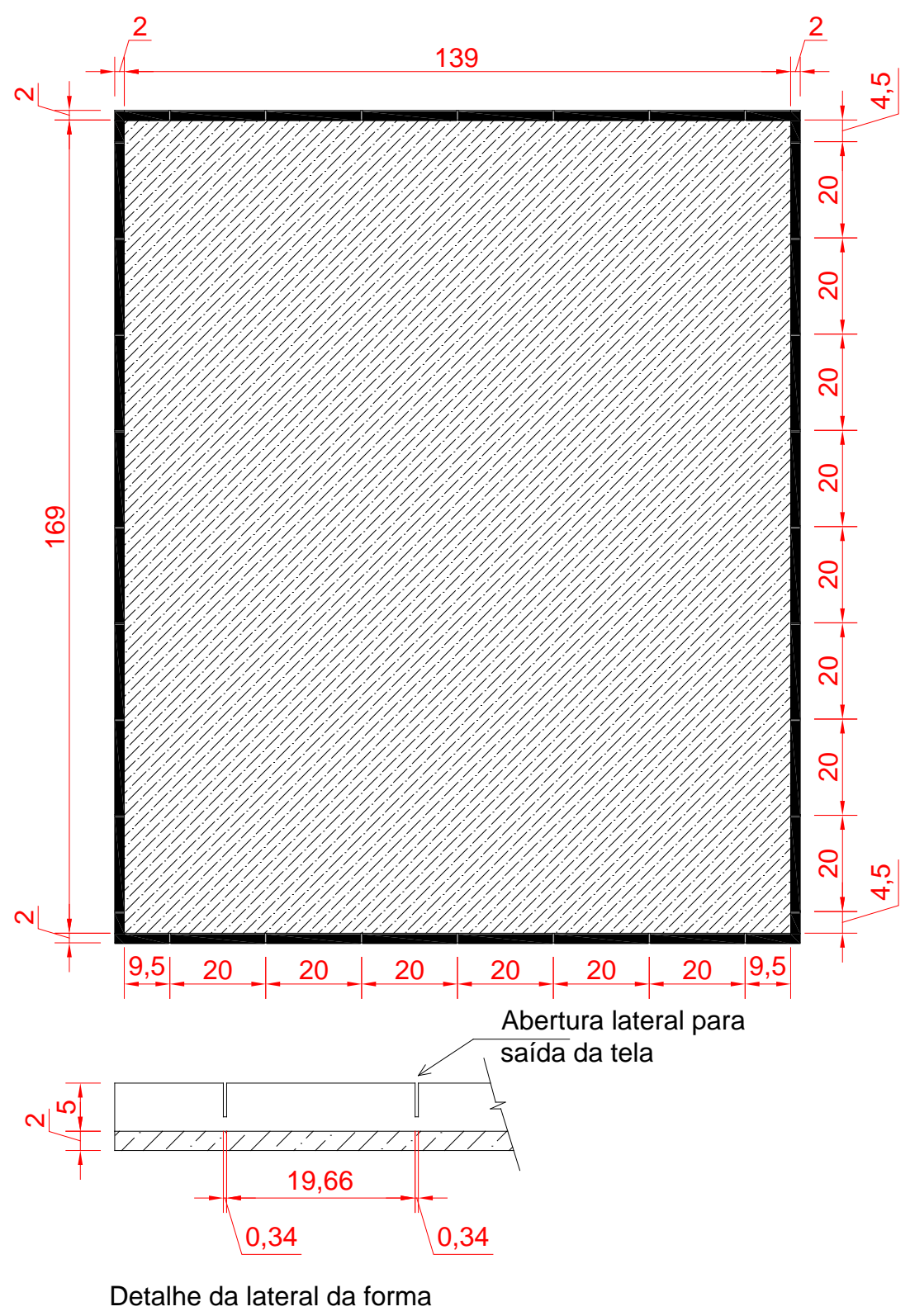

Figura 4.7 - Planta da forma dos painéis (cotas em centímetros).

A Figura 4.8 ilustra os passos da montagem e da concretagem de cada painel de laje. Observa-se que são dispostos quatro ganchos para o içamento de cada peça (Figura 4.9). A Figura 4.10 ilustra o posicionamento da armadura em tela. O dimensionamento das armaduras das lajes está descrito no Apêndice A. Nas Figuras 4.11 e 4.12 estão ilustrados o espaçador para garantir o cobrimento de $1,50 \mathrm{~cm}$ e o recorte na lateral da forma para a passagem da franja da tela, respectivamente.

As concretagens das lajes de CC e de CLEPE foram realizadas após a impregnação das formas com óleo hidráulico para desmoldagem. A Figura 4.13 ilustra a concretagem de um dos painéis. 


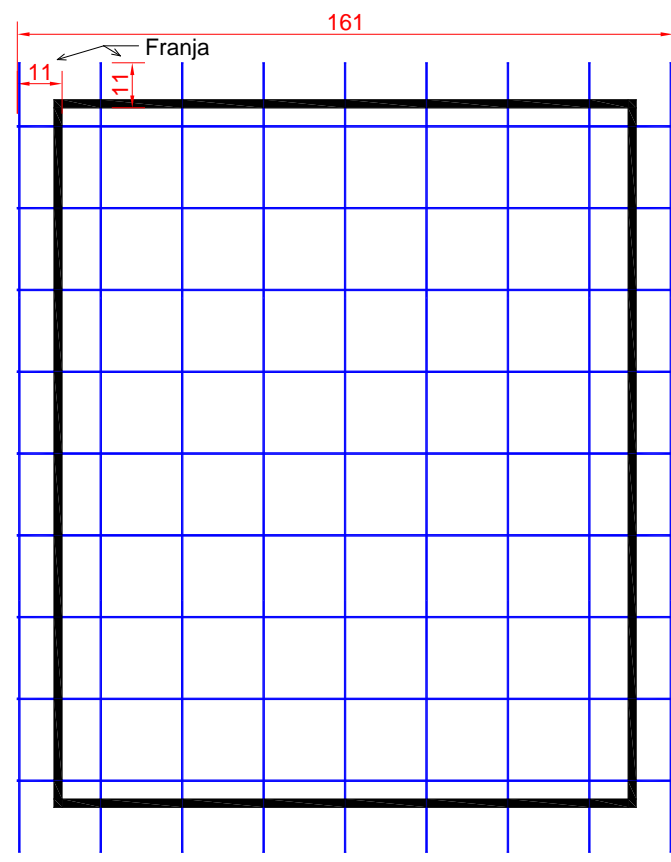

$1^{\circ}$ Passo - Posicionamento da tela Malha $\varnothing 3,4 \mathrm{~mm}$ a cada $20 \mathrm{~cm}$ nas duas direções

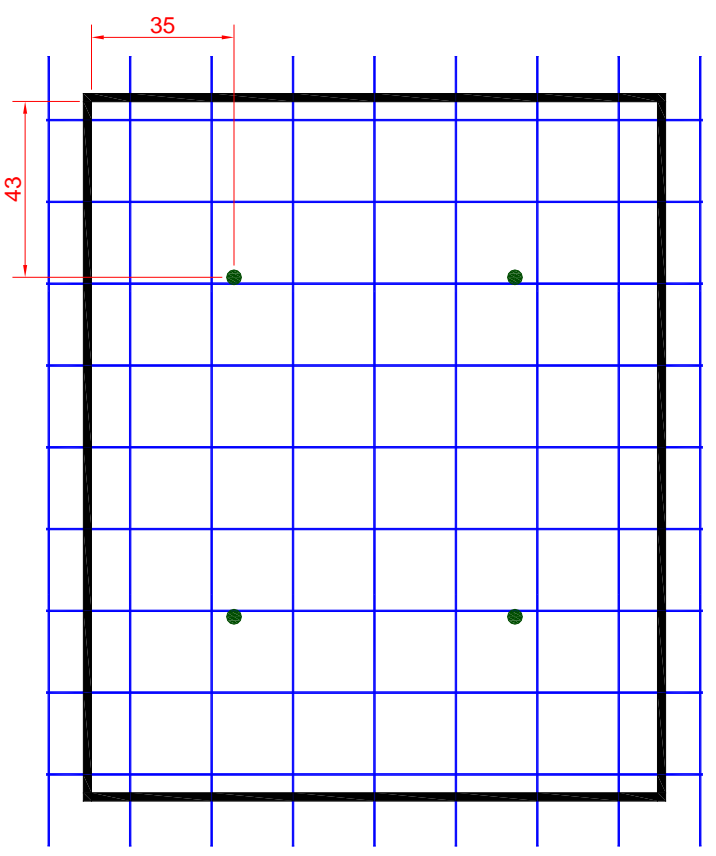

$2^{\circ}$ Passo - Posicionamento dos ganchos de içamento Barras $\varnothing 10 \mathrm{~mm}$ CA-25 em laço amarradas por baixo da tela

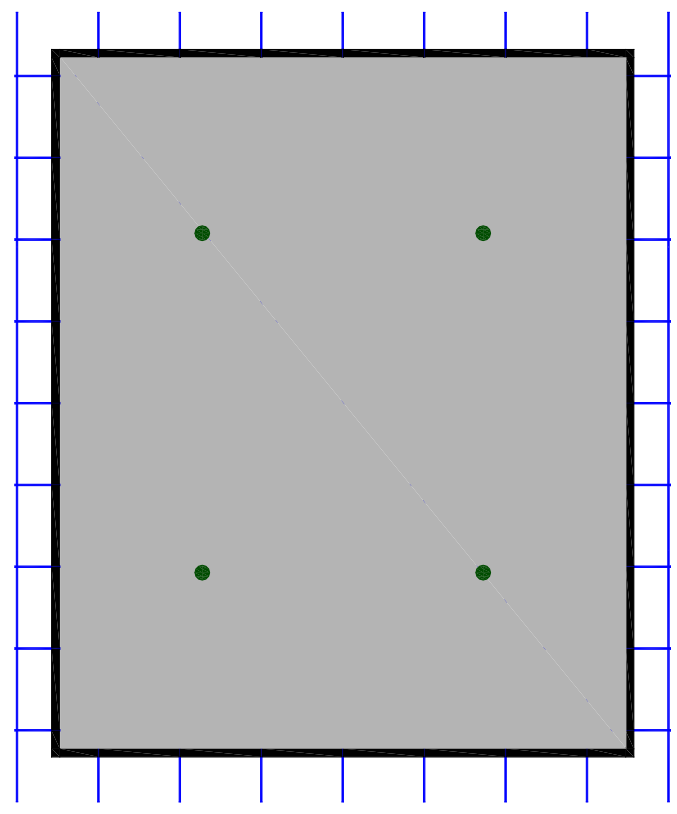

$3^{\circ}$ Passo - Concretagem

Figura 4.8 - Etapas da confecção dos painéis de laje (cotas em centímetros).

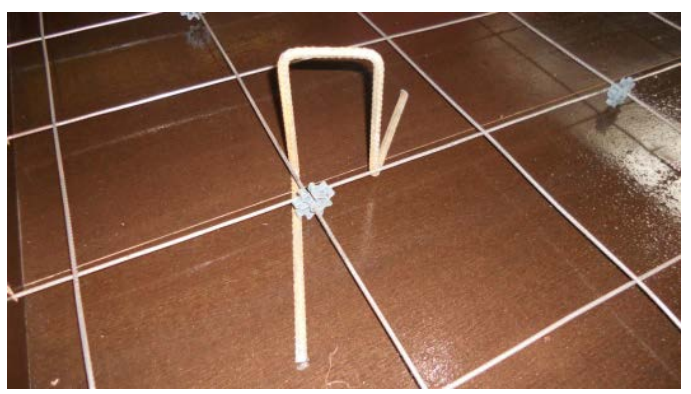

Figura 4.9 - Detalhe de um dos quatro ganchos para içamento. 


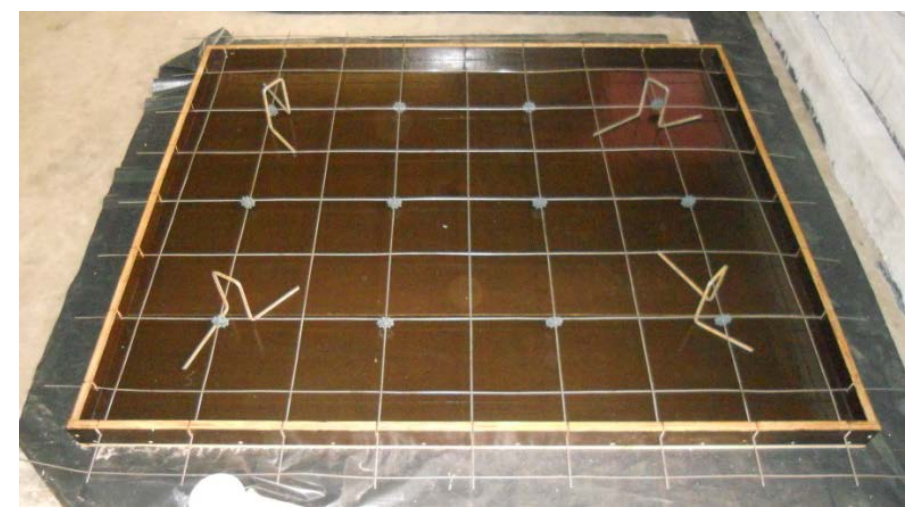

Figura 4.10 - Armadura em tela posicionada para a concretagem.

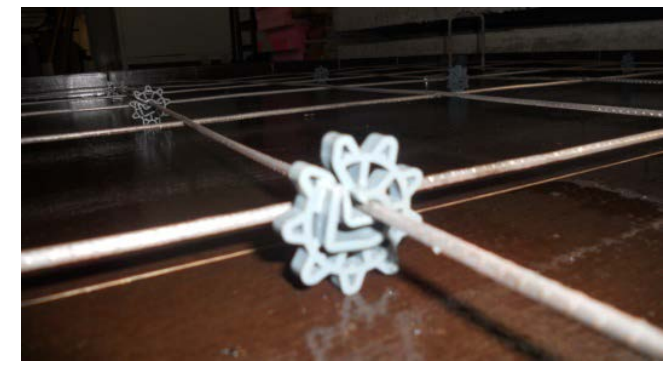

Figura 4.11 - Detalhe do espaçador de armadura para garantir cobrimento de $1,50 \mathrm{~cm}$.

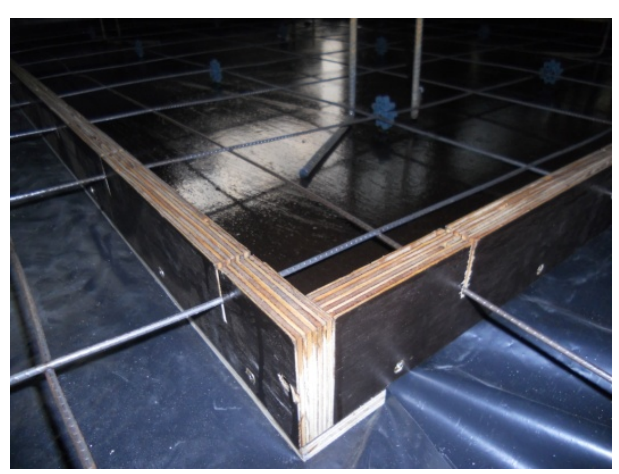

Figura 4.12 - Detalhe das aberturas laterais da forma para passagem da tela.
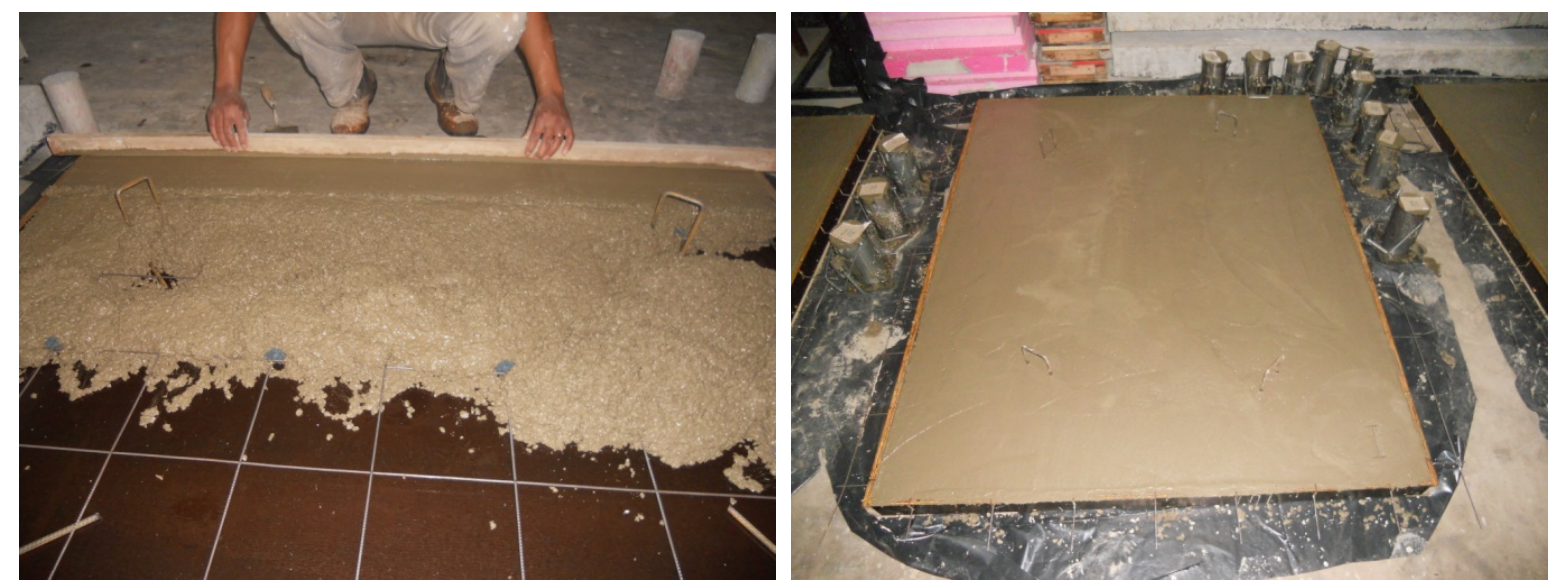

Figura 4.13 - Concretagem das lajes.

As lajes pré-moldadas foram sacadas com no mínimo 48 h de cura nas formas. Após a desmoldagem, as lajes foram armazenadas uma sobre a outra, no período de cura (no mínimo 28 dias), cobertas com uma lona plástica (Figura 4.14).

O apoio das lajes sobre a alvenaria estrutural foi feito por uma borda de $4 \mathrm{~cm}$ de largura, ficando livre sobre a canaleta um espaço de $11 \mathrm{~cm}$ para grauteamento que efetiva a 
ligação entre os painéis das lajes. O apoio da laje sobre a alvenaria foi feito utilizando-se argamassa magra, conforme ilustrado na Figura 4.15, para tentar garantir o contato de todas as bordas com a alvenaria. Os painéis das lajes foram posicionados sobre as alvenarias com o auxílio da ponte rolante do laboratório do SET.
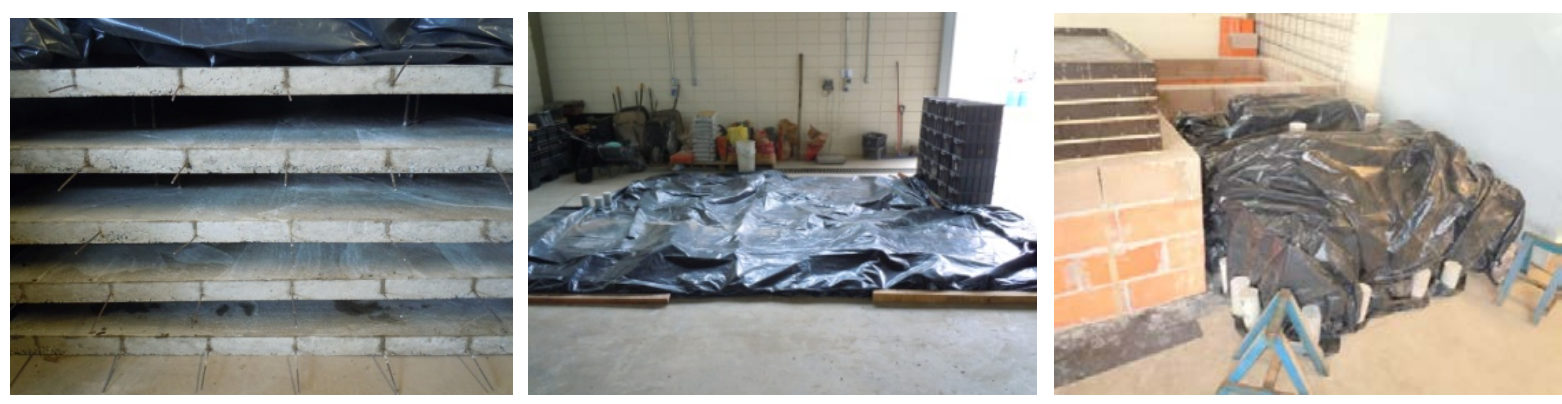

Figura 4.14 - Detalhe do armazenamento e cura das lajes.

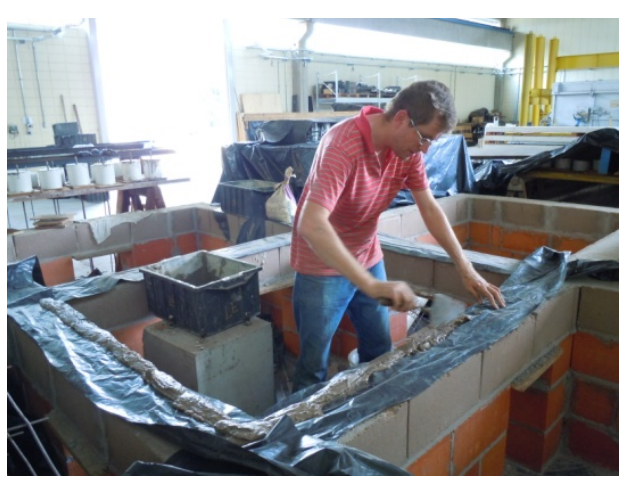

Figura 4.15 - Argamassa magra para apoio da laje sobre a alvenaria.

\subsubsection{Lajes de concreto convencional (CC)}

As lajes de concreto convencional (CC) foram moldadas no dia 17/10/2013. Foram feitas seis betonadas, uma para cada laje, em betoneira de capacidade de 0,300 $\mathrm{m}^{3}$. Os traços em massa de cada laje estão na Tabela 4.1. Os ensaios em que cada laje foi utilizada estão na Tabela B.1 (Apêndice B). Cada betonada gerava um volume de cerca 0,120 m³. Foi levado em conta o teor de umidade da areia (1,567\%) e do agregado graúdo (pedra britada de origem basáltica, 2,219\%).

A diferença dos traços da betonada 1 e das betonadas 2 a 5 justifica-se pela questão de trabalhabilidade. Já o traço da betonada 6 foi diferente, pois nela foi utilizado cimento CP II.

De cada betonada foram moldados três corpos de prova cilíndricos de $10 \mathrm{~cm}$ x $20 \mathrm{~cm}$ para os ensaios de caracterização do material. Observa-se que os mesmos corpos de prova que 
foram utilizados na caracterização dinâmica, foram posteriormente utilizados para a determinação estática da resistência à compressão. A resistência característica à compressão do concreto $\left(\mathrm{f}_{\mathrm{ck}}\right)$ esperada foi de no mínimo $25 \mathrm{MPa}$.

Tabela 4.1: Traços em massa de cada laje de CC.

\begin{tabular}{|c|c|c|c|c|c|}
\hline Laje & Betonada & $\operatorname{Traço}^{1}$ & Cimento & $\begin{array}{l}\text { Período de cura } \\
\text { na forma }\end{array}$ & $\begin{array}{l}\text { Período de cura fora } \\
\text { da forma }\end{array}$ \\
\hline 1 & 1 & 1:3:3:0,539 & \multirow{5}{*}{ CP V-ARI } & \multirow{6}{*}{4 dias } & \multirow{6}{*}{156 dias } \\
\hline 2 & 2 & \multirow{4}{*}{ 1:3:3:0,614 } & & & \\
\hline 3 & 3 & & & & \\
\hline 4 & 4 & & & & \\
\hline 5 & 5 & & & & \\
\hline 6 & 6 & $1: 2,4: 2,4: 0,511$ & CP II & & \\
\hline
\end{tabular}

\subsubsection{Lajes de CLEPE}

As lajes de CLEPE foram moldadas no dia 12/03/2014. Foram feitas cinco betonadas, sendo que algumas lajes foram moldadas com concretos de duas betonadas, o que não se mostrou uma boa solução. O CLEPE foi feito no misturador amarelo do laboratório do SET, em volumes de até $0,300 \mathrm{~m}^{3}$. A sequência de adição de materiais no misturador foi a seguinte:

- Primeiro colocou-se todo o EPS com toda a massa de areia e metade da massa de água;

- Após a mistura estar homogênea, foi adicionada a massa de cimento;

- A mistura do cimento com EPS e areia molhados forma pelotas que são dissolvidas com a introdução do restante da água e dos aditivos químicos superplastificantes de terceira geração.

Os traços de cada betonada estão na Tabela 4.2. Os ensaios em que cada laje foi utilizada estão na Tabela B.2 (Apêndice B). A areia utilizada foi seca ao sol.

Tabela 4.2: Traços de cada laje de CLEPE.

\begin{tabular}{|c|c|c|c|c|c|}
\hline Betonada & $\begin{array}{l}\text { Laje confeccionada } \\
\text { com cada betonada }\end{array}$ & Traço $^{1}$ da betonada & Cimento & $\begin{array}{c}\text { Período de } \\
\text { cura na } \\
\text { forma }\end{array}$ & $\begin{array}{c}\text { Período de } \\
\text { cura fora da } \\
\text { forma }\end{array}$ \\
\hline 1 & 1 & 1:1:0,0254:0,29:0,01 & \multirow{6}{*}{ CP V-ARI } & \multirow{6}{*}{6 dias } & \multirow{6}{*}{43 dias } \\
\hline 2 & 2 e $3 a$ & 1:1:0,0296:0,33:0,012 & & & \\
\hline 3 & 3a e 3b & 1:1:0,0296:0,32:0,012 & & & \\
\hline 4 & $3 b$ e 4 & 1:1:0,0285:0,33:0,01 & & & \\
\hline 5 & 6 & 1:1:0,0296:0,29:0,01 & & & \\
\hline 6 & 6 & 1:1:0,0198:0,317:0,01 & & & \\
\hline
\end{tabular}


Especial atenção deve ser dada para que não sejam introduzidos, em excesso, água e superplastificante, para evitar a flutuação do EPS. As Figuras 4.16 a 4.19 ilustram algumas das fases da mistura.

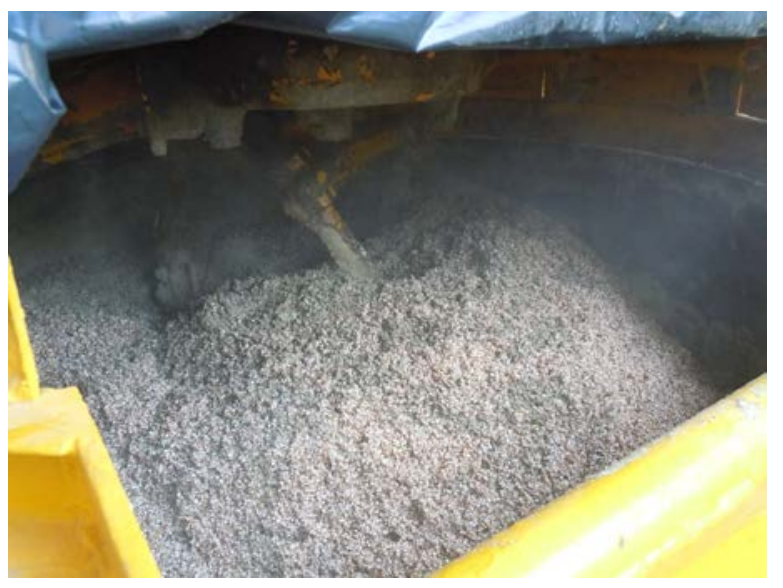

Figura 4.16 - Aspecto da mistura de areia, EPS e metade da água.

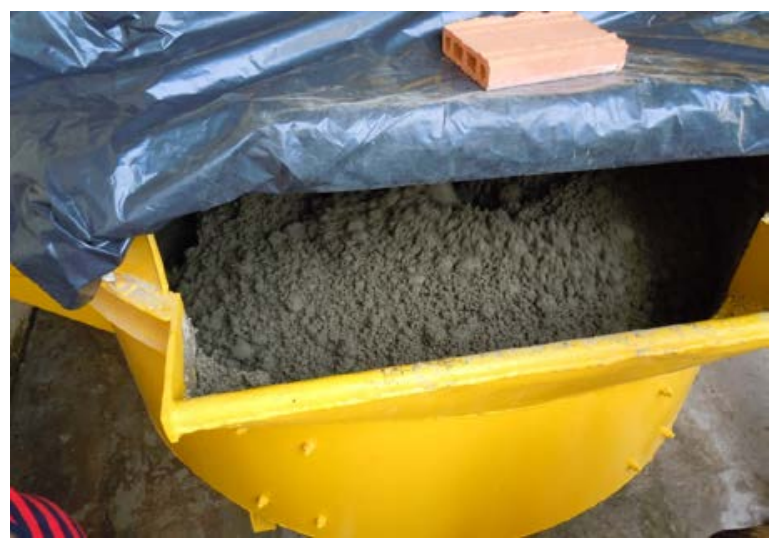

Figura 4.18 - Mistura com pelotas.

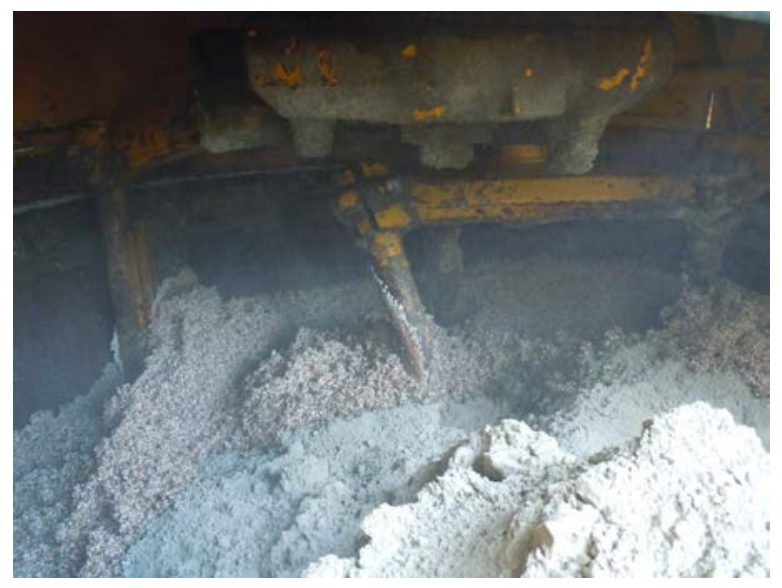

Figura 4.17 - Adição de cimento.

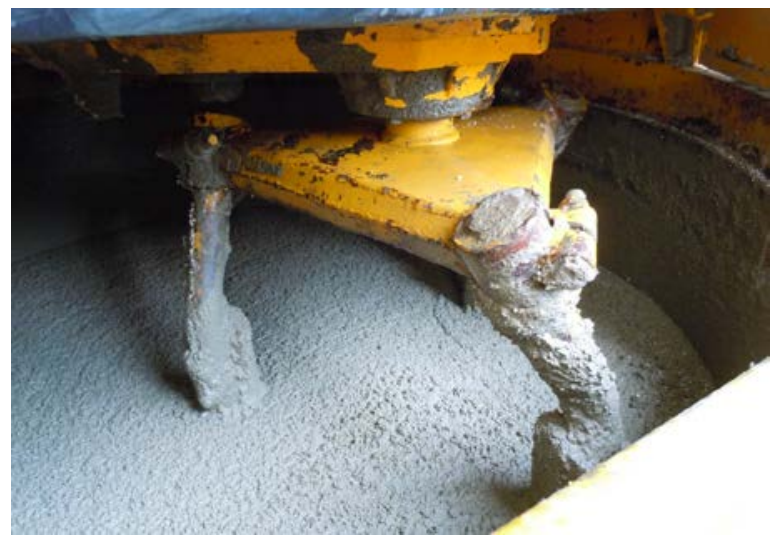

Figura 4.19 - Aspecto da mistura final com grande fluidez.

De cada betonada foram moldados quatro corpos de prova cilíndricos de dimensões $10 \mathrm{~cm}$ x $20 \mathrm{~cm}$ para os ensaios de caracterização do material. Destaca-se que os mesmos corpos de prova que foram utilizados na caracterização dinâmica, foram posteriormente utilizados para a determinação estática da resistência à compressão. A resistência característica do concreto à compressão $\left(\mathrm{f}_{\mathrm{ck}}\right)$ esperada foi de no mínimo $10 \mathrm{MPa}$.

As diferenças nos traços das betonadas são justificados pela trabalhabilidade e por flutuações que algumas misturas apresentaram. 


\subsubsection{Configuração dos ensaios dinâmicos das lajes}

Foram realizados seis ensaios dinâmicos para cada tipo de concreto, totalizando 12 ensaios dinâmicos. Todos esses ensaios totalizaram, para efeito de curiosidade: 138 leituras e 310 minutos de ensaios dinâmicos.

Em cada leitura foram utilizados quatro acelerômetros, quatro acelerômetros DeltaTron ${ }^{\circledR}$ Type 8344 da Brüel \& Kjaer, ilustrados na Figura 4.20. O sistema de aquisição de

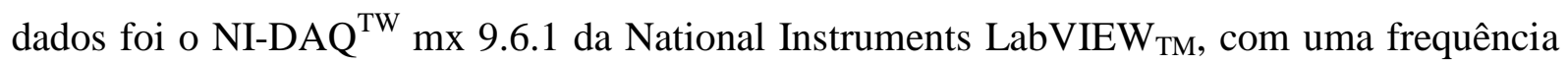
de aquisição de $1500 \mathrm{~Hz}$.

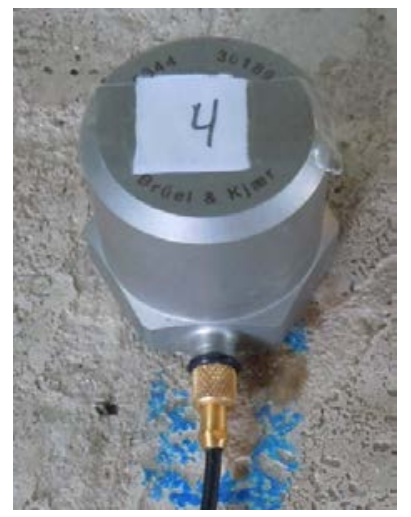

Figura 4.20 - Detalhe de um dos quatro acelerômetros utilizados.

A excitação dos ensaios foi um impulso por impacto com martelo de borracha, ilustrado na Figura 4.21. Brüel \& Kjaer (1997) comentam que a excitação por impacto fornece os meios mais rápidos de realizar um ensaio dinâmico estrutural. Embora a excitação de impacto nem sempre seja apropriada para um ensaio estrutural particular, devido à natureza da estrutura em análise ou para a aplicação específica dos dados do ensaio, as técnicas de ensaio de impacto são amplamente utilizadas, particularmente para a solução de problemas de ruído e de vibrações.

Os pontos escolhidos para a posição dos acelerômetros e também para a aplicação dos impactos foram definidos por meio de uma análise numérica prévia.

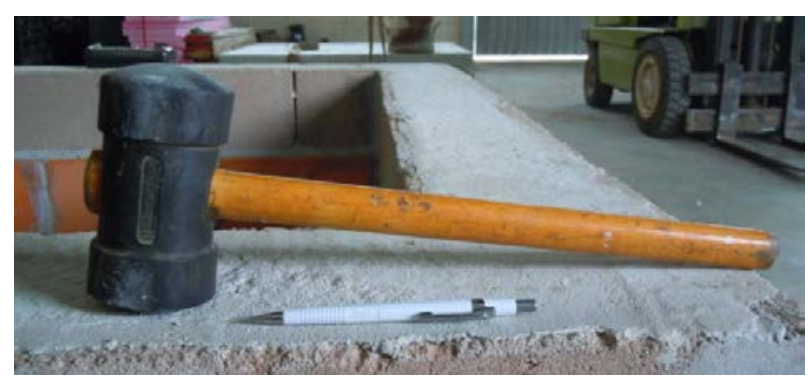

Figura 4.21 - Martelo de borracha utilizado como excitador de impacto. 
Uma análise modal prévia tem como objetivo nortear a análise modal experimental, auxiliando na escolha dos pontos de excitação e de aquisição dos dados. Caso essa análise não fosse realizada, os acelerômetros e/ou pontos de impacto poderiam ser posicionados sobre os nós modais. Esses nós, como comentado no Capítulo 2, não são adequados para descrever os movimentos, acelerações e deformadas de um determinado modo, pois nesse modo específico o nó modal possui aceleração, velocidade e deslocamento nulos.

O software utilizado para a análise numérica foi o SAP $2000^{\circledR}$, que trabalha com o Método dos Elementos Finitos (MEF).

Não é objetivo descrever aqui os métodos numéricos ou as propriedades específicas de algum elemento finito utilizado, porém buscou-se a compreensão dos modos de vibrar da estrutura utilizada. Ressalta-se que o termo "prévia” somente indica que ela é feita antes da realização dos ensaios laboratoriais.

As estruturas utilizadas na análise prévia foram modeladas em dois grupos, com cinco modelos para cada grupo. O primeiro grupo são as lajes com concreto de peso específico normal. Já no segundo grupo encontram-se os modelos que foram simulados com o CLEPE.

Os modelos de cada grupo são representados na Figura 4.22. Na Figura 4.22a tem-se um painel isolado. Nas Figuras 4.22b e 4.22c estão os painéis com uma e duas continuidades, respectivamente. Já a Figura 4.22d ilustra uma situação em que o painel central está ligado a três painéis. Finalmente, na Figura 4.22e, está o último modelo, com quatro continuidades da laje central. Em todos os modelos foi considerada uma malha quadrada de elementos finitos de $5 \mathrm{~cm}$, o que discretiza adequadamente a estrutura. Os nós extremos de cada painel foram travados no espaço, sendo impedidos de sofrerem translação nas direções dos eixos x, y e z.

Os elementos finitos foram definidos como Shell-thin. Tais elementos apresentam um bom desempenho na avaliação dinâmica da laje, justificando sua utilização.

As características físicas dos materiais foram:

- Concreto convencional

Peso específico considerando armadura igual a $25 \mathrm{kN} / \mathrm{m}^{3}$;

Resistência característica à compressão aos 28 dias igual a $25 \mathrm{MPa}$;

Módulo de elasticidade 1,3 vezes maior do que o módulo de elasticidade tangente inicial aos 28 dias igual a $36800 \mathrm{MPa}$.

\section{- CLEPE}

Peso específico considerando armadura igual a $13 \mathrm{kN} / \mathrm{m}^{3}$;

Resistência característica à compressão aos 28 dias igual a $14 \mathrm{MPa}$;

Módulo de elasticidade 1,3 vezes maior do que o módulo de elasticidade tangente inicial aos 28 dias igual a $14700^{6} \mathrm{MPa}$.

${ }^{6} \mathrm{O}$ valor aqui adotado tem como base a média dos resultados estáticos de módulo de elasticidade encontrados por Catoia (2012). 


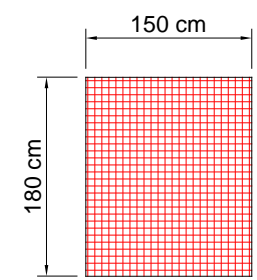

(a)

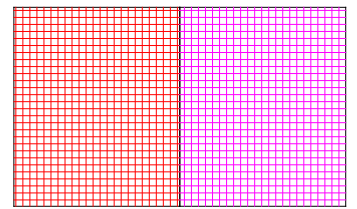

(b)

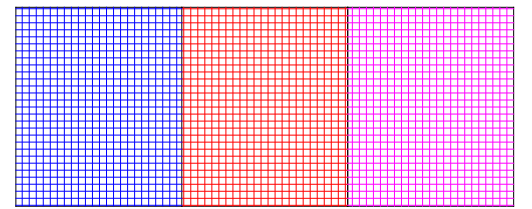

(c)

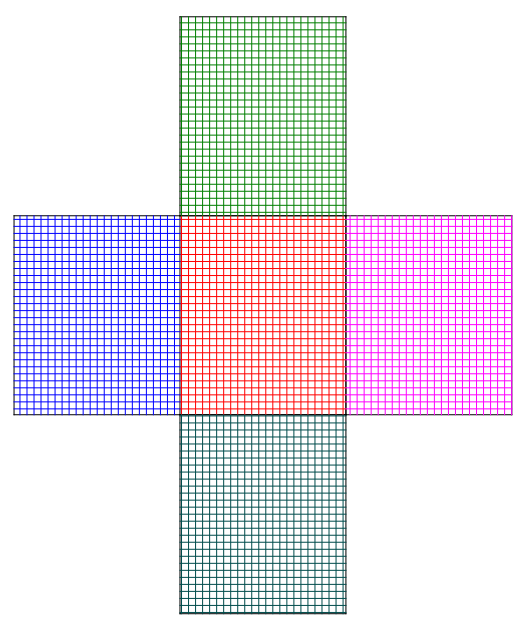

(e)

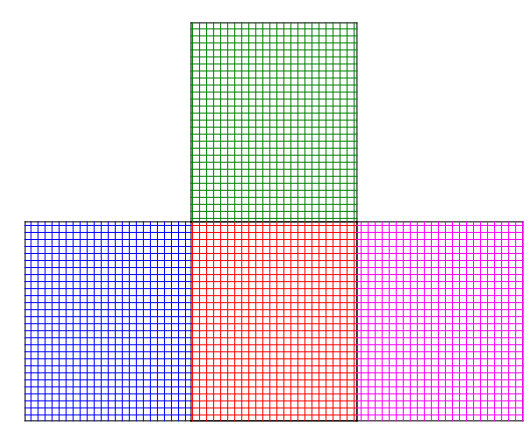

(d)

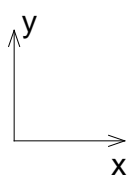

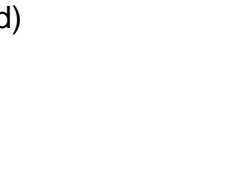

Figura 4.22 - Modelos analisados. (a) laje isolada, (b) laje com uma continuidade, (c) laje com duas continuidades, (d) laje com três continuidades e (e) laje com quatro continuidades.

Justifica-se a ampliação do módulo de elasticidade em 30\%, pois o módulo de elasticidade dinâmico, que deve ser considerado na análise dinâmica, é de $20 \%$ a 40\% maior que o estático tangente na origem.

Os resultados obtidos são semelhantes aos da Figura 4.23. Nessa figura podem ser observados os quatro primeiros modos de vibração de uma laje isolada. Não são apresentadas as deformadas modais dos demais modelos por se entender que essas figuras ocupariam um espaço excessivo, sem que fosse agregado algum dado relevante.

A partir da análise numérica prévia, podem ser feitos alguns comentários:

- O primeiro modo de vibrar de todos os modelos de um mesmo concreto tem frequências naturais iguais. Isto é justificado, pois o primeiro modo em todas as análises é o modo de flexão fundamental de uma laje retangular;

- As frequências naturais resultaram em valores elevados quando se analisam estruturas civis (de $58 \mathrm{~Hz}$ a $648 \mathrm{~Hz}$ em uma faixa de 12 modos de vibração). A explicação para esse fenômeno é que os modelos (painéis de lajes) estão em escala reduzida. A redução da escala eleva a rigidez da peça, pelo fato dos vãos serem menores. A elevação da rigidez tende a diminuir o período, e consequentemente elevar a frequência natural;

- Todos os modos obtidos foram flexionais. 


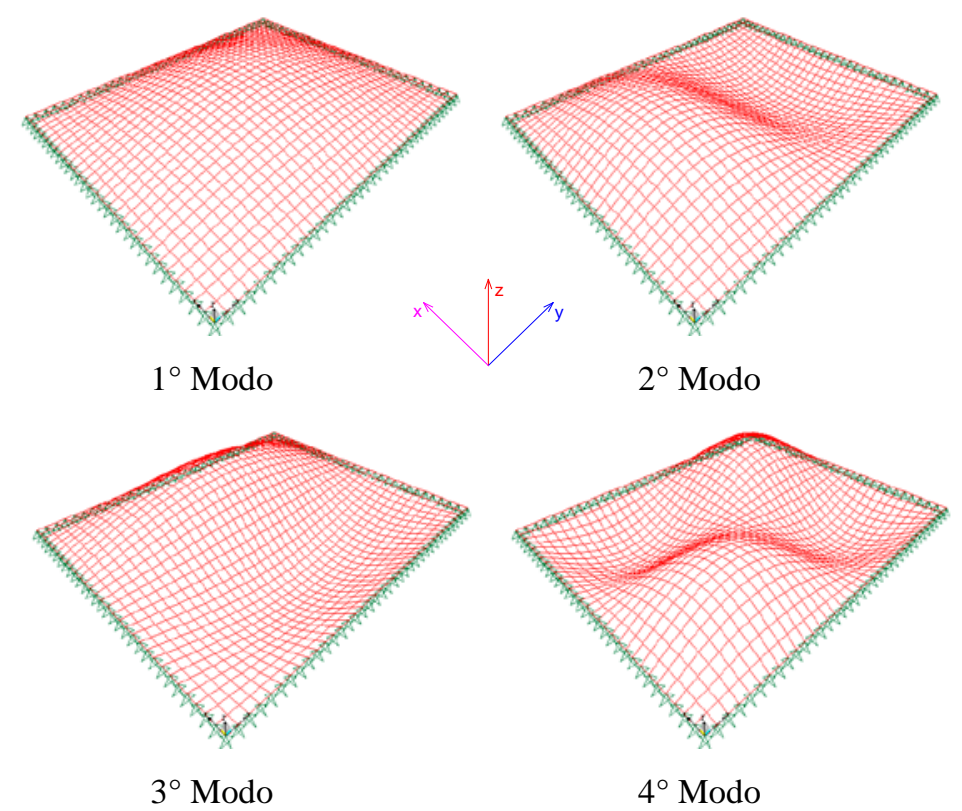

Figura 4.23 - Primeiras quatro deformadas modais de uma laje isolada.

A escolha dos pontos, com base nas deformadas modais da análise prévia, é descrita nos esquemas de ensaios, nos itens 4.2.3.1 a 4.2.3.6.

\subsubsection{Configuração do $1^{\circ}$ ensaio dinâmico}

O primeiro ensaio dinâmico foi realizado com o painel central, sem nenhuma continuidade, como ilustra a Figura 4.24. Nela também estão marcados os pontos onde foram feitas as leituras do acelerômetro e as excitações.

Neste ensaio foram usados 16 pontos de impacto, com dois impactos por ponto em cada leitura. Nove pontos de leitura, sendo que o ponto 1 com o acelerômetro 1 sempre foi a referência, gerando um total de três leituras, pois sempre foram utilizados quatro acelerômetros. A posição dos acelerômetros em cada leitura ficou como definido na Tabela B.3 (Apêndice B).

Para se ter ideia dos resultados e do comportamento dos painéis de laje, foi realizado um ensaio piloto com uma laje de CC (Laje 6), na configuração aqui descrita. Os resultados desse ensaio piloto mostraram que era possível seguir a análise experimental dinâmica dessa forma. Os resultados do ensaio piloto estão descritos no Capítulo 6. A Figura 4.25 ilustra as três leituras do ensaio piloto. 


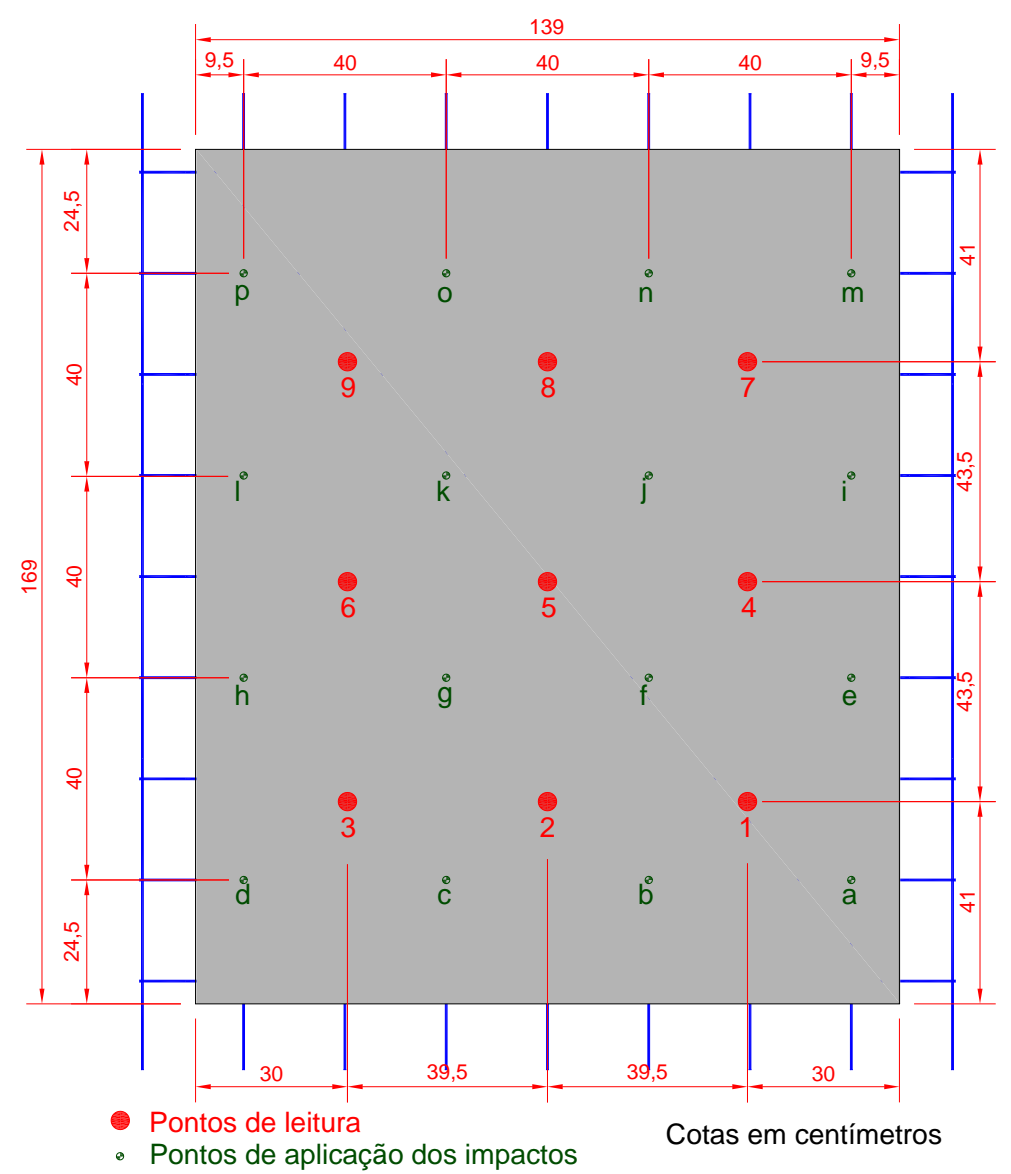

Figura 4.24 - Esquema do primeiro ensaio dinâmico de CC e de CLEPE.

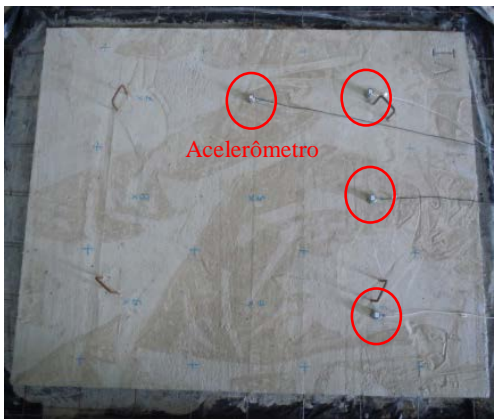

(a)

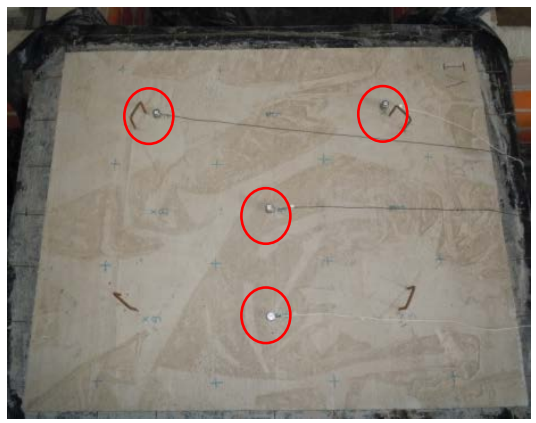

(b)

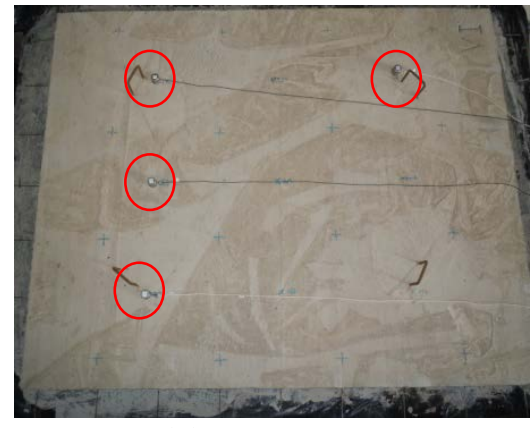

(c)

Figura 4.25 - Ensaio piloto. (a) $1^{\text {a }}$ leitura. (b) $2^{\mathrm{a}}$ leitura. (c) $3^{\mathrm{a}}$ leitura.

\subsubsection{Configuração do $2^{\circ}$ ensaio dinâmico}

Logo após a realização do primeiro ensaio, um segundo painel foi posicionado e ligado ao primeiro com o uso de um graute de alta resistência inicial, possibilitando que o $2^{\circ}$ ensaio dinâmico fosse realizado sete dias depois. A Figura 4.26 ilustra o esquema do ensaio e os pontos onde foram feitas as leituras do acelerômetro e as excitações. 


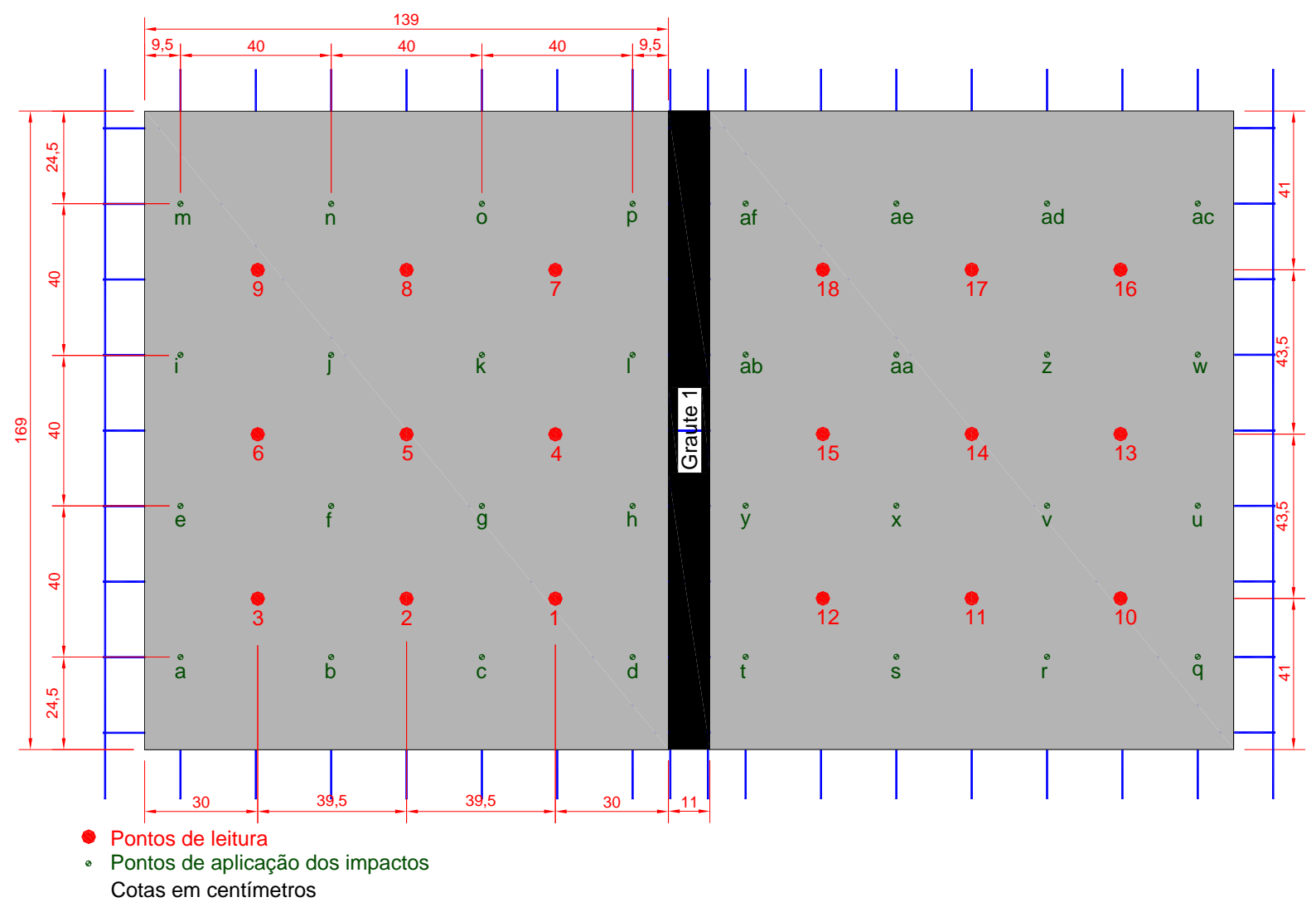

Figura 4.26 - Esquema do segundo ensaio dinâmico de CC e de CLEPE.

Nesse ensaio foram 32 pontos de impacto, com dois impactos por ponto em cada leitura. Sequência: a-p (duas vezes); q-af (duas vezes). Foram 18 pontos de leitura, sendo que o ponto 1 com o acelerômetro 1 foi a referência. Total de seis leituras com quatro acelerômetros. A posição dos acelerômetros em cada leitura ficou como definido na Tabela B.4 (Apêndice B).

\subsubsection{Configuração do $3^{\circ}$ ensaio dinâmico}

Logo após a realização do segundo ensaio, um terceiro painel foi posicionado e ligado ao primeiro com o uso de um graute de alta resistência inicial, possibilitando que o $3^{\circ}$ ensaio dinâmico fosse realizado sete dias depois. A Figura 4.27 ilustra o esquema do ensaio e os pontos onde foram feitas as leituras do acelerômetro e as excitações. 


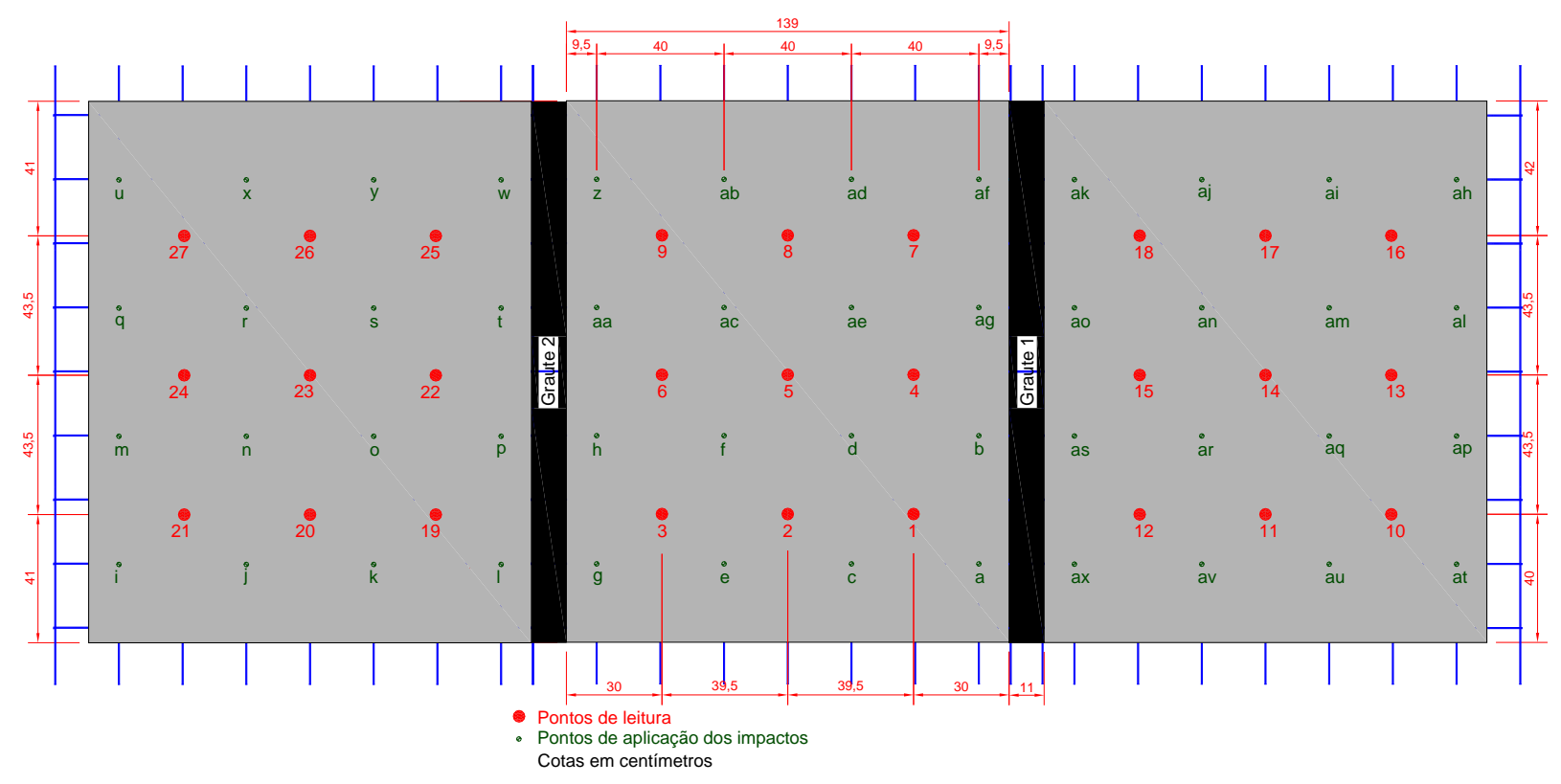

Figura 4.27 - Esquema do terceiro ensaio dinâmico de CC e de CLEPE.

Nesse ensaio foram 48 pontos de impacto, com dois impactos por ponto em cada leitura. Sequência: a-h (duas vezes); i-w (duas vezes); z-ag (duas vezes); ah-ax (duas vezes). Foram 27 pontos de leitura, sendo que o ponto 1 com o acelerômetro 1 sempre foi a referência. Total de nove leituras com quatro acelerômetros. A posição dos acelerômetros em cada leitura ficou como definido na Tabela B.5 (Apêndice B).

\subsubsection{Configuração do $4^{\circ}$ ensaio dinâmico}

Logo após a realização do terceiro ensaio, um quarto painel foi posicionado e ligado ao primeiro com o uso de um graute de alta resistência inicial, possibilitando que o $4^{\circ}$ ensaio dinâmico fosse realizado sete dias depois. A Figura 4.28 ilustra o esquema do ensaio e os pontos onde foram feitas as leituras do acelerômetro e as excitações.

No quarto ensaio dinâmico de CC foram 64 pontos de impacto, com dois impactos por ponto em cada leitura. Sequência: a-h (duas vezes); i-w (duas vezes); z-ac (duas vezes); ad-as (duas vezes); at-ax (duas vezes); ay-bm (duas vezes). Foram 36 pontos de leitura, sendo que o ponto 1 com o acelerômetro 1 sempre foi a referência. Total de 12 leituras com quatro acelerômetros. A posição dos acelerômetros em cada leitura ficou como definido na Tabela B.6 (Apêndice B). 


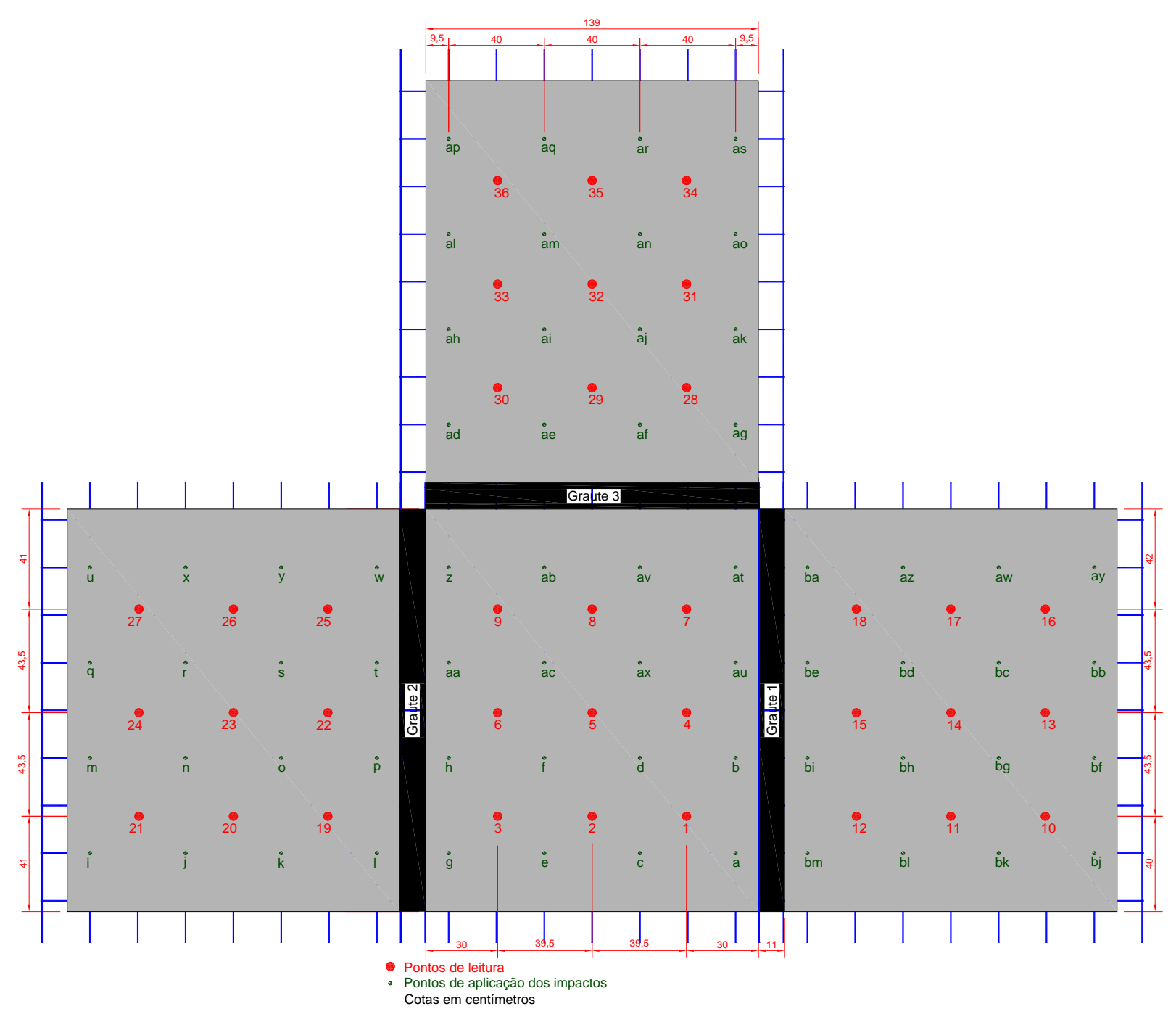

Figura 4.28 - Esquema do quarto ensaio dinâmico de CC e de CLEPE.

\subsubsection{Configuração do $5^{\circ}$ ensaio dinâmico}

Logo após a realização do quarto ensaio, um quinto painel foi posicionado e ligado ao primeiro com o uso de um graute de alta resistência inicial, possibilitando que o $5^{\circ}$ ensaio dinâmico fosse realizado sete dias depois. A Figura 4.29 ilustra o esquema do ensaio e os pontos onde foram feitas as leituras do acelerômetro e as excitações.

Neste ensaio foram 80 pontos de impacto, com dois impactos por ponto em cada leitura. Sequência: a-m (duas vezes); q-y (duas vezes); w-an (duas vezes); ao-ar (duas vezes); as-bh (duas vezes); bi-bl (duas vezes); bm-cb (duas vezes). Foram 45 pontos de leitura, sendo que o ponto 1 com o acelerômetro 1 sempre foi a referência. Total de 15 leituras com quatro acelerômetros. A posição dos acelerômetros em cada leitura ficou como definido na Tabela B.7 (Apêndice B). 


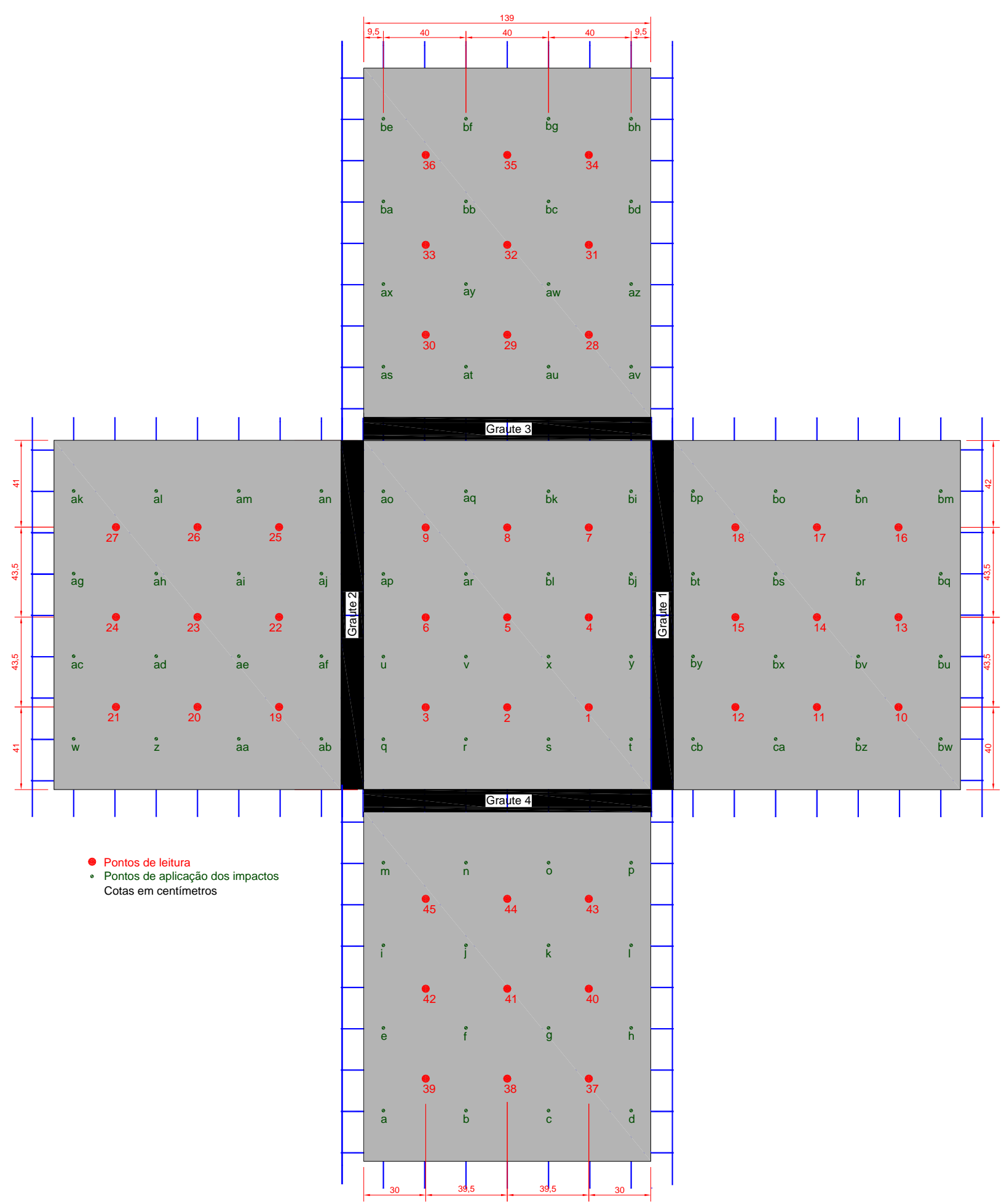

Figura 4.29 - Esquema do quinto ensaio dinâmico de CC e de CLEPE.

\subsubsection{Configuração do $6^{\circ}$ ensaio dinâmico}

Após a realização do quinto ensaio dinâmico, foi feito um corte com $2 \mathrm{~cm}$ de profundidade, sobre todas as ligações de graute, em toda sua extensão. Esse corte tem como 
objetivo simular uma fissura sobre o apoio de continuidade, devido à ausência da armadura negativa. Busca-se avaliar qual a influência desse dano nas propriedades dinâmicas. A configuração do sexto ensaio dinâmico foi a mesma do quinto. A Figura 4.30 ilustra o entalhe feito no graute.

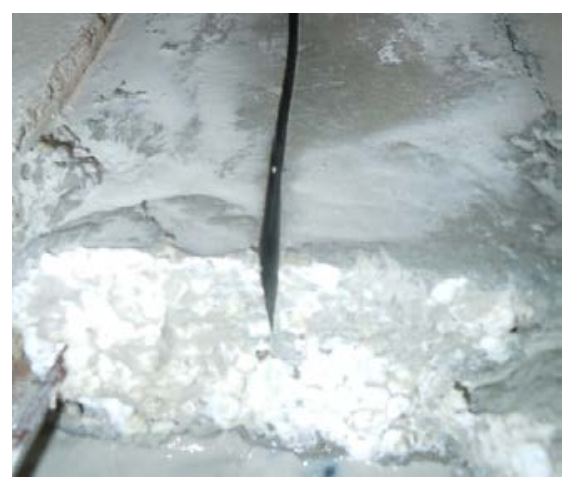

Figura 4.30 - Detalhe do entalhe feito na ligação entre as lajes.

\subsubsection{Graute de ligação das lajes}

A ligação que foi executada entre os painéis, sobre as alvenarias, possuía uma largura de $11 \mathrm{~cm}$ e uma profundidade aproximada de $6 \mathrm{~cm}$. Nessa região as franjas das telas ficavam transpassadas cerca de $10 \mathrm{~cm}$. Essa abertura foi preenchida com graute. O produto utilizado foi o Grauth $S G^{\circledR}$ da empresa Otto Baumgart, disponível em embalagens de $25 \mathrm{~kg}$. O traço em massa adotado para o graute sempre foi 1:0,12 (1 parte de graute: 0,12 partes de água) conforme indicado em Otto Baumgart (2014).

De cada ligação foram moldados seis corpos de prova cilíndricos de $5 \mathrm{~cm}$ x $10 \mathrm{~cm}$. Esses corpos de prova foram utilizados para a determinação do módulo de elasticidade dinâmico e, posteriormente, para a resistência do graute à compressão.

A Figura 4.31 ilustra a região que foi ligada. Na Figura 4.32 estão ilustrados alguns dos corpos de prova de graute e também a lona plástica que foi posicionada sobre a ligação, permitindo a cura durante sete dias.

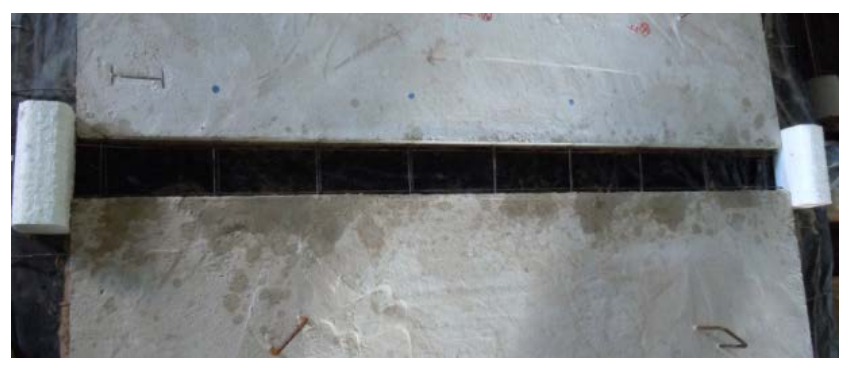

Figura 4.31 - Detalhe da região da ligação. 


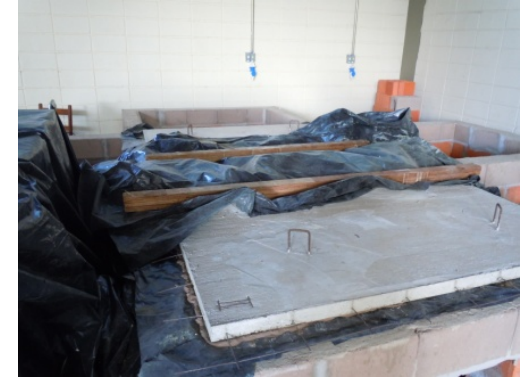

(a)

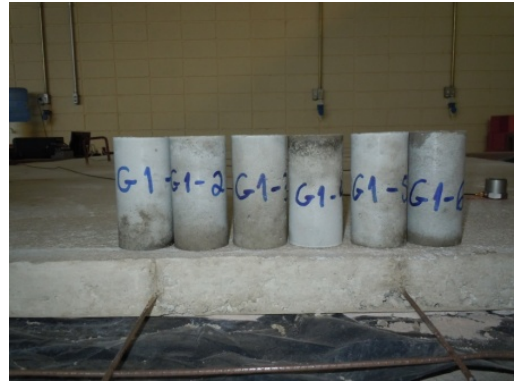

(b)

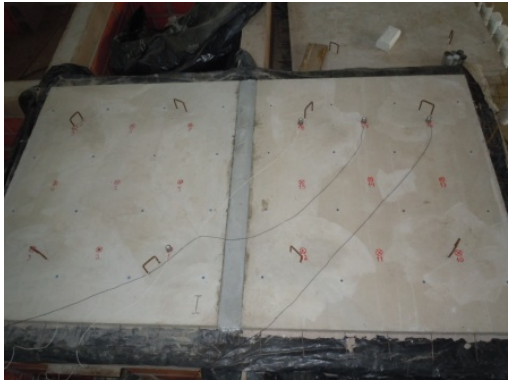

(c)

Figura 4.32 - Detalhes da ligação. (a) lona plástica para cura durante sete dias. (b) corpos de prova. (c) aspecto da ligação concluída. 


\section{Caracterização dos Materiais das Lajes sobre Alvenaria}

Este capítulo apresenta os resultados dos ensaios de caracterização do concreto e do graute empregados na primeira parte do programa experimental (ensaios descritos no Capítulo 4 e com resultados no Capítulo 6). A caracterização dinâmica envolve a determinação dos módulos de elasticidade flexural e longitudinal do material através do equipamento Sonelastic ${ }^{\circledR}$, conforme o que foi descrito no Capítulo 2. Também foram estimados os valores dos amortecimentos flexural e longitudinal. Esses fatores de amortecimento são os valores mais próximos aos fatores de amortecimento puros, dos materiais envolvidos no programa experimental.

A caracterização estática envolveu a determinação da resistência dos materiais à compressão, através da ruptura dos corpos de prova cilíndricos utilizados na caracterização dinâmica.

\subsection{Ensaios de caracterização dinâmica}

Os ensaios no Sonelastic ${ }^{\circledR}$ foram feitos a cada ensaio dinâmico descritos no Capítulo 4. Portanto, o volume de ensaios foi crescendo conforme o andamento dos ensaios dinâmicos, já que os corpos de prova não são destruídos, podendo ser avaliados em outra data. As Tabelas B.8 e B.9 (Apêndice B) apresentam o desdobramento dos ensaios de caracterização dinâmica (ECD). No total foram 103 ensaios para o CC e 116 ensaios para o CLEPE.

Em todos os ensaios no Sonelastic ${ }^{\circledR}$ foi considerado o coeficiente de Poisson de 0,24 para o CC e para o graute e 0,20 para o CLEPE. Esses valores são justificados por estarem próximos ao que é preconizado pela ABNT NBR 6118:2014, que possibilita a adoção do coeficiente de Poisson com o valor de 0,20 quando não existem ensaios específicos.

As Figuras 5.1 e 5.2 ilustram um ensaio no Sonelastic ${ }^{\circledR}$ de um corpo de prova de $10 \mathrm{~cm}$ x $20 \mathrm{~cm}$ e outro de $5 \mathrm{~cm}$ x $10 \mathrm{~cm}$ respectivamente. 


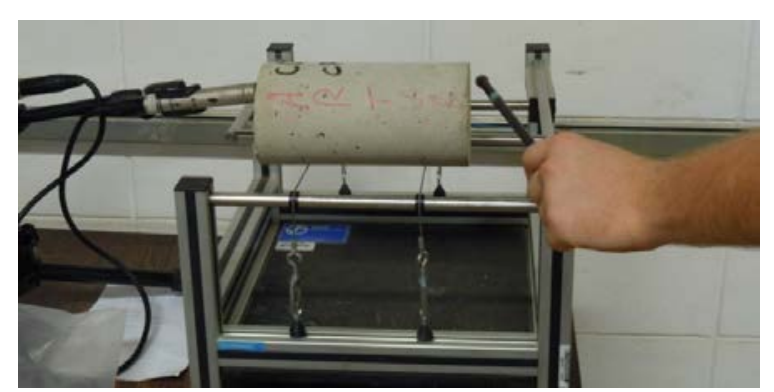

Figura 5.1 - Ensaio de corpo de prova

$10 \mathrm{~cm} \times 20 \mathrm{~cm}$ no Sonelastic ${ }^{\circledR}$.

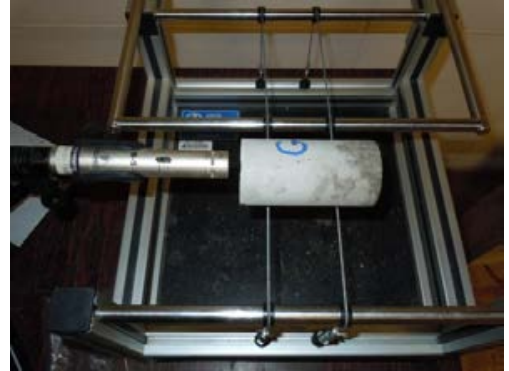

Figura 5.2 - Ensaio de corpo de prova $5 \mathrm{~cm}$ x $10 \mathrm{~cm}$ no Sonelastic ${ }^{\circledR}$.

\subsubsection{Resultados dos ECD para as lajes de CC}

As Tabelas B.10 a B.14 (Apêndice B) apresentam os resultados dos ECD do CC das lajes e do graute de ligação das lajes de CC. As Tabelas 5.1 a 5.3 apresentam os valores médios finais. Já as Figuras 5.3 a 5.7 ilustram graficamente a variação da massa, fator de amortecimento e módulo de elasticidade dos corpos de prova durante o período dos ensaios.

Tabela 5.1: Valores médios finais da massa das lajes de CC.

\begin{tabular}{|c|c|c|c|c|c|c|c|}
\hline \multirow{2}{*}{ Material } & \multirow{2}{*}{$\begin{array}{c}\text { 26/03/2014 } \\
1^{\circ} \text { Ensaio } \\
\text { dinâmico }\end{array}$} & \multirow{2}{*}{$\begin{array}{c}\text { 02/04/2014 } \\
2^{\circ} \text { Ensaio } \\
\text { dinâmico }\end{array}$} & \multirow{2}{*}{ 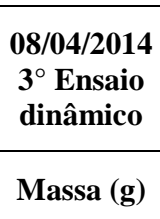 } & \multirow{2}{*}{$\begin{array}{c}\text { 16/04/2014 } \\
4^{\circ} \text { Ensaio } \\
\text { dinâmico }\end{array}$} & \multirow{2}{*}{$\begin{array}{c}\text { 23/04/2014 } \\
5^{\circ} \text { e } 6^{\circ} \\
\text { Ensaios } \\
\text { dinâmicos } \\
\text { Massa (g) }\end{array}$} & \multicolumn{2}{|c|}{$\begin{array}{l}\text { Média para ser utilizada na } \\
\text { análise numérica final }\end{array}$} \\
\hline & & & & & & Massa (g) & $\begin{array}{c}\text { Massa Específica } \\
\left(\mathbf{k N} / \mathbf{m}^{3}\right)\end{array}$ \\
\hline Laje 1 & 3685,70 & 3686,50 & 3684,27 & 3685,70 & 3639,83 & 3676,40 & 23,40 \\
\hline Laje 2 & --- & 3621,30 & 3618,00 & 3619,73 & 3569,97 & 3607,25 & 22,96 \\
\hline Laje 3 & --- & --- & 3592,50 & 3594,50 & 3554,17 & 3580,39 & 22,79 \\
\hline Laje 4 & --- & --- & --- & 3562,23 & 3502,17 & 3532,20 & 22,49 \\
\hline Laje 5 & --- & --- & --- & --- & 3550,33 & 3550,33 & 22,60 \\
\hline Graute 1 & --- & 441,73 & 438,00 & 437,48 & 424,65 & 435,47 & 22,18 \\
\hline Graute 2 & --- & --- & 444,67 & 442,53 & 427,90 & 438,37 & 22,33 \\
\hline Graute 3 & --- & --- & --- & 439,34 & 423,84 & 431,59 & 21,98 \\
\hline Graute 4 & --- & --- & --- & --- & 430,70 & 430,70 & 21,94 \\
\hline
\end{tabular}

Tabela 5.2: Valores médios finais dos fatores de amortecimento das lajes de CC.

\begin{tabular}{|c|c|c|c|c|c|c|c|c|c|c|c|c|}
\hline \multirow{3}{*}{ Material } & \multirow{2}{*}{\multicolumn{2}{|c|}{$\begin{array}{c}26 / 03 / 2014-1^{\circ} \\
\text { Ensaio dinâmico }\end{array}$}} & \multirow{2}{*}{\multicolumn{2}{|c|}{\begin{tabular}{|c|}
$\begin{array}{c}02 / 04 / 2014-2^{\circ} \\
\text { Ensaio dinâmico }\end{array}$ \\
F.A. $\left(\mathbf{x 1 0}^{-6}\right)$
\end{tabular}}} & \multirow{2}{*}{\multicolumn{2}{|c|}{\begin{tabular}{|c|}
$\begin{array}{c}08 / 04 / 2014-3^{\circ} \\
\text { Ensaio dinâmico }\end{array}$ \\
F.A. $\left(\times 10^{-6}\right)$
\end{tabular}}} & \multirow{2}{*}{\multicolumn{2}{|c|}{$\begin{array}{c}\begin{array}{c}16 / 04 / 2014-4^{\circ} \\
\text { Ensaio dinâmico }\end{array} \\
\text { F.A. }\left(\times 10^{-6}\right)\end{array}$}} & \multirow{2}{*}{\multicolumn{2}{|c|}{\begin{tabular}{|c|}
$\begin{array}{c}23 / 04 / 2014-5^{\circ} \mathrm{e} \\
6^{\circ} \text { Ensaios } \\
\text { dinâmicos }\end{array}$ \\
F.A. $\left(\times 10^{-6}\right)$
\end{tabular}}} & \multirow{2}{*}{\multicolumn{2}{|c|}{$\begin{array}{l}\text { Média final } \\
\text { F.A. }\left(\mathbf{x 1 0}^{-6}\right) \\
\end{array}$}} \\
\hline & & & & & & & & & & & & \\
\hline & $\mathbf{F}$ & $\mathbf{L}$ & $\mathbf{F}$ & $\mathbf{L}$ & $\mathbf{F}$ & $\mathbf{L}$ & $\mathbf{F}$ & $\mathbf{L}$ & $\mathbf{F}$ & $\mathbf{L}$ & $\mathbf{F}$ & L \\
\hline Laje 1 & 2650,47 & 2618,53 & 3202,63 & 2654,33 & 2681,43 & 2721,90 & 2502,63 & 2242,87 & 2626,50 & 2668,80 & 2732,73 & 2581,29 \\
\hline Laje 2 & --- & --- & 3095,97 & 2687,80 & 2553,03 & \begin{tabular}{|l|}
2735,57 \\
\end{tabular} & 2715,17 & 2554,07 & 3078,77 & 2921,20 & 2860,74 & 2724,66 \\
\hline Laje 3 & --- & --- & --- & --- & 2652,80 & 2323,73 & 2975,00 & 2598,77 & 2195,97 & 2795,93 & 2607,92 & 2572,81 \\
\hline Laje 4 & --- & --- & --- & --- & --- & --- & 2834,37 & 2444,43 & 2774,90 & 2758,10 & 2804,64 & 2601,27 \\
\hline Laje 5 & --- & --- & --- & \begin{tabular}{|c|}
--- \\
\end{tabular} & \begin{tabular}{|c|}
--- \\
\end{tabular} & \begin{tabular}{|c|}
--- \\
\end{tabular} & --- & \begin{tabular}{|c|}
--- \\
\end{tabular} & 2077,85 & \begin{tabular}{|l|}
2647,35 \\
\end{tabular} & 2077,85 & 2647,85 \\
\hline Graute 1 & --- & --- & 5325,52 & 4294,35 & 4808,20 & \begin{tabular}{|l|}
4474,77 \\
\end{tabular} & 4570,08 & 4292,27 & 4671,30 & 4276,03 & 4843,78 & 4334,36 \\
\hline Graute 2 & --- & --- & --- & --- & 4841,42 & 4536,53 & 4824,25 & 4578,53 & 4505,63 & 4211,90 & 4723,77 & 4442,32 \\
\hline Graute 3 & --- & --- & --- & --- & --- & --- & 5024,50 & 4692,44 & 4806,96 & 4317,10 & 4915,73 & 4504,77 \\
\hline Graute 4 & --- & --- & --- & --- & --- & --- & --- & --- & 4911,15 & 4623,10 & 4911,15 & 4623,10 \\
\hline
\end{tabular}


Tabela 5.3: Valores médios finais dos módulos de elasticidade das lajes de CC.

\begin{tabular}{|c|c|c|c|c|c|c|c|c|c|c|c|c|}
\hline \multirow[t]{3}{*}{ Material } & \multirow{2}{*}{\multicolumn{2}{|c|}{$\begin{array}{c}\text { 26/03/2014 - } \mathbf{1}^{\circ} \\
\text { Ensaio dinâmico }\end{array}$}} & \multirow{2}{*}{\multicolumn{2}{|c|}{$\begin{array}{c}\text { 02/04/2014 }-2^{\circ} \\
\text { Ensaio dinâmico }\end{array}$}} & \multirow{2}{*}{\multicolumn{2}{|c|}{$\begin{array}{c}\text { 08/04/2014 }-3^{\circ} \\
\text { Ensaio dinâmico } \\
\mathrm{E}(\mathrm{GPa})\end{array}$}} & \multirow{2}{*}{\multicolumn{2}{|c|}{$\begin{array}{c}\begin{array}{c}16 / 04 / 2014-4^{\circ} \\
\text { Ensaio dinâmico }\end{array} \\
\mathrm{E}(\mathrm{GPa})\end{array}$}} & \multirow{2}{*}{\multicolumn{2}{|c|}{$\begin{array}{c}23 / 04 / 2014-5^{\circ} \text { e } \\
6^{\circ} \text { Ensaios } \\
\text { dinâmicos } \\
E(G P a) \\
\end{array}$}} & \multirow{2}{*}{\multicolumn{2}{|c|}{$\begin{array}{c}\text { Média para ser } \\
\text { utilizada na análise } \\
\text { numérica final } \\
\text { E (GPa) }\end{array}$}} \\
\hline & & & & & & & & & & & & \\
\hline & $\mathbf{F}$ & $\mathbf{L}$ & F & L & F & L & $\mathbf{F}$ & L & $\mathbf{F}$ & L & F & L \\
\hline Laje 1 & 34,31 & 34,24 & 34,50 & 34,32 & 34,38 & 34,25 & 34,45 & 34,31 & 35,72 & 34,84 & 34,65 & 34,39 \\
\hline Laje 2 & --- & --- & 33,34 & 33,06 & 32,87 & 33,00 & 33,09 & 33,04 & 34,38 & 33,66 & 33,42 & 33,19 \\
\hline Laje 3 & --- & --- & --- & --- & 31,64 & 31,35 & 31,58 & 31,45 & 32,11 & 31,85 & 31,77 & 31,55 \\
\hline Laje 4 & --- & --- & --- & --- & --- & --- & 30,07 & 30,16 & 31,46 & 30,85 & 30,77 & 30,51 \\
\hline Laje 5 & --- & --- & --- & --- & --- & --- & --- & --- & 32,46 & 31,26 & 32,46 & 31,26 \\
\hline Graute 1 & --- & --- & 38,16 & 37,91 & 37,98 & 37,86 & 38,28 & 38,15 & 41,22 & 39,67 & 38,91 & 38,40 \\
\hline Graute 2 & --- & --- & --- & --- & 39,55 & 38,97 & 39,93 & 39,44 & 42,95 & 40,92 & 40,81 & 39,78 \\
\hline Graute 3 & --- & --- & --- & --- & --- & --- & 38,14 & 37,44 & 41,87 & 39,57 & 40,01 & 38,51 \\
\hline Graute 4 & --- & --- & --- & --- & --- & --- & --- & --- & 42,05 & 39,93 & 42,05 & 39,93 \\
\hline
\end{tabular}

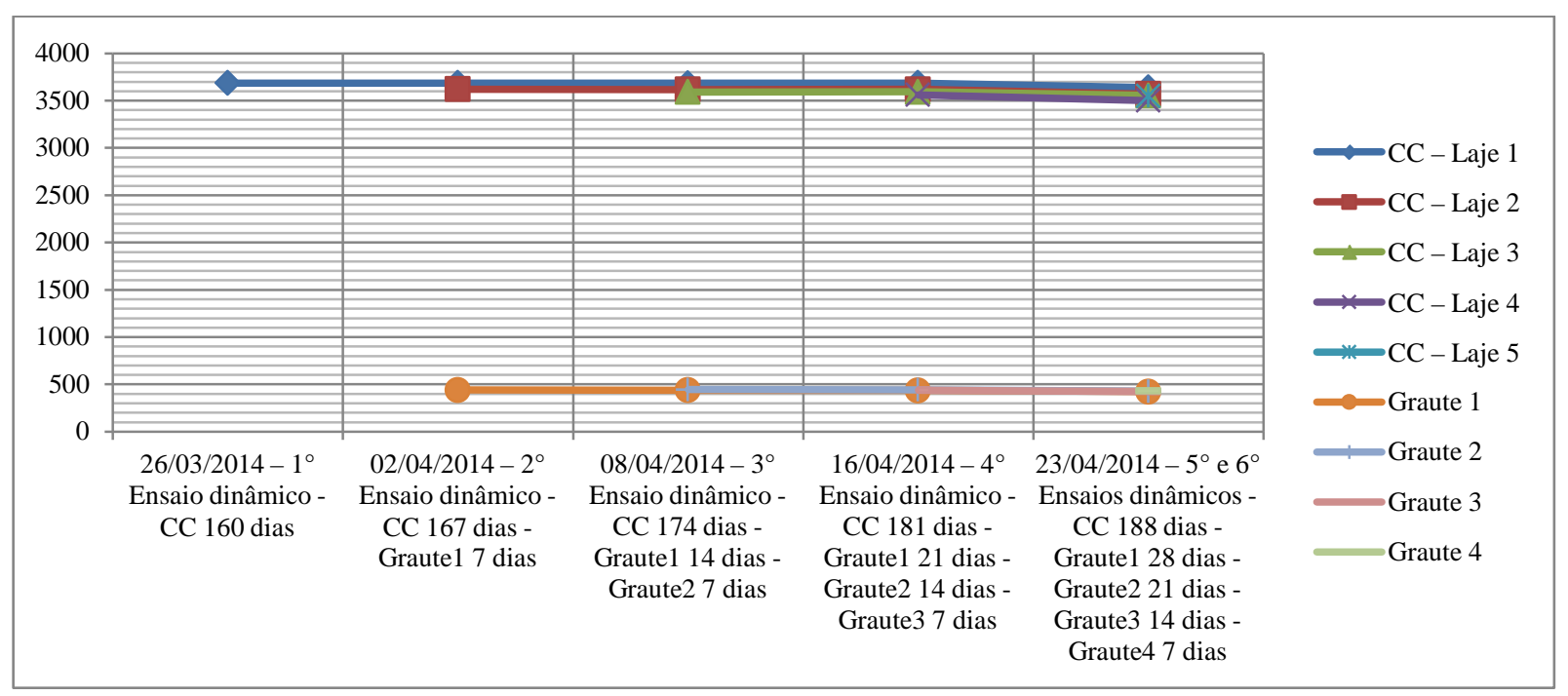

Figura 5.3 - Variação das massas dos corpos de prova das lajes de CC. Ordenadas em gramas.

Ordenadas em $\mathrm{kg} / \mathrm{m}^{3}$.

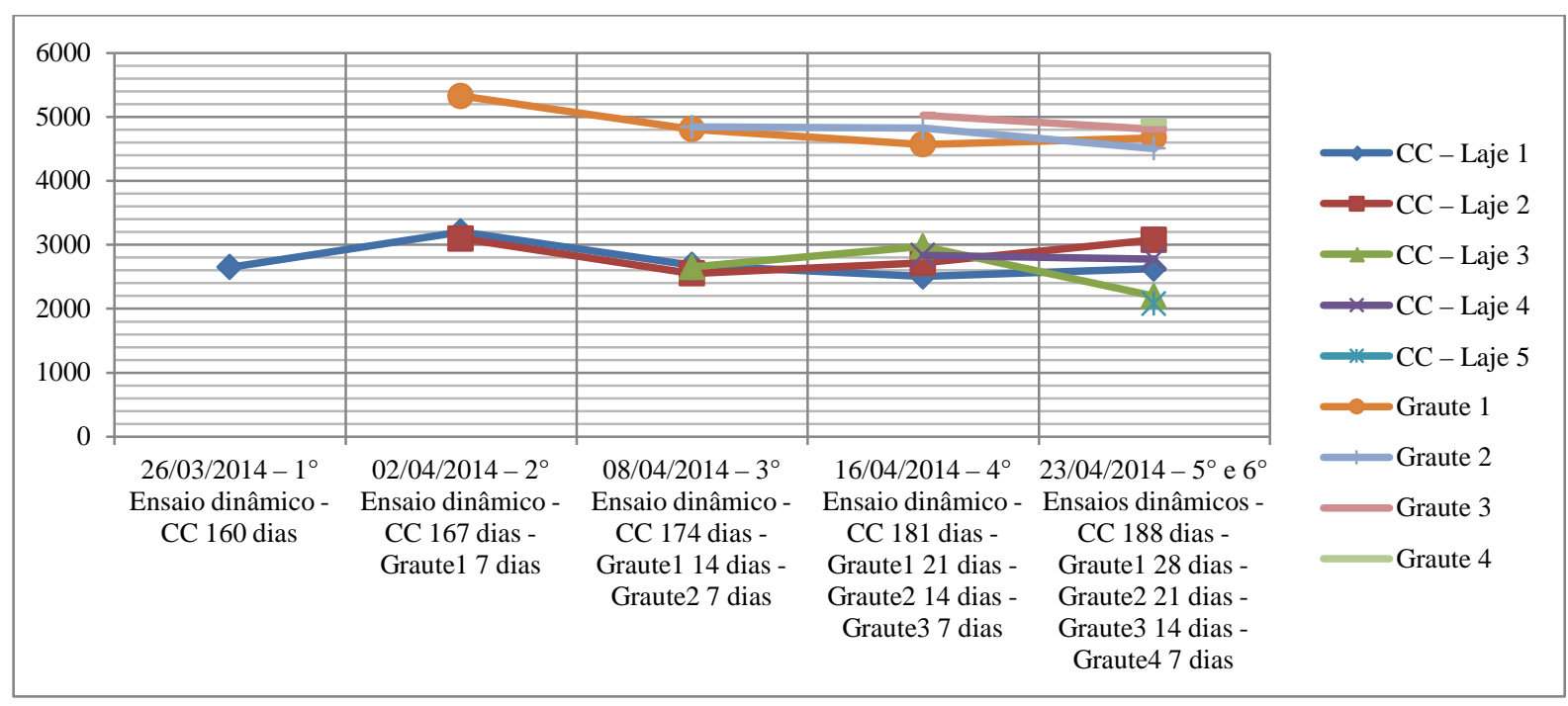

Figura 5.4 - Variação do fator de amortecimento flexural dos corpos de prova das lajes de CC.

Ordenadas $\times 10^{-6}$. 


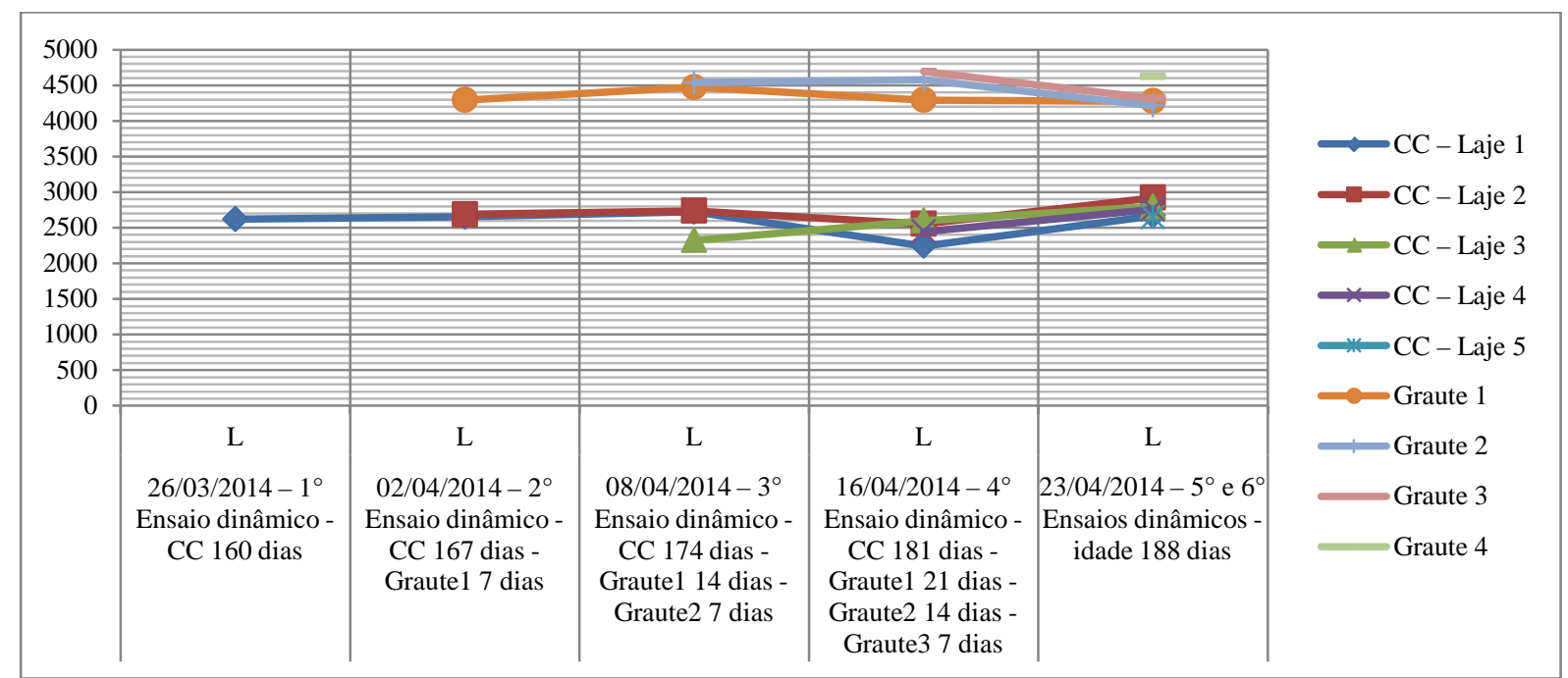

Figura 5.5 - Variação do fator de amortecimento longitudinal dos corpos de prova das lajes de CC. Ordenadas $\times 10^{-6}$.

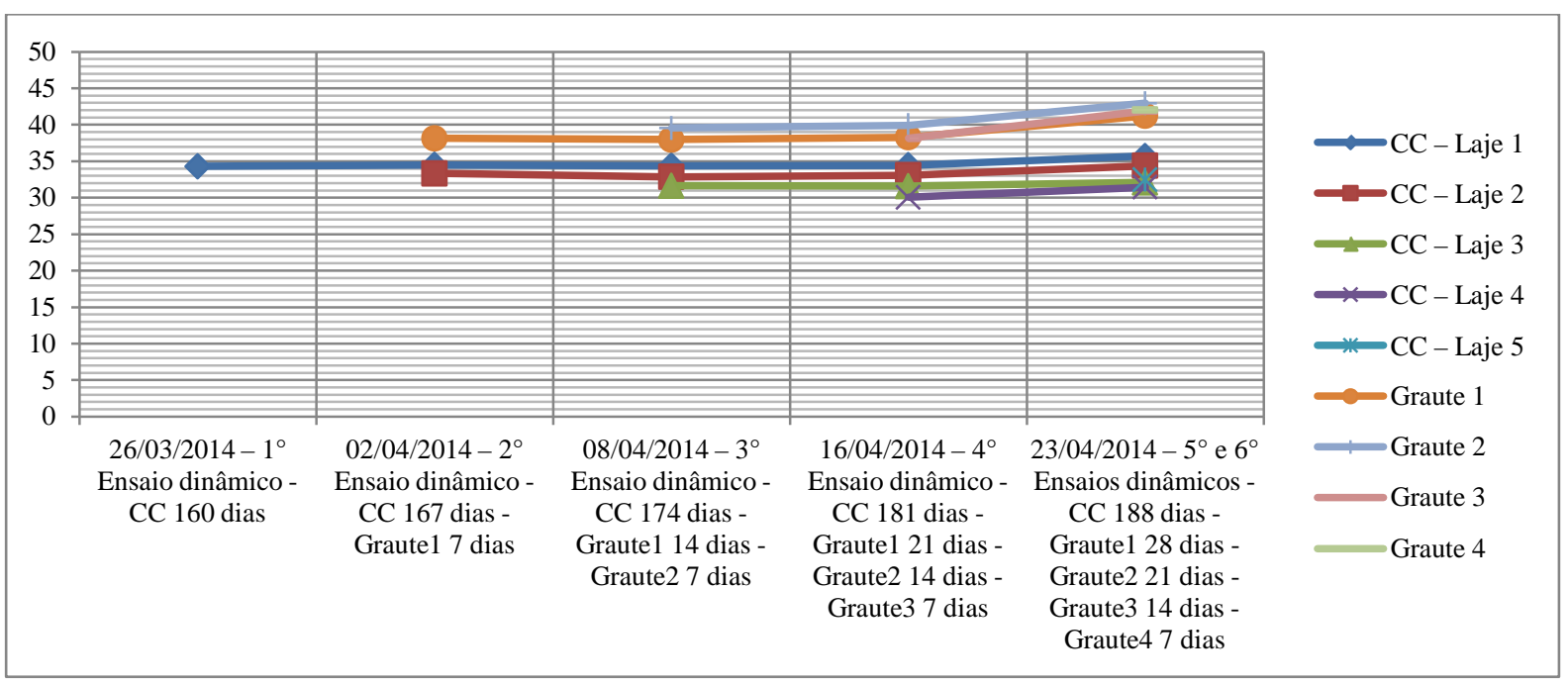

Figura 5.6 - Variação do módulo de elasticidade flexural dos corpos de prova das lajes de CC. Ordenadas em GPa.

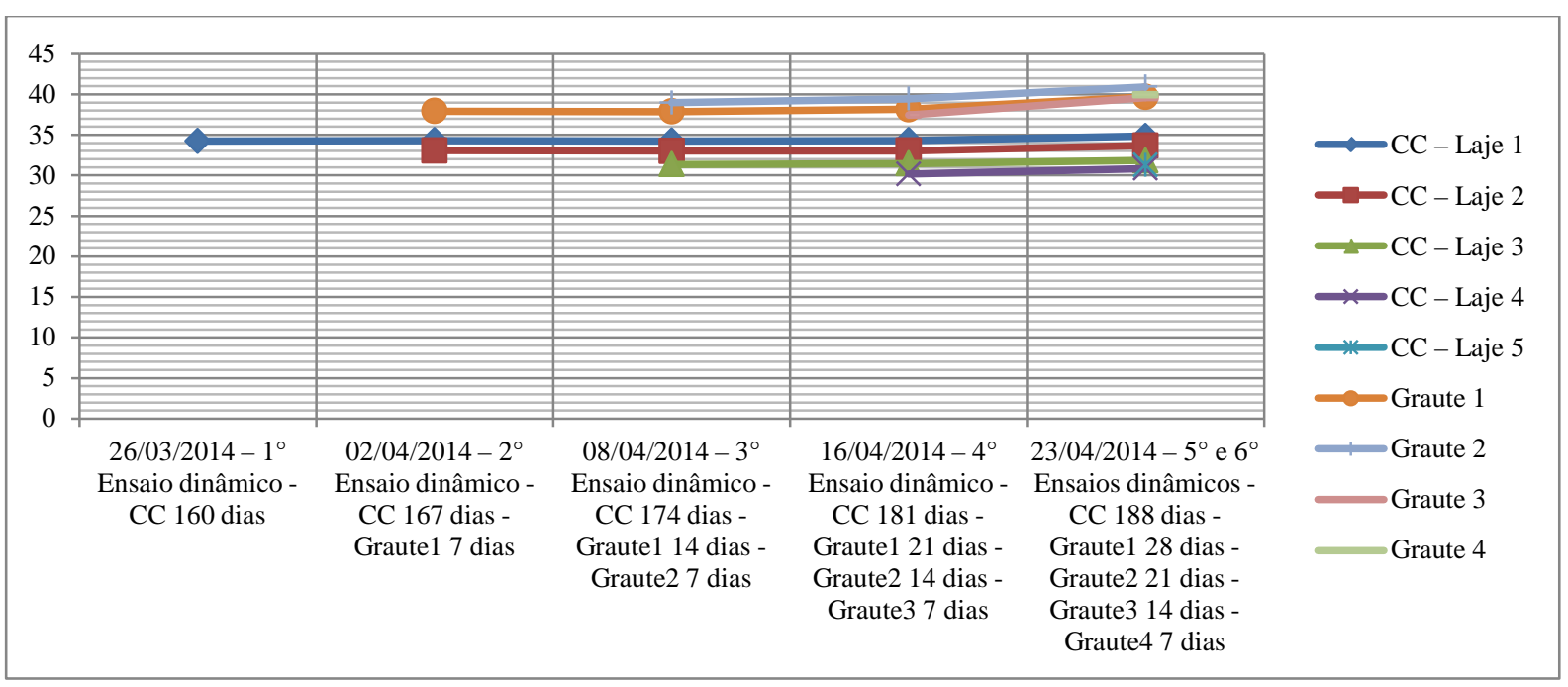

Figura 5.7 - Variação do módulo de elasticidade longitudinal dos corpos de prova das lajes de CC. Ordenadas em GPa. 
Observando-se as Tabelas 5.1 a 5.3 e as Figuras 5.2 a 5.7 verifica-se que:

- A variação da massa é quase nula no período dos ensaios;

- A variação dos fatores de amortecimento dos materiais é pequena;

- Os fatores de amortecimento dos grautes são maiores que os dos concretos das lajes;

- A variação dos módulos de elasticidade dos materiais é pequena no período dos ensaios;

- Os módulos de elasticidade dos grautes são cerca de 4 GPa maiores do que os do concreto das lajes;

- O concreto da laje 1 é o que apresenta maior massa específica e, consequentemente, os maiores valores de módulo de elasticidade;

- Todas as massas específicas ficaram menores do que o valor convencional de $24 \mathrm{kN} / \mathrm{m}^{3}$;

- Os ensaios dinâmicos de caracterização do concreto apresentam pouca variabilidade. Isto é muito adequado quando se deseja estudar o comportamento do material ao longo do tempo. Outra vantagem sobre os ensaios estáticos é a possibilidade de redução de amostras (corpos de prova), por manter uma variação pequena entre os resultados.

\subsubsection{Resultados dos ECD para as lajes de CLEPE}

As Tabelas B.15 a B.19 (Apêndice B) apresentam os resultados dos ECD do CLEPE das lajes e do graute de ligação das lajes de CLEPE. As Tabelas 5.4 a 5.6 apresentam os valores médios finais que são utilizados na análise numérica modal final. Já as Figuras 5.8 a 5.12 ilustram graficamente a variação da massa, fator de amortecimento e módulo de elasticidade dos corpos de prova durante o período dos ensaios.

Tabela 5.4: Valores médios finais da massa das lajes de CLEPE.

\begin{tabular}{|c|c|c|c|c|c|c|c|}
\hline \multirow{2}{*}{ Material } & \multirow{2}{*}{$\begin{array}{c}\text { 30/04/2014 } \\
1^{\circ} \text { Ensaio } \\
\text { dinâmico }\end{array}$} & \multirow{2}{*}{$\begin{array}{c}07 / 05 / 2014 \\
2^{\circ} \text { Ensaio } \\
\text { dinâmico }\end{array}$} & \multirow{2}{*}{$\begin{array}{c}\text { 14/05/2014 } \\
3^{\circ} \text { Ensaio } \\
\text { dinâmico }\end{array}$} & \multirow{2}{*}{$\begin{array}{c}\text { 20/05/2014 } \\
4^{\circ} \text { Ensaio } \\
\text { dinâmico }\end{array}$} & \multirow{2}{*}{$\begin{array}{c}\text { 28/05/2014 } \\
5^{\circ} \text { e } 6^{\circ} \\
\text { Ensaios } \\
\text { dinâmicos }\end{array}$} & \multicolumn{2}{|c|}{$\begin{array}{l}\text { Média para ser utilizada na } \\
\text { análise numérica final }\end{array}$} \\
\hline & & & & & & Massa (g) & $\begin{array}{c}\text { Massa Específica } \\
\left(\mathbf{k N} / \mathbf{m}^{3}\right)\end{array}$ \\
\hline Laje 1 & 2681,88 & 2678,73 & 2676,35 & 2675,53 & 2676,20 & 2677,74 & 17,05 \\
\hline Laje 2 & --- & 2265,20 & 2262,50 & 2261,03 & 2262,03 & 2262,69 & 14,40 \\
\hline Laje 3a & --- & --- & 1883,95 & 1883,05 & 1883,25 & 1883,42 & 11,99 \\
\hline Laje 4 & --- & --- & --- & 2497,75 & 2498,38 & 2498,07 & 15,90 \\
\hline Laje 3b & --- & --- & --- & --- & 1883,25 & 1883,25 & 11,99 \\
\hline Graute 1 & --- & 437,50 & 433,85 & 423,27 & 422,62 & 429,31 & 21,86 \\
\hline Graute 2 & --- & --- & 438,18 & 425,68 & 424,75 & 429,54 & 21,88 \\
\hline Graute 3 & --- & --- & --- & 435,63 & 433,58 & 434,61 & 22,13 \\
\hline Graute 4 & --- & --- & --- & --- & 440,05 & 440,05 & 22,41 \\
\hline
\end{tabular}


Tabela 5.5: Valores médios finais dos fatores de amortecimento das lajes de CLEPE.

\begin{tabular}{|c|c|c|c|c|c|c|c|c|c|c|c|c|}
\hline \multirow[t]{3}{*}{ Material } & \multirow{2}{*}{\multicolumn{2}{|c|}{$\begin{array}{c}\begin{array}{c}30 / 04 / 2014-1^{\circ} \\
\text { Ensaio dinâmico }\end{array} \\
\text { F.A. }\left(\times^{-6}\right)\end{array}$}} & \multirow{2}{*}{\multicolumn{2}{|c|}{$\begin{array}{c}\begin{array}{c}07 / 05 / 2014-2^{\circ} \\
\text { Ensaio dinâmico }\end{array} \\
\text { F.A. }\left(\mathbf{x 1 0}^{-6}\right)\end{array}$}} & \multirow{2}{*}{\multicolumn{2}{|c|}{$\begin{array}{c}\begin{array}{c}14 / 05 / 2014-3^{\circ} \\
\text { Ensaio dinâmico }\end{array} \\
\text { F.A. }\left(\times 10^{-6}\right) \\
\end{array}$}} & \multirow{2}{*}{\multicolumn{2}{|c|}{$\begin{array}{c}\begin{array}{c}20 / 05 / 2014-4^{\circ} \\
\text { Ensaio dinâmico }\end{array} \\
\text { F.A. }\left(\times_{10}^{-6}\right)\end{array}$}} & \multirow{2}{*}{\multicolumn{2}{|c|}{ 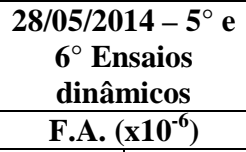 }} & \multirow{2}{*}{\multicolumn{2}{|c|}{$\begin{array}{l}\text { Média final } \\
\text { F.A. }\left(\times 10^{-6}\right) \\
\end{array}$}} \\
\hline & & & & & & & & & & & & \\
\hline & $\mathbf{F}$ & \begin{tabular}{|l}
$\mathbf{L}$ \\
\end{tabular} & $\mathbf{F}$ & L & \begin{tabular}{|l}
$\mathbf{F}$ \\
\end{tabular} & L & $\mathbf{F}$ & $\mathbf{L}$ & $\mathbf{F}$ & L & $\mathbf{F}$ & $\mathbf{L}$ \\
\hline Laje 1 & 4417,33 & 3528,80 & 3994,05 & 3305,08 & 4040,08 & 3565,80 & 4228,98 & 3805,13 & 4406,25 & 3751,10 & 4217,34 & 3591,18 \\
\hline Laje 2 & --- & --- & 4430,48 & 4223,20 & 4046,45 & 4546,45 & 4254,50 & 4658,00 & 4009,45 & 4123,28 & 4185,22 & 4387,73 \\
\hline Laje 3a & --- & --- & --- & --- & 3844,55 & 3912,45 & 5011,40 & 3884,20 & 3546,08 & 3912,55 & 4134,01 & 3903,07 \\
\hline Laje 4 & --- & --- & --- & --- & --- & --- & 4244,38 & 4212,50 & 3765,35 & 4143,10 & 4004,87 & 4177,80 \\
\hline Laje 3b & --- & --- & --- & --- & --- & --- & --- & --- & 3546,08 & 3912,55 & 3546,08 & 3912,55 \\
\hline Graute 1 & --- & --- & 5729,37 & 4690,35 & 5167,90 & 4073,80 & 5020,85 & 4970,03 & 4202,08 & 3758,97 & 5030,05 & 4373,29 \\
\hline Graute 2 & --- & --- & --- & --- & 4744,08 & 4397,28 & 4958,32 & 4873,03 & 4458,60 & 4166,15 & 4720,33 & 4478,82 \\
\hline Graute 3 & --- & --- & --- & --- & --- & --- & 5149,85 & \begin{tabular}{|l|}
4903,37 \\
\end{tabular} & \begin{tabular}{|l}
474,10 \\
\end{tabular} & 4073,48 & 4946,98 & 4488,43 \\
\hline Graute 4 & --- & --- & --- & --- & --- & --- & --- & --- & 5752,13 & 4454,12 & 5752,13 & 4454,12 \\
\hline
\end{tabular}

Tabela 5.6: Valores médios finais dos módulos de elasticidade das lajes de CLEPE.

\begin{tabular}{|c|c|c|c|c|c|c|c|c|c|c|c|c|}
\hline \multirow[t]{3}{*}{ Material } & \multirow{2}{*}{\multicolumn{2}{|c|}{$\begin{array}{c}\text { 30/04/2014 - } 1^{\circ} \\
\text { Ensaio dinâmico }\end{array}$}} & \multirow{2}{*}{\multicolumn{2}{|c|}{$\begin{array}{c}\text { 07/05/2014 }-2^{\circ} \\
\text { Ensaio dinâmico }\end{array}$}} & \multirow{2}{*}{\multicolumn{2}{|c|}{$\begin{array}{c}\text { 14/05/2014 - } 3^{\circ} \\
\text { Ensaio dinâmico }\end{array}$}} & \multirow{2}{*}{\multicolumn{2}{|c|}{$\begin{array}{c}20 / 05 / 2014-4^{\circ} \\
\text { Ensaio dinâmico }\end{array}$}} & \multirow{2}{*}{\multicolumn{2}{|c|}{$\begin{array}{c}\begin{array}{c}\text { 28/05/2014 }-5^{\circ} \text { e } \\
6^{\circ} \text { Ensaios } \\
\text { dinâmicos }\end{array} \\
\text { E (GPa) }\end{array}$}} & \multirow{2}{*}{\multicolumn{2}{|c|}{$\begin{array}{c}\begin{array}{c}\text { Média para ser } \\
\text { utilizada na análise } \\
\text { numérica final }\end{array} \\
\text { E (GPa) }\end{array}$}} \\
\hline & & & & & & & & & & & & \\
\hline & $\mathbf{F}$ & $\mathbf{L}$ & $\mathbf{F}$ & $\mathbf{L}$ & $\mathbf{F}$ & $\mathbf{L}$ & $\mathbf{F}$ & $\mathbf{L}$ & $F$ & $\mathbf{L}$ & $\mathbf{F}$ & $\mathbf{L}$ \\
\hline Laje 1 & 19,68 & 20,12 & 20,46 & 20,14 & 19,69 & 20,13 & 19,77 & 20,12 & 20,11 & 20,11 & 19,94 & 20,12 \\
\hline Laje 2 & --- & --- & 9,04 & 11,09 & 8,64 & 10,94 & 9,19 & 9,15 & 8,69 & 9,14 & 8,89 & 10,08 \\
\hline Laje 3a & --- & --- & --- & --- & 7,24 & 8,16 & 7,27 & 7,47 & 6,99 & 7,45 & 7,17 & 7,69 \\
\hline Laje 4 & --- & --- & --- & --- & --- & -- & 14,34 & 15,68 & 14,99 & 15,65 & 14,67 & 15,67 \\
\hline Laje 3b & --- & --- & --- & --- & --- & --- & --- & --- & 6,99 & 7,45 & 6,99 & 7,45 \\
\hline Graute 1 & --- & --- & 37,33 & 36,97 & 37,21 & 37,16 & 37,78 & 37,42 & 38,67 & 38,03 & 37,75 & 37,40 \\
\hline Graute 2 & --- & --- & --- & --- & 38,79 & 38,33 & 40,13 & 38,91 & 40,67 & 39,67 & 39,86 & 38,97 \\
\hline Graute 3 & --- & --- & --- & --- & --- & --- & 39,48 & 38,73 & 40,51 & 39,87 & 40,00 & 39,30 \\
\hline Graute 4 & --- & --- & --- & --- & --- & --- & --- & --- & 40,52 & 39,48 & 40,52 & 39,48 \\
\hline
\end{tabular}

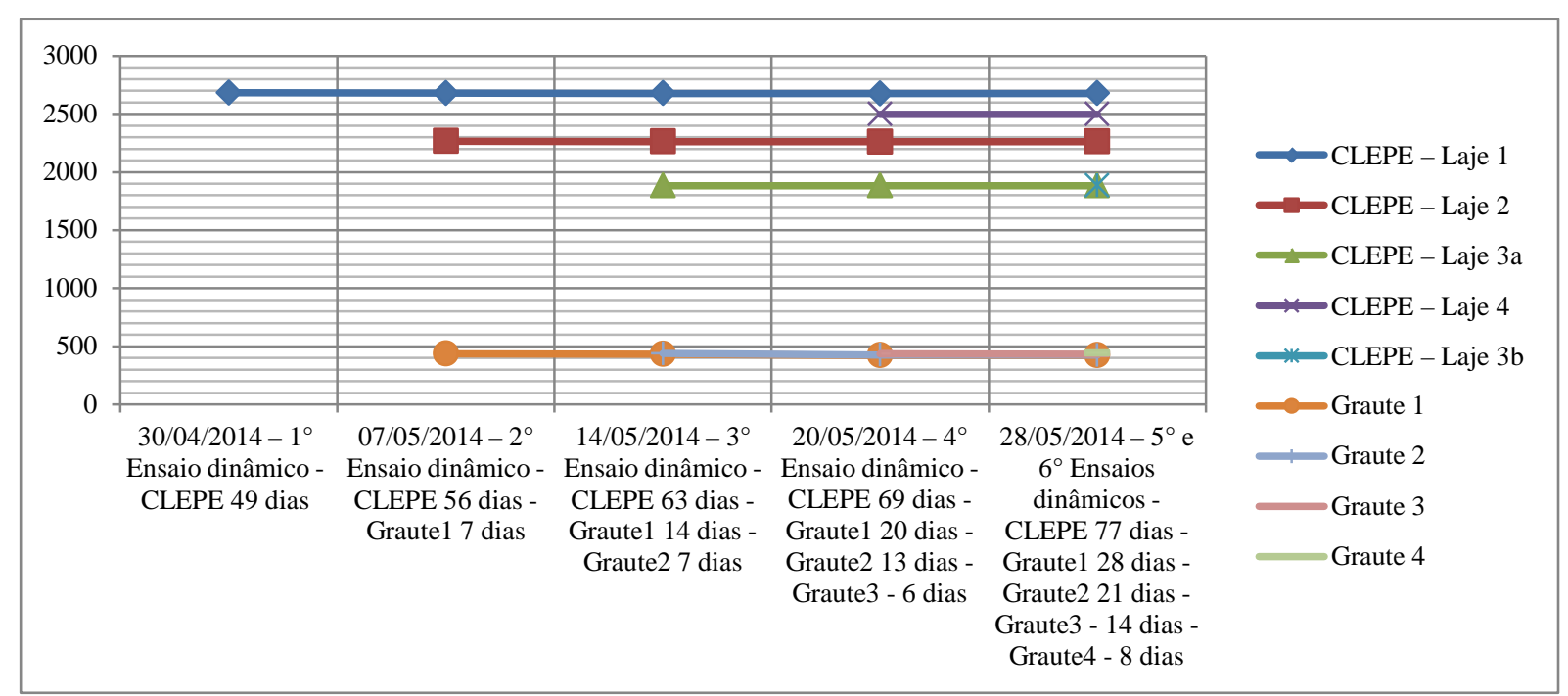

Figura 5.8 - Variação das massas dos corpos de prova das lajes de CLEPE. Ordenadas em gramas. Ordenadas em $\mathrm{kg} / \mathrm{m}^{3}$. 


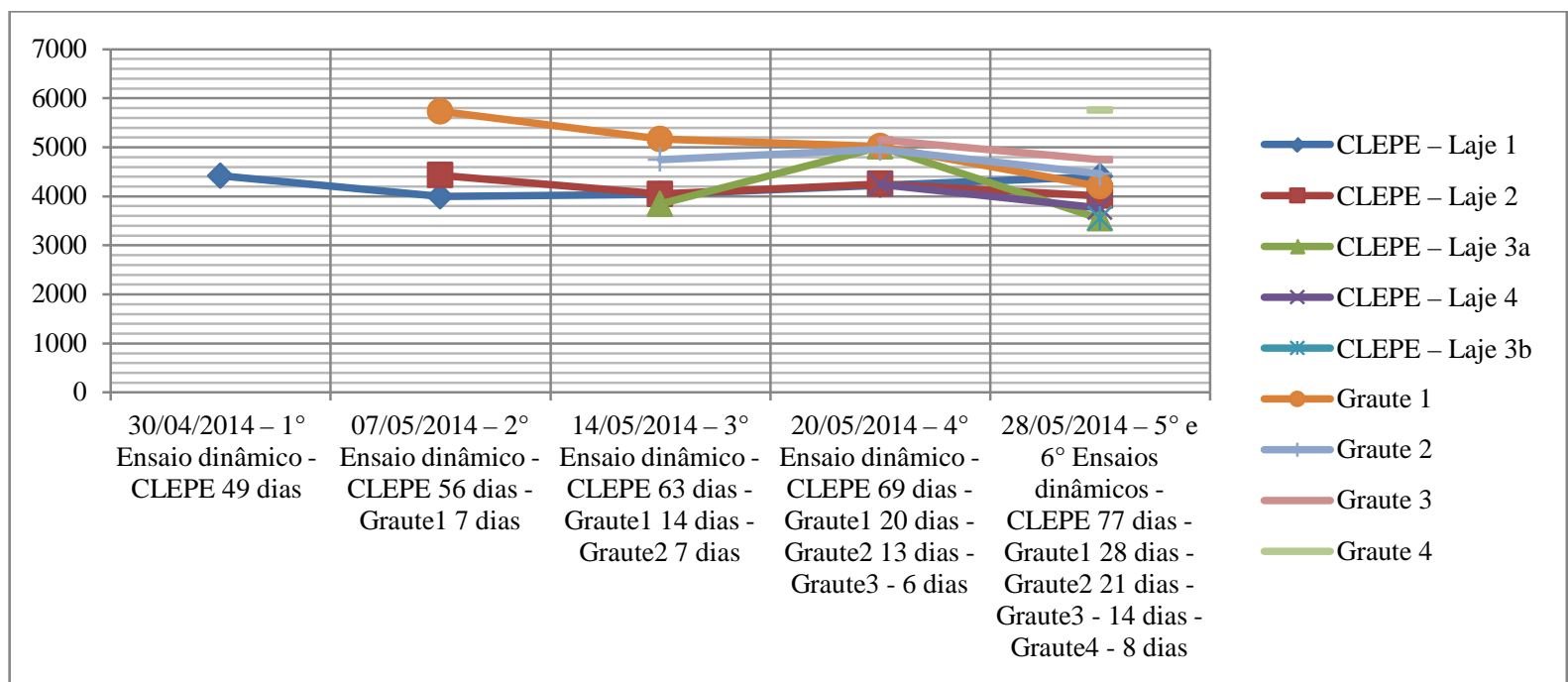

Figura 5.9 - Variação do fator de amortecimento flexural dos corpos de prova das lajes de CLEPE. Ordenadas $\times 10^{-6}$.

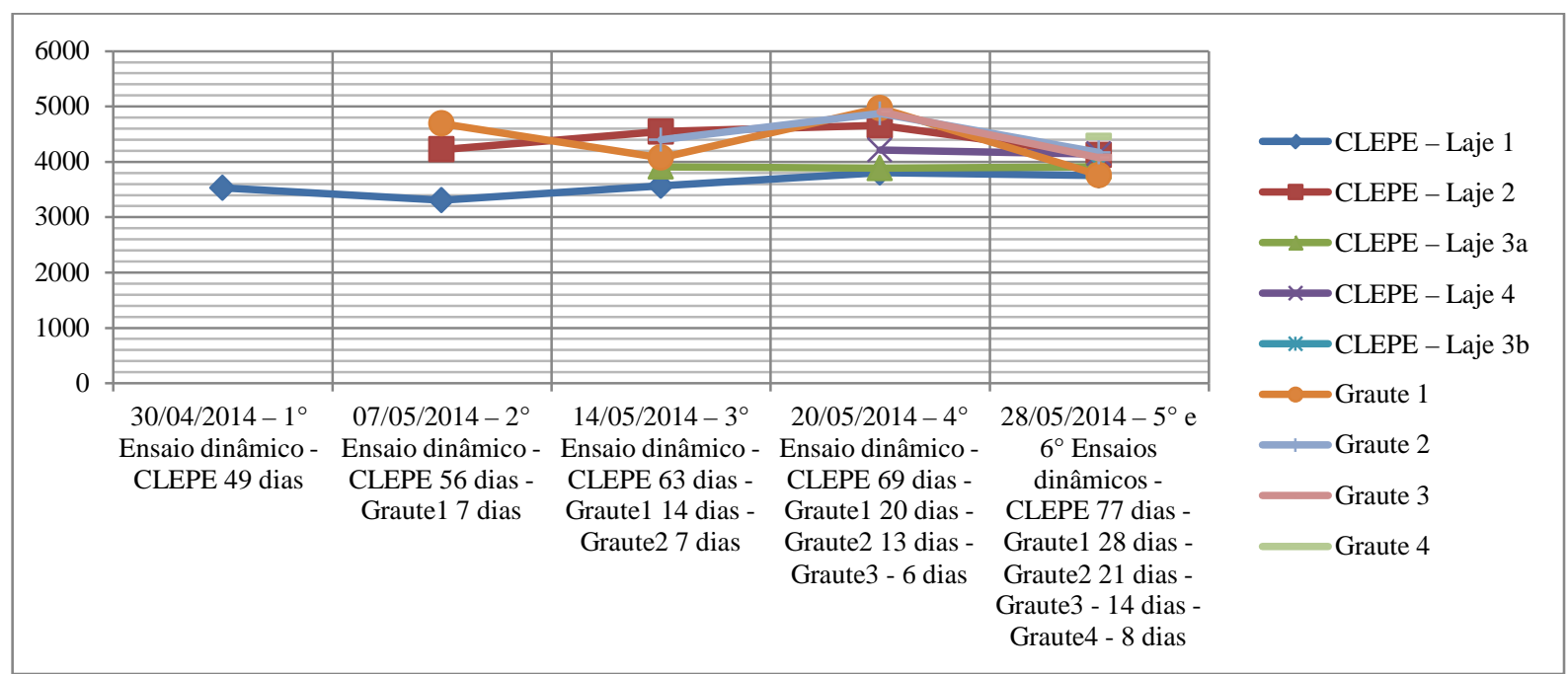

Figura 5.10 - Variação do fator de amortecimento longitudinal dos corpos de prova das lajes de CLEPE. Ordenadas $\times 10^{-6}$.

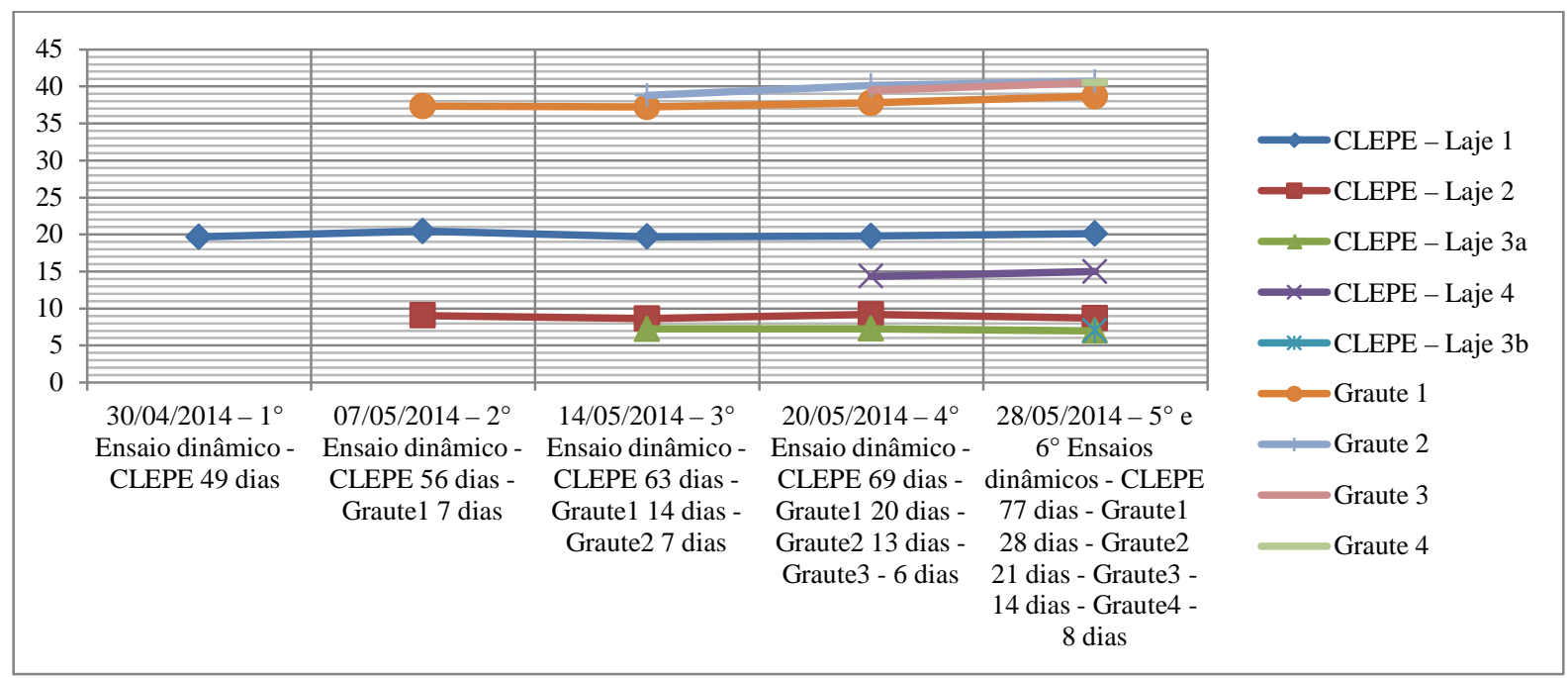

Figura 5.11 - Variação do módulo de elasticidade flexural dos corpos de prova das lajes de CLEPE. Ordenadas em GPa. 


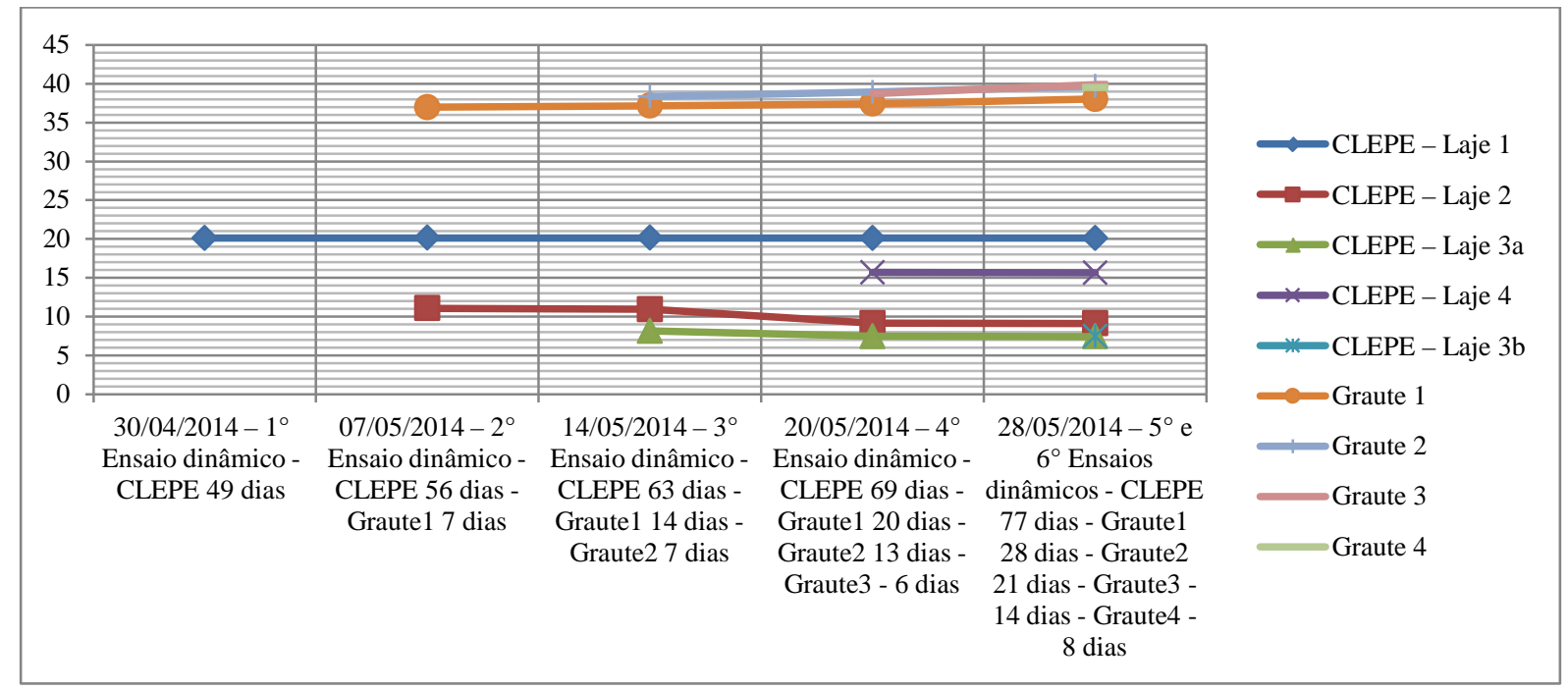

Figura 5.12 - Variação do módulo de elasticidade longitudinal dos corpos de prova das lajes de CLEPE. Ordenadas em GPa.

Observando-se as Tabelas 5.4 a 5.6 e as Figuras 5.8 a 5.12 verifica-se que:

- A variação da massa é quase nula no período dos ensaios;

- Comparando-se as Tabelas 5.2 e 5.5 é possível verificar-se que os fatores de amortecimento médios para o CC são menores do que para o CLEPE;

- A variação dos fatores de amortecimento dos materiais é maior que no CC, porém, podendo ser considerada pequena;

- Apesar da variação do fator de amortecimento do graute 1 ser maior, considerou-se que a possível discrepância que pode ser gerada seja desprezível na análise da estrutura em conjunto, pelo fato do graute estar posicionado sobre um apoio;

- Os fatores de amortecimento dos grautes são próximos aos dos concretos das lajes;

- A variação dos módulos de elasticidade dos materiais é pequena no período dos ensaios;

- Os módulos de elasticidade dos grautes são bem maiores do que os do concreto das lajes. Essa diferença é justificada pela presença do EPS no CLEPE, o que o torna um material poroso;

- O concreto da laje 1 é o que apresenta maior massa específica e, consequentemente, os maiores valores de módulo de elasticidade;

- Com exceção das lajes 3a e 3b, as demais massas específicas das lajes ficaram maiores do que o valor esperado de $12 \mathrm{kN} / \mathrm{m}^{3}$;

- Os ensaios dinâmicos de caracterização do concreto apresentam pouca variabilidade. Isto é muito adequado quando se deseja estudar o comportamento do material ao longo do tempo. Outra vantagem sobre os ensaios estáticos é a possibilidade de redução de amostras (corpos de prova), por manter uma variação pequena entre os resultados. 


\subsection{Ensaios de caracterização estática}

Os ensaios de caracterização estática (ECE) de corpos de prova de concreto geralmente englobam os ensaios de módulo de elasticidade e de resistência à compressão. Nesta pesquisa somente ensaios de resistência à compressão foram realizados. A não realização de ensaios de módulo de elasticidade estático tem a justificativa em dois fatores:

- A determinação de módulos de elasticidade estáticos é demorada e envolveria a necessidade de muitos corpos de prova, pois o ensaio é destrutivo, com grande variabilidade. Não havia disponibilidade laboratorial para isto;

- Na análise dinâmica de estruturas, o módulo de elasticidade que se busca é o dinâmico. Portanto, o módulo estático não seria de grande valor para análises dinâmicas.

A resistência dos corpos de prova foi avaliada após o término de todos os ensaios dinâmicos e os do Sonelastic ${ }^{\circledR}$. Isto é explicado pelo fato de os corpos de prova que foram rompidos para a determinação da resistência à compressão terem sido utilizados previamente para os ensaios do Sonelastic ${ }^{\circledR}$. As Figuras 5.13 e 5.14 ilustram os ensaios em corpos de prova de $10 \mathrm{~cm}$ x $20 \mathrm{~cm}$ de concreto e $5 \mathrm{~cm}$ x $10 \mathrm{~cm}$ de graute, respectivamente. O equipamento utilizado foi a prensa de marca $\mathrm{ELE}^{\circledR}$ com capacidade para $2000 \mathrm{kN}$. Os corpos de prova de $10 \mathrm{~cm}$ x $20 \mathrm{~cm}$ foram ensaiados com uma razão de carregamento de 2,40 kN/s. Já os corpos de prova de $5 \mathrm{~cm}$ x $10 \mathrm{~cm}$ foram ensaiados com uma razão de carregamento de 0,50 kN/s.

Antes do ensaio de compressão, todos os corpos de prova tiveram suas extremidades retificadas para garantir a distribuição homogênea de carga nas suas superfícies.

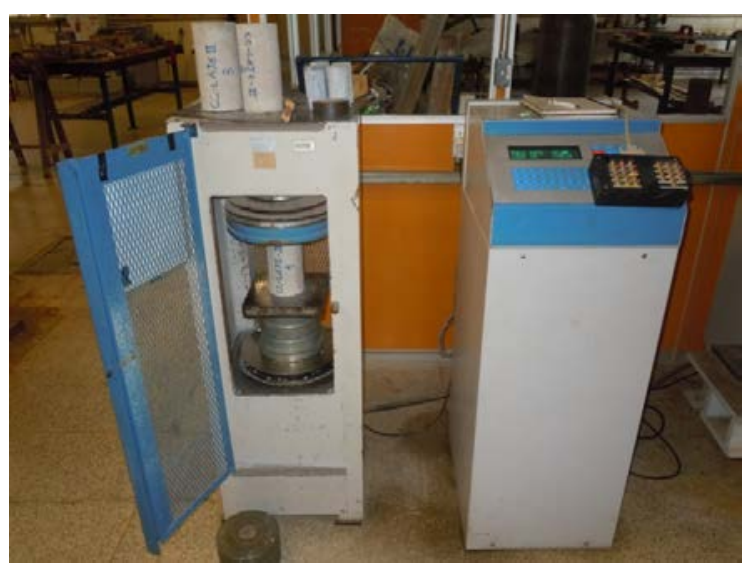

Figura 5.13 - Ensaio de corpo de prova de $10 \mathrm{~cm}$ x $20 \mathrm{~cm}$ na prensa $\mathrm{ELE}^{\circledR}$.

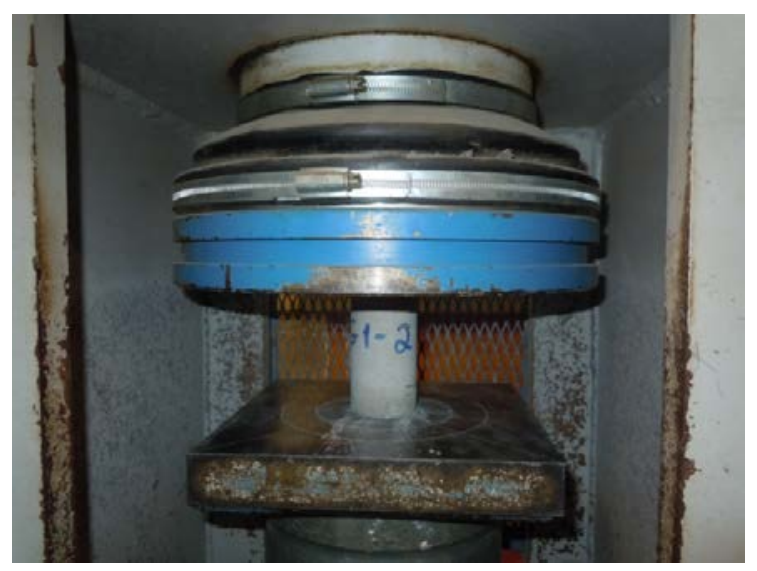

Figura 5.14 - Ensaio de corpo de prova de $5 \mathrm{~cm} \times 10 \mathrm{~cm}$ na prensa $\mathrm{ELE}^{\circledR}$. 
Cada corpo de prova gerou uma resistência $f_{c i}$. A média para os corpos de prova gera o valor de $f_{c m}$. Carvalho e Figueiredo Filho (2007) e Fusco (2008) apresentam a formulação para a determinação da resistência característica de um concreto ensaiado (Equação 5.1).

$$
f_{c k}=f_{c m}-1,645 . s
$$

Sendo:

$f_{c k}$ a resistência característica à compressão do concreto ou do graute, com a probabilidade de 5\% de ser ultrapassada no sentido desfavorável;

$f_{c m}$ a resistência média à compressão do concreto ou do graute, calculada por média simples;

$s$ o desvio padrão calculado através de $s=f_{c m} . \delta$;

$\delta$ a variância determinada pela Equação $5.2 \operatorname{com} N$ = número de corpos de prova do lote.

$$
\delta=\sqrt{\frac{1}{N} \cdot \sum_{i=1}^{N}\left(\frac{f_{c i}-f_{c m}}{f_{c m}}\right)^{2}}
$$

Os itens 5.2.1 e 5.2.2 apresentam os resultados dos ensaios de resistência à compressão dos concretos e dos grautes utilizados.

\subsubsection{Resultados e análise dos ECE para as lajes de CC}

A Tabela B.20 (Apêndice B) apresenta os resultados para os materiais das lajes de CC. A Figura 5.15 ilustra os resultados dos valores de resistência característica à compressão do concreto e do graute das lajes de CC.

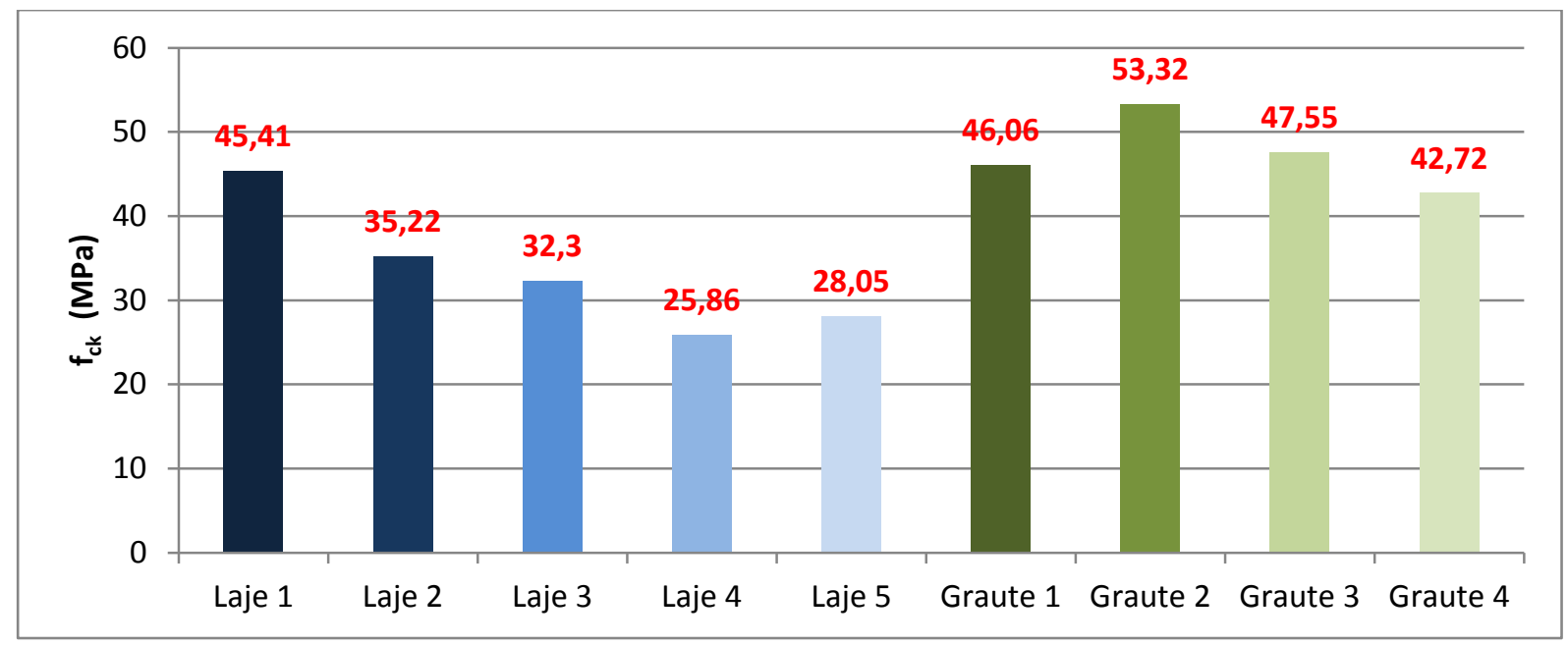

Figura 5.15 - Resultados das resistências característica à compressão do CC e de seus respectivos grautes. 
Ao ser analisada a Tabela B.20 (Apêndice B) e a Figura 5.15, podem ser feitos os seguintes comentários:

- As resistências dos corpos de prova de um mesmo concreto ou de um mesmo graute apresentaram pouca variação;

- O concreto das lajes possui uma grande variação entre os valores de $f_{c k}$ de cada laje. Essa diferença é explicada pela variação da relação água/cimento (a/c) (ver item 4.2.2.1);

- Com exceção do graute 2, os demais apresentaram resistências próximas;

- As resistências dos grautes são maiores que as dos concretos das lajes. Essa diferença pode ser atribuída à maior relação a/c dos concretos e à presença da zona de transição entre argamassa e agregado graúdo no concreto, o que não acontece nos grautes;

- As resistências dos concretos das lajes é superior ao esperado, de 25 MPa.

\subsubsection{Resultados e análise dos ECE para as lajes de CLEPE}

A Tabela B.21 (Apêndice B) apresenta os resultados para os materiais das lajes de CLEPE. A Figura 5.16 ilustra os resultados dos valores de resistência característica à compressão do concreto e do graute das lajes de CLEPE.

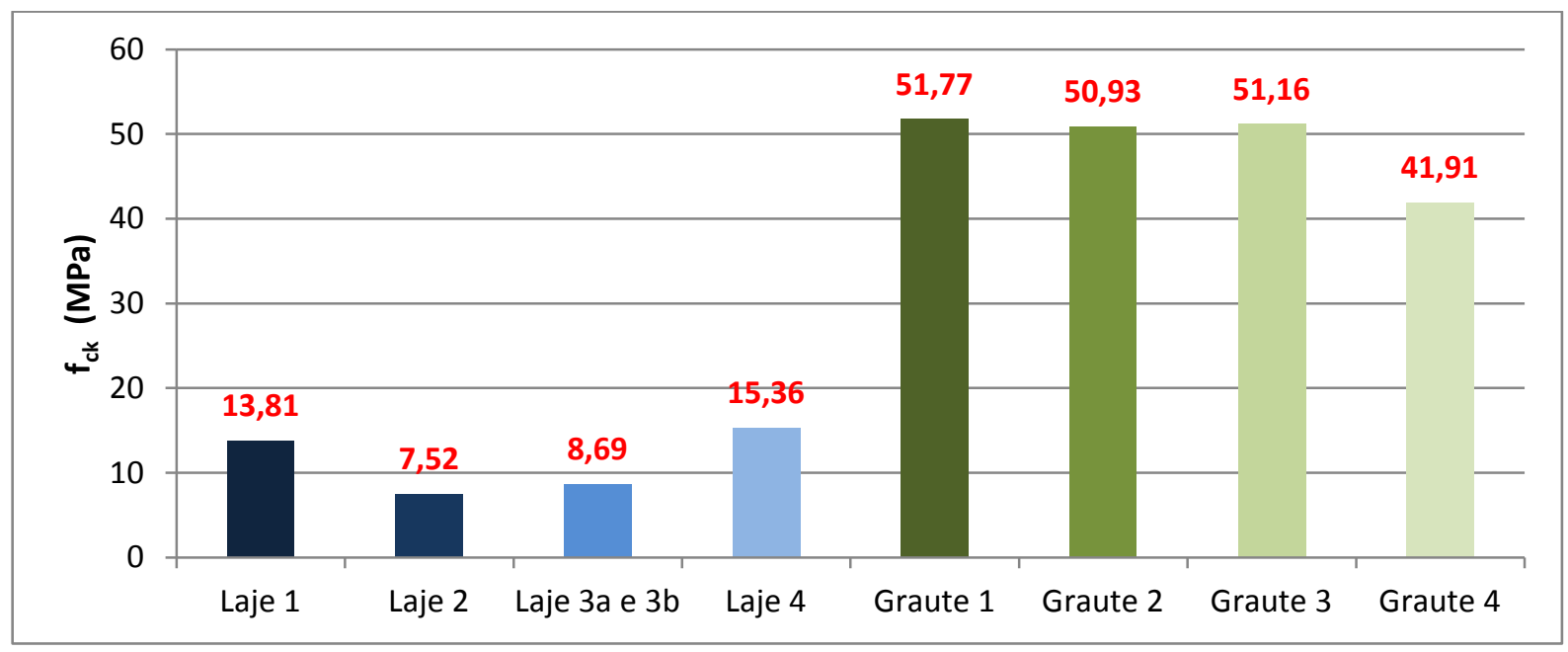

Figura 5.16 - Resultados das resistências característica à compressão do CLEPE e de seus respectivos grautes.

Ao ser analisada a Tabela B.21 (Apêndice B) e a Figura 5.16, podem ser feitos os seguintes comentários: 
- As resistências dos corpos de prova de um mesmo concreto, em média, apresentaram variação bem maior do que no CC. Por outro lado, os corpos de prova de um mesmo graute apresentaram pouca variação;

- O concreto das lajes possui uma grande variação entre os valores de $f_{c k}$ de cada laje. Essa diferença é explicada pela alteração do traço que foi feito em cada betonada. Esse foi um ponto negativo e que deve ser evitado em pesquisas futuras. A variação do traço foi comentada no item 4.2.2.2;

- Com exceção do graute 4, os demais apresentaram resistências próximas;

- As resistências dos concretos das lajes oscila em torno do valor esperado de 10 MPa. 


\section{Resultados dos Ensaios Dinâmicos sobre Alvenaria}

Neste capítulo são apresentados os resultados dos ensaios dinâmicos descritos no Capítulo 4. Também são traçadas breves discussões dos resultados de cada ensaio.

\subsection{Resultados do ensaio dinâmico piloto com a laje 6 de CC}

Para que existisse uma validação das rotinas de análise do programa experimental dinâmico nas lajes sobre alvenaria, foi realizado um ensaio-piloto com a laje 6 de CC. Esse ensaio-piloto consistiu em posicionar a laje 6 de CC no centro da alvenaria. A configuração do ensaio-piloto foi a mesma apresentada no item 4.2.3.1.

A ideia inicial era conseguir estimar algumas das frequências naturais da laje, suas respectivas deformadas modais e alguns fatores de amortecimento modais.

Para a análise dos resultados foram utilizadas rotinas no software Scilab ${ }^{\circledR}$ 5.4.1. Foram gerados gráficos de aceleração ao longo do tempo, espectro de densidade de potência, espectro de densidade de potência cruzado, transmissibilidade e coerência para cada leitura (no total foram três leituras para este ensaio). O gráfico de aceleração ao longo do tempo (Figura 6.1) tem a função de demonstrar a qualidade do sinal adquirido.

O gráfico do qual podem ser retirados os valores das frequências naturais é o de espectro de densidade de potência (PSD), conforme apresentado no item 2.3.2. A densidade de potência do sistema será maior em um ponto onde ocorre uma frequência natural do sistema. Portanto, quando é detectado um pico no gráfico de PSD, ali ocorre uma frequência natural. Entretanto, o pico deve ser bem definido, ou seja, bem pontiagudo.

Certos acelerômetros não conseguem ler adequadamente alguns valores modais por estarem próximos ou sobre nós modais. Sendo assim, é imprescindível que sejam analisados os PSD's de todas as leituras efetuadas, para que seja lido o maior número de frequências naturais. A Figura 6.2 ilustra os PSD das três leituras. O PSD é determinado com a função “pspect” do Scilab ${ }^{\circledR}$, que utiliza a média do periodograma de Welch. 

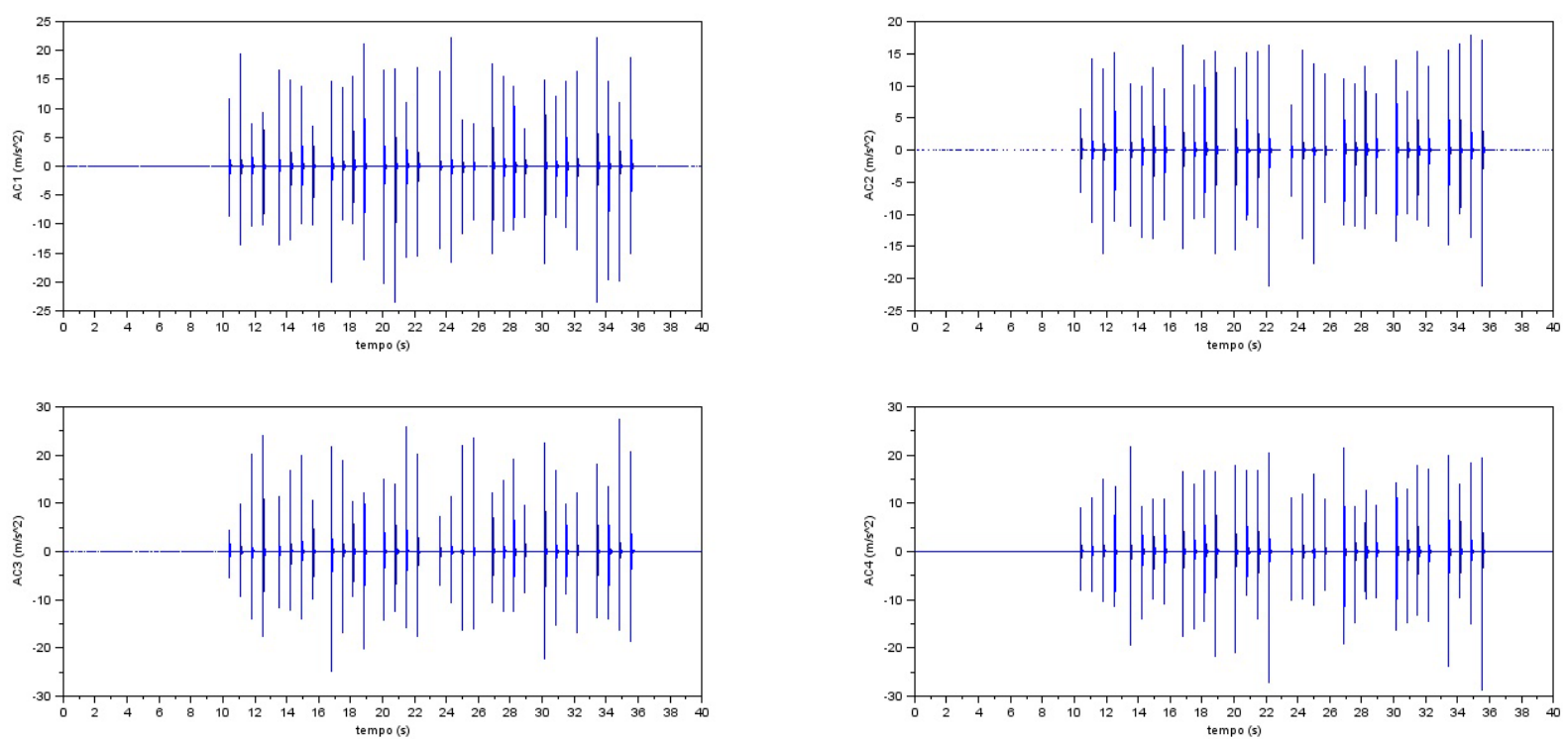

Figura 6.1 - Aceleração ao longo do tempo para a leitura 1. Cada gráfico representa a aceleração para um determinado acelerômetro $\mathrm{AC}_{\mathrm{i}}$.
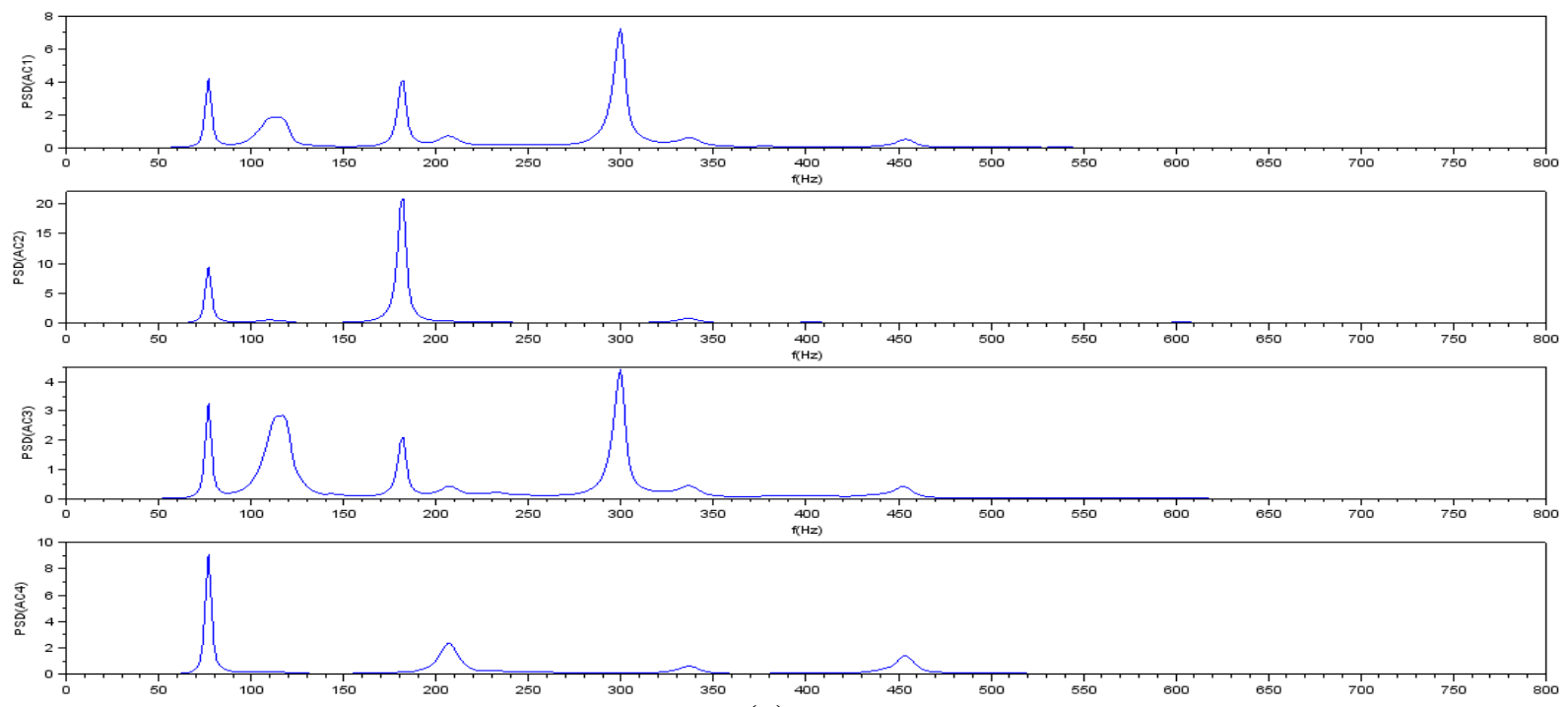

(a)
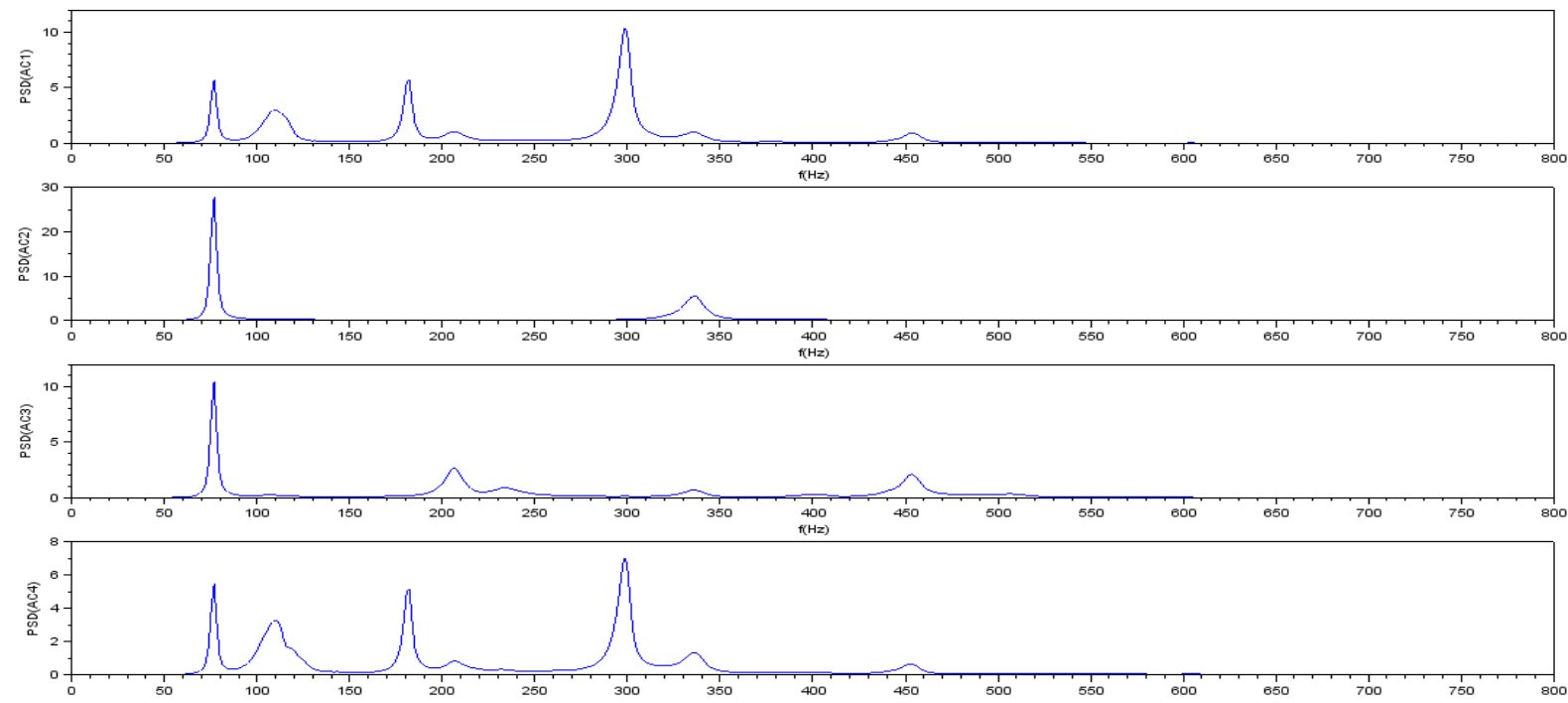

(b) 

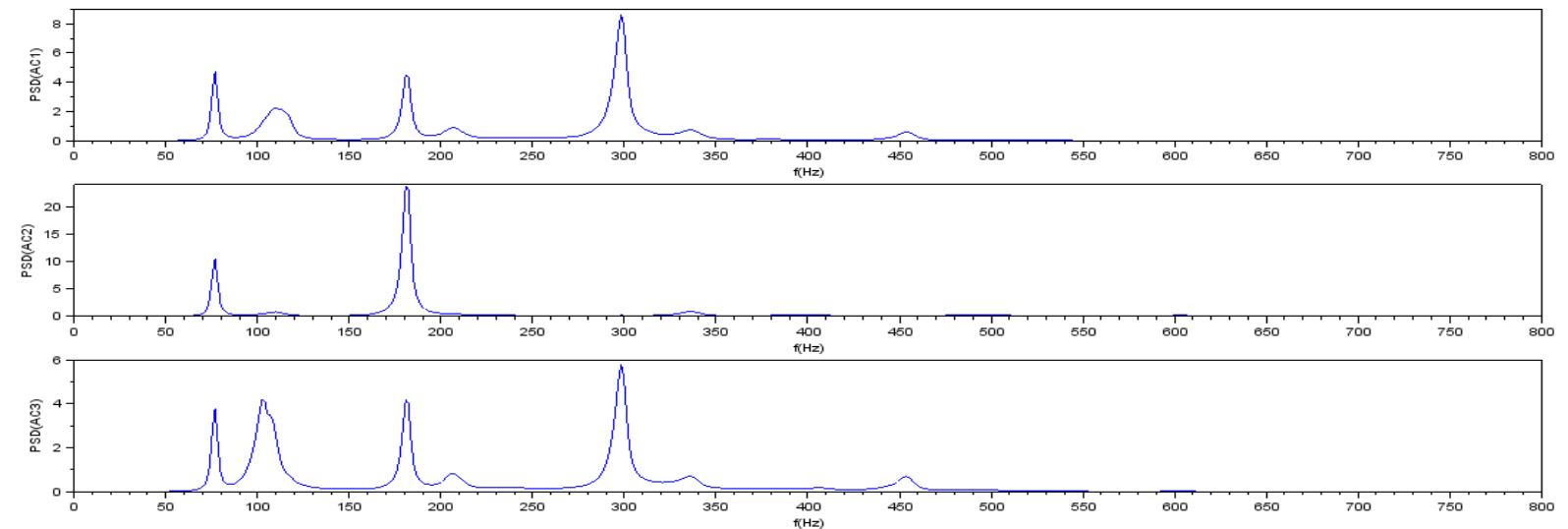

(c)

Figura 6.2 - Gráficos de PSD das três leituras. (a) Leitura 1. (b) Leitura 2. (c) Leitura 3.

Observam-se na Figura 6.2 os valores de frequências naturais do sistema, que foram lidas e estão relatados na Tabela 6.1.

Tabela 6.1: Valores das frequências naturais do ensaio-piloto.

\begin{tabular}{|c|}
\hline Frequência natural lida (Hz) \\
\hline $1^{\mathrm{a}}-76,807$ \\
\hline $2^{\mathrm{a}}-109,940$ \\
\hline $3^{\mathrm{a}}-182,229$ \\
\hline $4^{\mathrm{a}}-206,325$ \\
\hline $5^{\mathrm{a}}-299,699$ \\
\hline $6^{\mathrm{a}}-335,843$ \\
\hline
\end{tabular}

O tipo de janela utilizada foi a Hann, com 1000 pontos por janela e uma sobreposição de $50 \%$.

O gráfico de PSD cruzado analisa o diagrama de PSD de cada acelerômetro em relação ao acelerômetro de referência (no caso o acelerômetro 1). O PSD cruzado apresenta a primeira visualização da deformada modal. Por exemplo, na Figura 6.3, ilustram-se os gráficos de PSD cruzado das três leituras. Observa-se que para a frequência natural 299,699 Hz, o ponto onde está o acelerômetro 1 (ponto de referência) terá um deslocamento para um sentido. Já o ponto do acelerômetro 4 na leitura 2 (ponto 7 na laje), terá um deslocamento para o outro sentido.

As deformadas modais podem ser construídas com os dados do diagrama de transmissibilidade ilustrado na Figura 6.4. A transmissibilidade de deslocamento de um ponto em relação à referência pode ser expressa pela Equação 6.1.

$$
T_{i}=\frac{a_{i}}{a_{r e f}}
$$



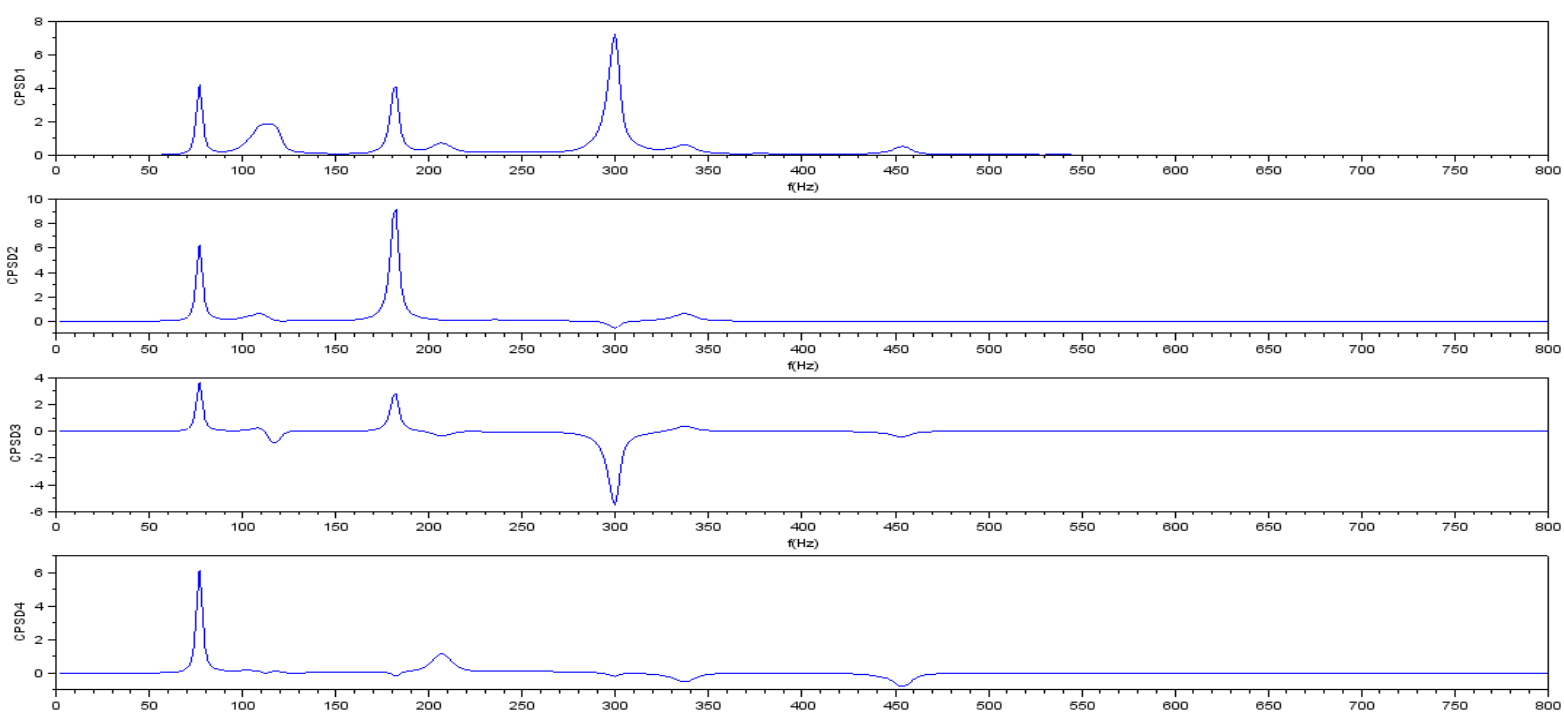

(a)
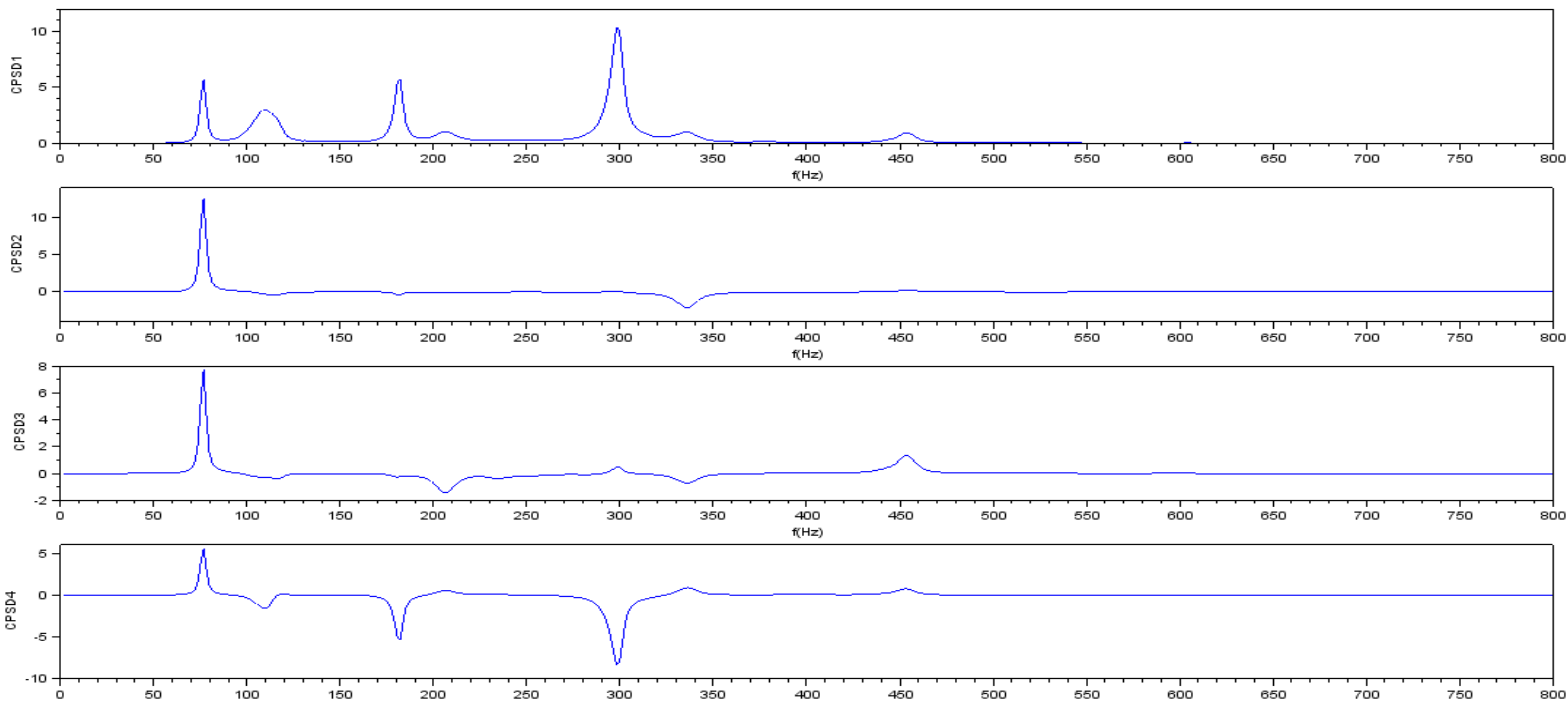

(b)
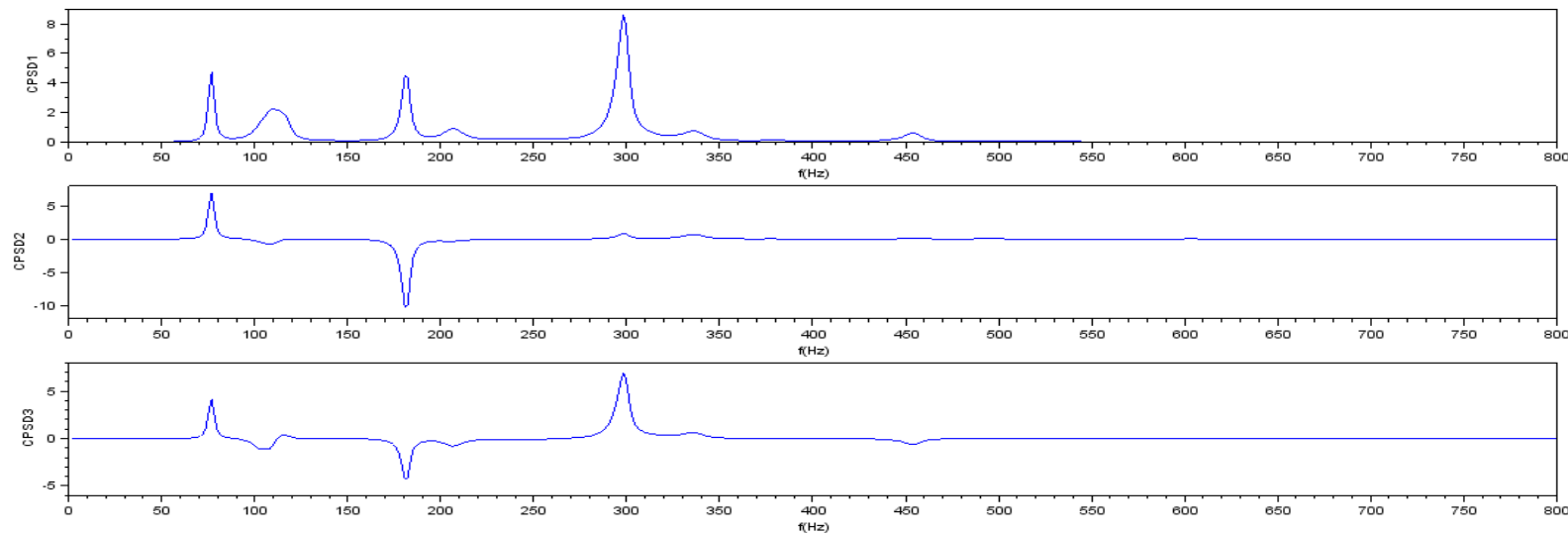

(c)

Figura 6.3 - Gráficos de PSD cruzado das 3 leituras. (a) Leitura 1. (b) Leitura 2. (c) Leitura 3.

Sendo:

$T_{i}$ a transmissibilidade de um ponto $i$ em relação ao ponto de referência do sistema; 
$a_{i}$ a deformação do ponto $i$;

$a_{r e f}$ a deformação do ponto de referência do sistema (nesta pesquisa, sempre o ponto 1) e adotada sempre com o valor unitário.

Assim sendo, a deformada modal pode ser obtida através dos valores da transmissibilidade de um determinado ponto, isolando-se o termo $a_{i}$.
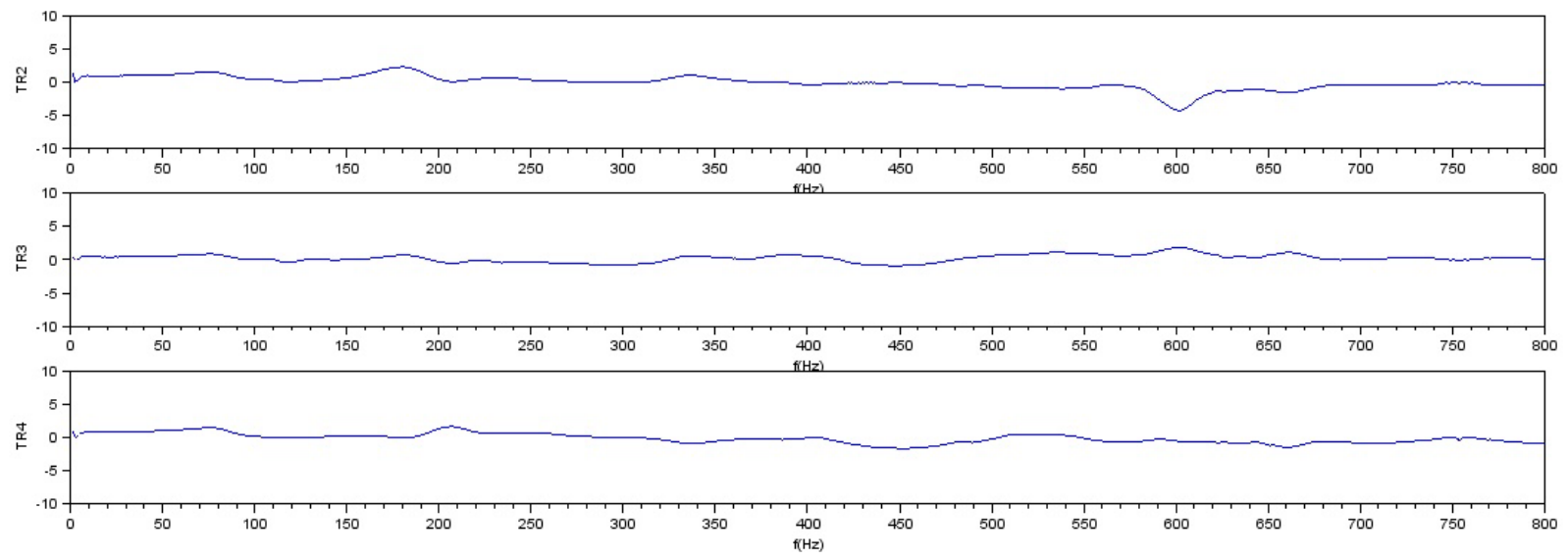

Figura 6.4 - Exemplo do gráfico de transmissibilidade da leitura 1.

A coerência dos dados pode ser avaliada pelo diagrama de coerência (Figura 6.5), onde se espera que o valor próximo a 1 seja atingido na região da frequência natural em questão. Tanto a transmissibilidade quanto a coerência sempre são estimados através do acelerômetro de referência (acelerômetro 1 no ponto 1 das lajes).
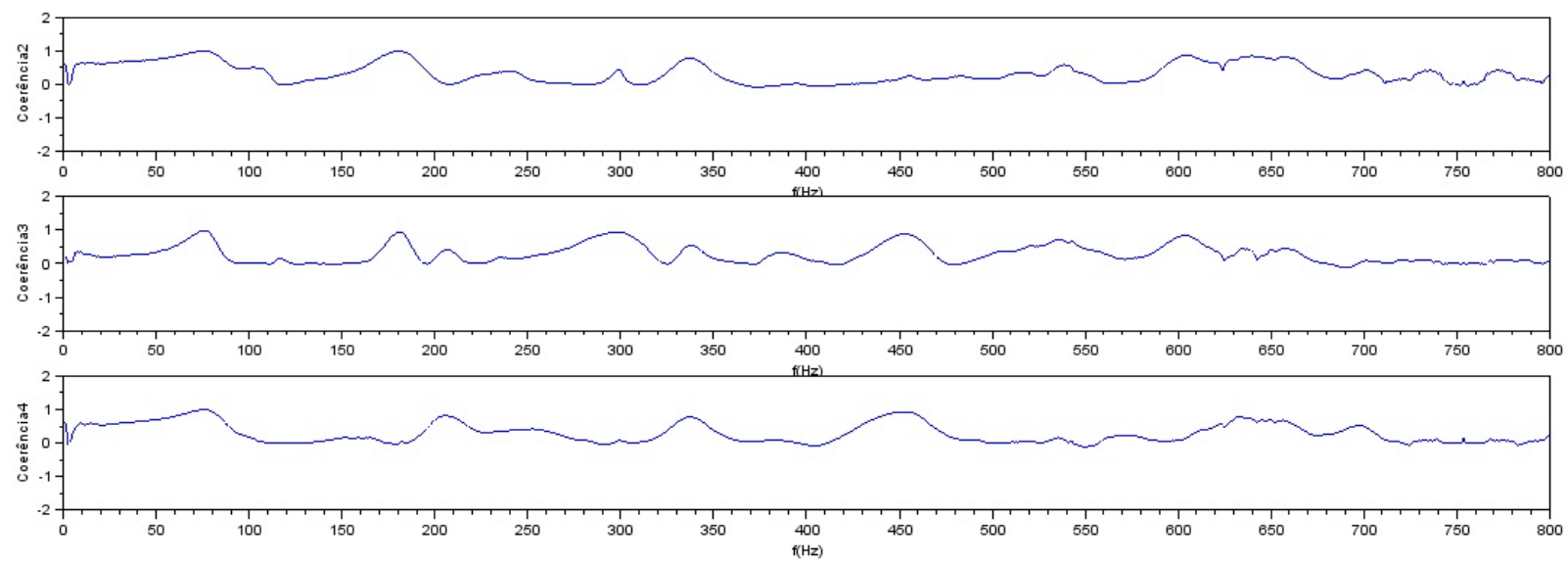

Figura 6.5 - Exemplo do gráfico de coerência da leitura 1.

As deformadas modais das frequências verificadas neste ensaio estão ilustradas na Tabela 6.2. 
Tabela 6.2: Frequências naturais e deformadas modais do ensaio-piloto.

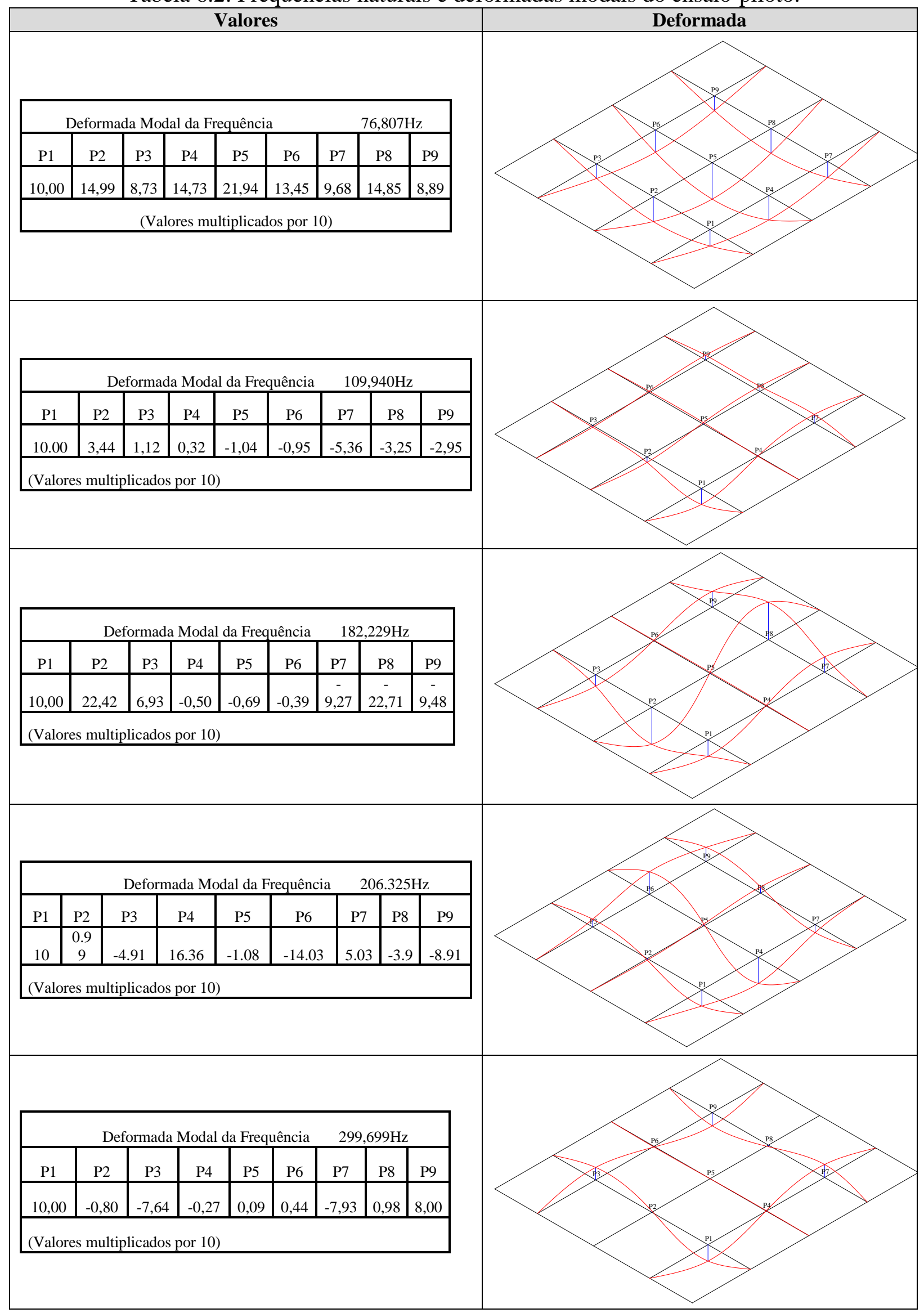




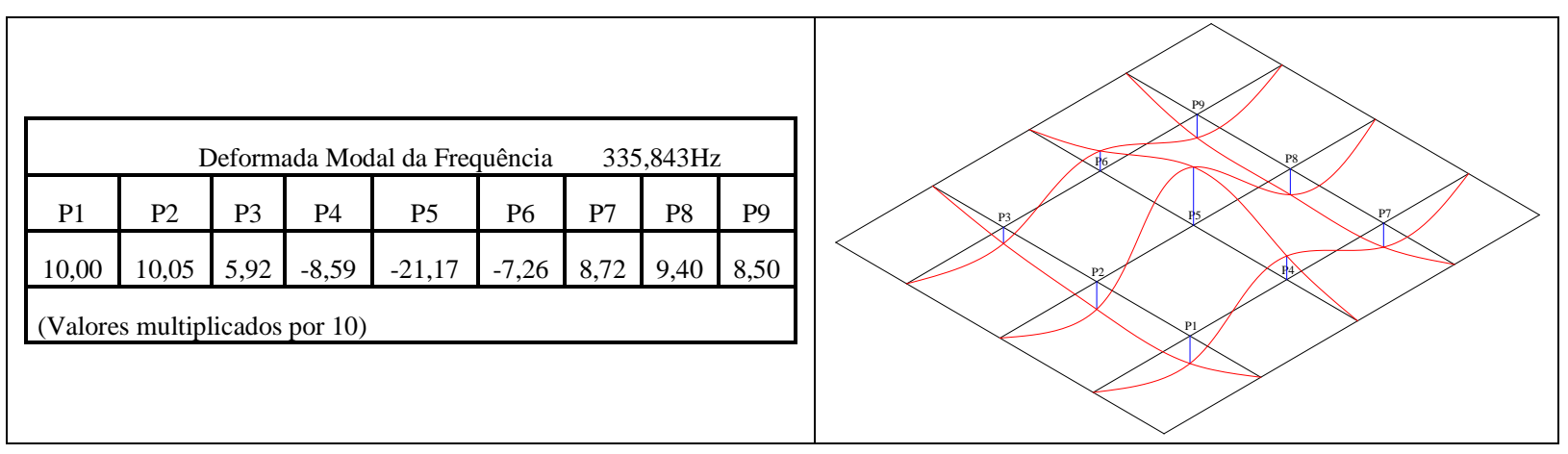

Observa-se na Tabela 6.2 que a frequência de 109,940 Hz não indica claramente uma deformada modal específica teórica. Ao serem reavaliados os gráficos de PSD, nota-se que essa frequência não é um pico bem definido. Assim sendo, não foi determinado o amortecimento modal dessa frequência.

Os amortecimentos dos modos indicados foram estimados por meio de ajuste visual da curva do sinal real com a curva teórica. Inicialmente foi aplicado um filtro no sinal adquirido, para que somente fosse separado o sinal que origina a frequência natural de interesse.

A função de filtro que foi utilizada no Scilab ${ }^{\circledR}$ foi a “iir". Essa função de filtro é definida por um conjunto de parâmetros, no formato da Equação 6.2.

$$
\text { iir(n,ftype,fdesign,frq,delta) }
$$

Sendo:

$n$ o número positivo com valor inteiro, a ordem do filtro;

ftype a sequência de caracteres especificando o tipo de filtro. Os tipos possíveis são: 'lp' (passa-baixo), ' $h p$ ' (passa-alto), 'bp' (passa-banda) e 'sb' (para-banda). No caso específico deste trabalho, foi usado o tipo $b p$;

fdesign o especificador do tipo de filtro, que pode ser 'butt', 'cheb1', 'cheb2' ou 'ellip'. O primeiro ('butt') foi o tipo usado neste trabalho. O tipo 'butt' refere-se ao filtro do tipo Butterworth; 'cheb1' e 'cheb2', aos filtros do tipo Chebyshev 1 e 2, respectivamente; o filtro Chebyshev 2 também é chamado de filtro Chebyshev inverso; 'ellip' corresponde aos filtros do tipo elíptico. O filtro Butterworth não tem ondulações na faixa de passagem, e lentamente aproxima-se de zero, na faixa de rejeição. Filtros Butterworth têm uma função de magnitude monotônica que muda com a carga, ao contrário de outros tipos de filtros, que têm ondulação não monotônica na banda passante e/ou na faixa de rejeição. Filtros Butterworth têm uma resposta de fase mais linear na banda passante do que os outros. Filtros Chebyshev têm uma ondulação íngreme e aproxima-se mais da ondulação na banda passante (tipo 1) ou ondulação para-banda (tipo 2) do que os filtros Butterworth. Filtros Chebyshev têm a propriedade de 
minimizar o erro entre o idealizado e a característica de filtragem efetiva através da faixa do filtro, mas com ondulações na banda de passagem. Filtro elíptico tem comportamento igualitário entre a ondulação da banda de passagem e a banda rejeitada;

frq a faixa de variação aceitável para o filtro. No trabalho foi utilizada uma faixa de $5 \mathrm{~Hz}$ para mais e para menos, da frequência que se desejava obter com o filtro;

delta o valor do erro permitido. Somente se utiliza esse parâmetro nos filtros tipo 'cheb1', ‘cheb2' e ‘ellip'.

Posteriormente foi feito o ajuste visual no aplicativo Excel ${ }^{\circledR}$ do Microsoft Office ${ }^{\circledR}$ da Microsoft Corporation ${ }^{\circledR}$. Foi escolhido esse procedimento devido a sua facilidade de análise. O ajuste visual foi comparado com o cálculo do decremento logarítmico. Ambos os procedimentos estão descritos no item 2.4.6.

A Figura 6.6 ilustra parte do sinal real para frequência natural de 76,807 Hz, após a aplicação do filtro. Observa-se nitidamente o sistema subamortecido.

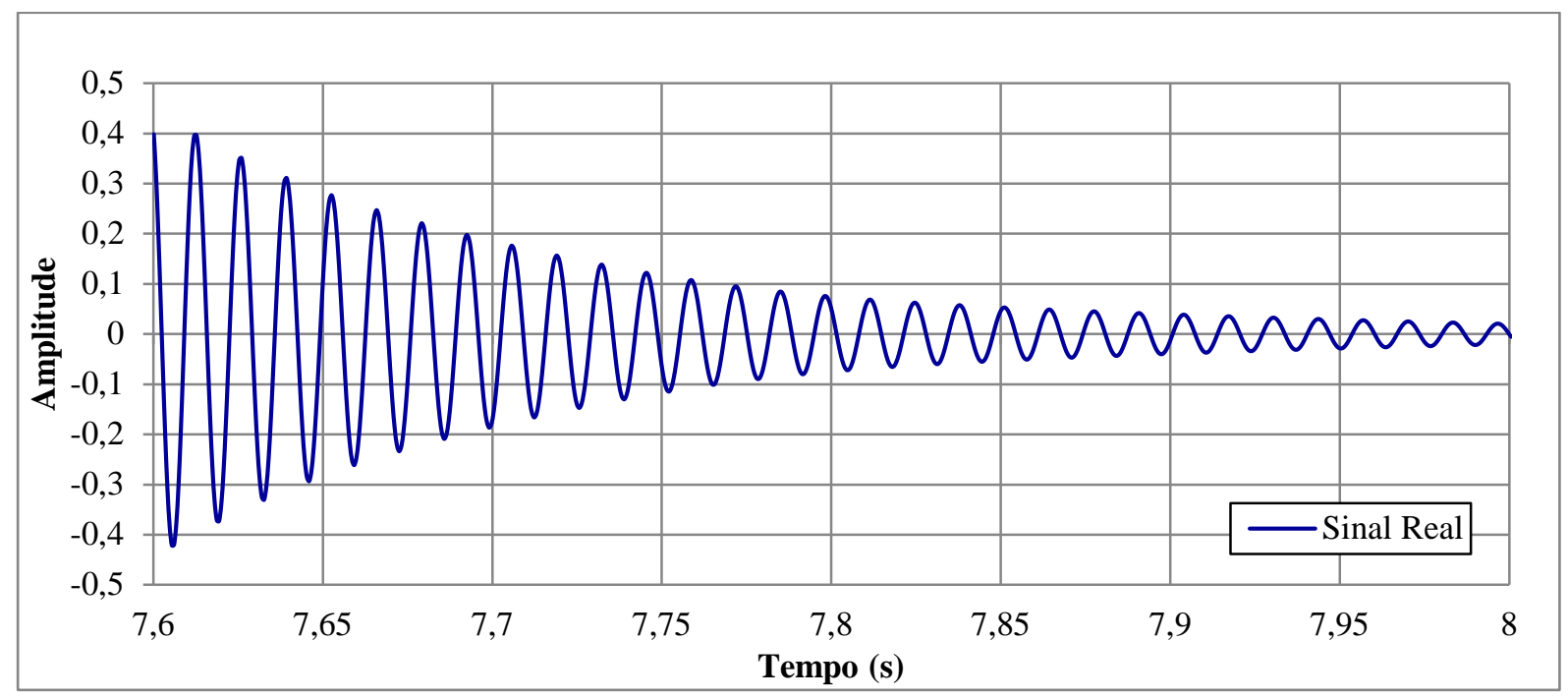

Figura 6.6 - Sinal real para frequência de 76,807 Hz na leitura 1.

Clough e Penzien (1995) apresentam a Equação 6.3 para descrever o movimento vibratório da Figura 6.6.

$$
v(t)=\rho \cdot \cos \left(\omega_{D} \cdot t+\theta\right) \cdot e^{(-\xi \cdot \omega \cdot t)}
$$

Sendo:

$v(t)$ a amplitude do movimento vibratório em função do tempo $t$;

$\omega$ a frequência circular do movimento vibratório analisado, que neste caso iguala-se à frequência natural circular do modo $\omega_{D}$; 
$\xi$ o fator de amortecimento;

$\rho$ um parâmetro dado pela Equação 6.4;

$\theta$ o ângulo de fase do movimento vibratório, dado pela Equação 6.5.

$$
\begin{aligned}
& \rho=\left\{x(0)^{2}+\left(\frac{\dot{x}(0)+x(0) \cdot \xi \cdot \omega}{\omega_{D}}\right)^{2}\right\}^{1 / 2} \\
& \theta=-\operatorname{arctg}\left(\frac{\dot{v}(0)+v(0) \cdot \xi \cdot \omega}{\omega_{D} \cdot v(0)}\right)
\end{aligned}
$$

Sendo:

$v(0)$ o deslocamento inicial no tempo $t=0$;

$\dot{v}(0)$ a velocidade inicial no tempo $t=0$.

A Figura 6.7 ilustra o desenvolvimento da curva teórica representada pela Equação 6.3.

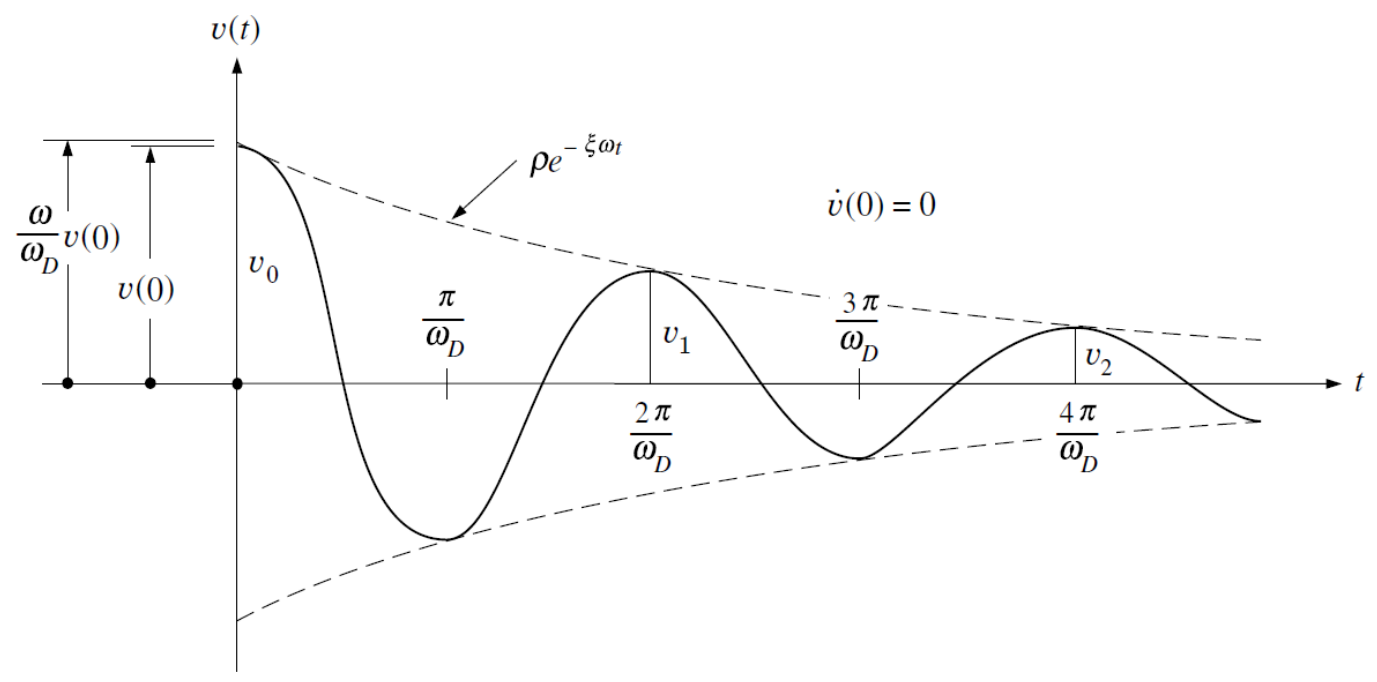

Figura 6.7 - Representação do desenvolvimento do sinal de um sistema subamortecido. Fonte: Clough e Penzien (1995), p. 28.

A ideia do processo para a obtenção do fator de amortecimento é ajustar os parâmetros $\omega_{D}, \omega, \theta$ e $\rho$ da Equação 6.3 e variar o fator de amortecimento $\xi$ para obter uma curva teórica o mais próximo da curva experimental. Quando isto for atingido, tem-se o fator de amortecimento do modo analisado.

A Figura 6.8 ilustra a curva teórica ajustada à curva experimental. Observa-se que a curva teórica e a experimental se sobrepõem por quase toda a extensão analisada. Para o ajuste da curva teórica (Equação 6.3), foram utilizados os valores de: $\omega_{D}=\omega=75,6 \mathrm{~Hz}$; 
tempo inicial de 7,599477 s e $\rho=0,455$. O valor do tempo inicial foi utilizado para ajustar a fase. O valor de $\rho$ é utilizado para ajustar a amplitude. O valor da frequência natural 75,6 Hz foi ajustado, pois a análise do sinal foi realizada com intervalos de frequência de $1.506024 \mathrm{~Hz}$. Isto faz com que a frequência natural exata real possa variar um pouco acima ou abaixo do valor encontrado no diagrama de PSD. Para esse sinal o valor do fator de amortecimento $\xi$ resultou em 0,018564 .

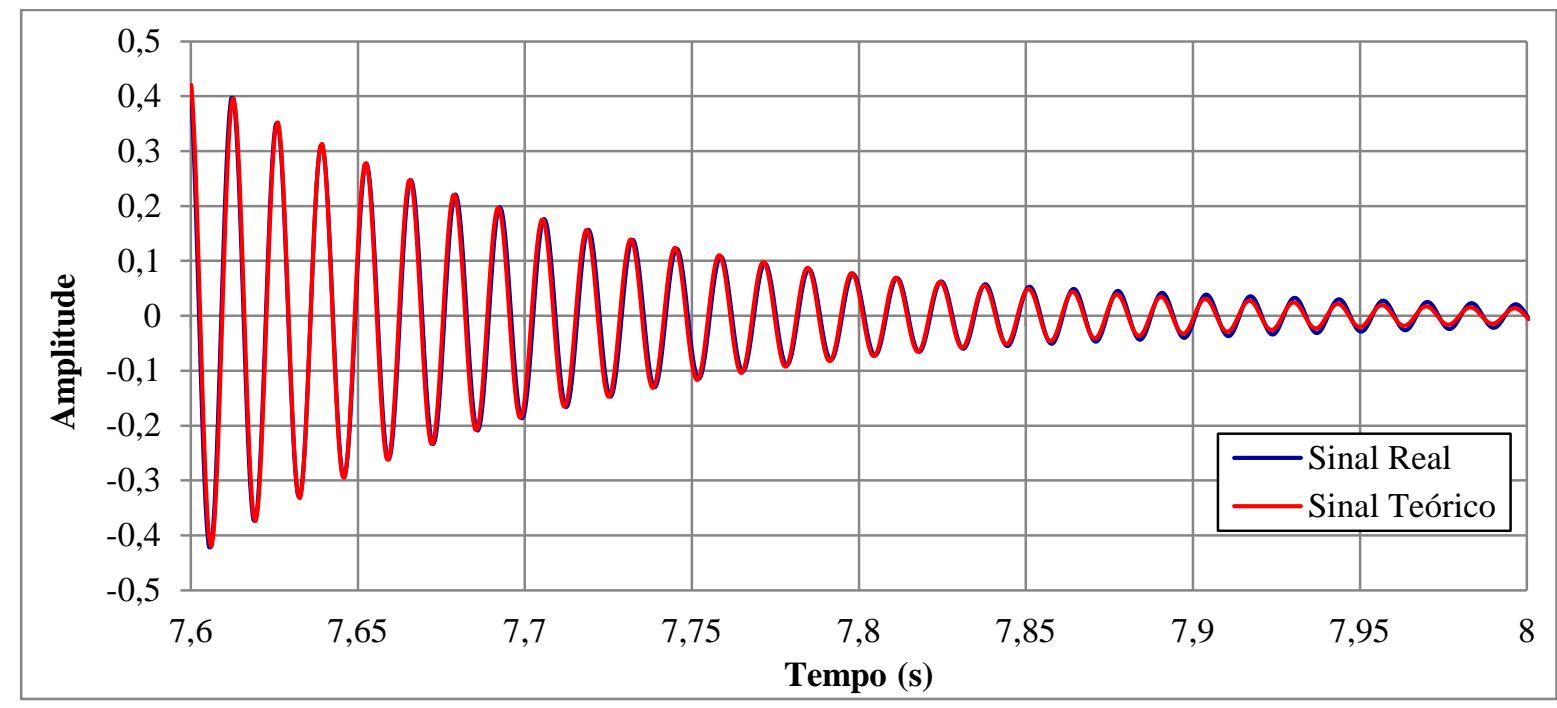

Figura 6.8 - Ajuste do sinal teórico com o experimental para frequência de 76,807 Hz na leitura 1.

Outra forma de avaliar o amortecimento é pelo decremento logarítmico descrito no item 2.4.6.1. Na Equação 2.45 é calculado o valor do decremento logarítmico $\delta$. Para o cálculo é necessário o valor da amplitude inicial $x_{0}$ e o valor da amplitude final $x_{p}$, depois de um determinado número de períodos $p$. No exemplo descrito têm-se os seguintes valores:

$$
\begin{aligned}
& \left.\begin{array}{l}
x_{0}=0,395925 \rightarrow t_{0}=7,612096 s \\
x_{p}=0,220943 \rightarrow t_{p}=7,679160 s
\end{array}\right\} p=5 \Rightarrow \delta=\frac{1}{p} \cdot \ln \left(\frac{x_{0}}{x_{p}}\right)=\frac{1}{5} \cdot \ln \left(\frac{0,395925}{0,220943}\right)=0,116664 \\
& \zeta=\frac{1}{\sqrt{1+(2 . \pi / \delta)^{2}}}=\frac{1}{\sqrt{1+(2 . \pi / 0,116664)^{2}}}=0,018564
\end{aligned}
$$

Observa-se que o processo do decremento logarítmico é muito simples e conduz a valores muito precisos. Destaca-se que na Figura 6.8 o valor do fator de amortecimento foi adotado com o valor determinado pelo processo do decremento logarítmico. Em consequência disso é que esse processo foi adotado para a determinação dos fatores de amortecimento modais na presente pesquisa. 
Para a obtenção de resultados mais confiáveis, foi realizado o cálculo do decremento logarítmico para três intervalos de sinal para a frequência natural considerada, calculando-se finalmente a média dos três cálculos.

A Tabela 6.3 apresenta os valores dos fatores de amortecimento modais calculados pelo processo do decremento logarítmico para o ensaio piloto. Observa-se que o valor médio é coerente com os valores apresentados por Bachmann et al. (1997) na Tabela 2.2.

Tabela 6.3: Valores dos fatores de amortecimento modais do ensaio piloto.

\begin{tabular}{|c|c|c|c|c|c|c|}
\hline \multirow{2}{*}{$\begin{array}{l}\text { Frequência natural } \\
(\mathrm{Hz})\end{array}$} & \multicolumn{5}{|c|}{ Primeiro $\xi$} & \\
\hline & $x_{0}$ & $x_{p}$ & $p$ & $\delta$ & $\xi$ & \\
\hline 76,807 & 0,395925 & 0,220943 & 5 & 0,116664 & 0,018564 & \\
\hline 182,229 & 0,995100 & 0,651897 & 7 & 0,060422 & 0,009616 & \\
\hline 206,325 & 0,958146 & 0,380292 & 8 & 0,115507 & 0,018380 & \\
\hline \multirow{2}{*}{$\begin{array}{l}\text { Frequência natural } \\
(\mathrm{Hz})\end{array}$} & \multicolumn{5}{|c|}{ Segundo $\xi$} & \\
\hline & $x_{0}$ & $x_{p}$ & $p$ & $\delta$ & $\xi$ & \\
\hline 76,807 & 0,560837 & 0,302958 & 5 & 0,123167 & 0,019599 & \\
\hline 182,229 & 1,863744 & 1,086116 & 7 & 0,077140 & 0,012276 & \\
\hline 206,325 & 0,246578 & 0,142354 & 4 & 0,137339 & 0,021853 & \\
\hline \multirow{2}{*}{$\begin{array}{c}\text { Frequência natural } \\
(\mathrm{Hz})\end{array}$} & \multicolumn{5}{|c|}{ Terceiro $\xi$} & $\xi$ \\
\hline & $x_{0}$ & $x_{p}$ & $p$ & $\delta$ & $\xi$ & $\begin{array}{l}\text { (média dos } \\
3 \text { cálculos) }\end{array}$ \\
\hline 76,807 & 0,430922 & 0,195788 & 7 & 0,112700 & 0,017934 & 0,018699 \\
\hline 182,229 & 0,759259 & 0,315886 & 12 & 0,073080 & 0,011630 & 0,011174 \\
\hline 206,325 & 0,142235 & 0,041138 & 10 & 0,124055 & 0,019740 & 0,019991 \\
\hline
\end{tabular}

Nesta pesquisa foram determinados apenas os fatores de amortecimento modais para as três primeiras frequências naturais. Essa decisão é justificada por uma análise que foi feita com modelos numéricos em escala real, com vãos de 4,3 m x 5,2 m, no SAP $2000^{\circledR}$. Nessa avaliação, observou-se que os modelos de escala real possuem frequências naturais maiores que as possivelmente aplicadas pela ação humana de caminhada. Assim, optou-se em estimar o amortecimento modal para os três primeiros modos, que apresentam frequências naturais que poderiam ser atingidas por excitações humanas oriundas de dança, pulos, corridas e/ou excitações provenientes de equipamentos, em modelos de escala real.

Com o ensaio piloto foram feitas as estimativas dos amortecimentos modais e foram colhidas informações quanto às frequências naturais do sistema e suas respectivas deformadas modais.

Observou-se, que, com as rotinas adotadas era possível a determinação de ao menos quatro frequências fundamentais do sistema. Era esperado não ser possível obter frequências de modos muito elevados. Entretanto, como modos mais elevados não são tão preocupantes 
na faixa de frequências excitadoras que podem solicitar a estrutura, os resultados colhidos foram considerados satisfatórios.

Verificou-se ainda que:

- As frequências naturais encontradas eram próximas às frequências naturais obtidas da análise numérica prévia. As diferenças são aceitáveis, pois a rigidez da laje 6 é maior do que foi considerado na análise numérica;

- Com os dados da transmissibilidade é possível determinar as deformadas modais;

- Os valores das coerências dos dados é razoavelmente próxima a 1 nas regiões das frequências naturais, validando a leitura e processamento dos dados;

- As frequências naturais lidas 76,807 Hz; 182,229 Hz; 206,325 Hz; 299,699 Hz e 335,843 Hz equivalem aos modos 1, 2, 3, 4 e 5, respectivamente na análise numérica prévia. Esses modos na análise numérica prévia tiveram os seguintes valores para suas frequências fundamentais: 65,80 Hz; 146,63 Hz; 182,25 Hz; 262,69 Hz e 281,35 Hz;

- A frequência natural lida 109,940 Hz não equivale a nenhum modo apresentado na análise teórica. Observa-se ainda que ela não é um pico bem definido nos gráficos de PSD. Pelos gráficos de PSD cruzado também se verifica que essa frequência não é um pico;

- As deformadas modais experimentais não são perfeitamente simétricas. Isto decorre de influências como a heterogeneidade do material, a heterogeneidade do apoio e pequenos desvios da armadura;

- O método do decremento logarítmico conduz a resultados satisfatórios na mensuração do fator de amortecimento modal;

- Os fatores de amortecimento modal encontrados na Tabela 6.3 estão adequados aos valores teóricos apresentados na Tabela 2.2.

Portanto, os modelos com tamanho reduzido analisados foram validados, bem como a técnica adotada de excitação por impulso. Decidiu-se então seguir o programa experimental da forma como havia sido programado.

\subsection{Resultados dos ensaios dinâmicos das lajes de CC}

Apresentam-se neste item os dados extraídos dos ensaios dinâmicos das lajes de CC. Os resultados estão divididos nos seis ensaios descritos no Capítulo 4. São apresentados os valores das frequências naturais, fatores de amortecimento e tabelas com dados e figuras com as configurações das três primeiras deformadas modais. Os gráficos de aceleração ao longo do tempo, PSD, PSD cruzado, transmissibilidade e coerência não são apresentados por terem grande semelhança com os das Figuras 6.1 a 6.5 já discutidas. 


\subsubsection{Primeiro ensaio dinâmico com lajes de CC}

A Tabela 6.4 apresenta os valores das frequências naturais, deslocamentos nos pontos de medição e deformadas modais para os três primeiros modos do primeiro ensaio dinâmico.

Tabela 6.4: Frequências naturais e deformadas modais do $1^{\circ}$ ensaio dinâmico de lajes de CC.

\begin{tabular}{|c|c|c|c|c|c|c|c|c|c|}
\hline \multicolumn{9}{|c|}{ Valores } & \multirow[t]{13}{*}{ Deformada } \\
\hline \multicolumn{9}{|c|}{$46,687 \mathrm{~Hz}$} & \\
\hline P1 & P2 & P3 & P4 & P5 & P6 & P7 & P8 & P9 & \\
\hline 10,00 & 9,62 & 5,21 & 18,03 & 15,94 & 9,27 & 12,82 & 11,78 & 8,15 & \\
\hline \multicolumn{9}{|c|}{ (Valores multiplicados por 10) } & \\
\hline \multicolumn{9}{|c|}{$94,88 \mathrm{~Hz}$} & \\
\hline P1 & P2 & P3 & P4 & P5 & P6 & P7 & P8 & P9 & \\
\hline 10,00 & 0,79 & $-3,94$ & 16,20 & $-4,84$ & $-14,50$ & 8,25 & $-8,12$ & $-17,19$ & \\
\hline \multicolumn{9}{|c|}{ (Valores multiplicados por 10) } & \\
\hline \multicolumn{9}{|c|}{$118,976 \mathrm{~Hz}$} & \\
\hline P1 & P2 & P3 & P4 & P5 & P6 & P7 & P8 & P9 & \\
\hline 10,00 & 12,52 & 7,54 & 0,66 & 3,89 & 1,36 & $-9,57$ & $-8,40$ & $-6,77$ & \\
\hline \multicolumn{9}{|c|}{ (Valores multiplicados por 10) } & \\
\hline
\end{tabular}

Os fatores de amortecimento modais para os três modos apresentados na Tabela 6.4 são listados na Tabela 6.5, e foram obtidos como descrito no item 6.1.

Foram identificadas diferenças significativas entre os modos teóricos da análise numérica prévia e os modos experimentais. Essas diferenças devem-se principalmente a pontos de descontinuidade no apoio da laje. A argamassa utilizada para nivelar e garantir o apoio da laje com as alvenarias não teve nem espessura nem largura uniforme. Isto é um fato que foi observado apenas após a execução dos ensaios. Essa é uma observação importante e que contribuiu na decisão de realizar um segundo grupo de ensaios dinâmicos descritos no Capítulo 7. A decisão de alterar o esquema de apoios, como será mostrado posteriormente, é baseada na dificuldade e impossibilidade de afirmar que determinadas deformadas modais experimentais sejam equivalentes às numéricas. Assim sendo, a partir deste ponto, não foi feita uma tentativa de identificar um modo experimental com algum modo teórico numérico, para evitar a inserção de erros. 
Tabela 6.5: Valores dos fatores de amortecimento modais do $1^{\circ}$ ensaio das lajes de CC.

\begin{tabular}{|c|c|c|c|c|c|c|}
\hline \multirow{2}{*}{$\begin{array}{l}\text { Frequência natural } \\
(\mathrm{Hz})\end{array}$} & \multicolumn{5}{|c|}{ Primeiro $\xi$} & \\
\hline & $x_{0}$ & $x_{p}$ & $p$ & $\delta$ & $\xi$ & \\
\hline 46,687 & 0,743300 & 0,237526 & 3 & 0,380274 & 0,060412 & \\
\hline 94,880 & 1,247128 & 0,288939 & 9 & 0,162487 & 0,025852 & \\
\hline 118,976 & 0,187099 & 0,045488 & 10 & 0,141420 & 0,022502 & \\
\hline \multirow{2}{*}{$\begin{array}{l}\text { Frequência natural } \\
\text { (Hz) }\end{array}$} & \multicolumn{5}{|c|}{ Segundo $\xi$} & \\
\hline & $x_{0}$ & $x_{p}$ & $p$ & $\delta$ & $\xi$ & \\
\hline 46,687 & 1,194467 & 0,228925 & 5 & 0,330411 & 0,052514 & \\
\hline 94,880 & 1,531970 & 0,212351 & 7 & 0,282295 & 0,044883 & \\
\hline 118,976 & 1,818831 & 0,421544 & 8 & 0,182753 & 0,029074 & \\
\hline \multirow{2}{*}{$\begin{array}{l}\text { Frequência natural } \\
\text { (Hz) }\end{array}$} & \multicolumn{5}{|c|}{ Terceiro $\xi$} & $\xi$ \\
\hline & $x_{0}$ & $X_{p}$ & $p$ & $\delta$ & $\xi$ & $\begin{array}{l}\text { (média dos } 3 \\
\text { cálculos) }\end{array}$ \\
\hline 46,687 & 1,243694 & 0,08759 & 8 & 0,331647 & 0,052710 & 0,055212 \\
\hline 94,880 & 1,622647 & 0,401645 & 8 & 0,174531 & 0,027767 & 0,032834 \\
\hline 118,976 & 2,004949 & 0,442355 & 8 & 0,188908 & 0,030052 & 0,027209 \\
\hline
\end{tabular}

A calibração de um modelo numérico para levar em conta a presença das alvenarias mostrou-se extremamente trabalhoso e não traria grandes benefícios práticos para os objetivos da pesquisa. Muitas incertezas foram levantadas, tais como: descontinuidade do apoio da argamassa; características da argamassa; características dos blocos cerâmicos; características dos blocos de concreto; características do concreto da cinta de amarração; características da argamassa de assentamento; aberturas nas alvenarias; interação das alvenarias com o piso do laboratório entre outras.

Quanto aos fatores de amortecimento, pode-se verificar que o fator no modo de 46,687 Hz é maior do que os dos outros dois, ficando equivalente a fatores de amortecimento de peças fissuradas completamente com alto nível de tensão nas armaduras (Tabela 2.2). Os outros dois fatores de amortecimento estão dentro do esperado para peças com nível de fissuração completa, porém com níveis mais baixos de tensão nas armaduras. Observa-se, no entanto, que as peças não estavam completamente fissuradas. Essa aparente discrepância também colaborou na decisão de serem realizados os ensaios do Capítulo 7.

\subsubsection{Segundo ensaio dinâmico com lajes de CC}

A Tabela 6.6 apresenta os valores das frequências naturais, deslocamentos nos pontos de medição e deformadas modais para os três primeiros modos do segundo ensaio dinâmico. 
Tabela 6.6: Frequências naturais e deformadas modais do $2^{\circ}$ ensaio dinâmico de lajes de CC.

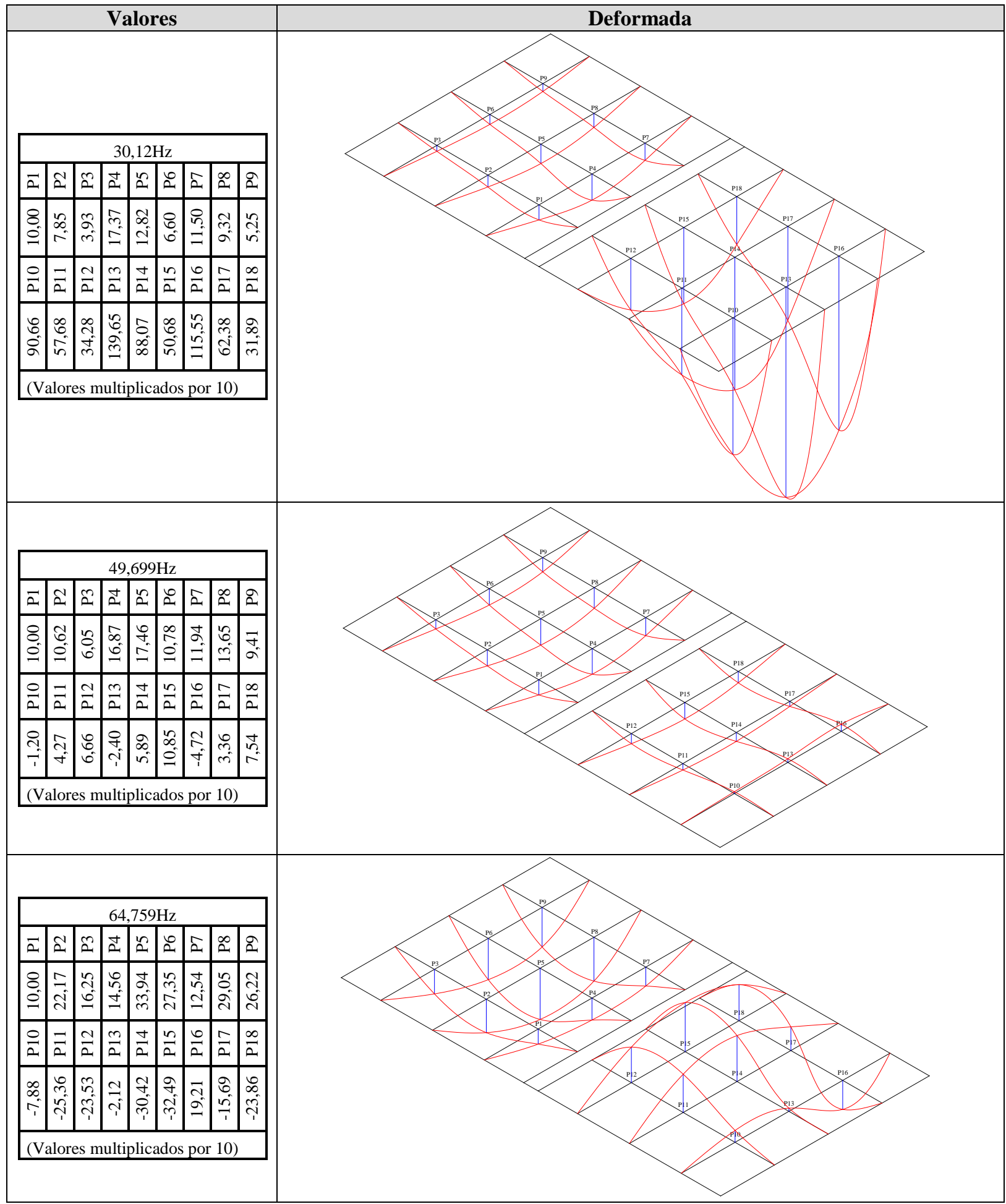

Os fatores de amortecimento modais para os três modos apresentados na Tabela 6.6 são listados na Tabela 6.7, e foram obtidos como descrito no item 6.1.

O modo com frequência 30,120 Hz indica um possível movimento de corpo rígido, devido a deficiências no apoio. 
Tabela 6.7: Valores dos fatores de amortecimento modais do $2^{\circ}$ ensaio das lajes de CC.

\begin{tabular}{|c|c|c|c|c|c|c|}
\hline \multirow{2}{*}{$\begin{array}{l}\text { Frequência natural } \\
(\mathrm{Hz})\end{array}$} & \multicolumn{5}{|c|}{ Primeiro $\xi$} & \\
\hline & $x_{0}$ & $x_{p}$ & $p$ & $\delta$ & $\xi$ & \\
\hline 30,120 & 0,067771 & 0,022136 & 5 & 0,223790 & 0,035595 & \\
\hline 49,699 & 0,885076 & 0,114618 & 7 & 0,292009 & 0,046425 & \\
\hline 64,759 & 0,650331 & 0,075150 & 11 & 0,196182 & 0,031208 & \\
\hline \multirow{2}{*}{$\begin{array}{l}\text { Frequência natural } \\
(\mathrm{Hz})\end{array}$} & \multicolumn{5}{|c|}{ Segundo $\xi$} & \\
\hline & $x_{0}$ & $x_{p}$ & $p$ & $\delta$ & $\xi$ & \\
\hline 30,120 & 1,775549 & 0,380958 & 6 & 0,256529 & 0,040794 & \\
\hline 49,699 & 0,518472 & 0,069519 & 6 & 0,334881 & 0,053222 & \\
\hline 64,759 & 0,540322 & 0,072792 & 9 & 0,222729 & 0,035426 & \\
\hline \multirow{2}{*}{$\begin{array}{c}\text { Frequência natural } \\
(\mathrm{Hz})\end{array}$} & \multicolumn{5}{|c|}{ Terceiro $\xi$} & $\xi$ \\
\hline & $x_{0}$ & $x_{p}$ & $p$ & $\delta$ & $\xi$ & $\begin{array}{l}\text { (média dos } \\
3 \text { cálculos) }\end{array}$ \\
\hline 30,120 & 0,249335 & 0,042561 & 6 & 0,294645 & 0,046843 & 0,041077 \\
\hline 49,699 & 1,399119 & 0,115953 & 10 & 0,249042 & 0,039605 & 0,046417 \\
\hline 64,759 & 1,601847 & 0,163130 & 14 & 0,163169 & 0,025960 & 0,030865 \\
\hline
\end{tabular}

Quanto aos fatores de amortecimento, pode-se verificar que, para os três modos calculados estão dentro do esperado para fatores de amortecimento para concreto fissurado, mas com baixo nível de tensão (Tabela 2.2). Vale, porém, a observação feita no item 6.2.1.

\subsubsection{Terceiro ensaio dinâmico com lajes de CC}

A Tabela 6.8 apresenta os valores das frequências naturais, deslocamentos nos pontos de medição e deformadas modais para os três primeiros modos do terceiro ensaio dinâmico.

Os fatores de amortecimento modais para os três modos apresentados na Tabela 6.8 são listados na Tabela 6.9, e foram obtidos como descrito no item 6.1.

Tabela 6.8: Frequências naturais e deformadas modais do $3^{\circ}$ ensaio dinâmico de lajes de CC.

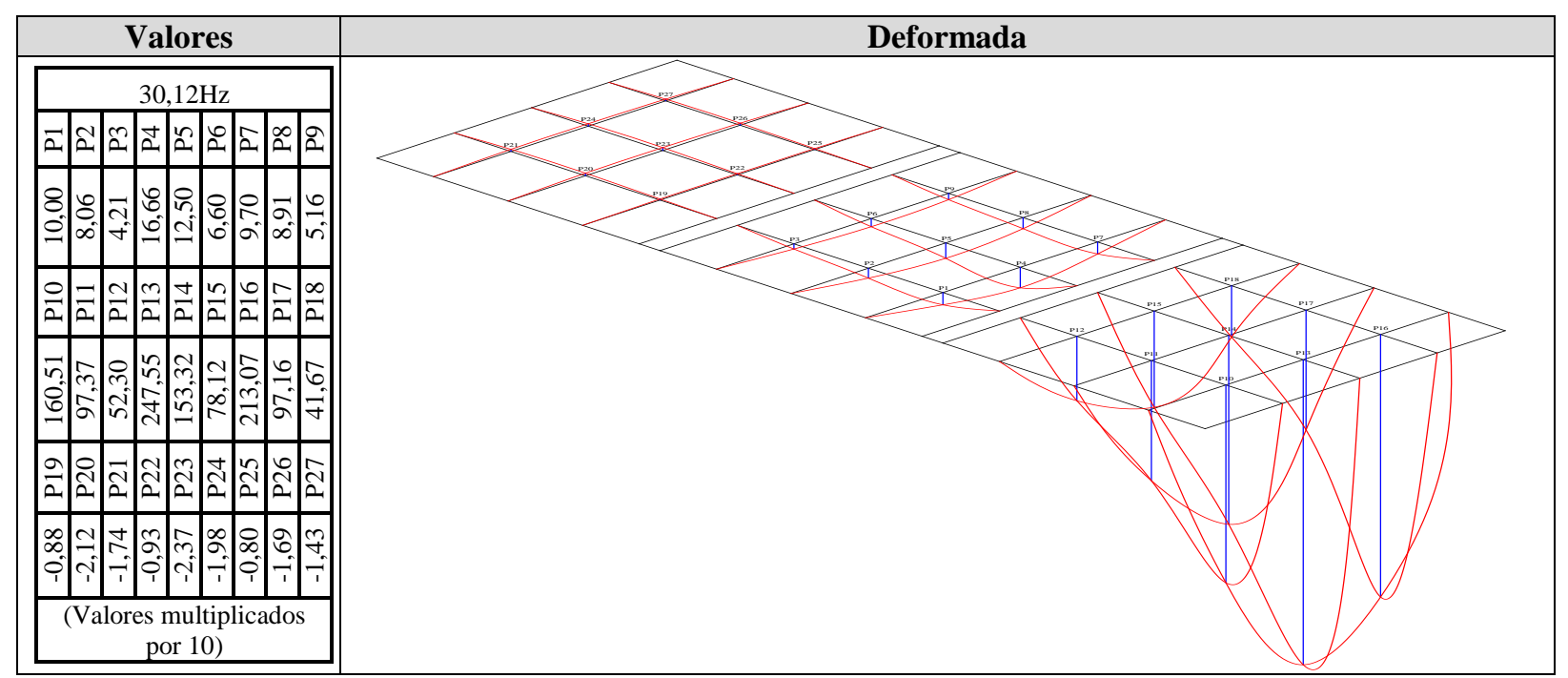




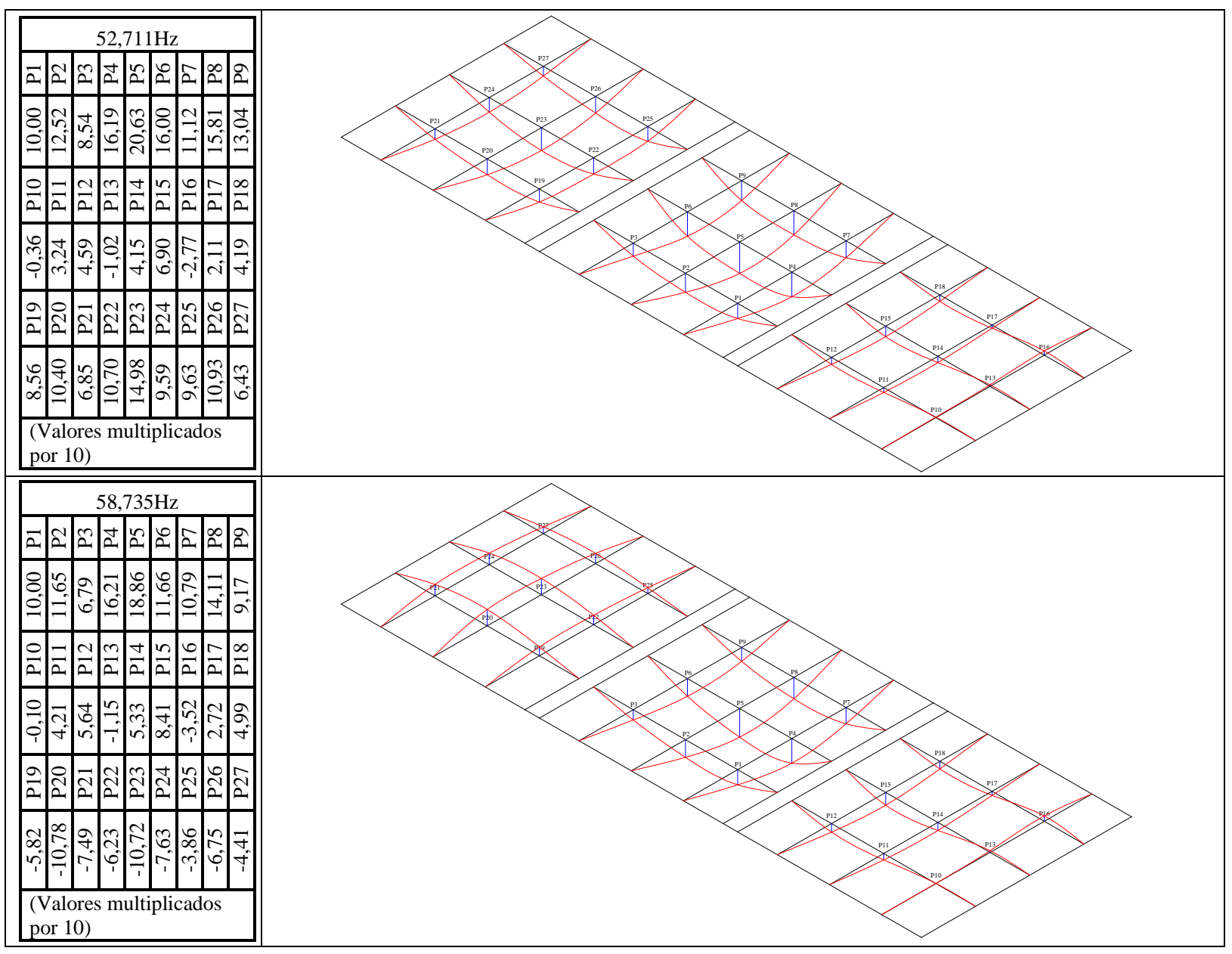

Tabela 6.9: Valores dos fatores de amortecimento modais do $3^{\circ}$ ensaio das lajes de CC.

\begin{tabular}{|c|c|c|c|c|c|c|}
\hline \multirow{2}{*}{$\begin{array}{l}\text { Frequência natural } \\
\qquad(\mathrm{Hz})\end{array}$} & \multicolumn{5}{|c|}{ Primeiro $\xi$} & \\
\hline & $x_{0}$ & $x_{p}$ & $p$ & $\delta$ & $\xi$ & \\
\hline 30,120 & 0,517343 & 0,111329 & 7 & 0,219460 & 0,034907 & \\
\hline 52,711 & 0,047510 & 0,008445 & 7 & 0,246768 & 0,039244 & \\
\hline 58,735 & 0,396075 & 0,055681 & 14 & 0,140140 & 0,022298 & \\
\hline \multirow{2}{*}{$\begin{array}{l}\text { Frequência natural } \\
\qquad(\mathrm{Hz})\end{array}$} & \multicolumn{5}{|c|}{ Segundo $\xi$} & \\
\hline & $x_{0}$ & $x_{p}$ & $p$ & $\delta$ & $\xi$ & \\
\hline 30,120 & 0,726519 & 0,094038 & 11 & 0,185870 & 0,029569 & \\
\hline 52,711 & 0,020199 & 0,011625 & 4 & 0,138132 & 0,021979 & \\
\hline 58,735 & 0,507150 & 0,114636 & 11 & 0,135185 & 0,021510 & \\
\hline \multirow{2}{*}{$\begin{array}{l}\text { Frequência natural } \\
\text { (Hz) }\end{array}$} & \multicolumn{5}{|c|}{ Terceiro $\xi$} & $\xi$ \\
\hline & $x_{0}$ & $x_{p}$ & $p$ & $\delta$ & $\xi$ & $\begin{array}{l}\text { (média dos } \\
3 \text { cálculos) }\end{array}$ \\
\hline 30,120 & 0,534783 & 0,120315 & 7 & 0,213107 & 0,033898 & 0,032791 \\
\hline 52,711 & 0,288491 & 0,058064 & 4 & 0,400779 & 0,063657 & 0,041627 \\
\hline 58,735 & 0,279024 & 0,061095 & 10 & 0,151887 & 0,024166 & 0,022658 \\
\hline
\end{tabular}

O modo com frequência 30,120 Hz indica um possível movimento de corpo rígido, devido a deficiências no apoio. 
Quanto aos fatores de amortecimento, pode-se verificar que os três modos calculados estão dentro do esperado para fatores de amortecimento para concreto fissurado, mas com baixo nível de tensão (Tabela 2.2). Vale, também, a observação feita no item 6.2.1.

\subsubsection{Quarto ensaio dinâmico com lajes de CC}

A Tabela 6.10 apresenta os valores das frequências naturais, deslocamentos nos pontos de medição e deformadas modais para o quarto ensaio dinâmico.

Os fatores de amortecimento modais para os três modos apresentados na Tabela 6.10 são listados na Tabela 6.11, e foram obtidos como descrito no item 6.1.

Tabela 6.10: Frequências naturais e deformadas modais do $4^{\circ}$ ensaio dinâmico de lajes de CC.

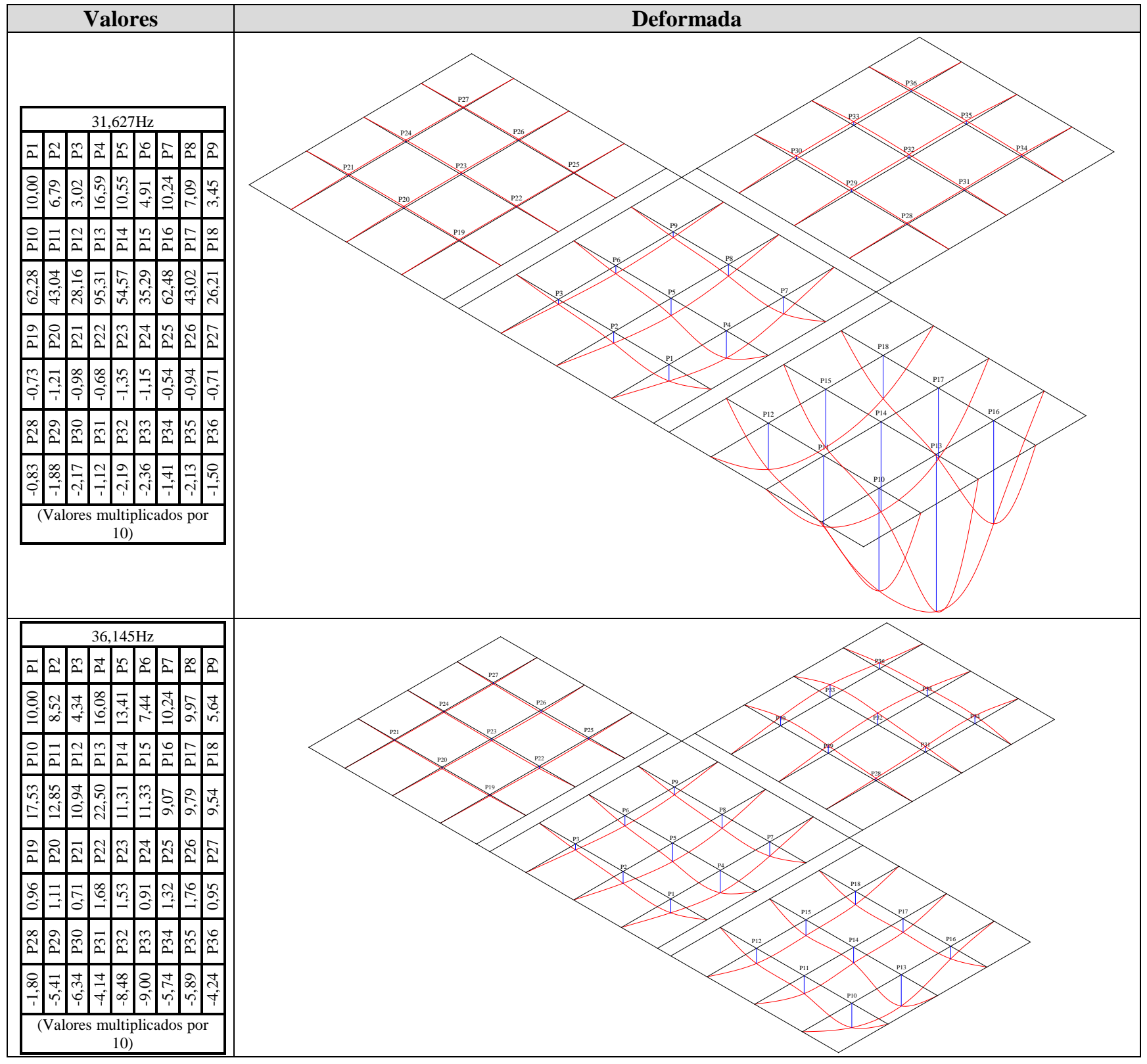




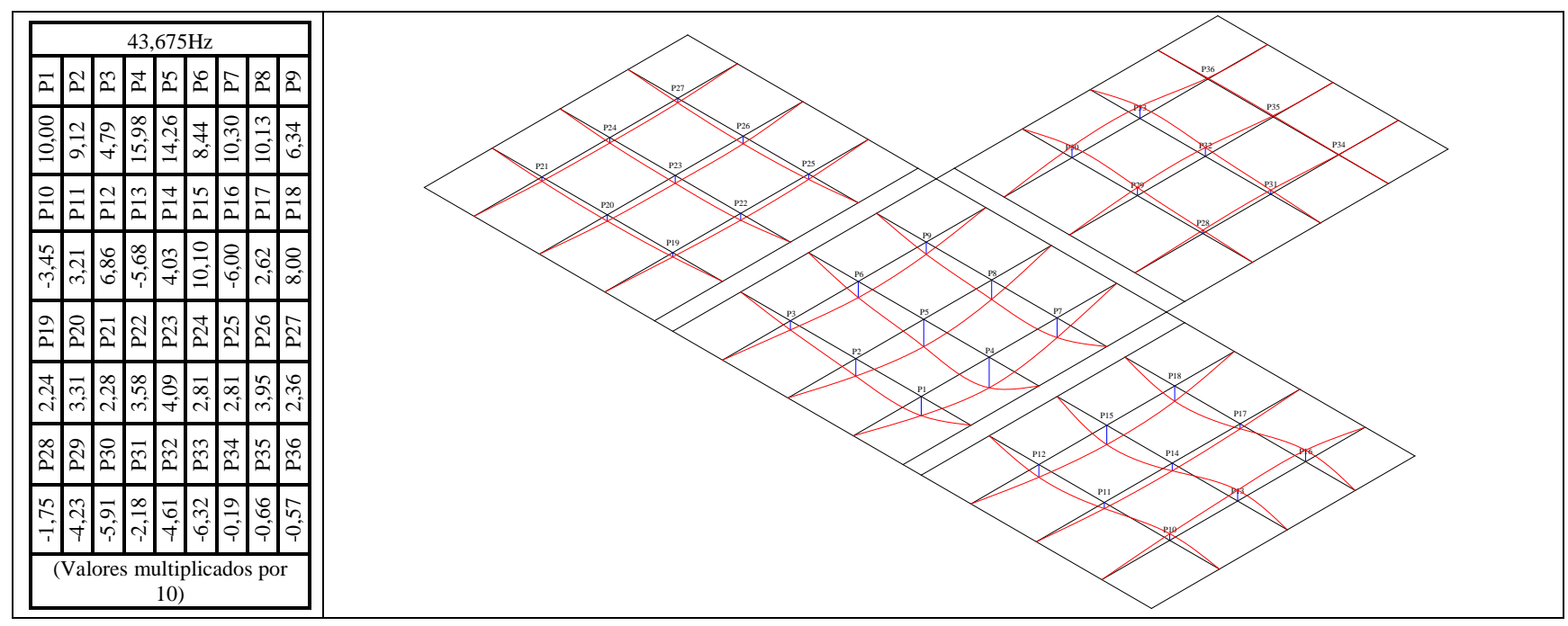

Tabela 6.11: Valores dos fatores de amortecimento modais do $4^{\circ}$ ensaio das lajes de CC.

\begin{tabular}{|c|c|c|c|c|c|c|}
\hline \multirow{2}{*}{$\begin{array}{c}\text { Frequência natural } \\
(\mathrm{Hz})\end{array}$} & \multicolumn{5}{|c|}{ Primeiro $\xi$} & \\
\hline & $x_{0}$ & $x_{p}$ & $p$ & $\delta$ & $\xi$ & \\
\hline 31,627 & 0,567133 & 0,045796 & 12 & 0,209699 & 0,033356 & \\
\hline 36,145 & 0,613926 & 0,064015 & 11 & 0,205523 & 0,032693 & \\
\hline 43,675 & 0,555162 & 0,089947 & 10 & 0,182003 & 0,028955 & \\
\hline \multirow{2}{*}{$\begin{array}{l}\text { Frequência natural } \\
(\mathrm{Hz})\end{array}$} & \multicolumn{5}{|c|}{ Segundo $\xi$} & \\
\hline & $x_{0}$ & $x_{p}$ & $p$ & $\delta$ & $\xi$ & \\
\hline 31,627 & 1,151004 & 0,195201 & 9 & 0,197151 & 0,031362 & \\
\hline 36,145 & 2,152803 & 0,246178 & 10 & 0,216847 & 0,034492 & \\
\hline 43,675 & 0,232197 & 0,104395 & 9 & 0,088818 & 0,014134 & \\
\hline \multirow{2}{*}{$\begin{array}{l}\text { Frequência natural } \\
\text { (Hz) }\end{array}$} & \multicolumn{5}{|c|}{ Terceiro $\xi$} & $\xi$ \\
\hline & $x_{0}$ & $x_{p}$ & $p$ & $\delta$ & $\xi$ & $\begin{array}{l}\text { (média dos } \\
3 \text { cálculos) }\end{array}$ \\
\hline 31,627 & 0,266468 & 0,038288 & 8 & 0,242513 & 0,038568 & 0,034429 \\
\hline 36,145 & 0,163202 & 0,033762 & 7 & 0,225094 & 0,035802 & 0,034329 \\
\hline 43,675 & 1,586573 & 0,156583 & 11 & 0,210522 & 0,033487 & 0,025525 \\
\hline
\end{tabular}

O modo com frequência 31,627 Hz indica um possível movimento de corpo rígido devido a deficiências no apoio;

Quanto aos fatores de amortecimento, pode-se verificar que os três modos calculados estão dentro do esperado para concreto fissurado, mas com baixo nível de tensão (Tabela 2.2). Entretanto, neste ensaio observa-se que os amortecimentos são menores que nos três ensaios anteriores. Isto pode ser justificado pela elevação da rigidez dos apoios da laje central com a ligação de graute entre os painéis adjacentes. Foi observado por Graepp e Stabenow Jr. (2014) que, em concretos comuns com diferentes tipos de agregados graúdos, ao ser elevada a densidade e a rigidez dos agregados graúdos, estes concretos apresentam amortecimento 
menor que os concretos comuns com agregados graúdos menos densos e mais porosos. Vale ainda a observação de que as placas não estavam fissuradas em níveis como os adotados na Tabela 2.2.

\subsubsection{Quinto ensaio dinâmico com lajes de CC}

Os fatores de amortecimento modais para os três modos apresentados na Tabela 6.13 são listados na Tabela 6.12, e foram obtidos como descrito no item 6.1.

A Tabela 6.13 apresenta os valores das frequências naturais, deslocamentos nos pontos de medição e deformadas modais para os três primeiros modos do quinto ensaio dinâmico.

Tabela 6.12: Valores dos fatores de amortecimento modais do $5^{\circ}$ ensaio das lajes de CC.

\begin{tabular}{|c|c|c|c|c|c|c|}
\hline \multirow{2}{*}{$\begin{array}{c}\text { Frequência natural } \\
(\mathrm{Hz})\end{array}$} & \multicolumn{5}{|c|}{ Primeiro $\xi$} & \\
\hline & $x_{0}$ & $x_{p}$ & $p$ & $\delta$ & $\xi$ & \\
\hline 21,084 & 0,752808 & 0,261238 & 9 & 0,117598 & 0,018713 & \\
\hline 30,120 & 0,768442 & 0,111307 & 11 & 0,175643 & 0,027944 & \\
\hline 37,651 & 1,368369 & 0,157430 & 9 & 0,240266 & 0,038212 & \\
\hline \multirow{2}{*}{$\begin{array}{l}\text { Frequência natural } \\
\qquad(\mathrm{Hz})\end{array}$} & \multicolumn{5}{|c|}{ Segundo $\xi$} & \\
\hline & $x_{0}$ & $x_{p}$ & $p$ & $\delta$ & $\xi$ & \\
\hline 21,084 & 0,547889 & 0,243672 & 6 & 0,135042 & 0,021488 & \\
\hline 30,120 & 0,839531 & 0,120293 & 11 & 0,176629 & 0,028100 & \\
\hline 37,651 & 0,691916 & 0,066203 & 10 & 0,234674 & 0,037323 & \\
\hline \multirow{2}{*}{$\begin{array}{l}\text { Frequência natural } \\
\text { (Hz) }\end{array}$} & \multicolumn{5}{|c|}{ Terceiro $\xi$} & $\xi$ \\
\hline & $x_{0}$ & $X_{p}$ & $p$ & $\delta$ & $\xi$ & $\begin{array}{l}\text { (média dos } \\
3 \text { cálculos) }\end{array}$ \\
\hline 21,084 & 0,315771 & 0,122624 & 8 & 0,118236 & 0,018815 & 0,019672 \\
\hline 30,120 & 1,586427 & 0,105894 & 14 & 0,193343 & 0,030757 & 0,028934 \\
\hline 37,651 & 0,948340 & 0,071811 & 11 & 0,234607 & 0,037313 & 0,037616 \\
\hline
\end{tabular}

O modo com frequência 30,120 Hz indica um possível movimento de corpo rígido devido a deficiências no apoio;

Quanto aos fatores de amortecimento, pode-se verificar que os três modos calculados estão dentro do esperado para concreto fissurado, mas com baixo nível de tensão (Tabela 2.2). Observa-se a continuidade da tendência de redução dos fatores de amortecimento com o aumento da rigidez estrutural promovida pelas ligações dos painéis. Painéis não fissurados na realidade. 
Tabela 6.13: Frequências naturais e deformadas modais do $5^{\circ}$ ensaio dinâmico de lajes de CC.

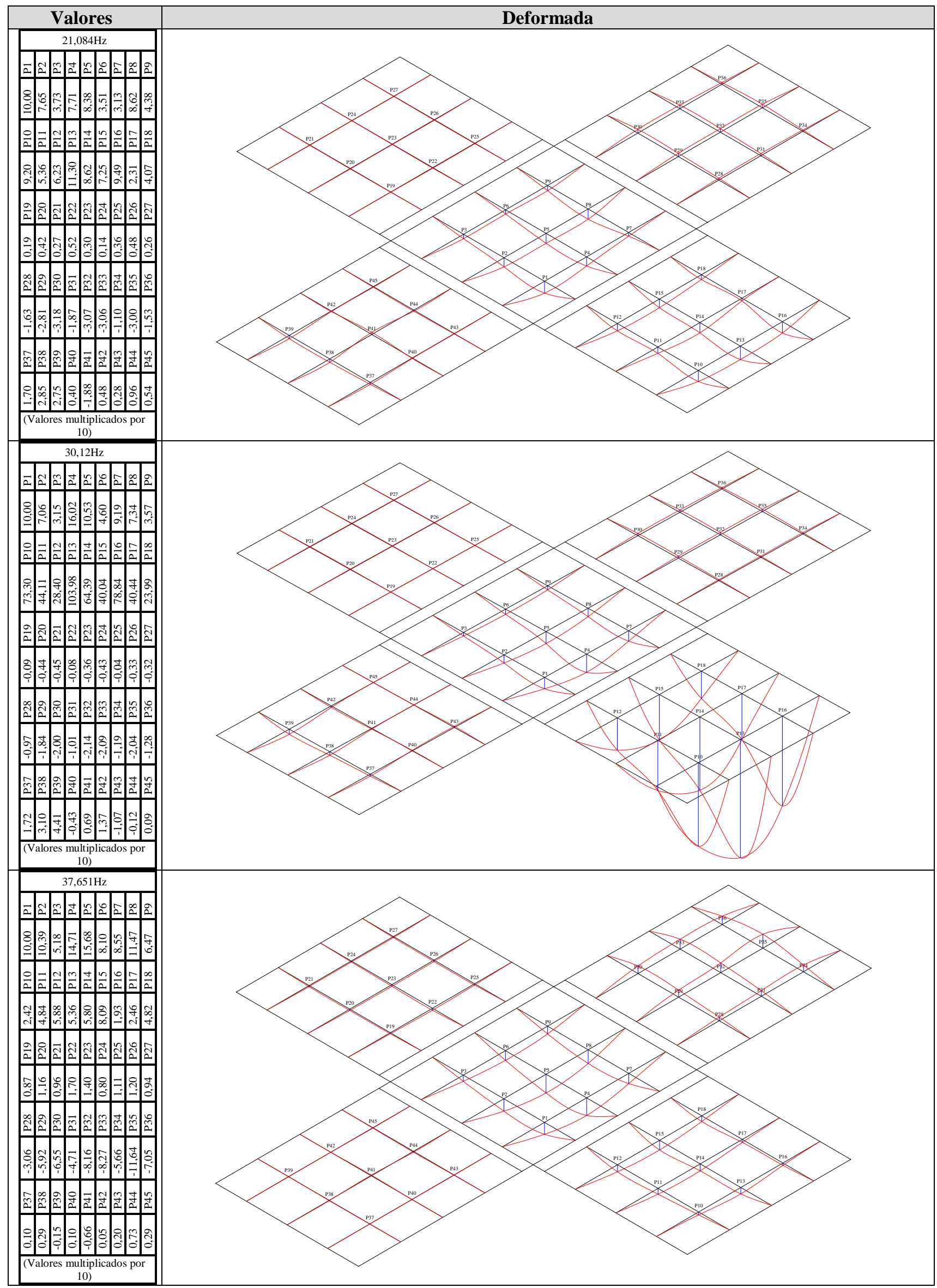




\subsubsection{Sexto ensaio dinâmico com lajes de CC}

Os fatores de amortecimento modais para os três modos apresentados na Tabela 6.15 são listados na Tabela 6.14, e foram obtidos como descrito no item 6.1.

A Tabela 6.15 apresenta os valores das frequências naturais, deslocamentos nos pontos de medição e deformadas modais para os três primeiros modos do sexto ensaio dinâmico.

Tabela 6.14: Valores dos fatores de amortecimento modais do $6^{\circ}$ ensaio das lajes de CC.

\begin{tabular}{|c|c|c|c|c|c|c|}
\hline \multirow{2}{*}{$\begin{array}{c}\text { Frequência natural } \\
(\mathrm{Hz})\end{array}$} & \multicolumn{5}{|c|}{ Primeiro $\xi$} & \\
\hline & $x_{0}$ & $x_{p}$ & $p$ & $\delta$ & $\xi$ & \\
\hline 21,084 & 0,793666 & 0,085087 & 16 & 0,139562 & 0,022207 & \\
\hline 30,120 & 0,180982 & 0,035182 & 10 & 0,163787 & 0,026059 & \\
\hline 39,157 & 1,477536 & 0,016832 & 15 & 0,298324 & 0,047426 & \\
\hline \multirow{2}{*}{$\begin{array}{l}\text { Frequência natural } \\
(\mathrm{Hz})\end{array}$} & \multicolumn{5}{|c|}{ Segundo $\xi$} & \\
\hline & $x_{0}$ & $x_{p}$ & $p$ & $\delta$ & $\xi$ & \\
\hline 21,084 & 0,223926 & 0,106582 & 7 & 0,106054 & 0,016877 & \\
\hline 30,120 & 0,412851 & 0,048874 & 14 & 0,152418 & 0,024251 & \\
\hline 39,157 & 0,077492 & 0,010889 & 7 & 0,280346 & 0,044574 & \\
\hline \multirow{2}{*}{$\begin{array}{l}\text { Frequência natural } \\
\qquad(\mathrm{Hz})\end{array}$} & \multicolumn{5}{|c|}{ Terceiro $\xi$} & $\xi$ \\
\hline & $x_{0}$ & $x_{p}$ & $p$ & $\delta$ & $\xi$ & $\begin{array}{l}\text { (média dos } \\
3 \text { cálculos) }\end{array}$ \\
\hline 21,084 & 0,098297 & 0,034622 & 9 & 0,115945 & 0,018450 & 0,019178 \\
\hline 30,120 & 0,231820 & 0,013510 & 22 & 0,129205 & 0,020559 & 0,023623 \\
\hline 39,157 & 0,241262 & 0,011629 & 12 & 0,252697 & 0,040185 & 0,044062 \\
\hline
\end{tabular}

O modo com frequência 30,120 Hz indica um possível movimento de corpo rígido, devido a deficiências no apoio;

Quanto aos fatores de amortecimento, pode-se verificar que para os três modos calculados estão dentro do esperado para concreto fissurado, mas com baixo nível de tensão (Tabela 2.2).

Observa-se que o modo de frequência 39,157 Hz apresentou um fator de amortecimento relativamente maior ao do modo de $37,651 \mathrm{~Hz}$ do $5^{\circ}$ ensaio. Verifica-se que estes modos no $5^{\circ}$ e $6^{\circ}$ ensaios são particularmente governados pela laje central. Essa laje no $6^{\circ}$ ensaio possui fissuras induzidas de $2,0 \mathrm{~cm}$ de profundidade sobre os apoios. 
Tabela 6.15: Frequências naturais e deformadas modais do $6^{\circ}$ ensaio dinâmico de lajes de CC.

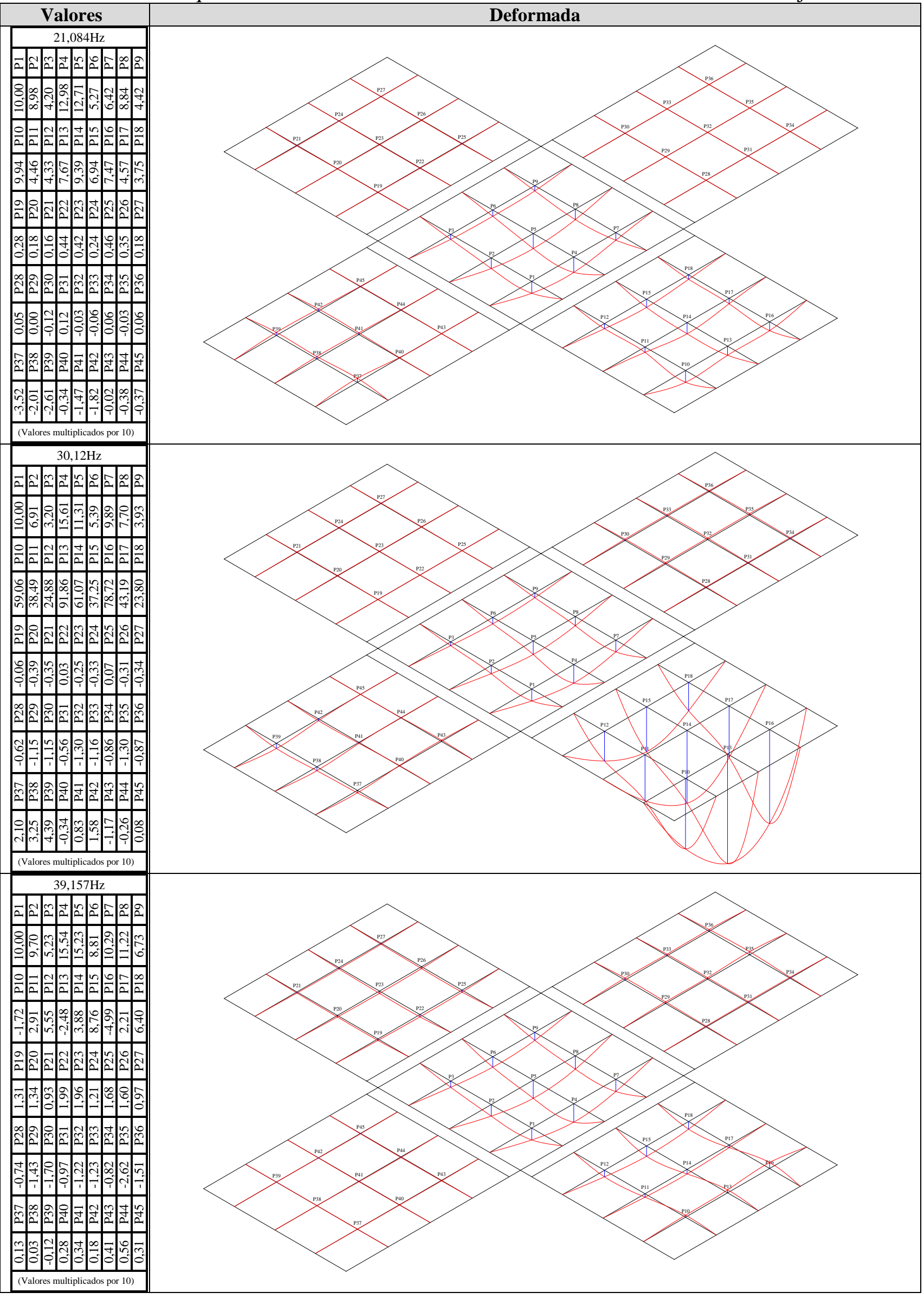




\subsection{Resultados dos ensaios dinâmicos das lajes de CLEPE}

Apresentam-se neste item os dados extraídos dos ensaios dinâmicos das lajes de CLEPE. Os resultados estão divididos nos seis ensaios descritos. São apresentados os valores das frequências naturais, fatores de amortecimento e tabelas com dados e figuras com as configurações das três primeiras deformadas modais. Os gráficos de aceleração ao longo do tempo, PSD, PSD cruzado, transmissibilidade e coerência não são apresentados por terem grande semelhança com as Figuras 6.1 a 6.5 já discutidas.

\subsubsection{Primeiro ensaio dinâmico com lajes de CLEPE}

A Tabela 6.16 apresenta os valores das frequências naturais, deslocamentos nos pontos de medição e deformadas modais para os três primeiros modos do primeiro ensaio dinâmico.

Tabela 6.16: Frequências naturais e deformadas modais do $1^{\circ}$ ensaio dinâmico de lajes de CLEPE.

\begin{tabular}{|c|c|c|c|c|c|c|c|c|c|}
\hline \multicolumn{9}{|c|}{ Valores } & \multirow{13}{*}{ Deformada } \\
\hline \multicolumn{9}{|c|}{$30,12 \mathrm{~Hz}$} & \\
\hline $\mathrm{P} 1$ & $\mathrm{P} 2$ & P3 & $\mathrm{P} 4$ & $\mathrm{P} 5$ & P6 & $\mathrm{P} 7$ & P8 & P9 & \\
\hline 10,00 & 12,71 & 15,18 & 16,49 & 18,01 & 20,56 & 12,43 & 11,52 & 12,87 & \\
\hline \multicolumn{9}{|c|}{ (Valores multiplicados por 10) } & \\
\hline \multicolumn{9}{|c|}{$43,675 \mathrm{~Hz}$} & \\
\hline P1 & P2 & P3 & $\mathrm{P} 4$ & P5 & P6 & $\mathrm{P} 7$ & P8 & P9 & \\
\hline 10,00 & $-3,40$ & $-18,75$ & 26,00 & $-0,95$ & $-24,59$ & 31,17 & 1,44 & $-17,40$ & \\
\hline \multicolumn{9}{|c|}{ (Valores multiplicados por 10) } & \\
\hline \multicolumn{9}{|c|}{$81,325 \mathrm{~Hz}$} & \\
\hline $\mathrm{P} 1$ & $\mathrm{P} 2$ & P3 & $\mathrm{P} 4$ & P5 & P6 & P7 & P8 & P9 & \\
\hline 10,00 & 8,35 & 0,64 & 7,53 & 5,88 & $-3,88$ & $-5,43$ & $-0,77$ & $-5,80$ & \\
\hline \multicolumn{9}{|c|}{ (Valores multiplicados por 10) } & \\
\hline
\end{tabular}


Os fatores de amortecimento modais para os três modos apresentados na Tabela 6.16 são listados na Tabela 6.17, e foram obtidos como descrito no item 6.1.

Novamente foram encontradas discrepâncias de forma das deformadas modais experimentais com as deformadas teóricas da análise numérica prévia. As diferenças são influenciadas significativamente pelas variáveis elencadas no item 6.2.1.

Quanto aos fatores de amortecimento, pode-se verificar que os dois modos calculados estão dentro do esperado para concreto armado não fissurado (Tabela 2.2).

O amortecimento do modo com 81,325 Hz não foi possível ser calculado, devido à qualidade do sinal estar ruim.

Tabela 6.17: Valores dos fatores de amortecimento modais do $1^{\circ}$ ensaio das lajes de CLEPE.

\begin{tabular}{|c|c|c|c|c|c|c|}
\hline \multirow{2}{*}{$\begin{array}{l}\text { Frequência natural } \\
\qquad(\mathrm{Hz})\end{array}$} & \multicolumn{5}{|c|}{ Primeiro $\xi$} & \\
\hline & $x_{0}$ & $x_{p}$ & $p$ & $\delta$ & $\xi$ & \\
\hline 30,120 & 0,505099 & 0,076102 & 22 & 0,086031 & 0,013691 & \\
\hline 43,675 & 0,426694 & 0,110752 & 23 & 0,058642 & 0,009333 & \\
\hline 81,325 & \multicolumn{5}{|c|}{ Não calculado } & \\
\hline \multirow{2}{*}{$\begin{array}{l}\text { Frequência natural } \\
\text { (Hz) }\end{array}$} & \multicolumn{5}{|c|}{ Segundo $\xi$} & \\
\hline & $x_{0}$ & $x_{p}$ & $p$ & $\delta$ & $\xi$ & \\
\hline 30,120 & 0,331315 & 0,103042 & 13 & 0,089841 & 0,014297 & \\
\hline 43,675 & 0,224960 & 0,074988 & 19 & 0,057821 & 0,009202 & \\
\hline 81,325 & & & calct & & & \\
\hline \multirow{2}{*}{$\begin{array}{l}\text { Frequência natural } \\
\qquad(\mathrm{Hz})\end{array}$} & \multicolumn{5}{|c|}{ Terceiro $\xi$} & $\xi$ \\
\hline & $x_{0}$ & $X_{p}$ & $p$ & $\delta$ & $\xi$ & $\begin{array}{l}\text { (média dos } \\
3 \text { cálculos) }\end{array}$ \\
\hline 30,120 & 0,215223 & 0,030579 & 23 & 0,084841 & 0,013502 & 0,013830 \\
\hline 43,675 & 0,442779 & 0,199616 & 12 & 0,066390 & 0,010566 & 0,009700 \\
\hline 81,325 & \multicolumn{6}{|c|}{ Não calculado } \\
\hline
\end{tabular}

\subsubsection{Segundo ensaio dinâmico com lajes de CLEPE}

A Tabela 6.18 apresenta os valores das frequências naturais, deslocamentos nos pontos de medição e deformadas modais para os três primeiros modos do segundo ensaio dinâmico.

Os fatores de amortecimento modais para os três modos apresentados na Tabela 6.18 são listados na Tabela 6.19, e foram obtidos como descrito no item 6.1.

Pode-se verificar que os fatores de amortecimento dos três modos calculados estão dentro do esperado para concreto armado fissurado com baixo nível de tensões (Tabela 2.2).

Os fatores de amortecimento neste segundo ensaio são maiores que no primeiro. Verifica-se que a laje adjacente à primeira elevou o nível do amortecimento do conjunto. 
Tabela 6.18: Frequências naturais e deformadas modais do $2^{\circ}$ ensaio dinâmico de lajes de CLEPE.

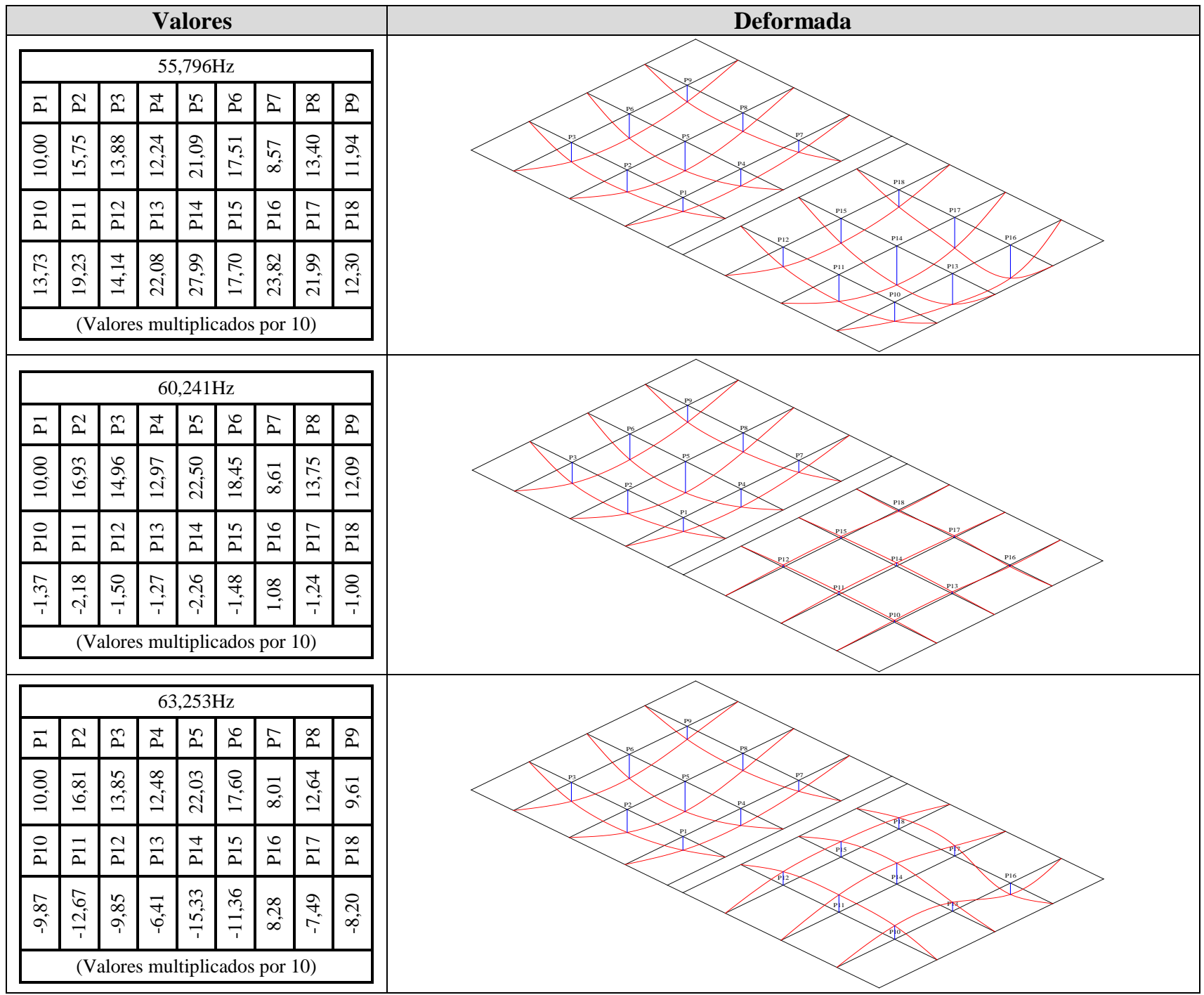

Tabela 6.19: Valores dos fatores de amortecimento modais do $2^{\circ}$ ensaio das lajes de CLEPE.

\begin{tabular}{|c|c|c|c|c|c|c|}
\hline \multirow{2}{*}{$\begin{array}{l}\text { Frequência natural } \\
\qquad(\mathrm{Hz})\end{array}$} & \multicolumn{5}{|c|}{ Primeiro $\xi$} & \\
\hline & $x_{0}$ & $x_{p}$ & $p$ & $\delta$ & $\xi$ & \\
\hline 55,796 & 0,584439 & 0,055640 & 14 & 0,167982 & 0,026726 & \\
\hline 60,241 & 0,502342 & 0,050030 & 14 & 0,164762 & 0,026214 & \\
\hline 63,253 & 0,308245 & 0,026068 & 17 & 0,145304 & 0,023120 & \\
\hline \multirow{2}{*}{$\begin{array}{l}\text { Frequência natural } \\
\qquad(\mathrm{Hz})\end{array}$} & \multicolumn{5}{|c|}{ Segundo $\xi$} & \\
\hline & $x_{0}$ & $x_{p}$ & $p$ & $\delta$ & $\xi$ & \\
\hline 55,796 & 0,124002 & 0,023729 & 11 & 0,150326 & 0,023918 & \\
\hline 60,241 & 0,801542 & 0,072370 & 13 & 0,184981 & 0,029428 & \\
\hline 63,253 & 0,305822 & 0,026156 & 23 & 0,106910 & 0,017013 & \\
\hline \multirow{2}{*}{$\begin{array}{c}\text { Frequência natural } \\
(\mathrm{Hz})\end{array}$} & \multicolumn{5}{|c|}{ Terceiro $\xi$} & $\xi$ \\
\hline & $x_{0}$ & $x_{p}$ & $p$ & $\delta$ & $\xi$ & $\begin{array}{l}\text { (média dos } \\
3 \text { cálculos) }\end{array}$ \\
\hline 55,796 & 0,751383 & 0,029680 & 23 & 0,140498 & 0,022355 & 0,024333 \\
\hline 60,241 & 0,890362 & 0,045452 & 18 & 0,165276 & 0,026295 & 0,027312 \\
\hline 63,253 & 0,495571 & 0,040155 & 17 & 0,147822 & 0,023520 & 0,021218 \\
\hline
\end{tabular}




\subsubsection{Terceiro ensaio dinâmico com lajes de CLEPE}

A Tabela 6.20 apresenta os valores das frequências naturais, deslocamentos nos pontos de medição e deformadas modais para os três primeiros modos do terceiro ensaio dinâmico.

Os fatores de amortecimento modais para os três modos apresentados na Tabela 6.20 são listados na Tabela 6.21, e foram obtidos como descrito no item 6.1.

Pode-se verificar que os fatores de amortecimento dos dois modos calculados estão dentro do esperado para concreto armado não fissurado e fissurado com baixo nível de tensões, respectivamente (Tabela 2.2).

O amortecimento do modo com 39,157 Hz não foi possível ser calculado, devido à qualidade do sinal estar ruim.

Os fatores de amortecimento neste terceiro ensaio estão na mesma linha dos fatores de amortecimento dos dois ensaios iniciais.

Tabela 6.20: Frequências naturais e deformadas modais do $3^{\circ}$ ensaio dinâmico de lajes de CLEPE.

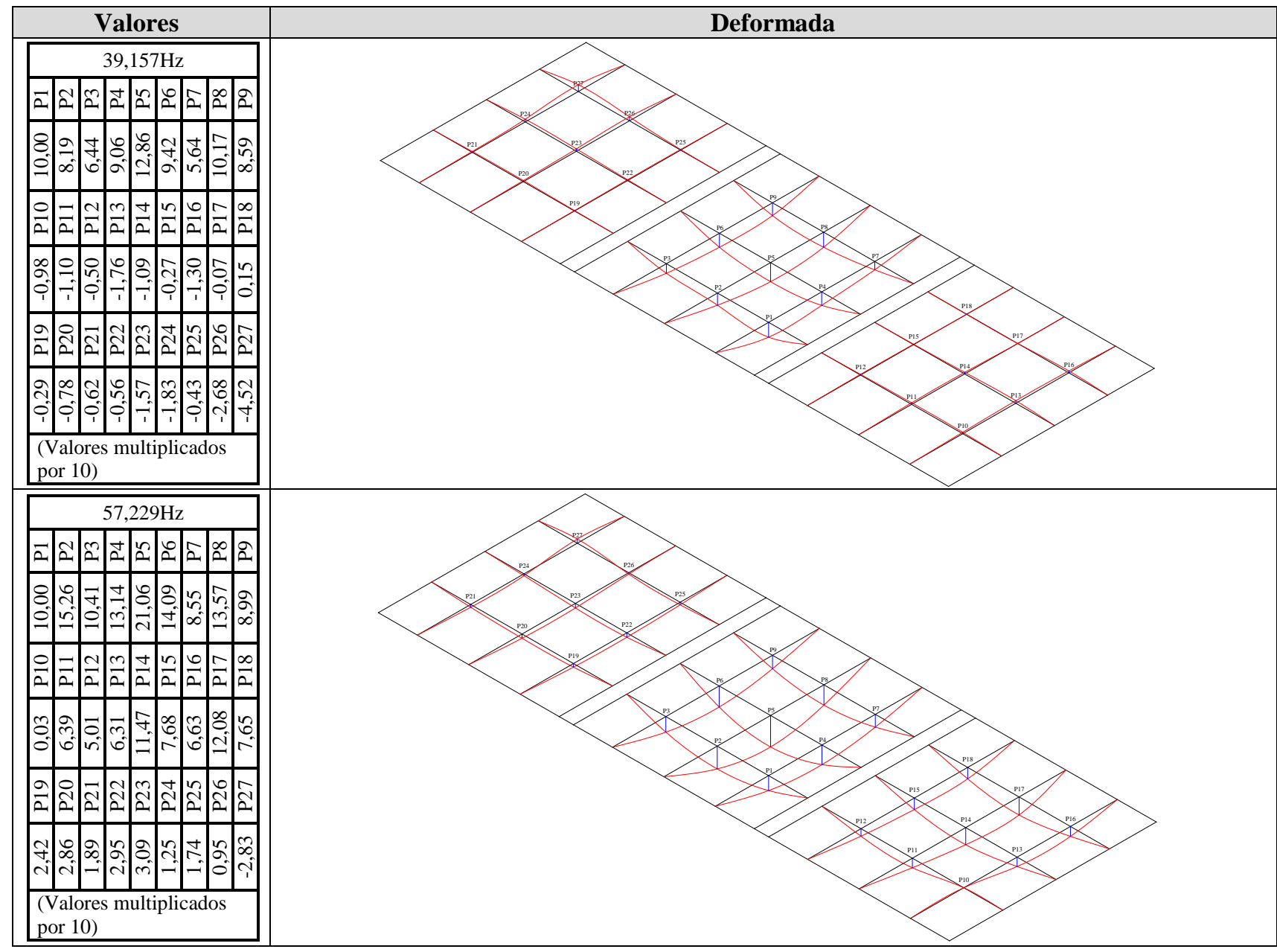




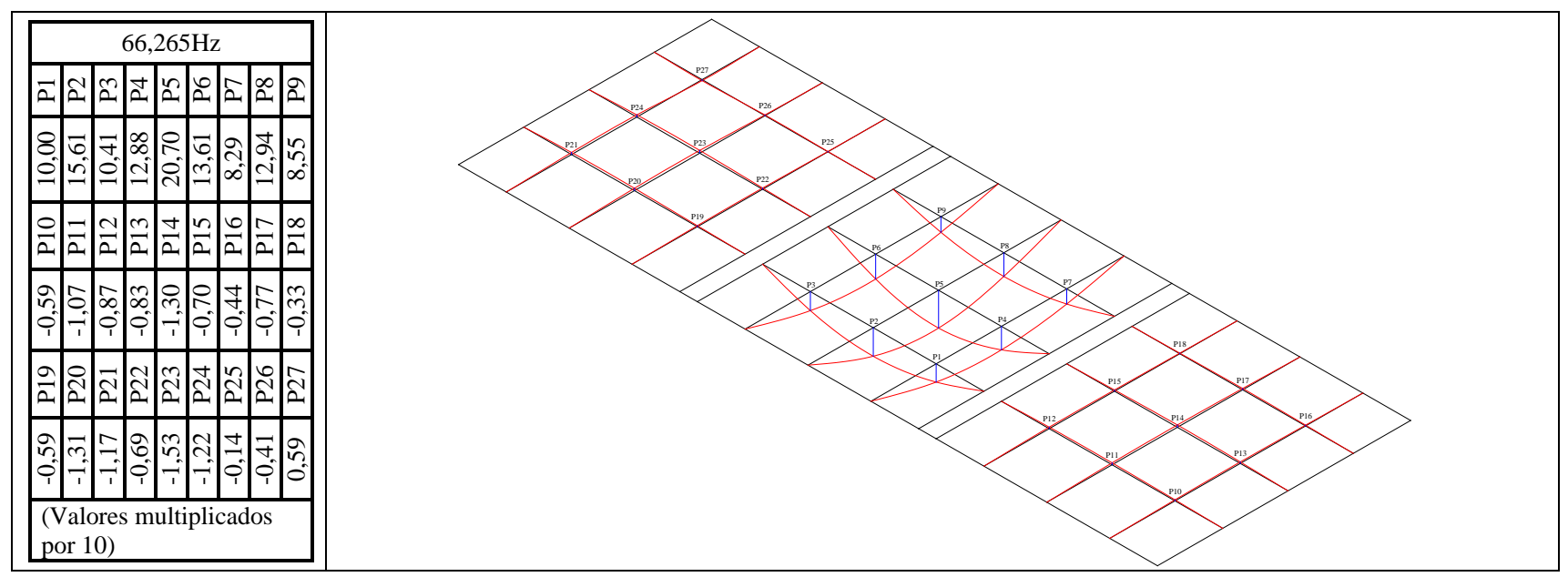

Tabela 6.21: Valores dos fatores de amortecimento modais do $3^{\circ}$ ensaio das lajes de CLEPE.

\begin{tabular}{|c|c|c|c|c|c|c|}
\hline \multirow{2}{*}{$\begin{array}{c}\text { Frequência natural } \\
\text { lida }(\mathrm{Hz})\end{array}$} & \multicolumn{5}{|c|}{ Primeiro $\xi$} & \\
\hline & $x_{0}$ & $x_{p}$ & $p$ & $\delta$ & $\xi$ & \\
\hline 39,157 & \multicolumn{5}{|c|}{ Não calculado. } & \\
\hline 57,229 & 1,537829 & 0,286961 & 16 & 0,104924 & 0,016697 & \\
\hline 66,265 & 0,749292 & 0,138166 & 10 & 0,169067 & 0,026898 & \\
\hline \multirow{2}{*}{$\begin{array}{c}\text { Frequência natural } \\
\text { lida }(\mathrm{Hz})\end{array}$} & \multicolumn{5}{|c|}{ Segundo $\xi$} & \\
\hline & $x_{0}$ & $x_{p}$ & $p$ & $\delta$ & $\xi$ & \\
\hline 39,157 & \multicolumn{5}{|c|}{ Não calculado. } & \\
\hline 57,229 & 0,927276 & 0,171233 & 16 & 0,105577 & 0,016801 & \\
\hline 66,265 & 0,265395 & 0,028199 & 12 & 0,186827 & 0,029721 & \\
\hline \multirow{2}{*}{$\begin{array}{c}\text { Frequência natural } \\
\text { lida }(\mathrm{Hz})\end{array}$} & \multicolumn{5}{|c|}{ Terceiro $\xi$} & $\xi$ \\
\hline & $x_{0}$ & $x_{p}$ & $p$ & $\delta$ & $\xi$ & $\begin{array}{l}\text { (média dos } \\
3 \text { cálculos) }\end{array}$ \\
\hline 39,157 & \multicolumn{6}{|c|}{ Não calculado. } \\
\hline 57,229 & 0,486688 & 0,084168 & 17 & 0,103224 & 0,016426 & 0,016641 \\
\hline 66,265 & 0,814505 & 0,102144 & 12 & 0,173016 & 0,027526 & 0,028048 \\
\hline
\end{tabular}

\subsubsection{Quarto ensaio dinâmico com lajes de CLEPE}

Os fatores de amortecimento modais para os três modos apresentados na Tabela 6.23 são listados na Tabela 6.22, e foram obtidos como descrito no item 6.1.

A Tabela 6.23 apresenta os valores das frequências naturais, deslocamentos nos pontos de medição e deformadas modais para os três primeiros modos do quarto ensaio dinâmico.

Em relação aos fatores de amortecimento, pode-se verificar que os dois modos calculados estão dentro do esperado para concreto armado não fissurado (Tabela 2.2).

$\mathrm{O}$ amortecimento do modo com 37,651 Hz não foi possível ser calculado, devido à qualidade do sinal estar ruim. 
Tabela 6.22: Valores dos fatores de amortecimento modais do $4^{\circ}$ ensaio das lajes de CLEPE.

\begin{tabular}{|c|c|c|c|c|c|c|}
\hline \multirow{2}{*}{$\begin{array}{l}\text { Frequência natural } \\
\qquad(\mathrm{Hz})\end{array}$} & \multicolumn{5}{|c|}{ Primeiro $\xi$} & \\
\hline & $x_{0}$ & $x_{p}$ & $p$ & $\delta$ & $\xi$ & \\
\hline 37,651 & \multicolumn{5}{|c|}{ Não calculado. } & \\
\hline 46,687 & 0,066328 & 0,048042 & 4 & 0,080634 & 0,012832 & \\
\hline 56,476 & 1,601234 & 0,623473 & 11 & 0,085748 & 0,013646 & \\
\hline \multirow{2}{*}{$\begin{array}{l}\text { Frequência natural } \\
\qquad(\mathrm{Hz})\end{array}$} & \multicolumn{5}{|c|}{ Segundo $\xi$} & \\
\hline & $x_{0}$ & $x_{p}$ & $p$ & $\delta$ & $\xi$ & \\
\hline 37,651 & \multicolumn{5}{|c|}{ Não calculado. } & \\
\hline 46,687 & 0,056732 & 0,031956 & 6 & 0,095662 & 0,015223 & \\
\hline 56,476 & 2,548058 & 1,137243 & 10 & 0,080673 & 0,012838 & \\
\hline \multirow{2}{*}{$\begin{array}{l}\text { Frequência natural } \\
\qquad(\mathrm{Hz})\end{array}$} & \multicolumn{5}{|c|}{ Terceiro $\xi$} & $\xi$ \\
\hline & $x_{0}$ & $x_{p}$ & $p$ & $\delta$ & $\xi$ & $\begin{array}{l}\text { (média dos } \\
3 \text { cálculos) }\end{array}$ \\
\hline 37,651 & \multicolumn{6}{|c|}{ Não calculado. } \\
\hline 46,687 & 0,063698 & 0,021973 & 9 & 0,118258 & 0,018818 & 0,015624 \\
\hline 56,476 & 0,777033 & 0,217803 & 16 & 0,079493 & 0,012651 & 0,013045 \\
\hline
\end{tabular}

Tabela 6.23: Frequências naturais e deformadas modais do $4^{\circ}$ ensaio dinâmico de lajes de CLEPE.

(1)




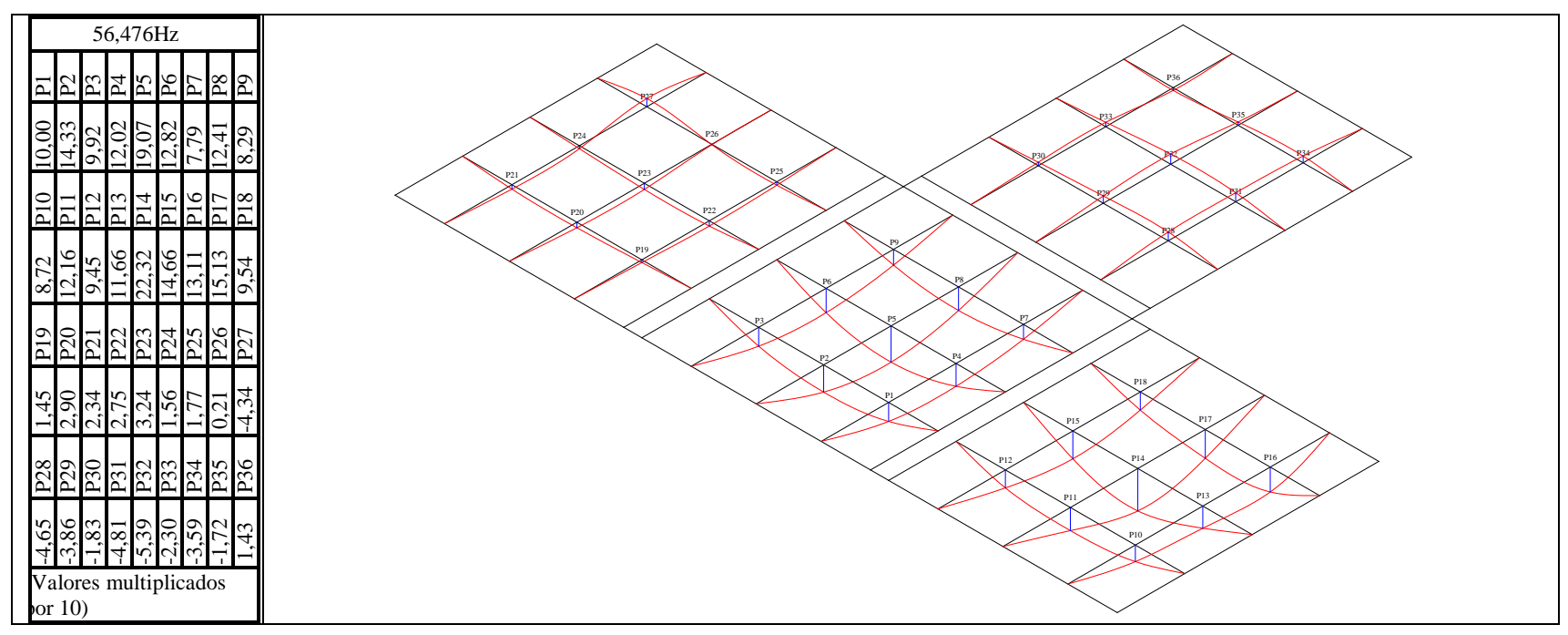

\subsubsection{Quinto ensaio dinâmico com lajes de CLEPE}

A Tabela 6.25 apresenta os valores das frequências naturais, deslocamentos nos pontos de medição e deformadas modais para os três primeiros modos do quinto ensaio dinâmico.

Os fatores de amortecimento modais para os três modos apresentados na Tabela 6.25 são listados na Tabela 6.24, e foram obtidos como descrito no item 6.1.

Tabela 6.24: Valores dos fatores de amortecimento modais do $5^{\circ}$ ensaio das lajes de CLEPE.

\begin{tabular}{|c|c|c|c|c|c|c|}
\hline \multirow{2}{*}{$\begin{array}{c}\text { Frequência natural } \\
(\mathrm{Hz})\end{array}$} & \multicolumn{5}{|c|}{ Primeiro $\xi$} & \\
\hline & $x_{0}$ & $x_{p}$ & $p$ & $\delta$ & $\xi$ & \\
\hline 39,157 & \multicolumn{5}{|c|}{ Não calculado. } & \\
\hline 48,193 & 1,004205 & 0,321357 & 11 & 0,103582 & 0,016483 & \\
\hline 54,970 & 0,841147 & 0,154240 & 16 & 0,106016 & 0,016871 & \\
\hline \multirow{2}{*}{$\begin{array}{l}\text { Frequência natural } \\
(\mathbf{H z})\end{array}$} & \multicolumn{5}{|c|}{ Segundo $\xi$} & \\
\hline & $x_{0}$ & $x_{p}$ & $p$ & $\delta$ & $\xi$ & \\
\hline 39,157 & \multicolumn{5}{|c|}{ Não calculado. } & \\
\hline 48,193 & 0,582326 & 0,178113 & 10 & 0,118461 & 0,018850 & \\
\hline 54,970 & 0,677015 & 0,231537 & 10 & 0,107295 & 0,017074 & \\
\hline \multirow{2}{*}{$\begin{array}{c}\text { Frequência natural } \\
(\mathrm{Hz})\end{array}$} & \multicolumn{5}{|c|}{ Terceiro $\xi$} & $\xi$ \\
\hline & $x_{0}$ & $x_{p}$ & $p$ & $\delta$ & $\xi$ & $\begin{array}{l}\text { (média dos } \\
3 \text { cálculos) }\end{array}$ \\
\hline 39,157 & \multicolumn{6}{|c|}{ Não calculado. } \\
\hline 48,193 & 0,405548 & 0,122915 & 10 & 0,119375 & 0,018996 & 0,018110 \\
\hline 54,970 & 0,392447 & 0,076179 & 11 & 0,149029 & 0,023712 & 0,019219 \\
\hline
\end{tabular}

Os fatores de amortecimento calculados estão dentro do esperado para concreto armado não fissurado (Tabela 2.2).

$\mathrm{O}$ amortecimento do modo com 39,157 Hz não foi possível ser calculado, devido à qualidade do sinal estar ruim. 
Tabela 6.25: Frequências naturais e deformadas modais do $5^{\circ}$ ensaio dinâmico de lajes de CLEPE.

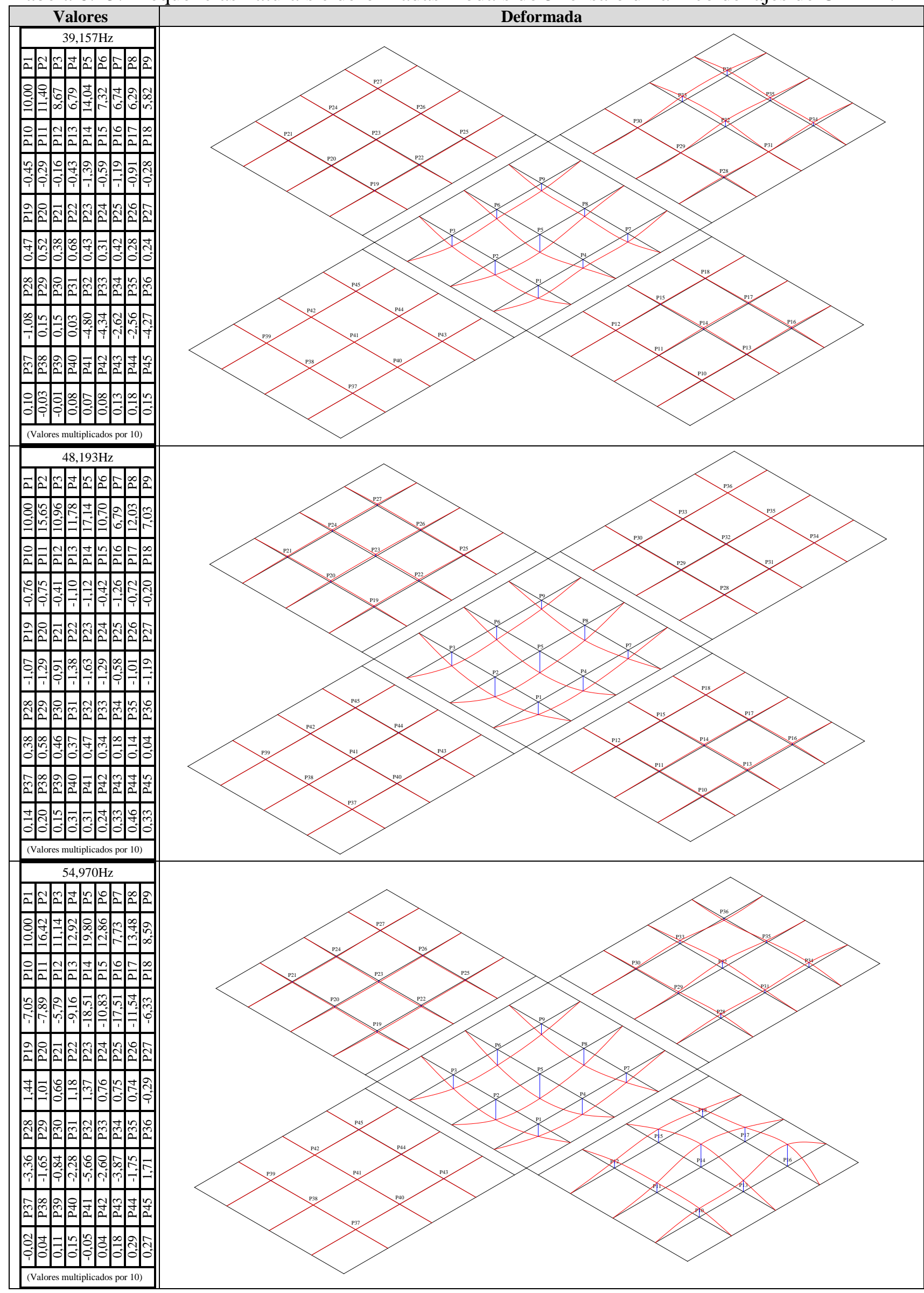




\subsubsection{Sexto ensaio dinâmico com lajes de CLEPE}

A Tabela 6.27 apresenta os valores das frequências naturais, deslocamentos nos pontos de medição e deformadas modais para os três primeiros modos do sexto ensaio dinâmico.

Os fatores de amortecimento modais para os três modos apresentados na Tabela 6.27 são listados na Tabela 6.26, e foram obtidos como descrito no item 6.1.

Os fatores de amortecimento estão dentro do esperado para concreto armado não fissurado (Tabela 2.2).

Tabela 6.26: Frequências naturais e deformadas modais do $6^{\circ}$ ensaio dinâmico de lajes de CLEPE.

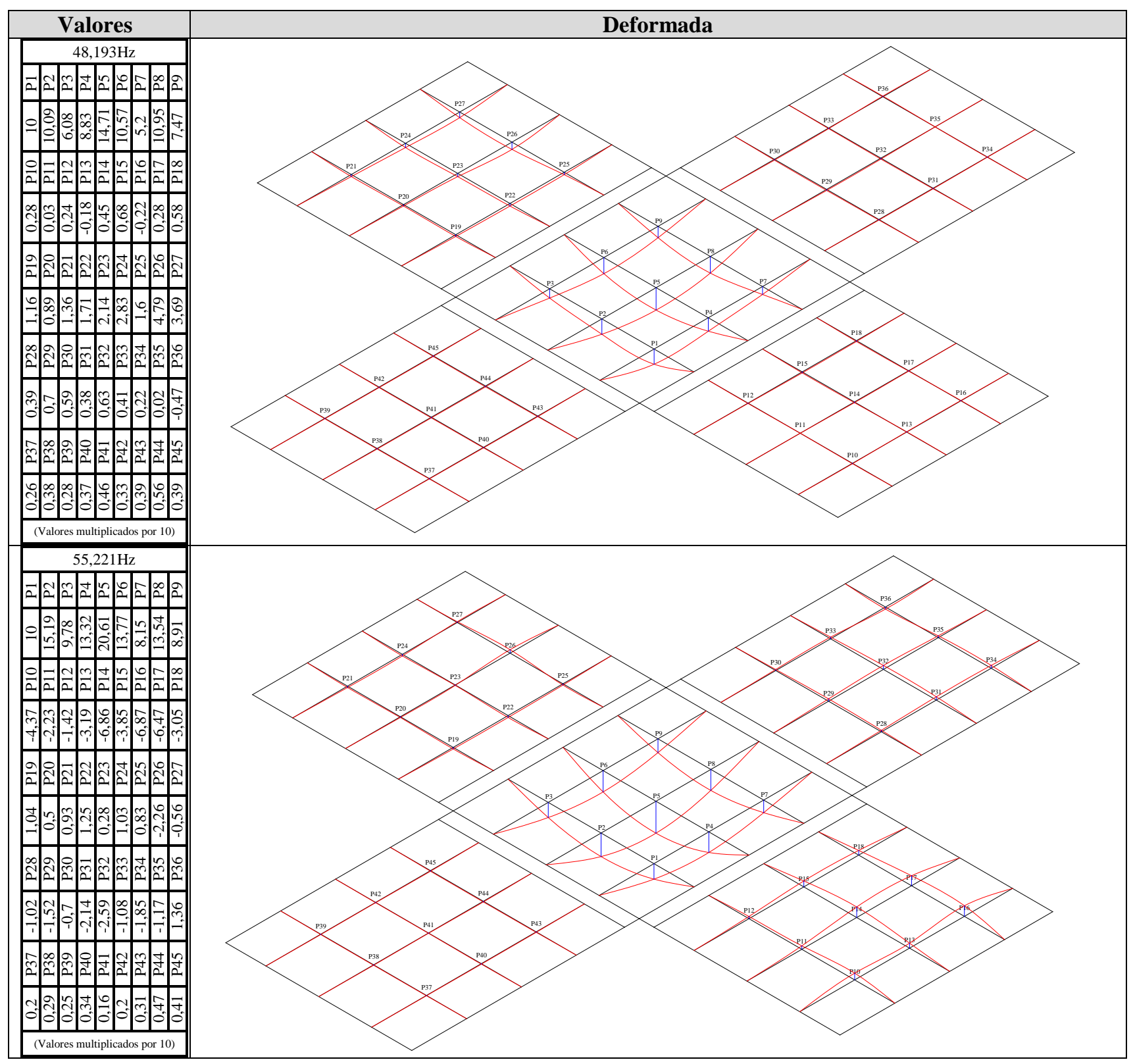




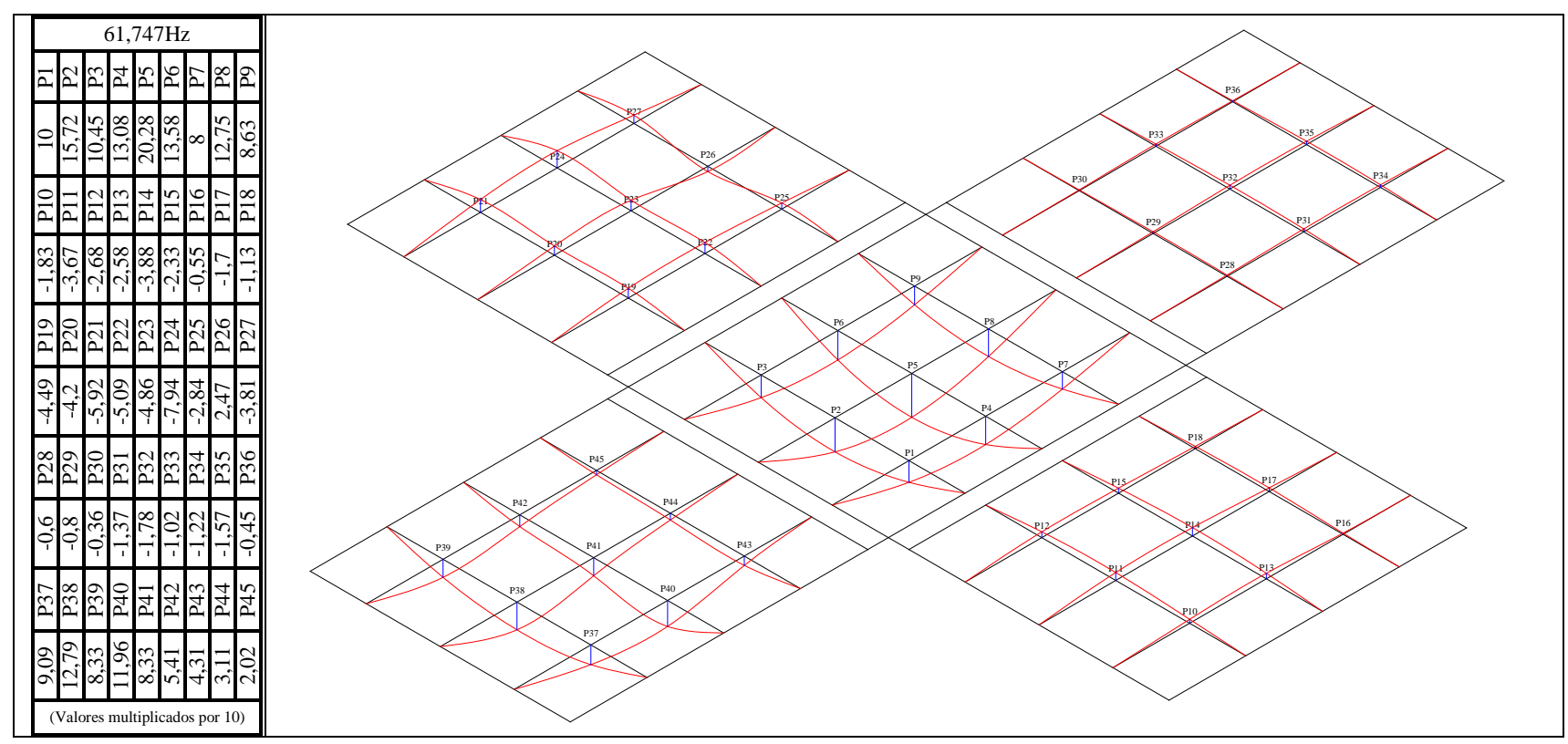

Tabela 6.27: Valores dos fatores de amortecimento modais do $6^{\circ}$ ensaio das lajes de CLEPE.

\begin{tabular}{|c|c|c|c|c|c|c|}
\hline \multirow{2}{*}{$\begin{array}{c}\text { Frequência natural } \\
\text { (Hz) }\end{array}$} & \multicolumn{5}{|c|}{ Primeiro $\xi$} & \\
\hline & $x_{0}$ & $x_{p}$ & $p$ & $\delta$ & $\xi$ & \\
\hline 48,193 & 2,095193 & 0,583452 & 10 & 0,127844 & 0,020343 & \\
\hline 55,221 & 0,598545 & 0,222856 & 13 & 0,075998 & 0,012095 & \\
\hline 61,747 & 0,661176 & 0,165747 & 11 & 0,125778 & 0,020014 & \\
\hline \multirow{2}{*}{$\begin{array}{l}\text { Frequência natural } \\
(\mathrm{Hz})\end{array}$} & \multicolumn{5}{|c|}{ Segundo $\xi$} & \\
\hline & $x_{0}$ & $x_{p}$ & $p$ & $\delta$ & $\xi$ & \\
\hline 48,193 & 0,643754 & 0,076314 & 16 & 0,133279 & 0,021207 & \\
\hline 55,221 & 0,208129 & 0,085892 & 11 & 0,080461 & 0,012805 & \\
\hline 61,747 & 1,548790 & 0,505886 & 12 & 0,093243 & 0,014838 & \\
\hline \multirow{2}{*}{$\begin{array}{c}\text { Frequência natural } \\
\qquad(\mathrm{Hz})\end{array}$} & \multicolumn{5}{|c|}{ Terceiro $\xi$} & $\xi$ \\
\hline & $x_{0}$ & $x_{p}$ & $p$ & $\delta$ & $\xi$ & $\begin{array}{l}\text { (média dos } \\
3 \text { cálculos) }\end{array}$ \\
\hline 48,193 & 0,848673 & 0,198692 & 11 & 0,131992 & 0,021003 & 0,020851 \\
\hline 55,221 & 1,527588 & 0,681345 & 9 & 0,089709 & 0,014276 & 0,013059 \\
\hline 61,747 & 1,175469 & 0,057832 & 31 & 0,097157 & 0,015461 & 0,016771 \\
\hline
\end{tabular}

\subsection{Observações gerais dos ensaios dinâmicos}

Ao serem analisados os resultados de deformadas modais e fatores de amortecimento dos ensaios dinâmicos descritos neste capítulo, ficam evidentes as seguintes observações:

- A interação das lajes com as demais variáveis listadas no item 6.2.1 causou distúrbios que não puderam ser evitados nos modelos ensaiados. A dificuldade de relacionar deformadas modais experimentais com teóricas implica em situações que não foram modeladas numericamente. Entre as diversas situações que não foram modeladas e que 
causaram distúrbios, podem ser citadas duas que o autor julga serem as de maior responsabilidade. Trata-se da ineficiência da continuidade da argamassa de assentamento das lajes e a interação da alvenaria com as lajes;

- Aparentemente as lajes de CC possuem um fator de amortecimento médio bem maior que as lajes de CLEPE. Entretanto, esta não pode ainda ser uma conclusão definitiva tendo em vista a interação das lajes com o restante da estrutura, conforme comentado anteriormente. Por outro lado, observa-se que os fatores de amortecimento são bem maiores que os obtidos no Capítulo 5. Comparando-se as Tabelas 5.2 e 5.5 é possível verificar-se que os fatores de amortecimento médios para o CC são menores do que para o CLEPE. Também os fatores de amortecimento do Sonelastic ${ }^{\circledR}$ são bem menores que os das lajes;

- O fator de amortecimento das lajes de CC foi muito maior do que o apresentado na literatura técnica para concreto armado com baixa ou nenhuma fissuração (Tabela 2.2). Assim, fica evidente que algo além do material CC contribuiu para este resultado. Novamente a suspeita recai sobre as condições de apoio que podem ter sido não uniformes;

- As observações feitas aqui e no item 6.2.1 sobre os fatores de amortecimento conduziram a uma conclusão clara de que seriam necessários novos ensaios que eliminassem, ou procurassem eliminar, as interferências dos apoios e demais elementos estruturais, facilitando a análise pura dos materiais envolvidos. Portanto, o programa experimental foi ampliado com os ensaios apresentados no Capítulo 7;

- É possível, com a metodologia adotada, determinar as frequências naturais de interesse, suas deformadas modais e seus respectivos fatores de amortecimento;

- As fissuras sobre os apoios influenciaram relativamente pouco as frequências naturais e os fatores de amortecimento. Verifica-se, portanto, que o dano não teve grande relevância no conjunto estrutural dos ensaios. Explica-se isso devido as fissuras estarem localizadas em regiões onde teoricamente os deslocamentos, velocidades e acelerações são nulos ou muito pequenos. No entanto, as diferenças entre os resultados do $5^{\circ}$ e $6^{\circ}$ ensaios são atribuídas a elas. 


\section{Ensaios Dinâmicos em Lajes sobre Molas}

Com a finalidade de refinar os resultados e eliminar problemas devidos às condições de contorno das regiões dos apoios, conforme comentado nos itens 6.2 .1 e 6.4, foram moldadas duas lajes com dimensões de $5 \mathrm{~cm}$ x $55 \mathrm{~cm}$ x $155 \mathrm{~cm}$ (espessura, largura e comprimento), as quais foram ensaiadas com a condição de bordo livre nos quatro lados. Para simular essa condição, as lajes foram apoiadas sobre quatro molas deformáveis, em pontos previamente escolhidos. Na literatura técnica, o recurso de apoiar uma estrutura sobre cordas esticadas ou molas é apresentado como uma alternativa para simular um comportamento de estrutura livre de vinculações.

A armadura adotada nas lajes consistiu em uma tela de malha quadrada com espaçamentos de $15 \mathrm{~cm} \times 15 \mathrm{~cm}$ e fios de diâmetro $5 \mathrm{~mm}$ de aço CA-60, o que atende com folga a armadura mínima prevista no Apêndice A.

As Figuras 7.1 e 7.2 ilustram a moldagem e a cura do concreto das novas lajes. Para a caracterização do material, foram moldados nove corpos de prova cilíndricos de $10 \mathrm{~cm}$ x $20 \mathrm{~cm}$ para ensaios no Sonelastic ${ }^{\circledR}$, e também para determinação da resistência, de cada tipo de concreto.

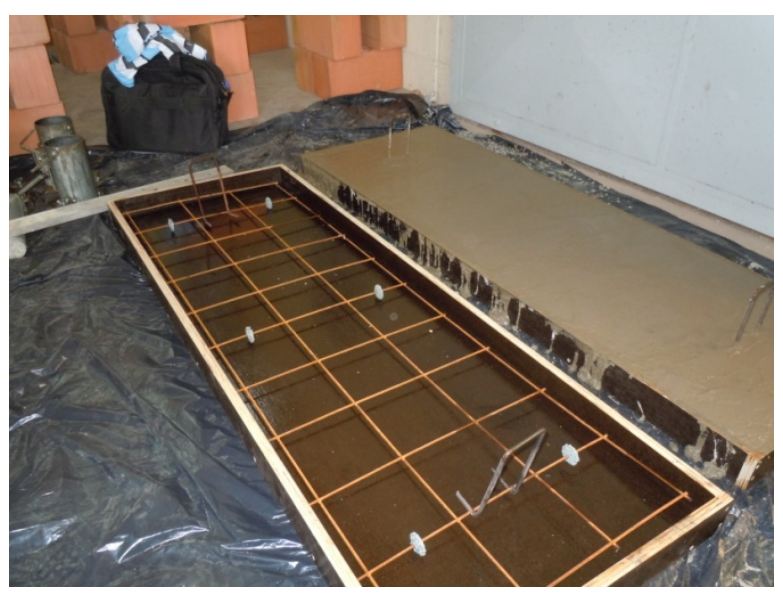

(a)

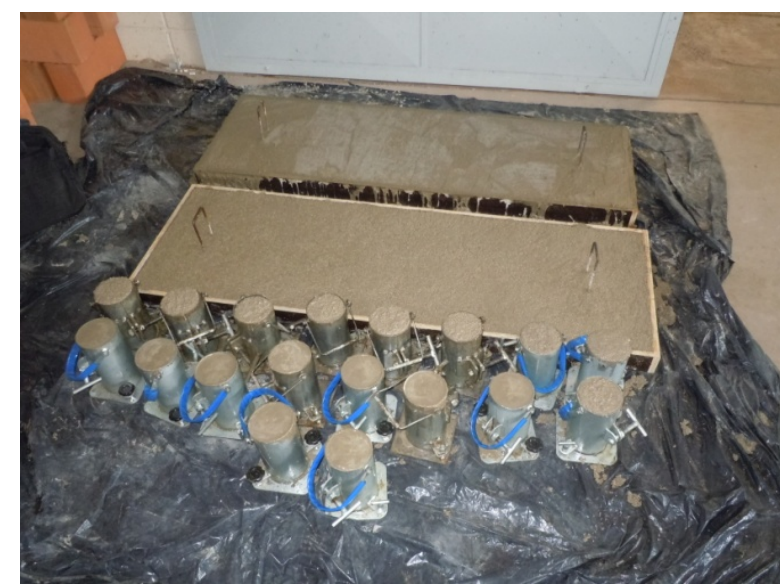

(b)

Figura 7.1 - Detalhe da forma (a) e das lajes concretadas, junto com os corpos de prova (b). 


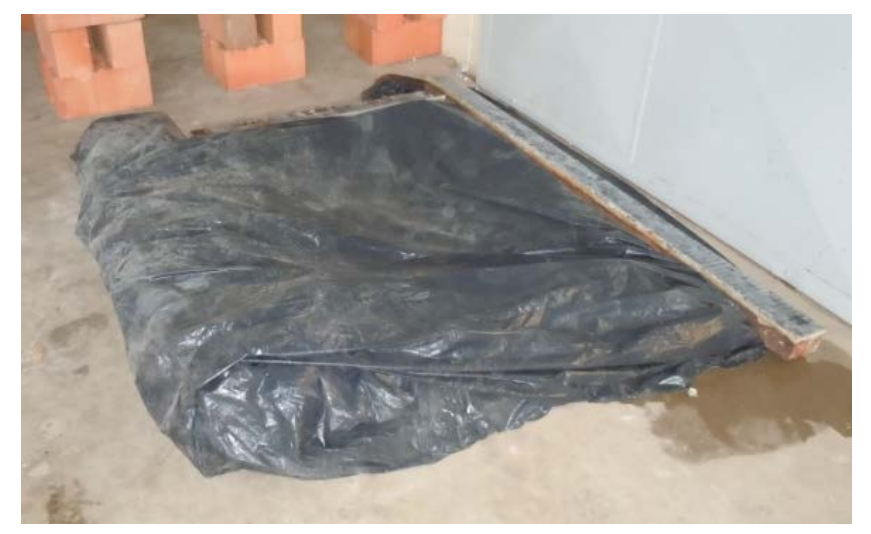

Figura 7.2 - Cura das lajes com auxílio de lona plástica.

O traço utilizado para o CLEPE foi de 1:1:0,03:0,28:0,0084 (cimento em massa: areia grossa em massa: EPS em volume $\left(\mathrm{m}^{3}\right)$ : água em massa: superplastificante em massa). O traço em massa para o CC foi de 1:1,88:2:0,66 (cimento: areia grossa: brita basáltica: água). A Figura 7.3 ilustra o aspecto do acabamento inferior das peças.

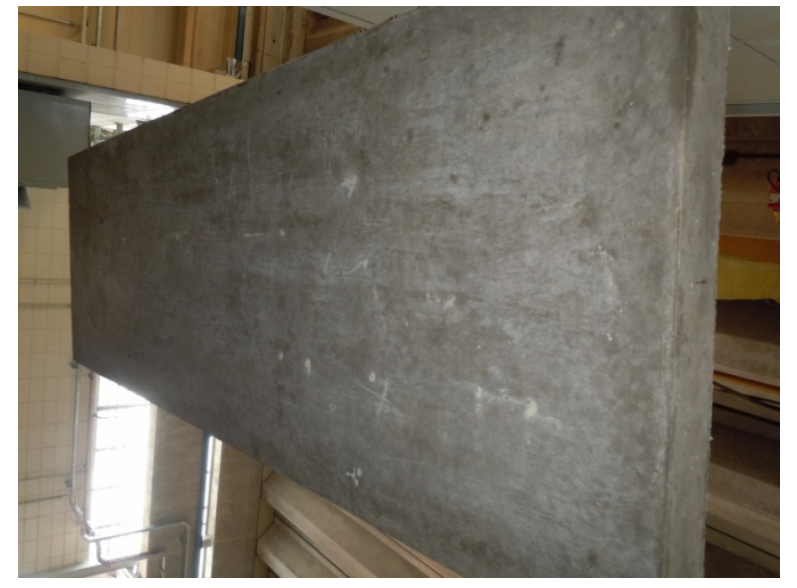

(a)

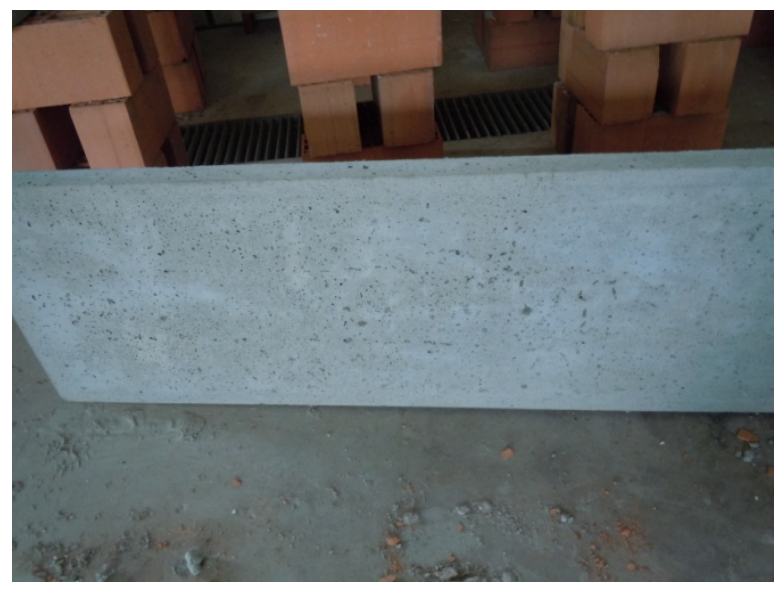

(b)

Figura 7.3 - Aspecto do acabamento inferior. (a) CC; (b) CLEPE.

Os ensaios de caracterização dos materiais, tanto dinâmicos como estáticos, foram realizados no mesmo dia dos ensaios dinâmicos. A idade do concreto (tanto o CC quanto o CLEPE) na realização dos ensaios foi 21 dias. Justifica-se a realização com idade inferior a 28 dias por conta da utilização de cimento CP V-ARI.

Antes de serem realizados os ensaios dinâmicos, foram processados dois modelos no software SAP $2000^{\circledR}$ com o objetivo da determinação dos pontos nodais nos primeiros modos de vibração, para que esses pontos fossem evitados por ocasião do posicionamento dos acelerômetros. Após os ensaios, os modelos, no software SAP $2000^{\circledR}$, foram calibrados com 
os resultados obtidos nos ensaios de caracterização dinâmica e estática. Esses resultados estão descritos no item 7.3.

Para o CC foi adotado um material com resistência característica à compressão de 35,60 MPa, módulo de elasticidade de 40,00 GPa e peso específico de 24,05 kN/m³ (massa da laje igual a 102,50 kg). Já o CLEPE foi modelado com uma resistência característica à compressão de $10 \mathrm{MPa}$, módulo de elasticidade de $10 \mathrm{GPa}$ e peso específico de $11 \mathrm{kN} / \mathrm{m}^{3}$ (massa da laje de CLEPE igual a 46,85 kg). As Tabelas 7.1 e 7.2 apresentam os seis primeiros modos de vibração para cada uma das lajes, obtidos numericamente com os modelos já com os materiais calibrados com os dados experimentais. Vale ressaltar que a modelagem numérica realizada admitiu a peça livre nos quatro bordos e uma malha de $5 \mathrm{~cm} \times 5 \mathrm{~cm}$.

Tabela 7.1: Modos de vibração teóricos da laje de CC.

\begin{tabular}{|c|c|c|c|c|}
\hline Modo & $\begin{array}{c}\text { Frequência } \\
\text { Natural (Hz) }\end{array}$ & $\begin{array}{c}\text { Período } \\
\text { (s) }\end{array}$ & Forma da deformada modal \\
\hline $1^{\circ}$ & 91,41 & 0,01094 & & \\
\hline $2^{\circ}$ & 168,59 & 0,00593 & & \\
\hline & & & \\
\hline
\end{tabular}




\begin{tabular}{|l|l|l|l|l|}
\hline $4^{\circ}$ & 351,70 & 0,00284 & & \\
\hline
\end{tabular}

Tabela 7.2: Modos de vibração teóricos da laje de CLEPE.

\begin{tabular}{|c|c|c|c|}
\hline Modo & $\begin{array}{c}\text { Frequência } \\
\text { Natural (Hz) }\end{array}$ & $\begin{array}{c}\text { Período } \\
(\mathrm{s})\end{array}$ & Forma da deformada modal \\
\hline $1^{\circ}$ & 67,58 & 0,01480 & \\
& & & \\
\hline
\end{tabular}




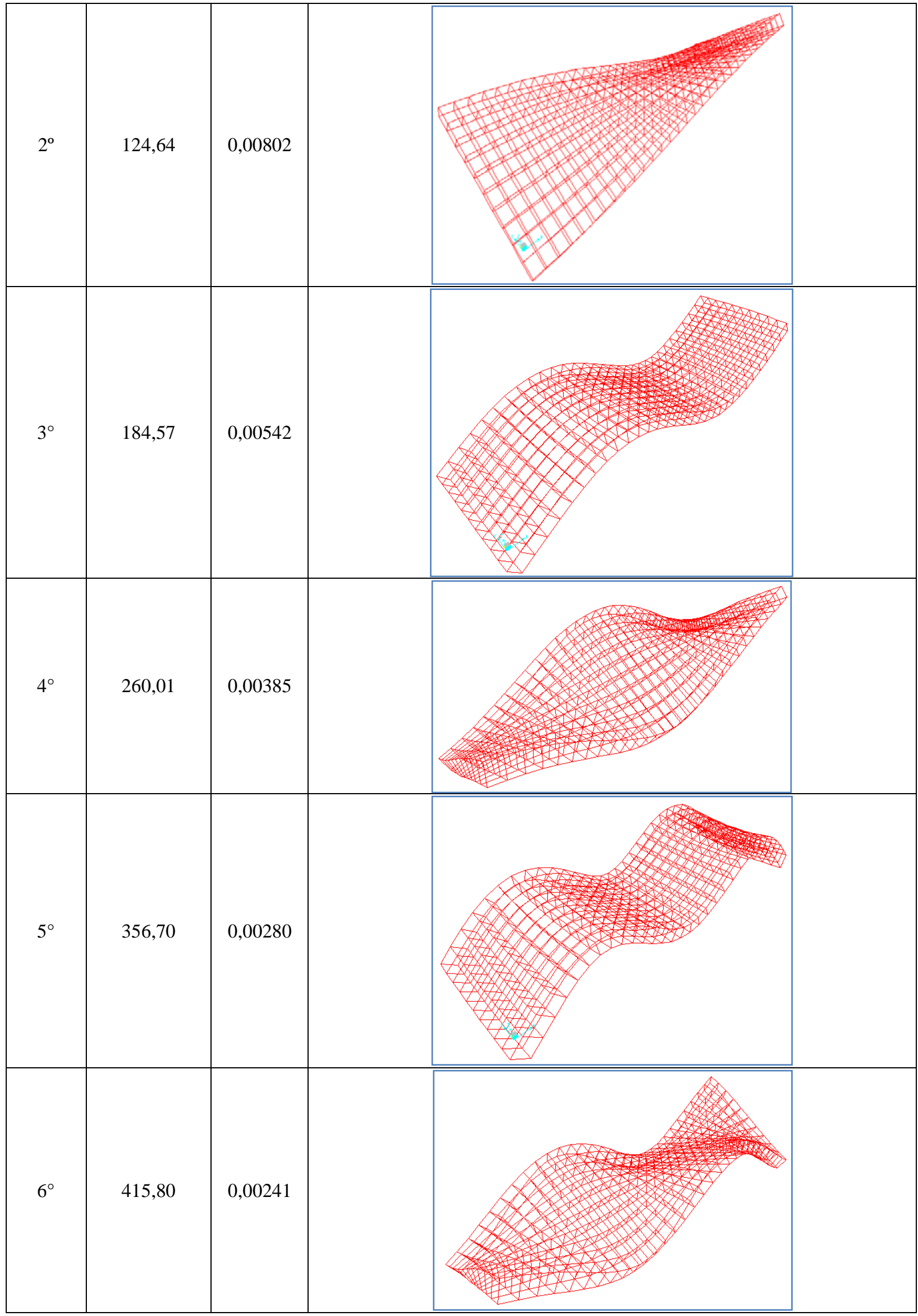


Observando-se os resultados das Tabelas 7.1 e 7.2 verifica-se que as deformadas modais possuem a mesma forma, apesar de possuírem frequências naturais diferentes. A Figura 7.4 ilustra a posição onde foram colocados os acelerômetros nos ensaios, buscando-se ao máximo estar afastado das linhas onde estão contidos os pontos nodais.

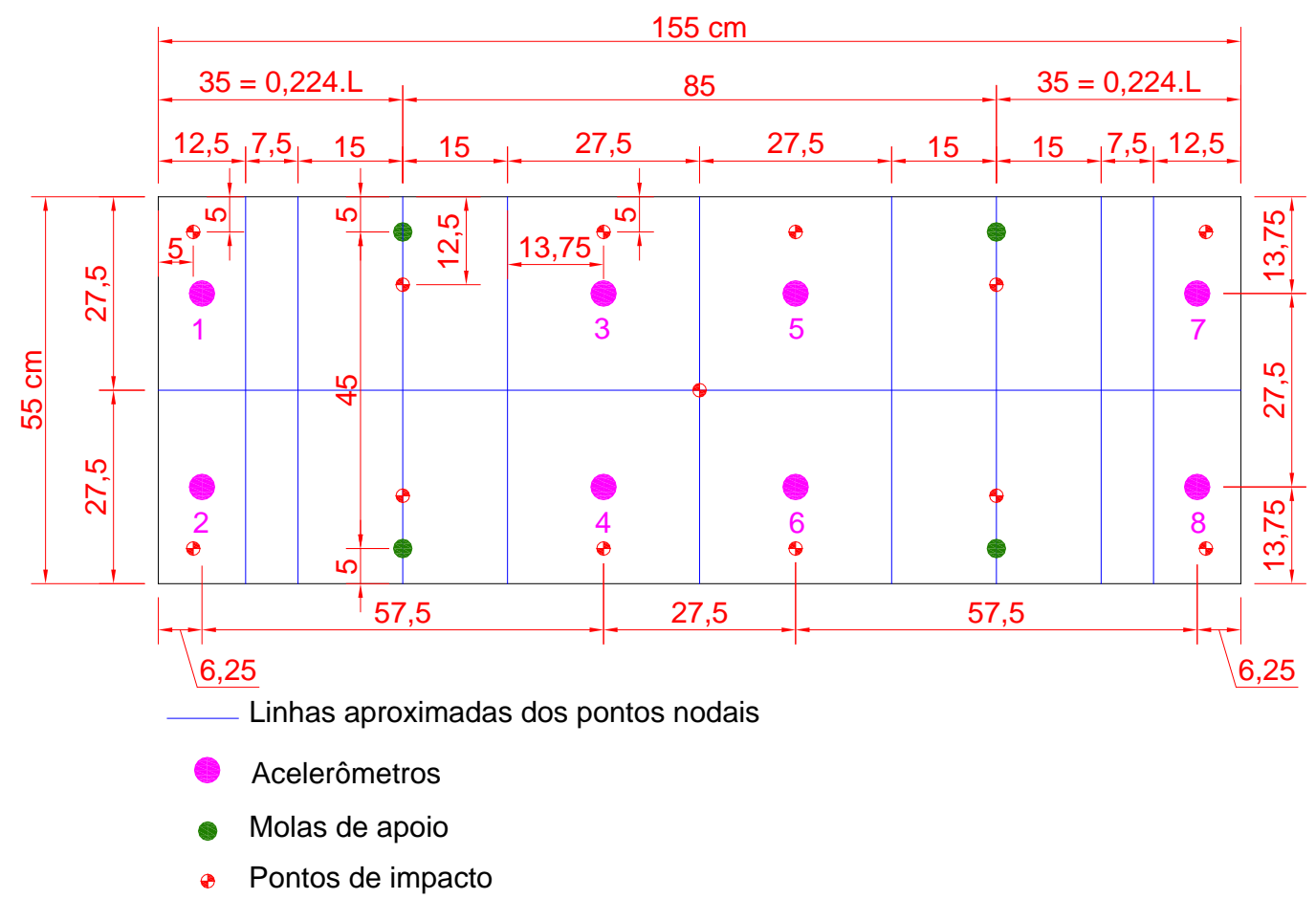

Figura 7.4 - Posição dos acelerômetros nos ensaios dinâmicos.

A excitação foi de impacto com martelo provido de esfera de aço na extremidade, igual ao ilustrado na mão do operador, na Figura 5.1. A frequência de captação do sinal dinâmico foi de $2 \mathrm{kHz}$. Foram utilizados oito acelerômetros, sendo que o da posição 1 foi adotado como de referência. Os acelerômetros utilizados foram fabricados pela empresa Brüel \& Kjaer. A Figura 7.5 ilustra as peças prontas para o ensaio dinâmico.

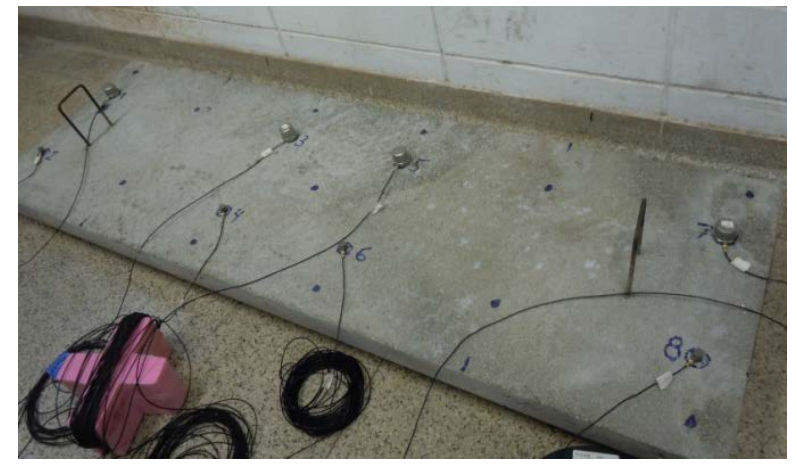

(a)

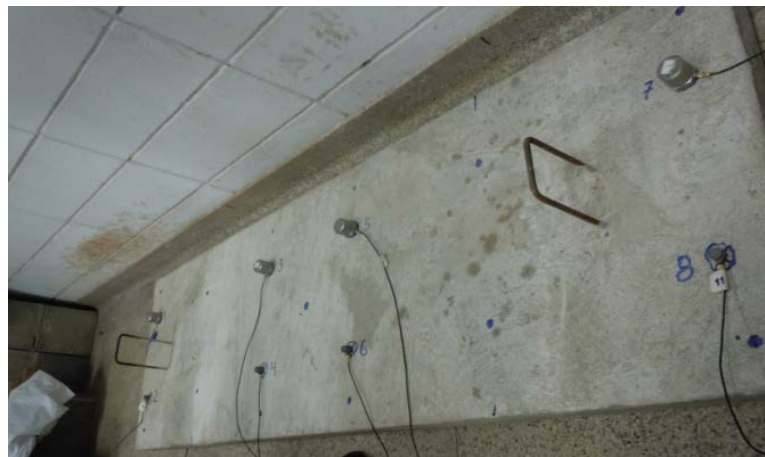

(b)

Figura 7.5 - Peças prontas para a realização dos ensaios. (a) CLEPE; (b) CC. 
O sinal captado foi processado pela mesma rotina que foi utilizada nos primeiros ensaios dinâmicos, possibilitando a obtenção das frequências naturais das lajes. Para cada uma dessas frequências, foi obtida a deformada modal e o fator de amortecimento modal pelo método do decremento logarítmico.

A Figura 7.6 ilustra os apoios nas molas para simulação de bordo livre nos quatro lados.

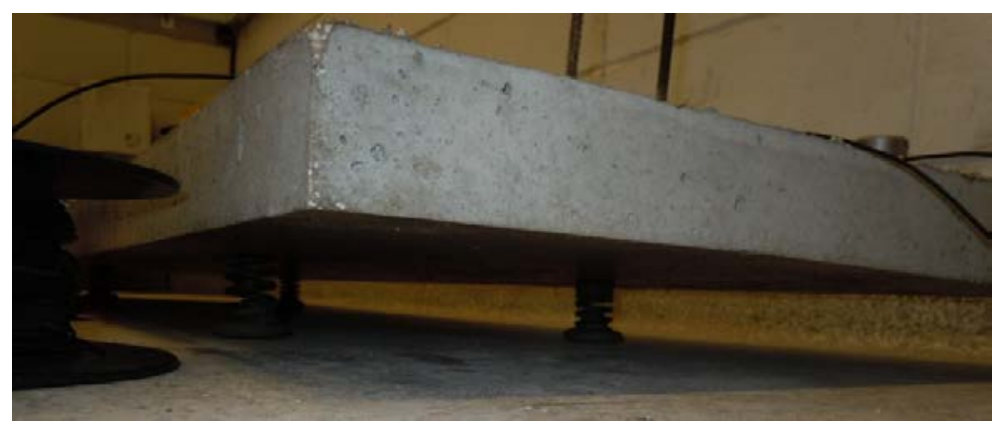

Figura 7.6 - Apoios nas molas.

\subsection{Resultados do ensaio dinâmico da laje de CC}

Nas Figuras 7.7 e 7.8 são ilustrados, respectivamente, os diagramas de PSD e de coerência para o ensaio dinâmico da laje de CC.

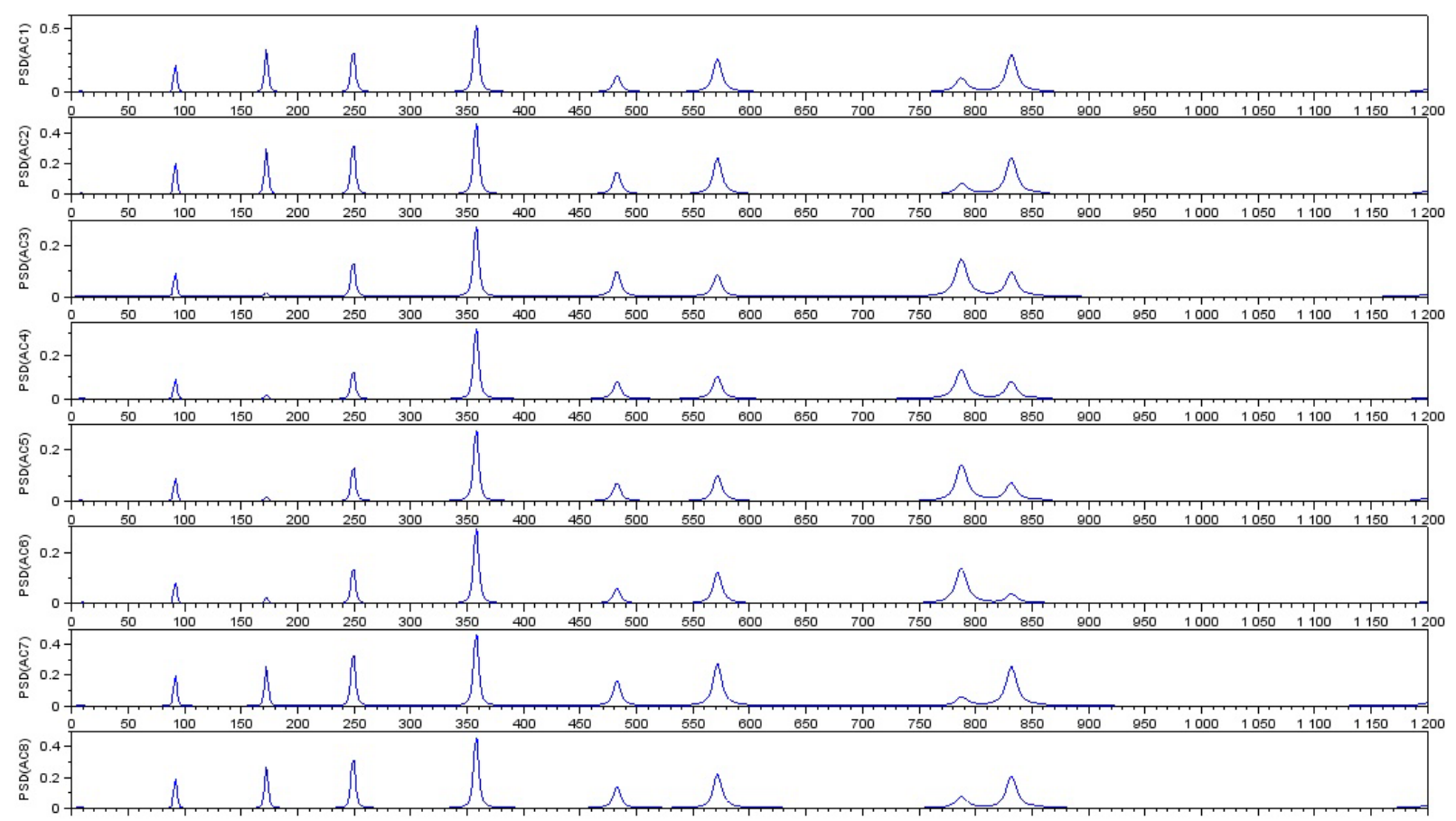

Figura 7.7 - Diagrama de PSD do ensaio da laje de CC (unidade no eixo das abscissas: Hz). 


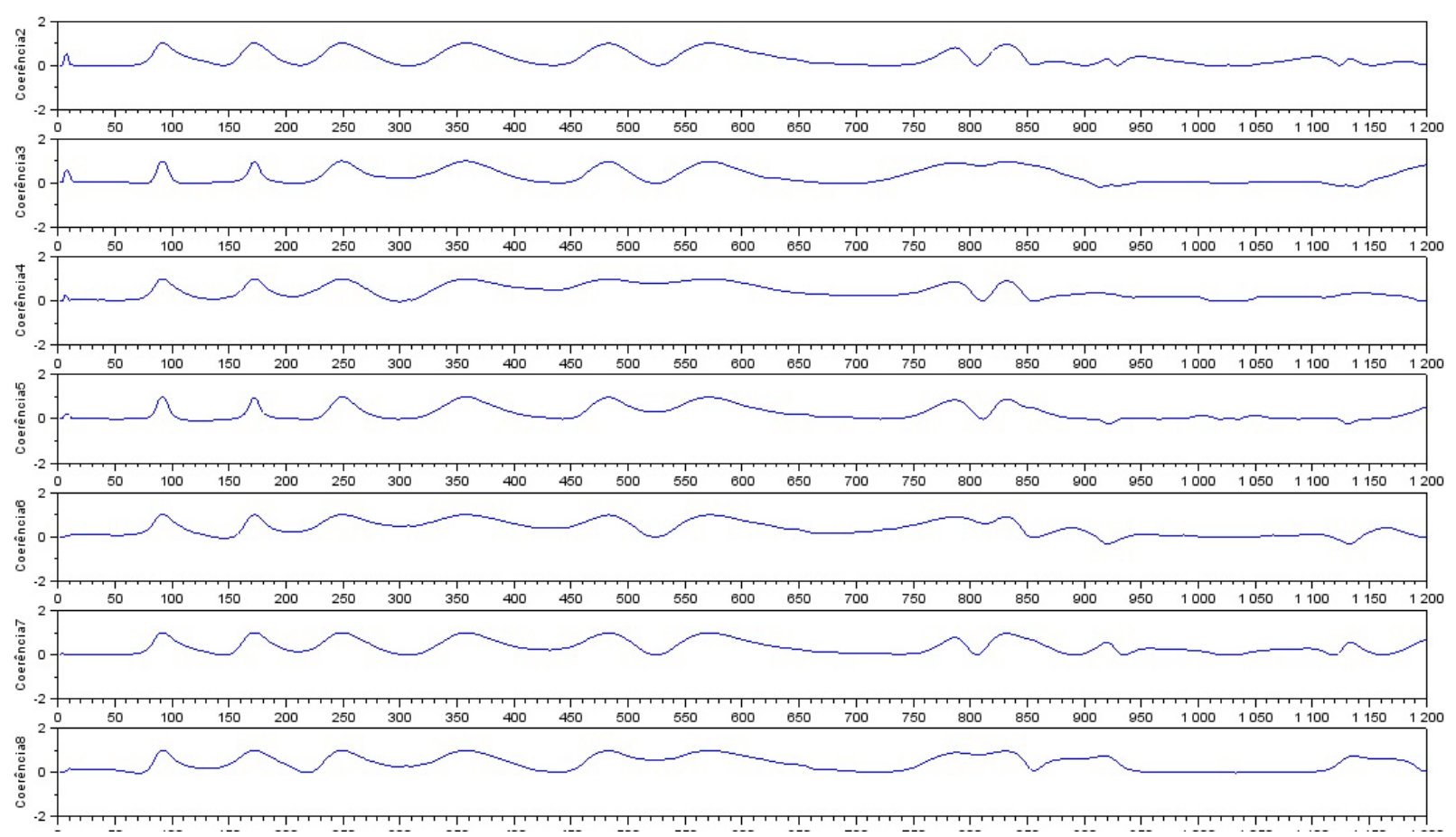

Figura 7.8 - Diagrama de coerência para o ensaio da laje de CC (unidade no eixo das abscissas: Hz).

Observa-se que a coerência fica próxima a 1 nos pontos de frequências naturais, o que é esperado. As deformadas modais são apresentadas na Tabela 7.3.

Tabela 7.3: Deformadas modais do ensaio da laje de CC.

\begin{tabular}{|c|c|c|c|c|c|c|c|c|}
\hline \multicolumn{8}{|c|}{ Valores } & \multirow{10}{*}{ Deformada } \\
\hline \multicolumn{8}{|c|}{ Deformada Modal da Frequência $\quad 92,213 \mathrm{~Hz}$} & \\
\hline $\mathrm{P} 1$ & $\mathrm{P} 2$ & $\mathrm{P} 3$ & $\mathrm{P} 4$ & $\mathrm{P} 5$ & P6 & P7 & $\mathrm{P} 8$ & \\
\hline 20,00 & 19,83 & $-13,10$ & $-13,03$ & $-12,88$ & $-12,55$ & 19,49 & 19,09 & \\
\hline \multicolumn{8}{|c|}{ (Valores multiplicados por 20) } & \\
\hline & & & & & & & & \\
\hline \multicolumn{8}{|c|}{ Deformada Modal da Frequência $\quad 172,131 \mathrm{~Hz}$} & \\
\hline $\mathrm{P} 1$ & $\mathrm{P} 2$ & $\mathrm{P} 3$ & $\mathrm{P} 4$ & P5 & P6 & P7 & P8 & \\
\hline 20,00 & $-18,7$ & 4,54 & $-4,80$ & $-4,82$ & 5,41 & $-17,35$ & 17,99 & \\
\hline \multicolumn{8}{|c|}{ (Valores multiplicados por 20) } & \\
\hline
\end{tabular}




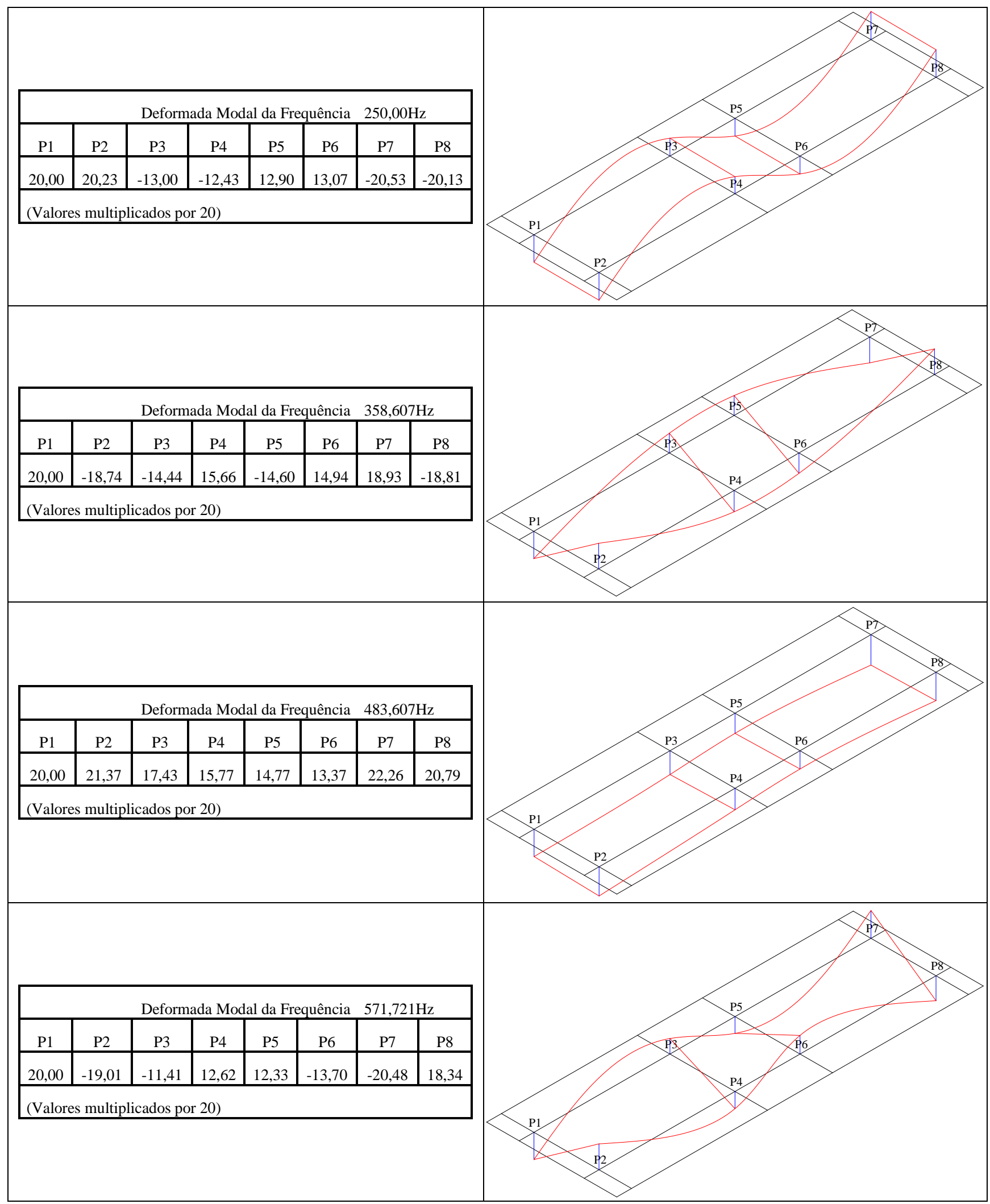




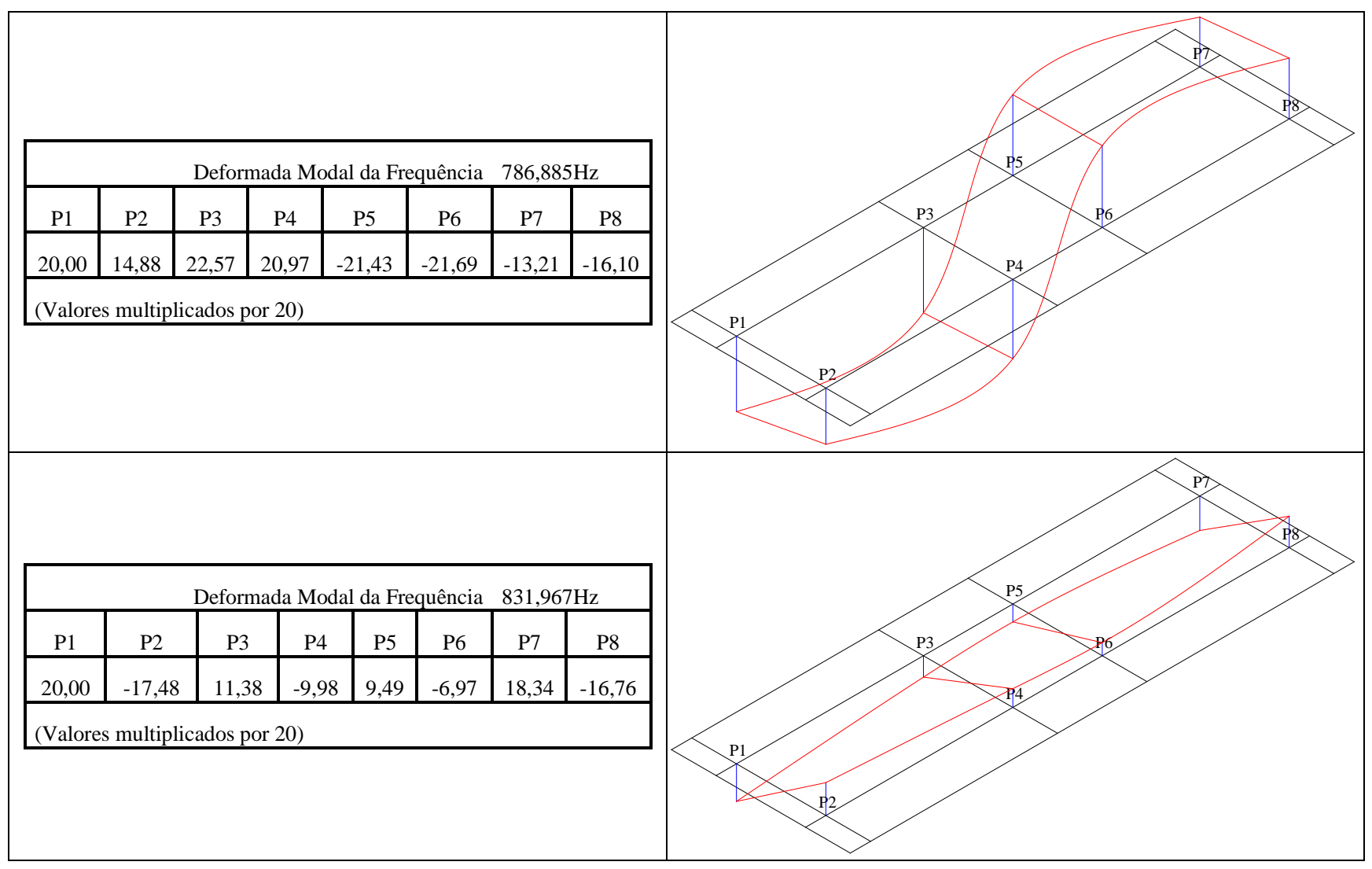

Observa-se que as frequências de 483,607 Hz e 831,967 Hz são, possivelmente, modos que não foram bem coletados, devido ao posicionamento dos acelerômetros. Por exemplo, o modo da frequência de 483,607 Hz, caso tivesse um refinamento na posição dos acelerômetros, provavelmente esse modo seria equivalente ao quinto modo da Tabela 7.1.

Os fatores de amortecimento modais, para os três primeiros modos apresentados na Tabela 7.3, são listados na Tabela 7.4 e foram obtidos como descrito no item 6.1 .

Tabela 7.4: Valores dos fatores de amortecimento modais do ensaio da laje de CC.

\begin{tabular}{|c|c|c|c|c|c|c|}
\hline \multirow{2}{*}{$\begin{array}{l}\text { Frequência natural } \\
(\mathrm{Hz})\end{array}$} & \multicolumn{5}{|c|}{ Primeiro $\xi$} & \\
\hline & $x_{0}$ & $x_{p}$ & $p$ & $\delta$ & $\xi$ & \\
\hline 92,213 & 0,100892 & 0,059659 & 18 & 0,029189 & 0,004645 & \\
\hline 172,131 & 0,033972 & 0,015086 & 30 & 0,027059 & 0,004307 & \\
\hline 250,000 & 0,075440 & 0,046360 & 21 & 0,023186 & 0,003690 & \\
\hline \multirow{2}{*}{$\begin{array}{c}\text { Frequência natural } \\
\text { (Hz) }\end{array}$} & \multicolumn{5}{|c|}{ Segundo $\xi$} & \\
\hline & $x_{0}$ & $x_{p}$ & $p$ & $\delta$ & $\xi$ & \\
\hline 92,213 & 0,102551 & 0,047827 & 26 & 0,029337 & 0,004669 & \\
\hline 172,131 & 0,198367 & 0,084174 & 32 & 0,026786 & 0,004264 & \\
\hline 250,000 & 0,197005 & 0,018915 & 84 & 0,027896 & 0,004440 & \\
\hline \multirow{2}{*}{$\begin{array}{c}\text { Frequência natural } \\
(\mathrm{Hz})\end{array}$} & \multicolumn{5}{|c|}{ Terceiro $\xi$} & $\xi$ \\
\hline & $x_{0}$ & $x_{p}$ & $p$ & $\delta$ & $\xi$ & $\begin{array}{l}\text { (média dos } \\
3 \text { cálculos) } \\
\end{array}$ \\
\hline 92,213 & 0,125015 & 0,090996 & 13 & 0,024432 & 0,003888 & 0,004401 \\
\hline 172,131 & 0,207038 & 0,136082 & 16 & 0,026228 & 0,004174 & 0,004248 \\
\hline 250,000 & 0,125811 & 0,103947 & 9 & 0,212100 & 0,003376 & $\mathbf{0 , 0 0 3 8 3 5}$ \\
\hline
\end{tabular}




\subsection{Resultados do ensaio dinâmico da laje de CLEPE}

Nas Figuras 7.9 e 7.10 são ilustrados, respectivamente, os diagramas de PSD e coerência para o ensaio dinâmico da laje de CLEPE.

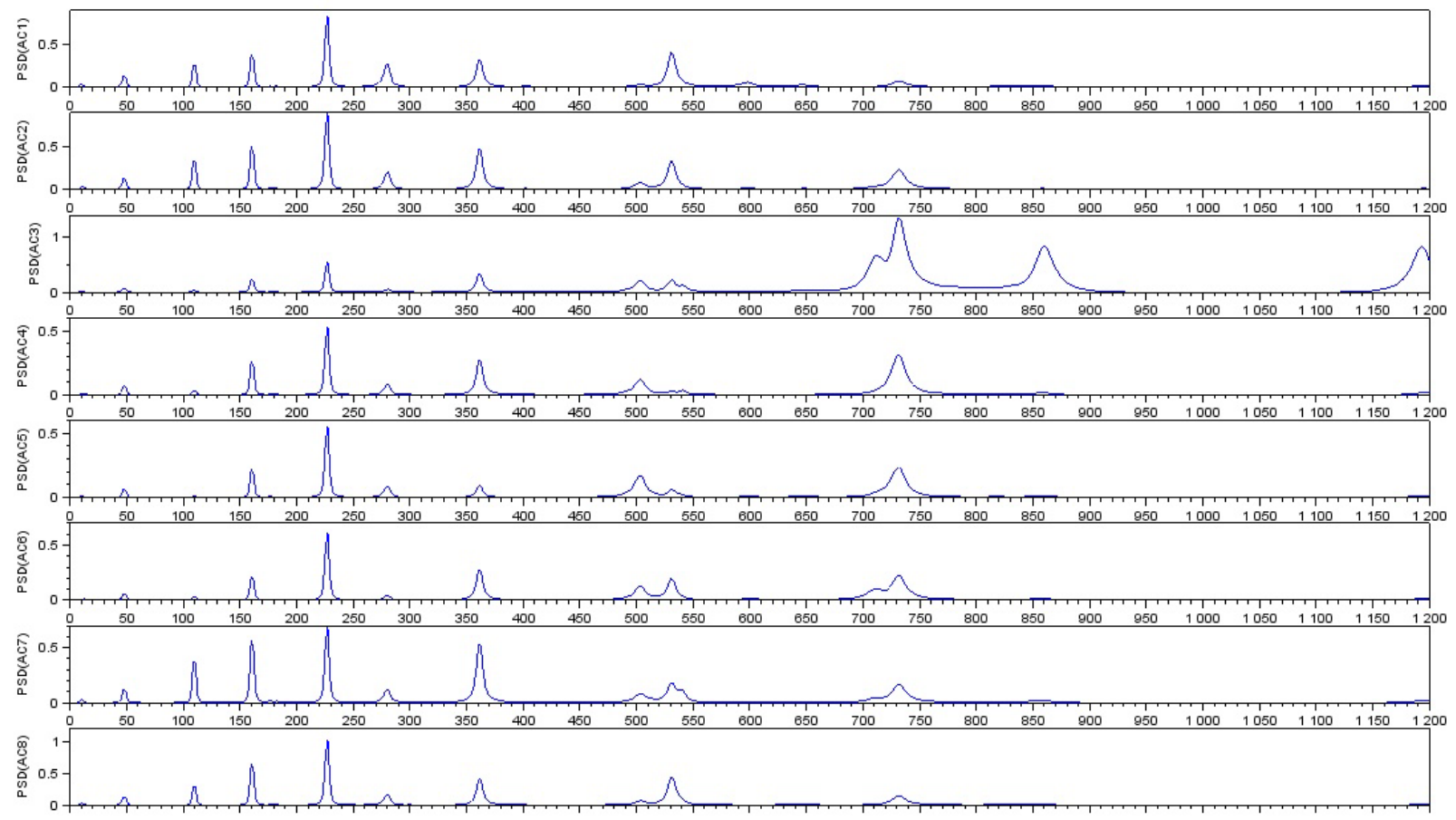

Figura 7.9 - Diagrama de PSD do ensaio da laje de CLEPE (unidade no eixo das abscissas: $\mathrm{Hz})$.

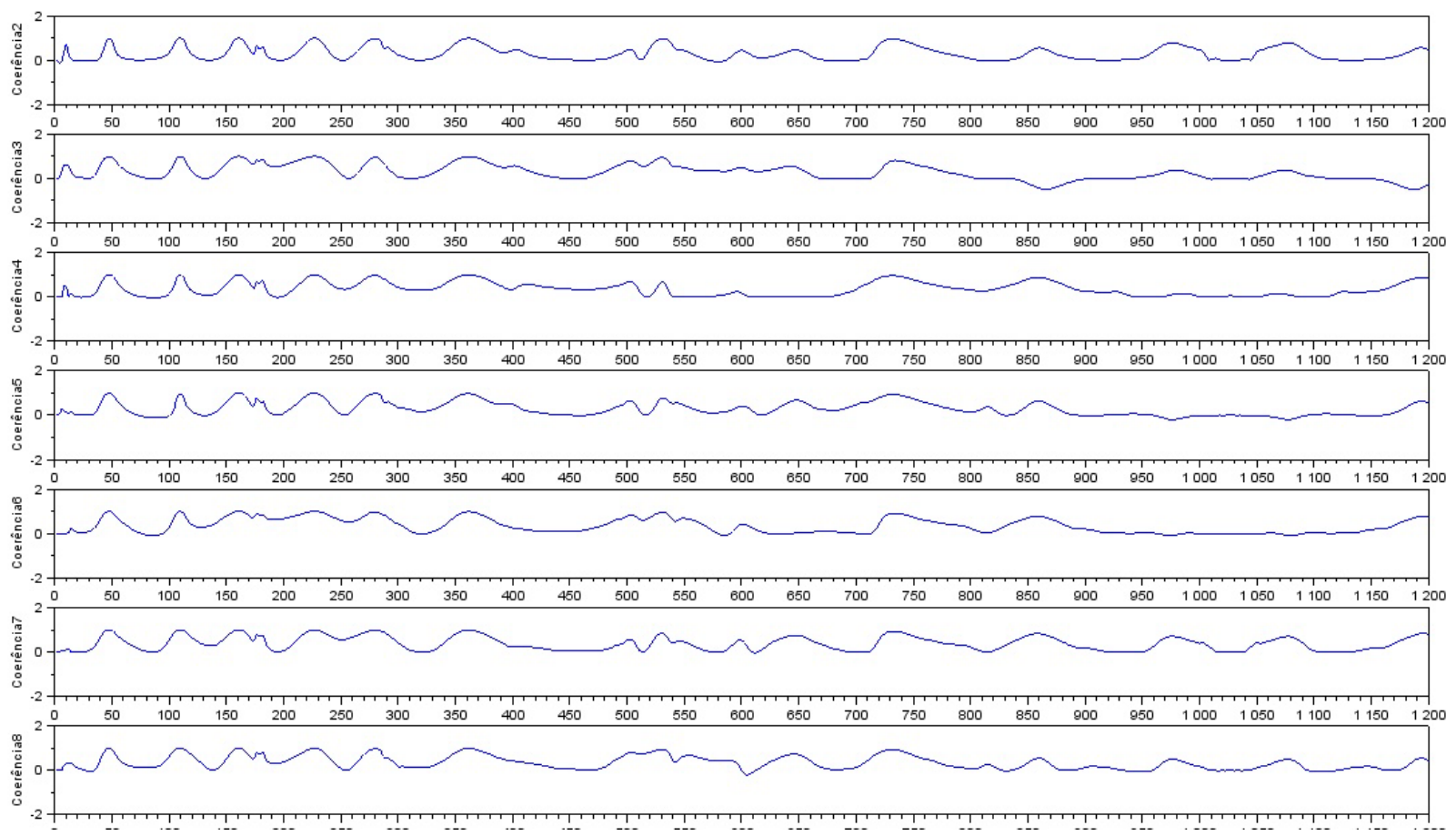

Figura 7.10 - Diagrama de coerência para o ensaio da laje de CLEPE (unidade no eixo das abscissas: $\mathrm{Hz})$. 
Observa-se que a coerência fica próxima a 1 nos pontos de frequências naturais, o que é esperado. As deformadas modais são apresentadas na Tabela 7.5.

Tabela 7.5: Deformadas modais do ensaio da laje de CLEPE.

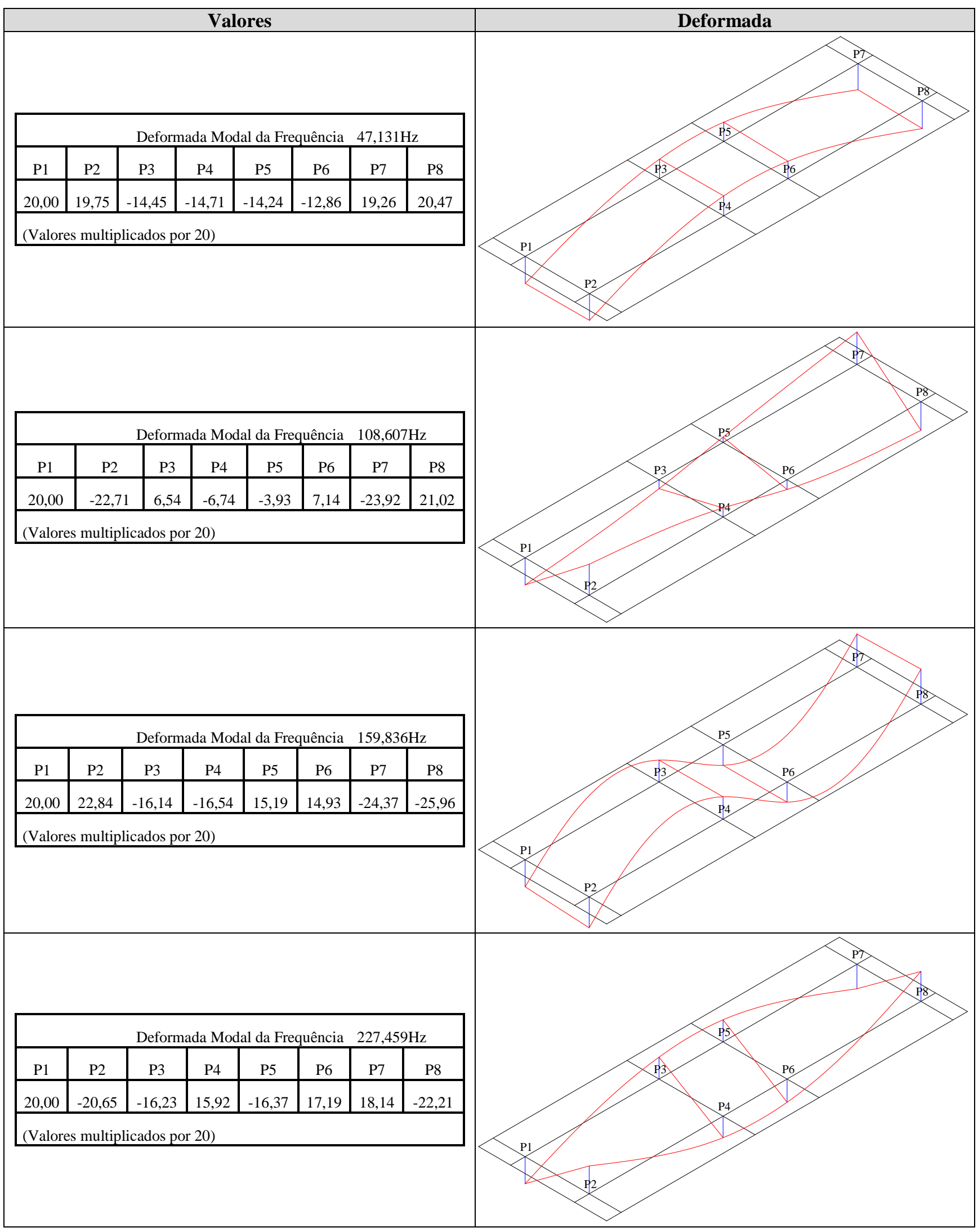




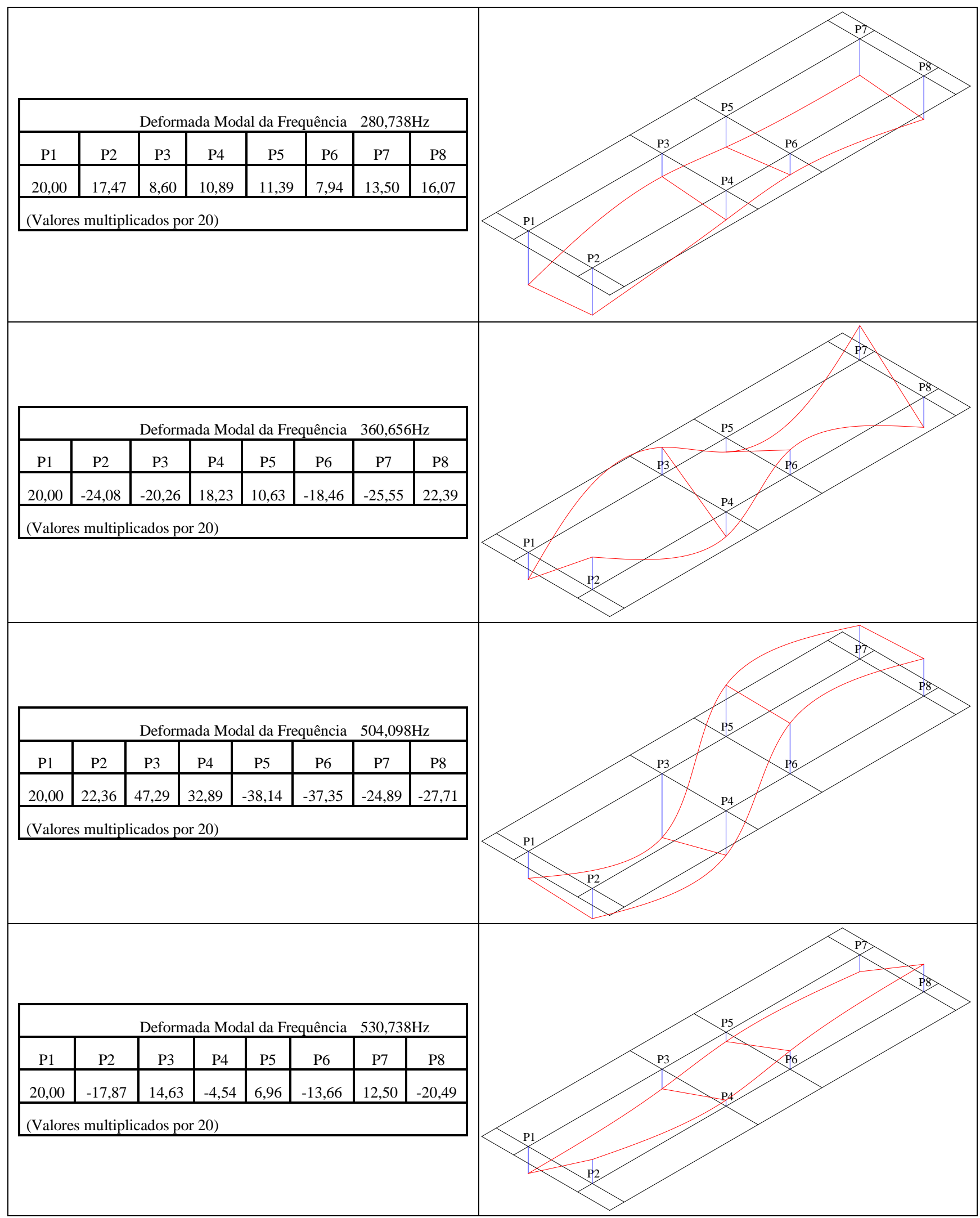




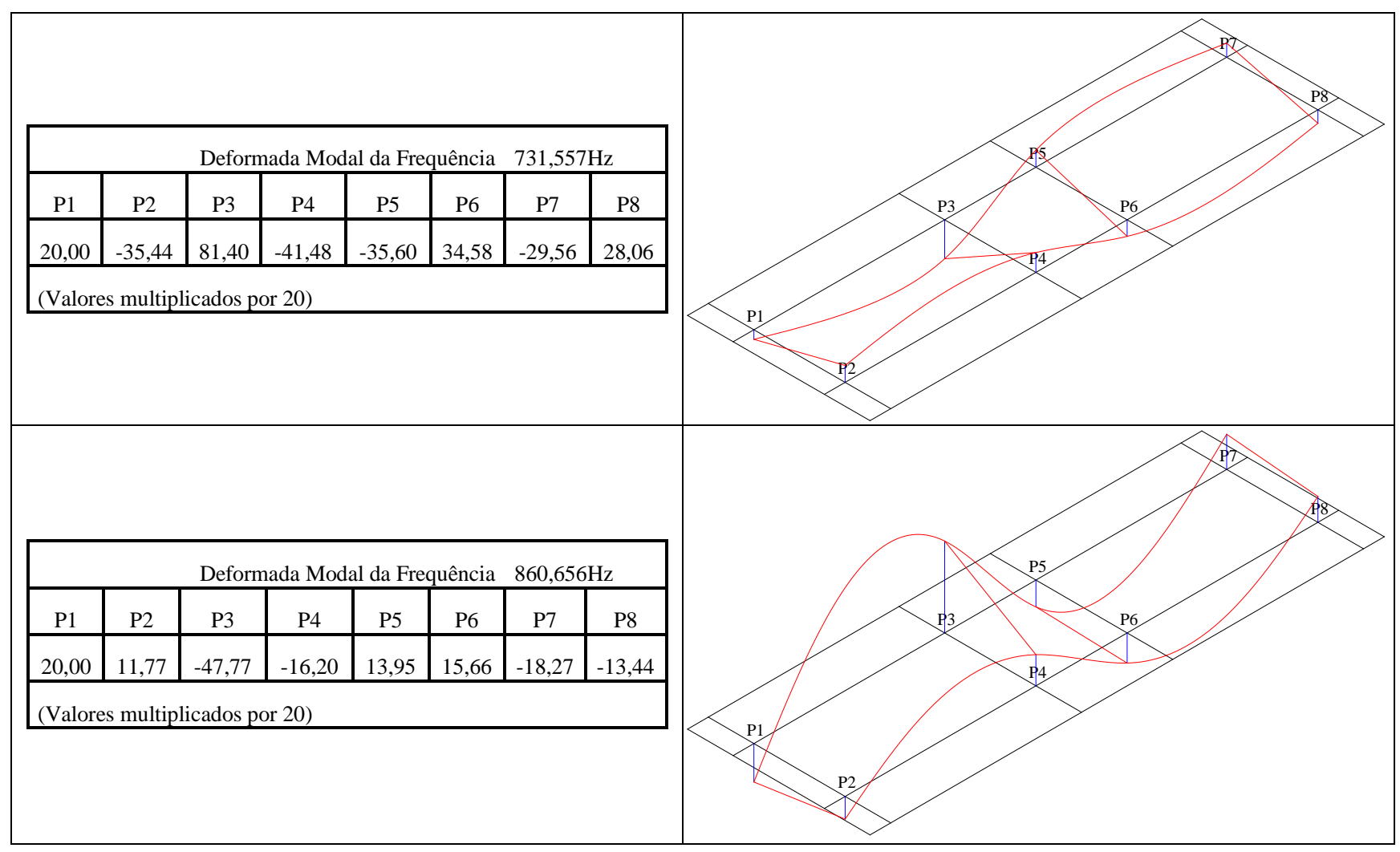

Observa-se que as frequências de 280,738 Hz e 530,737 Hz são, possivelmente, modos que não foram bem coletados, devido ao posicionamento dos acelerômetros. Por exemplo, o modo da frequência de $280,738 \mathrm{~Hz}$, caso tivesse um refinamento na posição dos acelerômetros, provavelmente esse modo seria equivalente ao quinto modo da Tabela 7.2.

Os fatores de amortecimento modais, para os três primeiros modos apresentados na Tabela 7.5, são listados na Tabela 7.6, e foram obtidos como descrito no item 6.1.

Tabela 7.6: Valores dos fatores de amortecimento modais do ensaio da laje de CLEPE.

\begin{tabular}{|c|c|c|c|c|c|c|}
\hline \multirow{2}{*}{$\begin{array}{l}\text { Frequência natural } \\
\text { lida }(\mathrm{Hz})\end{array}$} & \multicolumn{5}{|c|}{ Primeiro $\xi$} & \\
\hline & $x_{0}$ & $x_{p}$ & $p$ & $\delta$ & $\xi$ & \\
\hline 47,131 & 0,056956 & 0,020255 & 13 & 0,079529 & 0,012656 & \\
\hline 108,607 & 0,185186 & 0,045456 & 40 & 0,035115 & 0,005589 & \\
\hline 159,836 & 0,170449 & 0,030574 & 55 & 0,031242 & 0,004972 & \\
\hline \multirow{2}{*}{$\begin{array}{l}\text { Frequência natural } \\
\text { lida }(\mathrm{Hz})\end{array}$} & \multicolumn{5}{|c|}{ Segundo $\xi$} & \\
\hline & $x_{0}$ & $x_{p}$ & $p$ & $\delta$ & $\xi$ & \\
\hline 47,131 & 0,104833 & 0,009002 & 34 & 0,072203 & 0,011491 & \\
\hline 108,607 & 0,025768 & 0,005513 & 45 & 0,034268 & 0,005454 & \\
\hline 159,836 & 0,254804 & 0,042613 & 59 & 0,030311 & 0,004824 & \\
\hline \multirow{2}{*}{$\begin{array}{c}\text { Frequência natural } \\
\text { lida }(\mathrm{Hz})\end{array}$} & \multicolumn{5}{|c|}{ Terceiro $\xi$} & $\xi$ \\
\hline & $x_{0}$ & $X_{p}$ & $p$ & $\delta$ & $\xi$ & $\begin{array}{l}\text { (média dos } \\
3 \text { cálculos) }\end{array}$ \\
\hline 47,131 & 0,149784 & 0,012588 & 30 & 0,082548 & 0,013137 & 0,012428 \\
\hline 108,607 & 0,176516 & 0,126137 & 10 & 0,033604 & 0,005348 & 0,005464 \\
\hline 159,836 & 0,234083 & 0,106506 & 23 & 0,034238 & 0,005449 & 0,005082 \\
\hline
\end{tabular}




\subsection{Caracterização dinâmica e estática dos concretos das lajes sobre molas}

As caracterizações dinâmica e estática dos concretos seguiram as mesmas metodologias já apresentadas nos ensaios anteriores (Capítulo 5).

Foram realizados ensaios de caracterização dinâmica com nove corpos de prova cilíndricos de $10 \mathrm{~cm}$ x $20 \mathrm{~cm}$ tanto para o CC quanto para o CLEPE. Os resultados estão listados na Tabela 7.7. Observa-se que o CLEPE apresentou massa específica e módulo de elasticidade dentro do esperado.

Tabela 7.7: Resultados da caracterização dinâmica.

\begin{tabular}{|c|c|c|c|c|c|c|c|}
\hline CC & \multirow{2}{*}{$\begin{array}{c}\text { Massa } \\
\text { (g) }\end{array}$} & \multirow{2}{*}{$\begin{array}{c}\text { Altura } \\
\text { do cp } \\
\text { (cm) }\end{array}$} & \multirow{2}{*}{$\begin{array}{c}\text { Massa } \\
\text { específica } \\
\left(\mathbf{k g} / \mathbf{m}^{3}\right)\end{array}$} & \multicolumn{2}{|c|}{\begin{tabular}{|c|} 
Fator de Amortecimento \\
$\left(\mathrm{x10}^{-6}\right)$
\end{tabular}} & \multicolumn{2}{|c|}{$\begin{array}{l}\text { Módulo de elasticidade } \\
\text { (GPa) }\end{array}$} \\
\hline CP $(10 \mathrm{~cm} \times 20 \mathrm{~cm})$ & & & & \begin{tabular}{|l|} 
Flexural \\
\end{tabular} & Longitudinal & Flexural & Longitudina \\
\hline ср 1 & 3783,1 & 19,85 & 2426,60 & \begin{tabular}{|l|}
4451,4 \\
\end{tabular} & 4948,9 & 39,62 & 40,31 \\
\hline ср 2 & 3758,9 & 19,70 & 2429,43 & 4100,9 & 4732,8 & 39,19 & 39,78 \\
\hline ср 3 & 3712,4 & 19,70 & 2399,38 & 4157,5 & 3993,7 & 38,42 & 39,10 \\
\hline ср 4 & 3740,8 & 19,80 & 2405,52 & 4709,7 & 3251,5 & 38,46 & 39,32 \\
\hline cp 5 & 3753,4 & 19,60 & 2438,25 & 4382,0 & 4342,5 & 40,11 & 40,99 \\
\hline ср 6 & 3725,7 & 19,60 & 2420,26 & 3199,6 & 3697,0 & 40,22 & 41,51 \\
\hline ср 7 & 3704,0 & 19,65 & 2400,04 & 4189,3 & 3921,1 & 39,75 & 40,03 \\
\hline ср 8 & 3765,9 & 19,80 & 2421,66 & 3395,3 & 3973,0 & 39,90 & 40,31 \\
\hline ср 9 & 3695,8 & 19,50 & 2413,15 & 4172,1 & 4638,7 & 39,12 & 40,26 \\
\hline Média & 3737,78 & ---- & 2417,14 & 4084,2 & 4166,6 & 39,42 & 40,18 \\
\hline CLEPE & \multirow{2}{*}{$\begin{array}{c}\text { Massa } \\
\text { (g) }\end{array}$} & \multirow{2}{*}{$\begin{array}{c}\text { Altura } \\
\text { do cp } \\
\text { (cm) }\end{array}$} & \multirow{2}{*}{$\begin{array}{c}\text { Massa } \\
\text { específica } \\
\left(\mathbf{k g} / \mathbf{m}^{3}\right)\end{array}$} & \multicolumn{2}{|c|}{$\begin{array}{c}\text { Fator de Amortecimento } \\
\left(\mathrm{x10}^{-6}\right)\end{array}$} & \multicolumn{2}{|c|}{$\begin{array}{l}\text { Módulo de elasticidade } \\
\text { (GPa) }\end{array}$} \\
\hline CP $(10 \mathrm{~cm} \times 20 \mathrm{~cm})$ & & & & Flexural & Longitudinal & Flexural & Longitudina \\
\hline ср 1 & 1790,4 & 19,15 & 1190,60 & \begin{tabular}{|l|}
4732,5 \\
\end{tabular} & 4249,9 & 9,69 & 9,71 \\
\hline ср 2 & 1826,9 & 19,80 & 1174,79 & 4465,0 & 3714,4 & 9,92 & 9,76 \\
\hline ср 3 & 1852,3 & 20,20 & 1167,54 & 4262,5 & 4243,6 & 9,69 & 9,24 \\
\hline ср 4 & 1963,0 & 20,00 & 1249,68 & 5207,9 & 4511,9 & 11,42 & 11,36 \\
\hline ср 5 & 1910,6 & 19,80 & 1228,61 & 4549,7 & 4518,8 & 11,10 & 11,18 \\
\hline ср 6 & 1859,1 & 19,90 & 1189,49 & 3861,8 & 3853,7 & 10,36 & 9,96 \\
\hline ср 7 & 1887,2 & 20,35 & 1180,77 & 4458,8 & 4371,9 & 9,54 & 9,41 \\
\hline ср 8 & 1830,2 & 20,15 & 1156,47 & 4233,1 & 4048,6 & 9,26 & 8,97 \\
\hline ср 9 & 1918,1 & 20,05 & 1218,06 & 3924,6 & 4269,8 & 10,47 & 10,70 \\
\hline Média & 1870,87 & --- & 1195,11 & 4410,7 & 4198,1 & 10,16 & 10,03 \\
\hline
\end{tabular}

Na Tabela 7.8 estão listados os resultados dos ensaios de compressão simples em seis corpos de prova de CC e seis de CLEPE. Também foi obtido o valor da resistência característica à compressão. Observa-se que a resistência característica do CLEPE à compressão atende ao esperado. 
Tabela 7.8: Resistências características à compressão.

\begin{tabular}{|c|c|c|c|c|c|c|c|}
\hline CC & $\begin{array}{l}\text { Idade do } \\
\text { cp (dias) }\end{array}$ & $\begin{array}{c}\text { Carga de } \\
\text { Ruptura (kN) }\end{array}$ & $f_{c i}(\mathrm{MPa})$ & $f_{c m}(\mathrm{MPa})$ & $\delta$ & $s$ (MPa) & $\begin{array}{c}f_{c k} \\
(\mathrm{MPa})\end{array}$ \\
\hline ср 1 & 21 & 306,2 & 38,98 & \multirow{6}{*}{38,80} & \multirow{6}{*}{0,050} & \multirow{6}{*}{1,958} & \multirow{6}{*}{35,58} \\
\hline ср 2 & 21 & 294,6 & 37,51 & & & & \\
\hline ср 3 & 21 & 302,7 & 38,54 & & & & \\
\hline ср 4 & 21 & 317,0 & 40,36 & & & & \\
\hline ср 5 & 21 & 328,1 & 41,77 & & & & \\
\hline ср 6 & 21 & 279,9 & 35,64 & & & & \\
\hline CLEPE & $\begin{array}{l}\text { Idade do } \\
\text { cp (dias) }\end{array}$ & $\begin{array}{c}\text { Carga de } \\
\text { Ruptura (kN) }\end{array}$ & $f_{c i}(\mathrm{MPa})$ & $f_{c m}(\mathrm{MPa})$ & $\delta$ & $s$ (MPa) & $\begin{array}{c}f_{c k} \\
(\mathrm{MPa})\end{array}$ \\
\hline ср 1 & 21 & 83,7 & 10,66 & \multirow{6}{*}{10,82} & \multirow{6}{*}{0,038} & \multirow{6}{*}{0,413} & \multirow{6}{*}{10,14} \\
\hline ср 2 & 21 & 86,7 & 11,04 & & & & \\
\hline cp 3 & 21 & 79,3 & 10,09 & & & & \\
\hline ср 4 & 21 & 89,8 & 11,43 & & & & \\
\hline ср 5 & 21 & 86,4 & 11,00 & & & & \\
\hline ср 6 & 21 & 84,2 & 10,72 & & & & \\
\hline
\end{tabular}

\subsection{Comentários sobre os ensaios dinâmicos das lajes sobre molas}

Ao serem analisados e comparados os resultados dos ensaios dos Capítulos 5 e 6 com os apresentados no presente capítulo, podem ser traçados os seguintes comentários:

- Os resultados das deformadas modais dos novos ensaios, relatadas neste capítulo, são mais claras e facilmente identificáveis com as deformadas modais teóricas obtidas numericamente. Eventuais dificuldades de correlação entre as deformadas experimentais e as teóricas originam-se da ausência de acelerômetros em alguns pontos específicos;

- Comparando-se as frequências naturais experimentais e as teóricas numéricas, pode-se dizer que elas são relativamente próximas. A variação encontrada é devida à perturbação das molas de apoio e da não homogeneidade do material concreto;

- Os fatores de amortecimento dos ensaios dinâmicos das lajes deste capítulo são próximos aos valores encontrados no Sonelastic ${ }^{\circledR}$, tanto aqui quanto no Capítulo 5, refletindo uma coerência de que as peças não estavam fissuradas. Esses valores de amortecimento estão de acordo com os valores teóricos apresentados na Tabela 2.2. Confirma-se então a hipótese levantada no item 6.4, de que o fator de amortecimento foi influenciado pelo comportamento conjunto de lajes, apoios e demais elementos estruturais e incertezas como comentado no item 6.2.1. Logo, não é adequado que os fatores de amortecimento apresentados nos ensaios dinâmicos do Capítulo 6 sejam considerados em uma avaliação dos materiais envolvidos. Assim sendo, os valores apresentados neste capítulo são mais indicados para caracterizar os materiais; 
- O fator de amortecimento do primeiro modo do CLEPE (Tabela 7.6) é bem maior que os outros dois. A possível explicação para esse fenômeno está relacionada com a interação das molas de apoio com a laje. A massa da laje de CLEPE, sendo menor do que a de CC, possui um comportamento diferenciado na interação com as molas, fazendo com que parte da energia seja absorvida pelas molas. Recomenda-se que esse fator de amortecimento específico não seja considerado;

- Os fatores de amortecimento do CLEPE são ligeiramente maiores do que os do CC. Essa diferença era esperada no início da pesquisa. Entretanto, ela é mínima, e como foi observado nos resultados dos ensaios dinâmicos do Capítulo 6, o amortecimento é grandemente influenciado pelas condições de contorno, demais elementos estruturais e elementos construtivos fixados na estrutura em análise;

- Tendo em vista os comentários anteriores sobre os fatores de amortecimento, recomenda-se que sejam utilizados os valores deste capítulo quando se deseja avaliar o material isoladamente. Entretanto, quando for analisada a estrutura como um todo (não somente as peças de CLEPE), recomendam-se os valores teóricos listados na Tabela 2.2. Entende-se que esses valores são mais representativos para a grande variabilidade das estruturas. Caso sejam adotados os valores de amortecimento contidos neste trabalho (especificamente os do presente capítulo), ter-se-iam valores mais conservadores do que os indicados na Tabela 2.2. Caso sejam utilizados, em uma análise dinâmica, os valores dos fatores de amortecimento dos ensaios dinâmicos do Capítulo 6, ter-se-iam valores extremamente arrojados e que não são recomendados na literatura técnica. Logo, na análise paramétrica de previsão de vibração desenvolvida no Capítulo 8, é adotado um único valor para fator de amortecimento para CC e para o CLEPE, com valor médio de 1\%, que é um valor contido na faixa de concreto armado não fissurado da Tabela 2.2, entendendo-se, assim, que estaria contemplada certa interação da laje de CLEPE ou de CC com os demais elementos estruturais;

- As diferenças encontradas para frequências naturais entre as Tabelas 7.2 e 7.5 não são devidas à rigidez da mola. Essa análise foi feita calibrando-se um modelo numérico com molas de rigidez equivalente para o resultado encontrado experimentalmente. Apenas foi verificado que, no modelo calibrado com as molas aparecem movimentos de corpo rígido em frequências baixas ( $8 \mathrm{~Hz}$ a $10 \mathrm{~Hz}$ ). Esses movimentos foram captados experimentalmente e podem ser observados no gráfico de PSD da Figura 7.9. Então, a suspeita da diferença recai na possível variação do módulo de elasticidade dinâmico do concreto da laje de CLEPE em relação aos respectivos corpos de prova, apesar de ambos terem sido moldados com a mesma betonada. Diferenças de forma e de cura podem justificar essa alteração no módulo de elasticidade; 
- Ressalta-se que a determinação do amortecimento em estruturas não é tarefa simples, tendo em vista a facilidade de esse parâmetro ser influenciado pelas condições de contorno;

- As resistências características dos concretos à compressão e seus módulos de elasticidade são atrelados à massa específica, sendo que os resultados obtidos foram considerados satisfatórios para esta pesquisa. 


\section{Análise Paramétrica em Lajes de CC e de CLEPE}

O objetivo deste capítulo é desenvolver uma análise paramétrica para avaliar o comportamento dinâmico de lajes maciças isoladas de CC e de CLEPE, frente à solicitação do caminhar normal de uma pessoa com $80 \mathrm{~kg}$ de massa, no centro da laje.

Pavic e Reynolds (2002) afirmam que a excitação gerada por seres humanos é a mais relevante em pisos de edifícios.

Para o desenvolvimento deste estudo paramétrico, são utilizadas as informações contidas no item 2.6 e os valores de massas e módulos de elasticidade do Capítulo 7.

A modelagem da força dinâmica foi feita com base na Equação 2.72. Essa força foi analisada na função Time History do software SAP $2000^{\circledR}$, considerando-se uma força periódica. A malha foi discretizada em elementos do tipo Shell-Thin de $10 \mathrm{~cm} \mathrm{x} 10 \mathrm{~cm}$. Os apoios são considerados fixos para translações e livres para rotações.

Não foi feita uma análise considerando a variação da posição de aplicação da força sobre a laje. Somente foi considerada a força no nó central, onde também se localiza o ponto de maior amplitude de deslocamento do primeiro modo de vibrar de uma laje quadrada.

Marcos e Carrazedo (2014) estudaram a influência da variação de alguns parâmetros, tais como: módulo de elasticidade, espessura e vão de lajes alveolares simplesmente apoiadas. Os citados autores verificaram que a primeira frequência natural é mais afetada pelo vão da laje e pela variação do módulo de elasticidade do concreto do que pela variação da espessura da laje. Também foi observado que, quando a primeira frequência natural da laje era reduzida, havia uma elevação no pico de deslocamento. Krunka (2014) confirma essa observação ao afirmar que ressonâncias em frequências naturais elevadas geram menores deslocamentos do movimento vibratório.

A direção do carregamento dinâmico também influencia a estrutura. De maneira geral, as ações dinâmicas originadas por pessoas são preponderantemente verticais. Entretanto, existe uma parcela horizontal que pode ser dividida em lateral e longitudinal. Krunka (2014) pondera que, em princípio, as ações dinâmicas humanas horizontais não são preocupantes para lajes de edifícios em geral, devido a sua grande rigidez lateral e longitudinal. Porém, em 
casos especiais, principalmente em passarelas esbeltas, elas podem ser significativas.

Com base nas informações dos parágrafos anteriores, na presente análise paramétrica foram consideradas as variações dos materiais (CC e CLEPE), dos vãos e das espessuras das lajes maciças, mantendo-se fixas a vinculação das lajes (apoio fixo nas quatro bordas) e a geometria (laje quadrada).

As características consideradas para os concretos foram:

CC

- Peso específico 24,05 kN/m³;

- Resistência característica à compressão 35,60 MPa;

- Módulo de elasticidade dinâmico 40 GPa;

- Fator de amortecimento 1\% para todos os modos.

CLEPE

- Peso específico $11 \mathrm{kN} / \mathrm{m}^{3}$;

- Resistência característica à compressão 10 MPa;

- Módulo de elasticidade dinâmico 10 GPa;

- Fator de amortecimento 1\% para todos os modos.

Conforme já comentado, o valor de $1 \%$ para o fator de amortecimento foi adotado entendendo-se que assim estaria contemplada certa interação das lajes com o restante da estrutura.

A Tabela 8.1 apresenta a nomenclatura e as principais características dos 32 modelos processados na análise paramétrica.

Tabela 8.1: Nomenclatura e características dos modelos processados.

\begin{tabular}{|c|c|c|c|c|c|c|c|}
\hline Modelo & Concreto & Vão (m) & $\begin{array}{c}\text { Espessura da } \\
\text { laje } \mathbf{( c m})\end{array}$ & Modelo & Concreto & Vão (m) & $\begin{array}{c}\text { Espessura da } \\
\text { laje (cm) }\end{array}$ \\
\hline CC48 & CC & 4 & 8 & CLEPE48 & CLEPE & 4 & 8 \\
\hline CC412 & CC & 4 & 12 & CLEPE412 & CLEPE & 4 & 12 \\
\hline CC416 & CC & 4 & 16 & CLEPE416 & CLEPE & 4 & 16 \\
\hline CC420 & CC & 4 & 20 & CLEPE420 & CLEPE & 4 & 20 \\
\hline CC68 & CC & 6 & 8 & CLEPE68 & CLEPE & 6 & 8 \\
\hline CC612 & CC & 6 & 12 & CLEPE612 & CLEPE & 6 & 12 \\
\hline CC616 & CC & 6 & 16 & CLEPE616 & CLEPE & 6 & 16 \\
\hline CC620 & CC & 6 & 20 & CLEPE620 & CLEPE & 6 & 20 \\
\hline CC88 & CC & 8 & 8 & CLEPE88 & CLEPE & 8 & 8 \\
\hline CC812 & CC & 8 & 12 & CLEPE812 & CLEPE & 8 & 12 \\
\hline CC816 & CC & 8 & 16 & CLEPE816 & CLEPE & 8 & 16 \\
\hline CC820 & CC & 8 & 20 & CLEPE820 & CLEPE & 8 & 20 \\
\hline CC108 & CC & 10 & 8 & CLEPE108 & CLEPE & 10 & 8 \\
\hline CC1012 & CC & 10 & 12 & CLEPE1012 & CLEPE & 10 & 12 \\
\hline CC1016 & CC & 10 & 16 & CLEPE1016 & CLEPE & 10 & 16 \\
\hline CC1020 & CC & 10 & 20 & CLEPE1020 & CLEPE & 10 & 20 \\
\hline
\end{tabular}


Na Figura 8.1 ilustra-se o desenvolvimento da função da força dinâmica humana em um movimento de caminhada normal, de acordo com a Equação 2.72. Os parâmetros de carregamento são: peso de uma pessoa $G=800 \mathrm{~N}$; frequência da caminhada $f_{p}=2 \mathrm{~Hz}$; coeficiente de Fourier do $1^{\circ}$ harmônico $\alpha_{1}=0,2$; coeficiente de Fourier do $2^{\circ}$ harmônico $\alpha_{2}=0,1 ;$ ângulo de diferença de fase do $1^{\circ}$ harmônico $\phi_{1}=0$; ângulo de diferença de fase do $2^{\circ}$ harmônico $\phi_{2}=(\pi / 2)$ rad; número total de harmônicos considerados na análise $n=2$.

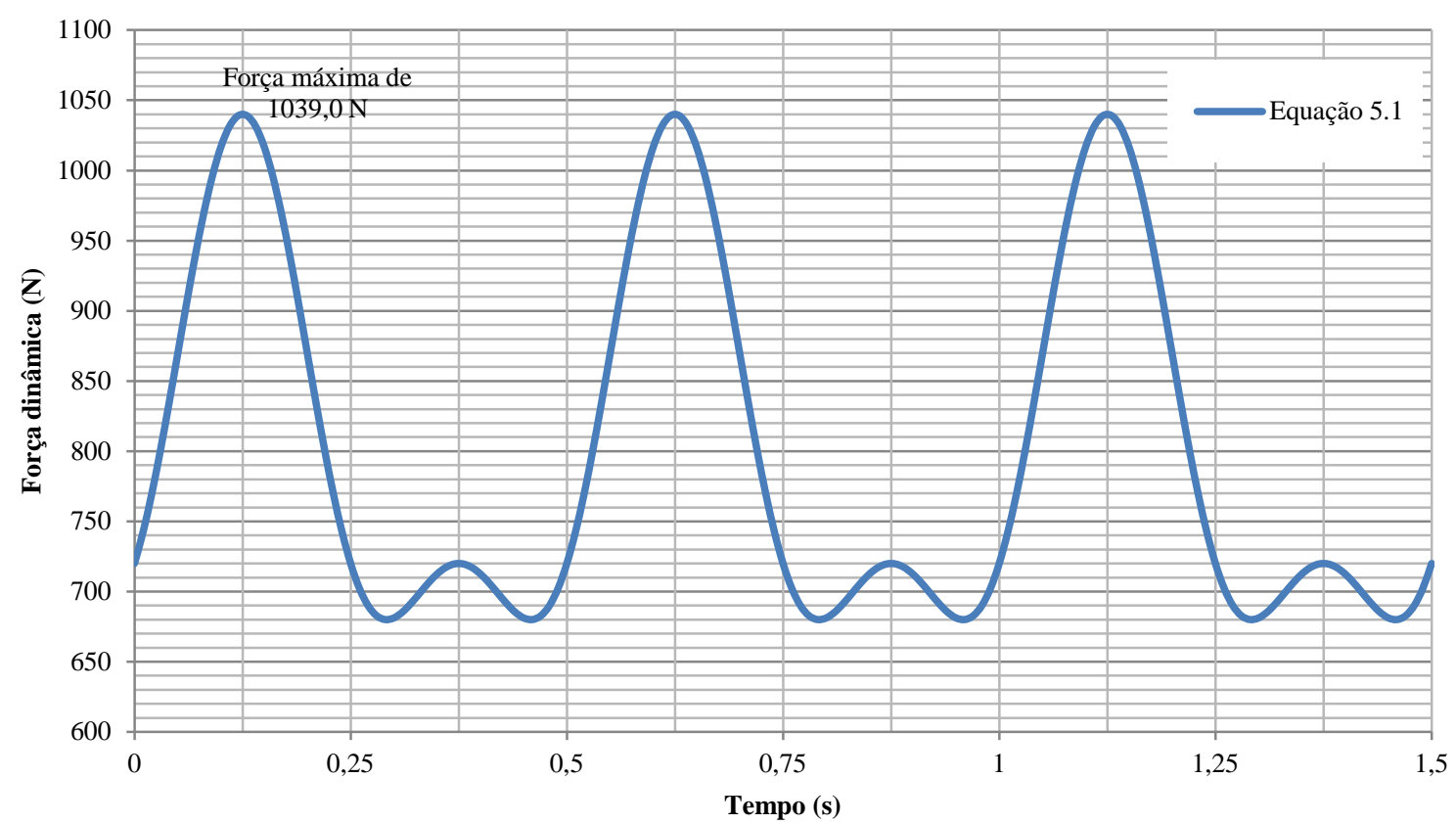

Figura 8.1 - Função de carregamento dinâmico para caminhada (Equação 5.1).

\subsection{Resultados}

Após o processamento dos modelos, foram extraídos os dados de aceleração, velocidade e deslocamento do movimento vibratório. Os valores máximos da aceleração e da velocidade foram comparados com os limites da Tabela 2.7. Com os valores da aceleração, foi realizada uma Transformada Rápida de Fourier (FFT - Fast Fourier Transform) para a análise dos picos de aceleração comparados com as curvas limites ilustradas na Figura 2.32. Os valores da velocidade e do deslocamento para um material foram comparados com os correspondentes do outro material.

Nas Figuras 8.2 a 8.4 são apresentados gráficos típicos do deslocamento, velocidade e aceleração dos modelos. 


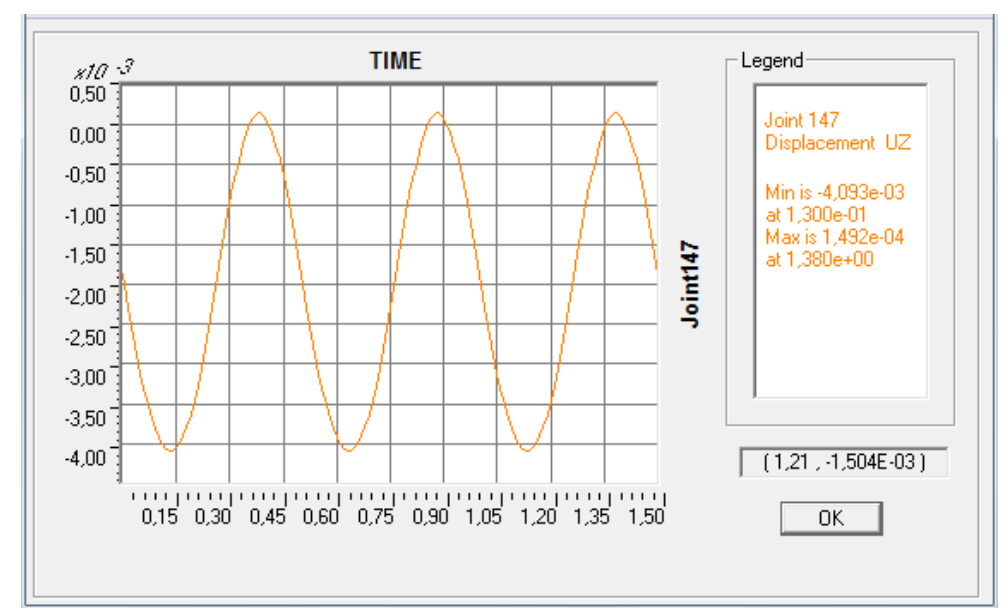

Figura 8.2 - Gráfico típico do deslocamento do movimento vibratório.

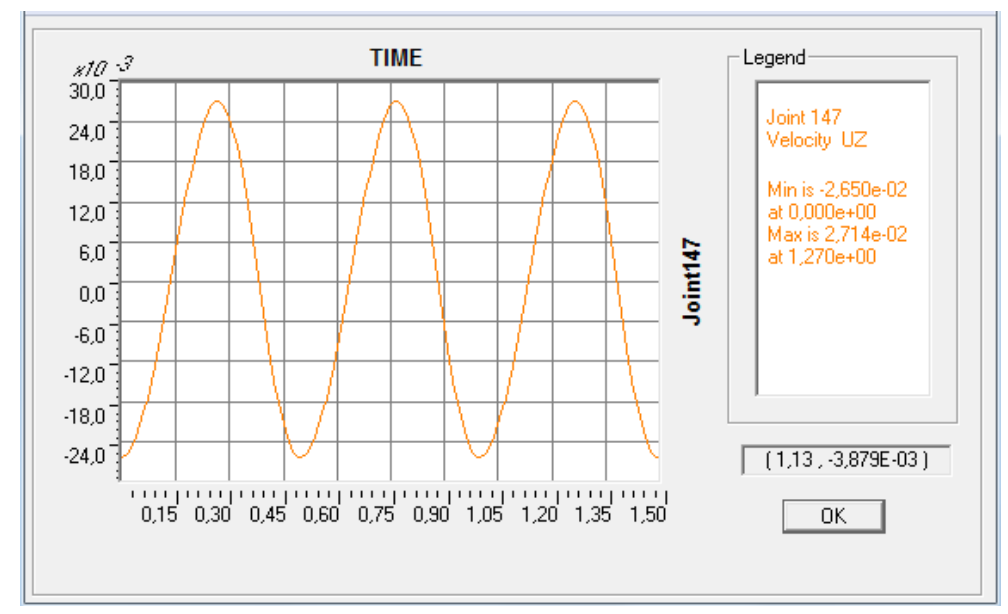

Figura 8.3 - Gráfico típico da velocidade do movimento vibratório.

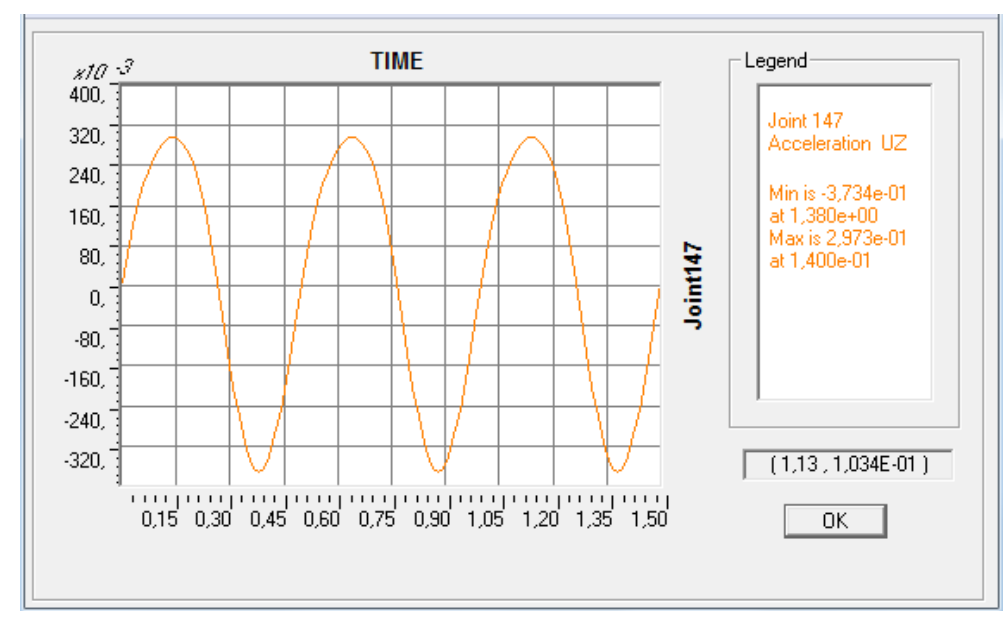

Figura 8.4 - Gráfico típico da aceleração do movimento vibratório.

Para cada modelo foram avaliados os três primeiros modos de vibração. A Figura 8.5 ilustra a deformada modal típica desses modos. A escolha dos três primeiros modos é 
justificada pelo fato de que suas frequências naturais são mais significativas, quando se analisa a ação humana. A Tabela 8.2 apresenta o valor das frequências naturais desses modos. Observa-se que, em alguns casos, a frequência natural é elevada e está muito acima do que pode ser obtido com a ação humana de caminhar, principalmente nas lajes de $4 \mathrm{~m}$ a $6 \mathrm{~m}$ de vão.
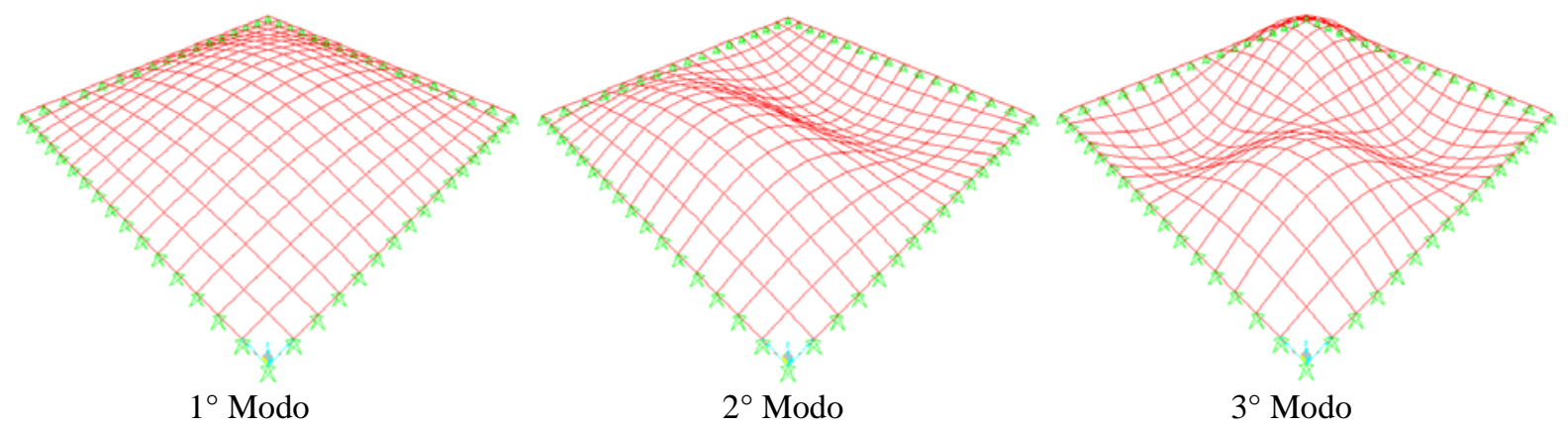

Figura 8.5 - Deformadas modais típicas dos três primeiros modos de vibração.

Tabela 8.2: Frequências naturais dos três primeiros modos de vibração.

\begin{tabular}{|c|c|c|c|c|c|c|c|}
\hline Modelo & $\begin{array}{l}1^{\circ} \text { Modo } \\
f_{n 1}(H z)\end{array}$ & $\begin{array}{c}2^{\circ} \text { Modo } \\
\mathbf{f}_{\mathrm{n} 2}(\mathrm{~Hz})\end{array}$ & $\begin{array}{c}3^{\circ} \text { Modo } \\
\mathbf{f}_{\mathrm{n} 3}(\mathrm{~Hz})\end{array}$ & Modelo & $\begin{array}{l}1^{\circ} \text { Modo } \\
\mathbf{f}_{\mathrm{n} 1}(\mathrm{~Hz})\end{array}$ & $\begin{array}{l}2^{\circ} \text { Modo } \\
\mathbf{f}_{\mathrm{n} 2}(\mathrm{~Hz})\end{array}$ & $\begin{array}{c}3^{\circ} \text { Modo } \\
\mathbf{f}_{\mathrm{n} 3}(\mathrm{~Hz})\end{array}$ \\
\hline CC48 & 18,64 & 46,51 & 73,90 & CLEPE48 & 13,78 & 34,39 & 54,64 \\
\hline CC412 & 27,96 & 69,77 & 110,85 & CLEPE412 & 20,67 & 51,58 & 81,96 \\
\hline CC416 & 37,27 & 93,02 & 147,80 & CLEPE416 & 27,57 & 68,77 & 109,27 \\
\hline CC420 & 46,59 & 116,28 & 184,75 & CLEPE420 & 34,45 & 85,97 & 136,59 \\
\hline CC68 & 8,28 & 20,67 & 32,85 & CLEPE68 & 6,12 & 15,28 & 24,28 \\
\hline CC612 & 12,42 & 31,01 & 49,27 & CLEPE612 & 9,19 & 22,92 & 36,42 \\
\hline CC616 & 16,57 & 41,34 & 65,69 & CLEPE616 & 12,25 & 30,57 & 48,57 \\
\hline CC620 & 20,71 & 51,68 & 82,11 & CLEPE620 & 15,31 & 38,21 & 60,71 \\
\hline CC88 & 4,66 & 11,63 & 18,48 & CLEPE88 & 3,44 & 8,60 & 13,66 \\
\hline CC812 & 6,99 & 17,44 & 27,71 & CLEPE812 & 5,17 & 12,89 & 20,49 \\
\hline CC816 & 9,32 & 23,26 & 36,95 & CLEPE816 & 6,89 & 17,19 & 27,32 \\
\hline CC820 & 11,65 & 29,07 & 46,19 & CLEPE820 & 8,61 & 21,49 & 34,15 \\
\hline CC108 & 2,98 & 7,44 & 11,82 & CLEPE108 & 2,20 & 5,50 & 8,74 \\
\hline CC1012 & 4,47 & 11,16 & 17,74 & CLEPE1012 & 3,31 & 8,25 & 13,11 \\
\hline CC1016 & 5,96 & 14,88 & 23,65 & CLEPE1016 & 4,41 & 11,00 & 17,48 \\
\hline CC1020 & 7,45 & 18,60 & 29,56 & CLEPE1020 & 5,51 & 13,75 & 21,85 \\
\hline
\end{tabular}

Considerando-se que a frequência de caminhar de $2 \mathrm{~Hz}$ tenha nos seus segundo e terceiro harmônicos as frequências de $4 \mathrm{~Hz}$ e $6 \mathrm{~Hz}$ respectivamente, observa-se que somente os modelos que estão marcados em negrito na Tabela 8.2 é que serão mais afetados pela ação de caminhar. Verifica-se que as lajes de CLEPE possuem frequências naturais menores, sendo mais facilmente suscetíveis à vibração causada pelo caminhar de uma pessoa.

As Figuras 8.6 a 8.9 ilustram a variação das frequências naturais com o vão, para as quatro espessuras dos modelos. 

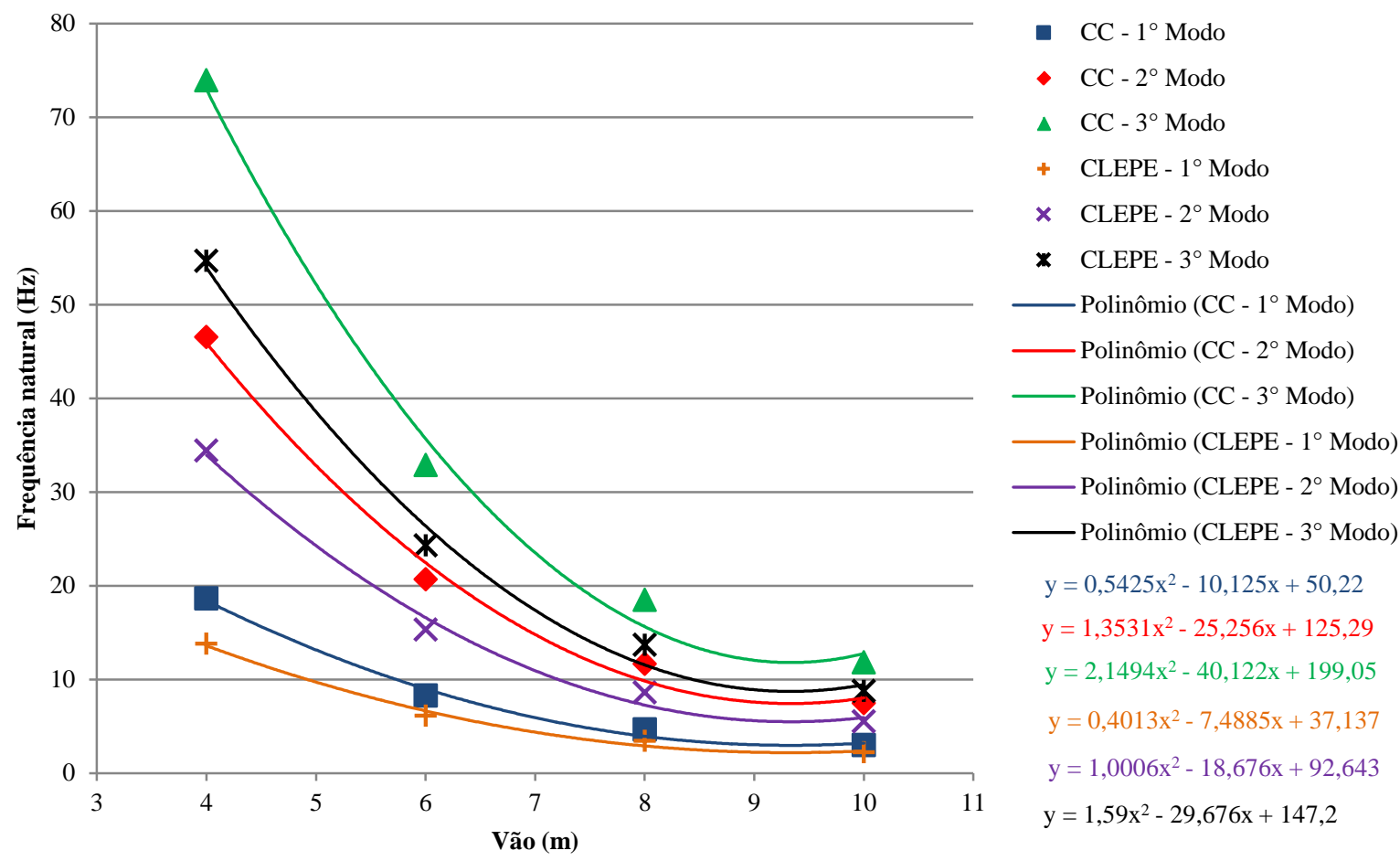

Figura 8.6 - Variação das frequências naturais com o vão, para espessura de 8 cm.
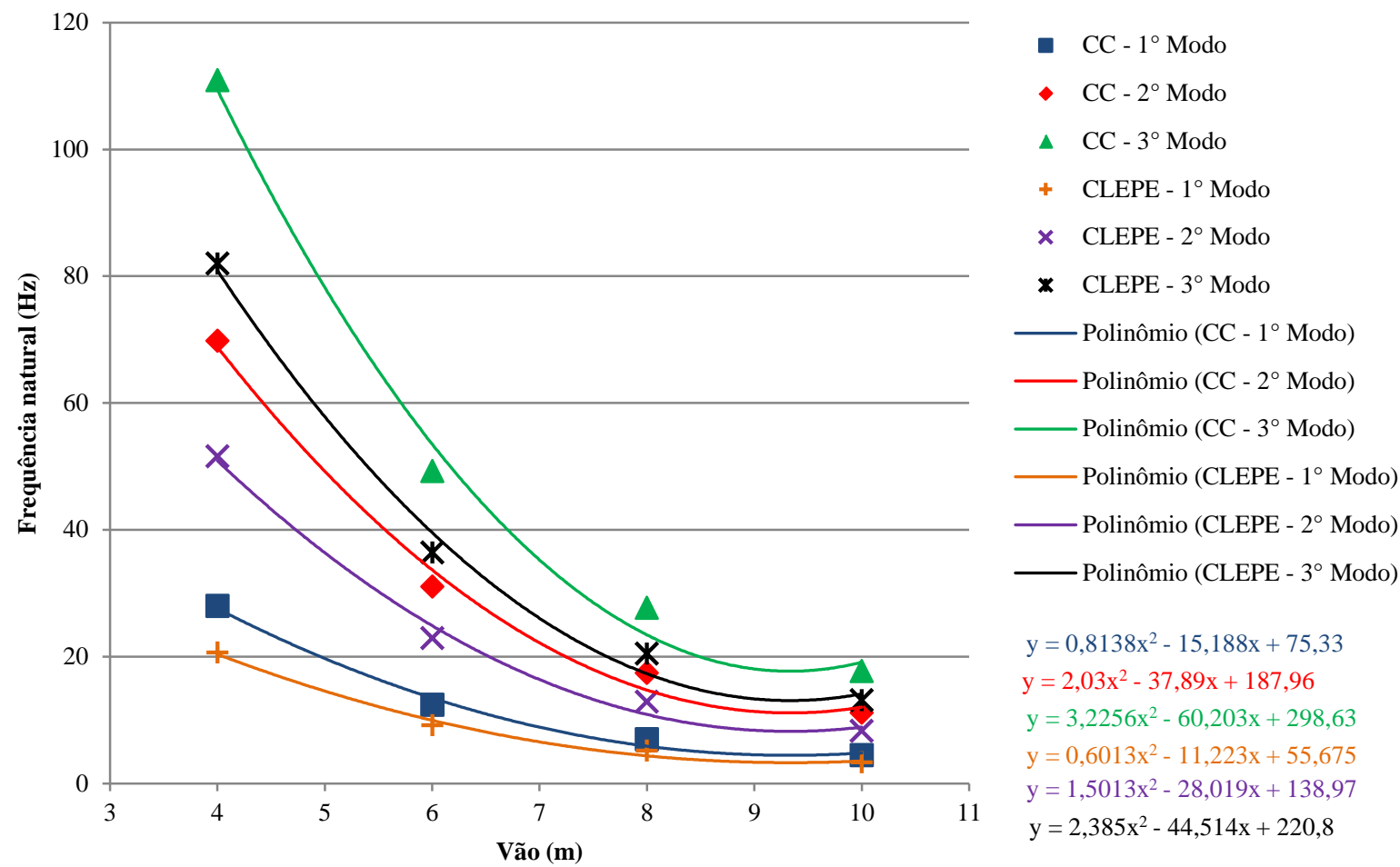

Figura 8.7 - Variação das frequências naturais com o vão, para espessura de 12 cm. 

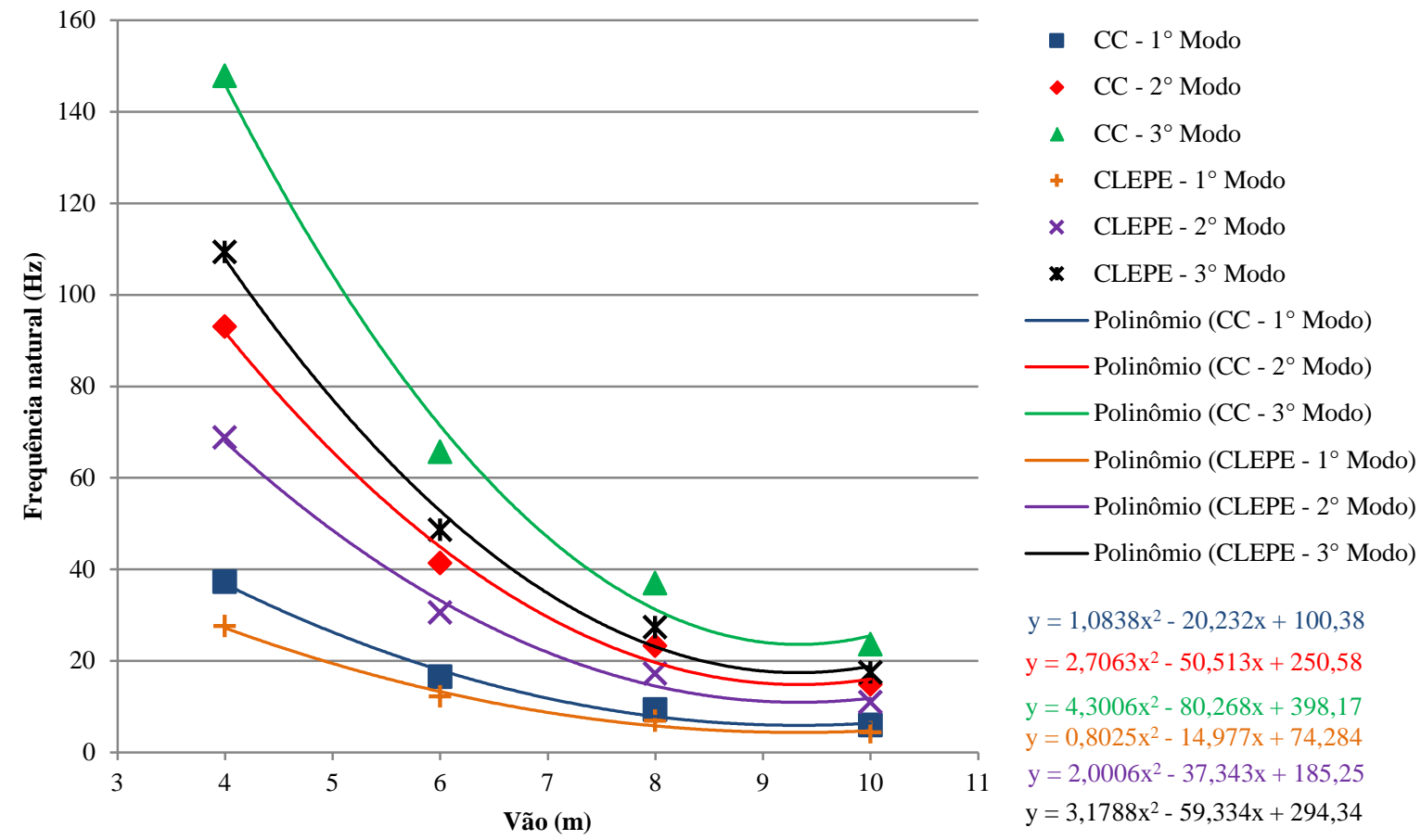

Figura 8.8 - Variação das frequências naturais com o vão, para espessura de 16 cm.
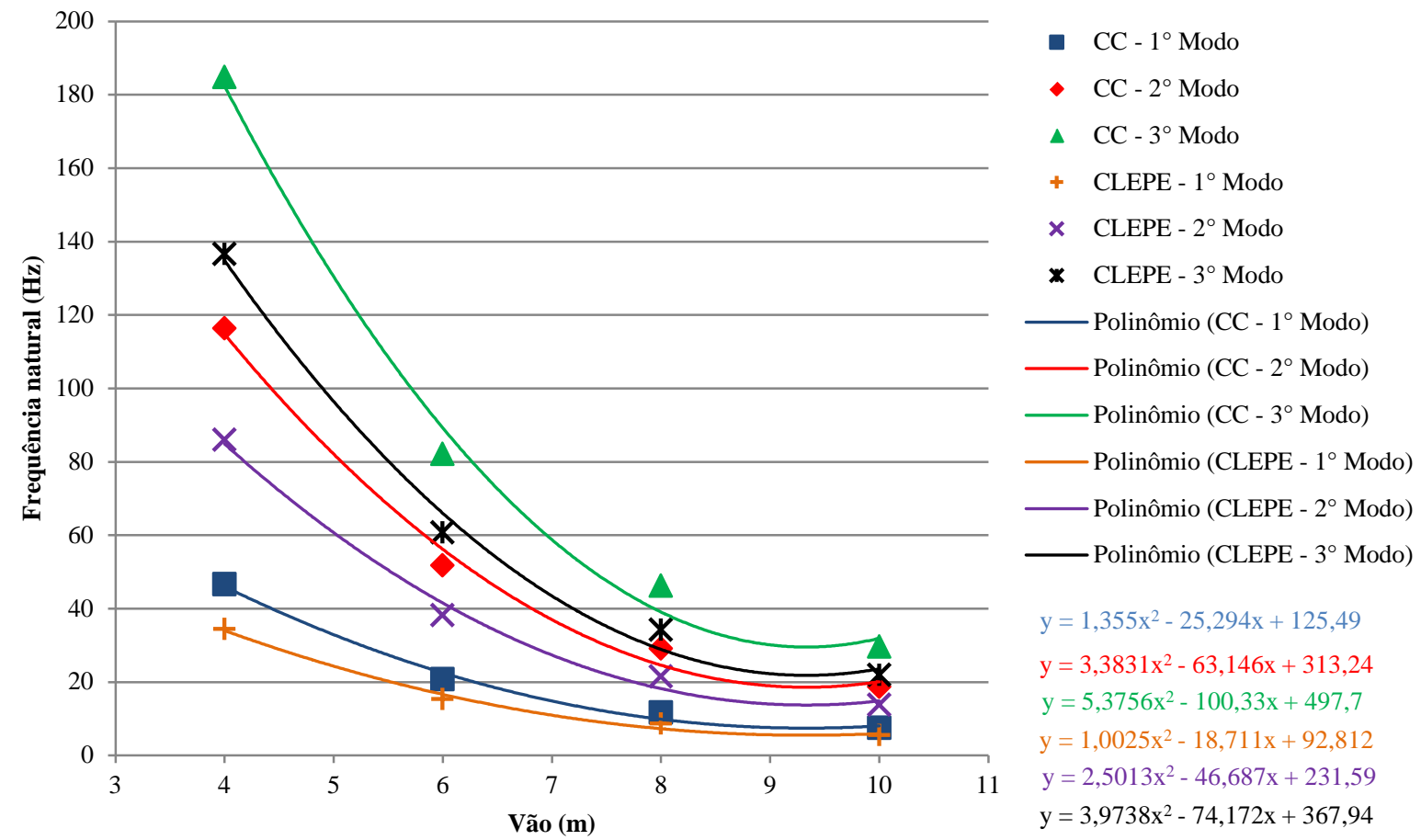

Figura 8.9 - Variação das frequências naturais com o vão, para espessura de 20 cm.

Na Tabela 8.3 são apresentados os valores de pico do deslocamento para cada modelo. Na Figura 8.10 é ilustrada a variação do deslocamento em função do vão, para cada uma das quatro espessuras de laje. 
Tabela 8.3: Picos de deslocamento do movimento vibratório.

\begin{tabular}{|c|c|c|c|c|}
\hline Modelo & $\begin{array}{c}\text { Amplitude } \\
\text { máxima (mm) }\end{array}$ & Modelo & $\begin{array}{c}\text { Deslocamento } \\
\text { máximo (mm) }\end{array}$ & $\begin{array}{c}\text { Razão de aumento } \\
\text { CLEPE / CC }\end{array}$ \\
\hline CC48 & 0,106 & CLEPE48 & 0,426 & 4,02 \\
\hline CC412 & 0,031 & CLEPE412 & 0,126 & 4,06 \\
\hline CC416 & 0,013 & CLEPE416 & 0,053 & 4,08 \\
\hline CC420 & 0,007 & CLEPE420 & 0,027 & 3,86 \\
\hline CC68 & 0,245 & CLEPE68 & 1,015 & 4,14 \\
\hline CC612 & 0,071 & CLEPE612 & 0,288 & 4,06 \\
\hline CC616 & 0,030 & CLEPE616 & 0,120 & 4,00 \\
\hline CC620 & 0,015 & CLEPE620 & 0,061 & 4,07 \\
\hline CC88 & 0,518 & CLEPE88 & 1,700 & 3,28 \\
\hline CC812 & 0,131 & CLEPE812 & 0,565 & 4,31 \\
\hline CC816 & 0,054 & CLEPE816 & 0,221 & 4,09 \\
\hline CC820 & 0,027 & CLEPE820 & 0,111 & 4,11 \\
\hline CC108 & 0,639 & CLEPE108 & 4,093 & 6,41 \\
\hline CC1012 & 0,257 & CLEPE1012 & 0,759 & 2,95 \\
\hline CC1016 & 0,089 & CLEPE1016 & 0,449 & 5,04 \\
\hline CC1020 & 0,044 & CLEPE1020 & 0,186 & 4,23 \\
\hline
\end{tabular}

Na Tabela 8.3 é evidente o grande aumento da amplitude do deslocamento vibratório nos modelos de CLEPE em relação aos de CC. Portanto, verifica-se que a diminuição da massa nos modelos de CLEPE diminui as forças inerciais, elevando o movimento. Os modelos destacados em negrito possuem deslocamentos maiores do que $1 \mathrm{~mm}$.

Essa observação confirma o que foi visto nos ensaios dinâmicos. Em alguns ensaios das lajes de CLEPE, o deslocamento vibratório induzido pelo impacto do martelo de borracha foi tão elevado que os acelerômetros se moviam de seus pontos de referência.

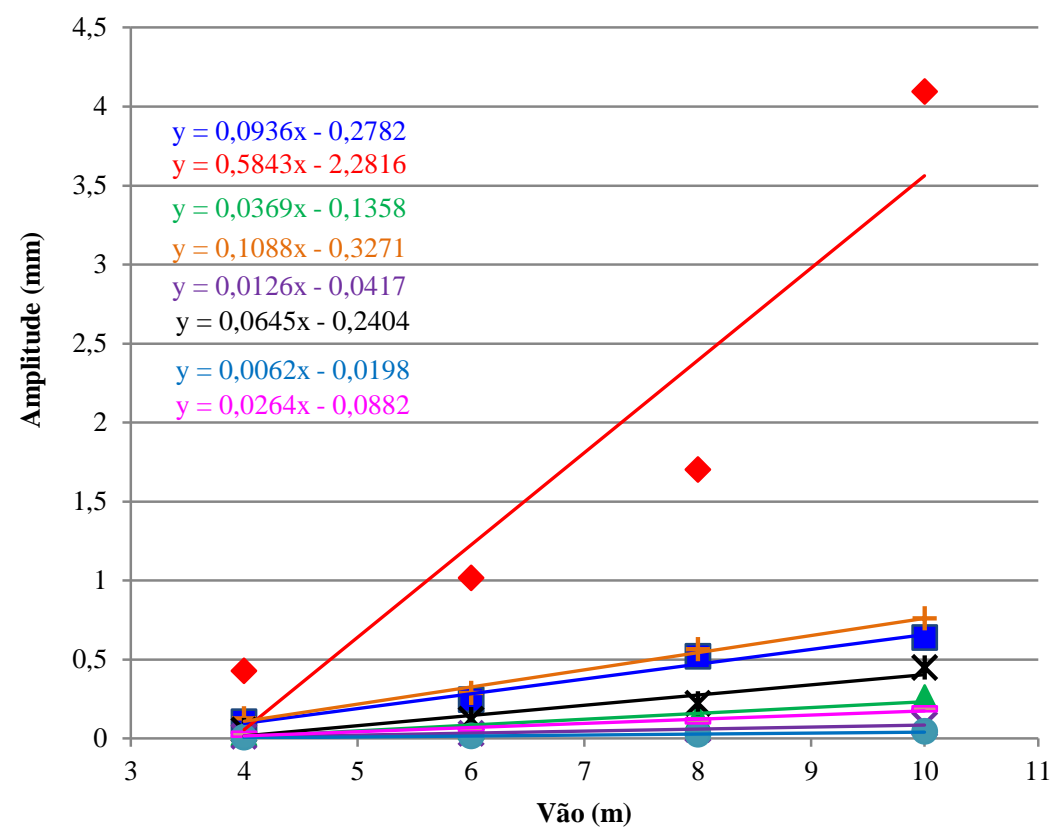

- CC - Espessura $8 \mathrm{~cm}$

- CLEPE - Espessura $8 \mathrm{~cm}$

$\triangle$ CC - Espessura $12 \mathrm{~cm}$

+ CLEPE - Espessura $12 \mathrm{~cm}$

$\times \quad$ CC - Espessura $16 \mathrm{~cm}$

× CLEPE - Espessura $16 \mathrm{~cm}$

- CC - Espessura $20 \mathrm{~cm}$

- CLEPE - Espessura $20 \mathrm{~cm}$

— Linear (CC - Espessura $8 \mathrm{~cm}$ )

— Linear (CLEPE - Espessura $8 \mathrm{~cm}$ )

— Linear (CC - Espessura $12 \mathrm{~cm}$ )

— Linear (CLEPE - Espessura $12 \mathrm{~cm}$ )

— Linear (CC - Espessura $16 \mathrm{~cm}$ )

- Linear (CLEPE - Espessura $16 \mathrm{~cm}$ )

— Linear (CC - Espessura $20 \mathrm{~cm}$ )

— Linear (CLEPE - Espessura $20 \mathrm{~cm}$ )

Figura 8.10 - Variação do deslocamento em função do vão. 
Na Tabela 8.4 são apresentados os valores de pico da velocidade para cada modelo. $\mathrm{Na}$ Figura 8.11 é ilustrada a variação da velocidade do movimento vibratório em função do vão, para cada uma das quatro espessuras de laje.

Tabela 8.4: Picos de velocidade do movimento vibratório.

\begin{tabular}{|c|c|l|c|c|l|c|}
\hline Modelo & $\begin{array}{c}\text { Velocidade } \\
\text { máxima } \\
\mathbf{( m m / s )}\end{array}$ & $\begin{array}{c}\text { Classificação } \\
\text { segundo a } \\
\text { Tabela 5.5 }\end{array}$ & Modelo & $\begin{array}{c}\text { Velocidade } \\
\text { máxima } \\
\text { (mm/s) }\end{array}$ & $\begin{array}{c}\text { Classificação } \\
\text { segundo a } \\
\text { Tabela 5.5 }\end{array}$ & $\begin{array}{c}\text { Razão de } \\
\text { aumento } \\
\text { CLEPE / CC }\end{array}$ \\
\hline CC48 & 0,375 & Pouco perceptível & CLEPE48 & 1,513 & Claramente perceptível & 4,03 \\
\hline CC412 & 0,108 & Pouco perceptível & CLEPE412 & 0,419 & Pouco perceptível & 3,88 \\
\hline CC416 & 0,045 & Pouco perceptível & CLEPE416 & 0,182 & Pouco perceptível & 4,04 \\
\hline CC420 & 0,023 & Pouco perceptível & CLEPE420 & 0,092 & Pouco perceptível & 4,00 \\
\hline CC68 & 0,950 & Pouco perceptível & CLEPE68 & 4,585 & Claramente perceptível & 4,83 \\
\hline CC612 & 0,256 & Pouco perceptível & CLEPE612 & 1,087 & Pouco perceptível & 4,25 \\
\hline CC616 & 0,105 & Pouco perceptível & CLEPE616 & 0,433 & Pouco perceptível & 4,12 \\
\hline CC620 & 0,051 & Pouco perceptível & CLEPE620 & 0,216 & Pouco perceptível & 4,24 \\
\hline CC88 & 3,604 & Claramente perceptível & CLEPE88 & 11,900 & Desagradável & 3,30 \\
\hline CC812 & 0,544 & Pouco perceptível & CLEPE812 & 3,098 & Claramente perceptível & 5,69 \\
\hline CC816 & 0,203 & Pouco perceptível & CLEPE816 & 0,926 & Pouco perceptível & 4,56 \\
\hline CC820 & 0,099 & Pouco perceptível & CLEPE820 & 0,426 & Pouco perceptível & 4,30 \\
\hline CC108 & 3,133 & Claramente perceptível & CLEPE108 & 27,140 & Intolerável & 8,66 \\
\hline CC1012 & 2,080 & Claramente perceptível & CLEPE1012 & 4,631 & Claramente perceptível & 2,23 \\
\hline CC1016 & 0,409 & Pouco perceptível & CLEPE1016 & 3,888 & Claramente perceptível & 9,51 \\
\hline CC1020 & 0,177 & Pouco perceptível & CLEPE1020 & 0,929 & Pouco perceptível & 5,25 \\
\hline
\end{tabular}

Observa-se na Tabela 8.4 que somente os modelos destacados em negrito, que possuem a primeira frequência natural maior que $10 \mathrm{~Hz}$, deveriam ser avaliados pela velocidade, conforme a Tabela 2.7. Verifica-se que os modelos de CLEPE apresentaram velocidade muito maior do que os de CC, conduzindo até a resultados desagradáveis e intoleráveis.
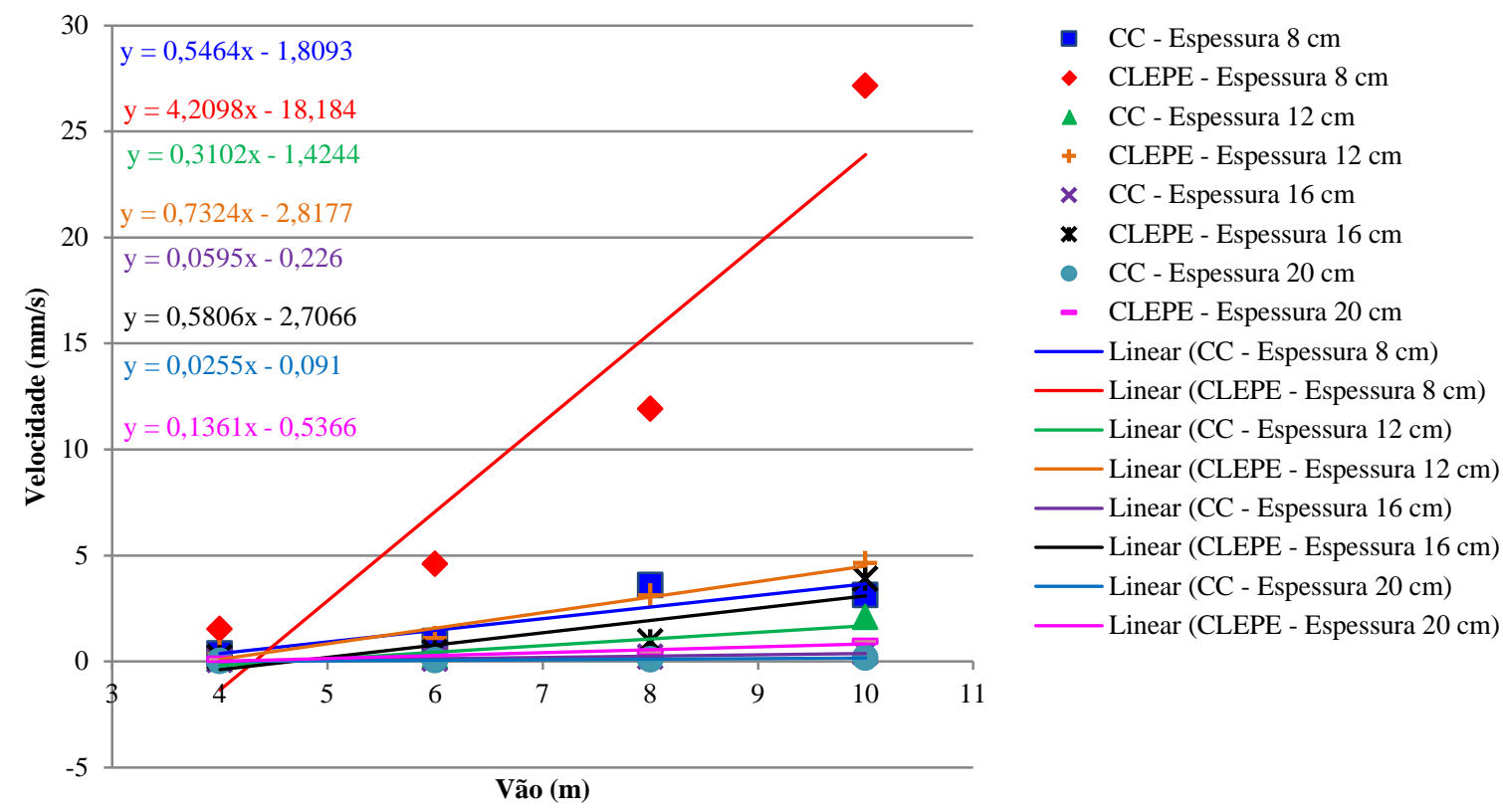

Figura 8.11 - Variação da velocidade em função do vão. 
Na Tabela 8.5 são apresentados os valores de pico da aceleração para cada modelo. Na Figura 8.12 é ilustrada a variação da aceleração do movimento vibratório em função do vão, para cada uma das quatro espessuras de laje.

Tabela 8.5: Picos de aceleração do movimento vibratório.

\begin{tabular}{|c|c|c|c|c|c|c|}
\hline Modelo & $\begin{array}{c}\text { Aceleração } \\
\text { máxima } \\
\left(\mathrm{mm} / \mathrm{s}^{2}\right)\end{array}$ & $\begin{array}{c}\text { Classificação } \\
\text { segundo a } \\
\text { Tabela } 5.5\end{array}$ & Modelo & $\begin{array}{c}\text { Aceleração } \\
\text { máxima } \\
\left(\mathrm{mm} / \mathbf{s}^{2}\right)\end{array}$ & $\begin{array}{c}\text { Classificação } \\
\text { segundo a } \\
\text { Tabela } 5.5\end{array}$ & $\begin{array}{c}\text { Razão de } \\
\text { aumento } \\
\text { CLEPE } \\
\text { CC }\end{array}$ \\
\hline CC48 & 3,552 & \begin{tabular}{|l|} 
Pouco perceptível \\
\end{tabular} & CLEPE48 & 26,620 & \begin{tabular}{|l} 
Pouco perceptível \\
\end{tabular} & 7,49 \\
\hline CC412 & 1,839 & \begin{tabular}{|l} 
Pouco perceptível \\
\end{tabular} & CLEPE412 & 22,480 & \begin{tabular}{|l} 
Pouco perceptível \\
\end{tabular} & 12,22 \\
\hline CC416 & 0,386 & \begin{tabular}{|l} 
Pouco perceptível \\
\end{tabular} & CLEPE416 & 3,259 & \begin{tabular}{|l} 
Pouco perceptível \\
\end{tabular} & 8,44 \\
\hline CC420 & 0,459 & Pouco perceptível & CLEPE420 & 1,133 & \begin{tabular}{|l|} 
Pouco perceptível \\
\end{tabular} & 2,47 \\
\hline CC68 & 13,790 & Pouco perceptível & CLEPE68 & 99,000 & Claramente perceptível & 7,18 \\
\hline CC612 & 5,317 & \begin{tabular}{|l|} 
Pouco perceptível \\
\end{tabular} & CLEPE612 & 20,680 & \begin{tabular}{|l|l} 
Pouco perceptível \\
\end{tabular} & 3,89 \\
\hline CC616 & 1,188 & \begin{tabular}{|l} 
Pouco perceptível \\
\end{tabular} & CLEPE616 & 9,433 & \begin{tabular}{|l} 
Pouco perceptível \\
\end{tabular} & 7,94 \\
\hline CC620 & 2,947 & Pouco perceptível & CLEPE620 & 3,182 & Pouco perceptível & 1,08 \\
\hline CC88 & 84,080 & \begin{tabular}{|l} 
Pouco perceptível \\
\end{tabular} & CLEPE88 & 267,000 & Claramente perceptível & 3,18 \\
\hline CC812 & 11,380 & Pouco perceptível & CLEPE812 & 69,980 & Pouco perceptível & 6,15 \\
\hline CC816 & 3,830 & \begin{tabular}{|l} 
Pouco perceptível \\
\end{tabular} & CLEPE816 & 19,450 & \begin{tabular}{|l} 
Pouco perceptível \\
\end{tabular} & 5,08 \\
\hline CC820 & 1,867 & Pouco perceptível & CLEPE820 & 8,362 & Pouco perceptível & 4,48 \\
\hline CC108 & 61,550 & \begin{tabular}{|l|} 
Pouco perceptível \\
\end{tabular} & CLEPE108 & 373,400 & Claramente perceptível & 6,07 \\
\hline CC1012 & 49,290 & Pouco perceptível & CLEPE1012 & 100,200 & Claramente perceptível & 2,03 \\
\hline CC1016 & 8,894 & \begin{tabular}{|l|} 
Pouco perceptível \\
\end{tabular} & CLEPE1016 & 92,274 & Claramente perceptível & 10,37 \\
\hline CC1020 & 3,640 & \begin{tabular}{|l|} 
Pouco perceptível \\
\end{tabular} & CLEPE1020 & 20,610 & \begin{tabular}{|l|l} 
Pouco perceptível \\
\end{tabular} & 5,66 \\
\hline
\end{tabular}

Nota-se na Tabela 8.5 que somente os modelos destacados em negrito, que possuem a primeira frequência natural menor que $10 \mathrm{~Hz}$, deveriam ser avaliados pela aceleração, conforme a Tabela 2.7. Verifica-se que os modelos de CLEPE apresentaram muito mais aceleração do que os de CC, conduzindo até a resultados claramente perceptíveis.

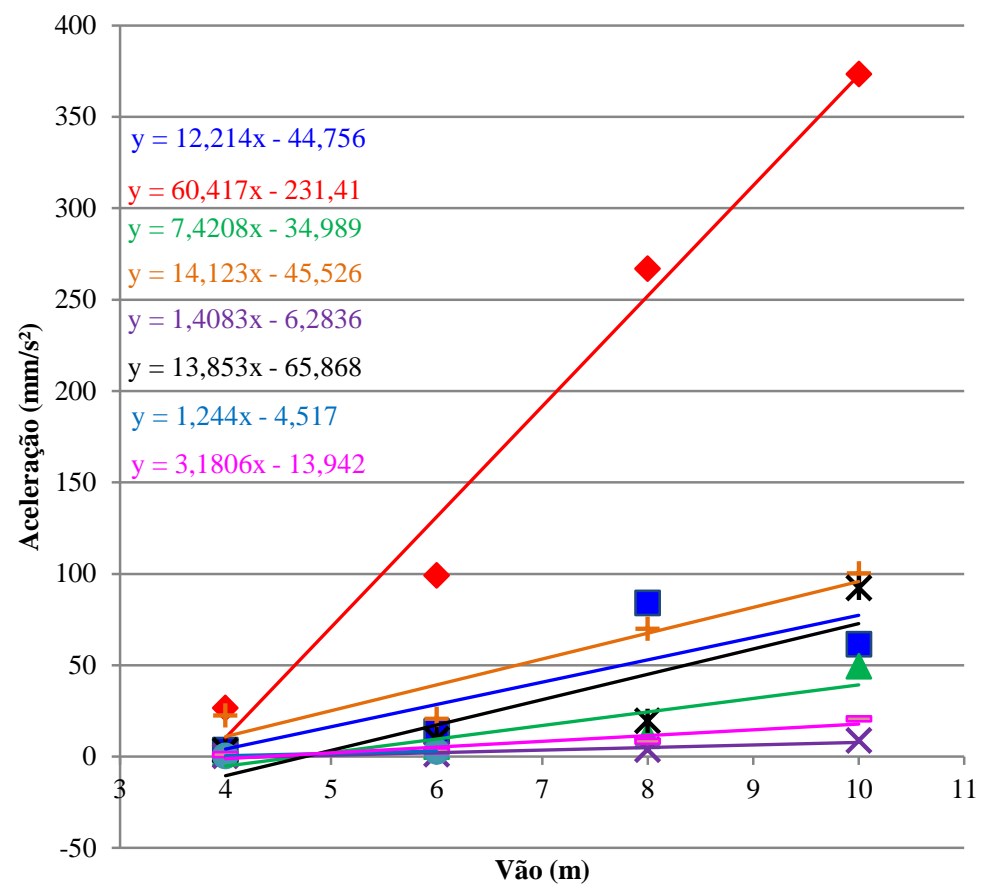

- CC - Espessura $8 \mathrm{~cm}$

- CLEPE - Espessura $8 \mathrm{~cm}$

$\triangle$ CC - Espessura $12 \mathrm{~cm}$

+ CLEPE - Espessura $12 \mathrm{~cm}$

$\times$ CC - Espessura $16 \mathrm{~cm}$

× CLEPE - Espessura $16 \mathrm{~cm}$

- CC - Espessura $20 \mathrm{~cm}$

- CLEPE - Espessura $20 \mathrm{~cm}$

— Linear (CC - Espessura $8 \mathrm{~cm}$ )

— Linear (CLEPE - Espessura $8 \mathrm{~cm}$ )

Linear (CC - Espessura $12 \mathrm{~cm}$ )

— Linear (CLEPE - Espessura $12 \mathrm{~cm}$ )

— Linear (CC - Espessura $16 \mathrm{~cm}$ )

— Linear (CLEPE - Espessura $16 \mathrm{~cm}$ )

— Linear (CC - Espessura $20 \mathrm{~cm}$ )

— Linear (CLEPE - Espessura $20 \mathrm{~cm}$ )

Figura 8.12 - Variação da aceleração em função do vão. 
Nas Figuras 8.13 a 8.20 estão ilustrados os resultados da FFT da aceleração em cada um dos modelos e as curvas-limite da ISO 2631-2 (1989) (Figura 2.32). Observa-se que os principais picos de aceleração acontecem na frequência de $2 \mathrm{~Hz}$ e de $4 \mathrm{~Hz}$, que correspondem respectivamente ao primeiro e ao segundo harmônicos considerados na formulação do carregamento. Verifica-se ainda que a soma dos valores de pico dessas frequências aproximase do valor de pico encontrado na Tabela 8.5.

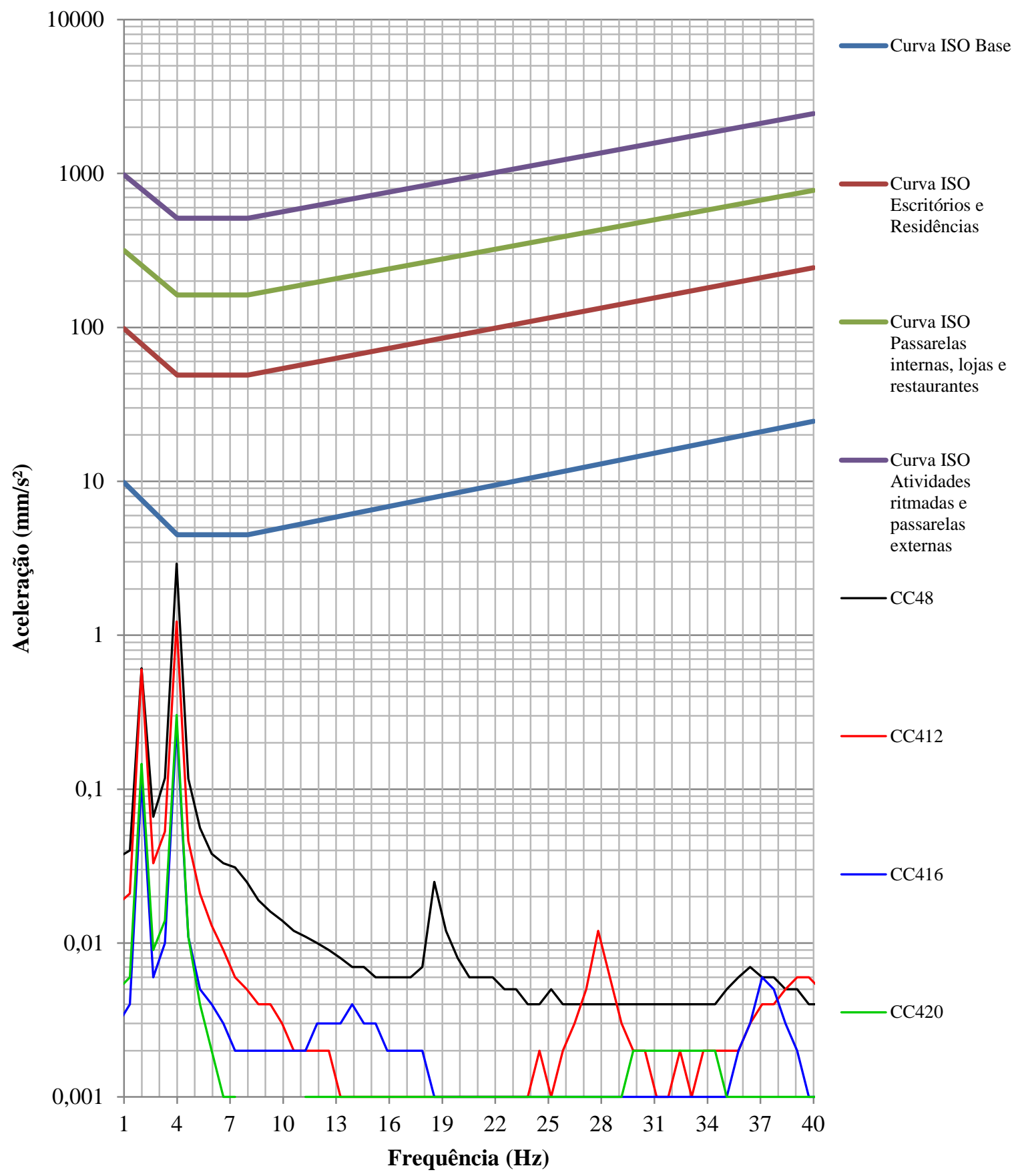

Figura 8.13 - Resultados da FFT para aceleração: dos modelos de CC, vão de 4 m. 


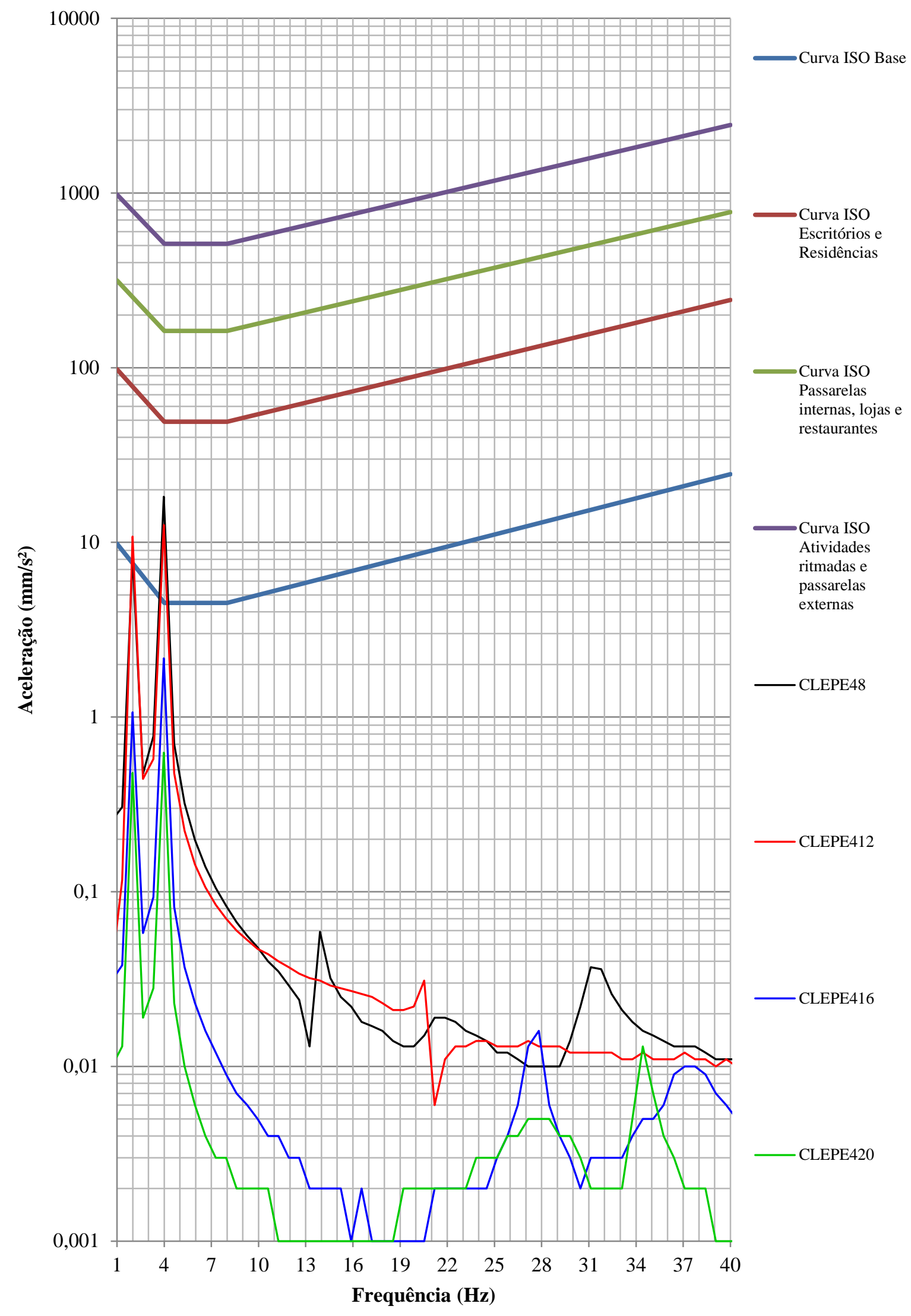

Figura 8.14 - Resultados da FFT para aceleração: dos modelos de CLEPE, vão de 4 m. 


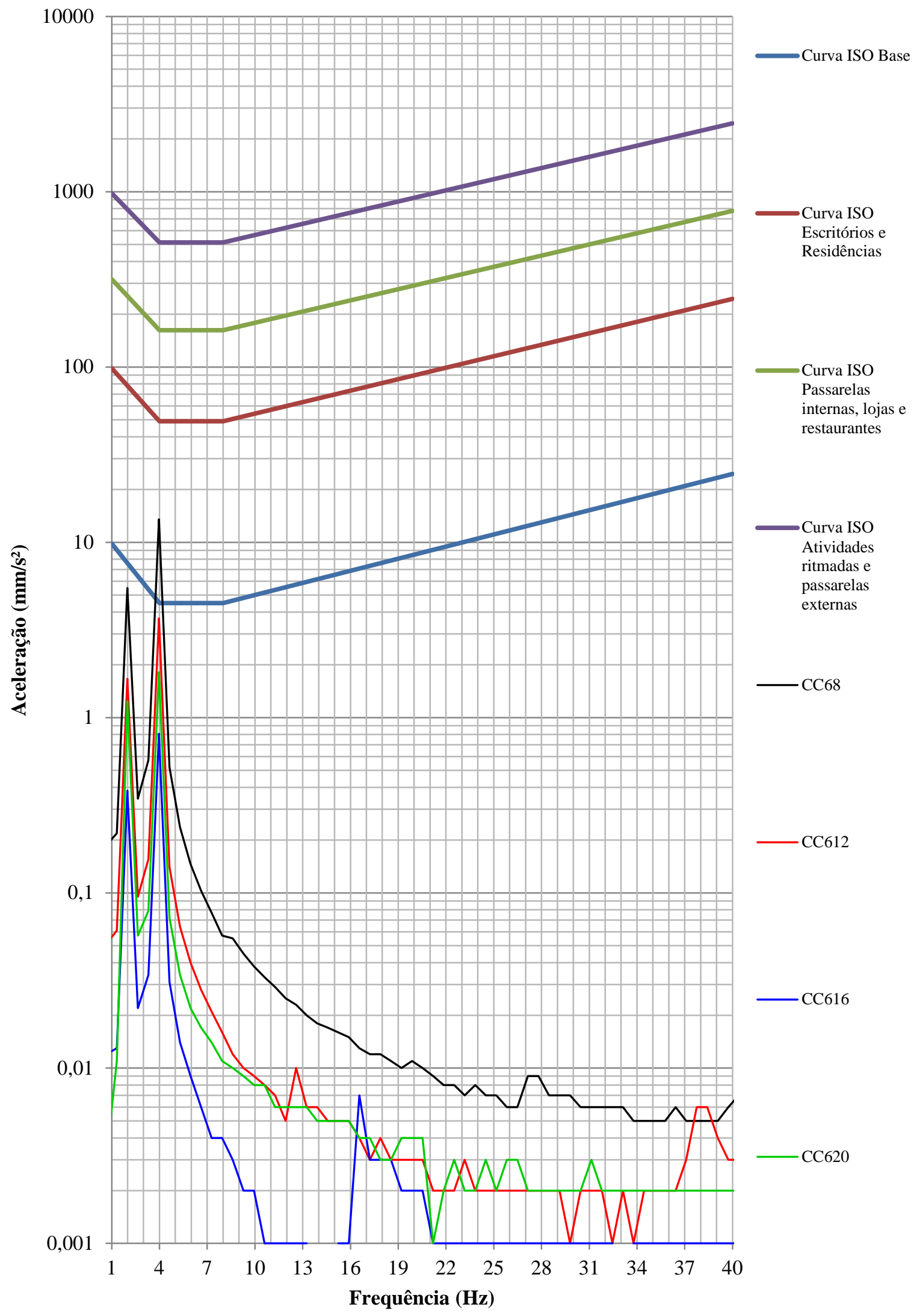

Figura 8.15 - Resultados da FFT para aceleração: dos modelos de CC, vão de 6 m. 


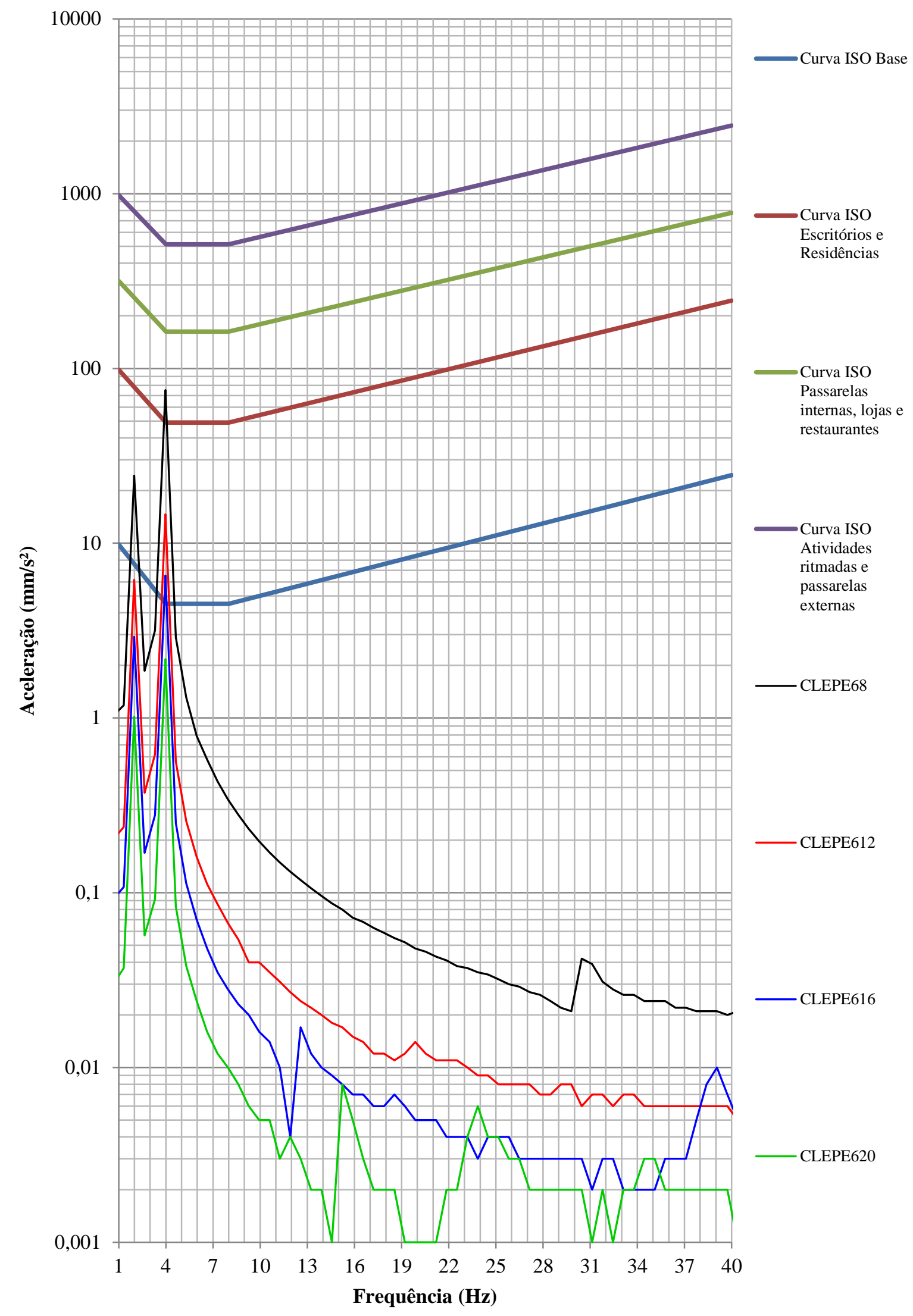

Figura 8.16 - Resultados da FFT para aceleração: dos modelos de CLEPE, vão de 6 m. 


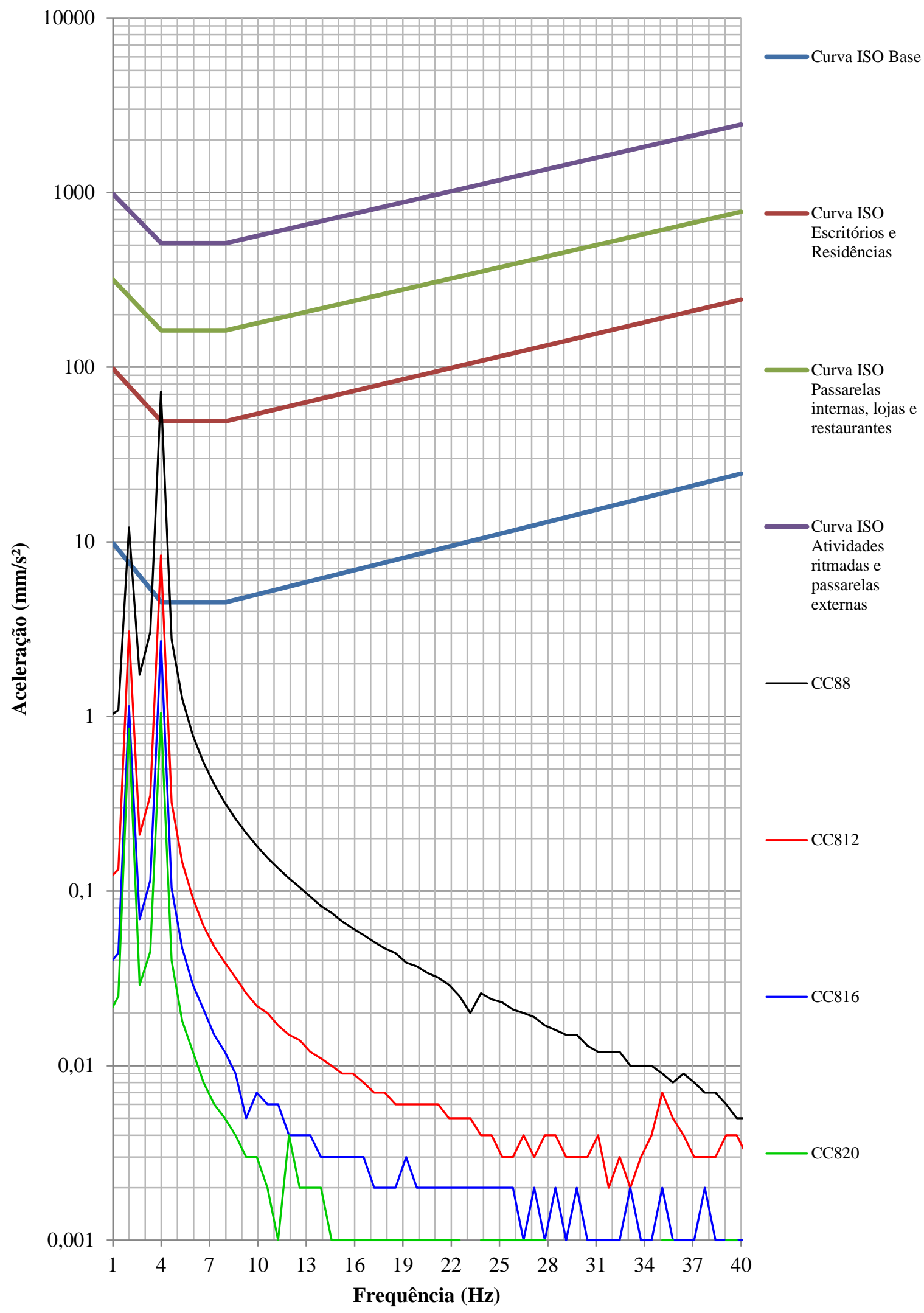

Figura 8.17 - Resultados da FFT para aceleração: dos modelos de CC, vão de 8 m. 


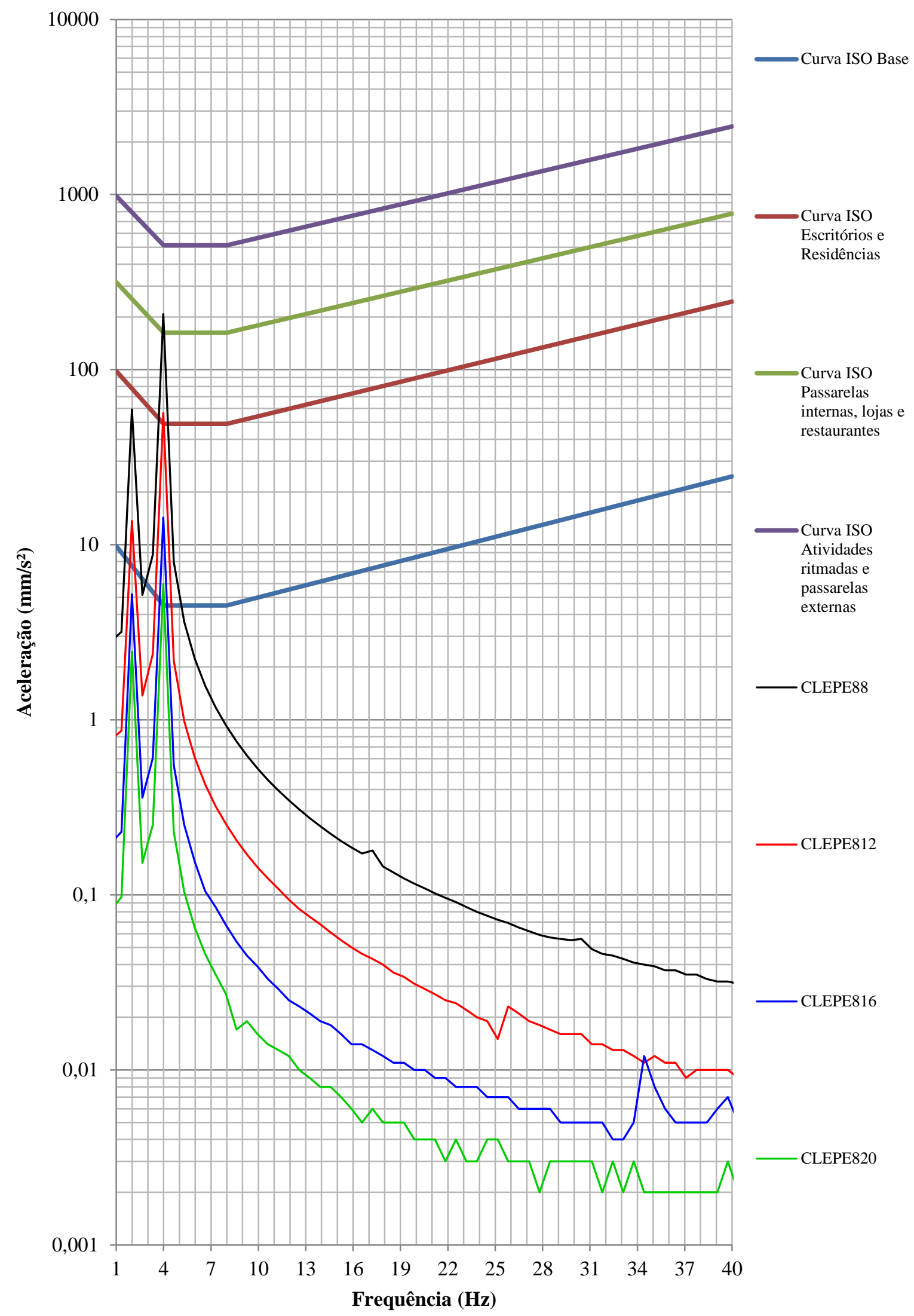

Figura 8.18 - Resultados da FFT para aceleração: dos modelos de CLEPE, vão de 8 m. 


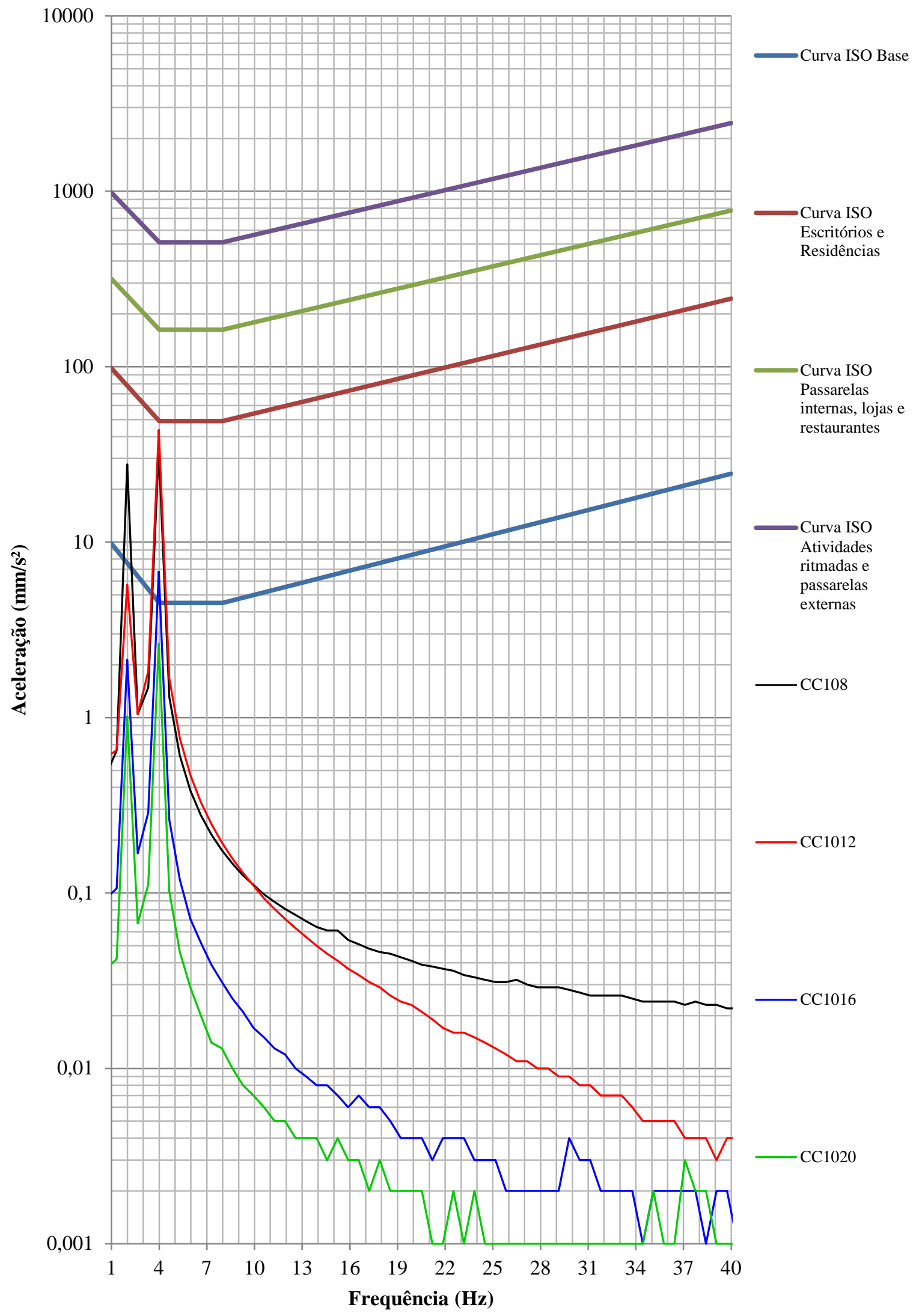

Figura 8.19 - Resultados da FFT para aceleração: dos modelos de CC, vão de 10 m. 


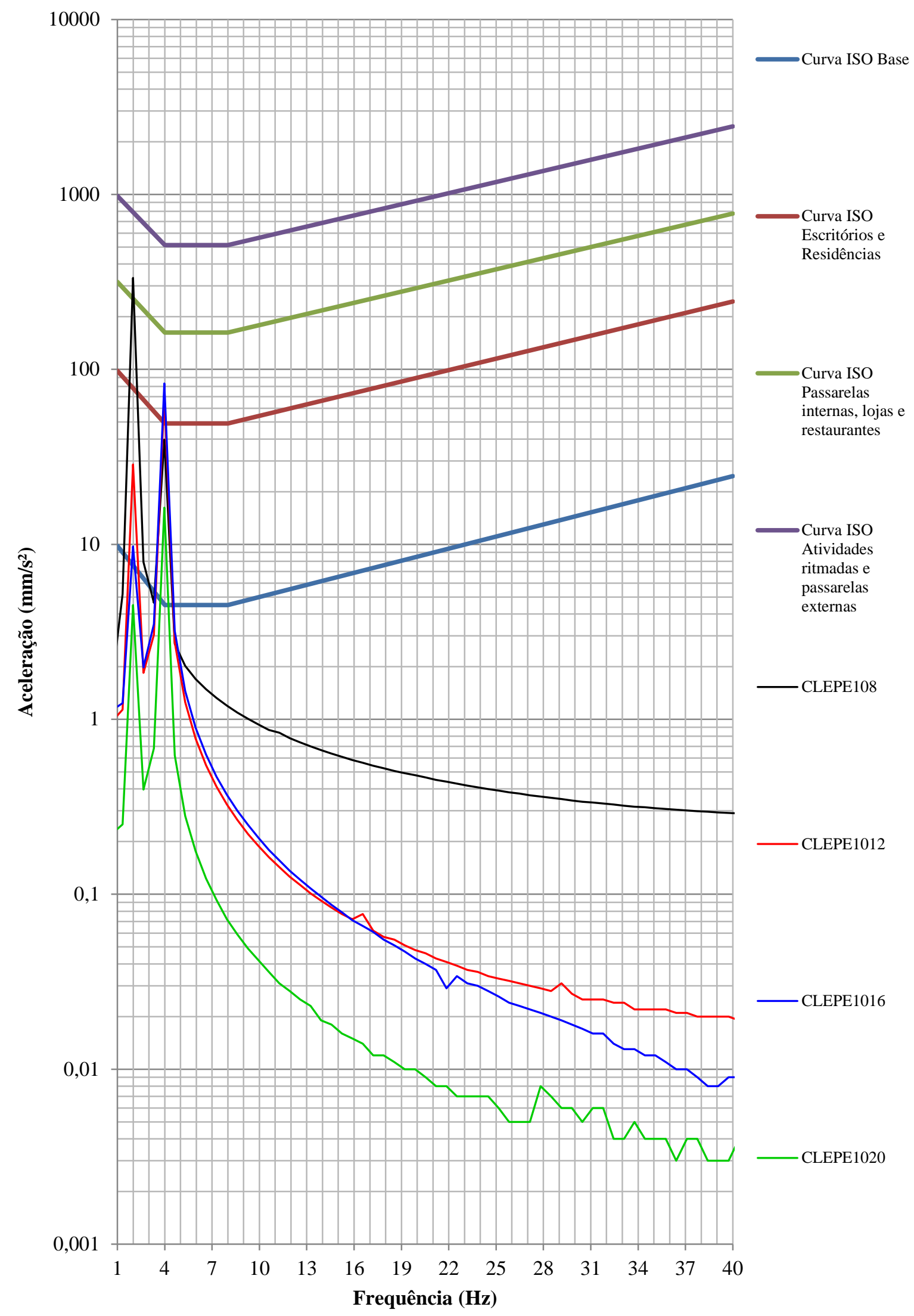

Figura 8.20 - Resultados da FFT para aceleração: dos modelos de CLEPE, vão de 10 m. 


\subsection{Análise dos resultados}

O objetivo do estudo paramétrico desenvolvido neste capítulo foi avaliar o comportamento dinâmico de lajes maciças isoladas de CC e de CLEPE, frente a uma solicitação do caminhar normal de uma pessoa com $80 \mathrm{~kg}$ de massa, no centro da laje.

Foi utilizado um carregamento periódico considerando a influência dos dois primeiros harmônicos de um movimento de caminhada com $2 \mathrm{~Hz}$ de frequência.

Observando-se os resultados obtidos, podem ser feitos os seguintes comentários:

- Na Tabela 8.2, verifica-se que as frequências naturais do CLEPE são menores que as do CC. Isso indica que a redução da rigidez do material é mais significativa do que a redução da massa. Ainda, ao serem analisadas as Figuras 8.6 a 8.9, constata-se que a variação das frequências naturais sofre influência significativa da espessura da laje e do vão, sendo que com o aumento do vão, as frequências naturais das lajes de CLEPE e de CC tendem a igualarse. Também se observa que a variação da terceira frequência natural é maior na distribuição de vão analisada, indicando que frequências naturais de modos mais elevados têm maior variação com o aumento do vão do que as primeiras. A variação das frequências naturais pode ser representada em uma parábola do segundo grau, com certa precisão;

- Da Figura 8.10, verifica-se que a variação do deslocamento do movimento vibratório da laje pode ser representada por uma reta. A Tabela 8.3 indica claramente que nos modelos em que a primeira frequência natural foi menor (Tabela 8.2), os deslocamentos foram maiores. Essa observação é válida também para a o pico de velocidade (Tabela 8.4) e o de aceleração (Tabela 8.5);

- As Figuras 8.10 a 8.12 indicam uma variação linear dos picos de deslocamento, velocidade e aceleração. Observa-se novamente que o vão e a espessura da laje contribuem para a elevação dos picos. Entre a espessura e o vão da laje, este último é o que mais influência o comportamento dinâmico das peças;

- Os deslocamentos, velocidades e acelerações das lajes de CLEPE são maiores que os de CC. Portanto, percebe-se que, para ser mantido o equilíbrio dinâmico da Equação 2.4, aconteceram dois efeitos simultâneos: com a diminuição da rigidez houve elevação do deslocamento; com a diminuição da massa houve elevação da aceleração. Esses dois efeitos combinados elevaram a velocidade do sistema. A velocidade está relacionada, na Equação 2.4, com o amortecimento. Apesar do amortecimento do CC e do CLEPE ser praticamente igual, a velocidade dos modelos de CLEPE é maior, indicando que ela sofre influência das parcelas inerciais e elásticas comandadas pela massa e pela rigidez. 
Das Figuras 8.13 a 8.20 observa-se:

- Em todas as FFT's existem dois picos de aceleração bem definidos: um na frequência de $2 \mathrm{~Hz}$ e outro na de $4 \mathrm{~Hz}$. Essas frequências são respectivamente as do primeiro e do segundo harmônicos da força excitadora. Portanto, o pico de aceleração encontrado na Tabela 8.5 equivale aproximadamente à soma dos picos de aceleração dessas duas frequências;

- Nas Figuras 8.13 a 8.15, todos os modelos verificados poderiam ser utilizados para quaisquer das atividades previstas na ISO 2631-2 (1989);

- Na Figura 8.16, o modelo CLEPE68 não está apto para utilização em escritórios e residências, devido ao segundo harmônico. Os demais modelos poderiam ser utilizados para quaisquer das atividades previstas na ISO 2631-2 (1989);

- Na Figura 8.17, o modelo CC88 não está apto para utilização em escritórios e residências, devido ao segundo harmônico. Os demais modelos poderiam ser utilizados para quaisquer das atividades previstas na ISO 2631-2 (1989);

- Na Figura 8.18, o modelo CLEPE88 não está apto para utilização em escritórios, residências e passarelas internas, devido ao segundo harmônico. O modelo CLEPE812 não está apto para utilização em escritórios e residências, devido ao segundo harmônico. Os demais modelos poderiam ser utilizados para quaisquer das atividades previstas na ISO 2631-2 (1989);

- Na Figura 8.19, o modelo CC108 está apto para utilização em escritórios e residências, quando se esperaria que o resultado fosse o contrário (modelo CC88). Entretanto, verifica-se que existe uma divisão equilibrada dos picos de aceleração entre o primeiro e segundo harmônicos, o que explica a redução de um único pico. Os demais modelos também poderiam ser utilizados para quaisquer das atividades previstas na ISO 2631-2 (1989);

- Na Figura 8.20, o modelo CLEPE108 não está apto para utilização em escritórios, residências e passarelas internas, devido ao primeiro harmônico. Os modelos CLEPE1012 e CLEPE1016 não estão aptos para utilização em escritórios e residências, devido ao segundo harmônico. O modelo CLEPE1020 poderia ser utilizado para quaisquer das atividades previstas na ISO 2631-2 (1989). 


\section{Conclusão}

Com base no objetivo geral do trabalho, que consistiu em avaliar o comportamento dinâmico de lajes maciças feitas com Concreto Leve Estrutural com Pérolas de EPS CLEPE, fazendo-se uma comparação com o comportamento dinâmico de lajes com as mesmas características, porém feitas com Concreto Convencional - CC, são apresentadas as principais conclusões.

Também são apresentadas sugestões para pesquisas futuras, tanto com ensaios dinâmicos ou estáticos, para o aperfeiçoamento da compreensão do material CLEPE ou com aplicação de qualquer outro tipo de material.

\subsection{Conclusões gerais}

Comentam-se neste item as conclusões de cunho geral em relação ao material CLEPE, aos ensaios dinâmicos de caracterização dos materiais e aos ensaios modais.

a) O CLEPE é um material que pode ser classificado como tendo propriedades dos concretos com agregados leves e também propriedades do concreto com ar incorporado. As principais relações do CLEPE com os concretos de agregados leves, quando comparados a concretos convencionais, são a baixa massa específica, o baixo módulo de elasticidade e a baixa resistência à compressão. Entretanto, o CLEPE difere dos concretos com agregados leves por ser praticamente impermeável e não apresentar agregados graúdos. A familiaridade do CLEPE com os concretos de ar incorporado, além das anteriormente mencionadas, é a presença de vazios. Considerando-se que o EPS em volume é $98 \%$ ar, uma pérola de EPS equivale a um vazio, porém, no CLEPE a permeabilidade é pequena e a absorção de água é quase nula, tendo em vista que o EPS não é absorvente; 
b) Nos ensaios dinâmicos de um mesmo concreto a dispersão dos resultados é pequena. Isso facilita a análise e confere confiabilidade aos dados medidos. Principalmente na obtenção dos valores dos módulos de elasticidade dinâmicos, a pouca variabilidade dos resultados contrasta fortemente com a intensa variação de resultados para um mesmo material, quando realizados ensaios estáticos de módulo de elasticidade. Outra vantagem sobre os ensaios estáticos é a possibilidade de redução de amostras (corpos de prova), por manter uma variação pequena entre os resultados;

d) Os elementos de contorno influenciaram de forma significativa os resultados dos ensaios do Capítulo 6;

e) A disposição de molas para simular o efeito de estrutura livre no contorno foi validada observando-se que as frequências naturais obtidas na análise experimental do Capítulo 7 são próximas às frequências teóricas numéricas;

g) As fissuras sobre os apoios, nos ensaios do Capítulo 6, influenciaram relativamente pouco as frequências naturais e os fatores de amortecimento. Verifica-se, portanto, que o dano não teve grande relevância no conjunto estrutural dos ensaios. Explica-se isso pelo fato das fissuras estarem localizadas em regiões onde teoricamente os deslocamentos, velocidades e acelerações são nulos ou muito pequenos. No entanto, as diferenças entre os resultados do $5^{\circ}$ e $6^{\circ}$ ensaios são atribuídas a elas;

h) Recomenda-se, quando o objetivo da pesquisa for avaliar as propriedades específicas do material da peça estudada, que seja realizado um ensaio modal com o mínimo de interferência externa de elementos de contorno, como os ensaios do Capítulo 7.

\subsection{Conclusões sobre as características dos materiais}

Neste item são apresentadas conclusões referentes aos resultados para módulo de elasticidade dinâmico, fator de amortecimento, massa específica e resistência à compressão.

\section{Módulo de elasticidade dinâmico}

a) A variação dos módulos de elasticidade dos materiais com o tempo é pequena;

b) Os módulos de elasticidade dos grautes são cerca de 4 GPa maiores do que os do CC das lajes. Essa diferença pode, entre outros fatores, ser atribuída à zona de transição no CC entre a matriz de argamassa e a superfície do agregado graúdo; 
c) Os módulos de elasticidade dos grautes são bem maiores do que os do CLEPE. Essa diferença é justificada pela presença do EPS no CLEPE, o que o torna um material poroso;

d) A mensuração dos módulos de elasticidade dinâmicos é imprescindível para a análise dinâmica de estruturas, sendo que sua variação é decrescente com o decréscimo da massa específica.

\section{$\underline{\text { Fator de amortecimento }}$}

e) A variação dos fatores de amortecimento de um determinado concreto é pequena, na comparação entre os resultados dos corpos de prova;

f) A variação dos fatores de amortecimento modais é maior do que entre corpos de prova no Sonelastic ${ }^{\circledR}$, porém verifica-se que, quando livres de interferências externas, os fatores de amortecimento modal possuem pequena variabilidade (Capítulo 7);

g) Novamente retoma-se o que foi discutido sobre a influência das condições de apoio, nos ensaios do Capítulo 6, sobre os dados dinâmicos das lajes. Os fatores de amortecimento dos ensaios dinâmicos das lajes do Capítulo 7 são próximos aos valores encontrados no Sonelastic ${ }^{\circledR}$, refletindo uma coerência de que as peças não estavam fissuradas. Esses valores de amortecimento estão de acordo com os valores teóricos apresentados na Tabela 2.2. Confirma-se então a hipótese levantada no item 6.2.1, de que o fator de amortecimento foi influenciado pelo comportamento conjunto de lajes com os demais elementos de contorno. Logo, não é adequado que os fatores de amortecimento apresentados nos ensaios dinâmicos do Capítulo 6 sejam considerados em uma avaliação dos materiais envolvidos. Assim sendo, os valores apresentados no Capítulo 7 são mais indicados para caracterizar os materiais;

h) Os fatores de amortecimento do CLEPE são ligeiramente maiores do que os do CC;

i) Ressalta-se que a determinação do amortecimento em estruturas não é tarefa simples, tendo em vista a facilidade desse parâmetro ser influenciado pelas condições de contorno.

\section{$\underline{\text { Massa específica }}$}

j) As massas específicas obtidas na investigação experimental atenderam ao esperado, sendo que o CLEPE apresenta valor médio de massa específica 50\% menor do que o CC. 


\section{$\underline{\text { Resistência à compressão }}$}

k) As resistências características à compressão estão dentro do esperado para os materiais com as dosagens adotadas;

l) Ressalta-se que a resistência à compressão do CLEPE do Capítulo 7 é a que melhor representa o material (cerca de $10 \mathrm{MPa}$, com peso específico de $11 \mathrm{kN} / \mathrm{m}^{3}$ ). Com essa capacidade resistente, é possível aplicar o CLEPE em lajes, painéis de vedação e até mesmo em edifícios com paredes de concreto.

\subsection{Conclusões sobre o estudo paramétrico entre lajes de CC e de CLEPE}

São aqui discutidas as conclusões referentes ao estudo paramétrico realizado no Capítulo 8.

a) As lajes com CLEPE possuem frequências naturais menores que as correspondentes de CC. Isso indica que a redução da rigidez do material é mais significativa do que a redução da massa;

b) Em lajes constata-se que a variação das frequências naturais sofre influência significativa da espessura da laje e do vão. Frequências de modos mais elevados, entretanto, são mais influenciadas pelo vão;

c) Com a elevação do vão, as lajes de CC e de CLEPE tendem a apresentar as mesmas frequências naturais;

d) Os deslocamentos, velocidades e acelerações das lajes de CLEPE são maiores que as de CC. Portanto, percebe-se que, para ser mantido o equilíbrio dinâmico indicado pela Equação 2.4, aconteceram dois efeitos simultâneos: com a diminuição da rigidez houve elevação do deslocamento; com a diminuição da massa houve elevação da aceleração. Esses dois efeitos combinados elevaram a velocidade do sistema. A velocidade está relacionada, na Equação 2.4, com o amortecimento. Apesar do amortecimento do CC e do CLEPE serem praticamente iguais, a velocidade dos modelos de CLEPE é maior, indicando que ela sofre influência das parcelas inerciais e elásticas comandadas pela massa e pela rigidez. 


\subsection{Sugestões para trabalhos futuros}

Como sugestões para trabalhos futuros utilizando técnicas dinâmicas, podem ser elencadas as seguintes opções:

I) Estudar uma correlação do módulo de elasticidade estático com o dinâmico;

II) Comparar a capacidade de isolamento acústico do CLEPE em relação à do CC;

III) Correlacionar a capacidade de isolamento acústico do CLEPE com o fator de amortecimento;

IV) Estudar a rigidez de ligações de elementos de CLEPE pré-moldados por meio da resposta dinâmica;

V) Avaliar a capacidade de resistência de estruturas com CLEPE frente a ações dinâmicas como vento e sismo;

VI) Estudar o comportamento dinâmico de lajes nervuradas com CLEPE.

\subsection{Comentários finais}

Verifica-se com a presente tese a possibilidade de aplicação do CLEPE em lajes maciças, fazendo-se a correta avaliação das vibrações (frequências naturais mínimas, deslocamentos, velocidades e acelerações).

Recomenda-se com este trabalho que, especificamente para o CLEPE estudado, quando de uma análise modal teórica (projeto estrutural), sejam adotados os seguintes valores:

- Peso específico $11 \mathrm{kN} / \mathrm{m}^{3}$;

- Resistência característica à compressão 10 MPa;

- Módulo de elasticidade dinâmico 10 GPa;

- Fator de amortecimento de $0,8 \%$ a $1 \%$ para todos os modos, considerando o conjunto de toda a estrutura;

- Fator de amortecimento de 0,4\% a 0,5\% para o CLEPE não fissurado isolado, sem interação com demais elementos estruturais.

Conclui-se finalmente que as lajes maciças de CLEPE são mais susceptíveis às vibrações do que as lajes maciças de CC, por apresentarem frequências naturais menores, deslocamentos, velocidades e acelerações maiores, apesar de seu fator de amortecimento ser ligeiramente maior que o do CC. 
Entretanto, esta última observação não invalida de forma alguma a aplicação do CLEPE, apenas destaca a necessidade de avaliação dinâmica no projeto estrutural, o que, também, espera-se que seja feito nas estruturas de CC.

O presente trabalho não esgota o estudo do CLEPE frente a ações dinâmicas. Na verdade, por ser esta uma pesquisa pioneira no estudo do CLEPE na dinâmica das estruturas, é de se esperar que, em trabalhos futuros, os conceitos, técnicas de ensaio e resultados sejam aperfeiçoados. 


\section{Referências Bibliográficas}

AÏTCIN, P. C. (2000). Concreto de alto desempenho. Tradução: SERRA, G. G. São Paulo: Pini.

ALLEMANG, R. J.; BROWN, D. L. (2002). Experimental modal analysis. In: HARRIS, C. M.; PIERSOL, A. G. Harris' shock and vibration handbook. 5.ed. New York: McGrawHill. Cap.21, p.21.1-21.72.

ALMEIDA, S. F. (2005). Análise dinâmica experimental da rigidez de elementos de concreto submetidos à danificação progressiva até a ruptura. 193f. Dissertação (Mestrado) - Escola e Engenharia de São Carlos, Universidade de São Paulo, São Carlos, 2005.

ALMEIDA, S. F. (2010). Análise experimental estática e dinâmica da rigidez de ligações viga-pilar de concreto pré-moldado. 204f. Tese (Doutorado) - Escola e Engenharia de São Carlos, Universidade de São Paulo, São Carlos, 2010.

AMERICAN CONCRETE INSTITURE (ACI). ACI 213R-87: Guide for structural lightweight aggregate concrete, 1995.

AMERICAN SOCIETY FOR TESTING AND MATERIALS (ASTM). ASTM C203: Standard test methods for breaking load and flexural properties of block-type thermal insulation. Philadelphia, 1999.

AMERICAN SOCIETY FOR TESTING AND MATERIALS (ASTM). ASTM C215-08: Standard test method for fundamental transverse, longitudinal and torsional frequencies of concrete specimens. Philadelphia, 2008.

AMERICAN SOCIETY FOR TESTING AND MATERIALS (ASTM). ASTM C597-09: Standard test method for pulse velocity through concrete. Philadelphia, 2009.

AMERICAN SOCIETY FOR TESTING AND MATERIALS (ASTM). ASTM C1611: Standard test method for slump flow of self-consolidating concrete. Philadelphia, 2006.

AMERICAN SOCIETY FOR TESTING AND MATERIALS (ASTM). ASTM C203: Standard test methods for breaking load and flexural properties of block-type thermal insulation. Philadelphia, 1999.

AMERICAN SOCIETY FOR TESTING AND MATERIALS (ASTM). C215-08: Standard test method for fundamental transverse, longitudinal and torsional frequencies of concrete specimens. Philadelphia, 2008. 
AMERICAN SOCIETY FOR TESTING AND MATERIALS (ASTM). C597-09: Standard Test Method for Pulse Velocity Through Concrete. Philadelphia, 2009.

AMERICAN SOCIETY FOR TESTING AND MATERIALS (ASTM). ASTM C1611: Standard test method for slump flow of self-consolidating concrete. Philadelphia, 2006.

AMERICAN SOCIETY FOR TESTING AND MATERIALS (ASTM). ASTM E1876-1: Standard test method for dynamic Young's modulus, shear modulus, and Poisson's ratio by impulse excitation of vibration. Philadelphia, 2005.

ANDRADE, J. J. O. (2007). Propriedades dos polímeros. In: ISAIA, G. C. Materiais de construção civil: princípios de ciência e engenharia de materiais. v.2. 1.ed. São Paulo: Ibracon. Cap.38, p.1263-1291.

ASMUSSEN, J. C. (1997). Modal analysis based on the random decrement technique: application to civil engineering structures. 227f. Thesis (Doctoral) - Department of Building and Structural Engineering, University of Aalborg, Aalborg, 1997.

ASSOCIAÇÃO BRASILEIRA DE NORMAS TÉCNICAS. NBR NM 35. Agregados leves para concreto estrutural - especificações. Rio de Janeiro, 1995.

ASSOCIAÇÃO BRASILEIRA DE NORMAS TÉCNICAS (2014). NBR 6118: Projeto de estruturas de concreto - procedimento. Rio de Janeiro.

ASSOCIAÇÃO BRASILEIRA DE NORMAS TÉCNICAS. NBR 7973: Poliestireno expandido para isolação térmica - determinação de absorção de água. Rio de Janeiro, 2007.

ASSOCIAÇÃO BRASILEIRA DE NORMAS TÉCNICAS. NBR 8081: Espuma rígida de poliuretano para fins de isolação térmica - permeabilidade ao vapor de água - método de ensaio. São Paulo, 1983.

ASSOCIAÇÃO BRASILEIRA DE NORMAS TÉCNICAS. NBR 8082: Espuma rígida de poliuretano para fins de isolação térmica - resistência à compressão - método de ensaio. São Paulo, 1983.

ASSOCIAÇÃO BRASILEIRA DE NORMAS TÉCNICAS. NBR 11752: Materiais celulares de poliestireno para isolamento térmico na construção civil e refrigeração industrial. Rio de Janeiro, 2007.

ASSOCIAÇÃO BRASILEIRA DE NORMAS TÉCNICAS. NBR 11948: Poliestireno expandido para isolação térmica - determinação da flamabilidade. Rio de Janeiro, 2007.

ASSOCIAÇÃO BRASILEIRA DE NORMAS TÉCNICAS. NBR 11949: Poliestireno expandido para isolação térmica - determinação da massa específica aparente. Rio de Janeiro, 2007.

ASSOCIAÇÃO BRASILEIRA DE NORMAS TÉCNICAS. NBR 12094: Espuma rígida de poliuretano para fins de isolação térmica - determinação da condutividade térmica - método de ensaio. Rio de Janeiro, 1991. 
ASSOCIAÇÃO BRASILEIRA DE NORMAS TÉCNICAS. NBR 15575-2: Edificações habitacionais - desempenho. Rio de Janeiro, 2013.

ASSOCIAÇÃO BRASILEIRA DO POLIESTIRENO EXPANDIDO (ABRAPEX). (2006). Manual de utilização do EPS na construção civil. São Paulo: Pini.

ASSOCIAÇÃO BRASILEIRA DO POLIESTIRENO EXPANDIDO (ABRAPEX). (2013). Resistência à compressão do EPS. São Paulo: Abrapex. Disponível em:

< http://www.abrapex.com.br/31Constra.html>. Acesso em: 23 jan. 2013.

ATCP (2012). Manual de instalação e operação - software Sonelastic ${ }^{\circledR}$ : versão 2.2. São Carlos: ATCP Engenharia Física.

BACHMANN, H. et al. (1997). Vibration problems in structures: practical guidelines. 2.ed. Berlin: Birkhäuser Verlag.

BALACHANDRAN, B.; MAGRAB, E. B. (2011). Vibrações mecânicas. São Paulo: Cengage Learning.

BARES, R. (1972). Tablas para el calculo de placas y vigas pared. Barcelona, Gustavo Gili.

BARRETT, A. R. et al. (2006). Observations from vibration testing of in-situ structures. In: Anais do Structures Congrees (ASCE), 2006, St. Louis. Anais... Reston: American Society of Civil Engineers (ASCE).

BRÜEL \& KJAER. (1988). Structural testing: modal analysis and simulation. Naerum, Denmark: Brüel \& Kjaer.

BRÜEL \& KJAER. (1989). Human vibration. Naerum, Denmark: Brüel \& Kjaer.

BRÜEL \& KJAER. (1997). The design of large impactors for structural testing: application notes. Naerum, Denmark: Brüel \& Kjaer.

BSI - BRITISH STANDARDS INSTITUTION. BS 8110-2: 1985 - Structural use of concrete - Part 2: Code of practice for special circumstances. London, UK, 2001.

CARGNELUTTI, A. L.; QUINTAS, J. P. R.; GOMES, H. M. (2011). Análise do nível de vibração em plataformas vibratórias para condicionamento físico frente à norma ISO 2631. Revista Engenharia Estudo e Pesquisa, Rio de Janeiro, v.11, n.2, p.16-27, jul-dez.

CARVALHO, R. C.; FIGUEIREDO FILHO, J. R. (2007). Cálculo e detalhamento de estruturas usuais de concreto armado. $3^{\circ}$ ed. São Carlos: Edufscar.

CASTRO, C. M. (2002). Concreto de alto desempenho: estudo da aderência com a armadura sob ações repetidas. São Carlos. 194f. Dissertação (Mestrado em Engenharia de Estruturas) - Escola de Engenharia de São Carlos da Universidade de São Paulo. São Carlos, 2002. 
CATOIA, T. (2012). Concreto Ultraleve ${ }^{\circledR}$ estrutural com pérolas de EPS: caracterização do material e estudo de sua aplicação em lajes. 154f. Tese (Doutorado) - Escola e Engenharia de São Carlos, Universidade de São Paulo, São Carlos, 2012.

CATOIA, T. et al. (2012). Concreto Ultraleve ${ }^{\circledR}$ com pérolas de EPS. In: Anais do 54 Congresso Brasileiro do Concreto, 2012, Maceió. Anais... São Paulo: Ibracon. 1 CD-ROM.

CAVALCANTI, F. S.; CARAM, R. M.; PINHEIRO, L. M. (2012). Concreto Ultraleve ${ }^{\circledR}$ em sistemas de vedação pré-moldados: sustentabilidade e conforto térmico. In: Anais do 54 Congresso Brasileiro do Concreto, 2012, Maceió. Anais... São Paulo: Ibracon. 1 CD-ROM.

CESAR, T. G; FREITAS, S. B.; SILVA, R. M. (2014). Estudo da aderência entre barras de aço e concreto leve com pérolas de poliestireno expandido (EPS). 105f. Dissertação (Graduação) - Centro Universitário Adventista de São Paulo, Campus Engenheiro Coelho, Engenheiro Coelho, 2014.

CHEN, B.; LIU, J.; CHEN, L. (2010). Experimental study of lightweight expanded polystyrene aggregate concrete containing silica fume and polypropylene fibers. J. Shanghai Jiaotong Univ. (Sci), Shanghai, v.15, n.2, p.129-137.

CHENG, F. Y. (2001). Matrix analysis of structural dynamics: applications and earthquake engineering. New York: Marcel Dekker, Inc.

CHOPRA, A. K. (2007). Dynamics of structures: theory and applications to earthquake engineering. 3ed. Upper Saddle River: Prentice Hall.

CHOWDHURY, I.; DASGUPTA, S. P. (2009). Dynamics of structure and foundation: a unified approach. London: CRC Press - Taylor \& Francis Group. v.1.

CHOWDHURY, I.; DASGUPTA, S. P. (2009). Dynamics of structure and foundation: a unified approach. London: CRC Press - Taylor \& Francis Group. v.2.

CLAEYSSEN, J.; GALLICCHIO, E.; TAMAGNA, A. (2004). Sistemas vibratórios amortecidos. Porto Alegre: Editora da Universidade Federal do Rio Grande do Sul.

CLOUGH, R. W.; PENZIEN, J. (1995). Dynamics of structures. 3.ed. Berkeley: Computers \& Structures.

COSSOLINO, L. C.; PEREIRA, A. H. A (2010). Módulos elásticos: visão geral e métodos de caracterização. São Carlos: ATCP Engenharia Física. Informativo Técnico-Científico ITC-ME/ATCP.

DIÓGENES, H. J. F. (2010). Análise tipológica de elementos e sistemas construtivos prémoldados de concreto do ponto de vista de sensibilidade a vibrações em serviço. 248f. Dissertação (Mestrado) - Escola e Engenharia de São Carlos, Universidade de São Paulo, São Carlos, 2010. 
DIÓGENES, H. J. F.; ALMEIDA, S. F.; HANAI, J. B. (2009a). Sensibilidade a vibrações em serviço de pisos formados por elementos pré-moldados de concreto tipo duplo-T. In: Anais do $51^{\circ}$ Congresso Brasileiro do Concreto, 2009, Curitiba. Anais... São Paulo: Ibracon. 1 CD-ROM.

DIÓGENES, H. J. F.; ALMEIDA, S. F.; HANAI, J. B. (2009b). Verificação de vibrações excessivas em pisos de lajes alveolares de concreto pré-fabricado. In: Anais do $2^{\circ}$ Encontro Nacional de Pesquisa-Projeto-Produção em Concreto Pré-moldado, 2009, São Carlos. Anais... São Carlos: Escola de Engenharia de São Carlos, Universidade de São Paulo. 1 CD-ROM.

DIÓGENES, H. J. F. et al. (2011). Determination of modulus of elasticity of concrete from the acoustic response. Revista IBRACON de Estruturas e Materiais, São Paulo, v.4, n.5, p.792-813, dec.

DIÓGENES, H. J. F. et al. (2012). Avaliação experimental de prismas de concreto com fibras de aço utilizando ensaios não destrutivos baseados na resposta acústica. In: Anais do $54^{\circ}$ Congresso Brasileiro do Concreto, 2012, Maceió. Anais... São Paulo: Ibracon. 1 CD-ROM.

EBRAHIMPOUR, A.; SACK, R. L. (2005). A review of vibration serviceability criteria for floor structures. Computers \& Structures, Berkeley, n.83, p.2488-2494.

EWINS, D. J. (1984). Modal testing: theory and practice. New York: John Wiley \& Sons.

EWINS, D. J. (2000). Basics and state-of-the-art of modal testing. Sãdhanã, Índia, v.25 - part 3, p.207-220.

FAISCA, R. G. (2003). Caracterização de cargas dinâmicas geradas por atividades humanas. 240f. Tese (Doutorado) - Universidade Federal do Rio de Janeiro, Rio de Janeiro, 2003.

FELÍCIO, L. C. (2007). Modelagem da dinâmica de sistemas e estudo da resposta. São Carlos: Rima.

FIGUEIREDO, E. P.; RÊGO, J. H. S. (2007). Materiais e produtos poliméricos. In: ISAIA, G. C. Materiais de construção civil: princípios de ciência e engenharia de materiais. 1.ed. São Paulo: Ibracon. Cap.40, p.1329-1354. v.2.

FRANCESCHINI, J.; GOMES, H. M. (2010). Avaliação de amortecimento estrutural usandose o método do "Random Decrement”. Revista Engenharia Estudo e Pesquisa, Santa Maria, v.10, n.1, p.39-48, jan./jun.

FUSCO, P. B. (2008). Tecnologia do concreto estrutural: tópicos aplicados. São Paulo: Pini.

GAUL, L.; SCHMIDT, A. (2007). Experimental determination and modeling of material damping. VDI-Berichte Journal, Düsseldorf, n.2003, p.17-40.

GAWRONSKI, W. K. (2004). Advanced structural dynamics and active control of structures. New York: Springer-Verlag. 
GRAEPP, A. M.; STABENOW Jr., E. (2014). Módulo de elasticidade dinâmico do concreto em função dos tipos de agregado. 91f. Dissertação (Graduação) - Centro Universitário Adventista de São Paulo, Campus Engenheiro Coelho, Engenheiro Coelho, 2014.

GRAWFORD, A. R.; GRAWFORD, S. (1992). The simplified handbook of vibration analysis. Knoxville: Computational Systems. v.1.

HANAI, J. B. (2005). Comportamento resistente, ductilidade e confinamento. In: ISAIA, G. C. Concreto: ensino, pesquisa e realizações. v.1. 1.ed. São Paulo: Ibracon. Cap.6, p.165-200.

HARRIS, C. M. (2002). Introduction to the handbook. In: HARRIS, C. M.; PIERSOL, A. G. Harris' shock and vibration handbook. 5.ed. New York: McGraw-Hill. Cap.1, p.1.1-1.27.

HE, J.; FU, Z. (2001). Modal analysis. Oxford: Butterworth Heinemann.

INMAN, D. J. (2001). Engineering vibration. 2.ed. Upper Saddle River: Prentice Hall.

INTERNATIONAL ORGANIZATION FOR STANDARDIZATION. ISO 2631-1: Mechanical vibration and shock - Evaluation of human exposure to whole body vibration Part 1: General requirements. Geneva, 1997.

INTERNATIONAL ORGANIZATION FOR STANDARDIZATION. ISO 2631-2: Evaluation of human exposure to whole body vibration - Part 2: Continuous and shockinduced vibrations in buildings (1 to $80 \mathrm{~Hz}$ ). Geneva, 1989.

INTERNATIONAL ORGANIZATION FOR STANDARDIZATION. ISO 2631-2: Mechanical Vibration and Shock - Evaluation of Human Exposure to Whole Body Vibration Part 2: vibration in buildings (1 Hz to $80 \mathrm{~Hz}$ ). Geneva, 2003.

JOAQUIM, M. B.; SARTORI, J. C. (2003) Análise de Fourier. Escola de Engenharia de São Carlos, Universidade de São Paulo. SEL/EESC/USP: São Carlos. CD-ROM.

JÖNSSON, J.; HANSEN, L. P. (1994). Man-Induced Vibrations. I Proceedings of "Dynamics of Structures". In: A WORKSHOP ON DYNAMIC LOADS AND RESPONSE OF STRUCTURES AND SOIL DYNAMICS, 1994, Denmark. Proceedings... Denmark: Aalborg University. p.1-7.

KARNOVSKY, I. A.; LEBED, O. I. (2004). Formulas for structural dynamics: tables, graphs, and solutions. New York: McGraw-Hill.

KERBAUY, M. J. (2010). Concreto estrutural ultraleve com desmoldagem rápida destinado à fabricação de placas, painéis e lajes. BR N. PI 1004268-7.

KRODKIEWSKI, J. M. (2008). Mechanical vibration. Melbourne: University of Melbourne.

KRUNKA, K. (2014). Dynamic loads induced by human motion. In: FORECAST ENGINEERING: GLOBAL CLIMATE CHANGE AND THE CHALLENGE FOR BUILT ENVIRONMENT, 2014, Weimar. Proceedings... Weimar: Bauhaus Summer School. p.1-22. 
KRYSINSKI, T.; MALBURET, F. (2007). Mechanical vibrations. London: ISTE.

LIMA, S. S.; SANTOS, S. H. C. (2008). Análise dinâmica das estruturas. Rio de Janeiro: Ciência Moderna.

LYNDON, F. D.; BALADRAN, R. V.. Some observations on elastic properties of plain concrete, Cement and Concrete Research, v.16, n.3, p. 314-24. 1986.

MALHOTRA, V. M. (1986). Testing hardened concrete: nondestructive methods. Detroit: American Concrete Institute.

MARCOS, L. K.; CARRAZEDO, R. (2014). Parametric study on the vibration sensitivity of hollow-core slabs floors. In: 9th INTERNATIONAL CONFERENCE ON STRUCTURAL DYNAMICS, 2014, Porto. Proceedings... Porto: EURODYN. p.1095-1102.

McCONNELL, K. G. (1995). Vibration testing: theory and practice. New York: John Wiley \& Sons.

MEHTA, P. K.; MONTEIRO, P. J. M. (2008). Concreto: microestrutura, propriedades e materiais. 1.ed. São Paulo: Ibracon.

MEIROVITCH, L. (2001). Fundamentals of vibrations. New York: McGraw-Hill.

MELLO, A. V. A. et al. (2007). Estudo do conforto humano em pisos mistos (aço-concreto). Revista Escola de Minas, Ouro Preto, v.60(2), p.409-418, abr-jun.

MELLO, A. V. A. et al. (2008). Dynamic analysis of composite systems made of concrete slabs and steel beams. Journal of Constructional Steel Research, Amsterdam, v.64, p.1142-1151, set. 2008.

MOMTAZI, A. S. et al. (2010). Durability of lightweight concrete EPS in salty exposure conditions. In: International Conference on Sustainable Construction Materials and Technologies, 2., 2010, Ancona. Proceedings... Ancona: Università Politecnica delle Marche. p.1-10.

MURRAY, T. M.; ALLEN, D. E.; UNGAR, E. E. (2003). Floor vibrations due to human activity. In: Steel design guide series. Washington: American Institute of Steel Construction. Cap.11, p.1-71.

MUSOLINO, B. C. (2011). Algoritmo de determinação do coeficiente de amortecimento em materiais refratários de alta alumina. 76f. Dissertação (Mestrado) - Escola de Engenharia de São Carlos, Universidade de São Paulo, São Carlos, 2011.

MÜLLER, S. M. T. et al. (2010). Estimativa de picos espectrais para composição de vetor de características de uma interface cérebro-computador. In: XVIII CONGRESSO BRASILEIRO DE AUTOMÁTICA, 2010, Curitiba. Anais... Curitiba: UFPR. p. 3794-3799.

NEVILLE, A. M. (1997). Propriedades do concreto. Tradução: GIAMMUSSO, S. E. São Paulo: Pini. 
NEVILLE, A. M.; BROOKS, J.J. (2013). Tecnologia do concreto. Tradução: CREMONINI, R. A. Porto Alegre: Bookman.

NÓBREGA, P. G. B. (2004). Análise dinâmica de estruturas de concreto: estudo experimental e numérico das condições de contorno de estruturas pré-moldadas. 285f. Tese (Doutorado) - Escola de Engenharia de São Carlos, Universidade de São Paulo, São Carlos, 2004.

OTTO BAUMGART. (2014). Disponível em:

<http://www.vedacit.com.br/images/stories/infoteca/biblioteca/folhetos/produtos/143.pdf>. Acessado em: 11 jul. 2014.

PAVIC, A.; REYNOLDS, P. (2002). Vibration serviceability of long-span concrete building floors. Part 1: Review of background information. Shock and Vibration Digest, v. 34, p. 191 - 211, 2002.

PEREIRA, A. H. A. et al. (2012). Algoritmo para determinação do amortecimento de materiais cerâmicos pela técnica das freqüências naturais de vibração via excitação por impulso. Revista Cerâmica, São Paulo, v.58, p.229-237, abr/mai/jun.

PETRUCCI, E. G. R. (1982). Concreto de cimento Portland. 9.ed. Rio de Janeiro: Globo.

PIERSOL, A. G. (2002). Concepts in vibration data analysis. In: HARRIS, C. M.; PIERSOL, A. G. Harris' shock and vibration handbook. 5.ed. New York: McGraw-Hill. Cap.22, p.22.1-22.37.

PINHEIRO, L. M. (2004). Tabelas gerais. Disponível em:

www.set.eesc.usp.br/mdidatico/concreto/Textos/. Acesso em 02 abr 2013.

PINHEIRO, L. M. (2007). Tabelas de lajes. Disponível em:

www.set.eesc.usp.br/mdidatico/concreto/Textos/. Acesso em 02 abr 2013.

POPOVICS, S. (1975). Verification of relationships between mechanical properties of concrete-like materials, Materials and Structures, v.8, n.45, p. 183-191.

PORTO, V. K. J. (2010). Análise experimental de concreto leve estrutural em função dos agregados graúdos. 92f. Monografia (Trabalho de Conclusão de Curso) - Curso de Engenharia Civil, Centro Universitário Adventista de São Paulo, Engenheiro Coelho, 2010.

RACIC, V.; PAVIC, A.; BROWNJOHN, J. M. W. (2009). Experimental identification and analytical modelling of human walking forces: Literature review. Journal of Sound and Vibration, Amsterdam, v.326, p.1-49, set. 2009.

RANDALL, R. B. (2002). Vibration analyzers and their use. In: HARRIS, C. M.; PIERSOL, A. G. Harris' shock and vibration handbook. 5.ed. New York: McGraw-Hill. Cap.14, p.14.1-14.42.

RANDALL, R. B.; TORDON, M. J. (2002). Data acquisition. In: BRAUN, S.; EWINS, D.; 
RAO, S.S., Ed. Encyclopedia of vibration. Academic Press, 2002. v.1, p.364-376.

RAO, S. S. (2011). Mechanical vibrations. 5.ed. Upper Saddle River: Prentice Hall.

RICHART JR., F. E.; HALL JR., J. R.; WOODS, R.D. (1970). Vibrations of soils and foundations. Upper Saddle River: Prentice Hall.

RODRIGUES, J. (2004). Identificação modal estocástica: métodos de análise e aplicações em estruturas de engenharia civil. 526f. Tese (Doutorado) - Laboratório Nacional de Engenharia Civil, Universidade do Porto, Porto, 2004.

ROSSIGNOLO, J. A.; AGNESINI, M. V. C. (2005). Concreto estrutural leve. In: ISAIA, G. C. Concreto: ensino, pesquisa e realizações. v.2. 1.ed. São Paulo: Ibracon. Cap.43, p.1331-1362.

ROSSIGNOLO, J. A.; AGNESINI, M. V. C. (2011). Concreto leve estrutural. In: ISAIA, G. C. Concreto: ciência e tecnologia. v.2. 1.ed. São Paulo: Ibracon. Cap.42, p.1531-1568.

ROSSIGNOLO, J. A. (2003). Concreto leve de alto desempenho modificado com SB para pré-fabricados esbeltos: dosagem, produção, propriedades e microestrutura. 220f. Tese (Doutorado) - Escola e Engenharia de São Carlos, Universidade de São Paulo, São Carlos, 2003.

ROSSIGNOLO, J. A. (2009). Concreto estrutural leve: produção, propriedades, microestrutura e aplicações. 1.ed. São Paulo: Pini.

SANT'HELENA, M. (2009). Estudo para aplicação de poliestireno expandido (EPS) em concretos e argamassas. 87f. Monografia (Trabalho de Conclusão de Curso) - Departamento de Engenharia Civil, Universidade do Extremo Sul Catarinense, Criciúma, 2009.

SBRIGHI NETO, C. (2011). Agregados naturais, britados e artificiais para concreto. In: ISAIA, G. C. Concreto: ciência e tecnologia. v.1. 1.ed. São Paulo: Ibracon. Cap.7, p.231-260.

SOTELO JR., J.; FRANÇA, L. N. F. (2006). Introdução às vibrações mecânicas. São Paulo: Blücher.

TESSARI, J. (2006). Utilização de poliestireno expandido e potencial de aproveitamento de seus resíduos na construção civil. 102f. Dissertação (Mestrado) - Programa de Pósgraduação em Engenharia Civil, Universidade Federal de Santa Catarina, Florianópolis, 2006.

THORBY, D. (2008). Structural dynamics and vibration in practice: an engineering handbook. Oxford: Butterworth Heinemann.

THOUNG, O.; GRIFFIN, M. J. (2011). The vibration discomfort of standing persons: 0.5 - $16 \mathrm{~Hz}$ fore-and-aft, lateral, and vertical vibration. Journal of Sound and Vibration, Amsterdam, v.330, p.816-826, fev. 2011.

TIMOSHENKO, S. (1937). Vibration problems in engineering. 2.ed. New York: D. Van Nostrand Company. 
TIPLER, P. A. (2000). Física: mecânica, oscilações e ondas, termodinâmica. 4.ed. Rio de Janeiro. 1v.

VIZOTTO, I.; SARTORTI, A. L. (2010). Soluções de lajes maciças, nervuradas com cuba plástica e nervuradas com vigotas treliçadas pré-moldadas: análise comparativa. Teoria e Prática na Engenharia Civil. Dunas: Rio Grande, v.10, n.15, p.19-28, Abril. Disponível em: <http://www.editoradunas.com.br/revistatpec/Art3_N15.pdf>. Acesso em: 23 jan. 2013. 


\section{APÊNDICE A - Dimensionamento da Armadura das Lajes}

Neste apêndice é determinada a armadura inferior das lajes. Elas não possuem armadura superior junto aos apoios. Isto é justificado pelo fato de elas (as armaduras superiores) não serem usadas em lajes pré-moldadas para edificações de pequeno porte. Nessas edificações, as lajes pré-moldadas são dispostas sobre as paredes e solidarizadas a elas com um graute. Assim sendo, essas lajes trabalham como simplesmente apoiadas ou com um pequeno grau de engastamento, promovido pela resistência do graute e do concreto das lajes à tração, junto à face superior das lajes, sobre os apoios, caso não haja fissuras nessa região.

\section{A.1 Lajes de concreto com densidade normal}

\section{- Carregamento}

O carregamento adotado para o dimensionamento foi o peso próprio, uma ação permanente adicional de $1 \mathrm{kN} / \mathrm{m}^{2}$ e uma ação variável de $2 \mathrm{kN} / \mathrm{m}^{2}$. Sendo assim, o carregamento para Estado Limite Último (ELU) é indicado na Equação A.1.

$$
p_{d}=p p_{k} \cdot 1,4+g_{k} \cdot 1,4+q_{k} \cdot 1,4=(1,25+1,00+2,00) \cdot 1,4=5,95 \mathrm{kN} / \mathrm{m}^{2}
$$

\section{A.1)}

Sendo:

$p_{d}$ o valor de cálculo do carregamento para ELU;

$p p_{k}$ o valor característico do peso próprio que, para uma laje de espessura $5 \mathrm{~cm}$ de concreto armado com densidade de $25 \mathrm{kN} / \mathrm{m}^{3}$, vale $1,25 \mathrm{kN} / \mathrm{m}^{2}$;

$g_{k}$ o valor característico da ação permanente adicional;

$q_{k}$ o valor característico da ação variável;

1,4 o coeficiente majorador de ações para combinação normal, segundo a ABNT NBR 6118:2014. 


\section{- Momentos fletores}

Para determinação dos momentos fletores, foi utilizada a tabela 2.3a de Pinheiro (2007), relativa a lajes simplesmente apoiadas. A Equação A.2 indica o cálculo dos momentos fletores.

$$
\begin{aligned}
& m_{x d}=\frac{\mu_{x} \cdot p_{d} \cdot \ell_{x}^{2}}{100}=\frac{5,75 \cdot 5,95 \cdot 1,50^{2}}{100}=0,77 \mathrm{kN} \cdot \mathrm{m} / \mathrm{m} \\
& m_{y d}=\frac{\mu_{y} \cdot p_{d} \cdot \ell_{x}^{2}}{100}=\frac{4,22 \cdot 5,95 \cdot 1,50^{2}}{100}=0,56 \mathrm{kN} \cdot \mathrm{m} / \mathrm{m}
\end{aligned}
$$

Sendo:

$m_{x d}$ e $m_{y d}$ os momentos fletores de cálculo em uma faixa de $100 \mathrm{~cm}$ de largura, com planos de flexão na direção x (do menor vão $\ell_{x}=1,50 \mathrm{~m}$ ) e y (do maior vão $\ell_{y}=1,80 \mathrm{~m}$ ), respectivamente;

$\mu_{x}$ e $\mu_{y}$ os coeficientes adimensionais tabelados, para cálculo dos respectivos momentos fletores (neste caso, para placas simplesmente apoiadas e relação entre os lados igual a 1,20); $\ell_{x}$ o menor vão da laje.

\section{- Altura útil}

A altura útil para cada direção é determinada pela Equação A.3.

$$
\begin{aligned}
& d_{x}=h_{\text {laje }}-c_{\text {nom }}-\frac{\phi_{\text {ref }}}{2}=5-1,5-\frac{0,5}{2}=3,25 \mathrm{~cm} \\
& d_{y}=d_{x}-\phi_{\text {ref }}=3,25-0,5=2,75 \mathrm{~cm}
\end{aligned}
$$

Sendo:

$d_{x}$ e $d_{y}$ as alturas úteis nas direções x e y respectivamente;

$h_{\text {laje }}$ a espessura da laje, adotada como $5 \mathrm{~cm}$;

$c_{\text {nom }}$ o cobrimento nominal, adotado de $1,5 \mathrm{~cm}$;

$\phi_{\text {ref }}$ o diâmetro de referência para armadura longitudinal de tração, adotado de 5 mm.

\section{- Dimensionamento por tabelas}

Para o dimensionamento, foram utilizados os parâmetros $k_{c}$ e $k_{s}$ definidos na tabela 1.1 de Pinheiro (2004). O $f_{c k}$ adotado foi de 25 MPa. As Equações A.4 e A.5 mostram o dimensionamento da armadura. 


$$
\begin{aligned}
& k_{c x}=\frac{b \cdot d_{x}^{2}}{m_{x d}}=\frac{100 \cdot 3,25^{2}}{77}=13,72 \Rightarrow \text { Domínio } 2 \Rightarrow k_{s x}=0,020(\mathrm{CA}-60) \\
& a_{s, c a l, x}=\frac{k_{s x} \cdot m_{x d}}{d_{x}}=\frac{0,020 \cdot 77}{3,25}=0,47 \mathrm{~cm}^{2} / \mathrm{m} \\
& k_{c y}=\frac{b \cdot d_{y}^{2}}{m_{y d}}=\frac{100 \cdot 2,75^{2}}{56}=13,50 \Rightarrow \text { Domínio } 2 \Rightarrow k_{s y}=0,020(\mathrm{CA}-60) \\
& a_{s, c a l, y}=\frac{k_{s y} \cdot m_{y d}}{d_{y}}=\frac{0,020.56}{2,75}=0,41 \mathrm{~cm}^{2} / \mathrm{m}
\end{aligned}
$$

Sendo:

$a_{s, c a l, x}$ e $a_{s, c a l, y}$ as áreas de aço calculadas para a faixa $b=100 \mathrm{~cm}$, nas direções x e y, respectivamente.

\section{- Armadura mínima}

A ABNT NBR 6118:2014 define, na tabela 19.1, que a armadura mínima de laje armada em duas direções deve respeitar uma taxa maior ou igual a $0,67 . \rho_{\min }$, sendo que $\rho_{\text {min }}$ é a taxa geométrica de armadura mínima contida na tabela 17.3 da mesma Norma, e para o caso em questão vale 0,15\%, considerando aço CA-50. Como o aço adotado é CA-60, deve ser adotada a taxa mecânica de armadura $\omega_{\min }=0,035$.

Sendo assim, a armadura mínima nas duas direções é determinada pela Equação A.6.

$$
\begin{aligned}
& a_{s, \min }=0,67 \cdot \omega_{\min } \cdot \frac{f_{c d}}{f_{y d}} \cdot A_{c} \\
& a_{s, \min }=0,67 \cdot 0,035 \cdot \frac{2,5 / 1,4}{60 / 1,15} \cdot(100 \cdot 5)=0,40 \mathrm{~cm}^{2} / \mathrm{m}(\mathrm{CA}-60)
\end{aligned}
$$

Sendo:

$f_{c d}$ a resistência de cálculo do concreto à compressão;

$f_{y d}$ a resistência de cálculo de escoamento de cálculo do aço;

$A_{c}$ a área da seção transversal de uma faixa de 100 cm de largura da laje.

Portanto, observa-se que a armadura calculada é maior que a mínima.

\section{- Armadura adotada}

Adotou-se uma tela Q45, cuja malha é $\phi 3,4 \mathrm{~mm}$ a cada $20 \mathrm{~cm}$, nas duas direções, totalizando uma área de 0,45cm²/m (CA-60) em cada direção. 


\section{A.2 Lajes de concreto com CLEPE}

Conforme mostrado por Catoia (2012), o dimensionamento de lajes com CLEPE pode seguir as mesmas hipóteses do concreto de densidade normal, sendo então o dimensionamento similar ao apresentado no item A.1.

\section{- Carregamento}

O carregamento adotado para o dimensionamento é o peso próprio, uma ação permanente adicional de $1 \mathrm{kN} / \mathrm{m}^{2}$ e uma ação variável de $2 \mathrm{kN} / \mathrm{m}^{2}$. Sendo assim, o carregamento para Estado Limite Último (ELU) é indicado na Equação A.7.

$$
p_{d}=p p_{k} \cdot 1,4+g_{k} \cdot 1,4+q_{k} \cdot 1,4=(0,65+1,00+2,00) \cdot 1,4=5,11 k N / m^{2} \quad \text { (Equação A.7) }
$$

Sendo:

$p_{d}$ o valor de cálculo do carregamento para ELU;

$p p_{k}$ o valor característico do peso próprio que, para uma laje de espessura $5 \mathrm{~cm}$ de concreto armado com densidade de $13 \mathrm{kN} / \mathrm{m}^{3}$, vale $0,65 \mathrm{kN} / \mathrm{m}^{2}$;

$g_{k}$ o valor característico da ação permanente adicional;

$q_{k}$ o valor característico da ação variável;

1,4 o coeficiente majorador de ações para combinação normal, segundo a ABNT NBR 6118:2014.

\section{- Momentos fletores}

Para a determinação dos momentos fletores foi utilizada a tabela 2.3a de Pinheiro (2007), referente a lajes simplesmente apoiadas. A Equação A.8 indica o cálculo dos momentos fletores.

$$
\begin{aligned}
& m_{x d}=\frac{\mu_{x} \cdot p_{d} \cdot \ell_{x}^{2}}{100}=\frac{5,75 \cdot 5,11 \cdot 1,50^{2}}{100}=0,66 \mathrm{kN} \cdot \mathrm{m} / \mathrm{m} \\
& m_{y d}=\frac{\mu_{y} \cdot p_{d} \cdot \ell_{x}^{2}}{100}=\frac{4,22 \cdot 5,11 \cdot 1,50^{2}}{100}=0,49 \mathrm{kN} \cdot \mathrm{m} / \mathrm{m}
\end{aligned}
$$

Sendo:

$m_{x d}$ e $m_{y d}$ os momentos fletores de cálculo em uma faixa de $100 \mathrm{~cm}$ de largura, com planos de flexão na direção $\mathrm{x}$ (do menor vão $=1,50 \mathrm{~m}$ ) e $\mathrm{y}$ (do maior vão $=1,80 \mathrm{~m}$ ), respectivamente; 
$\mu_{x}$ e $\mu_{y}$ os coeficientes adimensionais tabelados, para cálculo dos respectivos momentos fletores (neste caso, para placas simplesmente apoiadas e relação entre os lados igual a 1,20); $\ell_{x}$ o menor vão da laje.

\section{- Altura útil}

A altura útil para cada direção é determinada pela Equação A.9.

$$
\begin{aligned}
& d_{x}=h_{\text {laje }}-c_{\text {nom }}-\frac{\phi_{\text {ref }}}{2}=5-1,5-\frac{0,5}{2}=3,25 \mathrm{~cm} \\
& d_{y}=d_{x}-\phi_{\text {ref }}=3,25-0,5=2,75 \mathrm{~cm}
\end{aligned}
$$

Sendo:

$d_{x}$ e $d_{y}$ as alturas úteis nas direções x e y respectivamente;

$h_{\text {laje }}$ a espessura da laje adotada como $5 \mathrm{~cm}$;

$C_{\text {nom }}$ o cobrimento nominal adotado de $1,5 \mathrm{~cm}$;

$\phi_{\text {ref }}$ o diâmetro de referência para armadura longitudinal de tração adotado de 5 mm.

\section{- Dimensionamento por tabelas}

Para o dimensionamento, foram utilizados os parâmetros $k_{c}$ e $k_{s}$ definidos na tabela 1.1 de Pinheiro (2004). O $f_{c k}$ adotado foi de 14 MPa. As Equações A.10 e A.11 mostram o dimensionamento da armadura.

$$
\begin{aligned}
& k_{c x}=\frac{b \cdot d_{x}^{2}}{m_{x d}}=\frac{100 \cdot 3,25^{2}}{66}=16,00 \Rightarrow \text { Domínio } 2 \Rightarrow k_{s x}=0,020(\mathrm{CA}-60) \\
& a_{s, c a l, x}=\frac{k_{s x} \cdot m_{x d}}{d_{x}}=\frac{0,020 \cdot 66}{3,25}=0,41 \mathrm{~cm}^{2} / \mathrm{m} \\
& k_{c y}=\frac{b \cdot d_{y}^{2}}{m_{y d}}=\frac{100 \cdot 2,75^{2}}{49}=15,43 \Rightarrow \text { Domínio } 2 \Rightarrow k_{s y}=0,020(\mathrm{CA}-60) \\
& a_{s, c a l, y}=\frac{k_{s y} \cdot m_{y d}}{d_{y}}=\frac{0,020.49}{2,75}=0,36 \mathrm{~cm}^{2} / \mathrm{m}
\end{aligned}
$$

Sendo:

$a_{s, c a l, x}$ e $a_{s, c a l, y}$ as áreas de aço calculadas para a faixa $b=100 \mathrm{~cm}$, nas direções x e y, respectivamente. 


\section{- Armadura mínima}

A ABNT NBR 6118:2014 define, na tabela 19.1, que a armadura mínima de laje armada em duas direções deve respeitar uma taxa maior ou igual a $0,67 . \rho_{\min }$, sendo que $\rho_{\min }$ é a taxa geométrica de armadura mínima contida na tabela 17.3 da mesma Norma, e para o caso em questão vale 0,15\% considerando aço CA-50. Como o aço adotado é CA-60, deve ser adotada a taxa mecânica de armadura $\omega_{\min }=0,035$.

Sendo assim, a armadura mínima, nas duas direções, é obtida com a Equação A.12.

$$
\begin{aligned}
& a_{s, \min }=0,67 \cdot \omega_{\min } \cdot \frac{f_{c d}}{f_{y d}} \cdot A_{c} \\
& a_{s, \min }=0,67 \cdot 0,035 \cdot \frac{1,4 / 1,4}{60 / 1,15} \cdot(100 \cdot 5)=0,22 \mathrm{~cm}^{2} / \mathrm{m}(\mathrm{CA}-60)
\end{aligned}
$$

Sendo:

$f_{c d}$ a resistência de cálculo do concreto à compressão;

$f_{y d}$ a resistência de cálculo de escoamento de cálculo do aço;

$A_{c}$ a área da seção transversal de uma faixa de $100 \mathrm{~cm}$ de largura da laje.

Portanto, observa-se que a armadura calculada é maior que a mínima.

\section{- Armadura adotada}

Adotou-se uma tela Q45, cuja malha é $\phi 3,4 \mathrm{~mm}$ a cada $20 \mathrm{~cm}$, nas duas direções, totalizando uma área de 0,45 cm²/m (CA-60) em cada direção. 


\section{APÊNDICE B - Tabelas}

O Apêndice B destina-se a apresentar tabelas que são mencionadas ao longo do texto.

Tabela B.1: Ensaios em que cada painel de laje foi utilizado.

\begin{tabular}{|c|c|c|c|}
\hline Laje & Ensaio Dinâmico & $\begin{array}{c}\text { Ensaio Estático de Flexão } \\
\text { Bidirecional - Apêndice B }\end{array}$ & $\begin{array}{c}\text { Ensaio Estático de Força } \\
\text { Cortante - Apêndice B }\end{array}$ \\
\hline 1 & $1^{\circ} ; 2^{\circ} ; 3^{\circ} ; 4^{\circ} ; 5^{\circ}$ e $6^{\circ}$ & 1 ensaio & --- \\
\hline 2 & $2^{\circ} ; 3^{\circ} ; 4^{\circ} ; 5^{\circ}$ e $6^{\circ}$ & --- & -- \\
\hline 3 & $3^{\circ} ; 4^{\circ} ; 5^{\circ}$ e $6^{\circ}$ & --- & --- \\
\hline 4 & $4^{\circ} ; 5^{\circ}$ e $6^{\circ}$ & --- & 1 ensaio \\
\hline 5 & $5^{\circ}$ e $6^{\circ}$ & --- & --- \\
\hline 6 & Ensaio-piloto & 1 ensaio & \\
\hline
\end{tabular}

Tabela B.2: Ensaios em que cada painel de laje foi utilizado.

\begin{tabular}{|c|c|c|c|}
\hline Laje & Ensaio Dinâmico & $\begin{array}{c}\text { Ensaio Estático de Flexão } \\
\text { Bidirecional - Apêndice B }\end{array}$ & $\begin{array}{c}\text { Ensaio Estático de Força } \\
\text { Cortante - Apêndice B }\end{array}$ \\
\hline 1 & $1^{\circ} ; 2^{\circ} ; 3^{\circ} ; 4^{\circ} ; 5^{\circ}$ e $6^{\circ}$ & -- & 2 ensaios \\
\hline 2 & $2^{\circ} ; 3^{\circ} ; 4^{\circ} ; 5^{\circ}$ e $6^{\circ}$ & 1 ensaio & --- \\
\hline $3 \mathrm{a}$ & $3^{\circ} ; 4^{\circ} ; 5^{\circ} \mathrm{e} 6^{\circ}$ & 1 ensaio & 2 ensaios \\
\hline $3 \mathrm{~b}$ & $4^{\circ} ; 5^{\circ} \mathrm{e} 6^{\circ}$ & --- & 2 ensaios \\
\hline 4 & $5^{\circ} \mathrm{e} 6^{\circ}$ & --- & --- \\
\hline 6 & --- & 1 ensaio & \\
\hline
\end{tabular}

Tabela B.3: Posições dos acelerômetros em cada leitura do primeiro ensaio dinâmico.

\begin{tabular}{|c|c|c|}
\hline Leitura & Acelerômetro & Ponto de leitura na laje \\
\hline \multirow{4}{*}{1} & 1 & 1 \\
\cline { 2 - 3 } & 2 & 2 \\
\cline { 2 - 3 } & 3 & 3 \\
\hline \multirow{4}{*}{2} & 4 & 4 \\
\cline { 2 - 3 } & 1 & 1 \\
\cline { 2 - 3 } & 2 & 5 \\
\hline \multirow{4}{*}{3} & 3 & 6 \\
\cline { 2 - 3 } & 4 & 7 \\
\cline { 2 - 3 } & 1 & 1 \\
\cline { 2 - 3 } & 2 & 8 \\
\hline
\end{tabular}


Tabela B.4: Posições dos acelerômetros em cada leitura do segundo ensaio dinâmico.

\begin{tabular}{|c|c|c|c|c|c|}
\hline Leitura & $\begin{array}{l}\text { Acelerômetro } \\
\end{array}$ & Ponto de leitura na laje & Leitura & Acelerômetro & Ponto de leitura na laje \\
\hline \multirow{4}{*}{1} & 1 & 1 & \multirow{4}{*}{4} & 1 & 1 \\
\hline & 2 & 2 & & 2 & 11 \\
\hline & 3 & 3 & & 3 & 12 \\
\hline & 4 & 4 & & 4 & 13 \\
\hline \multirow{4}{*}{2} & 1 & 1 & \multirow{4}{*}{5} & 1 & 1 \\
\hline & 2 & 5 & & 2 & 14 \\
\hline & 3 & 6 & & 3 & 15 \\
\hline & 4 & 7 & & 4 & 16 \\
\hline \multirow{4}{*}{3} & 1 & 1 & \multirow{4}{*}{6} & 1 & 1 \\
\hline & 2 & 8 & & 2 & 17 \\
\hline & 3 & 9 & & 3 & 18 \\
\hline & 4 & 10 & & 4 & 16 \\
\hline
\end{tabular}

Tabela B.5: Posições dos acelerômetros em cada leitura do terceiro ensaio dinâmico.

\begin{tabular}{|c|c|c|c|c|c|c|c|c|}
\hline Leitura & Acel. & $\begin{array}{c}\text { Ponto de } \\
\text { leitura na } \\
\text { laje }\end{array}$ & Leitura & Acel. & $\begin{array}{c}\text { Ponto de } \\
\text { leitura na } \\
\text { laje }\end{array}$ & Leitura & Acel. & $\begin{array}{c}\text { Ponto de } \\
\text { leitura na } \\
\text { laje }\end{array}$ \\
\hline \multirow{4}{*}{1} & 1 & 1 & \multirow{4}{*}{4} & 1 & 1 & \multirow{4}{*}{7} & 1 & 1 \\
\hline & 2 & 2 & & 2 & 11 & & 2 & 20 \\
\hline & 3 & 3 & & 3 & 12 & & 3 & 21 \\
\hline & 4 & 4 & & 4 & 13 & & 4 & 22 \\
\hline \multirow{4}{*}{2} & 1 & 1 & \multirow{4}{*}{5} & 1 & 1 & \multirow{4}{*}{8} & 1 & 1 \\
\hline & 2 & 5 & & 2 & 14 & & 2 & 23 \\
\hline & 3 & 6 & & 3 & 15 & & 3 & 24 \\
\hline & 4 & 7 & & 4 & 16 & & 4 & 25 \\
\hline \multirow{4}{*}{3} & 1 & 1 & \multirow{4}{*}{6} & 1 & 1 & \multirow{4}{*}{9} & 1 & 1 \\
\hline & 2 & 8 & & 2 & 17 & & 2 & 26 \\
\hline & 3 & 9 & & 3 & 18 & & 3 & 27 \\
\hline & 4 & 10 & & 4 & 19 & & 4 & 25 \\
\hline
\end{tabular}

Tabela B.6: Posições dos acelerômetros em cada leitura do quarto ensaio dinâmico.

\begin{tabular}{|c|c|c|c|c|c|c|c|c|c|c|c|}
\hline Leit. & Acel. & $\begin{array}{c}\text { P. } \\
\text { Laje }\end{array}$ & Leit. & Acel. & $\begin{array}{c}P . \\
\text { Laje }\end{array}$ & Leit. & Acel. & $\begin{array}{c}\text { P. } \\
\text { Laje }\end{array}$ & Leit. & Acel. & $\begin{array}{c}\text { P. } \\
\text { Laje }\end{array}$ \\
\hline \multirow{4}{*}{1} & 1 & 1 & \multirow{4}{*}{4} & 1 & 1 & \multirow{4}{*}{7} & 1 & 1 & \multirow{4}{*}{10} & 1 & 1 \\
\hline & 2 & 2 & & 2 & 11 & & 2 & 20 & & 2 & 29 \\
\hline & 3 & 3 & & 3 & 12 & & 3 & 21 & & 3 & 30 \\
\hline & 4 & 4 & & 4 & 13 & & 4 & 22 & & 4 & 31 \\
\hline \multirow{4}{*}{2} & 1 & 1 & \multirow{4}{*}{5} & 1 & 1 & \multirow{4}{*}{8} & 1 & 1 & \multirow{4}{*}{11} & 1 & 1 \\
\hline & 2 & 5 & & 2 & 14 & & 2 & 23 & & 2 & 32 \\
\hline & 3 & 6 & & 3 & 15 & & 3 & 24 & & 3 & 33 \\
\hline & 4 & 7 & & 4 & 16 & & 4 & 25 & & 4 & 34 \\
\hline \multirow{4}{*}{3} & 1 & 1 & \multirow{4}{*}{6} & 1 & 1 & \multirow{4}{*}{9} & 1 & 1 & \multirow{4}{*}{12} & 1 & 1 \\
\hline & 2 & 8 & & 2 & 17 & & 2 & 26 & & 2 & 35 \\
\hline & 3 & 9 & & 3 & 18 & & 3 & 27 & & 3 & 36 \\
\hline & 4 & 10 & & 4 & 19 & & 4 & 28 & & 4 & 34 \\
\hline
\end{tabular}

Tabela B.7: Posições dos acelerômetros em cada leitura do quinto ensaio dinâmico

\begin{tabular}{|c|c|c|c|c|c|c|c|c|c|c|c|c|c|c|}
\hline Leit. & Acel. & $\begin{array}{c}P . \\
\text { Laje }\end{array}$ & Leit. & Acel. & $\begin{array}{c}\text { P. } \\
\text { Laje }\end{array}$ & Leit. & Acel. & $\begin{array}{c}\text { P. } \\
\text { Laje }\end{array}$ & Leit. & Acel. & $\begin{array}{c}\text { P. } \\
\text { Laje }\end{array}$ & Leit. & Acel. & $\begin{array}{c}\text { P. } \\
\text { Laje }\end{array}$ \\
\hline \multirow{4}{*}{1} & 1 & 1 & \multirow{4}{*}{4} & 1 & 1 & \multirow{4}{*}{7} & 1 & 1 & \multirow{4}{*}{10} & 1 & 1 & \multirow{4}{*}{13} & 1 & 1 \\
\hline & 2 & 2 & & 2 & 11 & & 2 & 20 & & 2 & 29 & & 2 & 38 \\
\hline & 3 & 3 & & 3 & 12 & & 3 & 21 & & 3 & 30 & & 3 & 39 \\
\hline & 4 & 4 & & 4 & 13 & & 4 & 22 & & 4 & 31 & & 4 & 40 \\
\hline \multirow{4}{*}{2} & 1 & 1 & \multirow{4}{*}{5} & 1 & 1 & \multirow{4}{*}{8} & 1 & 1 & \multirow{4}{*}{11} & 1 & 1 & \multirow{4}{*}{14} & 1 & 1 \\
\hline & 2 & 5 & & 2 & 14 & & 2 & 23 & & 2 & 32 & & 2 & 41 \\
\hline & 3 & 6 & & 3 & 15 & & 3 & 24 & & 3 & 33 & & 3 & 42 \\
\hline & 4 & 7 & & 4 & 16 & & 4 & 25 & & 4 & 34 & & 4 & 43 \\
\hline \multirow{4}{*}{3} & 1 & 1 & \multirow{4}{*}{6} & 1 & 1 & \multirow{4}{*}{9} & 1 & 1 & \multirow{4}{*}{12} & 1 & 1 & \multirow{4}{*}{15} & 1 & 1 \\
\hline & 2 & 8 & & 2 & 17 & & 2 & 26 & & 2 & 35 & & 2 & 44 \\
\hline & 3 & 9 & & 3 & 18 & & 3 & 27 & & 3 & 36 & & 3 & 45 \\
\hline & 4 & 10 & & 4 & 19 & & 4 & 28 & & 4 & 37 & & 4 & 43 \\
\hline
\end{tabular}


Tabela B.8: Desdobramento dos ECD para o CC.

\begin{tabular}{|c|c|c|c|}
\hline $\begin{array}{c}\text { Ensaio dinâmico nas } \\
\text { lajes / data }\end{array}$ & $\begin{array}{c}\text { Ensaios de caracterização } \\
\text { realizados }\end{array}$ & $\begin{array}{l}\text { Número de corpos de } \\
\text { prova }\end{array}$ & $\begin{array}{l}\text { Total de } \\
\text { ensaios }\end{array}$ \\
\hline $1^{\circ}-26 / 03 / 2014$ & Sonelastic ${ }^{\circledR}$ laje 1 & $3 \mathrm{cps} 10 \mathrm{~cm} \times 20 \mathrm{~cm}$ & 3 \\
\hline \multirow{3}{*}{$2^{\circ}-02 / 04 / 2014$} & Sonelastic $^{\circledR}$ laje 1 & $3 \mathrm{cps} 10 \mathrm{~cm} \times 20 \mathrm{~cm}$ & \multirow{3}{*}{12} \\
\hline & Sonelastic $^{\circledR Q}$ laje 2 & $3 \mathrm{cps} 10 \mathrm{~cm} \times 20 \mathrm{~cm}$ & \\
\hline & Sonelastic $^{\circledR}$ graute 1 & $6 \mathrm{cps} 5 \mathrm{~cm} \mathrm{x} 10 \mathrm{~cm}$ & \\
\hline \multirow{5}{*}{$3^{\circ}-08 / 04 / 2014$} & Sonelastic ${ }^{\circledR}$ laje 1 & $3 \mathrm{cps} 10 \mathrm{~cm} \times 20 \mathrm{~cm}$ & \multirow{5}{*}{21} \\
\hline & Sonelastic ${ }^{\circledR}$ laje 2 & $3 \mathrm{cps} 10 \mathrm{~cm} \times 20 \mathrm{~cm}$ & \\
\hline & Sonelastic $^{\circledR}$ laje 3 & $3 \mathrm{cps} 10 \mathrm{~cm} \times 20 \mathrm{~cm}$ & \\
\hline & Sonelastic ${ }^{\circledR}$ graute 1 & $6 \mathrm{cps} 5 \mathrm{~cm} \mathrm{x} 10 \mathrm{~cm}$ & \\
\hline & Sonelastic $^{(8)}$ graute 2 & $6 \mathrm{cps} 5 \mathrm{~cm} \times 10 \mathrm{~cm}$ & \\
\hline \multirow{7}{*}{$4^{\circ}-16 / 04 / 2014$} & Sonelastic ${ }^{\circledR}$ laje 1 & $3 \mathrm{cps} 10 \mathrm{~cm} \times 20 \mathrm{~cm}$ & \multirow{7}{*}{29} \\
\hline & Sonelastic ${ }^{\circledR}$ laje 2 & $3 \mathrm{cps} 10 \mathrm{~cm} \times 20 \mathrm{~cm}$ & \\
\hline & Sonelastic $^{\circledR}$ laje 3 & $3 \mathrm{cps} 10 \mathrm{~cm} \times 20 \mathrm{~cm}$ & \\
\hline & Sonelastic ${ }^{(8)}$ laje 4 & $3 \mathrm{cps} 10 \mathrm{~cm} \times 20 \mathrm{~cm}$ & \\
\hline & Sonelastic ${ }^{\circledR}$ graute 1 & $6 \mathrm{cps} 5 \mathrm{~cm} \times 10 \mathrm{~cm}$ & \\
\hline & Sonelastic ${ }^{\circledR}$ graute 2 & $6 \mathrm{cps} 5 \mathrm{~cm} \times 10 \mathrm{~cm}$ & \\
\hline & Sonelastic ${ }^{\circledR}$ graute 3 & $5 \mathrm{cps} 5 \mathrm{~cm} \times 10 \mathrm{~cm}$ & \\
\hline \multirow{9}{*}{$5^{\circ}$ e $6^{\circ}-23 / 04 / 2014$} & Sonelastic ${ }^{\circledR}$ laje 1 & $3 \mathrm{cps} 10 \mathrm{~cm} \times 20 \mathrm{~cm}$ & \multirow{9}{*}{38} \\
\hline & Sonelastic ${ }^{\circledR}$ laje 2 & $3 \mathrm{cps} 10 \mathrm{~cm} \times 20 \mathrm{~cm}$ & \\
\hline & Sonelastic $^{\circledR}$ laje 3 & $3 \mathrm{cps} 10 \mathrm{~cm} \times 20 \mathrm{~cm}$ & \\
\hline & Sonelastic ${ }^{\circledR}$ laje 4 & $3 \mathrm{cps} 10 \mathrm{~cm} \times 20 \mathrm{~cm}$ & \\
\hline & Sonelastic $^{\circledR}$ laje 5 & $3 \mathrm{cps} 10 \mathrm{~cm} \times 20 \mathrm{~cm}$ & \\
\hline & Sonelastic $^{(\mathbb{R})}$ graute 1 & $6 \mathrm{cps} 5 \mathrm{~cm} \times 10 \mathrm{~cm}$ & \\
\hline & Sonelastic ${ }^{\circledR}$ graute 2 & $6 \mathrm{cps} 5 \mathrm{~cm} \mathrm{x} 10 \mathrm{~cm}$ & \\
\hline & Sonelastic ${ }^{(1)}$ graute 3 & $5 \mathrm{cps} 5 \mathrm{~cm} \times 10 \mathrm{~cm}$ & \\
\hline & Sonelastic ${ }^{8}$ graute 4 & $6 \mathrm{cps} 5 \mathrm{~cm} \mathrm{x} 10 \mathrm{~cm}$ & \\
\hline & & Total & 103 \\
\hline
\end{tabular}

Tabela B.9: Desdobramento dos ECD para o CLEPE.

\begin{tabular}{|c|c|c|c|}
\hline $\begin{array}{c}\begin{array}{c}\text { Ensaio dinâmico nas } \\
\text { lajes / data }\end{array} \\
\end{array}$ & $\begin{array}{c}\text { Ensaios de caracterização } \\
\text { realizados }\end{array}$ & $\begin{array}{c}\text { Número de corpos de } \\
\text { prova }\end{array}$ & $\begin{array}{l}\text { Total de } \\
\text { ensaios }\end{array}$ \\
\hline $1^{\circ}-30 / 04 / 2014$ & Sonelastic ${ }^{\circledR}$ laje 1 & $4 \mathrm{cps} 10 \mathrm{~cm} \mathrm{x} 20 \mathrm{~cm}$ & 4 \\
\hline \multirow{3}{*}{$2^{\circ}-07 / 05 / 2014$} & Sonelastic ${ }^{\circledR}$ laje 1 & $4 \mathrm{cps} 10 \mathrm{~cm} \times 20 \mathrm{~cm}$ & \multirow{3}{*}{14} \\
\hline & Sonelastic $^{\circledR}$ laje 2 & $4 \mathrm{cps} 10 \mathrm{~cm} \times 20 \mathrm{~cm}$ & \\
\hline & Sonelastic $^{\circledR}$ graute 1 & $6 \mathrm{cps} 5 \mathrm{~cm} \times 10 \mathrm{~cm}$ & \\
\hline \multirow{5}{*}{$3^{\circ}-14 / 05 / 2014$} & Sonelastic ${ }^{\mathbb{Q}}$ laje 1 & $4 \mathrm{cps} 10 \mathrm{~cm} \times 20 \mathrm{~cm}$ & \multirow{5}{*}{24} \\
\hline & Sonelastic $^{\circledR}$ laje 2 & $4 \mathrm{cps} 10 \mathrm{~cm} \mathrm{x} 20 \mathrm{~cm}$ & \\
\hline & Sonelastic ${ }^{\circledR}$ laje 3a & $4 \mathrm{cps} 10 \mathrm{~cm} \times 20 \mathrm{~cm}$ & \\
\hline & Sonelastic ${ }^{\circledR}$ graute 1 & $6 \mathrm{cps} 5 \mathrm{~cm} \mathrm{x} 10 \mathrm{~cm}$ & \\
\hline & Sonelastic $^{(8)}$ graute 2 & $6 \mathrm{cps} 5 \mathrm{~cm} \times 10 \mathrm{~cm}$ & \\
\hline \multirow{7}{*}{$4^{\circ}-20 / 05 / 2014$} & Sonelastic ${ }^{\circledR}$ laje 1 & $4 \mathrm{cps} 10 \mathrm{~cm} \mathrm{x} 20 \mathrm{~cm}$ & \multirow{7}{*}{34} \\
\hline & Sonelastic ${ }^{\circledR}$ laje 2 & $4 \mathrm{cps} 10 \mathrm{~cm} \times 20 \mathrm{~cm}$ & \\
\hline & Sonelastic ${ }^{\circledR}$ laje 3a & $4 \mathrm{cps} 10 \mathrm{~cm} \times 20 \mathrm{~cm}$ & \\
\hline & Sonelastic ${ }^{(8)}$ laje 4 & $4 \mathrm{cps} 10 \mathrm{~cm} \mathrm{x} 20 \mathrm{~cm}$ & \\
\hline & Sonelastic ${ }^{\circledR}$ graute 1 & $6 \mathrm{cps} 5 \mathrm{~cm} \times 10 \mathrm{~cm}$ & \\
\hline & Sonelastic ${ }^{(8)}$ graute 2 & $6 \mathrm{cps} 5 \mathrm{~cm} \mathrm{x} 10 \mathrm{~cm}$ & \\
\hline & Sonelastic $^{\circledR}$ graute 3 & $6 \mathrm{cps} 5 \mathrm{~cm} \times 10 \mathrm{~cm}$ & \\
\hline \multirow{8}{*}{$5^{\circ}$ e $6^{\circ}-28 / 05 / 2014$} & Sonelastic ${ }^{\circledR}$ laje 1 & $4 \mathrm{cps} 10 \mathrm{~cm} \mathrm{x} 20 \mathrm{~cm}$ & \multirow{8}{*}{40} \\
\hline & Sonelastic $^{\circledR}$ laje 2 & $4 \mathrm{cps} 10 \mathrm{~cm} \times 20 \mathrm{~cm}$ & \\
\hline & Sonelastic $^{\mathbb{8}}$ laje $3^{\mathrm{a}}$ e 3b & $4 \mathrm{cps} 10 \mathrm{~cm} \times 20 \mathrm{~cm}$ & \\
\hline & Sonelastic ${ }^{\circledR}$ laje 4 & $4 \mathrm{cps} 10 \mathrm{~cm}$ x $20 \mathrm{~cm}$ & \\
\hline & Sonelastic $^{(8)}$ graute 1 & $6 \mathrm{cps} 5 \mathrm{~cm} \times 10 \mathrm{~cm}$ & \\
\hline & Sonelastic $^{\circledR}$ graute 2 & $6 \mathrm{cps} 5 \mathrm{~cm} \times 10 \mathrm{~cm}$ & \\
\hline & Sonelastic ${ }^{\circledR}$ graute 3 & $6 \mathrm{cps} 5 \mathrm{~cm} \mathrm{x} 10 \mathrm{~cm}$ & \\
\hline & Sonelastic $^{(1)}$ graute 4 & $6 \mathrm{cps} 5 \mathrm{~cm} \times 10 \mathrm{~cm}$ & \\
\hline & & Total & 116 \\
\hline
\end{tabular}

Tabela B.10: Resultados da caracterização dinâmica no dia 26/03/2014.

\begin{tabular}{|c|c|c|c|c|c|}
\hline Laje 1 & \multirow{2}{*}{ Massa (g) } & \multicolumn{2}{|c|}{ Fator de Amortecimento (x10 $\mathbf{- n}^{-\mathbf{6}}$ ) } & \multicolumn{2}{c|}{ Módulo de elasticidade (GPa) } \\
\cline { 4 - 6 } & & Flexural & Longitudinal & Flexural & Longitudinal \\
\hline CP (10 cm x 20 cm) & & 2609,5 & 2526,3 & 33,74 & 34,19 \\
\hline cp 1 & 3717,2 & 2680,0 & 2631,1 & 34,98 & 34,38 \\
\hline cp 2 & 3696,0 & 2661,9 & 2698,2 & 34,21 & 34,14 \\
\hline cp 3 & 3643,8 & $\mathbf{2 6 5 0 , 4 7}$ & $\mathbf{2 6 1 8 , 5 3}$ & $\mathbf{3 4 , 3 1}$ & $\mathbf{3 4 , 2 4}$ \\
\hline Média & $\mathbf{3 6 8 5 , 6 7}$ & &
\end{tabular}


Tabela B.11: Resultados da caracterização dinâmica no dia 02/04/2014.

\begin{tabular}{|c|c|c|c|c|c|}
\hline Laje 1 & \multirow{2}{*}{ Massa (g) } & \multicolumn{2}{|c|}{ Fator de Amortecimento $\left(\times 10^{-6}\right)$} & \multicolumn{2}{|c|}{ Módulo de elasticidade (GPa) } \\
\hline CP (10 cm x $20 \mathrm{~cm})$ & & Flexural & Longitudinal & Flexural & Longitudinal \\
\hline ср 1 & 3718,1 & 3702,3 & 2684,3 & 34,05 & 34,32 \\
\hline ср 2 & 3696,8 & 2868,6 & 2636,6 & 35,18 & 34,54 \\
\hline ср 3 & 3644,6 & 3037,0 & 2642,1 & 34,27 & 34,11 \\
\hline Média & 3686,50 & 3202,63 & 2654,33 & 34,50 & 34,32 \\
\hline Laje 2 & \multirow{2}{*}{ Massa (g) } & \multicolumn{2}{|c|}{ Fator de Amortecimento $\left(\mathrm{x}^{-6}\right)$} & \multicolumn{2}{|c|}{ Módulo de elasticidade (GPa) } \\
\hline CP (10 cm x $20 \mathrm{~cm})$ & & Flexural & Longitudinal & Flexural & Longitudinal \\
\hline cp 1 & 3610,5 & 2771,9 & 2749,3 & 32,86 & 33,01 \\
\hline ср 2 & 3597,4 & 3614,8 & 2431,5 & 33,36 & 33,11 \\
\hline ср 3 & 3656,0 & 2901,2 & 2882,6 & 33,79 & 33,05 \\
\hline Média & 3621,30 & 3095,97 & 2687,80 & 33,34 & 33,06 \\
\hline Graute 1 & \multirow{2}{*}{ Massa (g) } & \multicolumn{2}{|c|}{ Fator de Amortecimento $\left(\mathrm{x}^{-6}\right)$} & \multicolumn{2}{|c|}{ Módulo de elasticidade (GPa) } \\
\hline CP $(5 \mathrm{~cm} \times 10 \mathrm{~cm})$ & & Flexural & Longitudinal & Flexural & Longitudinal \\
\hline ср 1 & 441,4 & 5229,9 & 4113,8 & 40,48 & 39,65 \\
\hline ср 2 & 443,3 & 5760,5 & 4752,7 & 37,29 & 37,40 \\
\hline cp 3 & 441,4 & 5654,9 & 4047,9 & 39,74 & 39,08 \\
\hline ср 4 & 442,8 & 4588,2 & 3691,2 & 37,93 & 37,39 \\
\hline ср 5 & 443,3 & 5649,8 & 4748,9 & 37,67 & 38,08 \\
\hline ср 6 & 438,2 & 5069,8 & 4411,6 & 35,85 & 35,87 \\
\hline Média & 441,73 & 5325,52 & 4294,35 & 38,16 & 37,91 \\
\hline
\end{tabular}

Tabela B.12: Resultados da caracterização dinâmica no dia 09/04/2014.

\begin{tabular}{|c|c|c|c|c|c|}
\hline Laje 1 & \multirow{2}{*}{ Massa (g) } & \multicolumn{2}{|c|}{ Fator de Amortecimento $\left(\times 10^{-6}\right)$} & \multicolumn{2}{|c|}{ Módulo de elasticidade (GPa) } \\
\hline CP $(10 \mathrm{~cm} \times 20 \mathrm{~cm})$ & & Flexural & Longitudinal & Flexural & Longitudinal \\
\hline ср 1 & 3716,1 & 2683,6 & 2652,9 & 33,90 & 34,25 \\
\hline ср 2 & 3694,7 & 2569,9 & 2904,4 & 35,15 & 34,47 \\
\hline ср 3 & 3642,0 & 2790,8 & 2608,4 & 34,10 & 34,02 \\
\hline Média & 3684,27 & 2681,43 & 2721,90 & 34,38 & 34,25 \\
\hline Laje 2 & \multirow{2}{*}{ Massa (g) } & \multicolumn{2}{|c|}{ Fator de Amortecimento $\left(\mathrm{x10}^{-6}\right)$} & \multicolumn{2}{|c|}{ Módulo de elasticidade (GPa) } \\
\hline CP $(10 \mathrm{~cm} \times 20 \mathrm{~cm})$ & & Flexural & Longitudinal & Flexural & Longitudinal \\
\hline ср 1 & 3607,4 & 2681,0 & 2667,3 & 32,69 & 32,94 \\
\hline ср 2 & 3594,2 & 2601,1 & 2636,2 & 33,09 & 33,06 \\
\hline ср 3 & 3652,4 & 2377,0 & 2903,2 & 32,84 & 33,01 \\
\hline Média & 3618,00 & 2553,03 & 2735,57 & 32,87 & 33,00 \\
\hline Laje 3 & \multirow{2}{*}{ Massa (g) } & \multicolumn{2}{|c|}{ Fator de Amortecimento $\left(\mathrm{x}^{-6}\right)$} & \multicolumn{2}{|c|}{ Módulo de elasticidade (GPa) } \\
\hline CP $(10 \mathrm{~cm} \times 20 \mathrm{~cm})$ & & Flexural & Longitudinal & Flexural & Longitudinal \\
\hline ср 1 & 3599,3 & 2603,6 & 2658,0 & 30,37 & 30,07 \\
\hline ср 2 & 3566,5 & 2583,2 & 2221,1 & 31,75 & 32,21 \\
\hline ср 3 & 3611,7 & 2771,6 & 2092,1 & 32,80 & 31,77 \\
\hline Média & 3592,50 & 2652,80 & 2323,73 & 31,64 & 31,35 \\
\hline Graute 1 & \multirow{2}{*}{ Massa (g) } & \multicolumn{2}{|c|}{ Fator de Amortecimento $\left(\mathrm{x10}^{-6}\right)$} & \multicolumn{2}{|c|}{ Módulo de elasticidade (GPa) } \\
\hline CP (5 cm x $10 \mathrm{~cm})$ & & Flexural & Longitudinal & Flexural & Longitudinal \\
\hline ср 1 & 437,3 & 4496,3 & 4587,3 & 39,92 & 39,47 \\
\hline ср 2 & 439,1 & 5894,0 & 4568,2 & 36,55 & 37,12 \\
\hline ср 3 & 437,8 & 4569,9 & 4564,0 & 37,77 & 37,53 \\
\hline ср 4 & 439,8 & 5011,8 & 4469,1 & 40,05 & 39,21 \\
\hline ср 5 & 440,0 & 4318,7 & 4244,8 & 38,44 & 38,18 \\
\hline ср 6 & 434,0 & 4557,4 & 4415,2 & 35,15 & 35,67 \\
\hline Média & 438,00 & 4808,02 & 4474,77 & 37,98 & 37,86 \\
\hline Graute 2 & \multirow{2}{*}{ Massa (g) } & \multicolumn{2}{|c|}{ Fator de Amortecimento $\left(\mathrm{x}^{-6}\right)$} & \multicolumn{2}{|c|}{ Módulo de elasticidade (GPa) } \\
\hline CP (5 cm x $10 \mathrm{~cm})$ & & Flexural & Longitudinal & Flexural & Longitudinal \\
\hline ср 1 & 443,3 & 5046,4 & 4385,3 & 39,01 & 38,65 \\
\hline ср 2 & 447,4 & 4669,5 & 4497,4 & 39,93 & 39,27 \\
\hline ср 3 & 442,5 & 4741,5 & 4582,2 & 39,11 & 38,47 \\
\hline ср 4 & 445,5 & 4561,9 & 4602,3 & 40,42 & 39,53 \\
\hline ср 5 & 443,3 & 4832,2 & 4658,4 & 40,41 & 39,68 \\
\hline ср 6 & 446,0 & 5197,0 & 4493,6 & 38,42 & 38,23 \\
\hline Média & 444,67 & 4841,42 & 4536,53 & 39,55 & 38,97 \\
\hline
\end{tabular}


Tabela B.13: Resultados da caracterização dinâmica no dia 16/04/2014.

\begin{tabular}{|c|c|c|c|c|c|}
\hline Laje 1 & \multirow{2}{*}{ Massa (g) } & \multicolumn{2}{|c|}{ Fator de Amortecimento $\left(\times 10^{-6}\right)$} & \multicolumn{2}{|c|}{ Módulo de elasticidade (GPa) } \\
\hline CP $(10 \mathrm{~cm} \times 20 \mathrm{~cm})$ & & Flexural & Longitudinal & Flexural & Longitudinal \\
\hline ср 1 & 3717,2 & 2461,9 & 2447,7 & 34,10 & 34,25 \\
\hline ср 2 & 3696,2 & 2602,0 & 2388,6 & 34,73 & 34,56 \\
\hline cp 3 & 3643,7 & 2444,0 & 1892,3 & 34,51 & 34,13 \\
\hline Média & 3685,70 & 2502,63 & 2242,87 & 34,45 & 34,31 \\
\hline Laje 2 & \multirow{2}{*}{ Massa (g) } & \multicolumn{2}{|c|}{ Fator de Amortecimento $\left.\left(\mathrm{x}^{-6}\right)^{-6}\right)$} & \multicolumn{2}{|c|}{ Módulo de elasticidade (GPa) } \\
\hline CP (10 cm x $20 \mathrm{~cm})$ & & Flexural & Longitudinal & Flexural & Longitudinal \\
\hline ср 1 & 3609,2 & 2556,9 & 2418,7 & 32,88 & 32,95 \\
\hline ср 2 & 3596,0 & 3138,0 & 2367,2 & 33,34 & 33,11 \\
\hline ср 3 & 3654,0 & 2450,6 & 2876,3 & 33,06 & 33,06 \\
\hline Média & 3619,73 & 2715,17 & 2554,07 & 33,09 & 33,04 \\
\hline Laje 3 & \multirow{2}{*}{ Massa (g) } & \multicolumn{2}{|c|}{ Fator de Amortecimento $\left(\mathrm{x}^{-6}\right)$} & \multicolumn{2}{|c|}{ Módulo de elasticidade (GPa) } \\
\hline CP (10 cm x $20 \mathrm{~cm})$ & & Flexural & Longitudinal & Flexural & Longitudinal \\
\hline ср 1 & 3601,5 & 2594,3 & 2691,8 & 30,49 & 30,17 \\
\hline ср 2 & 3568,3 & 3593,0 & 2497,8 & 32,02 & 32,33 \\
\hline ср 3 & 3613,7 & 2737,7 & 2606,7 & 32,22 & 31,84 \\
\hline Média & 3594,50 & 2975,00 & 2598,77 & 31,58 & 31,45 \\
\hline Laje 4 & \multirow{2}{*}{ Massa (g) } & \multicolumn{2}{|c|}{ Fator de Amortecimento $\left.\left(\mathrm{x}^{-6}\right)^{-6}\right)$} & \multicolumn{2}{|c|}{ Módulo de elasticidade (GPa) } \\
\hline CP (10 cm x $20 \mathrm{~cm})$ & & Flexural & Longitudinal & Flexural & Longitudinal \\
\hline ср 1 & 3596,8 & 2357,6 & 2657,2 & 32,23 & 31,80 \\
\hline ср 2 & 3549,4 & 3614,6 & 2614,3 & 28,94 & 29,18 \\
\hline cp 3 & 3540,5 & 2530,9 & 2061,8 & 29,03 & 29,51 \\
\hline Média & 3562,23 & 2834,37 & 2444,43 & 30,07 & 30,16 \\
\hline Graute 1 & \multirow{2}{*}{ Massa (g) } & \multicolumn{2}{|c|}{ Fator de Amortecimento $\left.\left(\mathrm{x}^{-6}\right)^{-6}\right)$} & \multicolumn{2}{|c|}{ Módulo de elasticidade (GPa) } \\
\hline CP $(5 \mathrm{~cm} \times 10 \mathrm{~cm})$ & & Flexural & Longitudinal & Flexural & Longitudinal \\
\hline ср 1 & 437,0 & 4500,6 & 4573,2 & 40,22 & 39,81 \\
\hline ср 2 & 438,6 & 4754,9 & 4420,6 & 36,88 & 37,49 \\
\hline ср 3 & 437,2 & 4543,2 & 4442,6 & 37,99 & 37,74 \\
\hline ср 4 & 439,3 & 4484,8 & 4319,2 & 40,39 & 39,51 \\
\hline cp 5 & 439,4 & 4362,6 & 4202,5 & 38,68 & 38,40 \\
\hline ср 6 & 433,4 & 4774,4 & 3795,5 & 35,49 & 35,97 \\
\hline Média & 437,48 & 4570,08 & 4292,27 & 38,28 & 38,15 \\
\hline Graute 2 & \multirow{2}{*}{ Massa (g) } & \multicolumn{2}{|c|}{ Fator de Amortecimento $\left(\mathrm{x10}^{-6}\right)$} & \multicolumn{2}{|c|}{ Módulo de elasticidade (GPa) } \\
\hline $\mathrm{CP}(5 \mathrm{~cm} \times 10 \mathrm{~cm})$ & & Flexural & Longitudinal & Flexural & Longitudinal \\
\hline ср 1 & 441,1 & 4644,2 & 4457,2 & 39,30 & 39,03 \\
\hline ср 2 & 445,3 & 4465,6 & 4190,9 & 40,33 & 39,75 \\
\hline ср 3 & 440,4 & 5657,0 & 4649,4 & 39,35 & 38,94 \\
\hline ср 4 & 443,5 & 4706,0 & 4890,1 & 40,79 & 40,07 \\
\hline ср 5 & 441,4 & 4480,8 & 4952,9 & 40,82 & 40,26 \\
\hline ср 6 & 443,5 & 4991,9 & 4330,7 & 39,00 & 38,61 \\
\hline Média & 442,53 & 4824,25 & 4578,53 & 39,93 & 39,44 \\
\hline Graute 3 & \multirow{2}{*}{ Massa (g) } & \multicolumn{2}{|c|}{ Fator de Amortecimento $\left(\mathrm{x}^{-6}\right)$} & \multicolumn{2}{|c|}{ Módulo de elasticidade (GPa) } \\
\hline CP $(5 \mathrm{~cm} \times 10 \mathrm{~cm})$ & & Flexural & Longitudinal & Flexural & Longitudinal \\
\hline ср 1 & 438,1 & 5243,2 & 4708,4 & 38,30 & 37,70 \\
\hline ср 2 & 440,3 & 4530,3 & 4347,6 & 38,62 & 37,76 \\
\hline ср 3 & 439,9 & 5350,1 & 4635,0 & 37,80 & 37,17 \\
\hline ср 4 & 439,0 & 4839,6 & 5022,2 & 38,09 & 37,13 \\
\hline ср 5 & 439,4 & 5159,3 & 4749,0 & 37,91 & 37,46 \\
\hline Média & 439,34 & 5024,50 & 4692,44 & 38,14 & 37,44 \\
\hline
\end{tabular}

Tabela B.14: Resultados da caracterização dinâmica no dia 23/04/2014.

\begin{tabular}{|c|c|c|c|c|c|}
\hline Laje 1 & \multirow{2}{*}{ Massa (g) } & \multicolumn{2}{|c|}{ Fator de Amortecimento $\left(\times 10^{-6}\right)$} & \multicolumn{2}{|c|}{ Módulo de elasticidade (GPa) } \\
\hline $\mathrm{CP}(10 \mathrm{~cm} \times 20 \mathrm{~cm})$ & & Flexural & Longitudinal & Flexural & Longitudinal \\
\hline ср 1 & 3669,7 & 2883,2 & 2933,3 & 35,39 & 34,91 \\
\hline ср 2 & 3639,4 & 2721,2 & 2717,0 & 36,59 & 35,10 \\
\hline ср 3 & 3610,4 & 2275,1 & 2356,1 & 35,19 & 34,52 \\
\hline Média & 3639,83 & 2626,50 & 2668,80 & 35,72 & 34,84 \\
\hline Laje 2 & \multirow{2}{*}{ Massa (g) } & \multicolumn{2}{|c|}{ Fator de Amortecimento $\left.\left(\mathrm{x}^{-6}\right)^{-6}\right)$} & \multicolumn{2}{|c|}{ Módulo de elasticidade (GPa) } \\
\hline CP (10 cm x $20 \mathrm{~cm})$ & & Flexural & Longitudinal & Flexural & Longitudinal \\
\hline ср 1 & 3570,6 & 3679,6 & 3392,6 & 34,16 & 33,53 \\
\hline ср 2 & 3561,9 & 3225,9 & 2826,6 & 34,20 & 33,54 \\
\hline ср 3 & 3577,4 & 2330,8 & 2544,4 & 34,77 & 33,91 \\
\hline Média & 3569,97 & 3078,77 & 2921,20 & 34,38 & 33,66 \\
\hline
\end{tabular}




\begin{tabular}{|c|c|c|c|c|c|}
\hline Laje 3 & \multirow{2}{*}{ Massa (g) } & \multicolumn{2}{|c|}{ Fator de Amortecimento $\left(\times 10^{-6}\right)$} & \multicolumn{2}{|c|}{ Módulo de elasticidade (GPa) } \\
\hline CP $(10 \mathrm{~cm} \times 20 \mathrm{~cm})$ & & Flexural & Longitudinal & Flexural & Longitudinal \\
\hline ср 1 & 3555,9 & 3100,1 & 2881,4 & 30,42 & 30,65 \\
\hline cp 2 & 3541,1 & 3079,1 & 2732,2 & 32,59 & 32,54 \\
\hline ср 3 & 3565,5 & 3487,8 & 2774,2 & 33,33 & 32,37 \\
\hline Média & 3554,17 & 2195,97 & 2795,93 & 32,11 & 31,85 \\
\hline Laje 4 & \multirow{2}{*}{ Massa (g) } & \multicolumn{2}{|c|}{ Fator de Amortecimento $\left(\mathrm{x10}^{-6}\right)$} & \multicolumn{2}{|c|}{ Módulo de elasticidade (GPa) } \\
\hline CP $(10 \mathrm{~cm} \times 20 \mathrm{~cm})$ & & Flexural & Longitudinal & Flexural & Longitudinal \\
\hline ср 1 & 3549,4 & 3076,5 & 2790,9 & 33,61 & 32,38 \\
\hline ср 2 & 3511,4 & 2864,9 & 2825,3 & 30,09 & 29,70 \\
\hline ср 3 & 3445,7 & 2383,3 & 2658,1 & 30,67 & 30,46 \\
\hline Média & 3502,17 & 2774,90 & 2758,10 & 31,46 & 30,85 \\
\hline Laje 5 & \multirow{2}{*}{ Massa (g) } & \multicolumn{2}{|c|}{ Fator de Amortecimento $\left(\mathrm{x10}^{-6}\right)$} & \multicolumn{2}{|c|}{ Módulo de elasticidade (GPa) } \\
\hline CP $(10 \mathrm{~cm} \times 20 \mathrm{~cm})$ & & Flexural & Longitudinal & Flexural & Longitudinal \\
\hline ср 1 & 3552,9 & 1792,9 & 2785,0 & 32,04 & 31,02 \\
\hline ср 2 & 3563,7 & 2362,8 & 2509,7 & 32,97 & 31,76 \\
\hline ср 3 & 3534,4 & & & 32,36 & 31,00 \\
\hline Média & 3550,33 & 2077,85 & 2647,35 & 32,46 & 31,26 \\
\hline Graute 1 & \multirow{2}{*}{ Massa (g) } & \multicolumn{2}{|c|}{ Fator de Amortecimento $\left(\times 10^{-6}\right)$} & \multicolumn{2}{|c|}{ Módulo de elasticidade (GPa) } \\
\hline CP (5 cm x $10 \mathrm{~cm})$ & & Flexural & Longitudinal & Flexural & Longitudinal \\
\hline ср 1 & 423,3 & 5019,4 & 3890,0 & 43,32 & 41,25 \\
\hline ср 2 & 425,5 & 4021,8 & 4309,7 & 40,00 & 39,14 \\
\hline ср 3 & 424,7 & 4210,0 & 4367,9 & 41,01 & 39,33 \\
\hline ср 4 & 426,3 & 5692,3 & 4412,0 & 42,82 & 40,72 \\
\hline ср 5 & 426,4 & 4919,7 & 4410,1 & 41,88 & 40,08 \\
\hline ср 6 & 421,7 & 4164,6 & 4266,5 & 38,31 & 37,51 \\
\hline Média & 424,65 & 4671,30 & 4276,03 & 41,22 & 39,67 \\
\hline Graute 2 & \multirow{2}{*}{ Massa (g) } & \multicolumn{2}{|c|}{ Fator de Amortecimento $\left(\mathrm{x10}^{-6}\right)$} & \multicolumn{2}{|c|}{ Módulo de elasticidade (GPa) } \\
\hline CP $(5 \mathrm{~cm} \times 10 \mathrm{~cm})$ & & Flexural & Longitudinal & Flexural & Longitudinal \\
\hline ср 1 & 426,3 & 4331,7 & 4349,6 & 42,25 & 40,53 \\
\hline ср 2 & 430,8 & 4541,4 & 4280,6 & 43,42 & 41,34 \\
\hline ср 3 & 424,6 & 4702,4 & 4325,4 & 42,36 & 40,31 \\
\hline ср 4 & 429,9 & 3956,6 & 4199,3 & 43,42 & 41,38 \\
\hline cp 5 & 427,0 & 4857,4 & 3775,5 & 44,26 & 41,95 \\
\hline ср 6 & 428,8 & 4644,3 & 4341,0 & 41,97 & 40,01 \\
\hline Média & 427,90 & 4505,63 & 4211,90 & 42,95 & 40,92 \\
\hline Graute 3 & \multirow{2}{*}{ Massa (g) } & \multicolumn{2}{|c|}{ Fator de Amortecimento $\left(\mathrm{x10}^{-6}\right)$} & \multicolumn{2}{|c|}{ Módulo de elasticidade (GPa) } \\
\hline CP (5 cm x $10 \mathrm{~cm})$ & & Flexural & Longitudinal & Flexural & Longitudinal \\
\hline ср 1 & 423,5 & 4966,2 & 4252,5 & 42,40 & 39,85 \\
\hline ср 2 & 423,9 & 4563,6 & 4451,3 & 41,78 & 39,56 \\
\hline ср 3 & 423,1 & 4502,1 & 4283,5 & 41,34 & 39,17 \\
\hline ср 4 & 424,4 & 5704,5 & 4323,7 & 41,84 & 39,39 \\
\hline ср 5 & 424,3 & 4298,4 & 4274,5 & 42,01 & 39,86 \\
\hline Média & 423,84 & 4806,96 & 4317,10 & 41,87 & 39,57 \\
\hline Graute 4 & \multirow{2}{*}{ Massa (g) } & \multicolumn{2}{|c|}{ Fator de Amortecimento $\left.\left(\mathrm{x}^{-6}\right)^{-6}\right)$} & Módulo de & idade (GPa) \\
\hline CP (5 cm x $10 \mathrm{~cm})$ & & Flexural & Longitudinal & Flexural & Longitudinal \\
\hline ср 1 & 429,1 & 4728,3 & 4650,1 & 42,23 & 40,05 \\
\hline ср 2 & 431,6 & 4690,8 & 4593,7 & 42,78 & 40,34 \\
\hline ср 3 & 424,6 & 4439,7 & 4559,1 & 41,09 & 39,13 \\
\hline ср 4 & 429,4 & 4393,9 & 4642,7 & 42,33 & 40,21 \\
\hline cp 5 & 435,2 & 5019,6 & 4813,5 & 41,79 & 39,70 \\
\hline ср 6 & 434,3 & 6194,6 & 4479,5 & 42,05 & 40,12 \\
\hline Média & 430,70 & 4911,15 & 4623,10 & 42,05 & 39,93 \\
\hline
\end{tabular}

Tabela B.15: Resultados da caracterização dinâmica no dia 30/04/2014.

\begin{tabular}{|c|c|c|c|c|c|}
\hline Laje 1 & \multirow{2}{*}{ Massa (g) } & \multicolumn{2}{|c|}{ Fator de Amortecimento $\left(\times 10^{-6}\right)$} & \multicolumn{2}{|c|}{ Módulo de elasticidade (GPa) } \\
\hline CP $(10 \mathrm{~cm} \times 20 \mathrm{~cm})$ & & Flexural & Longitudinal & Flexural & Longitudinal \\
\hline ср 1 & 2713,4 & 4881,5 & 3359,9 & 20,84 & 20,67 \\
\hline ср 2 & 2729,7 & 3598,0 & 2913,5 & 21,57 & 22,21 \\
\hline ср 3 & 2654,5 & 4740,0 & 4004,2 & 19,77 & 20,88 \\
\hline ср 4 & 2629,9 & 4449,8 & 3837,6 & 16,54 & 16,70 \\
\hline Média & 2681,88 & 4417,33 & 3528,80 & 19,68 & 20,12 \\
\hline
\end{tabular}


Tabela B.16: Resultados da caracterização dinâmica no dia 07/05/2014.

\begin{tabular}{|c|c|c|c|c|c|}
\hline Laje 1 & \multirow{2}{*}{ Massa (g) } & \multicolumn{2}{|c|}{ Fator de Amortecimento $\left(\times 10^{-6}\right)$} & \multicolumn{2}{|c|}{ Módulo de elasticidade (GPa) } \\
\hline CP $(10 \mathrm{~cm} \times 20 \mathrm{~cm})$ & & Flexural & Longitudinal & Flexural & Longitudinal \\
\hline ср 1 & 2710,2 & 4376,8 & 3165,0 & 21,01 & 20,68 \\
\hline ср 2 & 2726,2 & 3723,7 & 2634,2 & 22,11 & 22,25 \\
\hline ср 3 & 2651,8 & 3667,3 & 3615,7 & 20,90 & 20,91 \\
\hline ср 4 & 2626,7 & 4208,4 & 3805,4 & 17,83 & 16,70 \\
\hline Média & 2678,73 & 3994,05 & 3305,08 & 20,46 & 20,14 \\
\hline Laje 2 & \multirow{2}{*}{ Massa (g) } & \multicolumn{2}{|c|}{ Fator de Amortecimento $\left(\times 10^{-6}\right)$} & \multicolumn{2}{|c|}{ Módulo de elasticidade (GPa) } \\
\hline CP $(10 \mathrm{~cm} \times 20 \mathrm{~cm})$ & & Flexural & Longitudinal & Flexural & Longitudinal \\
\hline ср 1 & 2264,4 & 4012,0 & 4195,8 & 8,11 & 7,86 \\
\hline ср 2 & 2218,6 & 4221,9 & 3835,8 & 9,28 & 14,04 \\
\hline ср 3 & 2362,8 & 5226,0 & 4827,4 & 10,81 & 13,74 \\
\hline ср 4 & 2215,0 & 4262,0 & 4033,8 & 7,95 & 8,72 \\
\hline Média & 2265,20 & 4430,48 & 4223,20 & 9,04 & 11,09 \\
\hline Graute 1 & \multirow{2}{*}{ Massa (g) } & \multicolumn{2}{|c|}{ Fator de Amortecimento $\left.\left(\mathrm{x}^{-6}\right)^{-6}\right)$} & \multicolumn{2}{|c|}{ Módulo de elasticidade (GPa) } \\
\hline CP (5 cm x $10 \mathrm{~cm})$ & & Flexural & Longitudinal & Flexural & Longitudinal \\
\hline ср 1 & 439,2 & 4373,9 & 4667,1 & 37,65 & 37,20 \\
\hline ср 2 & 442,5 & 7648,2 & 4711,1 & 36,62 & 36,56 \\
\hline ср 3 & 435,0 & 4913,4 & 4800,3 & 38,23 & 37,19 \\
\hline ср 4 & 434,7 & 5283,4 & 4516,7 & 37,82 & 37,23 \\
\hline ср 5 & 439,4 & 7102,2 & 4773,6 & 37,00 & 36,82 \\
\hline ср 6 & 434,2 & 5055,1 & 4673,3 & 36,68 & 36,82 \\
\hline Média & 437,50 & 5729,37 & 4690,35 & 37,33 & 36,97 \\
\hline
\end{tabular}

Tabela B.17: Resultados da caracterização dinâmica no dia 14/05/2014.

\begin{tabular}{|c|c|c|c|c|c|}
\hline Laje 1 & \multirow{2}{*}{ Massa (g) } & \multicolumn{2}{|c|}{ Fator de Amortecimento $\left(\mathrm{x}^{-6} 0^{-6}\right)$} & \multicolumn{2}{|c|}{ Módulo de elasticidade (GPa) } \\
\hline CP $(10 \mathrm{~cm} \times 20 \mathrm{~cm})$ & & Flexural & Longitudinal & Flexural & Longitudinal \\
\hline ср 1 & 2707,8 & 4875,2 & 3314,8 & 20,80 & 20,63 \\
\hline ср 2 & 2723,8 & 3957,1 & 3546,2 & 21,52 & 22,21 \\
\hline ср 3 & 2649,8 & 4340,5 & 4662,0 & 19,89 & 20,94 \\
\hline ср 4 & 2624,0 & 2987,5 & 2740,2 & 16,56 & 16,74 \\
\hline Média & 2676,35 & 4040,08 & 3565,80 & 19,69 & 20,13 \\
\hline Laje 2 & \multirow{2}{*}{ Massa (g) } & \multicolumn{2}{|c|}{ Fator de Amortecimento $\left(\mathrm{x}^{-6}\right)$} & \multicolumn{2}{|c|}{ Módulo de elasticidade (GPa) } \\
\hline CP (10 cm x $20 \mathrm{~cm})$ & & Flexural & Longitudinal & Flexural & Longitudinal \\
\hline ср 1 & 2261,0 & 3234,7 & 4211,1 & 7,79 & 7,82 \\
\hline ср 2 & 2216,5 & 4266,7 & 4642,6 & 9,24 & 10,34 \\
\hline ср 3 & 2360,5 & 4502,3 & 5202,4 & 9,69 & 13,74 \\
\hline ср 4 & 2212,0 & 4182,1 & 4129,7 & 7,84 & 11,86 \\
\hline Média & 2262,50 & 4046,45 & 4546,45 & 8,64 & 10,94 \\
\hline Laje 3a & \multirow{2}{*}{ Massa (g) } & \multicolumn{2}{|c|}{ Fator de Amortecimento $\left(\mathrm{x}^{-6}\right)^{-6}$} & \multicolumn{2}{|c|}{ Módulo de elasticidade (GPa) } \\
\hline CP (10 cm x $20 \mathrm{~cm})$ & & Flexural & Longitudinal & Flexural & Longitudinal \\
\hline ср 1 & 1914,0 & 4472,7 & 4019,2 & 7,51 & 10,49 \\
\hline ср 2 & 1850,3 & 3161,5 & 3491,9 & 7,43 & 7,40 \\
\hline ср 3 & 1870,3 & 3868,1 & 3982,3 & 6,52 & 7,18 \\
\hline ср 4 & 1901,2 & 3875,9 & 4156,4 & 7,50 & 7,58 \\
\hline Média & 1883,95 & 3844,55 & 3912,45 & 7,24 & 8,16 \\
\hline Graute 1 & \multirow{2}{*}{ Massa (g) } & \multicolumn{2}{|c|}{ Fator de Amortecimento $\left.\left(\mathrm{x}^{-6}\right)^{-6}\right)$} & \multicolumn{2}{|c|}{ Módulo de elasticidade (GPa) } \\
\hline CP (5 cm x $10 \mathrm{~cm})$ & & Flexural & Longitudinal & Flexural & Longitudinal \\
\hline ср 1 & 436,1 & 4796,8 & 4084,1 & 37,86 & 37,62 \\
\hline ср 2 & 438,5 & 4853,1 & 4114,0 & 36,25 & 36,61 \\
\hline ср 3 & 431,2 & 7285,0 & 3994,6 & 37,31 & 37,18 \\
\hline ср 4 & 431,4 & 5245,3 & 4041,7 & 37,73 & 37,65 \\
\hline cp 5 & 435,8 & 4569,4 & 3992,0 & 37,09 & 37,16 \\
\hline ср 6 & 430,1 & 4257,8 & 4216,4 & 37,04 & 36,74 \\
\hline Média & 433,85 & 5167,90 & 4073,80 & 37,21 & 37,16 \\
\hline Graute 2 & \multirow{2}{*}{ Massa (g) } & \multicolumn{2}{|c|}{ Fator de Amortecimento $\left(\times 10^{-6}\right)$} & \multicolumn{2}{|c|}{ Módulo de elasticidade (GPa) } \\
\hline CP (5 cm x $10 \mathrm{~cm})$ & & Flexural & Longitudinal & Flexural & Longitudinal \\
\hline ср 1 & 436,8 & 4358,2 & 4362,3 & 38,91 & 38,32 \\
\hline ср 2 & 438,4 & 5181,9 & 4593,9 & 38,47 & 37,82 \\
\hline ср 3 & 439,6 & 4861,3 & 4107,4 & 38,47 & 38,35 \\
\hline ср 4 & 437,6 & 4820,5 & 4525,1 & 39,19 & 38,41 \\
\hline ср 5 & 435,3 & 4825,7 & 4394,4 & 38,35 & 38,12 \\
\hline ср 6 & 441,4 & 4416,9 & 4400,6 & 39,36 & 38,98 \\
\hline Média & 438,18 & 4744,08 & 4397,28 & 38,79 & 38,33 \\
\hline
\end{tabular}


Tabela B.18: Resultados da caracterização dinâmica no dia 20/05/2014.

\begin{tabular}{|c|c|c|c|c|c|}
\hline Laje 1 & \multirow{2}{*}{ Massa (g) } & \multicolumn{2}{|c|}{ Fator de Amortecimento $\left(\mathrm{x10}^{-6}\right)$} & \multicolumn{2}{|c|}{ Módulo de elasticidade (GPa) } \\
\hline CP $(10 \mathrm{~cm} \times 20 \mathrm{~cm})$ & & Flexural & Longitudinal & Flexural & Longitudinal \\
\hline ср 1 & 2707,2 & 4572,6 & 3733,6 & 20,91 & 20,60 \\
\hline ср 2 & 2723,2 & 4208,6 & 3557,3 & 21,44 & 22,17 \\
\hline ср 3 & 2648,7 & 4406,3 & 4039,1 & 20,08 & 20,95 \\
\hline ср 4 & 2623,0 & 3728,4 & 3890,5 & 16,64 & 16,74 \\
\hline Média & 2675,53 & 4228,98 & 3805,13 & 19,77 & 20,12 \\
\hline Laje 2 & \multirow{2}{*}{ Massa (g) } & \multicolumn{2}{|c|}{ Fator de Amortecimento $\left(\mathrm{x}^{-6}\right)$} & \multicolumn{2}{|c|}{ Módulo de elasticidade (GPa) } \\
\hline CP $(10 \mathrm{~cm} \times 20 \mathrm{~cm})$ & & Flexural & Longitudinal & Flexural & Longitudinal \\
\hline ср 1 & 2259,6 & 3650,8 & 4911,5 & 7,87 & 7,77 \\
\hline ср 2 & 2215,2 & 4521,1 & 3925,4 & 9,24 & 10,31 \\
\hline cp 3 & 2358,8 & 4754,1 & 5104,5 & 10,82 & 9,86 \\
\hline ср 4 & 2210,5 & 4092,0 & 4690,6 & 8,84 & 8,65 \\
\hline Média & 2261,03 & 4254,50 & 4658,00 & 9,19 & 9,15 \\
\hline Laje 3a & \multirow{2}{*}{ Massa (g) } & \multicolumn{2}{|c|}{ Fator de Amortecimento $\left(\mathrm{x10}^{-6}\right)$} & \multicolumn{2}{|c|}{ Módulo de elasticidade (GPa) } \\
\hline $\mathrm{CP}(10 \mathrm{~cm} \times 20 \mathrm{~cm})$ & & Flexural & Longitudinal & Flexural & Longitudinal \\
\hline ср 1 & 1913,4 & 3667,5 & 4046,8 & 7,59 & 7,68 \\
\hline ср 2 & 1849,7 & 4736,4 & 4095,8 & 7,34 & 7,41 \\
\hline ср 3 & 1869,4 & 7163,3 & 4518,0 & 6,71 & 7,22 \\
\hline ср 4 & 1899,7 & 4478,4 & 2876,2 & 7,44 & 7,56 \\
\hline Média & 1883,05 & 5011,40 & 3884,20 & 7,27 & 7,47 \\
\hline Laje 4 & \multirow{2}{*}{ Massa (g) } & \multicolumn{2}{|c|}{ Fator de Amortecimento $\left(\times 10^{-6}\right)$} & \multicolumn{2}{|c|}{ Módulo de elasticidade (GPa) } \\
\hline CP $(10 \mathrm{~cm} \times 20 \mathrm{~cm})$ & & Flexural & Longitudinal & Flexural & Longitudinal \\
\hline ср 1 & 2213,3 & 4612,2 & 4040,2 & 10,58 & 14,17 \\
\hline ср 2 & 2588,6 & 4400,2 & 4101,9 & 13,85 & 14,83 \\
\hline ср 3 & 2694,2 & 4703,1 & 4380,2 & 17,44 & 18,66 \\
\hline ср 4 & 2494,9 & 3262,0 & 4327,7 & 15,50 & 15,07 \\
\hline Média & 2497,75 & 4244,38 & 4212,50 & 14,34 & 15,68 \\
\hline Graute 1 & \multirow{2}{*}{ Massa (g) } & \multicolumn{2}{|c|}{ Fator de Amortecimento $\left(\mathrm{x10}^{-6}\right)$} & \multicolumn{2}{|c|}{ Módulo de elasticidade (GPa) } \\
\hline CP $(5 \mathrm{~cm} \times 10 \mathrm{~cm})$ & & Flexural & Longitudinal & Flexural & Longitudinal \\
\hline ср 1 & 425,1 & 4900,5 & 5739,4 & 38,62 & 37,91 \\
\hline ср 2 & 427,5 & 5508,1 & 4875,3 & 36,78 & 36,94 \\
\hline ср 3 & 421,2 & 5254,5 & 4875,3 & 38,42 & 37,47 \\
\hline ср 4 & 421,2 & 5676,2 & 4723,3 & 38,56 & 37,80 \\
\hline ср 5 & 425,3 & 4937,6 & 4275,6 & 37,45 & 37,27 \\
\hline ср 6 & 419,3 & 3848,2 & 5331,3 & 36,87 & 37,13 \\
\hline Média & 423,27 & 5020,85 & 4970,03 & 37,78 & 37,42 \\
\hline Graute 2 & \multirow{2}{*}{ Massa (g) } & \multicolumn{2}{|c|}{ Fator de Amortecimento $\left(\times 10^{-6}\right)$} & \multicolumn{2}{|c|}{ Módulo de elasticidade (GPa) } \\
\hline CP $(5 \mathrm{~cm} \times 10 \mathrm{~cm})$ & & Flexural & Longitudinal & Flexural & Longitudinal \\
\hline ср 1 & 424,5 & 5793,1 & 4820,3 & 39,97 & 38,96 \\
\hline ср 2 & 427,2 & 5617,8 & 4910,0 & 38,88 & 38,11 \\
\hline ср 3 & 428,0 & 4667,9 & 4858,0 & 39,94 & 38,92 \\
\hline ср 4 & 426,0 & 4316,1 & 4893,3 & 39,91 & 38,80 \\
\hline ср 5 & 422,5 & 4188,0 & 5063,8 & 39,84 & 38,43 \\
\hline ср 6 & 425,9 & 5167,0 & 4692,8 & 42,24 & 40,23 \\
\hline Média & 425,68 & 4958,32 & 4873,03 & 40,13 & 38,91 \\
\hline Graute 3 & \multirow{2}{*}{ Massa (g) } & Fator & imento $\left({\left.\mathrm{x} 10^{-6}\right)}^{-6}\right.$ & Módulo d & idade (GPa) \\
\hline CP $(5 \mathrm{~cm} \times 10 \mathrm{~cm})$ & & Flexural & Longitudinal & Flexural & Longitudinal \\
\hline ср 1 & 435,6 & 5056,5 & 5040,1 & 38,76 & 38,41 \\
\hline ср 2 & 436,6 & 6715,6 & 4903,5 & 39,06 & 38,00 \\
\hline ср 3 & 436,0 & 3648,5 & 4890,1 & 39,89 & 38,96 \\
\hline ср 4 & 431,5 & 4802,7 & 4957,9 & 39,96 & 38,97 \\
\hline ср 5 & 432,2 & 5763,5 & 4856,6 & 40,36 & 39,34 \\
\hline ср 6 & 441,9 & 4912,3 & 4772,0 & 38,86 & 38,67 \\
\hline Média & 435,63 & 5149,85 & 4903,37 & 39,48 & 38,73 \\
\hline
\end{tabular}


Tabela B.19: Resultados da caracterização dinâmica no dia 28/05/2014.

\begin{tabular}{|c|c|c|c|c|c|}
\hline Laje 1 & \multirow{2}{*}{ Massa (g) } & \multicolumn{2}{|c|}{ Fator de Amortecimento $\left(\mathrm{x}^{-6} 0^{-6}\right)$} & \multicolumn{2}{|c|}{ Módulo de elasticidade (GPa) } \\
\hline CP $(10 \mathrm{~cm} \times 20 \mathrm{~cm})$ & & Flexural & Longitudinal & Flexural & Longitudinal \\
\hline ср 1 & 2708,2 & 6260,6 & 3368,6 & 21,06 & 20,68 \\
\hline ср 2 & 2723,7 & 3139,8 & 3332,8 & 22,02 & 22,19 \\
\hline ср 3 & 2649,3 & 3955,7 & 4087,7 & 20,77 & 20,90 \\
\hline ср 4 & 2623,6 & 4269,3 & 4215,3 & 16,58 & 16,68 \\
\hline Média & 2676,20 & 4406,35 & 3751,10 & 20,11 & 20,11 \\
\hline Laje 2 & \multirow{2}{*}{ Massa (g) } & \multicolumn{2}{|c|}{ Fator de Amortecimento $\left(\mathrm{x}^{-6} \mathrm{C}^{-6}\right)$} & \multicolumn{2}{|c|}{ Módulo de elasticidade (GPa) } \\
\hline CP $(10 \mathrm{~cm} \times 20 \mathrm{~cm})$ & & Flexural & Longitudinal & Flexural & Longitudinal \\
\hline ср 1 & 2260,3 & 3058,0 & 3521,5 & 7,51 & 7,74 \\
\hline ср 2 & 2216,4 & 3476,4 & 3242,6 & 9,21 & 10,29 \\
\hline cp 3 & 2359,7 & 4055,8 & 4583,4 & 9,75 & 9,87 \\
\hline ср 4 & 2211,7 & 5447,6 & 5145,6 & 8,30 & 8,67 \\
\hline Média & 2262,03 & 4009,45 & 4123,28 & 8,69 & 9,14 \\
\hline Laje 3a e 3b & \multirow{2}{*}{ Massa (g) } & \multicolumn{2}{|c|}{ Fator de Amortecimento $\left.\left(\mathrm{x}^{-6}\right)^{-6}\right)$} & \multicolumn{2}{|c|}{ Módulo de elasticidade (GPa) } \\
\hline CP $(10 \mathrm{~cm} \times 20 \mathrm{~cm})$ & & Flexural & Longitudinal & Flexural & Longitudinal \\
\hline ср 1 & 1913,3 & 3190,1 & 4240,9 & 7,14 & 7,68 \\
\hline ср 2 & 1849,8 & 3329,9 & 4200,6 & 6,98 & 7,37 \\
\hline ср 3 & 1869,8 & 3956,9 & 3783,5 & 6,44 & 7,21 \\
\hline ср 4 & 1900,1 & 3707,4 & 3425,2 & 7,40 & 7,52 \\
\hline Média & 1883,25 & 3546,08 & 3912,55 & 6,99 & 7,45 \\
\hline Laje 4 & \multirow{2}{*}{ Massa (g) } & \multicolumn{2}{|c|}{ Fator de Amortecimento $\left(\mathrm{x} 10^{-6}\right)$} & \multicolumn{2}{|c|}{ Módulo de elasticidade (GPa) } \\
\hline CP (10 cm x 20 cm) & & Flexural & Longitudinal & Flexural & Longitudinal \\
\hline ср 1 & 2213,7 & 3987,1 & 4936,4 & 11,83 & 14,17 \\
\hline ср 2 & 2589,3 & 4470,4 & 4386,8 & 14,87 & 14,73 \\
\hline ср 3 & 2694,9 & 3425,5 & 3526,5 & 17,49 & 18,64 \\
\hline ср 4 & 2495,6 & 3178,4 & 3722,7 & 15,78 & 15,05 \\
\hline Média & 2498,38 & 3765,35 & 4143,10 & 14,99 & 15,65 \\
\hline Graute 1 & \multirow{2}{*}{ Massa (g) } & \multicolumn{2}{|c|}{ Fator de Amortecimento $\left(\mathrm{x}^{-6} 0^{-6}\right)$} & Módulo d & idade (GPa) \\
\hline $\mathrm{CP}(5 \mathrm{~cm} \times 10 \mathrm{~cm})$ & & Flexural & Longitudinal & Flexural & Longitudinal \\
\hline ср 1 & 424,5 & 4020,1 & 3330,7 & 39,21 & 38,36 \\
\hline ср 2 & 426,8 & 4229,4 & 4241,7 & 37,33 & 37,48 \\
\hline ср 3 & 420,5 & 3824,0 & 3753,2 & 39,04 & 38,07 \\
\hline ср 4 & 420,6 & 4925,9 & 3699,9 & 39,26 & 38,53 \\
\hline cp 5 & 424,6 & 3785,5 & 3432,9 & 38,49 & 37,96 \\
\hline ср 6 & 418,7 & 4427,6 & 4095,4 & 38,70 & 37,79 \\
\hline Média & 422,62 & 4202,08 & 3758,97 & 38,67 & 38,03 \\
\hline Graute 2 & Masca ( $\mathbf{0})$ & Fator & imento $\left({\left.\mathrm{x} 10^{-6}\right)}^{-6}\right.$ & Módulo d & idade (GPa) \\
\hline $\mathrm{CP}(5 \mathrm{~cm} \times 10 \mathrm{~cm})$ & IVIassa (g) & Flexural & Longitudinal & Flexural & Longitudinal \\
\hline ср 1 & 423,7 & 4405,0 & 4207,3 & 41,24 & 39,70 \\
\hline ср 2 & 426,2 & 4148,5 & 4156,2 & 39,13 & 38,80 \\
\hline ср 3 & 427,0 & 4825,3 & 4133,1 & 40,75 & 39,62 \\
\hline ср 4 & 425,2 & 4509,8 & 4060,4 & 40,59 & 39,65 \\
\hline ср 5 & 421,7 & 4679,0 & 4194,1 & 39,97 & 39,29 \\
\hline ср 6 & 424,7 & 4184,0 & 4245,8 & 42,28 & 40,98 \\
\hline Média & 424,75 & 4458,60 & 4166,15 & 40,66 & 39,67 \\
\hline Graute 3 & Massa ( $\mathbf{\alpha})$ & Fator & imento $\left(\times 10^{-6}\right)$ & Módulo d & idade (GPa) \\
\hline CP $(5 \mathrm{~cm} \times 10 \mathrm{~cm})$ & IVIassa (g) & Flexural & Longitudinal & Flexural & Longitudinal \\
\hline ср 1 & 433,5 & 4255,4 & 4157,5 & 40,82 & 39,57 \\
\hline ср 2 & 434,6 & 6537,5 & 3724,9 & 39,91 & 39,19 \\
\hline ср 3 & 433,9 & 5202,4 & 4392,7 & 40,63 & 40,08 \\
\hline ср 4 & 429,5 & 5228,2 & 3846,2 & 40,89 & 40,11 \\
\hline ср 5 & 430,1 & 4807,2 & 4174,6 & 41,49 & 40,55 \\
\hline ср 6 & 439,9 & 2433,9 & 4145,0 & 39,33 & 39,74 \\
\hline Média & 433,58 & 4744,10 & 4073,48 & 40,51 & 39,87 \\
\hline Graute 4 & Masca (ब) & Fator & imento $\left(\mathrm{x} 10^{-6}\right)$ & Módulo d & dade (GPa) \\
\hline CP $(5 \mathrm{~cm} \times 10 \mathrm{~cm})$ & IVIssa (g) & Flexural & Longitudinal & Flexural & Longitudinal \\
\hline ср 1 & 443,3 & 4873,4 & 4576,3 & 40,54 & 39,73 \\
\hline ср 2 & 439,2 & 6971,4 & 4560,3 & 39,79 & 38,97 \\
\hline ср 3 & 438,7 & 6312,7 & 4418,3 & 41,11 & 39,97 \\
\hline ср 4 & 443,8 & 7604,5 & 4524,0 & 40,26 & 39,75 \\
\hline ср 5 & 438,0 & 4045,3 & 4597,2 & 40,65 & 39,60 \\
\hline ср 6 & 437,3 & 4705,5 & 4048,6 & 40,78 & 38,87 \\
\hline Média & 440,05 & 5752,13 & 4454,12 & 40,52 & 39,48 \\
\hline
\end{tabular}


Tabela B.20: Resistências características à compressão dos materiais das lajes de CC.

\begin{tabular}{|c|c|c|c|c|c|c|c|}
\hline Laje 1 & $\begin{array}{l}\text { Idade do cp } \\
\text { (dias) }\end{array}$ & $\begin{array}{c}\text { Carga de Ruptura } \\
\text { (kN) }\end{array}$ & $f_{c i}(\mathrm{MPa})$ & $f_{c m}(\mathrm{MPa})$ & $\delta$ & $s$ (MPa) & $\begin{array}{c}f_{c k} \\
(\mathrm{MPa})\end{array}$ \\
\hline ср $1-(10$ × 20$)$ & 188 & 372,4 & 47,42 & \multirow{3}{*}{46,49} & \multirow{3}{*}{0,01} & \multirow{3}{*}{0,66} & \multirow{3}{*}{45,41} \\
\hline cp $2-(10 \times 20)$ & 188 & 360,4 & 45,89 & & & & \\
\hline cp $3-(10 \times 20)$ & 188 & 362,7 & 46,18 & & & & \\
\hline Laje 2 & $\begin{array}{l}\text { Idade do cp } \\
\text { (dias) }\end{array}$ & $\begin{array}{l}\text { Carga de Ruptura } \\
\text { (kN) }\end{array}$ & $f_{c i}(\mathrm{MPa})$ & $f_{c m}$ (MPa) & $\delta$ & $s$ (MPa) & $\begin{array}{c}f_{c k} \\
(\mathrm{MPa})\end{array}$ \\
\hline ср $1-(10 \times 20)$ & 188 & 297,7 & 37,90 & \multirow{3}{*}{36,81} & \multirow{3}{*}{0,03} & \multirow{3}{*}{0,97} & \multirow{3}{*}{35,22} \\
\hline ср $2-(10 \times 20)$ & 188 & 290,4 & 36,97 & & & & \\
\hline cp $3-(10 \times 20)$ & 188 & 279,2 & 35,55 & & & & \\
\hline Laje 3 & $\begin{array}{c}\text { Idade do cp } \\
\text { (dias) }\end{array}$ & $\begin{array}{c}\text { Carga de Ruptura } \\
(\mathrm{kN})\end{array}$ & $f_{c i}(\mathrm{MPa})$ & $f_{c m}(\mathrm{MPa})$ & $\delta$ & $s$ (MPa) & $\begin{array}{c}f_{c k} \\
(\mathrm{MPa})\end{array}$ \\
\hline ср $1-(10 \times 20)$ & 188 & 255 & 32,47 & \multirow{3}{*}{33,41} & \multirow{3}{*}{0,02} & \multirow{3}{*}{0,67} & \multirow{3}{*}{32,30} \\
\hline cp $2-(10 \times 20)$ & 188 & 265 & 33,74 & & & & \\
\hline ср $3-(10 \times 20)$ & 188 & 267,1 & 34,01 & & & & \\
\hline Laje 4 & $\begin{array}{c}\text { Idade do cp } \\
\text { (dias) }\end{array}$ & $\begin{array}{l}\text { Carga de Ruptura } \\
(\mathrm{kN})\end{array}$ & $f_{c i}(\mathrm{MPa})$ & $f_{c m}$ (MPa) & $\delta$ & $s$ (MPa) & $\begin{array}{c}f_{c k} \\
(\mathrm{MPa})\end{array}$ \\
\hline ср $1-(10 \times 20)$ & 188 & 259,6 & 33,05 & \multirow{3}{*}{29,77} & \multirow{3}{*}{0,08} & \multirow{3}{*}{2,38} & \multirow{3}{*}{25,86} \\
\hline cp $2-(10 \times 20)$ & 188 & 216,1 & 27,51 & & & & \\
\hline ср $3-(10 \times 20)$ & 188 & 225,7 & 28,74 & & & & \\
\hline Laje 5 & $\begin{array}{l}\text { Idade do cp } \\
\text { (dias) }\end{array}$ & $\begin{array}{l}\text { Carga de Ruptura } \\
(\mathbf{k N})\end{array}$ & $f_{c i}(\mathrm{MPa})$ & $f_{c m}(\mathrm{MPa})$ & $\delta$ & $s$ (MPa) & $\begin{array}{c}f_{c k} \\
(\mathrm{MPa})\end{array}$ \\
\hline cp $1-(10 \times 20)$ & 188 & 222,8 & 28,37 & \multirow{3}{*}{28,54} & \multirow{3}{*}{0,01} & \multirow{3}{*}{0,30} & \multirow{3}{*}{28,05} \\
\hline cp $2-(10 \times 20)$ & 188 & 227,4 & 28,95 & & & & \\
\hline cp $3-(10 \times 20)$ & 188 & 222,2 & 28,29 & & & & \\
\hline Graute 1 & $\begin{array}{c}\text { Idade do cp } \\
\text { (dias) }\end{array}$ & $\begin{array}{l}\text { Carga de Ruptura } \\
\text { (kN) }\end{array}$ & $f_{c i}$ (MPa) & $f_{c m}(\mathrm{MPa})$ & $\delta$ & $s$ (MPa) & $\begin{array}{c}f_{c k} \\
(\mathrm{MPa})\end{array}$ \\
\hline ср $1-(5 \times 10)$ & 28 & 108,9 & 55,46 & \multirow{6}{*}{50,90} & \multirow{6}{*}{0,06} & & \\
\hline ср $2-(5 \times 10)$ & 28 & 96,2 & 48,99 & & & & \\
\hline cp $3-(5 \times 10)$ & 28 & 102,3 & 52,10 & & & ת & 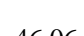 \\
\hline cp $4-(5 \times 10)$ & 28 & 90,8 & 46,24 & & & 2,95 & 46,06 \\
\hline cp $5-(5$ x 10) & 28 & 103,6 & 52,76 & & & & \\
\hline ср $6-(5 \times 10)$ & 28 & 97,9 & 49,86 & & & & \\
\hline Graute 2 & $\begin{array}{c}\text { Idade do cp } \\
\text { (dias) }\end{array}$ & $\begin{array}{l}\text { Carga de Ruptura } \\
(\mathrm{kN})\end{array}$ & $f_{c i}(\mathrm{MPa})$ & $f_{c m}(\mathrm{MPa})$ & $\delta$ & $s$ (MPa) & $\begin{array}{c}f_{c k} \\
(\mathrm{MPa})\end{array}$ \\
\hline ср $1-(5$ x 10) & 21 & 107,6 & 54,80 & & & & \\
\hline cp $2-(5 \times 10)$ & 21 & 109,5 & 55,77 & & & & \\
\hline cp $3-(5 \times 10)$ & 21 & 104,7 & 53,32 & 5608 & 003 & 168 & 5332 \\
\hline ср $4-(5 \times 10)$ & 21 & 114,1 & 58,11 & 56,08 & 0,03 & 1,68 & 53,32 \\
\hline cp $5-(5 \times 10)$ & 21 & 113,6 & 57,86 & & & & \\
\hline cp $6-(5 \times 10)$ & 21 & 111,2 & 56,63 & & & & \\
\hline Graute 3 & $\begin{array}{l}\text { Idade do cp } \\
\text { (dias) }\end{array}$ & $\begin{array}{l}\text { Carga de Ruptura } \\
(\mathrm{kN})\end{array}$ & $f_{c i}(\mathrm{MPa})$ & $f_{c m}(\mathrm{MPa})$ & $\delta$ & $s$ (MPa) & $\begin{array}{c}f_{c k} \\
(\mathrm{MPa})\end{array}$ \\
\hline cp $1-(5 \times 10)$ & 14 & 97,4 & 49,61 & & & & \\
\hline cp $2-(5$ x 10) & 14 & 96,5 & 49,15 & & & & \\
\hline ср $3-(5$ x 10) & 14 & 96,2 & 48,99 & 48,87 & 0,02 & 0,81 & 47,55 \\
\hline cp $4-(5 \times 10)$ & 14 & 92,9 & 47,31 & & & & \\
\hline cp $5-(5 \times 10)$ & 14 & 96,8 & 49,30 & & & & \\
\hline Graute 4 & $\begin{array}{c}\text { Idade do cp } \\
\text { (dias) }\end{array}$ & $\begin{array}{l}\text { Carga de Ruptura } \\
(\mathrm{kN})\end{array}$ & $f_{c i}(\mathrm{MPa})$ & $f_{c m}(\mathrm{MPa})$ & $\delta$ & $s$ (MPa) & $\begin{array}{c}f_{c k} \\
\text { (MPa) }\end{array}$ \\
\hline ср $1-(5 \times 10)$ & 7 & 86,8 & 44,21 & & & & \\
\hline ср $2-(5 \times 10)$ & 7 & 84,9 & 43,24 & & & & \\
\hline cp $3-(5 \times 10)$ & 7 & 86,2 & 43,90 & 4475 & ב & 123 & (4) 72 \\
\hline cp $4-(5 \times 10)$ & 7 & 91,5 & 46,60 & 44,75 & 0,03 & 1,23 & $42, / 2$ \\
\hline cp $5-(5 \times 10)$ & 7 & 87,0 & 44,31 & & & & \\
\hline ср $6-(5 \times 10)$ & 7 & 90,8 & 46,24 & & & & \\
\hline
\end{tabular}


Tabela B.21: Resistências características à compressão dos materiais das lajes de CLEPE.

\begin{tabular}{|c|c|c|c|c|c|c|c|}
\hline Laje 1 & $\begin{array}{c}\begin{array}{c}\text { Idade do cp } \\
\text { (dias) }\end{array} \\
\end{array}$ & $\begin{array}{c}\text { Carga de Ruptura } \\
\text { (kN) }\end{array}$ & $f_{c i}(\mathrm{MPa})$ & $f_{c m}$ (MPa) & $\delta$ & $s$ (MPa) & $f_{c k}(\mathrm{MPa})$ \\
\hline cp 1 - (10 x 20) & 153 & 185,1 & 23,57 & \multirow{4}{*}{18,77} & \multirow{4}{*}{0,16} & \multirow{4}{*}{3,02} & \multirow{4}{*}{13,81} \\
\hline cp $2-(10$ x 20$)$ & 153 & 143,2 & 18,23 & & & & \\
\hline ср $3-(10$ x 20$)$ & 153 & 119,6 & 15,23 & & & & \\
\hline ср $4-(10 \times 20)$ & 153 & 141,8 & 18,06 & & & & \\
\hline Laje 2 & $\begin{array}{c}\text { Idade do cp } \\
\text { (dias) }\end{array}$ & $\begin{array}{c}\text { Carga de Ruptura } \\
(\mathrm{kN})\end{array}$ & $f_{c i}(\mathrm{MPa})$ & $f_{c m}$ (MPa) & $\delta$ & $s$ (MPa) & $f_{c k}(\mathrm{MPa})$ \\
\hline cp $1-(10 \times 20 \mathrm{~cm})$ & 153 & 58,2 & 7,41 & \multirow{4}{*}{9,62} & \multirow{4}{*}{0,13} & \multirow{4}{*}{1,28} & \multirow{4}{*}{7,52} \\
\hline cp $2-(10 x 20 \mathrm{~cm})$ & 153 & 81,5 & 10,37 & & & & \\
\hline ср $3-(10 x 20 \mathrm{~cm})$ & 153 & 81,1 & 10,32 & & & & \\
\hline cp $4-(10 \times 20 \mathrm{~cm})$ & 153 & 81,5 & 10,38 & & & & \\
\hline Laje 3a e $3 b$ & $\begin{array}{c}\text { Idade do cp } \\
\text { (dias) }\end{array}$ & $\begin{array}{c}\text { Carga de Ruptura } \\
(\mathrm{kN})\end{array}$ & $f_{c i}(\mathrm{MPa})$ & $f_{c m}(\mathrm{MPa})$ & $\delta$ & $s$ (MPa) & $f_{c k}(\mathrm{MPa})$ \\
\hline cp $1-(10 \times 20)$ & 153 & 71,0 & 9,04 & \multirow{4}{*}{8,89} & \multirow{4}{*}{0,01} & \multirow{4}{*}{0,12} & \multirow{4}{*}{8,69} \\
\hline cp $2-(10 \times 20)$ & 153 & 68,4 & 8,72 & & & & \\
\hline ср $3-(10 \times 20)$ & 153 & 69,5 & 8,85 & & & & \\
\hline cp $4-(10$ x 20$)$ & 153 & 70,3 & 8,95 & & & & \\
\hline Laje 4 & $\begin{array}{l}\text { Idade do cp } \\
\text { (dias) }\end{array}$ & $\begin{array}{c}\text { Carga de Ruptura } \\
\text { (kN) }\end{array}$ & $f_{c i}(\mathrm{MPa})$ & $f_{c m}(\mathrm{MPa})$ & $\delta$ & $s$ (MPa) & $f_{c k}(\mathrm{MPa})$ \\
\hline ср $1-(10 \times 20)$ & 153 & 129,6 & 16,51 & \multirow{4}{*}{16,84} & \multirow{4}{*}{0,05} & \multirow{4}{*}{0,90} & \multirow{4}{*}{15,36} \\
\hline cp $2-(10 \times 20)$ & 153 & 131,1 & 16,69 & & & & \\
\hline cp $3-(10$ x 20$)$ & 153 & 143,8 & 18,31 & & & & \\
\hline ср $4-(10 \times 20)$ & 153 & 124,6 & 15,86 & & & & \\
\hline Graute 1 & $\begin{array}{l}\text { Idade do cp } \\
\text { (dias) }\end{array}$ & $\begin{array}{c}\text { Carga de Ruptura } \\
\text { (kN) }\end{array}$ & $f_{c i}(\mathrm{MPa})$ & $f_{c m}(\mathrm{MPa})$ & $\delta$ & $s$ (MPa) & $f_{c k}(\mathrm{MPa})$ \\
\hline сp $1-(5 \times 10)$ & 28 & 112,3 & 57,19 & \multirow{6}{*}{54,24} & \multirow{6}{*}{0,03} & \multirow{6}{*}{1,50} & \multirow{6}{*}{51,77} \\
\hline cp $2-(5$ x 10) & 28 & 107,4 & 54,70 & & & & \\
\hline ср $3-(5 \times 10)$ & 28 & 103,9 & 52,92 & & & & \\
\hline ср $4-(5 \times 10)$ & 28 & 106,8 & 54,39 & & & & \\
\hline cp $5-(5 \times 10)$ & 28 & 103,5 & 52,71 & & & & \\
\hline cp $6-(5 \times 10)$ & 28 & 105,1 & 53,53 & & & & \\
\hline Graute 2 & $\begin{array}{c}\text { Idade do cp } \\
\text { (dias) }\end{array}$ & $\begin{array}{c}\text { Carga de Ruptura } \\
\text { (kN) }\end{array}$ & $f_{c i}(\mathrm{MPa})$ & $f_{c m}(\mathrm{MPa})$ & $\delta$ & $s$ (MPa) & $f_{c k}(\mathrm{MPa})$ \\
\hline сp $1-(5 \times 10)$ & 21 & 105,8 & 53,88 & \multirow{6}{*}{53,40} & & & \\
\hline cp $2-(5 \times 10)$ & 21 & 100,6 & 51,24 & & & & \\
\hline cp $3-(5 \times 10)$ & 21 & 104,5 & 53,22 & & & 150 & 500 \\
\hline cp $4-(5 \times 10)$ & 21 & 105,2 & 53,58 & & 0,03 & 1,50 & 50,93 \\
\hline cp $5-(5 \times 10)$ & 21 & 102,8 & 52,36 & & & & \\
\hline cp $6-(5 \times 10)$ & 21 & 110,2 & 56,12 & & & & \\
\hline Graute 3 & $\begin{array}{c}\text { Idade do cp } \\
\text { (dias) }\end{array}$ & $\begin{array}{c}\text { Carga de Ruptura } \\
\text { (kN) }\end{array}$ & $f_{c i}(\mathrm{MPa})$ & $f_{c m}(\mathrm{MPa})$ & $\delta$ & $s$ (MPa) & $f_{c k}(\mathrm{MPa})$ \\
\hline cp 1 - (5 x 10) & 14 & 101,3 & 51,59 & & & & \\
\hline сp $2-(5 \times 10)$ & 14 & 101,9 & 51,90 & & & & \\
\hline cp 3 - (5 x 10) & 14 & 105,1 & 53,53 & 5309 & & 118 & 5116 \\
\hline сp $4-(5 \times 10)$ & 14 & 107,3 & 54,65 & 53,09 & 0,02 & 1,18 & 51,16 \\
\hline cp $5-(5 \times 10)$ & 14 & 103,1 & 52,51 & & & & \\
\hline ср $6-(5 \times 10)$ & 14 & 106,8 & 54,39 & & & & \\
\hline Graute 4 & $\begin{array}{l}\text { Idade do cp } \\
\text { (dias) }\end{array}$ & $\begin{array}{c}\text { Carga de Ruptura } \\
\text { (kN) }\end{array}$ & $f_{c i}(\mathrm{MPa})$ & $f_{c m}(\mathrm{MPa})$ & $\delta$ & $s$ (MPa) & $f_{c k}(\mathrm{MPa})$ \\
\hline ср $1-(5 \times 10)$ & 8 & 83,0 & 42,27 & & & & \\
\hline cp $2-(5$ x 10) & 8 & 83,8 & 42,68 & & & & \\
\hline cp $3-(5$ x 10) & 8 & 86,9 & 44,26 & 1336 & ?0? & 099 & 41 \\
\hline ср $4-(5 \times 10)$ & 8 & 87,7 & 44,67 & 45,50 & 0,02 & 0,00 & 41,91 \\
\hline cp $5-(5 \times 10)$ & 8 & 85,6 & 43,60 & & & & \\
\hline ср $6-(5 \times 10)$ & 8 & 83,8 & 42,68 & & & & \\
\hline
\end{tabular}

